\title{
ERRATA
}

\begin{tabular}{|c|c|c|}
\hline página & aonde se lê & leia-se \\
\hline número 26 & $\begin{array}{c}\text { ancorarem, quinta } \\
\text { linha de baixo para } \\
\text { cima }\end{array}$ & ancoragem \\
\hline número 28 & $\begin{array}{c}\text { sujeito o, terceira } \\
\text { linha de cima para } \\
\text { baixo }\end{array}$ & sujeito $\boldsymbol{t}$ \\
\hline número 153 & $\begin{array}{c}\text { entrevista, na última } \\
\text { linha }\end{array}$ & entrevistas \\
\hline número 175 & $\begin{array}{c}\text { administração direta, } \\
\text { décima terceira linha } \\
\text { de cima para baixo }\end{array}$ & democracia direta \\
\hline
\end{tabular}




\section{Reflexões Sobre a Política de Saúde do Município de São Paulo (1989-92)}

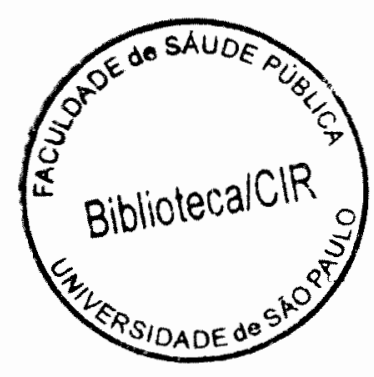

Tese de Doutoramento apresentada junto ao Departamento de Prática da Faculdade de Saúde Pública da Universidade de São Paulo

Orientador: Prof. Dr. Eurivaldo Sampaio de Almeida

São Paulo

1998 


\section{APRESENTAÇÃO}

Este texto é o resultado de uma pesquisa e reflexão sobre o trabalho desenvolvido pela Secretaria Municipal da Saúde de São Paulo entre 1989 e 1992. Durante este período ocorreram profundas e inovadoras alterações no modo de conduzir as políticas públicas no municipio, em especial a da saúde, que nos estimularam a refletir sobre algumas características desse trabalho.

No capitulo I apresentamos as justificativas, os objetivos, as hipóteses da pesquisa e a metodologia empregada.

No capítulo II descrevemos a Secretaria Municipal da Saúde no contexto do município de São Paulo, momento de onde estruturamos as categorias temáticas, que orientaram a organização do roteiro das entrevistas realizadas junto aos funcionários e cidadãos.

No capítulo III, procuramos identificar os discursos dos sujeitos coletivos (por categoria temática), através da interpretação das matrizes discursivas dos cidadãos e funcionários entrevistados.

No capitulo IV analisamos as idéias centrais dos dirigentes da Secretaria, relacionando-as entre si, a respeito da estratégia adotada para a implementação das principais diretrizes da política municipal da saúde.

No capítulo $V$ estabelecemos o confronto entre a estratégia da Secretaria com a percepção dos funcionários e cidadãos entrevistados.

No capitulo VI redigimos a conclusão.

Agradecimentos

Para os estudos e redação da tese contei com o apoio financeiro da CAPES e da FAPESP.

Foram muitas as pessoas que me auxiliaram na pesquisa. Não poderia deixar de agradecê-las.

Ao Professor Eurivaldo de Almeida Sampaio, meu orientador, pelo apoio recebido. 
Emiko Egry, a primeira pessoa a opinar sobre o objeto da pesquisa e a metodologia empregada.

Para as questões que compõem os anexos I, II e III, as observações Márcia Westfal de Faria foram decisivas.

Trabalhar nesses últimos anos no Nace-Consilos, com Carmen Vieira de Sousa Unglert, coordenadora do Núcleo, trouxe enormes contribuições para o amadurecimento das idéias sobre muitos dos aspectos que fazem parte desse trabalho. Quero ainda registrar a ajuda de Cleusa, Chammé e Ivone, da equipe do Nace.

Nilza Nunes da Silva contribuiu com sugestões sobre a definição da amostra dos sujeitos a serem entrevistados.

As discussões com Ana Simioni e Fernando Lefévre, apontaram o caminho para se chegar à construção do discurso do sujeito coletivo, e contribuiram para a definição da estrutura final do trabalho.

Paulo Capel, Maria, Nur e Marília me ajudaram nas questões de informática.

Lembro a todos os com quem tive a oportunidade de trabalhar na Administração Regional de Saúde de Pirituba-Perus, origem de minhas indagações e reflexões, especialmente Yoko, Maria Rosana, Roseli, Zé Carlos, Maria Palmira, Luiz Carlos, Denise, Pedro, Ana Maria, Sandra, Célia, Oscar, Mirna, Tanira, Mônica, Adelina, Vanda, Noro, Dora, Mario, Elisa, Salete, Eliana, Agnes, Kátia, Eliana P, Sandra Magali, Silvia e Regina.

Quero agradecer aos meus amigos Alexandre Nemes Filho, Álvaro Escrivão Júnior, Carlos Alberto Pletz Neder, Eduardo Jorge Martins Alves Sobrinho, Paulo Eduardo Mangeon Elias, Pedro Dimitrov e Virgínia Junqueira, dirigentes entrevistados. Lembro também entre outros, os amigos com os quais tive a honra conviver durante o governo Erundina: Morimoto, Paulão, Laudelina, Isamara, Dagmar, Jorge, Iracema, Osiris, Rubens, Yama, Rosa, Lourdes, Romualdo, Mauro, Manfredini, Romualdo, Ronaldo e Donini.

Dedico esta tese a meus pais e a meus filhos Dodi e Ju.

Uma agradecimento especial à Sílvia, pela leitura e revisão do trabalho, além de todo e básico apoio cotidiano. 


\section{RESUMO}

Em meio à profunda crise no setor, a Secretaria da Saúde do municipio de São Paulo, entre 1989 e 1992, procurou assumir e implementar as diretrizes e principios do Sistema Único de Saúde brasileiro, por meio de mudanças administrativas e gerenciais em sua rede de serviços. A partir da otica de servidores e cidadãos, cotejadas com a estratégia de trabalho adotada pela Secretaria, este projeto procura refletir em que medida as transformações estruturais e do processo de trabalho promovidas por aquela Administração contribuíram para a democratização, a participaçăo social, o desenvolvimento do pessoal, as ações interssetoriais, a reorganização do processo de trabalho e das práticas sanitárias e a promoção da cidadania no município de São Paulo.

Palavras-Chave: planejamento em saúde, modelo de atenção, participação social, integração, práticas sanitárias, democratização, cidadania. 


\begin{abstract}
Considering the serious crisis in the health sector, the Health Secretariat of São Paulo city, between 1989 and 1992, tried to assume and implement the policies and rules of the National Health Service (SUS), according to some management changes in the System.

From the point of view of the citizens and public health workers, and according to the work strategy adopted bay the Secretariat, this project attempt to contemplate in which matters the structural transformations and the work schemes promote by the administration in power from 1989 to 1992, contributed to democracy, community participation, health workers development, integrated activities, reforms of the work legal proceedings, the sanitary practices, and the promotion of citizenship in São Paulo city.
\end{abstract}

Key words: health planning, health care model, participation, integration, sanitary practices, democracy, citizenship. 


\section{Capítulo Um}

$\begin{array}{ll}\text { I. Justificativas } & 01\end{array}$

II. Objetivos 05

III. Questões da Pesquisa 05

$\begin{array}{ll}\text { IV. Material e Método } & 10\end{array}$

IV.1. Metodologia 10

IV.2. Execução do Trabalho de Campo 13

IV.3. Análise das Informações Coletadas 21

\section{Capítulo Dois}

V. O Governo Municipal 32

VI. A Secretaria Municipal da Saúde $\quad 42$

VI.1. As Primeiras Experiências- $\quad 42$

1. a reorganização das estruturas 50

2. o desenvolvimento dos recursos humanos 52

3. a participação social 58

4. o sistema de informações em saúde 63

VI.2. Estratégia Para Implantação do Novo

Modelo de Atenção à Saúde $\quad 66$

Capítulo Três

VII. A Percepção Coletiva 72

1. Análise das informações dos funcionários 72

2. Análise das informações dos cidadãos/usuários 103

Capítulo Quatro

VIII. As Idéias-centrais dos Dirigentes $\quad 111$

Capítulo Cinco

IX. O Confronto Entre as Distintas Visões:

Funcionários, Cidadãos e Dirigentes

Capitulo Seis

X. Conclusões 
Referências Bibliográficas

Apêndice

Anexo 1

Anexo II

204

Anexo III

208

Entrevistas com Funcionários

209

Entrevistas com Cidadãos/Usuários

242

Entrevistas com Dirigentes

256 


\section{CAPITULO I}

Justificativas, Objetivos, Questões da Pesquisa, Metodologia

\section{JUSTIFICATIVAS}

Esta pesquisa estuda as tentativas de mudança no modelo de atenção à saúde ocorridas na Secretaria Municipal da Saúde de São Paulo, no período compreendido entre janeiro de 1989 e dezembro de 1992. Descreve as alterações estruturais, as diretrizes políticas e analisa as inovações do processo de trabalho a partir da ótica dos servidores e cidadãos/usuários, tendo como parâmetro a implantação de um novo modelo de atenção à saúde. Nesse período a administração municipal investiu na transformação estrutural e no desenvolvimento técnico e gerencial dos recursos humanos da SMS. No entanto, passados alguns anos, ainda não são conhecidos os efeitos dessas mudanças no que se refere ao surgimento de novos perfis profissionais voltados para a prática da saúde coletiva e da saúde pública e, muito menos, seus reflexos na organização e na execução das práticas sanitárias.

O meu propósito foi descrever as mudanças organizacionais e refletir sobre a percepção que os funcionários e cidadãos/usuários tiveram da Secretaria da Saúde, particularmente quanto à construção de práticas inovadoras a partir de um novo modelo de atenção nas Unidades da Secretaria Municipal da Saúde de São Paulo.

Durante todo o exercício de minha atividade profissional tenho acompanhado as transformações que vêm ocorrendo no setor saúde, particularmente as do município de São Paulo. Sempre estive voltado para o campo das práticas da saúde coletiva e preocupado com o significado dos papéis exercidos pelo conjunto dos recursos humanos, além de investigar o sentido dos trabalhos desenvolvidos. Inicialmente pude acompanhar as políticas e a organização da Secretaria de Estado da Saúde, trabalhando durante vários anos seguidos em Centros de Saúde, Distritos Sanitários e Departamentos Regionais de Saúde. Mais recentemente, como diretor da Administração Regional de Saúde de Pirituba-Perus, ARS-8, vivenciei internamente as mudanças da Secretaria Municipal de Saúde entre 1989 e 1992. Portanto, muitas das questões colocadas no projeto, fizeram parte de minha vivência cotidiana. 
Após centenas de encontros e reuniões com representantes dos usuários e de outras secretarias municipais, penso ter acumulado algumas experiências em relação à participação social e à importância do trabalho intersetorial. Acompanhei também a elaboração de planos e projetos que visavam à transformação do modelo de atenção à saúde.

A partir da descentralização administrativa e distritalização dos equipamentos da SMS, foram introduzidos conceitos como 0 de territorialização, planejamento estratégico, micro-localização de problemas, eqüidade e vigilância à saúde, e passaram a ser incorporados modelos assistenciais alternativos e outros instrumentos gerenciais em sistemas locais de saúde.

O processo de implantação dos Distritos de Saúde, que visou à transformação das práticas sanitárias na rede municipal, exigiu a organização de mecanismos de participação social, mudanças de comportamento do conjunto dos trabalhadores e inserção de outros setores sociais nas questões da saúde. Daí meu interesse em refletir sobre um determinado período em que se investiu intensamente nessa direção. Esta pesquisa poderá contribuir para responder aos problemas mais comuns quando se pretende repensar práticas e mudar o processo de trabalho em saúde.

Os dirigentes da Secretaria Municipal da Saúde de São Paulo, no periodo compreendido entre 1989 e 1992, sabiam das dificuldades a serem enfrentadas no processo de transformação da Secretaria. Procuraram então, alicerçar-se em uma concepção mais abrangente de saúde, isto é, passaram a defender as mudanças não apenas dentro dos limites demarcados por este setor específico. O grupo de dirigentes preconizou uma ampla reforma no sistema municipal de saúde, de tal modo que o setor saúde pudesse oferecer respostas às diferentes necessidades dos distintos segmentos populacionais e, se possivel, viesse a promover a eqüidade. Os esforços do grupo caminharam no sentido do deslocamento do eixo de trabalho, historicamente consolidado na assistência individual, para alcançar uma intervenção coletiva, considerando os agravos ambientais e os fatores que condicionam a qualidade de vida e condições de saúde. Estas idéias que davam uma certa coesão homogênea ao grupo de dirigentes, eram originárias do Movimento da Reforma Sanitária, e diziam respeito à saúde enquanto um direito de cidadania, à universalização e integralidade do atendimento, à inclusão social 
e à participação social. Analisando esse Movimento, Elias' levanta dois problemas relativos à Reforma Sanitária, um (...) "a saúde é tratada como valor universal, indivisivel e núcleo subversivo da estrutura social, e nestes termos passa a ser entendida como possibilidade de promover a transformação social através através da construção de um bloco histórico ou, no minimo participar dela como um catalisador" (...) e, dois, (...) "a Reforma Sanitária passa como sendo a estratégia possivel para a transformação social".

Embasada nas propostas da Reforma Sanitária, e de certa forma alheia às suas críticas, a Secretaria abriu-se a outras frentes, inserindo-se na luta contra a violência urbana, buscando pensar São Paulo como uma cidade saudável por meio de ações integradas com outros setores e tentando promover a eqüidade nas ações que promovia. Esta postura serviu para reforçar a concepção que os serviços de saúde são parte de um conjunto maior de estruturas e operações, e que requer a articulação de políticas públicas de caráter intersetorial.

De acordo com essa visão, a reorganização dos serviços de saúde depende de alterações estruturais mais amplas, ligadas à capacitação e desenvolvimento da força de trabalho da Secretaria e ao envolvimento de lideranças e movimentos sociais.

Como um dos dirigentes da Secretaria naquele período, tive a oportunidade de participar desse intenso processo de mudança e reforma administrativa. Todos nós, naquele momento, acreditávamos que o maior legado a ser deixado por aquela administração seria a união entre os funcionários e cidadãos/usuários que, juntos, e reconhecendo o esforço e o valor do trabalho coletivo, lutariam lado a lado pela continuidade do plano iniciado naquele governo, houvesse o que houvesse. Tínhamos essa esperança.

Durante meu trabalho de investigação, procurei refletir sobre a percepção que os cidadãos/usuários e servidores tiveram da Secretaria Municipal de Saúde do governo Luiza Erundina, a partir das mudanças provocadas pela política de saúde da administração municipal.

Também procurei contextualizar todo o movimento desenvolvido por aquela administração, assim como traduzir o pensamento de seus dirigentes.

\footnotetext{
Elias. P.E.M. Análises Sobre a Reforma Sanitária e Concepções Políticas Subjacentes. Saúde $e$ Sociedade, São Paulo. 2 (1): 59-73. 1993.
} 
Neste caso, parti de uma abordagem que utilizou instrumentais do planejamento estratégico.

O que pretendi, prioritariamente, foi saber como funcionários e usuários perceberam essas mudanças, ou seja, como detectaram os movimentos e as transformações ocorridas no interior da Secretaria Municipal da Saúde.

Desenvolvi esta pesquisa a partir de determinados pressupostos, que denominei hipóteses ou questões da pesquisa. Esses pressupostos que nortearam os trabalhos da Secretaria durante os quatro anos de gestão, contemplam aspectos administrativos, técnicos e político-ideológicos, porque as ações de saúde estão permeadas de dimensões sociais e técnicas.

Na pesquisa de campo, realizei entrevistas com os servidores e com os cidadãos/usuários, através das quais colhi as informações necessárias para apreender de que forma os funcionários e os cidadãos/usuários dos serviços de saúde da rede municipal perceberam as transformações ocorridas. A expressão cidadão/usuário serve para designar os entrevistados que representam o segmento população. "Cidadão/usuário" significa simplesmente cidadão, seja ele, como se verá, usuário ou não da rede de serviços de saúde. Essa expressão foi utilizada com o propósito de reforçar o sentido da política de saúde, que tinha como um dos princípios a promoção da cidadania, a partir da participação popular, esta, vista enquanto "possibilidade de criação, transformação e controle sobre o poder, ou os poderes" (Benevides, 1991). No lugar da elaboração do orçamento-programa anual, por exemplo, tradicionalmente feito nos gabinetes da Secretaria, foi proposta a elaboração do "orçamento participativo", que passou a ser feito descentralizadamente, junto aos Conselhos Gestores das Unidades de Saúde; ou por meio de maior aproximação da Secretaria junto às organizações não governamentais, ou mesmo, através do apoio aos movimentos sociais, como saúde, moradias populares, creches, e outros

Confrontei os resultados encontrados nesta etapa da pesquisa com o projeto técnico-político implementado pela gerência da Secretaria. Os motivos que me levaram a estabelecer o confronto entre as duas visões, a dos funcionários e cidadãos/usuários com o projeto dos dirigentes, são de duas ordens. Inicialmente porque penso que as mudanças, a formulação e a implementação das práticas de saúde passam pelo pensamento desses três segmentos. Em seguida porque não é possível romper com o atual modelo de 
atenção, nem enfrentar os problemas de saúde, sem o envolvimento de cidadãos, funcionários e dirigentes do setor saúde.

\section{OBJETIVOS}

\section{GERAL}

Refletir sobre a política municipal de saúde do governo Luiza Erundina a partir de duas visões, a do funcionário do setor saúde $e$ a do cidadão/usuário, cotejadas com a estratégia de trabalho adotada pela administração municipal.

\section{ESPECÍFICOS}

A partir da comparação entre as duas óticas e instâncias de trabalho e recepção dos serviços, definir as mudanças ocorridas e refletir se a política municipal de saúde do periodo contribuiu para:

1. a participação social e democratização da tomada de decisão

2. a integração intersetorial

3. a mudança de modelo de atenção à saúde

4. o desenvolvimento de pessoal

\section{PRESSUPOSTOS OU QUESTÕES DA PESQUISA}

No periodo compreendido entre 1989 e 1992 a Secretaria Municipal de Saúde de São Paulo partiu de alguns pressupostos para o desenvolvimento de sua política de saúde. Estes pressupostos consideravam o processo saúde/doença como um fenômeno social, que dependia de variáveis econômicas, sociais, políticas, técnicas e administrativas. Assim, a política municipal de saúde deveria ser repensada a partir da inserção e integração da Secretaria em diferentes setores da sociedade, numa relação de comunicação com os distintos movimentos sociais. Sabe-se que os problemas de saúde decorrem principalmente de fatores relativos às condições de vida, e não exclusivamente das condições organizacionais do setor saúde. Dentro dessa visão, as ações de saúde seriam concebidas com a participação de outras esferas institucionais e sociais, que tradicionalmente definem seus planos de modo fragmentado e não integrado, como a educação, a cultura, o bem-estar social, a administração regional, os transportes públicos, as 
entidades e movimentos sociais, entre outros. Dessa forma, o setor passaria a se preocupar com o meio, com a qualidade de vida e com a produção da saúde e, o modelo de atenção, incorporaria critérios epidemiológicos para a reorganização das ações coletivas e individualizadas. Dentro deste contexto, ouvimos pela primeira vez a expressão "enfoque por problemas". Segundo a política oficial da Secretaria da Saúde, as práticas sanitárias não mais teriam como parâmetro as tradicionais "programações de saúde", mas seriam reorganizadas com base nos problemas de saúde distribuídos de forma desigual pelo município de São Paulo. A regionalização e a distritalização da Secretaria foram concebidas exatamente para que a planificação em saúde passasse a incorporar informações epidemiológicas e problemas distribuidos de modo heterogêneo pelo território de cada Distrito. Para tanto, o pessoal da saúde e os movimentos interessados nesta questão, deveriam se apropriar da situação sócio-epidemiológica dos distintos segmentos populacionais. Pois, a essência do enfoque por problemas é "identificar um problema, descrevê-lo, explicá-lo e montar operações para enfrentá-lo, articulando diferentes conheceres e fazeres num território determinado, especialmente na microárea"s. Segundo Castellanos", os conceitos tradicionais de saúde e enfermidade têm se aberto à confrontação com desenvolvimentos conceituais e metodológicos mais integrais, que revelam com maior capacidade de aprender a complexidade real dos processos determinantes, superar a visão simples e unilateral, descrever e explicar as relações entre os processos mais gerais da sociedade e a saúde dos individuos e grupos sociais.

Para Matus ${ }^{4}$, o planejamento tradicional trabalha com programas e por setores, enquanto que o planejamento estratégico situacional concentra-se em problemas. Diz ele:..."a realidade gera problemas, ameaças e oportunidades. O político trabalha com problemas e a população sofre problemas. É um conceito muito prático, reclamado pela própria realidade, que faz o planejamento aterrizar. Ao contrário, o conceito de setor é uma imposição analitica, é muito genérico, pouco prático e mais apropriado à

\footnotetext{
${ }^{2}$ Mendes.E.V. (org.) Distrito Sanitário: o processo social de mudança das práticas sanitárias do Sistema Únco de Saude. Hucitec-Abrasco, São Paulo-Rio de Janeiro, 1994, p. 173.

${ }^{3}$ Castelanos.P.L. Sobre el concepto de salud-enfermedad: un punto de vista epidemiológico. Cuadernos Médico-Sociales, CESS. Rosario. Argentina. Deciembre. 1987.

${ }^{4}$ Segundo Matus. o planejamento estratégico situacional é um método e uma teoria do planejamento estratégico público. Retiramos a citação de obra recente sobre os passos do PES. cujo título é: "Entrevista com Carlos Matus. o Método PES". publicado pelas Edições Fundap. São Paulo. 1995. Autoria de Franco Huertas. p. 35.
} 
análise macroeconômica. Os problemas reais cruzam os setores e têm atores que se beneficiam ou são prejudicados por eles. Em torno de problemas, a participação cidadã é possivel; em torno de setores, é impossivel. Os atores do jogo social lidam com problemas, não com setores (...) No planejamento estratégico falamos em processar problemas, o que significa quatro coisas: 1. explicar como nasce e se desenvolve o problema; 2. fazer planos para atacar as causas do problema mediante operações; 3. analisar a viabilidade política do plano ou verificar o modo de construir sua viabilidade; e 4. atacar o problema na prática, realizando operações planejadas".

Os dirigentes da Secretaria desejavam intervir sobre as diferentes realidades locais, de forma organizada, e planejavam a utilização de metodologias que identificavam como capazes de reconhecer e oferecer respostas aos problemas.

Com os Distritos, era possivel territorializar as diferentes qualidades de problemas. As informações geradas a partir desta ótica poderiam instrumentalizar ações de saúde mais eqüitativas e mais próximas das necessidades distribuídas de forma desigual. "Pretendia-se, portanto, quebrar - círculo vicioso no qual quem tem mais necessidades dispõe de menos serviços, e substituí-lo por um círculo virtuoso, no qual os que apresentam maior vulnerabilidade em relação aos problemas de saúde prioritários são privilegiados pelas equipes que atuam no território. Esse processo foi chamado de discriminação positiva, e seu instrumento técnico foi a microlocalização dos problemas com prioridade em áreas geográficas, cujo residentes são vítimas de iniqüidades sociais e de desigualdades em relação à oferta de serviços de saúde. Em outras palavras, a proposta do Blade Runner era agir como um instrumento capaz de subsidiar o planejamento, a implantação e a avaliação de práticas de vigilância à saúde"s.

A integração intersetorial se tornava imperiosa para trabalhar o enfoque por problemas e o caminhar nessa direção, segundo a interpretação da administração municipal, viria contribuir para a promoção da eqüidade. Quanto à esta última, não havia um conceito a seu respeito com aceitação unânime. Aquela administração empregou o termo simplesmente para caracterizar a busca e a promoção da justiça social. Assim víamos o seu uso.

\footnotetext{
${ }^{5}$ Di Villarosa, F.N.. Greco, C.. Tasca. R.. in: Teixeira, C.F.. Mello, C. (org.) Construindo Distritos Sanitários: a experiência da cooperação italiana no municipio de São Paulo. Hucitec. São PauloSalvador. 1995. p. 48-49. Nesta obra os autores fazem uma análise do trabalho realizado na SMS pela Cooperação Italiana. Durante esse periodo foi muito comum o uso da expressão "vigilância à saúde". como uma prática diferenciada para intervir no perfil de morbimortalidade e nas práticas sanitárias
} 
"A partir de diversos critérios sobre eqüidade, conclui-se que não existe uma única forma de defini-la. Esta vai depender da valoração que se faça sobre a eqüidade em si, bem como em relação aos outros objetivos do sistema de saúde, que são muitas vezes conflitantes"'. Nesta linha, foram sendo pensados meios para organizar as participaçōes dos funcionários, da população e de outros setores, visando a transformar o modo de produzir as ações de saúde, para enfrentar os problemas de saúde, com atribuição compartilhada de responsabilidades, e obter resultados favoráveis às condições de vida e saúde da população. Era sob esta ótica que se entendia, naquele momento, o conceito de vigilância à saúde, cuja definição se baseava nas reflexões de Mendes?, que interpreta a expressão, como intervenção integrada e multisetorial sobre os fatores determinantes dos problemas, sem prescindir das atividades setorizadas e especificamente individualizadas. Deste modo, segundo o mesmo autor, é possível identificar duas práticas sanitárias organizadas sob lógicas distintas, que poderiam ficar abrigadas, ambas, sob o manto do conceito de vigilância à saúde. Uma, multifacetadamente integrada e voltada para a intervenção sobre os problemas de enfrentamento continuo, eleitos no âmbito de distintos grupos populacionais, e outra, de caráter episódico e pontual, voltada para as demandas especificas e individuais, estruturada pela rede multivariada de serviços assistenciais. No caso do setor saúde, esta última pode ser associada ao denominado "atendimento clínico", latu sensu. Do lado da instituição Secretaria da Saúde, com a incorporação da prática da vigilância à saúde, pensava-se ser possivel promover as condições de saúde.

Procuramos fazer desses pressupostos as Questões da Pesquisa, e estudamos a percepção que os atores/sujeitos/agentes de transformação das práticas e do processo de trabalho da Secretaria Municipal da Saúde tiveram dos referidos pressupostos. Entenda-se atores como a equipe de dirigentes, funcionários, usuários e/ou seus representantes, entidades, associações e movimentos populares. Neste estudo deu-se prioridade aos sujeitos/funcionários, aos cidadãos/usuários e aos dirigentes da Secretaria.

Ao final da pesquisa, os resultados alcançados permitem a formulação de um julgamento, ainda que parcial, acerca do modelo teórico de trabalho

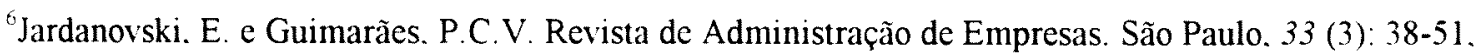
maio/junho 1993, p. 43.

Mendes. E.V. opus cit.
} 
adotado na Secretaria Municipal da Saúde ( SMS ), para a implantação de novas formas de planejar, organizar e gerenciar os serviços da rede municipal de saúde.

As questões da pesquisa são as seguintes:

1. A Secretaria Municipal da Saúde (SMS) procurou trabalhar de forma integrada com outros setores sociais, principalmente as Secretarias Municipais da Educação, do Bem-Estar-Social, da Habitação e das Administrações Regionais.

2. Desde o início, a SMS reconheceu que os problemas fundamentais decorriam das iniquidades, isto é, da injustiça social. Seriam priorizados os grupos sociais mais injustiçados, buscando-se a promoção da eqüidade nas ações de saúde.

3. A SMS reconhecia a necessidade de reformas políticas, sociais e administrativas, visando à descentralização do poder, à participação e ao controle popular. Essas mudanças readeqüariam os serviços com base nas necessidades da população. Acreditando nisso, a SMS regionalizou e distritalizou seus equipamentos, fortalecendo o poder decisório nas bases de sua estrutura

4. A SMS democratizou seu processo gerencial e administrativo, com a criação de 10 Administrações Regionais e 31 Distritos de Saúde. Desse processo participaram os funcionários, os representantes da população, as entidades e os movimentos sociais

5. A SMS entendeu que o modelo médico-assistencial-hospitalocêntrico estava em crise irreversivel, e procurou transformar as práticas sanitárias, no sentido da produção da saúde. Trabalhou para construir um modelo de atenção que priorizasse a vigilância à saúde, isto é, desenvolvesse ações a partir dos problemas e dos fatores que determinam as condições de saúde e não apenas atuasse sobre os efeitos dos agravos à saúde, prática de caráter eminentemente assistencial e curativo.

6. A SMS também reconheceu que as mudanças dependiam da política de pessoal. Houve investimento e valorização dos funcionários, através da 
recuperação salarial e do processo de educação continuada, intensamente desenvolvida em todos os niveis da estrutura.

7. Os servidores e a população organizados participaram do planejamento e das decisões da Secretaria, desde o nivel central até o local. Foram criados o Conselho Municipal da Saúde, os Conselhos Regionais, os Distritais e as Comissões Gestoras das Unidades de Saúde. Nesses quatro anos realizaramse Conferências distritais, regionais e municipais de saúde, todas com caráter deliberativo

\section{MATERIAL E MÉTODO}

\section{IV.1. METODOLOGIA}

Este trabalho adotou uma metodologia híbrida composta por cinco dimensões que se complementam. São elas:

\section{a. estudo descritivo -}

Baseado na descrição das propostas da política de saúde no contexto das políticas sociais da Prefeitura do município de São Paulo no período compreendido entre 1989 e 1992.

Teve início com a coleta, organização e análise dos documentos que foram produzidos no e para o setor saúde desde o início da década de setenta e que deflagraram o movimento pela reforma sanitária no Brasil. Foram utilizadas as principais teses do movimento da reforma sanitária que contribuiram para a definição das Leis Orgânicas da Saúde-Sistema Único de Saúde. Estabeleceram-se relações entre as diretrizes da reforma sanitária e do SUS e as diretrizes da Secretaria Municipal da Saúde.

Como fontes primárias, foram utilizados documentos produzidos por diferentes Secretarias da Administração Municipal, especialmente aquelas que compõem o espectro das áreas sociais, de onde destacam-se as pastas da Saúde, da Educação e da Cultura. A tentativa foi a de analisar a coerência interna e externa das politicas sociais, através da definição das relações entre a política da Secretaria da Saúde e as políticas das outras Secretarias Municipais. Incluíram-se relatórios de encontros, seminários, conferências, atas de reuniões, artigos de jornais, Diários-Oficiais, fotos, videos e outros documentos. 
Neste momento descritivo, foram levantadas as hipóteses ou questões da pesquisa. Estas foram posteriormente analisadas a partir das informações obtidas através das entrevistas de campo.

\section{b. estudo retrospectivo -}

Caracterizado pela tentativa de captar a percepção dos funcionários frente às diretrizes da política municipal de saúde durante a gestão Luiza Erundina.

Nesse caso, o objeto de análise foi o profissional, ou seja, o técnico da Secretaria da Saúde. O objetivo foi analisar o funcionário enquanto agente de transformação ou enquanto ator social, com capacidade para participar da construção de um novo modelo de atenção à saúde e para se manifestar criticamente em relação à política de saúde.

O instrumento utilizado foi um questionário com cerca de doze questões semi-estruturadas ( Anexo l), onde 0 entrevistado pode falar livremente sobre os temas propostos. O questionário viabilizou a sistematização das informações relativas ao periodo de interesse desta investigação, organizando-as em quatro categorias temáticas, estreitamente vinculadas às hipóteses da pesquisa.

Foram entrevistados trinta funcionários, entre os quais dez haviam aderido ao Plano PAS na ocasião da entrevista. As entrevistas desses funcionários foram realizadas em fevereiro de 1997 pois, no período préeleitoral, houve recusa desse segmento em participar da investigação. As entrevistas com os demais funcionários ocorreram entre os meses de agosto $e$ setembro de 1996.

\section{c. estudo transversal -}

O estudo transversal baseou-se num roteiro com cerca de dez questões semi-estruturadas, dirigidas aos cidadãos/usuários dos serviços de saúde do município ( Anexo II). A intenção também foi a de captar a percepção, deste segmento, frente as políticas de saúde, especialmente no periodo relativo à administração Luiza Erundina.

Esta etapa da pesquisa é denominada corte transversal porque, apesar das questões estarem focalizadas principalmente no periodo de governo em questão, os entrevistados se referiram com muita intensidade ao momento atual vivido por eles. Era o "hoje" que interessava. E "este hoje" já estava fora do período do governo Luiza Erundina. As entrevistas com os 
cidadãos/usuários, bem como com os funcionários da Secretaria, ocorreram no periodo imediatamente anterior às eleições municipais, isto é, entre os meses de agosto e setembro de 1996. Por comparação com a situação presente, separamos e utilizamos apenas as referências relativas ao período de interesse desta pesquisa. Da mesma forma que no anexo I, este roteiro de questões permitiu que as informações fossem organizadas e analisadas nas quatro categorias temáticas adotadas para as entrevistas com os funcionários.

Dentre as trinta pessoas entrevistadas nas cinco regiōes da cidade, foram priorizados os moradores das vizinhanças das Unidades de Saúde escolhidas, num raio de aproximadamente 100 metros

Durante o periodo de pré-testes para a aplicação dos questionários, observamos que nem todos os entrevistados haviam utilizado os serviços de saúde durante a gestão Erundina. Muitos deles eram usuários pela primeira vez e, por essa razāo, pouco tinham a dizer sobre aquele periodo de governo. Ainda durante a aplicação dos pré-testes, constatamos que os vizinhos das Unidades, mesmo não sendo usuários, conheciam a história da Unidade e tinham algo a dizer sobre o funcionamento do Serviço. A proximidade de moradia das Unidades de Saúde, de certa forma dava à vizinhança alguma segurança e informações adicionais que faltavam aos não-vizinhos. Daí a preferência por esse grupo.

\section{d. dimensão estratégica -}

Foi operacionalizada a partir de um questionário com nove questões abertas, aplicado especialmente a dirigentes da Secretaria Municipal da Saúde durante a gestão Luiza Erundina, (Anexo III). O interesse dessa investigação foi recuperar a política de trabalho adotada pelo comando da Secretaria, cotejando-a com sua apreensão por parte dos funcionários e dos cidadãos/usuários. A expressão dimensão estratégica foi adotada porque, nesta etapa, o trabalho procurou refletir sobre o caminho percorrido pela Secretaria com o fim de alcançar seus objetivos. A esse primeiro pressuposto, foram acrescentadas outras questões que, no decorrer do tempo, foram progressivamente sendo colocadas para a gerência dos serviços de saúde: Que realidade sanitária era aquela em que se queria intervir? Quais os principais problemas envolvidos naquela realidade? Onde se queria chegar? O que foi feito para superar as barreiras de resistência à implantação de um novo modelo de atenção? A que resultado se chegou? 


\section{e. modelo qualitativo de análise das informações}

Neste projeto foi utilizado um modelo de análise predominantemente qualitativo das informações coletadas através dos instrumentos de pesquisa, mencionados nos anexos I, II e III.

A técnica utilizada para o corte qualitativo foi a da análise de conteúdo de Minayo ${ }^{8}$ para os procedimentos analíticos dos dados coletados, agregada a outros instrumentos de pesquisa qualitativa, desenvolvidos por Simioni ${ }^{9}$. Através desses instrumentais de análise, procuramos confirmar ou não as sete hipóteses de pesquisa apresentadas no item III do projeto, que dizem respeito: ao trabalho intersetorial, à reforma administrativa da Secretaria Municipal da Saúde, à democratização do processo de trabalho, à mudança do modelo de atenção à saúde, ao desenvolvimento de pessoal, à participação e à promoção da eqüidade. Ao mesmo tempo, a metodologia ofereceu a oportunidade de compreender o que existe por trás dos conteúdos manifestos coletados nas entrevistas de campo.

Os instrumentos de coleta das informações ( anexos I, II e III ) sofreram modificações no desenvolvimento do projeto, de modo a adequar-se melhor aos objetivos propostos no periodo que antecedeu a pesquisa de campo. As falas dos funcionários da Secretaria e cidadãos/usuários, foram anotadas no decorrer da própria entrevista. Apenas no caso dos dirigentes foram gravadas em fita magnética e posteriormente transcritas.

\section{IV.2. A EXECUÇÃO DO TRABALHO DE CAMPO}

As estratégias propostas para a execução do trabalho de campo exigiram o apoio de uma equipe de pesquisadores, visto que as entrevistas com os funcionários e com os cidadãos/usuários foram previstas para serem realizadas simultaneamente nas zonas norte, sul, leste, oeste e central da cidade.

Para a coletivização da aplicação da pesquisa de campo, organizamos um treinamento para a equipe de quatro pesquisadores ( o quinto fui eu mesmo ), que constou dos seguintes tópicos:

- apresentação geral do projeto e justificativas

- objetivos

- situação atual dos serviços na área da pesquisa

\footnotetext{
${ }^{8}$ Minayo. M.C.S. (org.) Pesquisa Social: teoria, método e criatividade. Vozes. Petrópolis, 1996. ${ }^{9}$ Simioni. A.M. Dissertação de Mestrado
} 
- hipóteses da pesquisa ( pressupostos )

- metodologias empregadas

- instrumentos de pesquisa ( anexos I, II e III )

- organização estratégica do trabalho de campo

- métodos de análise das informações coletadas

- discussões.

Preparada a equipe, o município de São Paulo foi subdividido em 31 Distritos de Saúde, de acordo com a reforma administrativa da Secretaria Municipal da Saúde ocorrida durante a gestão Luiza Erundina. Os 31 distritos foram redistribuidos pelas cinco grandes zonas da cidade, da seguinte forma:

\section{CENTRO}

1. DS Sé ( Sé, Brás, Pari )

2. DS Bela Vista ( Cambuci, Liberdade, Bela Vista)

3. DS Consolação ( Consolação, República, Santa Cecilia, Barra Funda ) OESTE

4. DS Lapa ( Perdizes, Lapa, V. Leopoldina, Jaguaré, Jaguara )

5. DS Pinheiros (Pinheiros, Alto de Pinheiros, Jardim Paulista, Itaim)

6. DS Butantã ( Butantã, Vila Sônia, Morumbi, Rio Pequeno, Raposo Tavares)

\section{LESTE}

7. DS Mooca (Mooca, Belém, Vila Formosa, Água Rasa)

8. DS Vila Prudente (V.Prudente, São Lucas)

9. DS Vila Matilde ( Vila Matilde, Penha, Cangaíba)

10. DS Tatuapé ( Tatuapé, Carrão, Vila Prudente, São Lucas)

11. DS Itaquera ( Itaquera, José Bonifácio, Parque do Carmo)

12. DS Carmosina (Arthur Alvim, Cidade Lider)

13. DS São Matheus ( São Matheus, Iguatemi, São Rafael)

14. DS Sapopemba ( sapopemba, Aricanduva)

15. DS Guaianazes ( Guaianazes, Lajeado, Cidade Tiradentes)

16. DS São Miguel ( São Miguel Paulista, Vila Curuçá)

17. DS Itaim Paulista (Itaim Paulista, Jardim Helena)

18. DS Ermelino Matarazzo ( E. Matarazzo, Vila Jacuí, Ponte Rasa)

\section{NORTE}

19. DS Vila Maria ( Vila Maria. Vila Guilherme)

20. DS Jaçanã ( Jaçana, Vila Medeiros)

21. DS Freguesia do Ó (Freguesia do Ó, Limão, Casa Verde) 
22. DS Santana ( Santana, Mandaqui, Tucuruvi, Tremembé)

23. DS Brasilândia (Brasilândia, Vila Nova Cachoeirinha)

24. DS Pirituba ( Pirituba, Parque São Domingos)

25. DS Perus ( Perus, Anhanguera, Jaraguá)

\section{SUL}

26. DS Jabaquara ( Jabaquara, Campo Belo, Cidade Ademar)

27. DS Ipiranga ( Ipiranga, Sacomã, V. Mariana, Saúde, Cursino, Moema)

28. DS Pedreira (Pedreira, Santo Amaro, Campo Grande)

29. DS Grajaú ( Grajaú, Cidade Dutra, Capela do Socorro)

30. DS Campo Limpo (Campo Limpo, Vila Andrade)

31. DS M'Boi Mirim (M'Boi Mirim, Capão Redondo, Jd.S. Luís, Jd.Angela)

Foram sorteados cinco Distritos de Saúde, um para cada zona da cidade. O sorteio se realizou na sala de reuniōes do Departamento de Saúde Materno-Infantil da Faculdade de Saúde Pública da USP, com a presença da equipe de pesquisadores de campo. Estavam presentes Ana Paula França, Vera Lúcia Machado, José Paulo Pires Perestrelo e Andrea Felicissimo. Os distritos sorteados foram os seguintes:

- zona norte: Distrito de Saúde de Santana.

- zona sul: Distrito de Saúde do Ipiranga.

- zona leste: Distrito de Saúde de São Miguel Paulista.

- zona oeste: Distrito de Saúde de Pinheiros.

- zona central: Distrito de Saúde da Consolação.

Para cada um dos Distritos de saúde sorteados, indicamos uma Unidade de Saúde indice, a partir da qual seriam realizadas as entrevistas junto aos funcionários e cidadãos/usuários. Após a indicação da Unidadeindice, a relação DS/Unidade ficou com a seguinte correspondência:

a) zona norte: D.S. de Santana- unidade índice: UBS Joaquim Antonio Eirado, avenida Braz Leme, 2945, Fone 298-0733.

b) zona sul: D.S. do Ipiranga- unidade índice: UBS Água Funda, rua Rosa de Morais, 91, fone 275-6253.

c) zona leste: D.S. de São Miguel Paulista- unidade índice: Hospital Tide Setúbal, rua Dr. José Guilherme Eiras, 123, fone 297-0022.

d) zona oeste: D.S. de Pinheiros- unidade índice: UBS Dr. Manoel Joaquim Pera, rua Purpurina, 280, fone 210-9891. 
e) zona central: D.S. da Consolação- unidade índice: Pronto Socorro Municipal "Álvaro Dino de Almeida", rua Vitorino Carmilo, 717, fone 8265666 .

Sentimos uma certa frustração com o resultado do sorteio dos Distritos. Nossa expectativa era de um conjunto que contemplasse mais a periferia do municipio, pois temos consciência de que os cinco Distritos sorteados sugerem uma certa "centralidade da amostra".

Ao redor da unidade de saúde-índice por nós escolhida foram realizadas 6 entrevistas junto aos cidadãos/usuários, de modo que, ao todo, foram entrevistadas 30 pessoas, considerando-se os 5 Distritos Sanitários. Prioritariamente foram convidados os moradores vizinhos das Unidades de Saúde, pelas razões anteriormente mencionadas. Havendo recusa, convidouse o cidadão/usuário mais próximo, até um raio aproximado de 100 metros da Unidade escolhida. Também foram convidados a participar da entrevista alguns usuários presentes no momento da aplicação do questionário.

A partir da definição das 5 unidades-índice, todas pertencentes ao Plano de Assistência à Saúde - PAS ${ }^{10}$ - identificamos outras 5 Unidades de Saúde, estas não pertencentes ao PAS e, portanto, subordinadas à administração direta da Secretaria Municipal da Saúde e compostas apenas por funcionários públicos municipais, ou seja, integrantes do Quadro do Pessoal da Saúde. Estas Unidades apresentam uma situação diferente das Unidades do PAS, onde também trabalham profissionais que não pertencem ao quadro de servidores públicos municipais.

O critério para a identificação destas 5 Unidades foi geográfico, isto é, a Unidade localizada na menor distância da Unidade inicialmente escolhida como índice. A partir deste critério, as Unidades de Saúde municipais não integradas ao plano PAS foram as seguintes:

- zona norte: Centro de Referência DST/AIDS, rua Dr. Luís Lustosa da Silva, 339, Santana.

- zona sul: Centro de Referência DST/AIDS, avenida Ceci, 2235, fone 2769719

\footnotetext{
"Na data do sorteio a quase totalidade das Unidades de Saúde da Prefeitura pertencia ao PAS. ficando de fora os poucos Centros de Referência de Saúde do Trabalhador e os Centros de Referencia DST/AIDS, estes, ainda em fase de implantação.
} 
- zona leste: Centro de Referência DST/AIDS, rua Médio Iguaçú, 86, fone 2050255, Cidade Lider.

- zona oeste: COA Lapa, rua Cerro Corá, 309, fone 62-0792, Vila Ipojuca.

- zona central: Centro de Referência DSTIAIDS, alameda Cleveland, 374, fone 222-3066, Campos Eliseos.

Identificados os dois tipos de Unidades, as do PAS e as nãopertencentes ao PAS, teve início a pesquisa de campo, realizada através das entrevistas junto aos funcionários e aos cidadãos/usuário.

- Entrevistas junto aos funcionários ( aplicação do Anexo I ):

As entrevistas com os servidores municipais, num total de 30 , foram realizadas junto aqueles que aderiram ao PAS e junto aos funcionários que não aderiram ao PAS, na proporção de 66,6 \% para este grupo e 33,3 \% para os primeiros. Ou seja, realizamos vinte entrevistas junto aos funcionários municipais que não aderiram ao PAS e, considerando-se a referida "centralidade da amostra", optamos por realizar 6 entrevistas no DS de São Miguel, 3 no DS da Consolação, 3 no DS de Pinheiros, 4 em Santana e 4 no Ipiranga. Por fim, realizamos dez entrevistas junto aos servidores que fizeram adesão ao plano PAS, duas em cada uma das Unidades escolhidas como unidade-índice.

Das trinta entrevistas realizadas nas cinco zonas da cidade, cerca de $60 \%$ foram aplicadas junto a funcionários de nivel universitário e cerca de $40 \%$ junto a funcionários não universitários. Todas foram aplicadas entre categorias funcionais distintas. Entre os universitários, por exemplo, escolhemos um médico, um enfermeiro e um assistente social. Entre os não universitários, optamos por um auxiliar administrativo, um auxiliar de enfermagem e um contínuo porteiro. O entrevistador, por não conhecer qualquer um dos funcionários que iria entrevistar, assim que entrava na Unidade, convidava aleatoriamente o primeiro funcionário que encontrasse para participar da entrevista e, na recusa deste, convidava o próximo. Uma vez entrevistado um médico, por exemplo, mudava-se de categoria universitária, seguindo o mesmo raciocínio anterior, até completar o total previsto. Este procedimento não se realizou junto aos funcionários do PAS pois, neste caso, não pudemos tomar a iniciativa de convidar o entrevistado. As entrevistas com este grupo ocorreram apenas meses depois da data prevista. Inicialmente as chefias das unidades alegaram que precisariam da 
autorização do nível central da Secretaria. Consultado o Gabinete da Secretaria, houve demora para o atendimento do pedido. Somente em fevereiro de 1997 fomos autorizados para procurar as Unidades de Saúde. Para sermos atendidos, tivemos que deixar os questionários com antecedência e aguardar a definição das datas das entrevistas. Ao retornar finalmente às Unidades, já havia dois funcionários previamente escolhidos pelas Chefias para responder as perguntas. Das dez entrevistas realizadas entre os funcionários do PAS, três foram com funcionários que estavam na Secretaria há 3 anos e duas com funcionários com 1 ano de Prefeitura. Portanto, cinco entrevistas foram realizadas com funcionários que não trabalharam na Secretaria da Saúde durante o governo Luiza Erundina. Diante das circunstâncias expostas, e na falta de outra opção, estas entrevistas também foram consideradas, com exceção de uma delas.

Assim, as entrevistas realizadas junto aos funcionários públicos que não aderiram ao PAS ocorreram entre setembro e outubro de 1996.

Quando estávamos preparando o roteiro de entrevistas no início do ano, não imaginávamos que o PAS fosse implantado do modo como foi. Desta forma, a radical mudança da SMS provocou ressentimentos em grande parte do funcionalismo, que transpareceram durante as entrevistas, realizadas imediatamente após a implantação do plano.

As entrevistas realizadas junto aos integrantes do PAS aconteceram durante os meses de fevereiro e março de 1997, uma vez que no período anterior, não conseguimos autorização para a realização das mesmas.

\section{- Entrevistas junto a cidadãos/usuários ( aplicação do Anexo II )}

Nas cercanias de cada Unidade de Saúde-índice, foram realizadas de cinco a sete entrevistas com cidadãos/usuários, preferencialmente entre os moradores da vizinhança, perfazendo um total de trinta entrevistas. Elas também foram aplicadas entre setembro e outubro de 1996.

- Entrevistas junto a dirigentes ( aplicação do Anexo III )

As entrevistas com os dirigentes da gestão 89-92 foram gravadas em fitas magnéticas, perfizeram um total de sete. Dos entrevistados, 6 ocuparam cargos no Gabinete da Secretaria e 1 exerceu sua função a nível regional. As 
principais razões que nos levaram a escolher esses dirigentes foram as seguintes:

Eduardo Jorge Martins Alves Sobrinho ocupou a função de Secretário Municipal da Saúde durante os primeiros quinze meses da administração. Seu papel foi fundamental e decisivo para a concepção e condução da reforma administrativa e das diretrizes políticas da Secretaria da Saúde durante todos os quatro anos de administração. Levou-se em consideração, também, todo o trabalho que ele desenvolve no setor saúde no Brasil, em sua história de cidadão, médico sanitarista, deputado estadual e deputado federal. No final da década de 70, como médico sanitarista, participou ativamente do movimento popular de saúde da Zona Leste da capital paulista, que contribuiu para o fortalecimento de outros movimentos populares por melhores condições de vida e saúde em outras regiões do município de São Paulo e fora dele. Como deputado federal, sua presença na Câmara dos Deputados foi decisiva para a incorporação, no texto constitucional, das principais teses defendidas pelo Movimento da Reforma Sanitária Brasileira.

Carlos Alberto Pletz Neder, como médico sanitarista, teve grande participação na organização do movimento popular de saúde da zona leste, desde fins da década de 70. Assumiu a Chefia de Gabinete da Prefeita Luiza Erundina até abril de 1990, quando sucedeu Eduardo Jorge, tornando-se o principal responsável pela implementação do SUS, na única tentativa havida até hoje no município. Exerceu as funções de Secretário Municipal da Saúde até dezembro de 92. Atualmente é vereador da cidade de São Paulo, pelo Partido dos Trabalhadores.

Pedro Dimitrov, foi Chefe da Assessoria Técnica e Chefe de Gabinete da Secretaria Municipal da Saúde durante os quatro anos do governo Luiza Erundina. Como Chefe da Assessoria Técnica, teve um papel determinante na concepção, definição das diretrizes estratégicas e implementação da política municipal de saúde. Foi um dos ideólogos e defensores da regionalização e distritalização de todo o município e do modelo administrativo e gerencial adotado pela Secretaria. Sua contribuição teve como alicerce não apenas sua formação técnico-política, mas também a vasta experiência administrativa no campo das práticas da saúde pública, adquirida durante anos de trabalho na Secretaria de Estado da Saúde de São Paulo. 
Álvaro Escrivão Júnior, foi diretor do CEPI - Centro de Epidemiologia Pesquisa e Informação - órgão de assessoria do Gabinete da Secretaria, e pode ser considerado um dos principais responsáveis pela renovação da tipologia e fluxo das informações na rede municipal de saúde. Álvaro foi um dos dirigentes que mais se empenhou e estimulou o uso cotidiano das informações para o planejamento em saúde, contribuindo para que as informações fossem incorporadas no cotidiano, norteando as decisōes da Secretaria. Daí a importância de seu trabalho para os rumos e o grau de organização que alcançou o Sistema Municipal de Informações em Saúde.

Paulo Eduardo Eduardo Mangeon Elias, desempenhou papel técnico e político junto à Secretaria da Saúde, por representá-la, como assessor parlamentar junto a Câmara Municipal de São Paulo. Foi o grande responsável pelo esclarecimento e convencimento do poder legislativo sobre a importância dos projetos e políticas municipais de saúde implementadas no período. Seu trabalho foi de extrema eficácia pois, a Secretaria conseguiu ter seus projetos reconhecidos e aprovados pela Câmara de Vereadores.

Virgínia Junqueira, teve papel de destaque na Secretaria, ocupando função de coordenadora do COAS - Centro de Organização da Atenção à Saúde. O COAS abrigava um conjunto de profissionais de saúde de formações distintas, cujo papel era o de assessorar e acompanhar as políticas e programações específicas nos niveis regional e distrital. Havia profissionais voltados para a saúde mental, saúde bucal, saúde do escolar, do adolescente, da mulher, dos idosos, do trabalhador e outras áreas. Constituído por um conjunto de profissionais portadores de conhecimentos especificos, que deveriam divulgar suas idéias e pensamentos, o COAS acompanhava e assegurava o desenvolvimento das programações de saúde na rede de serviços. Representou, juntamente com a Coordenação dos Recursos Humanos e o Centro de Epidemiologia Pesquisa e Informação, a principal assessoria do Gabinete da Secretaria Municipal da Saúde.

Alexandre Nemes Filho foi Diretor da Administração Regional de Saúde-2Butantã, ARS-2. Assumiu suas funções na Secretaria Municipal de Saúde, depois de ter exercido relevante papel na Secretaria de Estado da Saúde. Trouxe ao município uma enorme experiência no campo da saúde coletiva. Nas decisões do Conselho Técnico Administrativo da Secretaria, sempre teve 
posições equilibradas, vendo os problemas da administração como um todo e nunca se colocando exclusivamente em defesa dos interesses da Regional de Saúde que representava. Penso que ele sintetiza o que se esperava de um Diretor de ARS.

\section{IV.3. ANÁLISE DAS INFORMAÇÕES COLETADAS:}

\section{IV.3.1. Relativas aos anexos I e II}

a) Organização e sistematização das informações obtidas através dos questionários:

Foi a fase inicial, de pré-análise, onde se fez a primeira leitura do material coletado para conhecer sua estrutura e descobrir orientações para as análises subseqüentes.

\section{b) Classificação e exploração das informações:}

Com base em leituras repetidas dos questionários, selecionei o que havia de relevante relacionado ao governo Luiza Erundina e organizei o material em quatro categorias temáticas. Com esse objetivo, procurei agrupar elementos, idéias, expressões ou sentimentos manifestos dos entrevistados, de modo a contemplar as sete hipóteses ou questões da pesquisa.

As categorias temáticas organizadas foram as seguintes:

1. Trabalho integrado da Secretaria com outros setores sociais.

2. Mudança de modelo de atenção/ novas programações.

3. Democratização, participação social, descentralização gerencial e administrativa.

4. Valorização e desenvolvimento de pessoal.

Os questionários ( anexos I, II e III ) foram organizados de modo que o entrevistado tivesse oportunidade de voltar a manifestar suas idéias à respeito das hipóteses da pesquisa em mais de uma questão. Assim, as categorias temáticas foram referendadas em várias questões, a saber:

- A categoria trabalho integrado da Secretaria com outros setores sociais foi construída, em relação ao anexo I, a partir da reunião da questão número 5 , item 5, e das questões números 8,9 e 10, ficando com a seguinte composição:

questão 5. Leia Atentamente e Fale Livremente Sobre o Texto Abaixo : 
Cada Administração Municipal que vem procura imprimir sua visão de organização de serviços de saúde. Assim, algumas privilegiam a assistência médica, outras enfatizam o trabalho multiprofissional. Algumas administrações valorizam seu pessoal e estimulam o trabalho intersetorial, outras, têm posturas radicalmente opostas. Fale como você vê (ou viu ) o trabalho na SMS enquanto um (a) funcionário (a) com respeito a :

- trabalho integrado com outros setores sociais;

questão 8. Você já desenvolveu trabalhos de saúde fora de sua Unidade de Saúde, junto a movimentos sociais, entidades, associações, etc., etc..

a)não sim quando

questão 9.Você trabalha ou já trabalhou integradamente com outras secretarias? Em que local?

a)não sim quando explique

Se você respondeu sim às 2 questões anteriores, responda a questão 10 .

10. Na sua opinião, qual foi o resultado deste trabalho de integração?

A mesma categoria, em relação ao anexo II, foi organizada a partir das respostas à questão número 5. Dessa forma, temos a seguinte composição: questão 5. Leia atentamente e comente o texto abaixo :

"Alguns prefeitos e seus auxiliares, procuraram integrar os trabalhos de algumas Secretarias como Saúde, Educação (escolas) e Bem-Estar-Social (creches). Nestas ocasiões, o pessoal da Secretaria da Saúde pensava que os principais problemas de saúde eram decorrentes das condições de vida das pessoas e por isso, procurou dar mais atenção aos mais necessitados. Ao mesmo tempo, a Secretaria da Saúde estimulou a participação dos funcionários e da população nas tomadas de decisão. Valorizou o seu pessoal, pagando melhores salários. Melhorou a qualidade da assistência, enfatizando a medicina preventiva."

Fale se alguma vez você percebeu esse tipo de conduta da Prefeitura e da Secretaria Municipal da Saúde. E em qual governo esse modo de governar aconteceu mais.

- A categoria temática mudança de modelo de atenção/novas programações foi construida, em relação ao anexo 1 , a partir da reunião da questão número 5 , item 3, questão 6 , questão 7 , itens a e $b$, e das questões de número 13 e 14. Desta forma a organização é a seguinte: questão 5 , item 3 - mudança do modelo de atenção à saúde; Questão 6. Ao se falar em mudanças, pensa-se 
em sair de uma situação em direção à outra. Se você sentiu mudanças em algum governo municipal, fale sobre elas. Fale sobre suas reações, seus sentimentos frente as mudanças que aconteceram na Secretaria da Saúde. Questão 7. Discorrer sobre:
a ) noção de novo ou moderno a partir da administração municipal de 1989.
b) práticas de saúde.

Questão 13. Você já ouviu falar de Hospital Aberto ( sim, não ), Política Antimanicomial

( sim, não ), Hospitais-Dia ( sim, não ), Centros de Referência de Saúde do Trabalhador ( sim, não ), Centros de Convivência e Cooperativa ( sim, não ) ? Disserte sobre cada um dos pontos relacionados.

Questão 14.Descrever porque os serviços melhoraram ou pioraram

A mesma categoria em relação ao anexo II, dirigido aos cidadãos/usuários, foi organizada a partir da reunião das questões de número 2, 3, 8 e 9. Desta forma, a organização é a seguinte: questão 2.Pelo que o Sr.(Sra.) tem ouvido falar, ou pelo que sabe, houve mudanças na qualidade dos serviços de saúde da Prefeitura?
a) houve mudanças para melhor
b) houve mudanças para pior
c) não houve mudanças
d) não sei informar
e) explique

Questão 3. Está havendo empenho ou preocupação da Prefeitura em melhorar os serviços de saúde do município?
a) está havendo muito empenho
b) está havendo pouco empenho
c) não está havendo empenho
d) não sei
e) explicar porque está havendo ou não empenho

Questão 8. Você já ouviu falar de Hospital Aberto (sim, não), Política Antimanicomial, quer dizer, desospitalização dos doentes mentais, (sim, não), Hospitais-Dia (sim, não), Centros de Convivência e Cooperativa (sim, não) ? Comentar cada um dos temas. Questão 9. Descrever porque os serviços de saúde melhoraram ou pioraram.

- A categoria temática democratização, participação social, descentralização
gerencial e administrativa foi construída, em relação ao anexo I, a partir da 
questão número 5 , itens 1,2 e 4 , da questão 7 , itens $f$ e g, e da questão número 12. Deste modo, temos o que se segue: questão 5 , itens democratização do processo de trabalho, - tomada de decisões, aperfeiçoamento dos procedimentos gerenciais e administrativos; Questão 7. Discorrer sobre: f ) cidadania (direito à saúde), g) participação elou controle social. Questão 12. Desde que você trabalha, alguma vez percebeu movimentação da Secretaria, no sentido da descentralização administrativa?
a) não
b) $\sin$
c) quando
d) explique

Em relação ao anexo II, esta categoria foi organizada a partir das questões de número 4, 5, 6 e 7 . Deste modo, temos o que se segue:

questão 4.Voce se lembra da Prefeitura ter criado condições para que os cidadãos/usuários e/ou funcionários e/ou entidades representativas pudessem participar dos processos decisórios e do planejamento da Secretaria da Saúde? ( Dar exemplos das Comissões Gestoras, Conselhos de Saúde ou Conselho Municipal de Saúde na época da administração Luiza Erundina ).
a) não me lembro
b) sim, me lembro
c) quando
d) explique

questão 6. Fale sobre participação popular na Secretaria da Saúde. ( Se a pessoa falar em democracia, pergunte o que ela representa ). Procure caracterizar o período, isto é, em qual governo que mais ocorreu a participação.

questão 7. Fale sobre direito à saúde. Isto lhe diz respeito? ( Se a pessoa falar em cidadania, peça para ela falar sobre o que pensa sobre isso).

- A categoria temática valorização e desenvolvimento de pessoal foi construída, em relação ao anexo I, a partir da reunião das questões de número 5 , item 6 e, 7 , itens d, e. Não se organizou esta categoria em relação ao anexo II. Eis a organização: questão 5, item - valorização do pessoal. Questão 7, item d ) consciência sanitária, item e ) desenvolvimento profissional

c) esquema de análise das informações 
Para cada uma das categorias temáticas, os discursos foram transcritos literal e integralmente a partir da fala de cada um dos entrevistados. Nosso interesse central foi captar a percepção que funcionários e cidadãos/usuários tiveram da gestão Luiza Erundina no setor saúde. Com o intuito de organizar e sistematizar as informações coletadas, escolhemos o procedimento metodológico desenvolvido por Simioni, que se baseia em quatro figuras de análise: as expressões-chave, a idéia-central, a ancoragem e o discurso do sujeito coletivo. Segundo a autora da metodologia, as expressões- chave representam a totalidade do discurso do entrevistado; a idéia-central, a síntese de suas expressões-chave; a ancoragem representa as teorias, os pressupostos, as idéias que sustentam o referido discurso e, quanto ao discurso do sujeito coletivo,..."consiste na reunião, num só discurso-síntese, de vários discursos individuais emitidos como resposta a uma mesma questão de pesquisa, por sujeitos social e institucionalmente equivalentes ou que fazem parte de uma mesma cultura organizacional e de um grupo social homogêneo na medida em que os indivíduos que fazem parte deste grupo ocupam a mesma ou posições vizinhas num dado campo social", Simioni" ${ }^{11}$. Com base nos procedimentos adotados, pudemos compreender o sentido das manifestações dos funcionários e cidadãos/usuários e, confrontando-os com a estratégia da administração municipal, refletir sobre os pressupostos da pesquisa, confirmando-os ou não.

Desta forma, através de cada uma das categorias temáticas buscou-se a construção de um ou mais discursos do sujeito coletivo ( DSC ). A título de exemplos, vamos tomar como modelo uma categoria temática - Mudança de Modelo de Atenção - para conhecer as trilhas percorridas para se chegar à construção do discurso do sujeito coletivo. Como mencionei anteriormente, as entrevistas com funcionários e cidadãos/usuários foram anotadas, e não gravadas em fita. Passo à organização por tópicos, para exemplificar o procedimento adotado. Quando selecionei as idéias principais do entrevistado, aglutinando-as para obter um discurso mais sintético e preciso, redigi as informações de forma livre, cuidando, entretanto, de me manter fiel aos depoimentos. Sempre que possível, transcrevo excertos das próprias entrevistas, mantendo as aspas para caracterizar a citação.

\section{a) nutricionista, 6 anos de funcionalismo expressões-chave:}

\footnotetext{
${ }^{11}$ Sinioni. A.M. opus cit.
} 
A funcionária considera que a partir de 1989 surgiu uma nova forma de gerenciamento, comprometido em definir a área de atuação da Unidade e, em identificar as áreas de risco. "Na administração passada o trabalho não era só dentro do Posto, mas nas áreas de risco. Havia um trabalho extensivo com a comunidade, com atividades preventivas sobre DST/AIDS e gravidez na adolescência. Hoje os trabalhos estão totalmente diferentes. O PAS foi uma mudança radical, brusca, deixando os funcionários revoltados. Desabou uma estrutura que funcionava. É incompetência administrativa".

\section{idéia central -}

A idéia central da funcionária é que a partir de 89 , surge uma nova forma de gerenciamento, com identificação da área de atuação da Unidade e das áreas de risco.

\section{ancoragem -}

O que sustenta o discurso da funcionária é a concepção de que, a partir de 1989, surgiu uma nova forma de gerenciamento, comprometido em definir a área de atuação da Unidade e em identificar as áreas de risco.

\section{b) enfermeira, 13 anos de funcionalismo}

\section{expressões-chave}

A funcionária julga que durante a administração anterior havia trabalhos educativos e preventivos nas escolas. Na Unidade, se fazia a avaliação do crescimento e do desenvolvimento das crianças por meio de gráficos. Depois de fornecido o leite, por exemplo, discutia-se com as mães a situação das crianças e a importância de outros alimentos para o seu crescimento. "A administração atual cortou tudo pela raiz, como se fosse um arrastão na saúde, sem a preocupação com nada, como se nada tivesse existido. Muitos colegas foram mandados para outras Secretarias. Estão em escolas, creches, parques, em desvio de função".

\section{idéia central}

A idéia central do discurso da funcionária é a de que, entre 1989-92, trabalhos educativos e preventivos foram realizados junto à população e às escolas.

\section{ancorarem}

A funcionária acredita que durante a administração anterior havia preocupação em promover a saúde por meio da aplicação de medidas de caráter preventivo, realizadas tanto no interior da UBS como em outros equipamentos, escolas, por exemplo. 


\section{c) administrativo, 6 anos de funcionalismo}

\section{expressões-chave}

O funcionário considera que na administração Luiza Erundina havia mais profissionais trabalhando. Os representantes da população participavam das decisões sobre como o trabalho deveria ser, durante as reuniões do Conselho de Saúde. "Tinha reuniões de grupo, trabalhos preventivos e educativos com a população. Começou o Curso Larga-Escala, para a formação de auxiliar de enfermagem. Para melhorar o atendimento. Agora tudo mudou, tem menos gente trabalhando. Separação das pessoas e deslocamento do lugar de trabalho. Estamos jogados e sem saber o que vai acontecer".

\section{idéia central}

A idéia central da entrevista é a de que, no governo Erundina havia participação social e desenvolvimento de pessoal.

\section{ancoragem}

O funcionário acredita que representantes da população participavam das decisões sobre como o trabalho deveria ser, durante as reuniões do Conselho de Saúde, e também através de reuniões de grupo, trabalhos preventivos e educativos com a população.

\section{d) auxiliar de enfermagem, 5 anos de funcionalismo}

\section{expressões-chave}

"A administração anterior pecou por dar muita liberdade ao pessoal. Foi melhor em relação aos cuidados e qualidade da assistência aos pacientes. Principalmente aos mais carentes e aos portadores de doenças como a AIDS, que precisam de cuidados especiais. O que eu aprendi eu mantenho. A administração atual foi restritiva demais. Reduziu os salários e provocou a demissão de pessoal".

\section{idéia-central}

O funcionário acredita que na administração anterior havia mais cuidado com o paciente.

\section{ancoragem}

"A administração anterior pecou por dar muita liberdade ao pessoal. Foi melhor em relação aos cuidados e qualidade da assistência aos pacientes". 
O mesmo procedimento foi utilizado com todas as entrevistas, organizadas uma a uma até o último funcionário entrevistado, isto é, até o sujeito 0 .

\section{O próximo passo foi agregar as ancoragens.}

Nesta categoria temática, as ancoragens foram agrupadas em quatro subtipos, em função da proximidade dos conteúdos dos discursos de determinados grupos de funcionários. Os quatro subtipos identificados são: modelo de atenção \& ações preventivas e programáticas ( agregado de ancoragens dos sujeitos b, d, e, o ), modelo de atenção \& "oficinas italianas" ( agregado de ancoragens dos sujeitos $a, h, j, k, l, n)$, modelo de atenção \& condições de vida e saúde ( sujeitos c, f, m ), modelo de atenção \& estrutura administrativa da Secretaria ( sujeitos g, i ). Tomemos como exemplo apenas o primeiro subtipo:

primeiro subtipo - modelo de atenção \& ações preventivas e programáticas ( agregado de ancoragens dos sujeitos $b, d, e, o$ ):

Inicialmente as ancoragens foram reunidas com citação do discurso dos entrevistados:

sujeito $b$, "durante a administração anterior havia trabalhos educativos $\mathrm{e}$ preventivos nas escolas. Na Unidade, avaliação do crescimento e desenvolvimento das crianças por meio de gráficos"; sujeito o, "tinha mais ações educativas e preventivas, também fora da Unidade"; sujeito $d$, "a administração anterior pecou por dar muita liberdade ao pessoal. Foi melhor em relação aos cuidados e qualidade da assistência aos pacientes"; sujeito e, "com o tempo os serviços foram se desorganizando. Eu tenho uma sensação estranha, porque em muitos lugares continuaram as mesmas pessoas que antes, só que desestimuladas, que acham que não vale mais a pena. É uma sensação de perda, de derrota".

Esta metodologia ofereceu a oportunidade de refletir sobre o que está por trás dos conteúdos manifestos pelos entrevistados. Por isso, a partir das ancoragens expressas pelos próprios discursos dos funcionários, construimos outras, desta vez com nossa leitura, feita a partir de nossa visão dos problemas, tentando descobrir o que está por trás da fala de cada sujeito individual. Assim, procuramos interpretar, traduzir o que se esconde por trás dos conteúdos manifestos nas entrevistas dos funcionários. 
sujeito b) A idéia que sustenta esse discurso é a da importância e do valor das ações programáticas em saúde e a da aplicação de medidas de caráter preventivo, especialmente aquelas voltadas para a prevenção primária ( promoção das condições de vida e saúde e proteção específica). A funcionária alicerça seu discurso no exemplo do acompanhamento do desenvolvimento da criança, por meio de gráficos e educação alimentar para os pais. Mostra seu descontentamento com a mudança da administração.

sujeito d) A administração do governo Erundina passou ao servidor uma imagem de maior cuidado no trato dos pacientes, especialmente aqueles que requerem tratamentos especiais, como os mais carentes ou portadores de doenças como a AIDS. Esta imagem de cuidar melhor, de ser mais acolhedora com os usuários dos serviços, pode ligar-se à grande ênfase dada à questão do corpo de funcionários. A administração procurou melhorar a qualidade da assistência, por meio da admissão de grande número de servidores, melhoria salarial e pelo investimento em sua formação e seu desenvolvimento profissional.

sujeito e) a entrevista revela preocupação em reorganizar a rede de serviços de saúde, de modo a apresentar respostas de atendimento integral ao usuário. O funcionário acredita nas programações de saúde como um meio de recuperação da doença e de proteção dos agravos à saúde, através de ações educativas e preventivas. Os serviços anteriores desenvolviam desta forma os seus programas de saúde, com atividades de pré-consulta, consulta, pósconsulta e visitas domiciliárias. Segundo o entrevistado, este era o modelo de atenção ideal, pois foi assim que the ensinaram na faculdade. Toda esta situação desmorona na atual administração, provocando no funcionário um sentimento de perda e de fraqueza, pela incapacidade em impedir que isso viesse a acontecer.

sujeito o) o funcionário entende que o modelo de atenção da administração anterior, baseado na prevenção e aberto à participação social, promove as condições de saúde. Findo esse período administrativo, reforça-se o modelo que prioriza as medidas curativas.

Por fim, fizemos a sintese de nossas leituras das ancoragens, com a finalidade de construir um padrão de Discurso do Sujeito Coletivo.

Sintese:

Ficou na percepção desse grupo de servidores a nítida preocupação da Secretaria do governo Luiza Erundina em organizar a rede de serviços de 
saúde de modo a apresentar respostas com atendimento integral, baseadas em ações programáticas de saúde. Essas ações incluiriam os níveis de aplicação de medidas preventivas, desde a promoção da saúde até a reabilitação do cidadão.

\section{A construção do Discurso do Sujeito Coletivo}

Uma vez sintetizadas as percepções dos funcionários e cidadãos/usuários foram construídos os discursos dos sujeitos coletivos.

\section{IV.3.2. Análises relativas ao anexo III}

Uma vez transcritas todas as entrevistas gravadas em fitas magnéticas, as expressões-chave de todos os dirigentes foram agregadas, segundo a temática abordada e de acordo com o roteiro que consta do anexo III. Desse agregado de expressões-chave ( ou discursos ) por tema, foram extraídas as idéias-centrais. A partir das Idéias-centrais, realizamos as sinteses dos discursos, com o intuito de cotejá-las com as percepções dos cidadãos/usuários e funcionários. Assim, os procedimentos de análise de discurso dos dirigentes foram diferentes em relação aos anexos I e II.

\section{IV.3.3. O confronto entre as percepções dos funcionários e cidadãos/usuários e a política municipal de saúde.}

Com o produto das percepções (as ancoragens) dos funcionários e cidadãos/usuários, construímos um quadro-síntese, com os discursos dos sujeitos coletivos organizados por categoria temática, no seguinte molde:

\begin{tabular}{|l|l|l|l|}
\hline Categorias Temáticas & funcionários & PAS & cidadãos/usuários \\
\hline $\begin{array}{l}\text { 1. mudança de modelo de } \\
\text { atenção à saúde }\end{array}$ & & & \\
\hline 2. democratização/ participação & & & \\
\hline 3. trabalho integrado & & & \\
\hline $\begin{array}{l}\text { 4. desenvolvimento e valorização } \\
\text { do pessoal. }\end{array}$ & & & \\
\hline
\end{tabular}

Desta forma, procuramos aproximar todos os discursos e proceder às reflexões sobre as transformações dadas pelos sujeitos envolvidos com a questão saúde na esfera do município de São Paulo. O confronto foi 
estabelecido entre as idéias-centrais dos dirigentes com as ancoragens dos cidadãos/usuários e dos funcionários.

A seguir, do embate entre os diferentes discursos ( dos dirigentes, dos funcionários e dos cidadãos/usuários ), procuramos refletir sobre a reforma administrativa e a política de saúde, o modelo de planejamento e a integração intersetorial, a participação social, as oficinas de trabalho, o modelo de atenção e a promoção da eqüidade. Na medida do possivel, arriscamos algumas respostas às indagações a respeito da realidade sobre a qual se pretendia intervir, os principais problemas detectados (do meio, do setor e do governo ), aonde se queria chegar, às medidas para a mudança do modelo de atenção.

\section{IV.3.4. As conclusões}




\section{CAPÍTULO II}

Secretaria da Saúde no contexto do governo municipal

\section{O GOVERNO MUNICIPAL}

Ao assumir a administração municipal de São Paulo em 1989, o governo Luiza Erundina estava determinado a contribuir para o processo de redemocratização do país, deflagrado no início da década. Procurou demonstrar isso desde o começo da gestão, ao propor a imediata descentralização administrativa, a recuperação do aparelho de Estado e a criação de mecanismos de participação social direta. O novo governo se apresentou como contraponto à política deflagrada poucos anos antes que vinha provocando o encolhimento, o esvaziamento e o distanciamento do Estado frente às crescentes e graves demandas sociais. Segundo Meirelles ${ }^{12}$, administração são os procedimentos que o Estado pratica para operacionalizar as opções políticas do governo, visando atender as necessidades da população.

O governo Luiza Erundina assumiu a Prefeitura da mais importante cidade do país declarando intenções de mudar as estruturas políticoadministrativas vigentes e chamou para si as responsabilidades de priorizar, na esfera municipal, as políticas sociais de interesse coletivo, a partir do estímulo à interlocução e interação com movimentos populares. Era voz corrente, no interior do governo, que seriam priorizados os grupos sociais marginalizados, os mais carentes, os excluídos, para que estes viessem a ser incluidos e reconhecidos como pessoas dotadas de direitos, como cidadãos comuns, iguais aos outros. Aquela administração procurou instaurar mecanismos inovadores de relação e de comunicação entre o poder executivo e as representações sociais.

Meses antes havia sido promulgada a Constituição Federal do Brasil, como se dizia na época, "a Constituição Cidadã", que instituiu mecanismos de descentralização administrativa e, por isso mesmo, serviu de alavanca ao novo governo que se iniciava e queria se afirmar como democrático e popular. O momento era politicamente propicio para se ampliar a cidadania, para o exercício da participação popular junto a administração municipal, para a valorização do coletivo, do social, sob a proteção da nova Constituição

\footnotetext{
12 Meirelles. H.L. Direito Administrativo Brasileiro. Malheiros Editora Ltda. 17'. edição, São Paulo, 1990. p. 61.
} 
Os primeiros pronunciamentos da prefeita anunciavam a inversão de prioridades, e o que de mais marcante se observava naquele momento, era a proposta de democratização do Estado. O governo externava o desejo de promover a democratização do Estado, por meio da participação social direta na gestão da coisa pública, a partir de setores organizados da sociedade civil. Afirmava-se a vontade de democratizar a máquina administrativa da Prefeitura, de prestar contas diretamente à população, de se tornar um governo efetivamente claro e transparente.

Assim que assumiu o comando da Prefeitura, o governo Luiza Erundina encontrou o Orçamento Municipal voltado para atender as prioridades estabelecidas pela antiga administração, isto é, ocupado em investir em grandes obras, com a maior parte dos recursos orçamentários comprometida com as grandes empreiteiras, enquanto as áreas sociais, consideradas prioritárias pelo governo que se iniciava, estavam preteridas e sucateadas. Imediatamente o novo governo procurou definir um plano de emergência, denominado Plano dos 100 Dias. Veja-se duas das prioridades desse plano de emergência:

1. Para a Secretaria Municipal da Educação:..."adquirir, de acordo com disponibilidades financeiras, equipamentos para cobrir o déficit estimado em 35.758 conjuntos de mesa/carteira (julho de 1988). Há quatorze escolas novas sem nenhuma carteira, mas com estrutura para funcionar em termos de pessoal e administração. Há falta de carteiras em escolas variadas e 2.800 carteiras não adquiridas por término do ano fiscal"...

2. Para a Secretaria Municipal da Saúde: ..." priorizar o atendimento às carências urgentes. O sistema de atendimento às urgências está caótico. Os Pronto-Socorros estão com pacientes atendidos em cadeiras ou mesmo no chão; pacientes "internados" em leitos de retaguarda dos Pronto-Socorros chegam a não receber alimentação ( muitas vezes até por três dias seguidos ). O sistema de resgate está falido ( de aproximadamente 3 mil chamadas/dia apenas 120 são atendidas e mesmo assim com demora média de 5 horas ). Cerca de $1 / 3$ da frota de ambulâncias está parada ( de 151 ambulâncias existentes, 51 estão quebradas ) $)^{113}$.

\footnotetext{
${ }^{13}$ Prefeitura do Município de São Paulo. Plano de emergência para a cidade de São Paulo. apresentado à população em primeiro de janeiro de 1989 . discorria sobre as principais medidas de governo. fruto do diagnóstico preliminar ( mimeo ).
} 
O grande déficit financeiro da Prefeitura existia em função de antigas dividas e atrasos de pagamentos a fornecedores. Os jornais da época se referiam a 1,5 bilhão de dólares em dívidas ${ }^{14}$. Os estoques de materiais de consumo estavam zerados. Grande parte dos equipamentos estava deteriorada por falta de manutenção e de reposição de peças. Essa constatação era voz corrente entre o secretariado municipal e os gestores públicos que tomavam posse.

As primeiras medidas administrativas do governo visavam à contenção das despesas, ao reequilíbrio das contas públicas e a impedir o colapso dos equipamentos municipais, principalmente nas áreas sociais como saúde, educação, bem-estar social e transportes. Para racionalizar o uso dos recursos e aumentar a eficiência da máquina pública, o governo procurou inovar os procedimentos administrativos. Para isso, procurou estimular o desenvolvimento de ações integradas, locais e regionais, entre as diferentes secretarias municipais. Criou canais de participação direta, através da abertura aos diferentes segmentos e representações populares nas discussões das políticas públicas municipais.

Para organizar as ações intersetoriais, logo no início do governo, em março de 1989, foram implantados os Núcleos Regionais de Planejamento ( NRP's ), esferas de decisão de gestores intersecretariais, que passaram a funcionar em cada uma das Administrações Regionais. A Secretaria das Administrações Regionais - SAR - era subdividida em 21 Administrações Regionais (AR's). Em cada uma das AR's instituiu-se um NRP, onde cada secretaria de governo tinha sua representação garantida junto às demais.

Ao empenhar-se em promover ações integradas intersecretariais, o governo buscava descentralizar o poder político-administrativo, antes concentrado no Gabinete do Prefeito, distribuindo-o entre as estruturas regionalizadas da Prefeitura, coordenadas pelos Administradores Regionais, subordinados à Secretaria das Administrações Regionais. Num dos documentos produzidos pela SAR, lia-se ..." o NRP é uma forma de reorganização da administração municipal. Ele dialoga com a sociedade civil

\footnotetext{
${ }^{14}$ Idem, Plano de emergência.
} 
local. Não é uma forma de organização da sociedade. Não é um conselho popular ou embrião do conselho local, mas dialoga com a populaçãon'.

No âmbito da Secretaria Municipal da Saúde, o número de Administrações Regionais de Saúde não coincidia com o número de Administrações Regionais da SAR. Eram 10 Administrações Regionais de Saúde contra 21 AR's. Dessa forma, era comum os funcionários do setor saúde participarem em mais de um NRP. A Administração Regional de Saúde de Pirituba-Perus, ARS-8, por exemplo, abrangia uma área geográfica de aproximadamente $104 \mathrm{Km}$ quadrados, com cerca de 320.000 habitantes. Correspondia a duas Administrações Regionais da SAR, a AR de PiritubaJaraguá e a AR de Perus. Os representantes da Secretaria Municipal da Saúde no âmbito da ARS-8, participavam, portanto, de reuniōes em dois núcleos regionais de planejamento: o NRP de Pirituba-Jaraguá e o NRP de Perus. Nessas reuniões, as propostas de trabalho, na maior parte das vezes, giravam em torno da implantação de uma forma democrática e integrada de administrar os equipamentos públicos. Buscava-se organizar as demandas populares de forma integrada, priorizando as áreas mais carentes, e encaminhando-se em direção à periferia mais desprovida de infra-estrutura urbana. Mesmo numa região periférica como Perus, existem extremas desigualdades, com alternância de micro-áreas desenvolvidas e subdesenvolvidas. Neste municipio, um dos traços homogêneos é a desigualdade social.

O Governo municipal tentava instaurar um planejamento transparente, democrático, aberto e descentralizado, que viesse a prosperar em pelo menos duas direções: na implantação de um planejamento intersetorial, integrado regionalmente, e na abertura de canais e representações, através dos quais a população pudesse expressar diretamente ao executivo suas necessidades, prioridades e carências. Através da abertura de canais de participação, no estímulo à democracia direta, buscava ampliar a participação popular nos processos decisórios da administração municipal. O governo afirmava que esta seria a maior obra a ser legada à população de São Paulo ao final dos quatro anos de gestão. As grandes obras viárias ou de infra-estrutura urbana seriam substituidas por uma obra de dimensão politica, que visava à participação e à promoção da cidadania.

\footnotetext{
${ }^{15}$ Prefeitura do Municipio de São Paulo. Secretaria Municipal de Planejamento - Seplan - documento inicial intitulado "Planejamento. descentralização e democratização da gestão municipal". a respeito da concepção e função dos Núcleos Regionais de Planejamento. Texto mimeografado.
} 
Algumas Secretarias conseguiram desenvolver essa proposta de forma mais eficaz. A Secretaria da Saúde foi um bom exemplo. Foram implantados Conselhos de Saúde em todas as esferas da Secretaria, desde a central, representada pelo Conselho Municipal da Saúde, até a local. Todos os conselhos tinham composição tripartite, com $50 \%$ dos membros representando os usuários dos serviços, $25 \%$ representando os trabalhadores ou prestadores de serviços e os $25 \%$ restantes, representando a administração municipal.

As reuniões públicas, que incluíam os representantes populares, também eram coordenadas pelos braços regionais da Secretaria das Administrações Regionais. Ocorriam em diferentes pontos da cidade, contando com a presença da própria prefeita ou de seu representante imediato. Nessas ocasiões, praticamente todas as Secretarias se faziam representar, destacando-se as da Saúde, Educação, Bem-Estar Social, Esportes, Planejamento, Cultura e Habitação, além da Secretaria da Administração Regional.

Parecia estar havendo uma revolução na administração da coisa pública, dado o modo como as pessoas expressavam livremente suas necessidades e manifestavam seus sentimentos, de forma clara e aberta, tanto no que se refere aos representantes da administração como no que diz respeito aos segmentos populares ${ }^{16}$.

Para facilitar a participação social, foram criados vários Conselhos Populares, especialmente na área da saúde, educação, bem-estar social, cultura e habitação. O Foro da Cidade, o Conselho da Criança e do Adolescente, o Conselho dos Deficientes Físicos, a Coordenação Especial do Negro, a Assessoria de Cidadania e o Conselho dos Idosos, são outros exemplos dos inúmeros mecanismos institucionais de participação. Essas representações civis e populares ganharam embasamento legal com a promulgação da Lei Orgânica do Município que, sancionada em 5 em abril de 1990, aprofundou o processo de democratização desencadeado na vida da cidade, regulamentando, através de vários dispositivos, a participação direta dos cidadãos comuns nas decisões da Prefeitura ${ }^{17}$.

\footnotetext{
${ }^{16}$ Para se conhecer o processo político do governo Luiza Erundina. recomendamos a leitura do livro $O$ desafio de ser governo: o PT na prefeitura de Sáo Paulo, autoria de Cláudio Gonçalvez Couto. Paz e Terra. São Paulo, 1995. O interesse desse livro reside no questionamento sério e competente sobre um governo de oposição oriundo de classes populares.
}

${ }^{i}$ Prefeitura Municipal de São Paulo - Experiências de Participação Popular - Programa Integrado de Educação e Participação Popular (PIEPP). março de 1992. Texto mimeo. 
Em agosto de 1989, a administração municipal apresenta o documento "Reforma da Administração Pública da Cidade de São Paulo". O objetivo era abrir caminhos para a ampla reforma administrativa da Prefeitura do Município de São Paulo, dentro dos principios de gestão democrática e participativa, com vistas à uma transparente prestação de contas e serviços à população do municipio $^{18}$. O documento propunha que a reforma administrativa não fosse apenas um rearranjo burocrático. Previa a descentralização do poder, concentrado nas mãos do prefeito, através da criação de subprefeituras, da diminuição do número de secretarias municipais, da integração das ações governamentais e da facilitação do acesso da população ao planejamento e às decisões governamentais. Cada subprefeitura, com autonomia políticoadministrativa e financeira, seria o polo aglutinador dos serviços regionais, distritais e locais. $O$ embrião desse processo já fora implantado com a criação dos núcleos regionais de planejamento.

Apesar do processo de reforma administrativa ter sido deflagrado em 1989, o projeto definitivo da "Proposta de Reforma Organizacional da Prefeitura do Município de São Paulo" foi enviado à Câmara Municipal apenas em meados de 1991, portanto, quase dois anos depois, e até o final governo não chegou a ser apreciado pelos vereadores. Foi retirado da Câmara pelo governo municipal que sucedeu Luiza Erundina.

No inicio de 1990, a Prefeitura abre a discussão sobre o Plano Diretor da Cidade de São Paulo. Segundo Singer ${ }^{19}$, titular da Pasta do Planejamento daquele governo, " planos diretores sempre despertam grandes esperanças como instrumentos de ordenação, regulação e racionalização do desenvolvimento geral das cidades. Além disso, esperava-se que promovessem eqüidade ao proporcionar aos marginalizados, que nunca haviam podido ganhar o bastante para adquirir no mercado moradias decentes, acesso à terra".

De acordo com outro documento, produzido pela Secretaria das Administrações Regionais, ..."o plano diretor delineia as formas de utilização do espaço físico da cidade que correspondem ao pleno desenvolvimento das

\footnotetext{
${ }^{18}$ Diário Oficial do Município - D.O.M. - Suplemento Especial - Quarta-feira. 2 de agosto de 1989.

"Paul Singer. Lim Governo de Esquerda para Todos, Ed. Brasiliense. São Paulo. 1996. p. 196. Neste livro o autor faz um balanço da gestão Luiza Erundina em São Paulo.
} 
funções sociais na cidade e que garantam o bem estar de seus habitantes, impondo limites para a ação dos agentes públicos e privados que produzem e servem a cidade, $e$ incentivos para que suas ações se dêem em determinada direção ${ }^{20}$.

Segundo definição constitucional, o Plano Diretor responderia às exigências fundamentais de ordenação que a propriedade urbana deve atender para cumprir sua função social, criando novas regras de ocupação e uso do solo. A principal estratégia da Prefeitura de São Paulo, para garantir a implantação do Plano Diretor foi abrir uma discussão pública, envolvendo o maior número possível de interessados, para que a população se sentisse comprometida com o projeto e, dessa forma, a Prefeitura viesse a ganhar adeptos que defendessem o plano, principalmente através de seus segmentos mais organizados.

Com essas diretrizes estratégicas em curso, o poder executivo acreditava estar contribuindo para transformações políticas e administrativas do município, adequando-o às demandas crescentes de uma metrópole deste porte. Procurava discutir questões complexas, como a do Plano Diretor ou da Reforma Administrativa em todos os setores da sociedade civil, como entidades, movimentos sociais, sindicatos, empresários, vereadores e partidos políticos. Passados alguns anos dessa tentativa, pode-se concluir que a estratégia do executivo não se mostrou correta, pois o governo ganhou pouco apoio popular, o mesmo acontecendo entre setores do empresariado e dos partidos políticos. Após um ano de discussão, a sorte do Plano Diretor enviado à Câmara Municipal no início de 1991, para apreciação e votação, foi praticamente a mesma do projeto de Reforma Administrativa da Prefeitura. Ambos foram retirados da Câmara no governo subseqüente.

Apesar das dificuldades, que se acentuaram com o passar dos meses, - governo Luiza Erundina trabalhou, até o final de seu mandato, para tornarse uma administração pública comprometida no combate à corrupção, na inversão de prioridades, na descentralização do poder, na valorização de seus recursos humanos e, na luta pëla reconquista de direitos sociais, como o direito à cidadania. Os gestores públicos municipais arriscavam ser reconhecidos pela população como os responsáveis por uma administração séria, honesta e voltada para o interesse coletivo.

\footnotetext{
¿"Prefeitura do Município de São Paulo - Secretaria das Administrações Regionais - SAR - Memorando Circular número 012 de $30 / 03 / 91$.
} 
Para justificar a opção por este caminho de trabalho, a Prefeitura valorizou o setor social também através da dotação orçamentária. Entre 1989 e 1992 , cerca de $48 \%$ do orçamento público municipal foi destinado às áreas sociais, como educação, saúde, habitação, transporte, bem-estar social, cultura e infra-estrutura urbana ${ }^{21} e^{22}$.

\footnotetext{
${ }^{21}$ Segundo a "Folha de São Paulo" de 13 de setembro de 1996, o governo que sucedeu Luiza Erundina, inverteu novamente as prioridades, colocando-as no mesmo patamar dos governos conservadores, deslocando recursos da área social para a realização de obras e o pagamento de dívidas às empreiteras..."entre janeiro de 1993 e junho de 1996, as secretarias sociais (Educação, Saúde. Habitaçâo e Bem-Estar Social) perderam o equivalente a R\$1,7 bilhões. Duas áreas foram beneficiadas com os cortes: a Secretaria das Vias Públicas teve um acréscimo de R\$868 milhões e R\$ 912,8 milhões foram destinados ao pagamento de dividas e aposentados"..

${ }^{22}$ Comparando-se com administrações vizinhas, verifica-se a elevação dos gastos nas áreas sociais do governo Luiza Erundina. Veja-se no gráfico abaixo, o montante de recursos aplicados nas áreas sociais, no periodo compreendido entre 1988 e 1994 :
}

\section{RECURSOS APLICADOS NA ÁREA SOCIAL ( EM MILHÕES DE REAIS)}

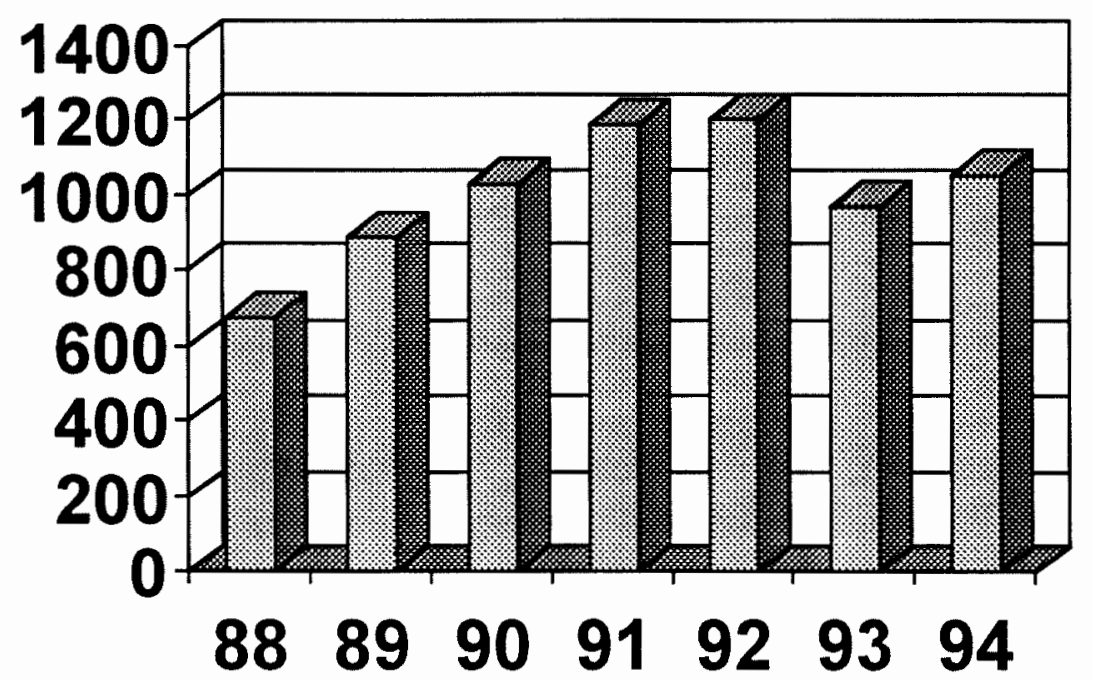

\section{Fonte: Folha de S.Paulo, 04/06/1995}


Os resultados puderam ser sentidos não apenas na Secretaria da Saúde. A Secretaria Municipal da Educação, por exemplo, investiu na recuperação dos salários dos educadores, elevando os gastos relativos ao pessoal em $40 \%$, se comparado aos anos anteriores. Houve melhorias nas condições de trabalho e qualidade de ensino nas Escolas Municipais, elevando-se o custo por aluno em mais de $250 \%$. As conseqüências dessas medidas se traduziram pelas sucessivas quedas nos índices de evasão e reprovação escolar ${ }^{23}$.

Também a Secretaria de Habitação e Desenvolvimento Urbano procurou enfrentar o grande déficit habitacional existente, particularmente na periferia de São Paulo. Conseguiu, em quatro anos, concluir 35.846 casas populares e destas, muitas foram erguidas em regime de mutirão com homens, mulheres e crianças se organizando em 106 equipes de trabalho para erguer suas próprias moradias, melhorando a qualidade e diminuindo o custo das construções, com economia para o poder público e a comunidade ${ }^{24}$.

Segundo dados de uma revista de grande circulação ${ }^{25}$ o governo Luiza Erundina aplicou $3,3 \%$ de seu orçamento em Habitação, estimulando o sistema de construção em mutirão e dando início ao processo de

\footnotetext{
${ }^{23}$ A "Folha de São Paulo" publicou um Caderno Especial ( 27/10/96) onde se lê que o governo Luiza Erundina investiu $10 \%$ do orçamento municipal na Secretaria da Educação e o governo que a sucedeu 8\%. Em 1992 havia 33.500 professores contra $31.700 \mathrm{em} \mathrm{1996.} \mathrm{Entre} 1989$ e 1992 foram matriculados 107 mil novos alunos no primeiro gráu. enquanto que entre 1993 e 1996 houve 25 mil novas matrículas. A média mensal salarial na gestão Luiza Erundina foi de $\mathrm{R} \$ 450,00$ e no governo sucessor foi de $R \$ 337.87$
}

\footnotetext{
${ }^{24}$ Segundo dados do "Relatório Progresso" da empresa Ductor. elaborado em dezembro de 1993. as casas construídas por mutirão custaram em média US\$150.00/metro quadrado. Este projeto foi tão bem sucedido, que chegou a ser premiado na Conferência da ONU Habitat 2, em Istambul, 1996. Outras 15.000 residências dos mesmos padrões foram iniciadas naquela gestão. com garantia de continuidade no governo seguinte, no entanto, quando o governo assumiu a prefeitura. impediu a construção de 8.000 casas. ao criar toda sorte de entraves burocráticos e acusações infundadas para suspender o repasse de recursos. De acordo com a revista Veja São Paulo ( ano 29- número 40 ) ..."os mutirões foram suspensos após a posse de Maluf e a Sehab passou ganhar fatias cada vez menores no bolo orçamentário. Esse quadro foi revertido no último ano do mandato. com o sucesso popular do projeto Cingapura - o investimento da prefeitura em habitação saltou de 90 milhões de reais em 1994 para mais de 358 milhões neste ano. A idéia de verticalizar as favelas, erguendo prédios no local onde antes havia barracos não é nova. Erundina já havia feito experiências semelhantes. Na gestão atual. os edificios ganharam cores. surgiram em locais de grande visibilidade e se transformaram em outdoors de concreto da administração malufista. Das 30.000 unidades do Cingapura que o prefeito pretendia entregar. 4.456 tinham sido construidas até 30 de setembro de $1996 " \ldots$
}

${ }^{25}$ VEJA SP. 2 de outubro. 1996. 
verticalização de favelas. O governo que o antecedeu, aplicou $1.5 \%$ do orçamento em Habitação, entregando cerca de 33.000 moradias, a maior parte com recursos do extinto $\mathrm{BNH}$. Iniciou os mutirões e a política dos pequenos conjuntos habitacionais. Já o governo que o sucedeu, aplicou $3 \%$ de seu orçamento em Habitação, construindo cerca de 16.000 habitações populares.

Quanto à Secretaria do Bem-Estar Social, priorizou os setores da população com renda familiar de até quatro salários mínimos mensais. Para oferecer um pouco mais de assistência social a esses grupos familiares, expandiu o número de vagas na rede de Creches, de 58.666 em 1989 para 73.781 em 1992, representando um acréscimo da ordem de $26 \%$. O gasto mensal per capta dobrou nesse período, atingindo o montante de 90 dólares por criança assistida em cada equipamento da Secretaria. Esse aumento de despesas decorreu da renovação do quadro de pessoal e do padrão de alimentação e possibilitou uma melhoria na qualidade de atendimento ${ }^{26}$.

No que diz respeito à Secretaria Municipal dos Transportes, depois de permanecer estagnada em 8.000 veículos por mais de 15 anos, a frota municipal ultrapassou os 10.000 ônibus no governo Luiza Erundina. Além disso, a lei da municipalização dos ônibus sancionada em 1991, talvez tenha sido a intervenção mais radical ocorrida nos transportes coletivos do município. Possibilitou à Secretaria o levantamento preciso do custo da modalidade de transporte sobre pneus em São Paulo, ao mesmo tempo que permitiu a expansão da frota em 2.300 unidades. Com o controle das despesas, a Prefeitura pode definir uma política de subsídio ao custo por passageiro, compatível com o orçamento municipal e às diferentes demandas sociais da cidade. A média do subsídio por passagem girou em torno de 0,45 dólares, não atingindo, entretanto, o subsídio integral do custo da passagem, pretendido pelo governo municipal ${ }^{2}$.

\footnotetext{
${ }^{26}$ Prefeitura do Município de São Paulo. Balanço Geral. 1989-92. Relatório Final de Governo.

- Em 1990. havia sido enviado à Câmara Municipal o projeto Tarifa Zero. que uma vez implantado. isentaria qualquer cidadão do pagamento de passagens no sistema municipalizado de ônibus da capital. $\mathrm{O}$ transporte coletivo seria custeado através de uma taxação mais elevada de Imposto Predial e Territorial Urbano (IPTU) para os grandes clubes. as mansões. as grandes indústrias e empresas e os terrenos vazios. O governo municipal argumentava que esses setores. inicialmente penalizados pela sobre-taxa de IPTU. receberiam beneficios indiretos imediatos pelo favorecimento aos trabalhadores de São Paulo. O projeto Tarifa Zero previa a isenção de pagamento de IPTU para cerca de $500 \mathrm{mil}$ residências. localizadas na periferia. em favelas e em cortiços. Parte do IPTU recolhido pelo projeto seria destinada à Secretaria Municipal de Educação. elevando em até $30 \%$ a fatia do bolo orçamentário
} 
Mesmo sem conseguir autorização para contrair empréstimos internacionais, que viabilizassem essa política de redistribuição de benefícios sociais, e mesmo sem receber os repasses financeiros do governo federal aos quais tinha direito - fatos inéditos, que ocorreram pela primeira vez nos quase 500 anos de história da cidade - o governo municipal não se afastou de suas diretrizes. Continuou a priorizar as áreas sociais e a governar a cidade de forma diferente, integrada, olhando a periferia e abrindo espaços à participação direta das representações populares.

\section{A SECRETARIA MUNICIPAL DA SAÚDE}

\section{VI.1. As primeiras experiências - a restruturação administrativa}

Em janeiro de 1989 a Secretaria revelava uma situação bastante precária, semelhante a do quadro geral da Prefeitura. Os funcionários aparentavam grande desmotivação. Os levantamentos preliminares indicavam que mais de $50 \%$ dos equipamentos da rede física estavam desativados. A produtividade era baixa: com a média de internação hospitalar girando em torno de $1.000 /$ mês, contra 7.000 internações/mês possiveis pela capacidade física instalada e cerca de 230.000 atendimentos ambulatoriais, contra 420.000 possiveis por mês.

O cenário era dramático. Numa cidade como S.Paulo, inserida em uma região metropolitana, afetada por um estado crônico de pobreza, violência e marginalidade social, o quadro sanitário com elevados índices de morbimortalidade preveniveis extrapolava a competência do setor saúde. Diante dessa situação, a Secretaria da Saúde se propôs a repensar os tradicionais conceitos de planejamento e começou a buscar parcerias junto a setores organizados da população e do funcionalismo público. Imediatamente passou a tomar uma série de medidas, amparadas em outra concepção de saúde, que serviria de base para a reorganização das estruturas administrativas. Buscava-se a mudança das práticas sanitárias, tendo em vista a implantação de um modelo inovador de atenção à saúde.

daquela Pasta e favorecendo a Educação de Base a cidade. O projeto Tarifa Zero. enviado à Câmara Municipal de São Paulo. teve a mesma sorte dos anteriores. não chegando a ser apreciado pelos vereadores. Observe-se o percentual do orçamento municipal investido no transporte público durante a gestão Luiza Erundina e nos dois governos vizinhos. 
A então "Secretaria de Higiene e Saúde" tinha uma estrutura administrativa centralizada, no Gabinete do Secretário, e se dividia em três grandes ramos, que não confluíam: a Superintendência Médico-Hospitalar ( MED ), que gerenciava os Hospitais e Pronto-Socorros Municipais, o Departamento de Saúde da Comunidade (DSC), responsável pelo gerenciamento das atividades ambulatoriais, e o Departamento de Apoio Técnico (DATE), encarregado da frota de veículos e da manutenção dos prédios e equipamentos.

A história da SHS registra períodos anteriores de maior participação. Segundo Marsiglia ${ }^{28}$ quando Mário Covas foi Prefeito "houve um crescimento do movimento do funcionalismo municipal, com várias manifestações, reivindicações e paralisações, inclusive na área da saúde. A administração sofreu pressão nesse período para que as direções dos serviços pudessem ser eleitas pelos funcionários e pela 'comunidade', isto é, pela população que dele se servissem (...) As experiências desta gestão foram abandonadas com a eleição de Jânio Quadros, em 1995". Enfim, quando a administração Erundina assumiu o governo, não havia acúmulo em participação social na saúde. A cultura institucionalizada era autoritária. A tarefa dos dirigentes era mudar radicalmente a situação estabelecida, realizando rapidamente uma reforma na estrutura organizacional da Secretaria, democratizando seu processo gerencial e promovendo a consciência e cidadania entre os funcionários e os usuários, em consonância com as diretrizes do governo municipal.

Em abril de 1989 configurou-se um novo desenho organizacional. A Secretaria de Higiene e Saúde, passou a denominar-se Secretaria Municipal da Saúde, SMS e, foi subdividida em 10 Administrações Regionais de Saúde, ARS's. Cada ARS ganhou maior autonomia político-administrativa e passou a assumir a responsabilidade de gerenciar todos os tipos de equipamentos municipais de saúde situados dentro de sua área geográfica.

A intenção era a de regionalizar e integrar os diferentes serviços de modo hierarquizado, a partir da implantação de sistemas locais de saúde - os denominados Distritos de Saúde - que viriam a ser implantados a partir dos primeiros passos da reforma administrativa, isto é, depois de serem consolidadas e estruturadas as ARS's. Assumimos a responsabilidade da gerência da Administração Regional de Saúde de Pirituba-Perus, ARS-8, uma

\footnotetext{
${ }^{28}$ Marsiglia. R.M.G. Servidor, Funcionário, Trabalhador: interesses e culturas organizacionais no setor público de saúde. Tese de Doutorado, FFLCH. USP. 1993, p. 243.
} 
das menores, quanto ao número de habitantes e de Unidades de Saúde entre as 10 ARS's criadas. Seus equipamentos constavam de um Hospital Geral ( Dr. José Soares Hungria), com apenas 60 leitos de internação, porém com um dos prontos-socorros mais movimentados da capital, em média 1.000 atendimentos por dia; um Ambulatório de Especialidades; um Centro de Convivência e Cooperativa; um Hospital-Dia para portadores de sofrimento mental; um Pronto-Socorro no Distrito de Perus; 6 Unidades Básicas de Saúde, dispersas pela área da ARS-8. As outras nove ARS's foram denominadas: ARS-1 (Centro), ARS-2 (Butantã), ARS-3 (JabaquaraIpiranga), ARS-4 (Penha-Tatuapé), ARS-5 (Itaquera- Guaianazes), ARS-6 (São Miguel), ARS-7 (Santana -Nossa Senhora do Ó), ARS-9 (Santo-Amaro) e ARS-10 (Campo Limpo) ${ }^{29}$.

O Gabinete do Secretário, juntamente com as dez Diretorias Regionais de Saúde, representavam a instância de maior poder decisório no interior da Secretaria Municipal da Saúde. Esta esfera de governo passou a ser denominada Conselho Técnico-Administrativo, CTA.

No cartograma da página seguinte, a representação gráfica da divisão administrativa da Secretaria Municipal da Saúde:

\footnotetext{
${ }^{29} \mathrm{O}$ decreto municipal número 27.724. publicado no D.O.M. em 12 de abril de 1989. definiu os limites e competencias das dez Administrações Regionais de Saúde e quarenta e quatro Distritos de Saúde.
} 


\section{Localização das ARS e Distritos Sanitarios}

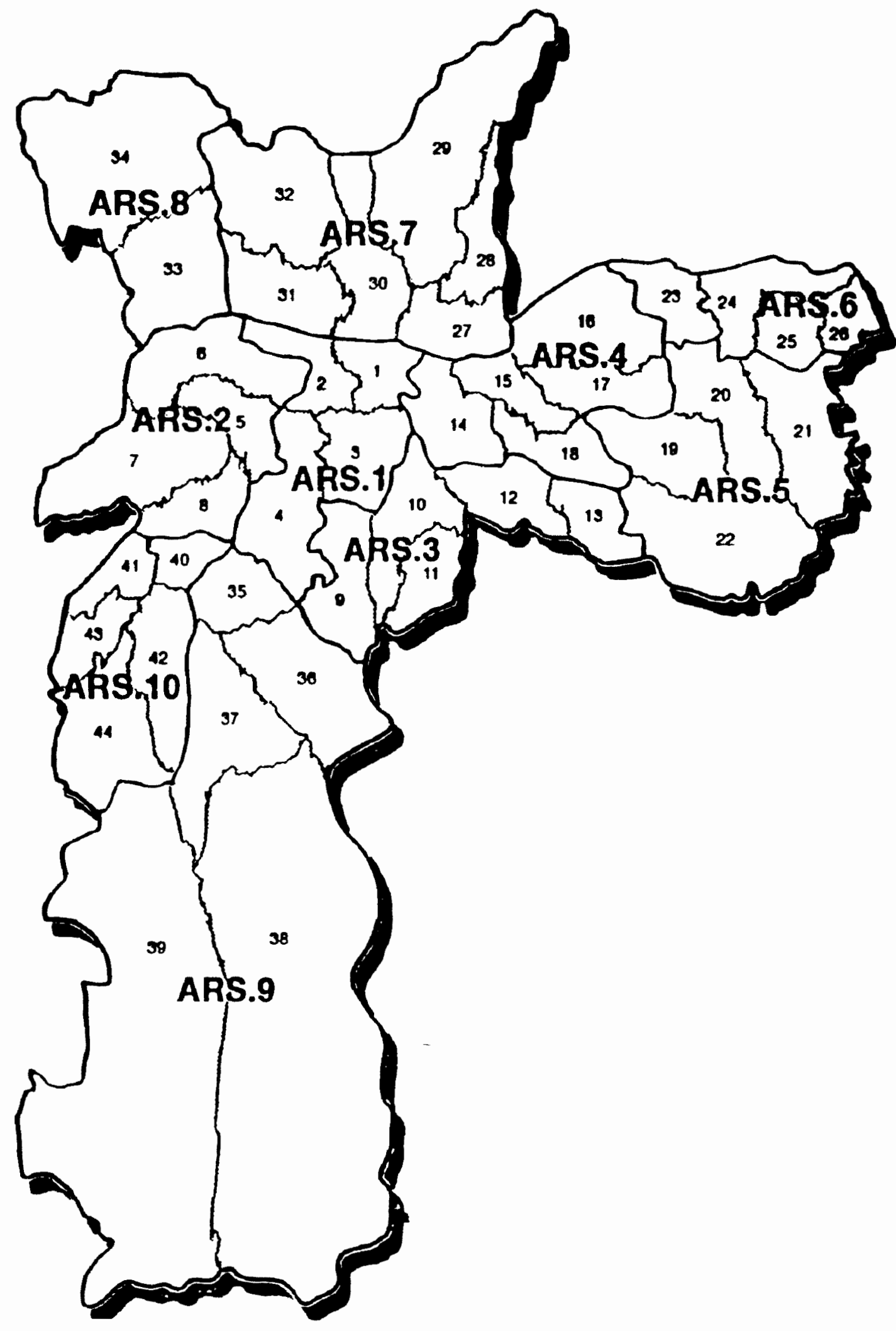




\section{ARS.1}

01. DS Sé (Sé, Bom Retiro, Pari, Brás)

02. DS Santa Cecilia (Santa Cecilia, Barra Funda, República, Consolação)

03. DS Vila Mariana (Vila Mariana, Bela Vista, Liberdade, Cambuci)

04. DS Ibirapuera (Ibirapuera, Jardim Paulista, Campo Limpo, Itaim)

\section{ARS.2}

05. DS Pinheiros (Pinheiros, Alto de Pinheiros)

06. DS Lapa (Lapa, Jaguaré, Vila Leopoldina, Perdizes)

07. DS Butantã (Butantã, Raposo Tavares, Rio Pequeno)

08. DS Vila Sônia (Vila Sônia, Morumbi)

\section{ARS.3}

09. DS Jabaquara (Jabaquara, Saúde)

10. DS Ipiranga (Ipiranga, Cursino)

11. DS Sacomã (Sacomã)

12. DS Vila Prudente (Vila Prudente, São Lucas)

13. DS Sapopemba (Sapopemba)

\section{ARS.4}

14. DS Moóca (Moóca, Belém, Água Rasa)

15. DS Tatuapé (Tatuapé, Carrão)

16. DS Penha (Penha, Cangaíba, Ponte Rasa)

17. DS Vila Matilde (Vila Matilde, Artur Alvim)

18. DS Jardim Iva (Vila Formosa, Aricanduva)

\section{ARS.5}

19. DS Cidade Líder (Cidade Líder, Parque do Carmo)

20. DS Itaquera (Itaquera, José Bonifácio)

21. DS Guaianazes (Guaianazes, Cidade Tiradentes, Lajeado)

22. DS São Mateus (São Mateus, São Rafael, Iguatemi)

\section{ARS. 6}

23. DS Ermelino Matarazzo (Ermelino Matarazzo, Vila Jacui)

24. DS São Miguel Paulista (São Miguel Paulista, Jardim Helena)

25. DS Vila Nova Conceição (Vila Curuçá)

26. DS Itaim Paulista (Itaim Paulista)

\section{ARS.7}

27. DS Vila Maria (Vila Maria, Vila Guilherme)

28. DS Jaçanã (Jaçanã, Vila Medeiros) 
29. DS Tucuruvi (Tucuruvi, Tremembé)

30. DS Santana (Santana, Mandaqui)

31. DS Freguesia do Ó (Freguesia do Ó, Limão, Casa Verde)

32. DS Brasilândia (Brasilândia, Cachoeirinha)

ARS.8

33. DS Pirituba (Pirituba, Jaguara, São Domingos)

34. DS Perus (Perus, Jaraguá, Anhanguera)

ARS.9

35. DS Santo Amaro (Santo Amaro)

36. DS Pedreira (Pedreira, Cidade Ademar, Campo Grande)

37. DS Cidade Dutra (Cidade Dutra, Socorro)

38. DS Grajaú (Grajaú)

39. DS Parelheiros (Parelheiros)

ARS.10

40. DS Vila Andrade (Vila Andrade)

41. DS Campo Limpo (Campo Limpo)

42. DS Jardim São Luis (Jardim São Luís)

43. DS Capão Redondo (Capão Redondo)

44. DS Jardim Ângela (Jardim Ângela)

Às ARS's cabiam algumas competências, como a coordenação e implementação das diretrizes da política municipal de saúde no conjunto dos distritos de saúde de sua área de abrangência, a promoção e articulação intersetorial, particularmente nos núcleos regionais de planejamento, onde participavam outras secretarias municipais do governo loco-regional e a avaliação do desempenho físico-financeiro e das ações de saúde produzidas pelo conjunto de equipamentos dos Distritos, tendo em vista os recursos e as necessidades de saúde da população adstrita.

Aos Distritos de Saúde cabiam competências mais próximas do controle das ações de saúde produzidas pelos serviços a eles diretamente subordinados, como a elaboração e execução de planos operativos anuais, o estabelecimento de objetivos e metas, e a definição de recursos necessários para o enfrentamento dos principais problemas de saúde em suas respectivas áreas de abrangência. Como se vê, aos distritos cabiam competências semelhantes às da ARS, porém nos limites de suas áreas geográficas. 
Com a distritalização da saúde, a Prefeitura do Município de São Paulo estaria capacitada técnica, política e administrativamente para a completa e definitiva municipalização dos serviços de saúde, passo fundamental para a implementação do Sistema Único de Saúde na cidade de São Paulo. As diretrizes do Sistema Único de Saúde tornaram-se as grandes bandeiras da política de saúde da Secretaria. Os Distritos funcionavam como alternativas táticas para o avanço do SUS e a conseqüente transformação das práticas de saúde. O ideário do SUS estava incorporado pelos novos dirigentes, que sonhavam poder lidar com as mudanças nos espaços jurídico-legais, institucionais e operativos, estes representados pelos Distritos. Pensava-se que o distrito sanitário era..." a resposta social a ser dada pela organização dos serviços de saúde, às necessidades de saúde da população expressas diferentemente segundo as classes e frações de classes sociais, numa dada organização social, cujo território é produto de dinâmica onde tensionam-se as forças sociais, produto este sustentado pela consciência sanitária ${ }^{430}$.

A partir dessa concepção, deflagrou-se no âmbito da Prefeitura do Município de São Paulo a luta pela municipalização dos serviços de saúde. Foram elaboradas inúmeras propostas de municipalização, mas a forte resistência que o governo do Estado ofereceu à sua implementação, impediu que o processo pudesse prosperar. Essa resistência também partiu do interior do próprio governo. Alguns setores posicionaram-se contrários à idéia, especialmente as Secretarias de Finanças, Planejamento e Administração. Aliás, a idéia da municipalização é muito antiga. Consta que pelo menos no município de São Paulo, desde 1828 são interesses políticos que resguardam a centralização do poder: "como se percebe, as medidas governamentais sobre a saúde refletiam mais uma 'guerra' de poderes do que propriamente $o$ enfrentamento das questões concretas de saúde da população. Alguns autores consideraram inclusive, que a medida de descentralização de 1828, com a proposta de municipalização sem que os municípios tivessem condições para assumir a atribuição, fez com que deixassem de existir de fato os serviços de saúde pública no Brasil, com exceção da fiscalização sanitária dos portos ${ }^{131}$.

\footnotetext{
3"Prefeitura do Município de São Paulo. Secretaria Municipal da Saúde. Distritalização do Municipio de São Paulo. texto mimeografado. sem data

${ }^{31}$ Secretaria de Higiene e Saúde da Cidade de São Paulo. História e Memórias. Documento elaborado por Aldaiza de Oliveira Sposati. Patrícia Servilha e Tullo Vigevani. Departamento de Patrimônio Histórico. 1985.
} 
Das mais de 300 Unidades Estaduais passiveis de serem municipalizadas, entre Hospitais, Ambulatórios e Unidades Básicas de Saúde, apenas 50 UBS e 1 Ambulatório de Especialidades foram efetivamente incorporados pelo conjunto de serviços da rede de saúde do municipio, até o final de 1992.

Observe-se na página seguinte dois momentos de uma passeata pela municipalização dos serviços, organizada pela Secretaria Municipal de Saúde. Partindo da sede da SMS, avenida Paulista, centenas de funcionários e representantes da população, dirigiram-se à Secretaria de Estado da Saúde. 


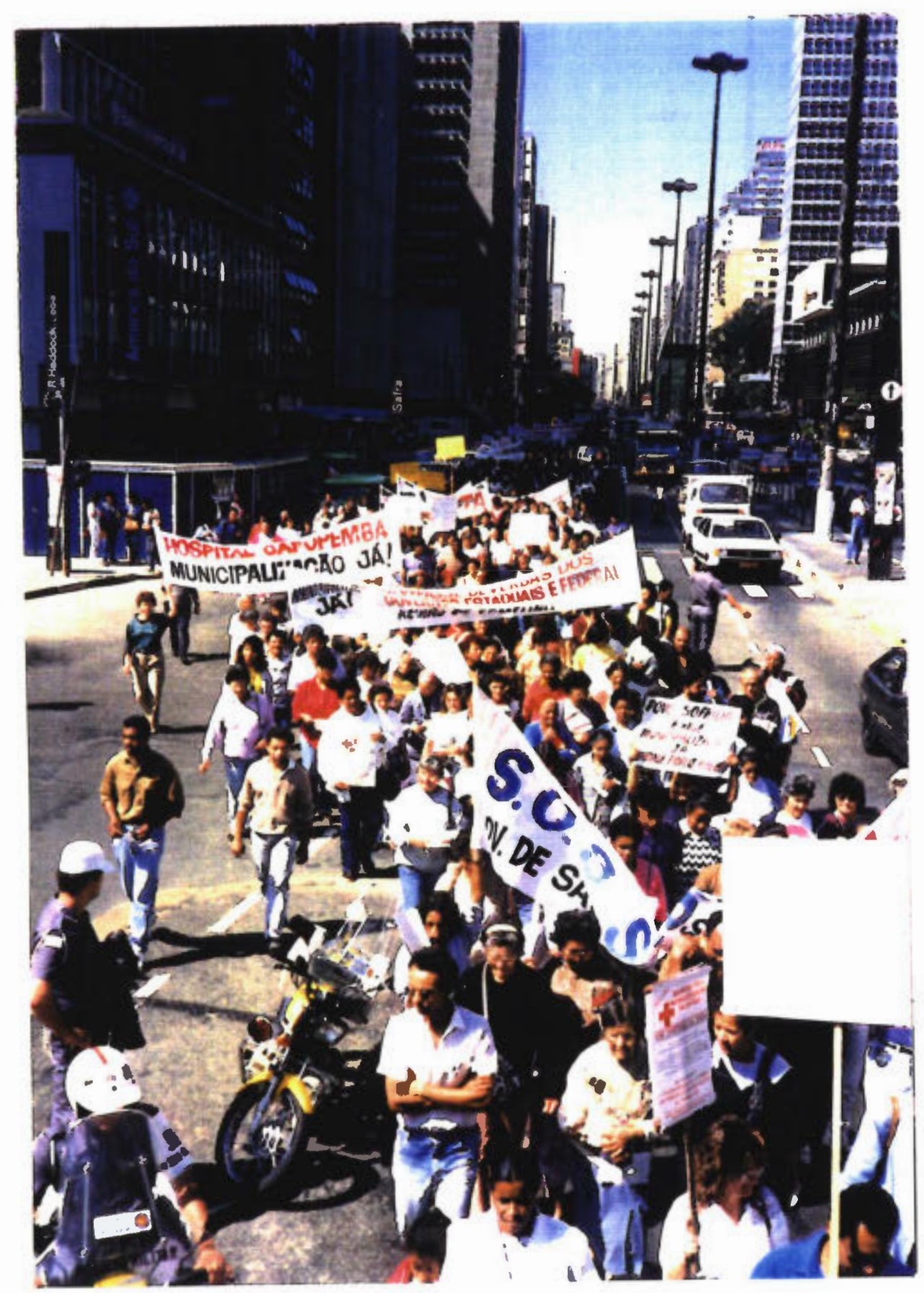

Passeata pela municipalização dos servicos de saúde. Integrada por movimentos populares e representantes da SMS. Avenida Paulista, 20 de agosto de 1991. 


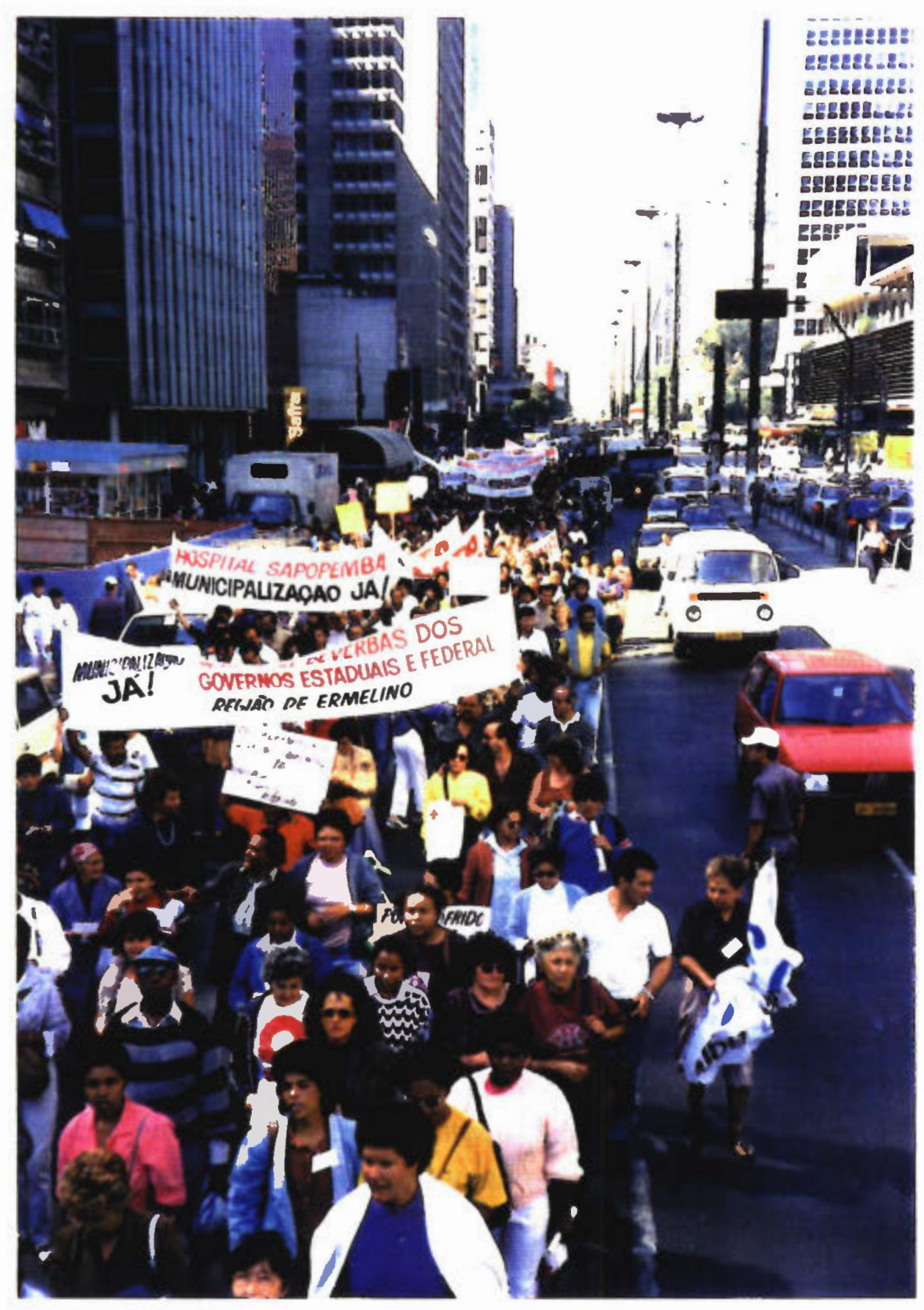

Passeata pela municipalização dos serviços de saúde. Integrada por movimentos populares e representantes da SMS. Avenida Paulista, 20 de agosto de 1991. 
O comando da Secretaria dispendeu grandes esforços para capacitar a gerência que se instalava, à implantação dos Sistemas Locais de Saúde, tendo em vista o novo modelo de planejamento e a racionalização dos procedimentos gerenciais e administrativos. Buscava-se o aumento da eficiência, da eficácia e a da avaliação do impacto das ações nas condições de vida da população.

Quatro aspectos foram decisivos para a implementação da distritalização, iniciada no município de São Paulo a partir de 1989:

1. a reorganização das estruturas gerenciais e administrativas, feita através da descentralização do poder e da criação das dez ARS's e trinta e um DS's.

2. o desenvolvimento e capacitação dos recursos humanos.

3. a participação social, com a implantação dos Conselhos Gestores.

4. a reorganização do sistema e do fluxo das informações.

\section{A Reorganização das Estruturas}

A implantação de Distritos de Saúde era parte da estratégia de descentralização gerencial e administrativa da Secretaria, feita a partir da divisão do poder e do trabalho, e que, se desejava, fosse compartilhada pelos servidores e a comunidade organizada.

Em maio de 1989 a SMS divulgou um documento intitulado "Plano Municipal de Saúde" ${ }^{132}$ onde explicitava as diretrizes da política municipal de saúde que norteariam cada Administração Regional.

O documento sinalizava para toda a rede o modelo gerencial a ser adotado para acompanhar a descentralização decorrente da reforma administrativa. A Secretaria passaria a ser estruturada em quatro niveis de gerência: o nível central, representado pelo Gabinete da Secretaria, o nivel regional, representado pelas Diretorias das Administrações Regionais de Saúde, o nível distrital, representado pelas Diretorias dos Distritos de Saúde, e finalmente, o nível local, representado pelas Diretorias das Unidades e Serviços de Saúde. Idealizava-se uma gerência democrática, participativa, compartilhada com representantes dos funcionários e da população. $O$ Gabinete da Secretaria se relacionaria com o Conselho Municipal de Saúde e

\footnotetext{
${ }^{3}$ Este documento foi organizado em três partes: a primeira voltada para analisar a situação de saúde do município: a segunda, relativa ao modelo de atenção tendo em vista a implantação do Sistema Único de Saúde e a terceira. abordou as estratégias para a implementação do Plano Municipal de Saúde.
} 
com a Plenária de Entidades e Movimentos Interessados na Questão Saúde do Município de São Paulo. A Plenária era um espaço livre à participação de todo e qualquer movimento ou entidade social que quisesse discutir os problemas de saúde do municipio. Era desse universo que saíam os representantes do Conselho Municipal de Saúde, cuja composição era tripartite $e$, naquele momento inicial de governo, tinha a seguinte representação: 12 representantes das estruturas de Estado (Prefeitura, União, Estado, Universidade e Câmara Municipal ), 8 representantes dos usuários dos serviços ( movimentos populares, sindicatos de empregados e empregadores ) e 8 representantes dos trabalhadores do setor saúde, fossem públicos ou privados. Mais tarde, como se verá, essa composição iria se modificar, ficando a representação popular com $50 \%$ dos seus membros. Os niveis regionais, distritais e locais deveriam estabelecer gerências compartilhadas com suas respectivas Comissões Gestoras, também tripartites, nas mesmas proporções. Essas esferas gerenciais deliberariam sobre os principais problemas de saúde de seus respectivos niveis de atuação.

O documento serviu de base conceitual para toda a política de saúde do governo Luiza Erundina e levava em conta três principios oriundos do Movimento da Reforma Sanitária Brasileira:

- o da democratização do processo de tomada de decisão,

- o da descentralização do poder para a periferia do sistema de saúde e

- o de buscar a integração de recursos, interna e externamente, com outros setores e movimentos sociais.

A Secretaria Municipal de Saúde procurava deste modo, demonstrar como seria o processo de transformação da lógica de organização dos serviços de saúde. O papel transformador não seria de responsabilidade exclusiva do poder executivo municipal. Abria a possibilidade da transformação das estruturas organizacionais, dos processos de trabalho e das práticas de saúde, incorporando a participação dos trabalhadores e da sociedade civil. Esse trabalho era um meio de favorecer a reorganização das ações de saúde a partir de um processo coletivo e, portanto, de caráter solidário, entre funcionários e usuários da rede de serviços municipais. Era um estímulo ao exercício da cidadania.

Para que a idéia de regionalização e municipalização de serviços pudesse prosperar, a Secretaria avançou em suas reformas administrativas 
internas. Promoveu a subdivisão das dez ARS's em trinta e um Distritos de Saúde. Os Distritos foram criados como unidades de planejamento $e$ organização de todas as ações de saúde a serem executadas no município. A tarefa de sua construção seria enorme mas, o desejo de um modelo de atenção à saúde racionalizado, além de mais humano e menos iníqüo, era desafiadora e estimulante.

Cada Distrito seria o produto de um conglomerado de Unidades de Saúde, UBS's, Hospital, Ambulatório de Especialidades, Pronto Socorro, responsável por uma determinada área de abrangência e contendo em média 200 a 300 mil habitantes. Dessa forma, estimava-se a implantação de 30 a 40 distritos em todo o municipio de São Paulo, no decorrer dos quatro anos de administração.

Formalmente, o Distrito de Saúde teria uma única gerência, com autonomia orçamentária e administrativa. Naturalmente, teriam que ser desenvolvidos novos instrumentos gerenciais de apoio ao planejamento, viabilização, manutenção e controle das ações desenvolvidas, como por exemplo um sistema unificado de informação ( referente à vigilância epidemiológica, à vigilância sanitária, à produtividade dos instrumentos, dos serviços, aos materiais, medicamentos, ao controle de qualidade ), um sistema de controle e gestão financeira, uma coordenação de recursos humanos. Foram essas as diretrizes que nortearam a implantação dos distritos.

\section{O Desenvolvimento dos Recursos Humanos}

A política de pessoal da Secretaria Municipal da Saúde assumiu alguns pressupostos básicos. Em primeiro lugar, a capacitação e a profissionalização do pessoal feita no sentido de resgatar, no trabalhador, a consciência de seu valor, não só pela melhoria do salário, mas também pela importância de sua prática. Tal premissa deu origem a inúmeras iniciativas de formação e desenvolvimento profissional, e propiciou a criação do Centro de Formação dos Trabalhadores da Saúde - CEFOR - em março de 1990. Este Centro organizou e desenvolveu cursos, oficinas de trabalho, seminários, reciclagens, treinamentos continuados, e outras formas de desenvolvimento de pessoal, tanto no interior de sua sede, como fora dela, sob a forma de assessorias junto às equipes de Recursos Humanos das ARS's e dos DS's. Participaram do processo coordenado pelo CEFOR outras instituições de 
ensino, como a Universidade de São Paulo, através do apoio de docentes da Faculdade de Saúde Pública, do Departamento de Medicina Preventiva da Faculdade de Medicina e do Departamento de Enfermagem em Saúde Coletiva da Escola de Enfermagem. Também se integraram ao processo de capacitação de pessoal, docentes do Departamento de Medicina Preventiva da Faculdade de Ciências Médicas da Universidade de Campinas ( UNICAMP ) e docentes do Departamento de Medicina Social da Faculdade de Ciências Médicas da Santa Casa de Misericórdia de São Paulo.

Através de um convênio celebrado entre a Secretaria Municipal de Saúde e a Cooperação Italiana, foram desenvolvidas formas alternativas de capacitação, denominadas Oficinas de Trabalho, disseminadas por toda a estrutura da Secretaria. As Oficinas concentraram suas atividades em três temáticas básicas: a Territorialização em Saúde, os Sistemas de Informação, e o Planejamento e Programação Local em Saúde.

O segundo pressuposto liga-se à democratização e ao desenvolvimento de consciências críticas, estimulados através da participação do funcionário em todo o processo de trabalho, desde o planejamento até a execução final. A tentativa era feita no sentido de liberar o trabalhador de práticas alienadas, devolvendo-lhe a capacidade de construção do conhecimento por meio de relações comunicativas e solidárias, entre seus pares e com a população. Isto é, através de um processo de construção coletiva entre os atores.

O pressuposto seguinte diz respeito à humanização do atendimento, subsidiada pela preocupação constante em desenvolver um modelo de atenção à saúde menos agressivo, baseado na relação entre trabalhador/ trabalhador e trabalhador/usuário.

O último pressuposto baseia-se no desenvolvimento de ações integradas interdisciplinarmente, tanto no processo de construção coletiva dos conhecimentos como na execução das práticas sanitárias.

Com o novo desenho organizacional em andamento, e com o processo de desenvolvimento de pessoal em curso, o Distrito de Saúde, passou a ocupar o centro das atenções da Secretaria, sendo considerado o principal núcleo de organização das ações e serviços frente às necessidades de saúde detectadas em cada nível local. 
Dentro dessa nova perspectiva, o corpo de dirigentes dos serviços de saúde vinha, gradativamente, recebendo o apoio da Secretaria para que suas carências gerenciais pudessem ser diminuídas. Estas se ligavam à necessidade de apropriação de metodologias e instrumentos gerenciais inovadores, que pudessem responder às diretrizes políticas, de um planejamento participativo, que prosperasse em direção a ações integradas, inclusive interssetorialmente, na lógica da construção dos sistemas locais de saúde.

A preocupação do comando central da Secretaria, nesse momento, era justamente dar conta das necessidades do pessoal do nível distrital/local. Distintas ações educativas foram desenvolvidas junto aos novos dirigentes, na tentativa de criar instrumentos e metodologias para novas práticas sanitárias, que tinham como doutrina, um conjunto de pressupostos voltados para o enfrentamento dos principais problemas de saúde de diferentes grupos populacionais, identificados a partir de suas inserções em distintos territórios/espaços-sociais.

O CEFOR esteve no comando das ações educativas desenvolvidas junto aos novos dirigentes. As ações de desenvolvimento de pessoal privilegiaram o trabalho com setores considerados estratégicos, por meio das seguintes atividades:

a. Formação geral e qualificação profissional dos trabalhadores de nível médio e elementar. Foram desenvolvidos o projeto Larga Escala, destinado à formação profissional do pessoal de nível médio e elementar, especialmente aos funcionários da SMS, o projeto Supletivo-Saúde, destinado à formação geral dos trabalhadores da saúde que não tivessem concluído o primeiro grau, por meio de um trabalho integrado com a Secretaria Municipal da Educação. Além destes, foram desenvolvidos Cursos de Estatística de Saúde, com cerca de 180 horas de duração, e participação aproximada de 250 alunos de nível médio.

b. Desenvolvimento gerencial através de cursos de aprimoramento e especialização, articulados com Instituições de Ensino Superior. Nessa linha de trabalho estão situados os Cursos de Especialização em Saúde Pública, os Cursos de Aprimoramento em Saúde Mental, em Saúde do Trabalhador e em Epidemiologia. 
c. Atividades de capacitação técnica e pedagógica destinadas às equipes envolvidas nas açōes de formação e desenvolvimento dos recursos humanos das ARS's, Distritos e Unidades de Saúde.

d. Apoio às atividades de reorganização dos serviços por meio do projeto denominado pesquisa-ação, que visou à produção de conhecimentos para a ação nos serviços e movimentos sociais, tendo em vista o enfrentamento das condições violentas de vida. Este projeto contribuiu para a implantação do Hospital Aberto, para a criação de Grupos de Orientação e Recepção à Demanda (GORD) e para a ampliação da rede de saúde mental, com a admissão de pessoal voltada para esse fim.

e. Criação de estruturas de apoio, em todos os níveis da rede, como as equipes de desenvolvimento de pessoal e as comissões de ensino.

Desse modo, o CEFOR e as equipes de recursos humanos das Administrações Regionais e dos Distritos, se envolveram com a capacitação de pessoal, respondendo às exigências da nova lógica de organização dos serviços e produção de ações de saúde.

Entre os vários exemplos de aplicação dessa política, ocorridos na rede da SMS, vale destacar aquele desenvolvido na Administração Regional de Saúde de Pirituba-Perus. Na ARS-8 desencadeou-se um projeto de desenvolvimento de pessoal distinto de outras regiões, com duração aproximada de 14 meses. Envolveu cerca de 270 pessoas, incluindo funcionários das Unidades Básicas de Saúde, dirigentes da ARS e dos Distritos de Saúde de Pirituba e Perus, e alguns representantes da comunidade. Docentes do Departamento de Enfermagem em Saúde Coletiva participaram da formulação e execução do projeto, através do Convênio de Integração Docente-Assistencial (PIDA), celebrado entre a Secretaria Municipal da Saúde e a Escola de Enfermagem da USP.

O trabalho permitiu a identificação dos problemas de saúde dos dois Distritos da ARS a partir de critérios epidemiológicos, ao mesmo tempo que permitiu o diagnóstico de toda a rede física dos distritos, de seus recursos humanos, materiais e financeiros. Houve uma tentativa incipiente de vincular esse quadro às políticas sociais e econômicas vigentes na época. Os participantes conseguiram identificar os principais problemas a serem trabalhados, o que possibilitou a revisão das ações de saúde e o ensaio de novas práticas sanitárias, assim como a identificação de procedimentos 
gerenciais e administrativos mais eficazes. Ao final dos 14 meses de trabalho, o conjunto de participantes ficou com a seguinte impressão: de que conseguiu realizar uma crítica ao modelo de atenção à saúde até então hegemônico, e propor um modelo mais adequado às novas necessidades descobertas; além disso, viabilizou o "aparecimento" de novos sujeitos, nas figuras de funcionários e representantes da população, mais aptos a compreender o quadro sanitário e repensar formas alternativas de planejamento em saúde. Concluiu-se que a metodologia aplicada facilitou a compreensão e a adesão dos funcionários às propostas de descentralização, regionalização e distritalização que estavam em curso na Secretaria.

No entanto, apesar das distintas iniciativas regionais, é provável que os maiores avanços alcançados no desenvolvimento do pessoal da Secretaria para as práticas sanitárias no campo da saúde coletiva, sejam decorrentes das denominadas Oficinas de Trabalho, realizadas em estreita parceria com a Cooperação Italiana. Iniciadas a partir do final de 1990 , as oficinas contaram com intensa participação do pessoal das Unidades de Saúde, dos Distritos, das ARS's e dos técnicos do nível central da SMS. Com elas, grande parte de servidores e representantes populares tiveram, muitos deles pela primeira vez, a oportunidade de se apropriar, de forma sistemática, de metodologias e técnicas adequadas à implantação de novos modelos de atenção à saúde, voltados para as necessidades básicas de saúde das diversas realidades locais onde os serviços se inseriam.

As Oficinas de Trabalho se concentraram em três temáticas básicas:

A Territorialização em Saúde, cuja metodologia enfocava o planejamento ascendente como estratégia de apropriação das especificidades de uma dada base territorial/local. A oficina desenvolvia um trabalho baseado em relações solidárias, estimulando a visão crítica dos participantes e oferecendo elementos básicos para o reconhecimento dos principais problemas da área de abrangência da Unidade de Saúde. A partir da delimitação dessa área, pensavam-se estratégias necessárias à prática da vigilância em saúde.

Os Sistemas de Informação em Saúde, oficinas que desenvolveram técnicas inovadoras na coleta e sistematização das informações. Os dados eram coletados entre os moradores da região e distribuídos espacialmente, organizados por micro-áreas-homogêneas segundo suas condições de vida. 
Esta forma de trabalhar com as informações desagregadas, atendia às necessidades da Secretaria estimulando ações integradas, participativas e intersetoriais.

O Planejamento e a Programação Local em Saúde, que buscava operacionalizar as ações de saúde para enfrentar os problemas de saúde identificados. Baseava-se em informações processadas pelas duas oficinas anteriores, seja a nivel distrital, seja no âmbito das Unidades de Saúde.

As oficinas abriram perspectivas inovadoras para a capacitação do pessoal, para a transformação da lógica de organização dos serviços e para a execução das ações de saúde. Gradativamente começava a ser incorporada pelos servidores da Secretaria a prática da vigilância à saúde, entendida como um conjunto de ações intersetoriais voltadas para a detecção dos fatores determinantes dos principais problemas de saúde de uma dada área, sem prescindir da assistência à demanda individual.

A metodologia que se adotou para o desenvolvimento do pessoal, visava uma mudança do objeto de análise e de intervenção. Desejava-se construir um projeto de trabalho integrado e articulado com outros setores sociais, construído a partir de uma rede de relações solidárias entre os serviços, os funcionários e os movimentos sociais. Os projetos comuns, que reunissem várias Secretarias, pensava-se, alcançariam maior impacto social.

Esse processo de desenvolvimento de pessoal produziu impactos no corpo gerencial da SMS. Fundamentalmente contribuiu para reforçar as estratégias para enfrentar os grandes problemas de saúde da população. Pode-se arriscar a afirmar, em razão dos resultados dos debates públicos, de encontros e conferências municipais de saúde, que entre o pessoal da saúde, ficava a impressão, subjetiva, que os grandes problemas de saúde não eram decorrentes da falta de novas tecnologias de intervenção para o enfrentamento dos mesmos, especialmente aqueles referenciados às populações mais sujeitas às iniqüidades. A adoção da estratégia conjunta partia da constatação de que a origem de muitos dos problemas estava fora do setor saúde, pois decorria das grandes desigualdades e da exclusão social, que, para serem combatidas, dependiam de mecanismos de intervenção de natureza essencialmente política. Constatava-se que a superação das dificuldades do setor saúde, dependia não de novas tecnologias de intervenção, mas da transformação do processo de trabalho e 
da superação das barreiras que impediam o trabalho integrado a outros setores do governo e da sociedade civil. O que faltava, portanto, era um projeto comum e integrado de trabalho, com força suficiente para envolver várias áreas sociais e a própria comunidade na busca de solução aos problemas mais comuns. Decorre daí a grande ênfase à participação social que norteou os quatro anos do governo Luiza Erundina.

\section{A Participação Social}

O compromisso com as diretrizes do Sistema Único de Saúde, conduziu a Secretaria a um projeto de promoção da cidadania, que possibilitava aos funcionários e à população, interferir nos rumos da política de saủde do município.

Era uma forma de ampliar a consciência sanitária de cidadãos e funcionários.

O modelo de assistência baseado na visão médico-hospitalar, historicamente hegemônico na rede municipal, começou a ser revisto exatamente a partir do momento em que novos sujeitos - funcionários e população - puderam participar da definição das políticas de saúde na cidade de São Paulo.

O modelo de participação mais desenvolvido na SMS foi organizado na forma de representações tripartites, conhecidas pelo nome de Conselhos de Saúde ou Comissões Gestoras, instalados em todas as esferas da Secretaria, do centro à periferia da cidade.

No âmbito do Gabinete do Secretário, por exemplo, constituiu-se o Conselho Municipal de Saúde, cujos componentes eram eleitos pela Plenária Municipal de Saúde. O CMS, de caráter deliberativo, foi nesse período o órgão decisório máximo das políticas municipais de saúde. Sua composição se modificou no decorrer da administração, chegando assumir a seguinte proporção: $50 \%$ de representantes da sociedade civil, $25 \%$ de representantes dos trabalhadores e produtores de serviços de saúde e os demais $25 \%$ de representantes da administração municipal. 
$\mathrm{Na}$ foto da página seguinte, o momento de posse do Conselho Municipal de Saúde, durante a realização da II Conferência Municipal de Saúde. Anhembi, São Paulo, maio de 1991.

A Plenária Municipal de Saúde era uma Plenária de Entidades e Movimentos Interessados nas Questões de Saúde do Municipio de São Paulo. Desse espaço, aberto à participação de qualquer entidade, instituição ou movimento social, saíam os candidatos a integrar o Conselho Municipal de Saúde. A Plenária chegou a contar com a participação de mais de duzentos Entidades e/ou Movimentos, tendo em suas reuniões mensais a participação média de oitenta setores representados.

Também junto ao Gabinete do Secretário foi criado o Conselho de Orientação do Fundo Municipal de Saúde - FUMDES - com representação da administração pública municipal, de vereadores da câmara municipal de São Paulo, do conselho municipal de saúde, dos servidores públicos e dos movimentos populares. A missão do Fumdes era a de fiscalizar e controlar o uso dos recursos financeiros destinados à Secretaria Municipal de Saúde.

No âmbito das ARS's, DS's e Unidades de Saúde passaram a funcionar as Comissões Gestoras tripartites, também de caráter deliberativo e com a mesma representação proporcional do Conselho Municipal de Saúde. De um total possivel de 200 Comissões, considerando-se o número total de Unidades de Saúde, Distritos e Administrações Regionais, acabaram sendo implantadas pouco mais de uma centena de Comissões Gestoras. É um número expressivo numa Secretaria que não tinha tradição em participação popular.

Às páginas 60 e 61 observam-se por representações esquemáticas, as posições dos Conselhos Gestores em todos os níveis da Secretaria Municipal da Saúde e as características das instâncias de decisão. 


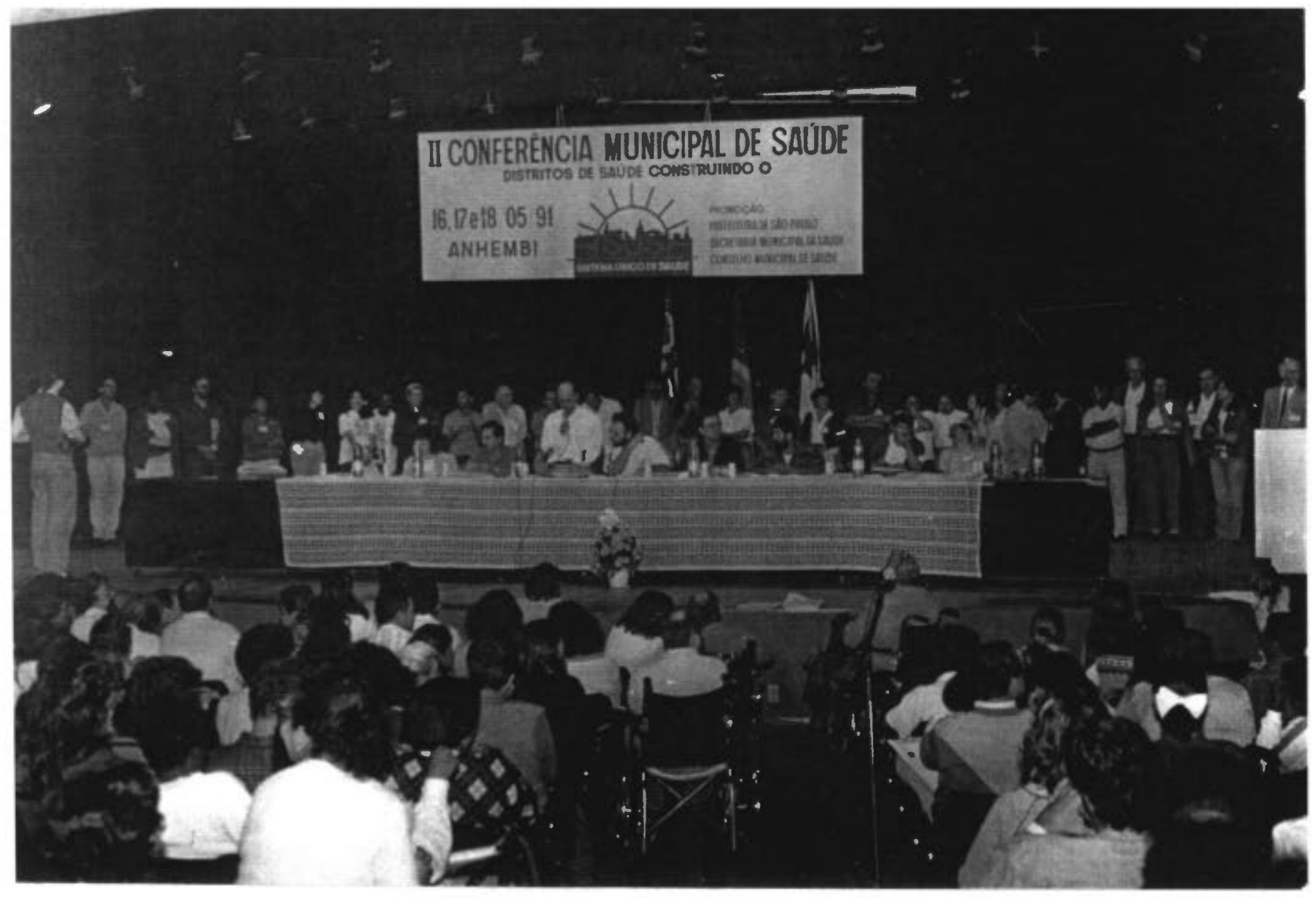

Momento de posse do Conselho Municipal da Saúde, durante a II Conferência Municipal. Anhembỉ, São Paulo, maio de 1991. 
Estrutura Organizacional da Direção da Secretaria Municipal de Saúde, São Paulo, 1989-92.

Características das Instâncias de Decisão:

\begin{tabular}{|c|c|c|c|c|}
\hline $\begin{array}{l}\text { Tipos } \\
\text { de } \\
\text { colegia- } \\
\text { dos }\end{array}$ & $\begin{array}{l}\text { Colegiado } \\
\text { com } \\
\text { representação } \\
\text { externa à SMS }\end{array}$ & $\begin{array}{c}\text { C. Individual } \\
\text { Funcionário } \\
\text { da } \\
\text { Secretaria }\end{array}$ & $\begin{array}{l}\text { Colegiado } \\
\text { com } \\
\text { representação } \\
\text { interna à SMS }\end{array}$ & $\begin{array}{l}\text { Colegiado } \\
\text { com } \\
\text { representação } \\
\text { interna à SMS }\end{array}$ \\
\hline caráter & $\begin{array}{c}\text { caráter } \\
\text { deliberativo }\end{array}$ & $\begin{array}{c}\text { caráter } \\
\text { executivo }\end{array}$ & $\begin{array}{c}\text { caráter } \\
\text { deliberativo }\end{array}$ & $\begin{array}{c}\text { caráter } \\
\text { consultivo }\end{array}$ \\
\hline $\begin{array}{c}\text { nivel } \\
\text { central }\end{array}$ & $\begin{array}{l}\text { Plenária e } \\
\text { Conselho } \\
\text { Municipal de } \\
\text { Saúde }\end{array}$ & $\begin{array}{l}\text { Secretário } \\
\text { Municipal da } \\
\text { Saúde }\end{array}$ & $\begin{array}{c}\text { Conselho } \\
\text { Técnico } \\
\text { Administrativo } \\
\text { Gabinete }\end{array}$ & $\begin{array}{l}\text { Assessoria } \\
\text { Técnica de } \\
\text { Planejamento } \\
\text { Gabinete }\end{array}$ \\
\hline $\begin{array}{c}\text { nivel } \\
\text { regional }\end{array}$ & $\begin{array}{l}\text { Comissão } \\
\text { Gestora }\end{array}$ & $\begin{array}{c}\text { Diretor da } \\
\text { Administraçã } \\
\text { o Regional de } \\
\text { Saúde }\end{array}$ & $\begin{array}{c}\text { Conselho } \\
\text { Técnico } \\
\text { Administrativo } \\
\text { da ARS }\end{array}$ & $\begin{array}{c}\text { Assistência } \\
\text { Técnica } \\
\text { da ARS }\end{array}$ \\
\hline $\begin{array}{c}\text { nivel } \\
\text { distrital }\end{array}$ & $\begin{array}{l}\text { Comissão } \\
\text { Gestora }\end{array}$ & $\begin{array}{c}\text { Diretor } \\
\text { do Distrito } \\
\text { de Saúde }\end{array}$ & $\begin{array}{c}\text { Conselho } \\
\text { Técnico } \\
\text { Administrativo } \\
\text { do Distrito }\end{array}$ & $\begin{array}{c}\text { Assistência } \\
\text { Técnica } \\
\text { do Distrito }\end{array}$ \\
\hline $\begin{array}{l}\text { nivel } \\
\text { local }\end{array}$ & $\begin{array}{c}\text { Comissão } \\
\text { Gestora }\end{array}$ & $\begin{array}{c}\text { Diretor } \\
\text { da Unidade } \\
\text { de Saúde }\end{array}$ & $\begin{array}{c}\text { Conselho } \\
\text { Técnico } \\
\text { Administrativo } \\
\text { da Unidade }\end{array}$ & $\begin{array}{c}\text { Assistência } \\
\text { Técnica } \\
\text { da Unidade }\end{array}$ \\
\hline
\end{tabular}


Estrutura Organizacional da Direção da SMS - SP

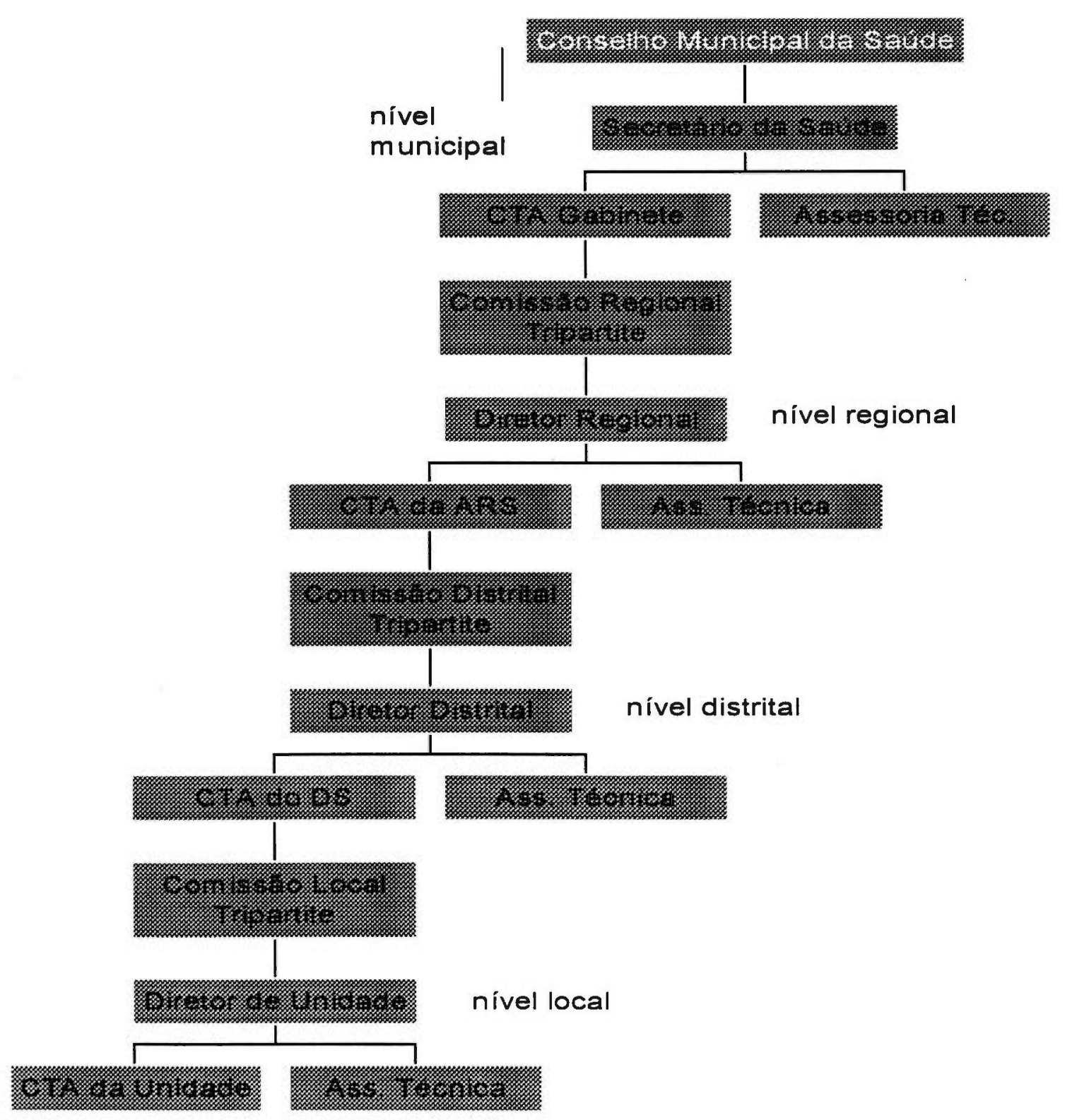


Com exceção de algumas regiões onde há anos vinham se desenvolvendo movimentos populares autônomos, na maior parte da SMS a implantação das Comissões Gestoras se deu por iniciativa dos próprios dirigentes. O processo de implantação não ocorreu com a mesma intensidade e velocidade nas dez ARS's. Os avanços foram mais significativos onde já havia algum tipo de organização de funcionários e/ou de movimentos populares. A título de exemplo, na Administração Regional de Saúde de Pirituba-Perus, ARS-8, oito Comissões Gestoras chegaram a ser constituídas, de um total de doze possíveis. Nos momentos de tomada de decisão sempre pesou mais o segmento representado pela administração. A impressão que tivemos foi a de que a representação popular ou confiava demais nas boas intenções da Secretaria, ou não estava suficientemente organizada para participar em pé de igualdade dentro do modelo proposto. O segmento representado pelos funcionários era o menos presente, e ao contrário da representação popular, parecia não confiar muito na administração. Diziam os servidores que não queriam participar do processo "para não serem cooptados". Mas participavam. Apesar de manterem um certo distanciamento dos conselhos gestores, postura que foi se acentuando no decorrer do tempo.

Algumas comissões gestoras foram compostas por meio de eleições diretas. Outras, a partir de lideranças já estabelecidas, que se apresentavam voluntariamente para representar a população nas comissões. Como se pode perceber pelo relato, não houve homogeneidade na forma de implantação das comissões gestoras no âmbito daquela regional de saúde. Processos semelhantes ocorreram nas outras administrações regionais. Quanto aos Conselhos Gestores, sua área de competência era a definição das políticas municipais de saúde e 0 acompanhamento de sua implementação pela Secretaria.

A seguir, duas ilustrações sobre momentos de discussão e votação numa Conferência Municipal de Saúde. 


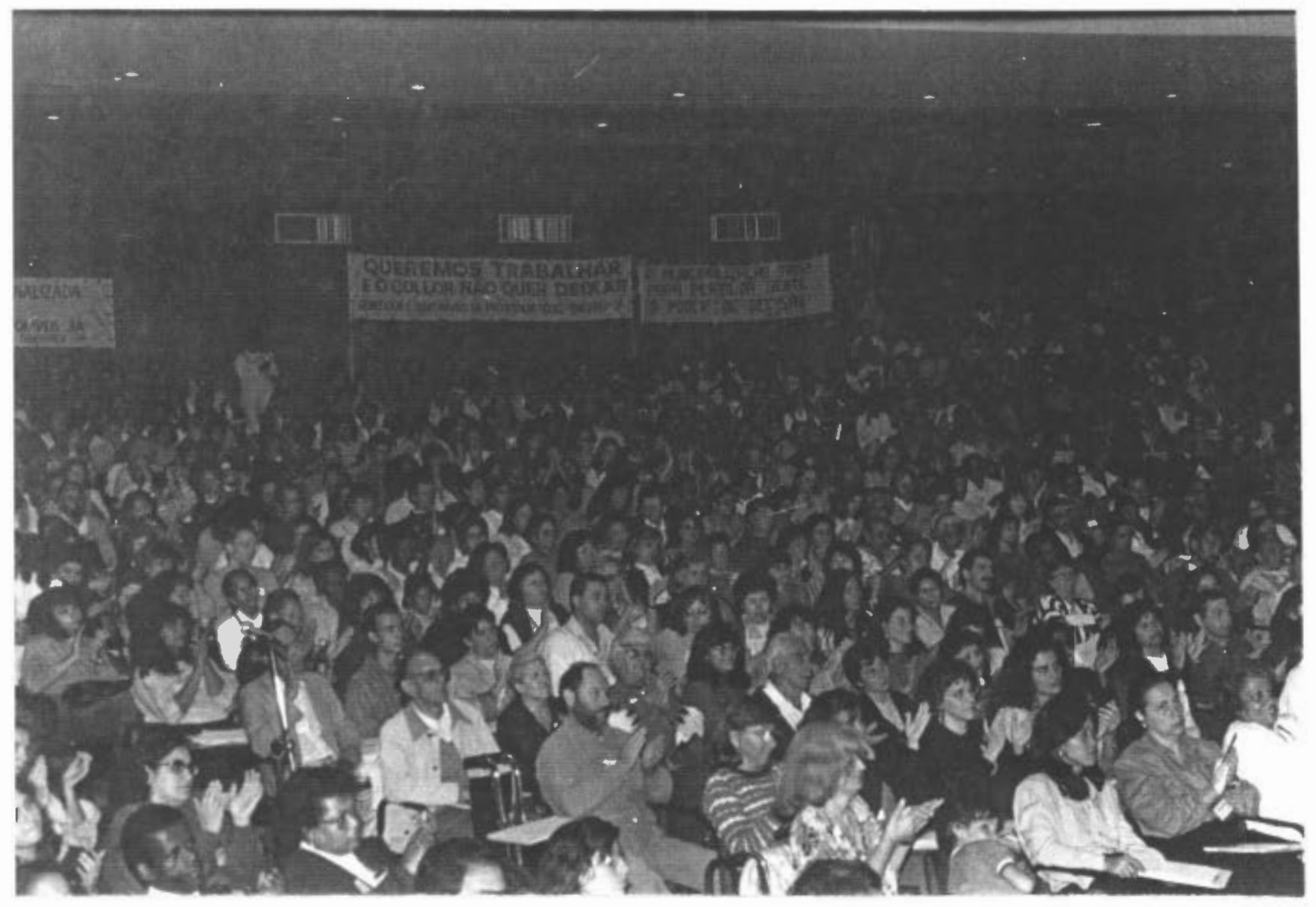

Plenāria Final da II Conferência Municipal da Saúde. Anhembi, São Paulo; maio de 1991. 


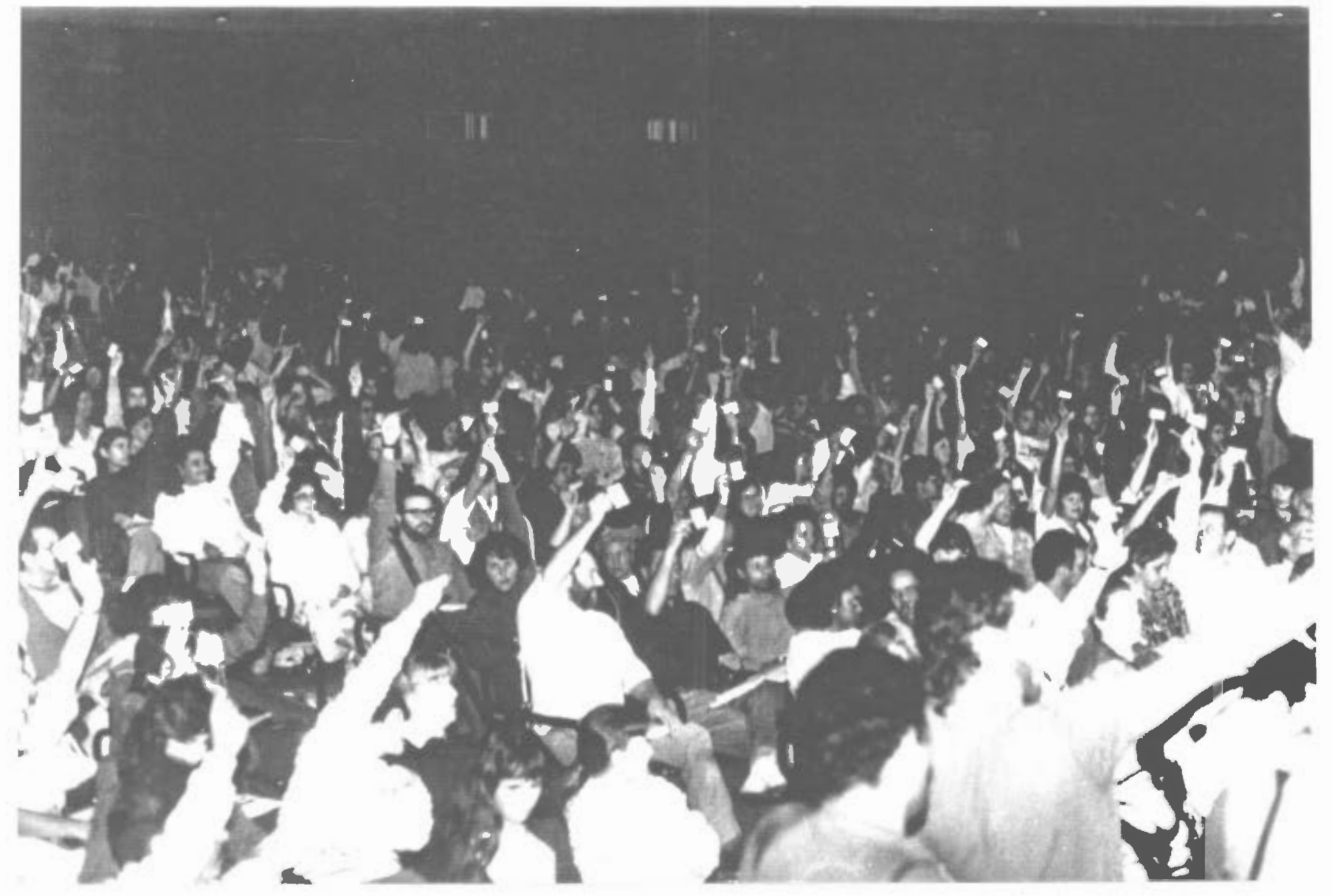

Momento de votação durante a Plenāria Final. II Conferência Municipal de Saúde. Anhembi, são Paulo, maio de 1991. 


\section{O Sistema de Informação em Saúde}

O sistema de informação em saúde foi concebido pela Secretaria como um instrumento gerencial. Enquanto tal, esteve em consonância com as diretrizes da política municipal de saúde e com o modelo de reorganização dos serviços. Foi organizado em função do processo de municipalização, regionalização e distritalização da rede de serviços da Secretaria Municipal da Saúde, visando contribuir para a implementação do Sistema Único de Saúde no município de São Paulo.

A base conceitual do novo modelo de atenção à saúde preconizado pela Secretaria pressupunha o trabalho permanente de Vigilância à Saúde nas áreas de abrangência das Unidades e dos Distritos de Saúde. Para que esse trabalho pudesse ser desenvolvido, os indicadores propostos para o Sistema Municipal de Informação em Saúde (SIMIS) seriam instrumentos gerenciais voltados para: planejar as ações de saúde a partir de critérios epidemiológicos nas Unidades, Distritos e Administrações Regionais de Saúde; administrar os recursos humanos, materiais e financeiros da SMS; promover a articulação e comunicação interna e externa à Secretaria; subsidiar o Conselho Municipal e as Comissões Gestoras de Saúde, e avaliar as ações desenvolvidas.

Com esse intuito, o Centro de Epidemiologia Pesquisa e Informação (CEPI) órgão ligado ao Gabinete da Secretaria, juntamente com equipes regionais, distritais e locais, comandou o processo de implantação do SIMIS com o objetivo de: desenvolver o Sistema a partir de indicadores epidemiológicos, de serviços, administrativos, sociais e também a partir da construção de "novos indicadores"; construir uma base estrutural de informações na Secretaria, para coleta, organização, sistematização e análise de dados.

A estrutura do SIMIS ficou definida da seguinte forma:

A nivel central o Centro de Epidemiologia, Pesquisa e Informação em Saúde (CEPI) e em cada Distrito de Saúde, o Núcleo de Epidemilogia, Pesquisa e Informação (NEPI). 
Coube ao CEPI coordenar a implantação do SIMIS, trabalhando de forma integrada com as demais estruturas regionais e distritais da Secretaria, particularmente com os NEPI's de cada Distrito e com os representantes de Unidades de Saúde.

O processo padronizou as informações e criou indicadores de saúde imprescindiveis para cada esfera decisória. Antes dessa nova organização da informação, os dados produzidos pelos serviços acumulavam-se e deixavam de se transformar em informação, não podendo ser operados para se transformarem em instrumentais de gerencia ou de decisão. Criava-se um círculo vicioso: por não se lidar com informação, não se aprendia; por não se saber lidar com a informação, ela não tinha valor de uso e não era incorporada ao dia-dia das atividades. Para evitar que a informação continuasse a se apresentar de forma fragmentada no interior dos serviços, o sistema de informação em saúde foi repensado a partir de cinco áreas temáticas: área de análise da situação de saúde ( voltada para a identificação dos problemas de saúde das distintas bases territoriais), área da vigilância em saúde ( voltada para a revisão das práticas, tendo como eixo norteador a metodologia da apropriação da base territorial, uma vez que o território local vinha sendo considerado um espaço estratégico para a mudança do modelo de atenção à saúde), área de epidemiologia de serviços ( que contribuía para estudos de acessibilidade, análises quantitativas e da qualidade dos serviços), área de projetos especiais e área de apoio em informática. Diante do exposto, pode-se perceber que os principios que nortearam a organização da informação na Secretaria foram os da descentralização e da unificação das áreas, promovendo a democratização dos mecanismos de comunicação tanto interna como externa à Secretaria.

O SIMIS-SP estimulou a pesquisa de novas metodologias de informação em saúde. A esse respeito, foram desenvolvidos inúmeros cursos, visando à capacitação do pessoal para o uso da informação e sua incorporação no cotidiano do planejamento ${ }^{33}$. Desse modo, a informação em saúde passou a ter um valor estratégico para a transformação das práticas.

\footnotetext{
3: Destacamos alguns dos projetos que constam do documento Prefeitura do Municipio de São Paulo. Secretaria Municipal da Saúde. Centro de Epidemiologia Pesquisa e Informação (CEPI). mimeo. 1992: 1. Área de Análise da Situação de Saúde - área que agregou programas voltados para a análise das condições de vida e de saúde no municipio. Exemplos:
} 


\subsection{Programa de informações de mortalidade no município de São Paulo - PROAIM.}

O PROAIM produziu informaçōes sobre mortalidade. necessárias para o planejamento. a vigilància e a avaliação das açōes de saúde. Este programa melhorou a qualidade das informaçôes sobre montalidade e estimulou seu uso como subsidio para planejamento ascendente em saúde. O programa proporcionou mudanças no uso das informaçōes e gerou subprogramas como: - integração com a Universidade para estudos e pesquisas sobre as principais causas de morte: - realização de Diagnósticos de Saúde Descentralizados por áreas de abrangência de Unidades e Distritos de Saúde.

\subsection{Programa Diagnóstico de morbidade.}

A finalidade deste programa foi o de analisar as morbidades registradas nas Unidades de Saude. Foram feitos levantamentos trimestrais dos atendimentos realizados na rede da Secretaria

1.3. Programa "Sistemas de Informaçōes Geográficas": foram adquiridos softwares para a espacialização das informações de mortalidade e de equipamentos sociais.

2. Área de Epidemiologia de Serviços - área do CEPI que se responsabilizou pela implantação do SIMIS na rede de serviços da Secretaria. assim como pelo controle do SIA/SUS (Sistema de Informação Ambulatorial do SUS) e o SIH/SUS (Sistema de Internação Hospitalar do SUS). Trabalhou com documentações de desempenho qualitativo e quantitativo dos serviços. Alguns exemplos:

\subsection{Programa Módulo Ambulatorial -}

Os objetivos deste programa foram: - produzir relatórios estatísticos sobre a produtividade dos serviços

( rendimento. cobertura e concentração). - produzir e acompanhar indicadores de qualidade. - subsidiar os procedimentos do SIA/SUS. As informações trabalhadas eram provenientes das Unidades Básicas de Saúde. dos Ambulatórios de Especialidades. dos Centros de Referência e de outros serviços da rede ambulatorial

2.2. Programa Urgência/Emergência - a finalidade foi a mesma do item anterior. mas estava voltado para os atendimentos de urgência/emergência dos Pronto-Socorros e Pronto-Atendimentos.

\subsection{Programa Módulo de Internação}

Este programa teve por objetivo a coleta. consolidação e análise das informações relativas às Unidades de Internação. Nesse caso trabalhou-se com: - indicadores da produtividade hospitalar. - indicadores da morbimortalidade hospitalar

3. Área da Vigilância à Saúde - área que englobou os programas referentes ao acompanhamento e monitoramento dos agravos à saúde. Alguns de seus subprojetos foram:

3.1. Sistema de Vigilància à Saúde - voltado para o desenvolvimento de ações interssetoriais relativas ao monitoramento e controle de agravos à saude e seus fatores determinantes

3.2. Vigilância das doenças de notificação compulsória.

3.3. Controle de Zoonoses

3.4. Vigilāncia Sanitária

4. Área de Projetos Especiais - área destinada a desenvolver projetos de duração limitada. Exemplos: 


\section{VI.2. Estratégia para implantação do novo modelo de atenção à saúde.}

Com o processo de distritalização da Secretaria, ficou mais fácil visualizar as desigualdades existentes. Com as informações desagregadas por distritos e micro-áreas, as equipes distritais e locais conseguiram ver com mais clareza as desigualdades e identificar os principais problemas de saúde. Estes problemas começaram a ser incorporados pelos funcionários como decorrentes de uma situação de deteriorização das relações sociais, vivida sob o impacto da violência urbana ${ }^{34}$. Entre julho e dezembro de1990, 12,9\% da mortalidade do município de São Paulo foi devida a causas externas, como homicídios e acidentes. As causas externas variavam de região para região, com um índice de $7,4 \%$ entre os moradores da região central, contra 17,8\% nas regiões periféricas de Campo Limpo e Parelheiros. As mesmas informações, desagregadas por faixa etária, mostravam uma nova dimensão da mesma realidade: a violência era o principal motivo de morte entre a faixa etária de 01 e 60 anos para o sexo masculino, notadamente na periferia do município. Naquele ano, as causas perinatais foram as principais responsáveis pela mortalidade infantil (ainda o são) e em sua maioria, também foram consideradas morte violenta, uma vez que, na maioria das vezes, seriam evitáveis, fato que denunciava as péssimas condições de natalidade no município de São Paulo. A situação da mortalidade materna ia na mesma direção, apresentando números assustadores. Além dos "acidentes" de trabalho, que pela sua previsibilidade e repetição mereceriam outro nome, as condições violentas de vida eram retroalimentadas pelo persistente reaquecimento de endemias, como a tuberculose, a hanseníase, a meningite e a ameaça de retorno do dengue e do cólera.

Esta constatação levou o corpo gerencial da Secretaria definir os problemas decorrentes das condições violentas de vida como eixo aglutinador do processo de transformação do modelo de atenção à saúde. A partir desse

4.1. Projeto "Capacitação de Recursos humanos em Epidemiologia e Informação"

Composto por Cursos. Oficinas de Trabalho e treinamentos para o desenvolvimento do pessoal. realizados em parceria com outras Instituições. como a Faculdade de Saúde Pública. a Escola de Enfermagem. a Faculdade de Medicina ( todas da Universidade de São Paulo ) e o Departamento de Medicina Preventiva e Social da UNICAMP. ( texto do CEPI. sem data. mimeo ).

\footnotetext{
${ }^{34}$ Prefeitura do Município de São Paulo. Secretaria Municipal da Saúde, Distritalização do municipio de São Paulo - estatégia para implantaçâo do SUS, p. 1. mimeo.
} 
eixo seriam praticadas ações integradas junto a outros setores governamentais articulados regionalmente. A intenção era a de oferecer, através de políticas públicas, respostas que viessem a fazer frente a essas condições de violência social, instaladas na cidade. Segundo a concepção de saúde do grupo dirigente, o quadro de violência nas condições de vida e de trabalho estava associado aos diferentes modos de viver, adoecer e morrer.

Utilizando como estratégia o combate às condições de violência urbana, a Secretaria tratou de implementar sua política de saúde. Procurou desenvolver ações coletivas sobre o corpo social e não apenas práticas de saúde sobre o indivíduo doente. Questionava-se a validade de uma prática de saúde voltada prioritariamente para o atendimento individual, para o combate aos efeitos de uma política geradora de violências e injustiças sociais. De que adiantava, por exemplo, criar bons prontos-socorros para o atendimento aos politraumatizados no caótico trânsito da cidade, sem se pensar numa política de transporte e uso civilizado do espaço público? De que adiantava serem criados os Centros de Referência de Saúde do Trabalhador, sem uma efetiva intervenção nos ambientes e processos de trabalho, geradores das condições que determinam o grave quadro da saúde ocupacional no município? 0 mesmo raciocínio poderia ser aplicado à situação dos homicidios na capital, resguardadas as especificidades dessa complexa questão.

O grande desafio da Secretaria era romper a barreira de um modelo de atenção à saúde hegemônico, individualista e centrado na assistência médica. Buscava-se um novo paradigma, pois a assistência médica em si não "resolve nossos problemas de saúde, não produz impactos epidemiológicos no quadro de morbimortalidade, não promove as condições de vida e saúde" ${ }^{135}$, embora, reconhecidamente seja necessária e indispensável no plano individual, especialmente às pessoas em situações que exigem um atendimento de urgência e/ou emergência.

"O profissional e o técnico se mesclam ao pessoal e ao político nas relações das instituições de saúde com a população. Esta se torna objeto de trabalho, se torna usuária dos serviços de saúde. Como se dá e quais os resultados desta relação? O usuário leva seu carecimento ( que é de várias ordens e expresso de maneira diferente e singular) a uma instituição que, em geral, o reduz a sua dimensão biológica individual, através do instrumental

\footnotetext{
${ }^{35}$ Prefeitura do Município de São Paulo. Secretaria Municipal da Saúde. Documento Municipalização mimeo, p. 3
} 
clínico e produz um juizo de valor em termos do que é normal ou patológico. Do que é ou não reconhecido como demanda legítima e de que tipo de atenção. Esta argumentação não é nova e baseia o conceito de medicalização da sociedade, enquanto um projeto de dominação articulado nos demais dispositivos de controle ${ }^{136}$

O problema de enfrentamento da violência urbana ganhou força em outros setores do governo municipal, reenergizando as intervenções da Secretaria da Saúde e das ações intersecretariais

Um bom exemplo dessa mescla é o da Secretaria Municipal da Cultura, cuja Secretária, a filósofa Marilena Chaui, afirmava... "entendemos por violência uma realização determinada das relações de força, tanto em termos de classes sociais quanto em termos interpessoais. Em lugar de tomarmos violência como violação e transgressão de normas, regras e leis, preferimos considerá-la sob dois outros ângulos. Em primeiro lugar, como conversão de uma diferença e de uma assimetria numa relação hierárquica de desigualdade com fins de dominação, de exploração e de opressão. Isto é, a conversão dos diferentes em desiguais e a desigualdade em relação entre superior e inferior. Em segundo lugar, como a ação que trata um ser humano não como um sujeito, mas como uma coisa. Esta se caracteriza pela inércia, pela passividade e pelo silêncio, de modo que, quando a atividade e a fala de outrem são impedidas ou anuladas, há violência'137.

A opção por esta problemática se deu, em primeiro lugar devido à forte expressão da violência no cotidiano da cidade e, em segundo, porque esse tema poderia mobilizar novas forças sociais, que poderiam concorrer para 0 sucesso das reformas administrativas mais amplas, há muito almejadas pelo governo municipal. No âmbito da Secretaria algumas propostas para o enfrentamento das condições de violência urbana concretizaram-se por meio da implantação do Hospital Aberto, da Política Antimanicomial, dos HospitaisDia para portadores de sofrimento mental, dos Centros de Convivência e Cooperativa, dos Centros de Referência de Saúde do Trabalhador, dos Comitês de Mortalidade Materna, das Emergências Psiquiáticas em todos os prontos-socorros municipais, entre vários outros programas e serviços. Para melhorar a qualidade da assistência, houve uma expressiva expansão do quadro de pessoal, praticamente dobrando o número de funcionários em

\footnotetext{
${ }^{36}$ Idem ibidem

3-Documento Distritalização do Município de São Paulo. opus cit.. p. 2.
} 
quatro anos de administração, de 24 para 40 mil servidores. O acréscimo de 16.000 incluiu mais de 3.000 médicos, mais de 1.400 enfermeiros e cerca de 2.000 outros profissionais universitários, como psicólogos, fonoaudiólogos, fisioterapeutas, terapeutas ocupacionais, assistentes sociais, educadores, odontólogos, sociólogos, além de 5.000 auxiliares de enfermagem. Em 1989 a cidade tinha 184 Unidades de Saúde. A rede cresceu em mais 111 unidades. O governo concluiu e inaugurou 6 novos Hospitais, implantando novas unidades ambulatoriais, com a municipalização de 51 outras unidades de saúde provenientes do governo estadual.

Com o apoio em estudos epidemiológicos, quatro programações foram escolhidas como modelo de ações em saúde para o enfrentamento da violência urbana: programa de intervenção sobre a morbimortalidade maternoinfantil, programa de intervenção sobre os acidentes de trabalho, programa de intervenção sobre os acidentes e programa de intervenção sobre a violência institucional.

\section{O Programa de Intervenção sobre a Morbimortalidade Materno- Infantil.}

É incrível que uma cidade da expressão de São Paulo, em pleno ano de 1989, ainda tivesse "médicos socorristas" nas portas dos prontos-socorros Municipais, atendendo todo e qualquer tipo de demanda. Somente a partir desse ano, os pediatras passaram a atender às crianças e os tocoginecologistas às patologias específicas. O mesmo acontecendo em relação a outros problemas. Todas as Unidades de Saúde passaram a contar com profissionais especializados na área. $A$ ampliação das ações programáticas para a mulher e criança, foi acompanhada por modificações no ambiente físico dos serviços de saúde, com o implemento do número de leitos de obstetricia e ginecologia. Comitês de Estudo e Prevenção de Mortalidade Materna foram implantados nas 10 ARS's. Investiu-se no desenvolvimento de pessoal para a melhoria da qualidade do atendimento ao recém-nascido. Como conseqüência dessas medidas, observou-se uma expressiva queda da mortalidade, particularmente em relação aos coeficientes de mortalidade perinatal e neo-natal precoce, nos berçários dos Hospitais Tide Setúbal, Campo Limpo e Vila Nova Cachoeirinha. A Terapia de Reidratação Oral foi implantada em todas as Unidades de Urgência e na Rede Básica 
Ambulatorial, contribuindo sobremaneira para o controle dos casos de diarréia, mais freqüentes na faixa etária inferior a um ano de idade.

O Programa de Intervenção Sobre os Acidentes de Trabalho visou à promoção das condições de saúde e à aplicação de todos os níveis de medidas preventivas aos acidentes em trabalhadores. Alguns Distritos de Saúde criaram os Centros de Referência de Saúde do Trabalhador (CRST's ), responsáveis pelo atendimento, diagnóstico e tratamento das doenças profissionais. Além deles, em todas as dez administrações regionais de saúde foram escolhidas UBS's responsáveis pelo atendimento ao acidentado de cada região, especialmente destinadas a realizar pequenas suturas, atender a queimaduras leves, contusões, curativos, além de fazer o seguimento ambulatorial. A todas as Unidades foram definidas reponsabilidades frente aos acidentes de trabalho que, assim que ocorressem, seriam notificados aos Núcleos de Epidemiologia, Pesquisa e Informação ( NEPI's ) e CRST's de cada Distrito de Saúde.

Os Programas de Intervenção sobre as Violências em Geral e sobre a Violência Institucional em particular, podem ser vistos dentro do quadro sanitário que caracteriza a cidade, onde prevalecem condições violentas de vida. Isto torna necessária a existência de uma rede de serviços de saúde mais humanizada e adaptada ao perfil de morbimortalidade prevalente. Com a expansão da rede e do quadro, e com a diversificação do pessoal, surgiram outras novas propostas de trabalho na linha de promoção da cidadania e produção da saúde.

Veja-se alguns excertos das propostas de "Hospital Aberto" contidos no documento "Distritalização do Município de São Paulo- estratégia para a implantação do Sistema Único de Saúde: ..."o Hospital Aberto é um instrumento concreto de viabilização de um novo modelo de saúde(...).(... A democratização dos serviços, sua abertura à participação dos usuários e o reconhecimento do caráter social do processo saúde-doença, podem ser melhor trabalhados a partir desta proposta.(...). A entrada do acompanhante no espaço hospitalar pode ser considerada como elemento desencadeante $e$ organizador de novas posturas da equipe de saúde frente ao paciente, que não poderia apenas ser visto como um corpo enfermo. Isto porque a relação estabelecida entre pacientes e acompanhante, elo com o mundo exterior, faz com que os envolvidos no processo de trabalho (paciente, acompanhante e 
trabalhador) se recoloquem como novos sujeitos de um processo coletivo em saúde... A proposta de Hospital Aberto tem dois eixos norteadores: um é a humanização das ações intra-hospitalares e outro são as políticas de desospitalização... Os conflitos gerados pelas novas situações, tanto para os pacientes e acompanhantes como, e principalmente, para os trabalhadores de saúde, devem ser explicitados e superados dentro de um processo permanente de discussão e reelaboração dos papéis dos sujeitos implicados, buscando a construção de uma nova ética institucional comprometida com o processo mais geral de transformação social ${ }^{198}$...

Um aspecto que pouco avançou, pelo menos em sentido práticooperacional, foi o do atendimento às emergências, feito através do sistema de resgate de pacientes. A Secretaria foi generosa na concepção de um projeto de restruturação do Sistema de Resgate, com a ampliação da frota de ambulâncias, devidamente equipadas para $O$ atendimento às urgências. Ao mesmo tempo, foram preparadas Equipes Especiais para este trabalho. Treinadas exclusivamente para o sistema, as equipes eram compostas por motorista, auxiliar de enfermagem e operadores do sistema de Rádiocomunicação com cerca de 420 funcionários treinados para esse fim. A despeito da concepção e do treinamento de pessoal, a implantação prática do modelo foi muito tardia, acontecendo apenas no final do governo.

${ }^{38}$ Idem ibidem, p. 41-46. SMS. 
CAPITULO III

\section{A PERCEPÇÃO COLETIVA.}

Os discursos de cada um, as idéias centrais, as ancoragens e a construção do discurso do sujeito coletivo.

\section{Análise das informações dos funcionários ${ }^{39}$}

O objetivo deste capítulo foi o de organizar os discursos, com o intuito de captar a percepção coletiva dos funcionários e cidadãos/usuários sobre as questões da pesquisa. Para realizar esse recorte, levei em conta, fundamentalmente, o que se chama de "ancoragem" (Simioni ${ }^{40}$ ) ou seja, a base de sustentação do discurso de cada um dos entrevistados, bem como a idéia central que norteou os depoimentos.

Feita essa seleção individual, passei à identificação do "discurso do sujeito coletivo", ou seja, do agrupamento das falas particulares a partir da ênfase nas quatro categorias temáticas discriminadas anteriormente: o modelo de atenção à saúde, a democratização e participação social, o trabalho integrado, e a valorização e desenvolvimento de pessoal. As falas dos sujeitos funcionários estão identificadas pelas letras do alfabeto de a a 0 , e as falas dos sujeitos cidadãos/usuários pelos algarismos arábicos de 1 a 30 .

Como as temáticas são abertas, o que se observou nos depoimentos foi que em geral, todos os funcionários se manifestaram de forma semelhante em relação à questão do desenvolvimento de pessoal. Quanto às demais temáticas, houve uma manifestação diversificada, o que nos induziu à identificação de subgrupos, reunidos a partir da confluência dos discursos na observação de um ou outro dos aspectos investigados. Dessa forma, obtivemos diferentes discursos de sujeito coletivo em cada categoria temática.

\section{A Construção do Discurso do Sujeito Coletivo}

\section{Funcionários públicos}

\section{1. funcionários que não aderiram ao plano PAS}

\subsubsection{Categoria temática: mudança de modelo de atenção à saúde}

\footnotetext{
${ }^{39} \mathrm{~A}$ íntegra dos depoimentos dos funcionários e cidadãos/usuários foi organizada a partir da metodologia desenvolvida por Simioni (1996) e está reproduzida no Apêndice deste trabalho.

${ }^{4 !}$ Opus cit.. item esquema de análise das informações, página 24 deste trabalho.
} 
Nesta categoria temática identificamos quatro tipos de discurso do sujeito coletivo:

primeiro: o modelo de atenção à saúde visto enquanto ações preventivas e programáticas.

Este primeiro tipo de discurso está caracterizado pelas falas dos sujeitos b, d, e, o, q. Segundo nossa interpretação das ancoragens, o modelo consistiria em ações de prevenção da doença, promoção e recuperação da saúde. Inclui as idéias de trabalho interdisciplinar e uma rede de serviços integrados e regionalizados, que foram organizados durante a administração do governo Luiza Erundina.

A percepção geral desse grupo de servidores é decorrente da preocupação da Secretaria da Saúde, durante o governo Luiza Erundina, com a reorganização da rede de serviços de saúde e com a busca de respostas às demandas da população, com destaque para o atendimento integral, tendo como parâmetro um conjunto de atividades racionalizadoras. Essas ações incluiriam os níveis de aplicação de medidas preventivas, desde a promoção da saúde até a reabilitação do cidadão.

As conclusões extraídas do conjunto dos depoimentos coletados, são visiveis, por exemplo, no discurso do sujeito sujeito $b$ pois a idéia que 0 sustenta é sobre da importância e do valor das ações programáticas em saúde e da aplicação de medidas de caráter preventivo, especialmente aquelas voltadas para a prevenção primária ( promoção das condições de vida e saúde e proteção especifica). O funcionário alicerça seu discurso no acompanhamento das fases de desenvolvimento da criança, feito por meio de gráficos, e na educação alimentar para os pais. Diz ele: "durante a administração anterior havia trabalhos educativos e preventivos nas escolas. Na Unidade, a avaliação do crescimento e desenvolvimento das crianças por meio de gráficos".

Para o sujeito d a administração do governo Erundina passou ao servidor uma imagem de maior cuidado com os pacientes, especialmente aqueles que requeriam tratamentos especiais, como era o caso dos mais carentes, ou de portadores de doenças específicas, como a AIDS, por exemplo.

O sujeito $d$ acrescenta uma crítica ao modelo gerencial do sistema de saúde: "a administração anterior pecou por dar muita liberdade ao pessoal. Foi melhor em relação aos cuidados e qualidade da assistência aos pacientes". Esta imagem de cuidar melhor, de ser mais acolhedora para os usuários dos 
serviços, pode estar ligada à importância dada aos funcionários, visando especialmente a melhorar a qualidade da assistência, por meio de concursos públicos para admissão de pessoal, pela melhoria salarial e pelo investimento na formação e desenvolvimento profissional.

A análise da entrevista do sujeito e revela sua compreensão a respeito da preocupação da Secretaria em reorganizar a rede de serviços de saúde, de modo a apresentar um atendimento integral ao usuário. $O$ entrevistado acredita na força das programações de saúde como um meio de recuperação da doença e de proteção dos agravos à saúde, através de ações educativas e preventivas. Pode-se concluir que o servidor que o servidor teve consciência da forma como administração desenvolvia os seus programas de saúde, com atividades de pré-consulta, consulta, pós-consulta, incluindo as visitas domiciliárias. Segundo o entrevistado, este é o modelo de atenção ideal, pois foi assim que the ensinaram na faculdade. Ainda de acordo com o entrevistado, tudo isso desaba na atual administração, provocando sentimento de perda e de fraqueza entre os funcionários, incapacitados de impedir que isso viesse acontecer. Diz ele: "com o tempo os serviços foram se desorganizando. Eu tenho uma sensação estranha, porque em muitos lugares continuaram as mesmas pessoas que antes, só que desestimuladas, que acham que não vale mais a pena. É uma sensação de perda, de derrota".

Quanto ao discurso do sujeito o, o funcionário entendeu que o modelo de atenção da administração anterior valorizava as medidas preventivas e estava aberto à participação social, promovendo as condições de saúde, pois "tinha mais ações educativas e preventivas, também fora da Unidade". Sua percepção é que, findo o governo, reforça-se novamente o modelo de atenção que prioriza as medidas curativas

O discurso do sujeito $q$ é decorrente de sua formação profissional. Como psicólogo centraliza sua crítica à desestruturação da saúde mental provocada pela presente administração pública do municipio: "antes havia mais organização no atendimento. A saúde mental foi a área mais desmantelada. A visão da saúde mental era mais moderna e arrojada no governo PT. Nesse governo há retrocesso, esta é uma forma de desmanchar o sistema de saúde".

segundo: $O$ modelo de atenção à saúde e o planejamento ascendente / participativo. 
O segundo tipo de discurso está caracterizado pelas intervenções dos sujeitos a, j, k, I, n, s. Reflete as potencialidades que os sujeitos possuem, em função das caracteristicas de cada administração pública, de transformar continuamente o processo de trabalho e as instituições onde estão inseridos.

A percepção desse grupo de funcionários, é uma resposta aos estímulos dados ao planejamento participativo, envolvendo funcionários e representantes da população. A identificação de problemas de saúde, a busca de suas respostas, a delimitação das áreas de abrangência das Unidades e das subjacentes micro-áreas de risco, aparecem como símbolos ( enraizados na memória desses trabalhadores ) das oficinas de territorialização em saúde, de estimativa rápida participativa e de planejamento e programação local em saúde. Essas metodologias inovaram o modo de pensar e organizar as ações de saúde. Passados mais de três anos - as entrevistas foram realizadas no final de 1996 - os funcionários se referem com entusiasmo a essas práticas, desenvolvidas pela administração Luiza Erundina. Ouvir referências às oficinas de trabalho, depois de tanto tempo, nos leva a pensar que elas tiveram êxito em seus propósitos de sensibilizar e preparar os funcionários para repensar as práticas de saúde.

As conclusões do discurso do sujeito coletivo podem ser verificadas pela análise da sua ancoragem. O sujeito a, afirma, por exemplo, que "a partir de 1989 surgiu uma nova forma de gerenciamento, comprometido em definir a área de atuação da Unidade e em identificar as áreas de risco". As oficinas de trabalho mencionadas pelo entrevistado, estavam voltadas para o desenvolvimento de pessoal, na área de planejamento em saúde. Ficaram conhecidas como Oficinas Italianas porque contaram com a participação da Cooperação Italiana, a partir de 1991. Novas tecnologias foram intensamente desenvolvidas durante as oficinas, com uso de metodologias para a apropriação e desvendamento das especificidades de cada base territorial/local, visando à identificação de micro-áreas de risco segundo as condições de vida dos habitantes do território, à reordenação do conceito e uso das informações em saúde, além de buscar definir operações para o enfrentamento dos principais problemas de saúde locais. A identificação da área de abrangência da Unidade de Saúde e suas respectivas micro-áreas de risco, segundo as condições de vida, representa para o funcionário um modelo inovador no planejamento e gerenciamento. Este trabalho de recortar, representar (com cartogramas, por exemplo) e explicar uma dada situação de saúde, é uma visão diferente da realidade, pois foge dos padrões 
convencionais. Os participantes eram levados a assumir uma posição politica à medida que se comprometiam com as explicações e respostas aos problemas de saúde. Esta visão foi difundida em toda a rede da Secretaria, através de oficinas de trabalho denominadas "Territorialização em Saúde" e "Estimativa Rápida Participativa"41. A metodologia proposta nas oficinas possibilitava a participação de funcionários de diferentes formações, além de ser acessivel a representantes da população. No decorrer do trabalho, os participantes identificavam os principais problemas de saúde nas áreas de abrangência das Unidades, estabeleciam sua ordem de prioridades e pensavam em ações e medidas para seu enfrentamento, de forma integrada $e$ articulada com outros setores sociais.

Passando à análise do discurso do sujeito $j$, percebe-se que este servidor, reconhece o valor dado pela administração anterior ao conceito de trabalhar com problemas. Afirma, em trecho de sua fala, que "no governo do $P T$ houve a preocupação de se fazer ações preventivas e educativas nas escolas e nas creches". O discurso contempla uma prática da Secretaria que visava à sua integração com outros setores. Objetivo que, na prática, deveria contribuir para a racionalização do uso dos recursos públicos e, conseqüentemente, para o aumento da eficácia social das ações de saúde, com redução dos custos.

O servidor cita a política de desospitalização, com a criação de novos modelos de atenção ao portador de sofrimento mental, como medida da promoção da saúde e recuperação do doente.

No que diz respeito ao discurso do sujeito $k$, pode-se concluir que o servidor reconhece a importância da informação como instrumento para a tomada de decisão elou para o uso de medidas preventivas no campo da saúde pública. Afirma que a administração anterior inovou quando conseguiu criar o Programa de Aprimoramento das Informações de Mortalidade. "Com o sistema de coleta de dados sobre mortalidade, implantado pelo governo anterior no serviço funerário da cidade de São Paulo (PROAIM), sabe-se do que se morre hoje em São Paulo e assim pode-se melhorar a prevenção".

\footnotetext{
${ }^{4 i}$ As oficinas de Territorialização em Saúde difundiram na rede municipal. a metodologia desenvolvida por Carmen Vieira de Sousa Unglert. A autora integrou a equipe de trabalho da Cooperação Italiana e teve participação direta em todo o processo. Os detalhes da metodologia da territorialização fazem parte de sua tese de Livre Docência "Territorialização em Saúde: a conquista do espaço local enquanto prática do planejamento ascendente". Universidade de São Paulo. USP. 1995. As oficinas sobre Estimativa Rápida Participativa, tiveram como texto básico, a referência "A Estimativa Rápida e a Divisão do Território no Distrito Sanitário", de autoria de Francesco Nortabartolo Di Villarosa. OPS. OMS. série de desenvolvimento de serviços de saúde. Brasília. 1993.
} 
Como se pode observar, o funcionário conclui que o conhecimento das causas de morte facilita $o$ acionamento de medidas preventivas. Nas palavras do entrevistado, "fala-se em prevenção há décadas, independentemente do governo, mas muito pouco se tem feito nesse campo".

Quanto ao sujeito $l$, ele se refere às ações coletivas promovidas pela Secretaria durante a administração Luiza Erundina. "Desenvolviam-se ações coletivas, sobre as necessidades das pessoas carentes, sem deixar de aplicar a assistência ou de usar os recursos tecnológicos disponíveis". O depoimento reforça a tese da necessidade de revisão do modelo de atenção, da produção da saúde e da participação social. Ao referir-se à implantação do PAS, o funcionário afirma que "este plano pretende acabar com a saúde pública, com a transferência de recursos para o setor privado".

Quanto ao sujeito $n$, valoriza a democratização gerencial e a descentralização do poder da Secretaria, com a abertura à participação de funcionários e da população, à tomada de decisão. Segundo ele, "antes havia mais participação, mais entusiasmo dos funcionários em participar das discussões". É a lógica do planejamento ascendente, participativo, oriundo das teses do movimento pela reforma sanitária e institucionalizado pela Secretaria. Cita como exemplos as propostas de Hospital-Aberto, a luta pela desospitalização dos portadores de sofrimento mental e a importância do trabalho em equipe multiprofissional.

$O$ discurso do sujeito $s$ também nos remete à lógica do planejamento ascendente, participativo, que possibilitava aos participantes a análise da situação da Unidade de Saúde e da população adscrita: "na administração anterior procurava-se conhecer a situação de saúde da população e dos serviços para melhor orientar e encaminhar os pacientes, e para reorganizar 0 trabalho".

terceiro: O modelo de atenção à saúde e as condições sociais.

O terceiro tipo de discurso está identificado nos sujeitos $c, f, m$. Observa-se uma clara identificação desses sujeitos com alguns dos pressupostos da política de saúde do governo anterior. Eles estão preocupados com movimentos sociais e com a incorporação dos processos participativos no cotidiano, o que sugere um vínculo entre saúde e sociedade, além de reforçar a política de uma cidadania em reconstrução. 
Entre os pontos de vista expressos por esse grupo de funcionários despontam as citações relativas aos aspectos sociais das ações de saúde. São mencionados a participação social no planejamento em saúde, o direito à saúde do cidadão, independente de classe, credo ou raça, e a importância do desenvolvimento dos funcionários para o trabalho integrado e em equipe, para melhor enfrentar os problemas de saúde. Vindos de servidores públicos, esses pressupostos refletem a existência de um movimento ascendente, que ganhava corpo em alguns setores do funcionalismo. Inequivocamente, o discurso desse grupo acena com uma nova cultura no seio dessa categoria de trabalhadores, que se revela mais aberta à participação, além de mais solidária e integrada com a sociedade civil. Isso pode sugerir um processo de modificação de valores, provocado pelas políticas de saúde da própria Secretaria e/ou, decorrente da penetração das teses da Reforma Sanitária Brasileira no seio do funcionários da Secretaria Municipal da Saúde. Os sujeitos/funcionários estariam, desse modo, demonstrando determinadas tendências, como o sentimento de participação, de solidariedade, de integração, além do interesse em trabalhar com problemas, pré-requisitos fundamentais para promover mudanças do modelo de atenção à saúde.

Passando ao discurso dos funcionários observa-se o sujeito $c$ destaca - papel dos Conselhos de Saúde como meio de participação social no processo de tomada de decisão para as questões da saúde. Segundo ele, "os representantes da população participavam das decisões sobre como o trabalho deveria ser, durante as reuniões do Conselho de Saúde. Tinha reuniões de grupo, trabalhos preventivos e educativos com a população". O funcionário se refere também à importância da formação profissional para a melhoria da qualidade da atenção, mencionando o Curso de Larga Escala para formação de Auxiliares de Enfermagem. Após a mudança de administração restou uma sensação de perda e separação.

Quanto ao sujeito $f$, sustenta em seu discurso o valor que a administração Luiza Erundina dedicou aos aspectos sociais. "A administração olhou mais para o social. Teve aberturas para o trabalho multiprofissional. Os treinamentos de pessoal se intensificaram". Dá como exemplo a qualidade da merenda escolar, que, segundo ele, "era muito mais completa". Com os escolares melhor alimentados, poderia haver um maior aproveitamento escolar e, conseqüentemente, mais saúde. Continua seu discurso valorizando o trabalho em equipe multiprofissional, grupo que supõe reunir melhores condições técnicas e operativas para atuar de forma abrangente nos 
problemas de saúde. Destaca a importância do desenvolvimento de pessoal, tão valorizado na gestão Luiza Erundina, desenvolvendo práticas de saúde dirigidas ao indivíduo e ao meio.

O sujeito $m$ discute a saúde enquanto um direito do cidadão. Entende que a administração anterior procurou respeitar esse direito. Alicerça seu discurso no modelo de saúde mental priorizado por aquela administração, onde o outro, qualquer que fosse ele - até mesmo o portador de sofrimento mental - tinha direitos de cidadão. "Durante a administração anterior havia respeito pela pessoa, qualquer que fosse ela, independente do sexo e da cor". O discurso está sintonizado com prática daquela administração junto aos doentes mentais, com a criação dos Hospitais-Dia e dos Centros de Convivência e Cooperativa, onde estava implícita a idéia da "inclusão social". A proposta dos CeCCo's era a de trabalhar com idosos, menores de rua, drogaditos, adolescentes e outras minorias normalmente excluidas pela sociedade atual.

\section{Quarto: $O$ modelo de atenção e os entraves decorrentes da estrutura burocratizada da Saúde.}

O quarto tipo de discurso foi identificado nas falas dos sujeitos $\mathrm{g}, \mathrm{h}, \mathrm{i}, \mathrm{p}$, $r$, t. Nesse caso, a estrutura administrativa da Secretaria da Saúde foi a referência dos discursos. No espaço institucional percebido como excessivamente burocratizado e ineficiente, os funcionários se sentem sem poder para participar e interferir no processo de reconstrução do modelo de atenção à saúde.

A percepção desse grupo de funcionários reflete certo desencantamento e frustração com as experiências vividas dentro da instituição Secretaria da Saúde. A sensação seria provocada ou pela priorização da burocracia em detrimento do estímulo à capacidade crítica e criativa dos funcionários, ou pela incapacidade do governo em operar suas próprias teses. Ou, às vezes, pela incapacidade de articulação da Secretaria da Saúde com outros setores sociais e com a sociedade civil organizada para conseguir a efetiva mudança do modelo de atenção à saúde, de modo a atender as expectativas dos funcionários e da população.

Passando às conclusões decorrentes da interpretação dos discursos dos funcionários, observamos que o sujeito $g$ passa a idéia de que nos serviços públicos, independentemente do governo, o que impera é o excesso de burocracia. Há grande quantidade de entraves à fluência do trabalho e, por 
conseqüência, o atendimento direto aos clientes continua o mesmo, isto é, demorado e insuficiente. "Há muita burocracia e pouca atenção às pessoas que procuram os serviços". Defende sua tese baseado em sua própria experiência de 25 anos de serviço público. Afirma que sempre houve mudanças, no tipo de formulários necessários ao funcionamento burocrático, mas nunca na qualidade do atendimento. Quanto à burocracia, o funcionário acredita que esta foi ficando cada vez mais complexa, sem apresentar, entretanto, resultados práticos evidentes.

Para o sujeito $h$, a administração anterior tinha boas idéias, mas não conseguiram tirá-las do papel. "A partir de 89, a idéia que eles passaram para a população de baixa renda era muito boa, mas muitas idéias que eles passaram não conseguiram sair do papel. Eles não conseguiram colocá-las em prática". Essa critica nos leva a pensar que, para o entrevistado, boas idéias não bastam. Para ele, o mais importante seria substituir as antigas idéias, pelas novas, reconhecidas como boas. No entanto, ele não discrimina - teor dessas boas idéias. Pelo que diz na entrevista, sobre o bom funcionamento da Vigilância Epidemiológica na administração anterior, podese deduzir, a partir da base operacional da V.E. - o controle de doenças - que as boas idéias que não saíram do papel sejam relativas ao controle dos problemas de saúde que acometem as populações mais carentes, grupos mais vulneráveis aos agravos e doenças infecciosas. De acordo com o entrevistado, para que essas idéias pudessem sair do papel, seria necessário o envolvimento da sociedade e de outros setores de atuação social. $E$ isso a administração anterior foi incapaz de promover. Para o funcionário, o que de fato provocou mudanças no modelo de atenção à saúde foi o PAS, que interferiu inclusive na vida pessoal dos funcionários segundo ele, para pior.

Quanto ao sujeito i, reconhece melhorias nas condições de trabalho da Secretaria, devidas provavelmente à recuperação física dos equipamentos, à melhoria salarial, ao ingresso de novos funcionários e ao desenvolvimento de pessoal. Diz ele, "o que vi de novo no governo do PT foi o treinamento $e$ reciclagens dos funcionários. Tinha muito".

O discurso do sujeito $p$ reflete sua frustração com o atual momento da instituição Secretaria da Saúde: "estou arrependida de ter saido do Estado e de um hospital particular para vir trabalhar na Prefeitura. Eu achava que renderia mais se tivesse um único emprego e ganhasse bem. Nessa época muita gente veio para a Prefeitura. Agora estou arrependida porque o Maluf 
entrou e acabou com tudo. Eu achava que o PAS não ia lá no PS. E nós saimos como indigentes. Eu me senti muito mal mesmo".

O sujeito $r$ segue a mesma linha do anterior: "tive uma ansiedade muito grande por não aderir ao PAS e ser deslocada para outro lugar. Aqui no Hospital-Dia o atendimento é bom. Com o PAS aumentou a reclamação do pessoal com o atendimento. Nesta administração os materiais foram sucateados".

A opinião do sujeito $t$ é centrada no aspecto administrativo excluindo qualquer preocupação social: "agora eu não vejo mais pessoas amontoadas nas macas no corredor do hospital. Antes era mais fácil de internar".

\subsubsection{Categoria Temática: Democratização, Descentralização, Participação.}

Identificamos dois tipos de Discurso do Sujeito Coletivo a respeito da categoria temática democratizaçāo/participação social:

primeiro: A democratização como decorrente da reforma administrativa da Secretaria.

Este tipo de discurso foi identificado nas falas dos sujeitos $c, d, f, g, h, i$, $j, I, m, n, p, q, t$, que se referem à reconfiguração institucional da estrutura gerencial da Secretaria como fator determinante das mudanças do processo de trabalho e das práticas sanitárias.

Quando se reflete sobre os discursos desse grupo de funcionários, observa-se a presença de valores democráticos. Os funcionários reconheceram a administração Luiza Erundina como promotora desses valores, por abrir espaços de reflexão sobre o resgate da solidariedade e de reconstrução de movimentos de interesse coletivo. Embora apareçam menções ao fracasso de algumas iniciativas, os discursos, em sua maior parte, de alguma forma reconhecem resultados no projeto de democratização e de participação social da Secretaria. Nesse sentido, a apreensão, por parte dos funcionários, do movimento pela democratização e participação social, tornou-se um indicador da força de institucionalização dessa política no interior da Secretaria. Configura um processo identificado e reconhecido por boa parte dos funcionários

Passando aos discursos propriamente ditos, observamos que o sujeito $c$ percebeu o sentido da descentralização gerencial e administrativa que 
ocorreu na administração anterior, feito através da regionalização e da distritalização. Cita como exemplos a constituição das Comissões Gestoras e dos Conselhos Técnicos Administrativos. Diz ele: "na administração anterior existiam várias instâncias de decisão com participação da comunidade, como as Comissões Gestoras". Ao final da entrevista, entretanto, o funcionário levanta dúvidas sobre a participação e pergunta: "Era mesmo para valer?"

O sujeito $d$ percebeu que a reforma administrativa do governo Erundina permitiu a tomada de decisão de modo mais compartilhado e aberto. Ficou na percepção do funcionário as diferenças de enfoque entre as diversas administrações públicas: "Cada administração tem sua visão: a da Erundina era mais aberta, as decisões mais compartilhadas". Mesmo reconhecendo o rigor do processo de descentralização no controle e na aplicação dos recursos públicos, questiona sua eficácia quanto aos resultados. Segundo ele, o processo foi mais eficiente, mas pouco eficaz. A diferença entre os dois conceitos fica mais evidente quando ele usa o exemplo do PAS, ao afirmar que este modelo "tem mais agilidade administrativa com os recursos humanos e materiais". Portanto, segundo o funcionário, o PAS possui instrumentos de gestão mais eficazes que os da administração pública direta, aplicados durante a gestão Erundina. No entanto, critica o PAS por ser autoritário e restringir o acesso da população a determinadas áreas de atendimento.

O discurso do sujeito $f$ reflete a percepção das mudança na Secretaria, bem como a compreensão da política de saúde da gestão anterior. Entende que a reforma administrativa da Secretaria, com a criação das administrações regionais e distritos de saúde, e a implantação das comissões gestoras nas Unidades de Saúde, aproximou a esfera decisória dos funcionários e da população. "No governo Erundina o poder foi descentralizado para mais perto dos funcionários e da população". Afirma também que na administração atual a situação se inverteu, com a centralização do poder no gabinete da Secretaria.

O sujeito $g$ continua o discurso relativo ao poder e sua localização na estrutura da Secretaria, ora centralizado no gabinete do Secretário, ora descentralizado e mais próximo dos funcionários e da população. Diz o funcionário: "na gestão Luiza Erundina havia incentivos à participação". Poderse-ía pensar que a lógica que sustenta esses discursos é a de que, para se produzir mudanças, é necessário se dispor de poder. O deslocamento de poder para a periferia do sistema, em direção à sociedade civil e à 
descentralização, tornaria a Secretaria mais suscetivel às interferências da sociedade, e portanto, mais aberta às mudanças ${ }^{42}$.

Seguindo a mesma linha de raciocínio o sujeito $h$ reflete sobre a estratégia do governo Erundina de deslocamento de poder do centro para a periferia do sistema. Reconhece a criação de condições à participação dos funcionários e da população, mencionando os movimentos e as organizações. Diz ele: "entre 1989-92 existiam condições de participação" ${ }^{\prime 43}$. Pode-se deduzir, através da fala do servidor, que a prática da participação social seria condição para as transformações pretendidas.

Para o sujeito i, a participação tem aspectos positivos ("acho que a participação tem o seu lado bom"), mas pode resultar na fiscalização dos serviços e dos funcionários por parte da população, com o que não concorda. Isto seria competência exclusiva da administração pública. Ao se referir à reforma administrativa, demonstra uma visão racionalizadora e sistêmica de serviços de saúde, ao afirmar que "é mais fácil administrar 7-8 unidades do que 50". Esta afirmação nos remete ao diagnóstico administrativo de Mário Testa. O autor afirma que, na visão administrativa, o que interessa é a eficácia e a eficiência do sistema de saúde. O enfoque tem raizes sólidas na planificação em saúde e ainda encontra solo fértil para reprodução em nosso meio $^{44}$.

Para o sujeito j, a democratização e a participação representaram a oportunidade de se trabalhar com equipes multiprofissionais. "Trabalhava-se em equipe com psicólogos, assistentes sociais e enfermeiros". Segundo o funcionário havia mais união e mais discussões em torno dos projetos de trabalho. As atividades diárias incluiam visitas domiciliárias, o que. segundo o funcionário, ampliou sua visão dos problemas de saúde dos usuários e da população em geral.

O sujeito / reconhece que a reforma administrativa da Secretaria no governo Luiza Erundina, com a criação as ARS's e DS's, contribuiu para o trabalho integrado entre diferentes categorias profissionais. Afirma que "as decisões eram democráticas; tanto o trabalho médico como o dos demais

\footnotetext{
42A fala do servidor nos remete ao pensamento estratégico de Mario Testa. mais particularmente ao diagnóstico estratégico. $\mathrm{O}$ autor menciona que as mudanças que interessam ao diagnóstico estratégico são as relativas a redistribuição do poder dentro do setor saúde. (Testa. M. 1978).

${ }^{43}$ Matus refere-se a teoria da produção social. abordando o fenómeno da produção e reprodução uma dada formação social. Segundo o autor. esse fenômeno seria decorrente da interação de atores e de organizações sociais que guardam determinados condicionamentos e restriçōes historicamente acumulados. ( Matus. C. 1980).

${ }^{44}$ Testa. M. opus cit.
} 
profissionais eram valorizados". O trabalho em equipe, deve ter marcado sua visão profissional, pois seu interesse, mesmo numa situação adversa como a atual, continua sendo a atividade coletiva. O funcionário relaciona a administração anterior com aspectos democráticos, como a luta pela cidadania, pelo direito de manifestação, e pelo trabalho em grupo por algo de interesse coletivo.

A percepção do sujeito $m$ contradiz as observações do depoimento anterior. De acordo com o funcionário, os serviços não mudaram, incluindo o periodo da administração Luiza Erundina. A reforma administrativa da Secretaria não foi suficiente para provocar qualquer observação relativa a participação e democratização. "Eu não sei falar sobre participação e democratização", talvez foi a resposta do entrevistado, revelando desinteresse pelas propostas básicas da gestão Luiza Erundina.

A análise do discurso do sujeito $n$ revela certo ressentimento. 0 funcionário acredita que o governo não cuida como poderia das pessoas que necessitam de assistência. Sua experiência com Conselho de Saúde não credencia esta instância como meio para se conquistar melhorias na assistência à saúde. $\dot{E}$ o que se percebe neste trecho de seu depoimento: "participei de Conselhos de Saúde mas não acho que houve melhorias com participação". No entanto, em seu discurso, continua defendendo a participação social.

O discurso do sujeito $p$ revela sua percepção relativa à democratização: "antes a Prefeitura era aberta à participação. O pessoal sempre foi muito bom e amigo. Ali no PS Bandeirantes onde trabalhei, a chefia sempre consultava o pessoal para tomar as decisões e informar sobre as coisas. Tinha mais reuniões. A população também ia lá para discutir".

O discurso do sujeito $q$ revela sua percepção das distintas posturas das administrações públicas frente ao processo democrático, porém, revela uma certa reserva no que diz respeito ao movimento popular: "hoje a administração não é democrática. As decisões vêm de cima, prontas. São de cúpula, autoritárias. A participação social é baixa, e a população gosta do PAS; ela foi contra a implantação de um serviço de doença infecto contagiosa lá no Posto na época do PT. Nesse tempo havia mais autonomia dos Distritos de Saúde".

Para o sujeito $t$ não existem diferenças entre as distintas administrações públicas: "não percebi mudanças na administração; algumas decisões são democráticas". 
segundo: A democratização decorrente da concepção da saúde enquanto um direito e conquista da cidadania.

O segundo tipo de discurso está caracterizado pelas intervenções dos sujeitos $a, b, e, k, o, r, s$. Neste tipo, há referências à participação popular e dos funcionários nas decisões da política de saúde, à ampliação da consciência sanitária, à possibilidade de mobilização e à organização social, com resgate do papel do cidadão na busca de soluções para os problemas de natureza coletiva.

Pode-se afirmar que esse grupo de funcionários toca de perto a questão do direito de cidadania: todos devem ter o direito de se expressar, de participar e de lutar por melhores condições de vida e saúde. Só haverá cidadania se houver a prática de participaçãa ${ }^{45}$.

Veja-se, por exemplo, o discurso do sujeito a. Seu o pensamento reflete a preocupação do governo Erundina com as questões sociais. $O$ funcionário reconhece que para trabalhar estas questões, a Secretaria abriu caminhos à participação social. "Um grupo da comunidade estava bem integrado no Posto na época da Erundina". No entanto, em outro segmento do discurso, verifica-se que o funcionário não reconhece esse processo como descentralização do poder, pois não o relaciona às reformas administrativas que aconteceram na Secretaria durante a gestão.

Quanto ao sujeito $b$, acredita que no governo Petista, a saúde foi vista como um bem e como um direito do cidadão. Caberia ao Estado promover o direito à saúde, e à população participar e fiscalizar esse processo. Entretanto, acha que os trabalhos da Secretaria no campo da participação social não foram organizados. "Havia maior preocupação com participação popular mas, não havia muita organização nas reuniões". De acordo com o discurso do funcionário, a idéia da participação/democratização ganhou força com a criação das administrações regionais e dos distritos de saúde, pois

\footnotetext{
${ }^{45}$ Nesse sentido, a administração Luiza Erundina foi estratégica, pois procurou institucionalizar os espaços e mecanismos de participação social. através da ação de sujeitos ou movimentos populares. Muitos funcionários que ocuparam postos importantes na Secretaria - e que haviam participado do movimento da reforma sanitária brasileira -. inseriram-se nos movimentos populares. municiando a população com informações para que esta alcançasse sucesso em suas lutas por melhores condições de vida e saúde. Recorde-se dos textos básicos da Reforma Sanitária. Praticamente todos enfatizavam a importância da participação popular e o papel dos profissionais de saúde no processo de formação de lideranças. $\mathrm{O}$ atendimento às necessidades de saúde - e de outras - depende dos direitos de cidadania. Daí a proliferação durante o governo Erundina de movimentos e organizações populares por melhores escolas, creches. serviços de saúde, para se fortalecer a democracia direta. ampliar o espaço político para a sociedade civil. reforçar os laços de solidariedade. e o papel do cidadâo comum. na luta contra as injustiças sociais.
} 
essas estruturas, institucionalizaram espaços públicos destinados à participação social.

Já o discurso do sujeito e reflete a importância do planejamento ascendente, da participação, da liberdade e do estímulo à criatividade. Diz o funcionário: "Havia abertura e liberdade de criatividade no trabalho, para se buscar várias alternativas de respostas para os problemas de saúde ${ }^{146}$. Ao se referir ao deslocamento de poder para os distritos de saúde, percebe-se a preocupação do funcionário em discutir a localização e estrutura de poder dentro da instituição. Descentralizado, o poder poderia ser utilizado para promover as condições de saúde da população. "Hoje", diz ele, "o que se vê é um mecanismo inverso, com perda de direitos dos funcionários e diminuição da cidadania da população".

O sujeito $k$ continua a linha de pensamento anterior, e também se identifica com as diretrizes da política de saúde da administração Erundina, à medida que reconhece que aquele governo abriu espaços à participação social, estimulou o exercício da cidadania e promoveu o enfrentamento dos problemas sanitários. Entende que a saúde é um direito e uma conquista da cidadania, que define como "você ser uma pessoa, ter um espaço, condição de viver, de poder dizer aquilo que pensa, de fazer parte de um grupo, de poder lutar pelos seus direitos". Quanto à consciência sanitária, acredita que "é poder compreender quais são os fatores que determinam as condições de saúde das populações". O funcionário percebe que a gestão anterior abriu espaços à participação e que esses espaços foram extremamente importantes para o exercício da cidadania. Ficou perplexo com a qualidade do pessoal da Secretaria e diz ter aprendido muito naquele período. É possivel que, ao se referir ao processo mais democrático da administração anterior (..."tanto na organização como na condução"...), esteja estabelecendo algum tipo de relação causal com o novo desenho da estrutura organizacional, regionalizado e distritalizado, e com o modo como o processo de trabalho foi efetivamente conduzido pelas equipes gerenciais durante aquele período de governo.

\footnotetext{
${ }^{46}$ Isto nos remete aos momentos das "oficinas italianas", a respeito das técnicas da estimativa rápida participativa, dos métodos da territorialização em saúde e dos momentos do planejamento e programação local em saúde, para o enfrentamento dos problemas de saúde. As oficinas, procuravam desenvolver o planejamento em saúde, organizar uma rede de relaçôes solidárias e demonstrar a força de superação que o pessoal da saúde adquire. quando se trata da ruptura de um modelo em direção a outro. e/ou quando se constroi livre, criativa e coletivamente seu próprio conhecimento. Assim, percebese que desenho organizacional da Secretaria. construído pela administração Luiza Erundina, promoveu a descentralização do poder para o nível local.
} 
O funcionário representado pelo sujeito o afirma que 0 trabalho na Prefeitura nunca foi democrático, ressalvando que, apesar disso, durante a administração anterior havia mais participação. No entanto, seu discurso revela contradições. Afirma, por exemplo, que atualmente é a diretora do Posto quem toma as decisões, enquanto que, durante a administração anterior, as pessoas da comunidade e os funcionários se reuniam para definir as prioridades. Diz: "antes, as pessoas da comunidade se reuniam de dois em dois meses para tirar as prioridades". De certa forma, ele pontua, em seu discurso algumas diferenças de postura entre a administração anterior, mais aberta, e o fechamento da atual administração.

Na percepção do sujeito $r$ durante "o governo da Erundina a população era muito presente. Havia reunião com os dirigentes para discutir sobre os profissionais e as necessidades da população. A população da zona leste era politizada. Na Vila Prudente havia participação. Atualmente não há. O PAS foi instalado sem diálogo. A atual administração desconhece o que é cidadania".

O sujeito $s$ tem um discurso análogo ao anterior: "antes os diretores do Posto apresentavam seus programas e a equipe multiprofissional colocava seu trabalho. Havia respaldo da chefia. Hoje está tudo muito confuso. Ninguém decide nada. $O$ gerenciamento é feito sob pressão, é autoritário. Antes havia o Conselho Gestor da Unidade. A participação era com as mulheres da comunidade que se reuniam, lutavam e levavam suas reivindicações para o Secretário da Saúde. Eu mesma participava das reuniões. A Igreja ajudava na mobilização das mulheres. As reivindicações eram bem recebidas e procuravam soluções. Cidadania tem a ver com direitos, deveres, esperança e democracia".

\subsubsection{Categoria Temática: Trabalho Integrado}

Identificamos dois tipos de Discurso do Sujeito Coletivo na categoria temática "Trabalho Integrado":

O primeiro tipo afirma que não houve ou desconhece integração (a integração vista enquanto um fracasso), e está caracterizado pelos discursos dos sujeitos $e, m, n, o, r, s, t$.

O segundo tipo reconhece a integração enquanto promotora do trabalho em equipe interdisciplinar no interior da Secretaria, e/ou, a integração enquanto uma diretriz de governo, porém, resumida a ações episódicas 
e pontuais, e está identificado no discurso dos sujeitos a, b, c, d, f, g, h, i, j, k, I, p, q.

A grande maioria dos funcionários reconhece que o tema integração recebeu grande apoio da administração anterior. No entanto, sentimos certa frustração em relação aos depoimentos quanto a essa categoria temática. Porque a impressão que ficou em boa parte dos entrevistados - apesar da valorização dos propósitos da integração - talvez represente a incapacidade da administração em desenvolver uma política institucional integrada, que produza raizes e influencie tanto os movimentos sociais organizados quanto o corpo de seus próprios funcionários para a prática da integração intra e interinstitucional. Um exame um pouco mais acurado do discurso daqueles que se refereriram à integração, sugere que o movimento da Secretaria - e do governo como um todo - não contribuiu efetivamente para mudar as práticas institucionais e nem tampouco a dos movimentos sociais. Arriscamos algumas explicações para este malogro da Secretaria: as ações de saúde deveriam ser organizadas a partir do "enfoque por problemas" e contar com a participação de outros setores que normalmente definem seus planos de modo fragmentado e não integrado, como a educação, a cultura, o bem-estar social, a administração regional, os transportes públicos, as entidades e movimentos sociais. Deste modo, as práticas sanitárias não mais teriam como parâmetro as tradicionais "programações de saúde", e passariam a ser desenvolvidas com base nos problemas de saúde. Para tanto, haveria a necessidade de se valer de instrumentais metodológicos mais integrais, que possibilitariam maior capacidade de aprender a complexidade dos fenômenos sociais, gerando oportunidades de ações integradas. No entanto, com base na análise dos discursos, ficamos com a impressão que não se conseguiu operacionalizar esses novos instrumentos para subsidiar um planejamento integrado. Em que pese o esforço para se encontrar meios de integração entre os funcionários, a população e outros setores, para enfrentar os problemas de saúde, como se viu, essa diretriz não conseguiu produzir os resultados esperados.

Entretanto, internamente à Secretaria, a maioria dos entrevistados reconhece que o movimento de integração contribuiu para promover o trabalho em equipe interdisciplinar. Mas fora da instituição saúde, as mencionadas ações integradas se caracterizaram, na opinião dos funcionários, principalmente como ações episódicas e pontuais, obtendo respostas a determinadas demandas e/ou necessidades imediatas, e se 
pautando por algumas aproximações interinstitucionais decorrentes sobretudo dos interesses e da capacidade de articulação dos dirigentes loco-regionais, que detinham algum tipo de poder na administração pública municipal.

Assim, em relação ao primeiro tipo de DSC, os discursos dos funcionários $e, m, n, o, r, s, t$, negam ou desconhecem os movimentos de integração. Apesar de o sujeito e reconhecer o movimento da Secretaria em direção à integração, sugere que esta foi um fracasso, inclusive em relação ao trabalho de participação social. Segundo o funcionário, "durante a administração anterior se tentou mas, no final, até a população se desinteressou de participar". Este discurso, acrescido aos dos sujeitos $m$ "nunca houve trabalho integrado - $n$-"desconhece trabalhos integrados" - 0 "não sabe o que dizer sobre trabalho integrado" - $r$ - "não percebi integração" $s$ - "não senti mudança" - $t$ - "não houve integração", é revelador do quanto esta diretriz atingiu os trabalhadores do setor da administração que mais discursou e se preocupou com a prática da integração.

Por outro lado, os sujeitos $a, b, c, d, f, g, h, i, j, k, l, p, q$, mencionaram práticas sanitárias integradas entre a Saúde e outros setores sociais, sobretudo junto às Secretarias da Educação, Bem-Estar Social, Cultura e Esportes. Isto não significa que, de fato, houve integração. É o caso, por exemplo, do sujeito a, que trabalhou como auxiliar de cirurgião dentista em escolas municipais de primeiro grau. Durante a administração Luiza Erundina, os cirurgiões-dentistas ficaram vinculados à Unidade Básica de Saúde e desenvolveram suas atividades profissionais ora no interior da UBS, ora junto às escolas municipais. O trabalho nas escolas incluía as ações coletivas, com medidas de caráter educativo e preventivo, como as técnicas de escovação dos dentes e bochechos com água fluorada. Todas as atividades de odontologia sanitária eram realizadas com o apoio do pessoal auxiliar. Sempre. O funcionário reconhece estas atividades como de integração, embora nem sempre o fossem. Geralmente, eram atividades realizadas na escola, porém não com o pessoal da escola. Entretanto, a referência à integração significa que esses funcionários perceberam o movimento de articulação da Saúde com outros setores da administração municipal, promovendo a troca de informações e de saberes ${ }^{4}$. Provavelmente por terem

\footnotetext{
$4^{4} E$ É o caso de se lembrar que durante a gestão Luiza Erundina foram criados os Núcleos Regionais de Planejamento. os NRP's. Dada a priorização às políticas sociais durante o governo Erundina, as Secretarias ditas sociais estreitaram as suas relações. especialmente as da Saúde. Educação. Bem-Estar Social . Cultura. Habitação e a Secretaria das Adminstrações Regionais. Nos NRP's estabeleciam-sc atividades comuns entre as diferentes Secretarias. sobretudo entre as acima mencionadas.
} 
tomado conhecimento, ou vivenciado o processo de aproximação interssecretarial, feito através dos NRP's, é que os funcionários tenham fizeram as afirmações a respeito da integração da Saúde com outros setores durante o governo Luiza Erundina. Essa perspectiva de trabalho intersetorial diretriz da política do governo municipal e da saúde - era tida como uma estratégia para o setor saúde contribuir para a reordenação das políticas públicas sociais.

Do mesmo modo que a do funcionário a, as opiniões de outros sujeitosfuncionários refletem a intenção da Secretaria em trabalhar integradamente com outros setores sociais. Seguindo a mesma linha de reflexão, o sujeito b afirma que "a partir de 89 houve integração com outros setores"; o sujeito c concorda que "alguns funcionários buscaram contato com outros setores"; o sujeito d lembra que "na época da Erundina as Educadoras e as Assistentes Sociais viviam saindo do Posto para trabalhar com outros setores"; o sujeito $f$ se refere ao fato de que "entre 89-92 existia muita ansiedade da população e ela participava de todos os movimentos da Secretaria"; o sujeito $g$ reconhece que entre 89 e 92 participou de trabalhos "junto com outras Secretarias, o que me foi muito gratificante"; o sujeito $h$ diz que no governo PT teve "a oportunidade de trabalhar juntamente com outras Secretarias"; o sujeito j confirma: "eu mesmo tive a oportunidade de representar a minha Unidade em reuniões com outras Secretarias"; o sujeito k aponta: "a diretriz da integração transpassava todos os níveis da Secretaria", e o sujeito I ressalta que "houve trocas de experiências entre nós da Saúde e funcionários de outras Secretarias". Do mesmo modo se posiciona o sujeito q: "teve integração com as escolas, creches, com ong's, associações de moradores, etc". Quanto ao sujeito $i$, refere-se ao trabalho em equipe interdisciplinar e ao trabalho em grupo. Segundo ele, "na administração anterior se estimulou o desenvolvimento do trabalho em equipe" pois é um tipo de trabalho que tem a ver com integração multiprofissional, feita por meio de ações interprofissionais ${ }^{48}$. O sujeito $p$ também percebeu integração entre as equipes de saúde: "vi mais integração entre o pessoal da saúde. No resto eu não sei".

\footnotetext{
${ }^{48} \mathrm{~A}$ troca de experiências entre os diferentes serviços e profissionais, sinaliza para a valorização do componente produção da saúde dentro do sistema de saúde. Esse trabalho coletivo. em grupo, ou trabalho interdisciplinar e em equipe, contribuiu para a integração das ações preventivas e curativas. Sem dúvida, o trabalho em equipe fortalece a tese da integração. uma vez que em grupo, são reforçadas as possibilidades de integração entre os diferentes saberes no vasto campo de aplicação da saúde coletiva.
} 


\subsubsection{Categoria Temática: Desenvolvimento e Valorização de Pessoal}

Identificamos apenas um tipo de Discurso do Sujeito Coletivo na categoria temática "Desenvolvimento e Valorização do Pessoal": os servidores reconhecem a administração Luiza Erundina enquanto promotora da valorização e desenvolvimento de pessoal, na busca de um novo objeto de trabalho.

Nesta categoria temática - valorização e desenvolvimento de pessoal - há praticamente convergência de opiniões. Expressões como respeito ao funcionário, melhores salários, valorização, desenvolvimento de pessoal (cursos, treinamentos, reciclagens) se repetem entre todos os entrevistados. Concluímos que a política de pessoal da administração Luiza Erundina encontrou reconhecimento no âmbito do servidor da saúde, tanto do ponto de vista salarial quanto em relação ao desenvolvimento e capacitação profissional.

Em se tratando de uma administração pública, isso representa um especial reconhecimento, e se torna uma rara conquista. Vindo da categoria dos funcionários públicos, que historicamente vem se mostrando cada vez mais insatisfeita com as políticas governamentais, o sentimento de gratidão e reconhecimento em relação àquela administração tem importância ainda maior. Eis as ancoragens dos discursos dos servidores, sujeito a: "na gestão anterior nós éramos mais valorizados"; sujeito b: "no governo Erundina os salários eram melhores, havia mais diálogo e respeito com o pessoal"; sujeito $c$ : "antes havia investimento em pessoal, o funcionário era mais valorizado, tinha uma importância maior"; sujeito d: "atualmente a Secretaria não tem política de desenvolvimento de pessoal, muito diferente da administração Erundina, que investiu no pessoal e melhorou os salários"; sujeito e: "na administração anterior havia trabalho em equipe e sensibilização do pessoal, para participação e conscientização sobre problemas de saúde"; sujeito f: "na administração anterior tive crescimento pessoal, cresci muito"; sujeito g: "hoje você valoriza mais a administração anterior por causa da situação negativa atual"; sujeito $h$ : "no governo passado tinha respeito $e$ valorização do funcionário"; sujeito i: "entre 89-92 houve grande valorização do pessoal em função das melhorias das condições de trabalho. Havia mais recursos e equipamentos. Os salários eram melhores. Cursos"; sujeito j: "cursos de desenvolvimento de pessoal sempre teve, como atualmente com os cursos de capacitação para AIDS, que a Secretaria vem desenvolvendo"; 
sujeito k: "na gestão anterior investiu-se mais no desenvolvimento do pessoal. Pagava-se melhor"; sujeito I: "todos os últimos governos me desvalorizaram. Somente no governo Covas me senti valorizada"; sujeito $m$ : "houve crescimento profissional porque você tinha espaço para trocar idéias e discutir práticas de atendimento, como por exemplo, com o supervisor de saúde mental"; sujeito n: "na época da Erundina o salário era bem melhor que hoje"; sujeito o: "na administração da Erundina foi criado o Cefor, para dar cursos e treinamentos de pessoal, de todos os niveis de formação. Havia essa preocupação, de capacitar o pessoal da rede. Hoje a gente sente a diferença"; sujeito p: "agora eu me sinto desvalorizada, abandonada. Antes a gente estava sempre em atividade, agora não. Até o salário piorou. Dá vontade de ir embora"; sujeito q: "sinto-me valorizada pelos colegas e pelos pacientes. A área da saúde mental por ser muito dinâmica exige reciclagens e cursos de especialização. Os treinamentos são insuficientes. A Prefeitura não nos considera"; sujeito $r$ : "a parte salarial piorou neste governo. Continua tendo treinamentos, mas deixa muito a desejar"; sujeito s: "nesta gestão o funcionário não é valorizado, virou um lixo. Já era para estarmos na rua se não houvesse Constituição. A escolha pública do local de trabalho, que saiu no $D O$, foi desrespeitada. O funcionário foi mandado para qualquer lugar. Antes havia muito mais chances de você participar de cursos e treinamentos"; sujeito t: "sempre me senti valorizada na Prefeitura".

Não há dúvida que um dos desafios da Secretaria foi exatamente este: o de promover o desenvolvimento profissional dos funcionários.

Pode-se dizer que a disponibilidade e o movimento da Secretaria foram no sentido da construção coletiva do conhecimento percebidos pelo conjunto dos servidores municipais, como se observou nos depoimentos dos entrevistados. Além da preocupação em promover a admissão de quadros efetivos em números compativeis com às demandas e necessidades dos serviços, a grande questão que sempre esteve presente na mente dos dirigentes era a seguinte: como capacitar todo esse pessoal ( entre 1989-92 foram admitidos cerca de 20 mil funcionários ) de modo à articular todo este corpo de trabalhadores e profissionais ao nosso objeto de trabalho, ou seja, à mudança do processo de trabalho e das práticas sanitárias na rede dos serviços de saúde? Uma das razões da criação do Centro de Formação de Recursos Humanos - Cefor - foi no sentido de apresentar respostas à essa questão fundamental. Por trás estava a preocupação em mudar o modelo de atenção à saúde, tendo em vista as ações de vigilância à saúde, com 
participação de outros setores sociais e de movimentos sociais organizados. Havia a valorização do trabalho em equipe interdisciplinar, não propriamente como contraponto à hegemonia do saber médico, mas principalmente, no sentido da construção coletiva do conhecimento. Habermas ${ }^{49}$ ao desenvolver sua teoria do agir comunicativo, inclui um processo de cooperação interdisciplinar, no qual o sujeito interagente seria capaz de se conhecer e entender-se com os demais, mantendo uma situação de crítica constante ao saber disciplinar, o que poderia levar à renovação constante das práticas de saúde. Havia também a preocupação em esclarecer o sentido de se trabalhar com o enfoque em problemas ${ }^{50}$. A preocupação era para criar as bases para as práticas da vigilância em saúde. Discutia-se como melhorar a qualidade da assistência à saúde e como abrir a administração à participação dos funcionários, fossem eles de nivel operacional, médio ou superior, para o planejamento de todo o processo de trabalho. Todas essas temáticas buscavam resgatar o funcionário da saúde do trabalho alienado e elevar a sua consciência critica, possibilitando a ele desenvolver suas habilidades e exercitar a sua cidadania.

\section{2. funcionários que aderiram ao PAS.}

Obs: os sujeitos a, b, c, d, e, trabalharam na administração Luiza Erundina, e os sujeitos $f, g, h, i$, não.

\subsubsection{Categoria temática: mudança de modelo de atenção}

Identificamos dois tipos de Discurso do Sujeito Coletivo na categoria temática "Mudança de Modelo de Atenção à Saúde".

primeiro: os funcionários que aderiram ao PAS reconhecem como
positivo o estímulo da administracão positivo o estímulo da administração Luiza Erundina, ao

\footnotetext{
${ }^{49}$ Habermas. J. Teoria de la ación comunicativa. $2^{\mathrm{a}}$. ed.. Madrid. Taurus, 1988.

${ }^{50}$ Naquele momento a expressão trabalhar com problemas se difundia e, gradativamente, o pessoal da saúde foi se apropriando do conceito, que tinha carater unificador. O problema unia os diferentes setores numa prática comum, pois os grandes problemas da saúde não são específicos do setor. A estratégia que se adotou. então, foi a de gerar dados de interesse para outros setores, para que estes se engajassem na busca de respostas comuns. Em torno de problemas é possivel integrar o trabalho interdisciplinar da área da saúde, a setores da comunidade e outros setores públicos. Trabalhar com problemas significava: 1. explicar as causas e fatores determinantes dos problemas, 2 . definir um plano com um conjunto de operações coletivas para o enfrentamento dos problemas. 3. analisar a viabilidade do plano. 4. realizar as ações planejadas com participação de diferentes categorias profissionais. da população e de outros setores
} 
desenvolvimento do trabalho em equipe interdisciplinar, entre as distintas categorias profissionais.

segundo: a qualidade dos serviços mudou para melhor com a introdução do PAS.

O estímulo ao trabalho em equipe entre as distintas categorias profissionais, ocorrido durante a administração anterior, provocou impacto positivo, mesmo entre os entrevistados que aderiram ao PAS. Pelo menos, é o que se verifica entre os servidores que trabalharam na SMS durante o governo Erundina.

A proposta da equipe de saúde de assumir a responsabilidade do trabalho, seja sobre o individuo, seja sobre a coletividade, deve ter contribuido para despertar o interesse e o compromisso do funcionário com o serviço público, aumentando seu empenho nos programas de saúde da Secretaria como um todo.

Entretanto, entre aqueles funcionários que não trabalharam durante a gestão Luiza Erundina, há unanimidade a respeito da melhoria da qualidade dos serviços com a introdução do PAS. Desse modo, pode-se verificar que o discurso do sujeito a tangencia a administração Luiza Erundina. Refere-se ao governo Covas, dizendo que ele incentivou o trabalho em equipe multiprofissional e estimulou as atividades fora da Unidade de Saúde. Recorda-se da administração anterior como um periodo de dificil resolução dos problemas funcionais. "Na administração Erundina era muito difícil de resolver os problemas funcionais, como por exemplo, as situações dos funcionários-problema". Afirma que, com a implantação do PAS, a situação mudou para melhor. Atualmente, como não existe vínculo empregatício, o trabalhador do PAS pode ser demitido, sem nenhum problema para a administração. A nova situação funcional é, portanto, radicalmente oposta à política de recursos humanos proposta pelos defensores do Sistema Único de Saúde, desde a VIII Conferência Nacional de Saúde, realizada em $1986^{51}$. É interessante observar que esse discurso vem de um funcionário há 21 anos no serviço publico, e que pertence à uma categoria profissional - educador

\footnotetext{
${ }^{51}$ Entre outras medidas propostas na Conferència. destacam-se a defesas do regime jurídico único em cada esfera de governo. o estabelecimento de mecanismos permanentes de avaliaçâo de desempenho dos servidores. além de mecanismos de educação continuada. Ministério da Saúde. VIII Conferência Nacional de Saúde. Brasilia. 1986.
} 
sanitário -, com carreira e presença quase que exclusiva no setor público de saúde.

O sujeito b não menciona o governo Luiza Erundina. Na entrevista, ele refere-se à importância do trabalho em equipe multiprofissional, à abertura da Secretaria à participação social, à valorização das atividades de caráter preventivo e à implementação do Sistema Único de Saúde como objeto de preocupação de governos anteriores a aquele instalado em 1989. "Antes de 1989 já havia proposta de trabalho multiprofissional, envolvendo médico, educador, assistente social e outros. Já se falava em sistema único de saúde. Já havia sido iniciado o processo de aproximação da população, para facilitar o acesso da população aos serviços de saúde. Mesmo antes de 1989 já havia discussões sobre o SUS e sobre tendências para se desenvolver ações preventivas, mesmo que sem eficácia". Mesmo sem intenção, o funcionário parece reconhecer as referidas atividades como caracteristicas do modelo de atenção à saúde proposto durante a administração Erundina, apenas deslocando-as para periodos anteriores a esse governo.

Quanto ao sujeito $c$, durante 15 anos de funcionalismo, experimentou diferentes administrações públicas, reconhecendo em cada uma aspectos positivos e negativos. Segundo ele, em todas elas sempre conseguiu crescer profissionalmente. "Cada administração tem sua própria característica em relação ao modelo de atenção à saúde. Há o lado positivo e o lado negativo em todas as administrações. Vejo como crescimento profissional. Até em visão negativa há esse crescimento". Em sua percepção, o modelo de atenção muda a cada troca de governo. Durante a última administração, teve oportunidade de trabalhar com portadores de AIDS e seus familiares, buscando restabelecer os laços e reabilitar o paciente junto a seus parentes. Afirma que este tipo de trabalho está tendo continuidade com o PAS. É conveniente notar, entretanto, que o PAS não desenvolve as programações voltadas para combater a AIDS.

Embora o sujeito $d$ aproveite a oportunidade da entrevista para promover o PAS, reconhece a importância do trabalho da equipe multiprofissional, valorizado durante a administração anterior. Com 6 anos de funcionalismo, o profissional ingressou na administração pública em plena administração Erundina, época em que havia forte tendência à valorização do trabalho em equipe interdisciplinar. Segundo ele, "só o médico responsável pelo atendimento não é correto. O certo é o atendimento multiprofissional, sempre com uma estrutura governamental, pelo menos para manter o mesmo 
sistema a longo prazo. O que houve de moderno após 1989 foi exatamente o trabalho multiprofissional, forte no governo Luiza Erundina". Com a mudança de governo, durante os primeiros anos da nova administração, houve um refluxo da tendência, que culminou com a implantação do PAS.

O discurso do profissional identificado como sujeito $e$ passa a impressão de que o modelo de atenção à saúde continua o mesmo. Ruim agora como antes, independentemente da ideologia das administrações anteriores. Ao dizer que "mudaram os atores, mas a peça é a mesma, e meus sentimentos frente ao PAS são os piores possiveis", ou ainda "a expectativa era a de melhorar, mas nada disso aconteceu", o funcionário reflete o otimismo e a confiança depositados no plano PAS, que na prática não se concretizaram.

Os sujeitos $f, g, h$ e $i$ não trabalharam na administração Luiza Erundina, e têm discursos muito próximos. Vejamos como se manifesta o sujeito $f$, "com - PAS mudou para melhor. Há mais recursos e mais agilidade no atendimento". Quanto ao sujeito g, afirma que: "com mais recursos melhorou o atendimento em relação aos exames, aos diagnósticos". O sujeito $h$ acredita que existe "menos burocracia, mais agilidade, mais recursos com o PAS". Para o sujeito $i$ o PAS "é um modelo bem organizado, com mais recursos do que antes do PAS". Todos são unânimes ao afirmar que o PAS trouxe melhores condições de trabalho e mais recursos materiais e, por esse motivo, $\circ$ atendimento aos usuários cresceu em número e qualidade.

\subsubsection{Categoria Temática: Democratização, Descentralização, Participação}

Nesta categoria temática - "Democratização, Descentralização, Participação" - sentimos dificuldade em identificar o discurso do sujeito coletivo entre os funcionários que aderiram ao PAS. As percepções sobre 0 modo como se conduziu o processo de trabalho são díspares, variando desde: na administração pública sempre houve democracia e liberdade de participação e essa tendência é crescente; passando por: não há e nunca houve democracia, as decisóes são sempre de cima para baixo; ou: a administração Erundina favoreceu a democratização e a participação e terminando com: com o PAS veio a descentralização e a participação. 
Como se observa, os discursos são contraditórios. Para alguns sempre houve liberdade e democracia, e essa tendência é crescente no serviço público. Para outros, as decisões sempre foram tomadas de cima para baixo, e nunca houve democracia nos serviços de saúde da Prefeitura.

São também identificadas algumas referências à participação durante a gestão anterior, focalizada sob dois pontos de vista: como algo não representativo dos legítimos interesses da população e dos funcionários e enquanto estrutura de canais institucionais montados e estruturados com essa finalidade. Finalmente, há os que entendem que o PAS foi o verdadeiro responsável pela promoção da participação social e da descentralização administrativa.

As reflexões mencionadas a seguir foram extraídas dos discursos desse grupo de funcionários.

O discurso do sujeito a reflete sua visão de liberdade e de democracia nas diferentes administrações por que passou, em seus 21 anos de funcionalismo público. Para ele, "sempre houve possibilidades de discussão. A democracia está presente. As decisões nunca foram fechadas. Sempre tive oportunidade de trabalhar com liberdade". De acordo com seu ponto de vista, sempre houve democracia no trabalho, inclusive em sua atividade atual, no PAS. Não menciona quaisquer diferenças entre as administrações públicas municipais durante todos esses anos de trabalho. No entanto, afirma que a população se submete a diferentes situações sem reagir. Ou seja, indiretamente, admite que as situações mudam. Elas não são estáticas. Apesar disso, continua a sustentar que as administrações públicas são imunes às mudanças promovidas pelos diferentes governos.

Quanto ao sujeito $b$, acredita que as decisões inevitavelmente são tomadas de cima para baixo. O que vale, sempre, é o cumpra-se. "O processo de trabalho nunca é muito democrático. Parece que é, quando se está administrando, mas quando se está na ponta da linha operacional, isso não ocorre. Poucos funcionários são ouvidos. As decisões quase sempre são de cima para baixo". Apesar de ter vivido duas administrações bastante distintas, não menciona diferenças entre elas. Mesmo a respeito do Conselho de Saúde, sua opinião é negativa, afirmando que há pouca representatividade da população.

A opinião do sujeito $c$ é de que há uma tendência à participação social, e à decisão compartilhada no serviço público. Segundo ele, "sempre teve incentivos à democratização do serviço público. As decisões sempre foram 
tomadas com participação da equipe multiprofissional da Unidade. Para se tomar uma decisão é necessário compartilhar com outros colegas, de outras áreas, para se chegar a um denominador comum frente aos problemas e soluções". De acordo com ele, as decisões sempre foram democráticas, e há um movimento crescente pela participação.

A percepção do sujeito $d$ de é que as administrações municipais são distintas. A cada nova administração mudam-se as políticas públicas, o que acarreta prejuizos financeiros aos profissionais e aos serviços de saúde. Reconhece que durante a administração Luiza Erundina houve participação social, porém ressalva que se tratou de "uma participação absurda, de segmentos sociais não representativos da comunidade; não acredito em democratização, uma vez que não há uma condição cultural e educacional da população para participar. Se não se conhece a estrutura da Secretaria, como é possivel se tomar decisões por meio de votação, com participação?" 0 funcionário defende a idéia de que a população não está preparada para participar. Não acredita em democratização porque "não há uma condição cultural e educacional da população". Ao mesmo tempo afirma que "a população não se vê como cidadã". O que revela certas contradições em seu discurso. Ao final, reconhece certa abertura no governo anterior, mas não a considera legítima.

Para o sujeito e não há democracia no trabalho e em qualquer administração por que passou, em seus 27 anos de funcionalismo público. Agora. que trabalha no PAS, a situação continua a mesma. Segundo o entrevistado, não há democracia no trabalho porque "as decisões não são compartilhadas com os funcionários. Apesar disso, "os funcionários da saúde têm consciência sanitária. Quanto a população, "a população não exercita sua cidadania, não há participação social". Para este funcionário, foi o PAS que promoveu a descentralização administrativa, e ela não se deve à reforma da Secretarıa na gestão Luiza Erundina.

O discurso do sujeito $f$ associa a não participação à falta de consciência da população sobre sua própria condição de cidadania. "Não há participação ou controle social porque a população não tem consciência de seu próprio direito. A população deveria ser melhor orientada. Na época da Erundina eles sempre falavam de descentralização administrativa, mas isto nunca foi feito". Para o funcionário, a administração Erundina, vivia apregoando a descentralização, sem, no entanto, realizá-la. Ela só veio mais tarde, com a implantação do PAS.

No que diz respeito ao sujeito $g$, há 
uma clara percepção de que, antes do PAS, havia trabalho em equipe interdisciplinar e espaços institucionalizados reservados à participação popular. Com a mudança de governo, o processo democrático de trabalho deixou de existir, e as opiniões dos funcionários e dos movimentos populares não são levadas em consideração. "Não existe democracia no processo de trabalho. Tudo vem de cima para baixo. Com o PAS mais ainda".

$\mathrm{Na}$ percepção do sujeito $h$, a privatização dos serviços contribuiu para a democratização na saúde. Segundo ele, com o novo modelo - PAS - houve diminuição da burocracia, com os problemas sendo resolvidos descentralizadamente, e com participação do pessoal da base, dos funcionários e dos representantes da população. "Eu vejo como democratização do trabalho o fato de agora se trabalhar fora do setor público. Hoje as decisões são tomadas levando-se em conta o pessoal que está na base, no atendimento".

A percepção do sujeito $i$ é idêntica a de seu antecessor. Porém, com um dado a mais: o medo de que o PAS deixe de existir. "A administração é super-positiva, democrática, aberta às idéias dos colegas. As decisões são compartilhadas. As pessoas têm medo que o PAS acabe".

\subsubsection{Categoria temática: trabalho integrado}

Nesta categoria temática, foram reconhecidos dois tipos de discurso do sujeito coletivo:

Primeiro: nunca houve movimento pela integração na Saúde;

Segundo: a integração da Saúde com outros setores sociais recebeu estímulos durante a administração Luiza Erundina.

É notória a divergência de opinião entre os entrevistados a respeito da categoria temática "trabalho integrado": A integração é vista enquanto trabalho educativo, dirigido aos despossuídos de saberes, mas também é negada enquanto diretriz no interior da instituição Secretaria da Saúde. Há ainda o reconhecimento da promoção do trabalho integrado durante a gestão Luiza Erundina.

Essas conclusões, extraídas do conjunto dos depoimentos coletados, são visíveis, por exemplo, no discurso do sujeito a, que diz que "o trabalho integrado com outros setores, vem desde o governo Mário Covas". Ele não 
menciona diferenças qualitativas de integração entre as diversas administrações. Ao afirmar que "desenvolveu trabalhos educativos, ensinando", passa-nos a impressão de ter assumido um papel de quem sabe, dirigido para quem não sabe. Diz ele: "a partir do governo Covas trabalhei em creches, comunidade e igreja, desenvolvendo trabalhos educativos, ensinando". No mínimo é uma concepção oposta àquela que acredita ser o processo educativo uma comunicação bidirecional, que leva à trocas e a transformação de saberes em ambos os lados que se relacionam.

$O$ discurso do sujeito $b$ reconhece a integração da Secretaria com outros setores durante a administração Luiza Erundina. Destaca, inclusive, os setores que mais se envolveram com a Saúde, citando a Educação, a Cultura e o Bem-Estar Social. "Na administração anterior os equipamentos sociais que mais se integraram com a saúde foram as escolas, os centros de juventude, as creches, os centros esportivos e a Secretaria da Cultura". Acredita que este trabalho contribuiu para promover a cidadania dos funcionários e da população.

Para o sujeito c a Secretaria da Saúde sempre desenvolveu trabalho integrado com outros setores. Diz que, no momento, com a presença do PAS, ainda não há integração. Porém, acredita que haja interesse e movimento político para que isto venha a ocorrer. Segundo sua percepção: "sempre existiu trabalhos integrados com outros setores. Atualmente há interesse do PAS, que ocorra essa integração. Está havendo mobilização junto a vários setores, com o objetivo de se formalizar a integração". O entrevistado não faz qualquer menção à política de integração durante a administração Luiza Erundina. Ao afirmar que sempre houve integração nas administrações municipais, o funcionário diminui o peso que esta diretriz recebeu na administração Erundina. O sujeito $d$ destaca em seu discurso a integração da Secretaria com outros setores institucionais durante a administração Luiza Erundina. Porém, acrescenta que sua experiência com a proposta não foi suficiente para Ihe incutir confiança na política de integração. "Não existem trabalhos integrados com outros setores. Já teve na época da Erundina; tinha muitas reuniões, mas sem resultados práticos".

No que se refere ao sujeito e, ele afirma que durante seus 27 anos de funcionalismo, nunca desenvolveu trabalhos integrados fora da Unidade de Saúde. Justifica o fato pela existência de resistências contra a integração dentro dos próprios serviços. Evidentemente podemos imaginar que durante todo o periodo de trabalho do servidor existiram governos com maior ou 
menor disponibilidade para a integração. Entretanto, seguramente não faltaram oportunidades para trabalhar nesta direção. Nossa interpretação é que as resistências mencionadas vêm do próprio servidor.

Quanto aos sujeitos $f, g, h$ e $i$, não trabalharam na administração Luiza Erundina e não se pronunciaram sobre o tema integração.

\subsubsection{Categoria Temática: Desenvolvimento e Valorização de Pessoal}

Caracterizam-se dois tipos de discurso de sujeito coletivo na categoria temática "valorização e desenvolvimento de pessoal".

O primeiro tipo afirma que as distintas administrações públicas municipais vêm assumindo a mesma postura junto ao quadro de pessoal, no que diz respeito ao desenvolvimento de pessoal, e aparece entre os funcionários que trabalharam na administração Erundina ( sujeitos a a e ).

O segundo tipo afirma que a valorização dos funcionários aumentou com - PAS, através da melhor remuneração do pessoal, e aparece entre os que não trabalharam na administração Erundina.

Segundo a percepção dos sujeitos a, b, c, d, e, não há diferenças qualitativas entre as distintas administrações municipais no que diz respeito ao investimento e desenvolvimento de pessoal. As práticas clientelistas continuaram as mesmas nas diferentes administraçōes. Cursos e outros mecanismos de aprimoramento profissional existiram, mas foram oferecidos aleatoriamente, e os funcionários participaram deles segundo seus próprios interesses e/ou disponibilidades pessoais. Entre aqueles que não participaram da administração Erundina, há unanimidade a respeito valorização de pessoal com a implantação do plano PAS, feita através do aumento salarial.

Passando aos discursos dos entrevistados, observamos que o sujeito a distingue valorização de desenvolvimento de pessoal. Para o servidor, a valorização tem variado muito através das administrações. Quanto ao desenvolvimento pessoal, depende do interesse do próprio funcionário. Diz o entrevistado: "tem havido possibilidade de crescimento pessoal. Se o funcionário tem interesse, ele é considerado, ele se desenvolve. Se não, não". Portanto, para este sujeito, a valorização de pessoal depende da administração, enquanto o desenvolvimento depende do interesse do funcionário. 
O sujeito $b$ também considera que o desenvolvimento de pessoal ( valorização, segundo ele ) depende do interesse e disponibilidade do servidor junto à Instituição. De acordo com o funcionário, "tem sido razoável a valorização profissional; depende da disponibilidade do profissional junto da Instituição". Cita como exemplo o período da administração Luiza Erundina, em que se implantou um Ambulatório de Especialidades, quando teve oportunidade de se desenvolver dentro de sua especialidade médica. Passanos a impressão de ter participado do processo, sem, no entanto, referir-se às condições estruturais que permitiram sua inserção nele.

Quanto ao sujeito $c$, afirma que o governo, qualquer que seja ele, sempre tem interesse político em que o trabalho seja bem desenvolvido. "O meu trabalho é valorizado, sempre sou incentivada com elogios e apoios. Há interesse político e administrativo para que o trabalho seja bem realizado".

De acordo com o sujeito $d$, é comum a administração pública oferecer cursos e treinamentos para os funcionários. Afirma, entretanto, que essas iniciativas desconhecem a realidade de seu público-alvo. Apenas os privilegiados participam das atividades de desenvolvimento de pessoal. Aqueles que não têm tempo disponível, porque precisam de outros empregos para sobreviver, não conseguem participar dos cursos e treinamentos. Em suas palavras, "a nível prático nenhuma administração sabe das necessidades de desenvolvimento profissional. Meu desenvolvimento se deve exclusivamente às minhas iniciativas pessoais". Acreditando-se em seu discurso, podemos concluir que talvez aqueles que mais precisem, sejam os que menos oportunidades têm de se desenvolver profissionalmente. $E$ as administrações municipais, indistintamente segundo seu ponto de vista, vêm contribuindo para a manutenção dessa situação.

O discurso do sujeito e sustenta que todas as administrações são iguais quanto à valorização de pessoal, em função do apadrinhamento politico. "Não há nenhuma diferença entre as administrações quanto à valorização do pessoal, por causa do apadrinhamento político". A partir dessa afirmação, ficamos com a impressão de que, para o funcionário, ser valorizado significa ocupar postos-chave, de chefia ou de comando na administração pública. Historicamente, esses postos têm sido reservados aos funcionários mais próximos aos detentores do poder executivo municipal. Segundo o funcionário, quando o governo muda, mudam-se as chefias, independente da capacidade ou competência técnica do funcionário escolhido para exercer a função. Afirma, ainda, que essa tendência foi predominante mesmo durante a 
administração Luiza Erundina. Por esse motivo, ela foi considerada idêntica às demais. "Em nenhuma administração houve essa preocupação de desenvolvimento profissional, inclusive na da Erundina". No caso deste funcionário, todo o processo de investimento em desenvolvimento de pessoal, implementado durante a gestão foi simplesmente desconsiderado.

Os discursos dos sujeitos $f, g, h$, $i$ focalizam o aumento da remuneração salarial e a melhoria das condições de trabalho, resultantes da implantação do plano PAS. Os dois fatores são considerados elementos básicos para a valorização do pessoal. Vemos, entretanto, certas divergências nos depoimentos. O sujeito $f$, por exemplo, afirma que apenas "a valorização melhorou um pouco, pela melhor remuneração. Falta melhorar mais". Quanto ao desenvolvimento de pessoal, afirma entretanto, que não houve mudanças. "O profissional sempre aprende no local de trabalho";

Quanto ao sujeito $g$, considera que "o funcionário hoje está mais valorizado em termos monetários. O desenvolvimento profissional continua o mesmo. A Prefeitura manteve os mesmos cursos". O sujeito $h$ afirma: "nós estamos tendo melhores condições de atendimento dos pacientes, com a melhoria das condições humanas e materiais". Quanto ao sujeito $i$, associa a democracia à valorização profissional, acreditando que ambas coexistem no PAS: "O PAS propiciou o desenvolvimento do pessoal".

\section{Cidadãos/usuários}

\subsection{Categoria Temática: Mudança de Modelo de Atenção à Saúde}

São reconhecidos dois tipos de discurso do sujeito coletivo nesta categoria temática:

O primeiro tipo afirma que a qualidade dos serviços de saúde municipais mudou para melhor; a razão dessa mudança de qualidade foi a implantação do plano PAS.

O segundo tipo considera que a qualidade dos serviços de saúde não mudou, continua ruim; as qualidades do PAS não passam de propaganda eleitoral.

Nunca se viu tantas críticas ao funcionamento dos serviços de saúde municipais, quanto as provenientes da própria administração pública municipal durante os meses que antecederam a implantação do PAS. Da 
mesma forma, nenhuma administração anterior foi tão pródiga e enfática em difundir e enaltecer as qualidades de seu próprio modelo de saúde, implantado com o PAS. Este plano de assistência foi igualado aos melhores planos privados de saúde. A propaganda do plano, feita maciçamente através dos meios de comunicação de massa, mostrava tudo o que a população desejava para o bem próprio e do serviço público. Este cenário, sem dúvida, favoreceu a polarização de opiniões. De um lado, estavam os que viam no PAS as tão aguardadas melhorias na rede da saúde pública - rapidez no atendimento, respeito e consideração ao usuário, pleno funcionamento dos serviços e melhoria de qualidade. De outro, ficavam aqueles que não concordavam com o plano e desconfiavam de sua eficácia, entendendo-o como mais um artifício de propaganda política, sacado do bolso do colete às vésperas de uma nova eleição.

Nas conclusões extraídas do conjunto dos depoimentos dos cidadãos/usuários são percebíveis as influências dessa propaganda.

Os cidadãos/usuários $1,2,5,7,9,10,11,12,14,15,17,18,19,20,25$ e 30, por exemplo, manifestam opiniões semelhantes, todas relativas aos esforços que a Prefeitura vem desenvolvendo para melhorar os serviços de saúde. As afirmações mais freqüentes dizem respeito à maior rapidez no atendimento ao usuário e às supostas melhorias advindas da implantação do plano PAS, que teve início em janeiro de 1996 na região de Pirituba-Perus, a noroeste da capital. Todas as entrevistas foram realizadas em setembro de 1996, período de maior presença da propaganda eleitoral nos meios de comunicação de massa. Na ocasião, o plano PAS era um dos principais trunfos políticos do partido do atual governo municipal e recebia reiterados $\mathrm{e}$ freqüentes elogios da grande maioria dos candidatos. $O$ novo modelo assistencial, centrado na consulta médica, correspondia às expectativas de grande parcela da população, por responder à demanda de consultas médicas vindo da clientela tradicionalmente usuária dos serviços públicos. Mesmo com o aumento da demanda às Unidades de Saúde, resultante da propaganda eleitoral, os usuários não deixaram de ser atendidos, e relatam as melhorias na qualidade atenção por parte dos servidores vinculados ao PAS. As entrevistas não forneceram maiores detalhes para a compreensão das razões que levaram a maioria dos entrevistados a se referir à melhoria da qualidade dos serviços. No entanto, a semelhança entre as respostas e os itens reforçados na propaganda eleitoral, fazem supor uma influência determinante da segunda sobre as primeiras. A maior rapidez de atendimento, 
a presença dos profissionais de saúde no serviço e o funcionamento pleno do atendimento no periodo de trabalho previsto, especialmente dos prontossocorros, foram as qualidades do PAS mais mencionadas ${ }^{52} e$, a melhoria na qualidade da atenção, notadamente a dos médicos. Vejamos agora alguns exertos das entrevistas concedidas pelos cidadãos/usuários. Os cidadãos/usuários 1, 5 e 17 relacionam qualidade do serviço com rapidez no atendimento. Para o entrevistado 1, "a qualidade dos serviços mudou para melhor. O atendimento é mais rápido, a emergência é mais rápida". Para o 5 , "a qualidade do atendimento melhorou, está mais rápido, mais ágil" e, pelo que eu vejo na televisão sobre o PAS, acho que o governo está dando mais atenção aos pobres". Da mesma forma, para o 17, "o atendimento está mais rápido, está melhor".

Os cidadãos/usuários $2,7,9,10,11,12,18,19,20$ e 25 entendem que, com o PAS, a Prefeitura está finalmente empenhada na melhoria da qualidade dos serviços de saúde. Para o entrevistado 2, por exemplo, "a Prefeitura agora está se empenhando bastante para atender a população pobre que não tem condições de pagar um convênio". Quanto ao cidadão/usuário 7, acredita que "fizeram o PAS para melhorar". Também o cidadāo/usuário 9 considera que "a Prefeitura está se empenhando para melhorar os serviços; mudou para melhor". O cidadão/usuário 10 recorre aos conhecidos para referendar sua opinião, favorável: "a vizinhança diz que o Posto melhorou bastante". Quanto ao cidadão/usuário 11, ressalta que "pelo menos se vê que estão tentando fazer alguma coisa diferente". Para os entrevistados 12 e 18, respectivamente, "está havendo empenho para melhorar" e "mudou para melhor". Para o 19, "depois do PAS o serviço mudou para melhor". O cidadão/usuário 20, apesar de acreditar em melhorias com a implantação do PAS, faz uma ressalva: "Falta me/horar mais. Está havendo empenho para isso. As mulheres que freqüentam o serviço e os funcionários pensam assim". Para o cidadão/usuário 25, "está havendo muito empenho da Prefeitura para melhorar". Finalmente, os cidadãos/usuários 14, 15 e 30, tecem suas considerações a respeito do maior volume de recursos humanos e materiais mobilizados com o PAS. Assim, de acordo com o cidadão/usuário 14, "hoje há mais remédios, mais organização". Na opinião do 15, "o PAS melhorou muito o atendimento, tanto por parte dos médicos como dos funcionários". E para o cidadão/usuário 30, "não existem mais aquelas

\footnotetext{
${ }^{52}$ A partir de 93 e antes da implantação do PAS, era comum o fechamento das portas de inúmeros estabelecimentos desse tipo. principalmente nos feriados. finais de semana e durante o período noturno.
} 
filas imensas, os médicos não saem mais do hospital para tomar cafezinho e ficar batendo papo no bar".

Por outro lado, os cidadãos/usuários $3,4,6,8,13,16,21,22,23,24$, 26, 27, 28 e 29 apresentam outra visão a respeito do mesmo serviço. Alguns discordam da melhoria e outros, apesar de admiti-la, relacionam a mudança a interesses eleitorais imediatistas. Desconfiam da propaganda e dos objetivos do plano PAS. É provável que a vizinhança período eleitoral tenha contribuído para que estes últimos vinculassem a implantação apressada do PAS a interesses políticos imediatos. De acordo com os entrevistados, estes seriam os reais motivos que levaram a Prefeitura a mostrar empenho na melhoria da qualidade de atendimento. Vejamos suas opiniōes. Os cidadãos/usuários 6,8 , $13,23,24,26,27$ e 28 não acreditavam, no momento da entrevista, que houvesse melhorias na qualidade dos serviços de saúde. Para o cidadão/usuário 6, por exemplo, "não houve mudanças na qualidade do atendimento". Para 0 8, "não houve mudanças, os serviços continuam ruins". Para o cidadão/usuário 13, "numa cidade como São Paulo, por mais que se faça sempre é pouco". Para o cidadão/usuário 23, "parece que no início o PAS foi bom, mas depois piorou. É só política". Para o entrevistado 24, "eles tentam mostrar que a Prefeitura está se empenhando para melhorar os serviços de saúde mas, na verdade, isso não acontece". Para o 26, "não houve mudanças na qualidade; está a mesma coisa que antes". Enquanto para o 27, "uma hora melhora e outra piora". O cidadão/usuário 28 afirma que "não houve melhoria na qualidade do serviço. Os funcionários da Prefeitura foram postos para fora". Os cidadãos/usuários 16, 21, 22 e 29 se referem diretamente às questões eleitorais. O cidadão/usuário 16 afirma: "acho que está melhorando, não sei se é por causa das eleições", opinião compartilhada pelos cidadãos/usuários 21 e 22, respectivamente: "a Prefeitura está se empenhando para melhorar os serviços por causa das eleições" e "acho que a Prefeitura está se empenhando por causa das eleições. São interesses políticos". Também para o cidadão/usuário 29, "está havendo muita propaganda do PAS por causa das eleições".

Do ponto de vista quantitativo, os cidadãos/usuários com menor escolaridade são de opinião que os serviços de saúde melhoraram, enquanto os de maior escolaridade opinaram que a qualidade não mudou. Assim, $76 \%$ dos entrevistados com escolaridade até o curso primário referem melhorias nos serviços, e $54 \%$ dos entrevistados com nível universitário, são de opinião 
que a qualidade dos serviços permaneceu inalterada até o momento da pesquisa.

\subsection{Categoria Temática: Participação/Democratização}

Identificamos quatro tipos de discursos de sujeitos coletivos na categoria temática "participação/democratização".

O primeiro tipo considera a participação/democratização tributária do direito à saúde, direito esse garantido constitucionalmente pelo Estado. O segundo tipo acredita que a participação/democratização aumentou com a implantação do PAS.

O terceiro tipo afirma que a democratização/participação foi decorrente da política de saúde do governo Luiza Erundina.

O quarto tipo entende que não há democratização/participação.

De modo geral, pode-se afirmar que a maioria das pessoas tem algo a dizer sobre o movimento pela participação/democratização dos serviços públicos implementado pelo governo Luiza Erundina. Entretanto, existe um grupo considerável que nega ou desconhece a participação social nos serviços públicos municipais.

Em relação ao primeiro tipo de discurso do sujeito coletivo, sua construção deu-se a partir das ancoragens dos sujeitos 1, 2, 3, 4, 5, 11, 12 e 28, que apresentaram concepções relativas à questão do direito e das necessidades básicas de saúde, relativas às condições de vida dos cidadãos A essência da fala dos entrevistados pode resumir-se à opinião seguinte: "eu existo e trabalho, logo tenho direitos, ou devo tê-los, e cabe ao Estado garanti-los". Percebe-se também que a questão dos direitos faz parte da vida dos cidadãos, em sua maioria representantes das classes populares, que mais vêm sofrendo violações desses direitos, pois, como se vê, está inserida em seus pensamentos. Eis algumas das expressões registradas nas entrevistas: sujeito 1: "todos têm esse direito, de participar e de ser atendido"; sujeito 2: "o povo tem o direito de ser bem atendido e de ganhar o remédio quando não pode comprar"; sujeito 3: "nós temos o direito de ser atendidos"; sujeito 4: "a gente paga impostos, por isso temos o direito de ser atendidos"; sujeito 5: "democratização é você poder ser bem atendido e bem tratado e ter o seu problema resolvido"; sujeito 11: "eu sei que tenho direitos porque pago 
impostos, mas também tenho o dever de ver se os serviços estão funcionando bem"; sujeito 12: "todo mundo tem o direito de ser atendido porque paga imposto"; sujeito 28: "todos deveriam ter assistência médica gratuita".

No que diz respeito ao segundo tipo de discurso do sujeito coletivo - a participação/democratização aumentou com a implantação do PAS - sua construção foi feita a partir dos discursos dos sujeitos 19, 21 e 22. Todos estes cidadãos/usuários afirmaram que o direito à saúde aumentou com a implantação do plano PAS. O sujeito 19, por exemplo, afirma que "com a implantação do PAS a Prefeitura deu mais direito à saúde para a população". De acordo com o sujeito 21, "o direito à saúde aumentou depois do PAS". Para o sujeito 22, "atualmente as pessoas participam mais e com o PAS aumentou o direito à saúde".

Quanto à construção do terceiro tipo de discurso do sujeito coletivo - a democratização/participação foi decorrente da política de saúde do governo Luiza Erundina - ele foi desenvolvido a partir dos discursos dos sujeitos 7, 8, $10,20,24,25$ e 27. Todos eles fazem referência à participação social, com comentários sobre o governo Luiza Erundina. O que há em comum entre esse grupo de cidadãos/usuários é a memória do projeto de participação política direta nos assuntos da coisa pública, desencadeado durante a administração Erundina, especialmente através dos Conselhos e Comissões Gestoras de Saúde.

As opiniões dos sujeitos 7 e 25 coincidem, pois ambos afirmam que atualmente a participação é maior. Vejamos dois exertos de suas entrevistas: "agora o povo participa mais, está reagindo, não só na saúde mas em geral" (sujeito 7); "a população vem cada vez mais participando da saúde" (sujeito 25). O sujeito 8 afirma que "na época da Erundina procurou-se dialogar com a população, mas faltou experiência e capacidade de comunicação à administração". Na opinião do sujeito 10, "na época da Erundina tinha mais preocupação com o bem-estar do povo, com o direito de todos serem atendidos". Concordando com a opinião anterior, o sujeito 20 afirma que "na época da Erundina o pessoal participava mais, mas parou por acomodação". O sujeito 24 endossa a afirmação, confirmando que "no governo anterior tinha participação da população". A percepção do sujeito 27 é diferente. De acordo com ele, "deveria haver mais participação da população, para cobrar melhor 
assistência". Finalmente, encerramos a organização com a fala do sujeito 8 , por julgarmos que ela acrescenta um dado diferencial à situação do governo Erundina: "a dificuldade de se comunicar complicou o trabalho da Prefeitura. A população não está preparada para uma administração popular, mais voltada para o social. Os funcionários comentavam que o PT falava demais, mas não resolvia os problemas. As pessoas não estão acostumadas a pensar"

A construção do quarto discurso do sujeito coletivo - não há democratização/participação - foi feita a partir das entrevistas dos cidadãos/usuários $9,13,14,17,18,23,26,29$ e 30, que constitui o grupo que nega ou desconhece a participação social na administração da Prefeitura. Vejamos as falas dos entrevistados: sujeito 6: "não tenho nada a dizer"; sujeito 9: "não se exercita a democracia"; sujeito 13: "nunca participei e não conheço ninguém que participou"; sujeito 14: "não há participação em nada"; sujeito 15: "a população não tem direito à saúde"; sujeito 17: "não sei falar sobre isso"; sujeito 18: "desconheço participação na saúde e não há respeito ao direito de todos serem atendidos"; sujeito 23: "todos deveriam ter direito à saúde. Não existe participação"; sujeito 26: "nunca existiu participação"; sujeito 29: "não existe participação; nunca houve"; sujeito 30: "nunca houve participação na Prefeitura".

\subsection{Categoria Temática: Trabalho Integrado}

Foram identificados dois tipos de discurso do sujeito coletivo na categoria temática "trabalho integrado".

O primeiro tipo afirma que a integração de recursos e a participação social são promessas de eleição.

O segundo tipo entende que o governo Luiza Erundina promoveu a integração dos serviços visando a racionalização do uso dos recursos públicos.

Sobre esta categoria temática, apenas dez emitiram opiniões. Vinte dos trinta cidadãos/usuários entrevistados não se pronunciaram. A questão apresentada aos entrevistados afirmava que durante o governo Luiza Erundina procurou-se trabalhar de forma integrada com outras Secretarias, de modo a promover a melhoria das condições de vida. Ao final, pedia-se que o entrevistado comentasse o tema. Dentre os dez cidadãos/usuários que se 
manifestaram, cinco relacionaram a integração às propostas do governo Luiza Erundina ${ }^{53}$.

O primeiro tipo de discurso do sujeito coletivo - a integração de recursos e a participação social são promessas de eleição - foi construído a partir da opinião dos cidadãos/usuários 1,2 e 6 . 0 entrevistado 1 acredita que "trabalhos de integração e participação popular só em época de eleição". De acordo com o entrevistado número 2, "isso de integração nunca aconteceu". Também na opinião do cidadão/usuário 6, "melhorar as condições de vida e priorizar os mais necessitados, só se for jogada política".

O segundo tipo de discurso do sujeito coletivo - o governo da Luiza Erundina promoveu a integração dos serviços visando à racionalização do uso dos recursos públicos - foi identificado a partir dos discursos dos sujeitos 3,4 , 7, 8, 9 e 10. O sujeito 3 acredita que "houve alguma integração no governo anterior, mas não sei explicar o que foi"; De acordo com o sujeito 4, "no governo da Erundina teve algum tipo de integração porque ela se preocupava mais com as condições de vida". Quanto ao sujeito 7, afirma que "na época da Erundina teve integração com creches e escolas". Segundo o sujeito 8, "a Erundina se preocupou mais com isso. la mais nos bairros ver o que estava acontecendo". O sujeito 9 também reconhece que "no governo anterior havia mais recursos à disposição da população". O sujeito 10 lembra de Erundina como um periodo em que se procurou "integrar os serviços e melhorar as condições de vida e dar mais atenção aos mais necessitados".

\footnotetext{
${ }^{53} \mathrm{O}$ trabalho integrado entre diferentes setores do governo é um tema pouco conhecido entre os gestores públicos. Esta afirmação é. seguramente ainda mais válida em relação aos cidadãos comuns. Com a criação de canais de participação direta. como os movimentos setoriais da saúde, por exemplo, era possivel o acesso direto ao respectivo Secretário da Pasta. Conseqüentemente, os representantes dos movimentos loco-regionais também tinham acesso direto aos representantes regionais de cada Secretaria. reinvidicando e disputando verbas e outros recursos do governo junto às diversas secretarias municipais. Ao mesmo tempo que contribuiram para a integração intra e interinstitucional, por meio da racionalização do uso dos recursos públicos, provocavam efeitos opostos. segregando diversos setores sociais em movimentos de defesa de interesses particulares e demandas específicas. Esta situação talvez explique. as dificuldades de articulação de políticas sociais integradas, e permita compreender porque apenas $30 \%$ dos entrevistados conseguiu pronunciar-se sobre o tema integração.
} 


\section{CAPÍTULO IV}

\section{As idéias-centrais dos dirigentes}

Os aspectos abordados neste capitulo são um resumo das entrevistas realizadas com os dirigentes, cujo texto integral consta do Apêndice. Através de segmentos dos discursos que denominamos idéias-centrais, destacamos as principais propostas de trabalho relacionadas com a implementação do sistema único de saúde, seus avanços e dificuldades.

De um modo geral, percebe-se que, para os dirigentes entrevistados, os princípios do SUS que nortearam a implementação das diretrizes políticas no município de São Paulo foram os seguintes: a universalização da cobertura ( que deu origem a inúmeras propostas e tentativas realizadas pela Secretaria, visando à municipalização dos serviços de saúde ), a promoção da eqüidade ( que motivou a organização de todo o processo de desenvolvimento de pessoal, assim como a incorporação de novas tecnologias e instrumentos gerenciais, tendo em vista a mudança de modelo de atenção rumo à prática da vigilância à saúde), a descentralização administrativa e a integração dos serviços ( que foi contemplada pela descentralização administrativa, com a regionalização e distritalização dos equipamentos ), e a participação e controle social ( caracterizada pela implantação dos conselhos e comissões de saúde ).

Essas diretrizes estão relacionadas à história do Partido dos Trabalhadores, que desde o início de sua criação vem defendendo o sistema público de saúde e o direito de acesso da população à saúde e à assistência integral de qualidade. Ao assumir a Prefeitura de São Paulo, o PT trouxe a proposta de participação da população como uma questão central para a definição das políticas públicas. No âmbito da saúde, o governo municipal procurou executar o instrumento mais moderno no que diz respeito à redefinição do papel do Estado frente as políticas sociais: o SUS. Moderno porque redefine a responsabilidade de cada esfera de governo, e propõe a transformação das práticas. Portanto, a dimensão política da reforma de Estado foi a base de sustentação das diretrizes do setor saúde.

Parte da equipe de saúde que dirigiu a Secretaria teve participação ativa no movimento da reforma sanitária brasileira, e os discursos dos dirigentes refletem a medida da transformação da cultura política desejada na 
instituição SMS. Assim, o comando da Secretaria Municipal da Saúde de São Paulo assumiu determinadas diretrizes políticas porque era composto por um grupo originado do movimento da Reforma Sanitária Brasileira. Este grupo acreditou que a reforma de Estado, prevista na Constituição Brasileira que instituiu o Sistema Único de Saúde, em 1988, era necessária e viável, e que suas bases filosóficas deveriam ser aplicadas às últimas conseqüências.

As mudanças ocorridas na Secretaria da Saúde trouxeram problemas para a administração municipal. Naquele momento, a visão centralizadora do governo ainda era grande, principalmente em relação ao Gabinete da Prefeita e de três Secretarias, Finanças, Administração e Planejamento. A posição do governo municipal era a de promover a reforma administrativa da Prefeitura como um todo, e não parcialmente, como era o caso da Saúde. Foi necessária muita discussão dentro do Secretariado municipal, e muita pressão direta junto à prefeita, inclusive através dos movimentos populares, para que as resistências à descentralização e reforma administrativa da Saúde pudessem ser vencidas.

A verdade é que os caminhos percorridos para a implementação das diretrizes políticas eram muito amplos, e cada dirigente entrevistado levantou distintos aspectos da realidade vivida dentro da Secretaria. Procuraremos revelar as opiniões dos dirigentes a respeito dessas diretrizes e, dentro das possibilidades, estabelecer conexões entre os discursos de cada um.

\section{A implementação das diretrizes}

Os dirigentes manifestaram diversas opiniões a respeito do conceito e do modo de implementar as principais diretrizes da política municipal de saúde. Segundo Junqueira ${ }^{54}$, que ocupou a coordenação do Centro de Organização da Atenção à Saúde (COAS), o processo geral de trabalho da Secretaria, que sofreu fortes influências do governo, foi caracterizado pelo conflito.

"(...) a prefeita, que era a liderança máxima, começou num pique que não persistiu (...) Se no começo ela despontava como alguém que tinha a capacidade de manter esse relacionamento com a população mais pobre, com a maioria da população, conversar com a população interpretando suas necessidades, enfim tentando aproximar essa população desta esfera de poder (...) a partir de um certo momento (...) perdeu essa capacidade. E essa

\footnotetext{
${ }^{54}$ Virginia Junqueira. foi coordenadora do COAS. SMS, SP.
} 
perda de capacidade pelo governante máximo, de fazer essa vinculação com a população e de tomar decisões administrativas que estivessem dando sustentação ao discurso da democratização, fez com que a coisa fosse mais embolada ainda nos planos da Secretaria da Saúde. A nossa Secretaria era a que tinha esse maior ímpeto, essa maior iniciativa para a democratização, até dos processos administrativos. Ela foi extremamente emperrada por esse conflito existente no interior do governo municipal (...) A nossa Secretaria mostrou um caminho, ainda que muito restrito, porque estava cerceada por todos os lados".

Passando para a análise das diretrizes propriamente ditas, vejamos a avaliação de Eduardo Jorge no que diz respeito à primeira das diretrizes mencionadas, ou seja, a universalização da cobertura. De acordo com Eduardo Jorge ${ }^{55}$, que até abril de 1990 foi Secretário da Saúde, tendo se afastado do cargo para se candidatar a deputado federal, a universalização, que estava envolta por uma multiplicidade de determinantes políticoideológicos: "implicava em contatos com três outras áreas: a iniciativa privada, o governo do Estado e o governo Federal. Na verdade sendo o primeiro grande governo do PT em uma grande cidade, esse contato com outras esferas governamentais e com a iniciativa privada, foi muito marcado por uma certa visão que o PT tinha de si próprio e da sociedade brasileira. $E$ também marcado pela visão que os outros tinham de nós mesmos. Portanto, a relação institucional buscando atingir a universalização foi muito dificil. A relação com o governo estadual era feita com muito atrito. A relação com o governo federal maior ainda e a relação com a iniciativa privada era nenhuma. Porque a visão que nós tínhamos, na verdade, (...) o que nós queríamos mesmo, era a estatatização total do sistema. Portanto, a relação com a iniciativa privada era passageira, destinada a ser superada pela estatização a médio e longo prazo. Então, a relação com a iniciativa privada não existia. Mesmo com entidades tipo Santa Casa, que é uma entidade filantrópica muito tradicional, conservadora, mas com um atendimento muito grande à população, inclusive população pobre, praticamente a relação foi muito pequena. Com o governo estadual, houve uma relação de guerra permanente, porque não havia critérios de repasse de verbas do governo federal, que é o dinheiro básico para a saúde. E o governo estadual usava critérios essencialmente políticos

\footnotetext{
${ }^{55}$ Eduardo Jorge Martins Alves Sobrinho, foi Secretário Municipal da Saúde no período de janeiro de 89 a abril de 1990 .
} 
para distribuir os recursos financeiros, beneficiando municípios $A, B$, ou $C$ e prejudicando os municípios D, E ou F. Com o governo federal era uma relação de beligerância total. O Lula e o Collor tinham disputado a presidência e a nossa relação era de inimigos. Interessante que, em virtude do governo estadual ter fechado completamente as portas ao repasse dos recursos federais, nós fomos obrigados a fazer uma negociação com esse inimigo governo federal - com o ministro da saúde da época, que levou o municipio de São Paulo a receber alguns recursos para a saúde nos últimos anos. Porque nos primeiros anos, o repasse do governo federal via governo do Estado foi zero. Não houve".

Dentro da mesma temática da universalização da cobertura, Dimitrov ${ }^{56}$, parte de um conjunto de questões externas à Secretaria da Saúde relativas ao atendimento das necessidades mais imediatas da população, sob o prisma administrativo, isto é, da regionalização, integração e hierarquização dos equipamentos. Diz ele: "porque na realidade ou se constrói o SUS com alguma competência - o que significa você realmente trabalhar a questão da saúde na área metropolitana como um todo, incluindo os serviços da Secretaria de Estado da Saúde e aí você consegue montar um sistema de saúde municipalizado, hierarquizado, regionalizado e aproveita todo o potencial do municipio na assistência à saúde -, ou fica uma situação extremamente difícil (...) $\mathrm{Na}$ medida em que não foi possivel fazer a municipalização, dificultou muito o potencial de trabalho da Prefeitura. Então, por mais que nós melhorássemos os nossos serviços, (...) por mais que abríssemos hospitais novos, tentássemos ampliar as nossas Unidades, esses serviços foram absolutamente insuficientes para atender a toda população do município. Quanto mais nós melhorávamos os serviços municipais, os serviços estaduais pioravam na mesma proporção. O resultado foi zero a zero. Este foi um problema central da universalização da cobertura, pois foram feitas todas as tentativas para a municipalização do serviços de saúde. Há uma série de documentos que podem ser levantados, que foram produzidos na época, com objetivos muito concretos, que podem ser até quantificados financeiramente, a respeito do que significava municipalizar região por região. Havia uma proposta de municipalizar todos os serviços de saúde, seguindo um cronograma para cada região. Tanto que a reforma da Secretaria Municipal de Saúde foi feita compatibilizando a área geográfica com os

\footnotetext{
${ }^{56}$ Pedro Dimitrov. foi Chefe da Assessoria Técnica da SMS. SP, em 1989, e Chefe de Gabinete da Secretaria no período compreendido entre 1990 e 1992.
} 
ERSA's da época, exceto os ERSA's da zona leste e da zona norte, que eram muito grandes e nós colocamos 2 ARS's em cada um desses ERSA's. Eram 8 ERSA's e 10 ARS's nossas. Mas o perímetro externo era compativel. Portanto, era perfeitamente possível nós juntarmos um ERSA com uma ARS nossa, municipalizarmos os serviços de saúde daquele local, organizarmos os serviços lá, utilizando os hospitais e todos os equipamentos. Não foi possivel fazer a municipalização conforme tinha sido proposto e com os planos descritos (...) O impedimento central foram os recursos financeiros. O Estado não estava disposto a investir nesta área naquele momento. $O$ que é que foi possivel fazer? Foi possivel identificar o principal problema que havia na época para a população, a que não se dava solução, que era fundamentalmente o atendimento às emergências. Em relação a este nócrítico, dentro do planejamento na Secretaria, com aquela visão de planejamento estratégico situacional, nos propusemos então a desenvolver um acúmulo de forças junto aos outros municípios da área metropolitana, junto ao movimento de saúde e, com isso, articulando o movimento de saúde, a associação Sebastião de Moraes, com os 28 municípios da área metropolitana, foi possivel forçar a Secretaria de Estado da Saúde a entrar numa proposta para a área metropolitana. Esta proposta para atendimento de urgência/emergência para a área metropolitana, foi aprovada, foi sancionada. Há alguns documentos, inclusive publicados em D.O., com prefeitos, secretários municipais, assinando o documento com o compromisso de trabalho conjunto. A partir dai, então, começou a funcionar um sistema para a área metropolitana, tanto do ponto de vista do atendimento pré-hospitalar como do ponto de vista hospitalar. O pré-hospitalar é o resgate, com as ambulâncias da própria Prefeitura do município de São Paulo e com ambulâncias do corpo de bombeiros para os municipios da área metropolitana (...) Para a questão hospitalar, foram identificados os hospitais de alta complexibilidade, que serviram de referência para as cirurgias mais complexas ou para as intervenções mais complexas em termos de acidentados. Houve inclusive uma certa especialização de alguns hospitais. Alguns hospitais voltaram-se mais a cirurgia craniana, outros para cirurgia na área buco maxilo-facial, outros para cirurgia oftalmológica e assim sucessivamente. Então, foi possivel organizar um atendimento aos politraumatizados e queimados, acidentados de forma geral, na área metropolitana, que funcionou de forma bem razoável, durante um ano e meio 
a dois anos. Esta estrutura foi desativada a partir do primeiro ano subseqüente ao governo do PT".

No que diz respeito à segunda diretriz, a da promoção da eqüidade, os esforços da Secretaria visavam à mudança das práticas sanitárias, e nesse sentido, novos investimentos foram feitos para desenvolver os recursos humanos e incorporar tecnologias e instrumentos gerenciais inovadores.

Segundo a opinião de Nemes ${ }^{57}$, Diretor da ARS-2, foi muito importante a experiência trazida pelos novos dirigentes, de seu trabalho na Secretaria de Estado da Saúde, que de algum modo contribuiu para a promoção da eqüidade. Segundo o dirigente, foram utilizados critérios epidemiológicos para a definição das atividades de saúde, e através de análises de risco, instituídas ações singulares de acordo com cada realidade local: "A composição do PT tem muito sanitarista, e a gente trouxe a experiência da Secretaria de Estado da Saúde, construindo uma rede básica de saúde que contemplasse o conjunto das necessidades da população, privilegiando a questão de saúde coletiva, mas tentando dar conta da prestação de serviços, através de uma rede pública que tivesse os três niveis de serviços. A gente tentou criar uma certa tecnologia, que fosse baseada numa visão mais epidemiológica, ou seja, tentou construir modelos de intervenção, com essa orientação, para resolver os problemas de saúde, atingir os grupos mais desfavorecidos e conseguir contemplar a eqüidade.

(...) Nós privilegiamos a população mais carente, ao fortalecer o serviço público, ao montar Unidades mais consistentes, com maior número de profissionais, com equipes multiprofissionais. A população se beneficiou muito com a nossa política. Se você junta a Saúde, com a creche, com a escola pública, chegamos à conclusão que a administração promoveu a eqüidade. Eu não tenho dúvidas a respeito disso".

Entretanto, um pouco mais à frente, em um outro segmento do discurso do mesmo dirigente, observamos o apontamento de dificuldades encontradas pelo governo quanto à mudança das práticas sanitárias, especialmente no que diz respeito ao aspecto político-administrativo do trabalho da Secretaria: "Porque do mesmo modo que nós queríamos ser inovadores, nós administrávamos da forma mais tradicional possivel, no sentido da administração direta, seguindo todos os fluxos, seguindo todas as normas dessa coisa de ter muitos niveis (...) A Unidade de Saúde, o Distrito

\footnotetext{
${ }^{57}$ Alexandre Nemes Filho. foi Diretor da ARS-2. Butantã.
} 
Sanitário, a ARS, o Gabinete, é muita conversa, é muito esforço para botar o serviço para funcionar. Nós não conseguimos essas coisas, acho que por duas razões: um impasse político - não tínhamos força política para negociar na Câmara e não tínhamos uma proposta gerencial melhor - não tínhamos nada. Nós não conseguimos dar autonomia de fato à Unidade (...) $\mathrm{A}$ alternativa seria ir contra as leis e fazer menos reformas administrativas/institucionais, fazer menos grandes movimentos como o da remoção zerada, e criar mais projetos- piloto que pudessem dar para a gente mais visibilidade. Hoje, por exemplo, a história do PAS é uma inovação. Não estou comparando, não estou dizendo que o PAS é melhor. Não é, nós sabemos disso. Mas, de qualquer forma, a gente não tinha essa coisa na cabeça de mexer na administração direta (...) A visão administrativa da Secretaria Municipal de Saúde foi a mais tradicional na forma de mexer com os recursos. Os mecanismos administrativos mesmo eram bem tradicionais. Não houve de fato uma descentralização, uma autonomia das Unidades. Botar um hospital para se autogerenciar, para enfim, você criar locais mais autônomos que competissem entre si na criação de modelos, com diferentes graus de autonomia. Nesse sentido é que eu acho que a gente não conseguiu avançar muito. A regras, as normas, eram muito rígidas. Acho que não mexemos muito nisso. Entretanto, o pessoal do nivel local se sentiu como planejador, mais envolvido. A população também participava muito mais. Então teve um lado inovador de realmente se criar algum planejamento local. Mas eu não sei se foi uma prática ascendente, se conseguiu se fazer um processo mais completo de planejamento ascendente. Eu penso que não. A gente tinha uma coisa mais inicial mesmo. Um exercício inicial".

Outro dirigente, Escrivão ${ }^{58}$, que dirigiu o Centro de Epidemiologia, Pesquisa e Informação no período, tem opiniões positivas a respeito do enfrentamento das iniqüidades pela Secretaria da Saúde. Afirma que "isso é uma das coisas que eu não tenho dúvidas. Tenho dúvidas sobre quase tudo. Com certeza a gente avançou muito. Eu acho que toda a nossa política de voltar $o$ atendimento para a periferia, era um critério praticado de enfrentar as iniqüidades. $O$ adicional à distância, todas as políticas, indicam que a gente queria realmente trabalhar isso aí, a eqüidade".

Entretanto, é sabido que o problema da eqüidade envolve políticas sociais integradas que compensem os efeitos das injustiças. A esse respeito, o mesmo dirigente, pouco mais à frente, faz uma afirmação que reflete as

\footnotetext{
${ }^{58}$ Álvaro Escrivão Júnior. foi Diretor do Centro de Epidemiologia. Pesquisa e Informação, CEPI.
} 
inseguranças e contradições do governo, pois segundo ele, os formuladores de políticas sociais teriam que explicitar com mais clareza os seus objetivos, metas, recursos, e identificar os aliados e adversários: "Você não tinha um pensamento estratégico para enfrentar os problemas. O que existia era um pensamento administrativo, baseado em combater as emergências. Isto também é absolutamente tradicional. Você tinha dificuldades em ter uma discussão politica mais geral (...) Os problemas que eu vejo são as dificuldades políticas do governo. Isto é um outro ponto muito sério, porque se fazia muita confusão em função disso. Os grupos dentro do partido. As brigas. A ciumeira em torno da Luiza Erundina (...) No Gabinete da Secretaria Municipal da Saúde, freqüentemente você tinha trombadas, que eram trombadas onde o problema precisava ser enfrentado enquanto problema, e não enquanto relação interpessoal. $E$ a gente enfrentava enquanto interpessoal, isto é, entre os personagens que estavam envolvidos com os problemas, e não enquanto problemas. Então, você tinha uma coesão muito frágil".

Concordando com as opiniões desse dirigente a respeito das dificuldades técnico-politicas do governo Elias ${ }^{59}$, que desenvolveu seu trabalho junto à Câmara Municipal de São Paulo enquanto interlocutor da SMS, faz algumas criticas ao modelo de planejamento adotado na Secretaria que, como se verá mais à frente, trouxe dificuldades para a promoção da eqüidade pelo setor saúde. Ele nos esclarece que a Secretaria, ao definir um plano de reforma de Estado, estava mergulhada numa dinâmica institucional repleta de interesses, disputas e conflitos internos. Sugere que faltou mais empenho para organizar melhor o processo de tomada de decisão, e na definição do desenho de ações operativas: "Na verdade, o ápice desse planejamento ascendente seria o Conselho Técnico Administrativo da Secretaria da Saúde. Mas não estavam definidas as instâncias de decisão política. Onde se daria a decisão entre visões conflitantes, por exemplo? Qual o mecanismo de decisão? Onde era isso? Como é que se faz isso? São problemas extremamente complexos. Isto no plano do ideário. Você pode ter tido processos que foram mais ou menos coletivos. Eu não acredito que possa ter tido processos de verdade, muito coletivos. A impressão de quem estava nessa posição é de que não teve uma coisa muito ascendente. $E$ você teve sim, um planejamento cujas diretrizes foram determinadas de cima para baixo.

${ }^{59}$ Paulo Eduardo Mangeon Elias. foi assessor da Secretaria Municipal da Saúde, junto à Câmara Municipal. 
E era um pouco esse modelo, porque se você viesse com o planejamento ascendente, com a cultura existente na Prefeitura, você iria se chocar com a visão de quem estava chegando. Dá até para compreender porque o planejamento tinha que ser um pouco impositivo. Se ele viesse de baixo para cima ele vinha com a cultura, com a mentalidade do funcionalismo da SMS, e iria se chocar com essa revolução toda que estava acontecendo. Então o planejamento nem poderia deixar de ser um pouco impositivo na minha opinião, se você quisesse fazer algum tipo de transformação".

Junqueira retoma as mesmas teses de Elias, e amplia o problema do planejamento para fora do âmbito da Secretaria da Saúde. "As pessoas travaram conhecimento com uma outra possibilidade de planejar, e que pode ser usada de maneira democrática. Agora, travaram conhecimento de uma maneira muito dispersa, fragmentada. A Secretaria não tinha uma assessoria de planejamento. Tinha várias pessoas que intervinham no planejamento, toda a Assessoria do Gabinete da Secretaria Municipal de Saúde intervinha no processo. A possibilidade de se botar realmente um planejamento estratégico a serviço da democracia foi muito frágil. Foi um aceno, um acenozinho que passou pela Secretaria". Para ela, o processo de trabalho não possibilitou a apropriação de instrumentos metodológicos eficazes. (...) "Mas eu não vejo o problema só no interior da Secretaria Municipal de Saúde. Para mim, o problema era da Secretaria de Planejamento como um todo. O que me impressionou foi a incapacidade da SEPLAN de se articular intersetorialmente com as diversas Secretarias do setor social (...) Não considerava que o planejamento da cidade se faz com todo mundo junto, local e regionalmente".

A mesma dirigente continua seu discurso colocando a questão da eqüidade no conjunto das políticas sociais do governo. Quando se volta para a Secretaria, manifesta sua opinião sobre a promoção da eqüidade. "Vamos pegar uma questão mais específica, que aborda essa questão da eqüidade, não como um todo, é verdade. Aliás, a gente aflorou a questão, a gente mostrou que a administração tinha essa intenção de enfrentar a questão da eqüidade, através de questões específicas como a dos idosos, a questão das mulheres, dos portadores de deficièncias e dos portadores de sofrimento mental. Era uma questão de dar enfrentamento à desigualdade, com uma resposta que significasse eqüidade. Ou seja, fazendo com que a cidade pudesse ser desfrutada, vivida pelos portadores de deficiências, em condições não de igualdade, mas em condições menos desfavoráveis, que 
era fazer guias, botar ônibus assim-assado, enfim, criar condições apropriadas para os portadores de deficiências e uma série de outras coisas".

Dimitrov, com respeito do processo de planejamento praticado pela SMS, desenvolve uma abordagem mais favorável à Secretaria, sugerindo que - processo caminhou no sentido de acumular mais poder nos diversos colegiados instituídos, através do estabelecimento de uma relação comunicativa entre a rede e o gabinete do secretário. "Atrás de todas as propostas de nível central, tinha o modelo do planejamento estratégico situacional. Toda a reforma da Secretaria foi pensada em cima disso. O planejamento desde o início foi pensado como um processo, e não como um órgão, e quem deveria planejar eram as pessoas que executavam as atividades. Portanto, todo o Planejamento foi pensado, num primeiro momento, como o próprio Conselho Técnico Administrativo do Gabinete da Secretaria Municipal de Saúde, para estar levando este planejamento mais global e, (...) numa situação mais interna, um colegiado de apoio de planejamento para o Secretário, com um número menor de pessoas, que eram os órgãos do Gabinete do Secretário com representação dos diretores de região. E havia uma outra perspectiva de você construir uma coisa de baixo para cima de planejamento, com envolvimento da população, dos funcionários, processo mais lento também necessário, também importante mas que, do ponto de vista do tempo político, é que seria muito lento. Então na realidade você teve dois movimentos: um movimento de alguns diretores com experiência, que conseguiram tocar um pouco mais o planejamento estratégico para as suas regiões. $E$ as coisas avançaram tanto que construíram seus Distritos Sanitários com mais facilidade. Seus próprios Distritos Sanitários passaram a ter este tipo de conduta dentro dos colegiados de diretores de suas Unidades, e a coisa até chegou a funcionar com uma certa qualidade do processo de decisão, do processo de planejamento mais coletivo das ações a serem desenvolvidas. Esta é uma situação que ocorreu na Secretaria".

$\mathrm{Na}$ visão deste dirigente, predominou o encaminhamento mais adequado da planificação em saúde, pois, segundo ele, o modo de pensar os problemas de saúde contribuiu para a promoção da eqüidade: "A gente pode dizer (...) que Secretaria enfrentou a questão da eqüidade, mas os seus serviços eram absolutamente insuficientes. Durante quatro anos nós invertemos as prioridades da Secretaria, direcionamos a Secretaria para atender realmente a população de forma mais adequada, para enfrentar as 
dificuldades da população mais carente. Isso foi feito, foram alocados mais recursos para a periferia, recursos humanos, materiais, equipamentos, enfim. Mas a rede da Prefeitura foi insuficiente para mudar qualitativamente a situação de saúde do conjunto da população da capital. Acho que o governo como um todo, em relação às outras Secretarias teve essa mesma preocupação de combater as injustiças sociais. Tanto é que o atendimento das escolas na periferia teve um papel importante, 0 atendimento das bibliotecas da SMC (...) e assim em relação a todas as Secretarias. O governo como um todo teve esta preocupação, e neste sentido eu acho que houve mudança importante".

Neder $^{(x)}$, que assumiu o comando da Secretaria da Saúde entre abril de 89 a dezembro de 92, também fez algumas considerações a respeito da eqüidade: "Nós incorporamos a idéia da eqüidade não como sendo tudo igual para todo mundo, mas dentro do conceito de que nós tínhamos que dar mais para aqueles que tinham menos (...) Qual era o conceito de eqüidade entre a gente? Era garantir, dentro da filosofia que acabou imperando no governo, com o lema São Paulo Para Todos, que nós deveriamos dar igualmente a distribuição dos recursos para todos os setores da sociedade, independente da forma como eles estavam inseridos no contexto do municipio, indiferente às injustiças e à exclusão social, ou se nós deveríamos dar mais a quem tinha menos (...) Eu acho que acabou imperando dentro do nosso governo e da própria Secretaria da Saúde a idéia que nós tínhamos que nos voltar cada vez mais para aqueles que tinham menos, sem que isso significasse voltar as costas para aqueles que, sendo cidadãos com direitos respeitados e com uma inserção diferenciada na economia, na sociedade, também tinham o direito de freqüentar e usar os serviços (...) A prioridade nossa estava colocada para aqueles setores mais excluidos". Provavelmente o dirigente estava se referindo à implantação dos Distritos de Saúde, tidos com espaços privilegiados para a reorganização das informações e dos serviços, no sentido da produção da saúde e promoção da eqüidade.(...) "Na área da Saúde, no momento em que nós resolvemos procurar aqueles que estavam nos cortiços, aqueles que estavam nas áreas de risco, aqueles que estavam sujeitos à inundação, à leptospirose, aqueles que estavam excluídos de qualquer possibilidade de participação na sociedade e no sistema de saúde, na verdade nós optamos pela eqüidade, mesmo mantendo as Unidades abertas à burguesia, à classe média, à pequena burguesia, nós procuramos alguns

\footnotetext{
${ }^{61}$ Carlos Alberto Pletz Neder. foi Chefe de Gabinete da Prefeitura e Secretário Municipal da Saúde.
} 
setores que poderiam se aliar com a gente na consolidação desse projeto, pelo menos na área da saúde (...) Isso foi mais intenso na Secretaria da Saúde do que propriamente no governo. O governo quando fez a opção pelo lema São Paulo Para Todos, na verdade ele acabou tendo decorrências dessa opção feita, seja no sentido da radicalização da proposta política de governo, seja no sentido da radicalização da proposta da descentralização da gestão. Coisa que na Saúde nós tentamos fazer com um ritmo e com um enfoque diferenciados (...) O lema São Paulo Para Todos foi importante no sentido de uma compreensão de que nós não poderiamos governar a cidade apenas para um partido ou para um segmento, mas por outro lado, sempre me pareceu insuficiente no sentido de que nós tivéssemos uma definição mais clara de quais eram os nossos aliados preferenciais, até para dar continuidade a esse projeto político e de governo".

Outro segmento do discurso do dirigente, destaca que em relação ao modelo de atenção à saúde, a Secretaria pode consolidar uma concepção de integração da política de saúde com o intersetorial, rompendo com a lógica de separação entre a atenção ambulatorial e a atenção hospitalar. Para tanto, segundo sua visão, a Secretaria não economizou esforços para estabelecer canais de participação, abertos à comunicação e ao entendimento, intra e extra-setorialmente: "Isso eu acho que a gente conseguiu romper, mas nós não conseguimos introduzir um novo processo de trabalho no cotidiano do funcionamento das Unidades e das equipes de saúde que fosse totalmente coerente com essa nossa preocupação. E não porque a gente não tenha tentado, quer dizer, eu acho que nós abrimos as nossas Unidades, eu acho que a gente rompeu com aquela idéia da Unidade de Saúde que ficava passivamente esperando uma demanda espontânea. Nós mostramos a necessidade da equipe fazer a territorialização, procurar os problemas, detectar de forma mais abrangente o que interferia nas condições de saúde e na qualidade de vida da população. Mostramos para a equipe que ela era parte de um exercício de cidadania. Portanto, o servidor também era um cidadão com direitos, com opiniōes, e com possibilidade de interferir nessa dinâmica. Mas eu acho que, do ponto de vista do processo de trabalho, nós tivemos dificuldade de demonstrar para cada um dos servidores qual era a lógica que nós estávamos tentando implementar, quer dizer, o que é que justificava esse governo da Luiza Erundina, e o que diferenciava esse governo dos governos anteriores". 
$\mathrm{Na}$ opinião de Eduardo Jorge houve a promoção da eqüidade, especialmente devido à expansão dos serviços em direção à periferia. Entretanto, Eduardo aponta alguns problemas em relação a outros programas: "A Luiza Erundina conseguiu inaugurar hospitais em regiões com 1 milhão de habitantes que tinha zero leitos (...) a política de saúde como um todo, foi na direção da eqüidade. Se foi insuficiente, ela foi, é claro, como toda política nossa, mas o vetor era esse. Eu, vendo hoje, acho que uma coisa que a gente não fez e poderia ajudar muito nessa questão da eqüidade, e até na melhoria dos serviços, era o Programa de Saúde da Família, com agentes comunitários e com internação domiciliar. Eram todos programas estratégicos e nós não tivemos clareza, nós não os desenvolvemos. Então eu sinto nós não termos tido clareza para desenvolver esses programas, que eu acho que ajudariam muito na busca da eqüidade. Mas no conjunto, a política de pessoal e de investimento foi nessa direção".

Elias foi o dirigente que mais críticas fez à forma como a Secretaria trabalhou a questão da eqüidade. Segundo ele, "o problema da eqüidade passou muito longe da Secretaria Municipal de Saúde. E nem poderia deixar de ser desta forma, porque a forma como foi organizada a gestão da Secretaria Municipal de Saúde, ela dificultava a busca da eqüidade. Por que? Porque você tinha de um lado o Conselho Técnico Administrativo e de outro você tinha uma outra instância, muito importante, que era o Conselho Municipal de Saúde. Em ambas essas instâncias, a dinâmica de funcionamento não contemplava a eqüidade. Por que não contemplava? Cada diretor regional chegava no Conselho Técnico-Administrativo para defender a sua região. Buscava o maior número de recursos para a sua região. Você tinha as regiões e os Distritos que competiam entre si fraternalmente (...) $E$ isso dificultava você ter uma visão mais global do município. Você ficava com uma visão muito regional. Esta que é a desvantagem de você ter uma estrutura regionalizada. Você tem vantagens, mas como tudo na vida, tem desvantagens". Segundo nosso entendimento, na opinião do dirigente o conjunto de interesses era produto dos conteúdos ético-político de cada diretor e, na maior parte das vezes, os interesses foram conflitantes, pois (...) "a Secretaria nunca se preocupou em buscar mecanismos institucionais para corrigir ou controlar esta desvantagem. De outro lado, você tinha o Conselho Municipal de Saúde que funcionava mais ou menos do mesmo jeito. Você tinha os movimentos sociais competindo entre si fraternalmente, pelos recursos. Não como inimigos, mas competindo pelos recursos. $\mathrm{Na}$ verdade 
você teve demandas imensas, e as demandas eram muito maiores do que as possibilidades que você tinha. A dinâmica de funcionamento da Secretaria não contemplava a eqüidade. Como que você vai tratar desigualmente aquilo que é desigual. E aí, como é que faz? $\mathrm{Na}$ base do que? $\mathrm{Na}$ base do convencimento? A única coisa que eu acho que tinha nessa linha da eqüidade, e isso é muito mais um primado politico que outra coisa, era a coisa de voltar para a periferia. Você quer ver um exemplo típico, que não privilegiou a eqüidade? A remoção zerada. Além dos aspectos políticos de como ela foi feita, ela foi invocada em nome de uma justiça, em abstrato. Então, com o preceito da justiça, nós vamos fazer a remoção zerada. Só que, com o critério que foi montado para fazer a remoção zerada, qual foi o resultado dela? Ela esvaziou a periferia. Não era a intenção, muito menos o discurso. O que é eficácia social? Atrapalhar o funcionamento dos serviços? Entre essas duas coisas, o serviço funcionar melhor ou você fazer uma justiça em abstrato que redima toda a história, o que você escolhe? $\dot{E}$ isso que o administrador público tem que fazer. $E$ é aí que vai mostrar onde está o compromisso desta história".

O objetivo principal da remoção zerada, alvo das críticas de Elias, era deflagrar um processo periódico de escolhas públicas dos cargos da SMS, baseado nos próprios méritos dos funcionários - tempo de serviço e classificação em concursos. A remoção zerada realizou-se apenas no último ano do governo Luiza Erundina, e em nossa opinião, não esvaziou a periferia. Ao contrário, o processo de admissão de pessoal acabou levando os funcionários mais recentes a escolherem os locais mais distantes do centro, que desta forma, não foram prejudicados pela remoção zerada.

No que diz respeito à terceira diretriz mencionada, a descentralização administrativa, a regionalização e a integração dos serviços no âmbito local, a principal estratégia foi a criação das Administrações Regionais e os Distritos de Saúde. Entretanto, a proposta de autonomia administrativa dos Distritos ficou aquém das expectativas, pois não havia Unidades Orçamentárias e nem cargos em número compativel com o novo desenho organizacional.

$\mathrm{Na}$ opinião de Eduardo Jorge a aposta na integração com outras Secretarias, era o embrião da descentralização integrada da Prefeitura em várias regiões. Era o encaminhamento para uma "verdadeira Prefeitura regional, que se responsabilizasse no âmbito, por exemplo, de uma região 
como Itaquera ou Pirituba, por todas essas tarefas possiveis de serem descentralizadas na Prefeitura, como saúde, educação, cultura, etc. A SMS apoiou, participou da definição dessa estrutura descentralizadora, mas isso avançou muito pouco, também em um ritmo insuficiente na Prefeitura, de forma que, vou ter essa cidade de 10 milhões de habitantes dividida em 20 estruturas regionais, com estrutura inclusive de legislativo local, eleito pelo povo, com essa responsabilidade, dividindo o poder com a Prefeita e com a Câmara Municipal de São Paulo. Era uma verdadeira revolução democrática que o PT poderia ter feito e não fez. Não se avançou e até hoje ficou inviabilizado, porque criaria 20 Prefeituras regionais, integrando as várias áreas. Democratização, porque nessas 20 Prefeituras regionais, teria uma câmara de vereadores locais, eleitos, fiscalizando, controlando, discutindo política e, ao invés de 50 vereadores, 1.000 vereadores na cidade de São Paulo. Isso não foi feito também porque, a meu ver, existiam resistências grandes. Era verdade, não tinha maioria na Câmara Municipal. Mas um problema maior, era dentro da própria cabeça dos militantes do PT, que viamos nisso uma forma de você diluir o poder, que concentrado na mão da prefeita, seria a única forma de quebrar resistências para impor nosso programa.

(...) Existia uma tendência à autonomia administrativa, dificultada porque não havia cargos, nem mecanismos, nem leis suficientes. Mas existia, a meu ver, uma mentalidade uniformizadora muito grande entre nós. Uma tendência a achar o seguinte: tinha que caminhar todo mundo junto, todo mundo no mesmo ritmo. E o que nós precisávamos, era o oposto, ou seja, de um modelo de administração mais descentralizado e com mais autonomia entre nós mesmos, entre as ARS's e os DS's. Essa visão descentralizadora é a visão que acredita na sociedade civil, que acredita na politização, no crescimento, na possibilidade do povo assumir responsabilidades muito mais do que a consistência político-ideológica de meia dúzia de dirigentes. Mas isso nós não tivemos clareza de fazer".

Para Eduardo Jorge, em que pese a falta de condição material para a consolidação da reforma administrativa e dos Distritos, também fez falta uma visão politica dos dirigentes, que estimulasse a autonomia dos distintos movimentos, em função das desigualdades regionais/locais. Desigualdades que eram sociais e institucionais, e para as quais não foram desenhados projetos capazes de incorporar ações gerenciais especificas, próprias para as diferentes realidades locais. 
Quanto a Virgínia Junqueira, a dirigente menciona outro tipo de dificuldade. Retoma um dos aspectos da descentralização administrativa, referindo-se aos núcleos regionais de planejamento, e faz considerações sobre as dificuldades em articular a produção da saúde com a assistência individual. "Uma das grandes barreiras para o avanço era a questão da articulação intersetorial. Os núcleos regionais de planejamento são a prova. Tanto é que se matou os NRP's. Dentro da Secretaria da Saúde, o discurso de que saúde é muito mais do que atendimento médico era claro. O que não era muito claro era como fazer as duas coisas ao mesmo tempo. Aí a estratégia da Secretaria muitas vezes titubeou (...) Se você não fizer uma análise muito rigorosa dos problemas da população, você não vai conseguir um atendimento médico perfeito. Isso você pode tirar da sua cabeça. Nós não sabíamos como organizar o atendimento sem que este nos consumisse. Isso nós não conseguimos fazer. Na hora de operacionalizar a produção da saúde, nós não tínhamos clareza de como fazer. Esta era a grande questão (...). Esses dois eixos eu acho fundamentais, de democratização das decisões e vinculação com as necessidades da população. Nós não sabiamos operacionalizar isso (...) É muito complicado. Agora, a gente se propunha a resolver. Nós tivemos a pretensão, não de uma maneira perfeita, mas a gente se achava competente para resolver". A dirigente, ao levantar essas últimas questões, provavelmente estava fazendo referencias às oficinas de trabalho desenvolvidas com o apoio da Cooperação Italiana. Nestas, propunha-se reorganizar o planejamento em saúde, a partir da apropriação das distintas bases territoriais locais. Deste modo, seriam desenhados projetos de intervenção, priorizando-se as populações com maior risco de adoecer $\mathrm{e}$ morrer, por meio de coletivas voltadas à promoção da saúde e prevenção dos danos e agravos. Aspectos que foram dificeis de serem incorporados pelo conjunto dos funcionários.

Na visão de Pedro Dimitrov, as questões básicas da administração da saúde estavam no Documento Número Um, e diziam respeito à integração dos serviços de saúde: as Unidades Básicas de Saúde, os laboratórios, os Hospitais, os serviços de epidemiologia. Tudo seria integrado sob um único comando, numa determinada área geográfica, num mecanismo de descentralização do poder que o levasse para perto do usuário e do prestador de serviços. "Lógico que, vinculado a isso, estão subentendidas aquelas idéias, como a possibilidade de controle social pela população, a questão de você ter uma racionalização do uso do recurso e reduzir a quantidade de 
recursos humanos utilizados na área administrativa, colocando mais pessoas na atividade-fim, reduzindo assim as ações dos serviços verticalizados".

Referindo-se à integração intersetorial no âmbito regional, o mesmo dirigente afirma que houve proposta de planejamento em nivel local de modo integrado, encabeçado pela SAR e pela Secretaria de Planejamento, visando à criação dos Núcleos Regionais de Planejamento. "Os NPR's passaram a ter um papel importante, a ter um caráter político, tentando integrar as várias Secretarias e dar solução aos problemas comuns. Ocorreu um conflito entre o órgão local-intersetorial, ou seja, um órgão horizontal, com as Secretarias, que são verticais e setorializadas. Os conflitos chegaram a um ponto de intensificação que fez com que a corda se rompesse para o lado mais fraco, e os NRP's foram desativados. Aí, o que houve? Houve uma ruptura deste processo, retornando tudo para o sentido verticalizado das Secretarias. Cada Secretaria se fechou em seu feudo".

Escrivão complementa as opiniões dos dirigentes anteriores a respeito do trabalho integrado apontando o interesse da Secretaria em aprimorar o sistema de informações e, em colocar, dentro das prioridades dos diversos setores sociais, indicadores epidemiológicos de saúde. "Algumas questões interessantes mostravam uma certa insuficiência tecnológica sobre como fazer para trabalhar integradamente. O pessoal da Secretaria de Obras, por exemplo, uma vez pediu para que a gente dissesse quais eram os pontos em que as obras da cidade deveriam ser priorizadas, em relação a enchentes e tal, do ponto de vista de doenças, tanto do risco de adquirir o cólera, quanto de leptospirose, e outras doenças. E nós não sabíamos o que responder para eles. Porque talvez o indicador epidemiológico não fosse o único indicador de risco. Talvez porque não haja indicadores em que seja possível, sem medo de se cometer injustiças, de você afirmar que aqui é melhor canalizar este córrego, e não aquele ali, porque aqui o risco de doença é maior".

O dirigente conclui que, a despeito das experiências positivas e negativas, a intenção de realizar um trabalho integrado era grande.

Quanto à implementação da última diretriz - a participação e controle social - apresentamos os enfoques dos dirigentes entrevistados distinguindo dois aspectos. Em primeiro lugar, aparecem as reflexões sobre os movimentos da população, e a seguir, as observações que dizem respeito à participação dos funcionários. 
Segundo informação de Eduardo Jorge, a discussão com os movimentos populares da cidade de São Paulo teve início antes da instalação do governo. "Foram realizadas assembléias em várias regiōes. Gente da zona sul, da zona norte, mas muita gente mesmo da zona leste, que tinha um movimento mais forte. Leste e sudeste. $E$ a idéia que os militantes do movimento popular tinham é que, com a nossa vitória, eles teriam participação e controle da gestão das Unidades Básicas. E eles queriam ter uma administração direta com as UBS's. A discussão com eles serviu para ver que, para isso acontecer, teria que haver, por um lado, um amadurecimento dos administradores, dos funcionários e dos próprios militantes do movimento popular. E que fosse algo processual, que passasse por instituir organismos permanentes de gestão. Caso contrário, você poderia ter pessoas que desestruturariam completamente os mecanismos de gestão de uma região. A nossa proposta era de que, aonde houvesse um predomínio total dos movimentos populares, nós dividíssemos a gestão em 3 partes: entre os dirigentes, os funcionários e a população, gerando um sistema de gestão tripartite. Foi dai que nasceu inclusive a idéia de se formar os Conselhos de Gestão nas próprias Unidades, que é o local onde os movimentos eram mais fortes. Para eles poderem exercer diretamente a sua influência na gestão. Os movimentos eram mais fortes no nível local, onde eles poderiam exercer uma influência mais direta. Isto não era previsto no horizonte da Legislação. Nós abrimos um debate com os movimentos sobre a possibilidade de serem criados os Conselhos de Gestão nas Unidades, nos quais eles participariam, dividindo as responsabilidades conosco, numa estrutura tripartite". Eduardo Jorge afirma que a criação dos Conselhos contribuía para acelerar a integração e, nesse caso, a presença na Prefeitura facilitava o entrosamento antre ss mevimentos, que tinham pouco contato ontro si. Esto fói uim p̄īs̄ō importante para a constituição mais rápida do Conselho Municipal de Saúde, um dos primeiros do Brasil a se formar, e que teve uma responsabilidade progressiva na definição da politica de saúde do município.

Eduardo Jorge levanta outro aspecto vinculado à participação da população, destacando a ineficácia da política de comunicação da Secretaria diante da magnitude do movimento social. "O que aconteceu no final das contas é que houve uma ampliação muito grande dos Conselhos Gestores, do Conselho Municipal de Saúde. No final do governo nós tínhamos mais de uma centena de conselhos. O conselho gestor das unidades, inclusive $O$ defendido em todo o Brasil, começou aqui em São Paulo. Isto não estava 
previsto na lei do SUS. Foi para responder a uma pressão dos movimentos já organizados de longa data que foram criados os Conselhos de Gestão. Quando terminamos a gestão havia mais de uma centena de conselhos. Isto envolvia pelo menos 1.500 a 2.000 pessoas da população, usuários, participando junto conosco da co-gestão, num nível razoavelmente intenso. Isso num universo de 10 milhões de pessoas é pouquíssimo, e a grande falha neste ponto de vista é a falta de trabalho com a comunicação externa à SMS. $\mathrm{Na}$ Prefeitura Municipal de São Paulo como um todo, mas mais particularmente na SMS, que tinha mais clareza disso aí. Não se avançou quase nada na comunicação externa".

$\mathrm{Na}$ mesma linha de avaliação da política de comunicação, estão as considerações de Escrivão. "O que faltou para a gente foi a política de comunicação, a prática da comunicação. Na área da comunicação da gente acabou ficando muito enfatizada a prática da participação direta. Não ficou claro para as pessoas o que se pretendia com esse tão falado novo modelo de atenção ou qualquer coisa assim. A gente não fez uma política de comunicação que fosse capaz de passar claramente o que se pretendia e ganhar apoio sincero, ideal, espontâneo do pessoal. A população como um todo entendeu muito pouco e eu acho que o que se criou foi um grupo de pessoas da população que passou a aderir aos conselhos, que muitas vezes era o pessoal mais interessado em se organizar. Já não era organizado, mas mais interessado, e que foi estimulado pela gente, pela Secretaria, pela Prefeitura, e passou a participar. Esta é a visão que eu fiquei ao cabo dessas coisas".

Segundo Elias, a questão da participação contém dois aspectos. $\mathrm{O}$ primeiro está ligado à vontade das pessoas de incorporar todos os segmentos da população numa perspectiva de construção da cidadania: "O que era cidadania? Essa palavra era uma palavra unificadora. Mas o que é cidadania para cada uma dessas pessoas, ou para cada um dos diretores, ou para quem tinha necessidade de mando, para quem tinha poder de mando mesmo? Precisa ver qual a leitura que se tinha de cidadania. A palavra era a mesma. Mas o que era ser cidadão para cada um deles? Então em acho que isso também passa por um filtro político e ideológico". O segundo aspecto, de acordo com Elias, liga-se à freqüência dos movimentos sociais organizados e sua influência na Secretaria: "Sem dúvida que os movimentos sociais organizados e os funcionários tiveram influência na nova estrutura administrativa da Secretaria. Em graus distintos. O que unifica tudo isso é o 
pensamento da Reforma Sanitária que penetra no movimento social. Se você for estudar os movimentos de saúde, você vai reconhecer lá o pensamento da reforma sanitária. E mais, não só o pensamento da reforma sanitária. Eu acho que, pelas características de quem era o Secretário e quem era o grupo que estava ali na Secretaria, esse movimento de saúde teve seu ideário, suas expectativas contempladas, senão totalmente, eu diria que pelo menos significativamente. No caso do funcionalismo essa penetração do ideário da reforma sanitária foi mais esmaecido. Mas mesmo assim ele existia e também foi contemplado. O que eu quero dizer é que no caso do movimento de saúde, - movimento de saúde forneceu quadros para a administração (...) Para começar, o próprio Secretário começou sua vida politica no movimento de saúde, para não falar de outros exemplos, como assessores de todos os niveis (...) Quem forneceu quadros mesmo foi o movimento de saúde, em todos os níveis. Eu acho que isto é uma coisa diferenciada".

Na percepção de Dimitrov, trabalhar com os movimentos populares não trouxe nenhuma dificuldade para a gerência da Secretaria. Pelo contrário, trabalhar com a população teve um valor estratégico. Diz ele: "em relação à população foi uma coisa muito tranqüila porque havia uma experiência muito grande acumulada de participação popular. As pessoas que estavam na direção da Secretaria tinham experiência com participação popular. Havia clareza da direção da Secretaria quanto a importância e necessidade de se montar os Conselhos Gestores, deliberativos, tripartites, que eram a garantia de que a reforma administrativa que foi feita, de cima para baixo, viesse a dar certo. Ela só daria certo se tivesse o controle do nivel local pelo usuário".

Nemes complementa as considerações sobre a participação popular, ao afirmar que "para a população foi uma experiência interessante, porque a população tinha um canal para reivindicar, pleitear mudanças na prestação de serviços. Esse canal eram os Conselhos. Tinha uma interlocução direta, sem intermediários, com os gerentes. Isso é uma coisa interessante, menos provida da idéia do clientelismo. Essa participação da população levou a uma certa definição de prioridades em alguns casos. Tiveram interferência de fato. Ganharam bastante com isso. Aprendizado politico mesmo, de cidadania e de ter um serviço próximo que fosse melhor". Assim, segundo os dirigentes, apesar das deficiências da Secretaria à sua politica de comunicação externa, principalmente junto aos grandes meios de comunicação, o processo de envolvimento do movimento popular possibilitou ganhos de ambos os lados. 
Quanto ao segundo aspecto da participação, ou seja, o que diz respeito à inserção dos funcionários públicos, os resultados alcançados ficaram aquém daqueles dos movimentos populares. Iniciamos as considerações com a opinião de Eduardo Jorge: "Os sindicatos e os funcionários queriam imediatas e impossíveis mudança das condições de trabalho e de salário, e usavam esse tipo de reivindicação como pretexto para não assumir as tarefas ou os três caminhos ${ }^{61}$ que nós propusemos para eles. Então essa tensão foi permanente. Após aquele momento mágico, de se identificar conosco na possivel mudança mágica também, que não era possível quando se concretizaram os três caminhos - a mudança de modelo, a mudança da forma de tratar a população, que inclui a questāo de se respeitar os horários, e a necessidade de dividir a responsabilidade que nós colocávamos para eles, isto é, a co-gestão - houve um refluxo de boa parte desse sentimento. $E$ essa questão salarial, essa questão puramente sindical, se colocou o tempo todo como tensão em relação a esses três caminhos. Chegou a ponto de se formular, junto aos setores mais organizados, uma visão que é a seguinte: "nós não temos a responsabilidade de governar com vocês. $E$ vocês da administração, estão colocando os representantes da população para nos fiscalizar". Esse tipo de tensão nós vivemos os quatro anos de governo. $E$ isso foi se acentuando".

Dimitrov destaca outro aspecto da dificuldade de envolvimento dos servidores com o processo de democratização da Secretaria. Para o dirigente, os servidores, historicamente, não estavam habituados com a participação. "Eles estavam habituados a se organizar por categorias especificas. Não havia uma articulação interprofissional no nível local. As articulações se davam verticalmente por categorias profissionais. Essa foi uma dificuldade. $O$ Sindicato não aproveitou o espaço que tinha para poder reorganizar os servidores e atuar de uma forma mais conseqüente em relação aos serviços de saúde. Os servidores tiveram um papel, do meu ponto de vista, muito pobre na construção do SUS aqui em São Paulo".

\footnotetext{
${ }^{61}$ Os três caminhos referidos por Eduardo Jorge são os seguintes: "1.mudança de modelo de atenção, com a integração da medicina preventiva com a curativa; 2.compromisso do funcionário com as obrigações e deveres em relação ao trabalho (o funcionário é um agente do poder público que tem que respeitar a população, tem que servir a população); 3.abrir um espaço aos funcionários através de seus representantes eleitos. de seus sindicatos. para dividir a responsabilidade de governar conosco. Os Conselhos de gestão. os conselhos regionais e o CMS estavam abertos à representação dos funcionários. alguns eleitos diretamente, ou via representação dos sindicatos, para vir a dividir a responsabilidade de gestão dos serviços de saúde conosco".
} 
Virgínia Junqueira também concorda com a falta de envolvimento dos funcionários na definição das políticas de saúde. Acredita que de certo modo, a Secretaria contribuiu para que isso viesse acontecer. "Eu acho que, para os funcionários não-médicos, talvez a maior queixa é que não houve suficiente envolvimento na definição do que deveria ser feito, na condução mesmo dos processos de decisão. No diálogo com os funcionários, é muito importante o papel do Secretário, ninguém pode substituir ele nisto. Foi uma coisa que acabou ficando reservada para o momento das Conferências de Saúde. A Conferência era aquele momento em que o funcionário podia falar alguma coisa. Mas era, eu acho, precário ter só este momento de Conferência, distrital, regional e municipal, como fórum para o funcionário poder se expressar. Eu acho que isso é a comunicação maior de como é que você operacionalizava essa questão de democracia no interior do funcionalismo, que tem muitos problemas, que está viciado com anos e anos de muitas práticas, que não são do interesse da população e nem sequer de si mesmo. Porque o que acontece é que acaba o funcionalismo ficando com essa má fama, que permite a um governante como o Maluf destroçar tudo, botar todo mundo para escanteio. Até contrariando seus próprios interesses, o funcionário desenvolve uma prática que precisa ser mudada, e que para isso não tem que ter benevolência. Então eu acho que da nossa parte houve essa contradição, de querer fazer a democratização e estar muitas vezes passando a mão na cabeça dos funcionários, principalmente na dos médicos, por uma suposta preocupação com a democratização. Eu acho que houve isso, ou seja, timidez excessiva com certos contingentes do funcionalismo, como o dos médicos, e a não participação real da maior parte do funcionalismo. Eu acho que não houve um real processo de participação do funcionário em seu dia-adia. Agora, eu não vejo outra maneira de fazer a coisa, que não seja com o envolvimento do funcionário no planejamento do que esta Unidade vai fazer em níveis sucessíveis de complexidade. Eu não vejo outra maneira de fazer. Eu acho que aí está a questão da gente conseguir desenvolver o planejamento, os planos locais de saúde, os planos regionais de saúde e discutir a questão maior da Instituição que é a questão da saúde, das condições de vida da população e de como é que os funcionários estão envolvidos na resolução desses problemas. Eu penso que isso falhou completamente, digo completamente sim". 
Destacamos três ordens de problemas enfrentados pela Secretaria durante a implementação da política de saúde, decorrentes das relações que se estabeleceram com o governo municipal, ou oriundos do interior da própria Secretaria da Saúde.

Com respeito às dificuldades originadas do governo municipal, observamos as resistências à reforma administrativa proposta pela Saúde. $\mathrm{Na}$ opinião de Neder, as dificuldades surgidas entre a SMS e o governo municipal decorrem sobretudo de indefinições no programa e da forma como foi composta a equipe de governo. "Naquele momento, a lógica das tendências acabou imperando - a lógica das tendências dentro do Partido. Foi um governo bastante centrado no Partido dos Trabalhadores. Só no final é que ele foi se abrindo para a idéia da participação de outras forças políticas, seja partidária, seja na questão do Fórum da Cidade. Houve dificuldade em definir o núcleo de poder dentro do governo, e eu acho que o momento mais significativo desse embate teórico, vamos dizer assim, no bom sentido, foi ao final do ano de 89 , onde diferentes teses foram apresentadas para discussão dentro do governo sobre qual era a forma mais adequada de gestão pública no municipio de São Paulo. Naquela ocasião, nós elaboramos conjuntamente - eu tive participação nisso e o Eduardo também -, um documento que questionava a falta de planejamento estratégico no governo, a falta de comando político do governo, e a necessidade de nós definirmos, com maior radicalidade, qual seria o caminho da descentralização do poder e de toda gestão municipal ${ }^{62}$ (...) no caso da Saúde, nós tentamos fazer aquilo que a gente propôs para o governo e que não conseguiu que fosse uma proposta de governo, que é tentar fazer o planejamento (...) a partir de um dinamismo dado pelo próprio trabalho, ou seja, você teria uma representação de órgãos. portanto uma representação de diferentes dinâmicas, uma representação de diferentes modalidades de implementação de ações de saúde.

(...) O governo optou por um outro caminho. Optou pelo não planejamento estratégico, optou por nāo fazer a gestão politica através de um comando, através de programas e de políticas que fossem definidas em função de campanhas centradas, e que dessem visibilidade às ações de

\footnotetext{
${ }^{62}$ Este documento intitulado Dimensão Politica da Gestão definia as estratégias de atuação da prefeitura de São Paulo. Dezembro de 89 (mimeo).
} 
governo, e ao mesmo tempo, acabou optando por uma estratégia gradualista na implantação da reforma administrativa".

Segundo Neder, todas as Secretarias pagaram um preço pelas relações estabelecidas entre elas, sobretudo entre as secretarias-meio e as secretarias-fim. As Secretarias das Finanças, Planejamento e Administração tinham extrema dificuldade em entender as demandas crescentes da Saúde, em recursos humanos e financeiros. A impressão que ficamos de seu discurso foi a de que, findo o período de governo, as três secretarias referidas continuaram sem compreender (ou concordar com) o sentido da política de saúde desenvolvida pela SMS. "Então, basta analisar, por exemplo, qual foi o investimento feito na área da Saúde de 89 até 92 e a gente percebe que se elevou os gastos a um patamar muito superior que historicamente se gastava. Em toda a história da Secretaria nunca se gastou mais do que 8 a $9 \%$ do orçamento municipal em Saúde, e nós já fomos para um patamar de 10 , depois passamos para 11, para 12 e acabamos gastando $14,7 \%$ do orçamento em 1992. Então eu acho que isso gerou alguns conflitos também".

Segundo Eduardo Jorge, um dos maiores entraves à política de descentralização e democratização dos serviços de saúde foi a mentalidade centralizadora, que duvidava da eficácia de uma administração descentralizada e participativa da forma como preconizou a Saúde. "Essa mentalidade centralizadora, é importante frisar, não estava somente na estrutura tradicional da Prefeitura e em outros órgãos governamentais do país. Ela estava na cabeça dos próprios militantes de esquerda, porque a tradição da esquerda é uma tradição centralizadora. É uma tradição unificadora por cima, própria de uma estrutura organizativa de vanguarda, que nós sempre achamos uma tradição nossa, necessária para vencer as resistências existentes de fusão de uma ideologia dominante e burguesa, no seio do próprio povo, do próprio trabalhador. Essa visão era uma visão da máquina tradicional da Prefeitura e de outros órgãos de governo, mas era a visão também na cabeça dos militantes do PT que estavam assumindo o governo. Então, era uma visão tradicional, centralizada, autoritária do Estado brasileiro, com a mentalidade da tradição vanguardista, autoritária nossa, dos militantes de esquerda que estavam assumindo o governo via Prefeitura Luiza Erundina. Vencer todos esses obstáculos não foi fácil, e novamente a saida foi ter uma proposta, ter o apoio popular, ter o apoio dos funcionários que se identificaram com a nossa proposta de trabalho, e negociar direto com a 
prefeita. Para forçar a descentralização, nós fomos obrigados a apelar diretamente para o rei".

Paulo Elias tem a mesma opinião de Eduardo Jorge, e afirma que a tensão entre descentralização e centralização existente no governo municipal também perpassou a Secretaria. "Vou começar com o maior problema deles que era o seguinte: a Secretaria da Saúde tinha uma concepção no plano do ideário, de descentralização muito radical, num governo que não tinha esse ideário homogeneamente. Este é o primeiro grande problema. Como é que você vai fazer uma descentralização numa Secretaria, sendo que boa parte do que ia ser descentralizado tinha relações íntimas com o restante do governo, com as outras Secretarias, que não tinham essa concepção? Um grande problema era o seguinte: achar que a Secretaria da Saúde era a vanguarda, era a que tinha o caminho iluminado, e os outros eram aqueles que eram atrasados, aqueles que não enxergavam e que por razões... e aí vinham várias explicações. Então era um esquema assim, o bem e o mal, maniqueísta, e mais do que isto, pessoal. Esse problema era tratado em termos pessoais (...) "Claro que isto não perpassava todo o conjunto da Secretaria, não é todo mundo que achava isso. Eu estou dizendo que era uma visão muito presente, se não enunciada desta forma, mas o comportamento das pessoas era voltado para este tipo de visão (...) Esse pensamento e essa diretriz de que você tinha centralização e descentralização. Teve uma tensão aí, também interna à Secretaria da Saúde, em determinados segmentos da Secretaria. Isto não perpassou totalmente a Secretaria, mas esta tensão se reproduziu também no interior da Secretaria".

Dimitrov reforça a opinião dos três dirigentes, quando opina sobre as dificuldades surgidas entre a saúde e o governo municipal. Segundo ele, as pessoas que tinham algum poder dentro do governo, ficaram impossibilitadas de desenvolver a política de descentralização, porque a máquina administrativa da Prefeitura estava estruturada para ser extremamente centralizada. "Embora a Prefeitura como um todo tivesse um discurso de descentralização, a Secretaria de Finanças e a Secretaria de Administração tinham uma política altamente centralizadora".

Quanto ao conjunto de problemas identificados no interior da Secretaria, distinguimos dois subconjuntos. Um deles é relativo ao desenho da estrutura organizacional e outro diz respeito à mudança do modelo de atenção à saúde. 
Quanto ao primeiro, começamos a abordagem com as reflexões de Elias: "O que se fez foi uma grande mudança administrativa. O Gabinete mudou mas não mudou. Não sei se consigo te dizer como é que é. Ele mudou mas não mudou. Foi feita uma grande reforma administrativa, dentro de uma cultura institucional. Não dá pra você esquecer qual era a cultura e qual era a base material de sustentação (...) A definição de competências, por exemplo, esta não ficou clara, objetiva, de maneira geral, em todos os niveis. Eu acho que em algumas atribuições você conseguiu objetivar isso, mas de maneira geral, não. Não ficou claro, por exemplo, qual era o papel da ARS. Tinha um discurso sobre isso, mas você não tinha uma estrutura, nem uma estrutura material, nem precisão inequívoca de quais eram as competências daquilo. Você tinha as coisas emitidas no papel, idéias, diretrizes, que não consubstanciam responsabilidades imediatas. E digo mais, você tinha responsabilidades concorrentes entre o nivel central da Secretaria, a Administração Regional e o Distrito (...) Onde todos podem, ninguém é responsável. Onde é que estava a responsabilidade disso? Eram responsabilidades indefinidas, esmaecidas, que eram concomitantes, concorrentes". Gostaríamos de clarear nossa compreensão a respeito das considerações de Elias sobre a reforma administrativa. Em nosso modo de ver, o processo transferiu poderes do nível central às Administrações Regionais e aos Distritos de Saúde e, desta forma, estaria revestido de um manto político, vindo a se transformar em um fenômeno de disputa de poder interno à Secretaria, fato que por si só, poderia explicar as concorrências de competências.

Ainda a respeito das deficiências da estrutura organizacional da SMS, também Escrivão faz considerações sobre a indefinição de competências e sobre o processo de tomada de decisão desenvolvido pelo nível central da Secretaria: "Ficou muito pouco clara a definição de competência dos diferentes niveis da Secretaria. Alguns desses órgãos, ligados diretamente ao Gabinete da Secretaria Municipal de Saúde, acabaram acumulando funções de mando ,e na prática, centralizando. Embora a decisão fosse toda tomada no Conselho Técnico Administrativo, o CTA na verdade funcionava não só como uma reunião de decisão, mas como um lugar onde todos se informavam sobre tudo o que estava acontecendo. Era mais um mecanismo de comunicação do que um mecanismo realmente de decisão. Da maneira como ele funcionava, ele não tinha condições de funcionar como centro de 
decisões. Isto era um processo de centralização da decisão. Isso tudo era colocado em função da necessidade de agilizar. Era um processo bastante contraditório (...) Qualquer processo onde você não se sinta participante, você não se sente responsável. Isto, é claro que as pessoas não diziam. Nesse sentido, a gente começou a reproduzir a hegemonia do funcionamento da máquina".

Nemes, por sua vez, emite opiniões sobre os problemas internos da estrutura organizacional da Secretaria, refletindo a respeito da situação jurídico-administrativa dos Distritos de Saúde: "A gente conseguiu criar legalmente alguns Distritos Sanitários, outros não foram criados. E na hora que você não faz isso, você cria determinadas estruturas de Distritos Sanitários de um jeito e as outras estruturas ficam diferentes. Isso dá uma confusão terrível. Além de você não ter dinheiro para pagar as pessoas, fica uma coisa assim de militância, que junta com a dificuldade de institucionalização dos tais Distritos Sanitários. Outra coisa é a própria concepção de Distrito Sanitário que era muito variável. Tinha gente que entendia mais administrativamente. Outros, como uma coisa mais para mobilizar a população, de ser um canal de participação da população. Essas indefinições, trabalhar com muita gente, incorporar muita gente, também traziam confusões junto com as indefinições sobre como montar os Distritos Sanitários. Essa coisa não foi muito clara até o final da gestão, mas, bem ou mal, a gente montou 32 Distritos Sanitários que começaram a trabalhar. Mas não houve tempo suficiente para se estruturar $e$, não podendo se legalizar, ter cargos para todos, o trabalho ficou limitado, porque faltou estrutura legal. Assim, ficou sempre aquela coisa improvisada. Eu vejo assim, a improvisação, as limitações legais e o afã de querer fazer tudo, de fazer muita reforma, de enfatizar o meio. Eu faria menos, bem menos".

A opinião de Nemes é compartilhada por Paulo Elias, que aponta as dificuldades de uma estrutura frágil na Secretaria. "Essa tensão entre centralização/descentralização que tinha no governo foi reproduzida na Secretaria da Saúde e com efeitos díspares e, dependendo da situação (...), às vezes você queria fazer as coisas sem as bases materiais. É como se você falasse, no peito e na raça, mas você não faz nada no peito e na raça (...)

(...) Você pode não ter a estrutura completa, acabada, etc. e tal, mas também sair do nada para construir alguma coisa, sem nenhuma base, sem nenhum alicerce, é complicado. E tão mais complicado isso fica, tão mais perto é de coisas que são mais fundamentais na Secretaria. Mais 
fundamentais na dinâmica do funcionamento cotidiano da Secretaria. Porque ai as repercussões são muito intensas. Eu me lembro, por exemplo, da descentralização orçamentária. Como fazer a descentralização se você não tem capacitação nem no nível regional, nem no distrital para processar isso? É uma insanidade fazer isso. E o resultado é avançar? Pelo contrário, é recuar. Porque a descentralização, ela foi entendida na Secretaria como um fim. E ela não é um fim. Ela é um meio. Ela foi entendida sempre como um fim em si. A descentralização em si. Se você descentralizar você estará avançando, porque em si mesmo, ela está eivada desta positividade, e ela nunca foi. Em raros momentos a descentralização pode ser considerada um fim. Em rarissimas situações ela pode ser considerada um fim. Na maior parte das situações ela é sempre um meio (...) Eu acho que a grande reformulação foi administrativa. Foi a grande mudança. Porque nesta outra parte, da definição das responsabilidades, isso não foi precisado". Naquele momento, enquanto diretor de uma ARS, a nossa visão sobre o processo de descentralização da Secretaria é que ele poderia ser um fim em si mesmo. Porque haveria o deslocamento do eixo de poder do centro para a periferia e desta forma, aumentaria o compromisso com a democratização, decorrente da ampliação de espaços de participação do funcionalismo e dos movimentos sociais, nos processos de tomada de decisão. E também porque, pensávamos, com a descentralização haveria maior agilidade administrativa, diminuição da burocracia estatal, e definição de ações coladas às distintas realidades locais.

Com outra abordagem do problema, Pedro Dimitrov procurou encontrar respostas às dificuldades internas da Secretaria, afirmando que não há uma resposta única para uma questão com esse grau de complexidade: "Na realidade nós não tínhamos a possibilidade de estar definindo coisas fixas, estanques. Por que? Porque cada região tinha uma capacitação de trabalho, com seu grau de amadurecimento. Alguns Distritos avançaram mais num aspecto, outros Distritos Sanitários avançaram mais em outros. O que eu sempre insisti na época é que fossem definidas as instâncias onde as coisas fossem discutidas, e definidas as atribuições muito mais como processo do que como uma coisa acabada, como um decreto, uma lei, uma resolução ou coisa do gênero. Tanto que grande parte da preocupação nossa era consolidar as instâncias de decisão da Secretaria, como o Conselho Técnico Administrativo" 
A seguir, o mesmo dirigente faz um balanço da evolução dos principais órgãos assessores do Gabinete da Secretaria, concluindo com uma avaliação sobre o COAS. A sua opinião corrobora com nossa visão sobre a descentralização administrativa, enquanto deslocamento de poder, fato que poderia explicar a existência dos problemas decorrentes. "Quanto aos novos órgãos criados, como o CEPI, o COAS e o $\mathrm{CRH}$, eu acho que o órgão que mais clareou o seu papel, e aos poucos foi construindo uma proposta para a Secretaria, foi o CEPI. A segunda área que mais avançou para mim, foi a área de Recursos Humanos. Entendo que avançou bastante, às vezes de uma forma atrapalhada, porque era um envolvimento muito grande de trabalho, isso tem que ser reconhecido. Um número muito grande de trabalho, de concursos públicos, de processos que mexiam com os envolvidos e com a dificuldade com que você fazia os concursos. E por último, acho que a área de maior conflito e dificuldade foi realmente o COAS, e aí fica claro. Gostaria de registrar a minha visão sobre isso. Algumas pessoas que participavam deste fórum desde o inicio, não assumiram funções executivas deste tipo, e acabaram ficando nos órgãos assessores, no CEPI, ou COAS ou $\mathrm{CRH}$, que são órgãos assessores e não órgãos de linha de mando. Mas algumas dessas pessoas que ficaram no $\operatorname{COAS} e$, que eram responsáveis por alguns programas específicos - Saúde do Trabalhador, Saúde da Mulher, Saúde Mental e outros - insistiram em ter uma linha de mando. Não admitiram a reforma da própria Secretaria, que tinham contribuido para fazer. $E$ aí havia um conflito permanente entre o diretor da região que, como diretor, tinha que escolher seus assessores nas várias áreas, e os assessores do $\mathrm{Sr}$. Secretário, dessas várias áreas que estavam no COAS, querendo indicar os assessores para os diretores das regiões. É como se voltasse a ter uma estrutura vertical, por programas, comandada pelo COAS. Não era essa a estrutura proposta pela Secretaria. Então aí foi o órgão assessor que demorou mais para entender o seu papel, e teve algumas pessoas que ficaram os 4 anos e não entenderam. Ficaram até o final da gestão criando conflitos com os Diretores das ARS's e dos DS's".

Com a experiência acumulada de quem coordenou um órgão estratégico da Secretaria, Virgínia Junqueira também faz considerações a respeito das contradições surgidas entre as equipes do COAS: "o COAS é a expressão própria da contradição, porque você tinha ali pessoas escolhidas em vários fóruns para, enfim, expressar reivindicações de vários tipos de movimentos junto à Secretaria. Desde os movimentos de mulheres que tinham 
delegado para que uma pessoa estivesse representando suas reivindicações, suas problematizações junto à Secretaria Municipal de Saúde, até o assessor de Saúde Mental, na luta antimaniconial enfim, e por aí vai. Então você tinha pessoas lá dentro da Secretaria que tinham sido impostas por esses movimentos, os mais diversos. Eram pessoas que tinham chegado lá, não por uma escolha do Secretário, mas tinha havido uma negociação entre o Secretário e esses movimentos, essas representações. O problema é que essas pessoas que vinham dessas representações, muitas vezes se confrontavam com o movimento da descentralização. Ao final, ao cabo, elas se tornaram defensoras dos Distritos. O que matou nossos Distritos veio do governo municipal. Acho que o que matou os nossos Distritos não foi o conflito que esses representantes de movimentos traziam para a Secretaria. Eu acho que esse conflito, quando bem articulado, ele produzia avanços. Pelo diálogo, se avançava. Como é que foi a definição dos papéis? Foi uma definição apenas incipiente. Tanto do diretor regional como do diretor distrital, que estavam no meio dessa confusão toda. As várias pessoas estavam confusas por conta de uma confusão maior. Em todos os niveis, todos. Essa confusão começou na Prefeitura, claro. Ela não era uma confusão que se instala em uma Secretaria por si. Ela começa na Prefeita, que começou a titubear a partir do segundo ano, quando era preciso quebrar o poder das três Secretarias Finanças, Administração e Planejamento".

Quanto à segunda dimensão de problemas internos à Secretaria, relativa à mudança de modelo de atenção à saúde, Paulo Elias faz suas considerações identificando três padrões de racionalidade. Destaca uma racionalidade política, representada pela ideologia da política de saúde oriunda das teses do Movimento da Reforma Sanitária, uma racionalidade burocrática, apoiada na cultura da instituição, e uma racionalidade subjetiva, estruturada em função das características pessoais de cada dirigente. Segundo ele, "o modelo supunha uma construção coletiva e tinha também um discurso ideológico que era muito forte e muito presente, mas que não tinha substrato na realidade concreta, para que pudesse vicejar. Essa que é a verdade. Então tinha uma vontade, uma intencionalidade, e uma concretude das coisas que dependiam de outros fatores e que faziam as coisas andarem de um certo jeito (...) O papel do diretor era muito importante. A cultura da instituição era hierárquica. A hierarquia da Secretaria era uma coisa muito cara ao funcionalismo e eu creio que esse papel, de diretor, por menos que 
ele quisesse - ai eu vou entrar em um terreno especulativo -, eu acho que às vezes, no ideário dele, ele não queria, mas na prática ele queria. Então tinha essa idéia, os famosos coletivismos. Tudo era construção coletiva. Tudo era coletivo, mas quando você olhava a realidade - e eu fui nesse sentido um observador privilegiado -, eu via que a realidade não se construía daquela forma. Então você tinha o ideário e você tinha uma realidade que constrangia aquilo. Não era uma coisa única. Não era porque as pessoas queriam. É que você não tinha bases materiais para sustentar aquele pensamento. É como se você tivesse um pensamento imenso e uma base material muito pequena, que não dava sustentação a ele. Ou seja, aquilo era o ideário, que eu chamo de ideário, era no plano ideológico. $E$ ai você tem que ver as relações sociais concretas que se estabeleciam. Os constrangimentos estavam dados ali. $E$ as pessoas ficavam muito desesperadas, e qualquer momento que se apontava essa tensão, entre ideário e bases concretas, era motivo para as mais variadas dissensões, e às vezes, até problemas de relação pessoal por causa disso. As pessoas tomavam pessoalmente. Por que? Porque elas tinham uma missão. Então eu estava dizendo: primeiro, você não vai encontrar um padrão único; segundo, este padrão vai perpassar. $E$ ai há uma proeminência muito grande de cada Diretor Regional. Mesmo que ele não quisesse. Porque nesta estrutura, ele era o diretor e ele tinha seus assessores. $E$ ai vai descendo tudo isso. $E$ aí, essas diretrizes todas, elas também vão sendo lidas de formas distintas. Quando chega lá na ponta, provavelmente o funcionário vai tomar isso esvaziado, todo o conteúdo político e de todo o conteúdo de transformação que isso tem. Ele vai tomar (...) como uma ordem a ser cumprida. Porque era essa a estrutura da Secretaria. Então você não implanta e não muda o modelo. Eu fico à vontade para falar isso porque eu sempre fui essa voz de quem participava das reuniōes da Gabinete da Secretaria Municipal de Saúde. Você não implanta, não faz mudanças de mentalidade em quatro anos. Você não faz isso (...) Era uma mentalidade, como você disse, era uma cultura que tinha na Prefeitura. Então começa politizado lá em cima e chega lá embaixo, que é onde vai operar (...) como uma ordem, porque era essa a estrutura, e é até hoje a estrutura do serviço público. Então essa idéia de que todos pensam. Primeiro porque nem todos têm as informações indispensáveis. Para isso exigiria mudanças gigantescas. $E$ as pessoas achavam que iam fazer isso na base da vontade, da conversa, da solidariedade, do compromisso. Então, você vai encontrar padrões bastante dispares e, uma das explicações para isso, eu acho, é o do perfil do 
administrador regional. Esse é um padrão que era absolutamente administrativo, de funcionário da Prefeitura (...) O que eu acho, no fundo dessa história, é o seguinte: esse ideário da Reforma Sanitária, certo ou errado, pelo bem ou pelo mal, ele não estava ainda, como ainda não está até hoje, não tem uma concepção técnica que the dê respaldo (...) No momento em que a Reforma Sanitária é convocada a dizer o que fazer, tá perfeito. $O$ como tem que vir com um discurso técnico, pois a dimensão técnica tem que comparecer para demonstrar como é que você opera isso. $E$ isto não fica claro. Ai você tem uma assimetria completa ".

Neder também destaca a situação funcional e a prática institucional dos servidores, referendando, de certa forma, as conclusões de Elias. "Nós tivemos que enfrentar também o problema da cultura do funcionalismo. Um funcionalismo que, na sua maior parte, tinha sido contratado pela lei 9.160 , a título precário, muitas vezes por indicação política. $E$, de repente, assume um governo de esquerda, em que há toda uma expectativa de que esse governo vai priorizar o funcionário público, e não propriamente a questão da população. E a gente é obrigada a introduzir esse contraponto, mostrando que antes de tudo ele tinha que ser servidor do povo, e que portanto, a politica do funcionalismo teria que estar adequada a um objetivo maior. $E$ a Saúde não poderia ter um enfoque isolado de outras políticas sociais, de outras políticas de governo. E que ao lado disso, era necessário mudar a prática desses servidores. Daí inclusive a importância do Cefor e de todo o trabalho que se fez no investimento de pessoal, na qualificação da mão de obra. Eu acho que a gente acabou não tendo tempo suficiente para consolidar uma proposta, que era uma proposta que vinha no sentido correto, que era de introduzir novas práticas, e ao mesmo tempo trabalhar a visão das pessoas sobre o trabalho que desempenhavam. E nesse sentido, eu temo que boa parte de nossas propostas não tenha chegado a implicar numa mudança efetiva no dia-dia do trabalho das pessoas. Em que pese toda a radicalidade da proposta, eu não sei se nós conseguimos chegar a mudar a prática de saúde no seu cotidiano, do ponto de vista das ações de saúde. Pegar uma cidade com 10 milhões de habitantes, 1.500 quilômetros quadrados de área geográfica, com toda a sorte de problemas, com a diversidade muito grande entre as regiões, ter que formular uma política de saúde que tivesse diretrizes comuns, mas que tivesse a flexibilidade para que as prioridades e os programas fossem compatíveis com o diagnóstico epidemiológico de cada região, que você tivesse mecanismos de aferição de cumprimento de metas. 
Então, tendo que implantar as dez administrações regionais de saúde, que acho que foi uma decisão correta, depois gradativamente implantar os Distritos de Saúde e readequar o papel das regionais. E sempre me pareceu que as regionais não deveriam ser extintas. Quer dizer, alguns advogavam uma redução tal do papel das regionais, a ponto de chegar a uma extinção das regionais. Eu já entendia de uma forma diferente, que acho que ficou expressa na proposta que fizemos no decreto de dezembro de 92, e no projeto de lei que a gente acabou não conseguindo fazer chegar até a Câmara, que era uma Administração Regional bastante enxuta, com papel de coordenação numa área geográfica maior, mas com grande grau de autonomia para os Distritos, ainda que tendo que dialogar entre si em torno de metas e objetivos a serem cumpridos. Então, eu acho que este esforço de definição de diretrizes nas Conferências, de definição de prioridades naqueles encontros que nós fazíamos no começo de cada ano, para definir prioridades e metas a partir das diretrizes das Conferências, a avaliação permanente das metas nos Conselhos instituidos na Secretaria, sobretudo os Conselhos Técnico-Administrativos, e a tentativa de mudar a prática, foi um processo gigantesco. Agora, é impensável achar que nós conseguimos consolidar um processo desse em quatro anos, ainda que sabendo das dificuldades que nós tínhamos para encontrar os melhores caminhos para poder implementar essa proposta num prazo mais curto".

O apontamento dos vários problemas surgidos no percurso continua no depoimento de Escrivão: "Se por um lado a decisão estava centralizada, por outro lado havia uma autonomia muito grande do processo decisório, porque você não tinha um processo de normatização estabelecido. Voltava-se muitas vezes à mesma discussão. Tolerância fazia parte do processo. Isso para mim é uma coisa contraditória daquilo que eu estava falando da centralização. $\mathrm{Na}$ verdade havia uma centralização, no sentido do que se decidir, mas também havia uma autonomização de como implantar. Não havia mecanismos de avaliação. Estava-se sempre discutindo problemas e fazendo propostas, como se fosse o primeiro dia de governo. Nós fomos até o último dia de governo quase que como se nós estivéssemos no primeiro dia, fazendo propostas e implantando novidades. Os processos de avaliação não davam certo. Nunca houve nenhum processo de avaliação, e se você não avalia o que você esta fazendo, você pode estar acertando ou errando. Acho até que a gente acertou mais do que a gente errou. Foi muito passional, voluntarista". 
Finalmente, queremos complementar as opiniōes dos dirigentes, abordando as difíceis relações do governo municipal com a Câmara Municipal de São Paulo. Procurando superar as dificuldades, a Secretaria estabeleceu uma relação mais próxima com o poder legislativo, através de pessoas deslocadas especificamente para este fim. Segundo informações de Eduardo Jorge, ao contrário da Prefeitura que subestimou e não deu o devido respeito à Câmara, "A SMS procurou ter uma relação mais aberta com a Câmara Municipal de São Paulo, e tinha pessoas de alto gabarito, responsáveis por esse contato com os vereadores, com os partidos. Que iam à Câmara Municipal dar satisfação a eles, explicar os processos, dizer os nãos necessários aos pedidos clientelistas, mas dizer os nãos explicando que existia uma política de pessoal, explicando que ia haver uma reforma, por isso que não podia ser atendido tal caso. Esta relação com a Câmara Municipal ajudou muito a SMS a levar adiante, quando precisava, a aprovação de seus projetos de criação de cargos e de unidades orçamentárias. A Câmara Municipal e é preciso que se diga isso, quando a SMS precisava da criação de cargos e de U.O's, pela expansão da rede, não nos faltou. Votou e aprovou praticamente tudo que nós queriamos. Isso ajudou muito a SMS. Coisa que faltou, vamos dizer assim na relação do conjunto do governo com a Câmara Municipal, que se caracterizou por uma relação de beligerância total.

Outra questão política fundamental que nos prejudicou foi o fato que nós queríamos governar sozinhos. Isso afetou a SMS e afetou o governo como um todo. A idéia do PT era a de governar sozinho. Era um movimento a meu ver para o qual encontramos resistências entre nós mesmos. A tendência era distribuir mais e mais cargos entre os militantes do PT, porque eram os únicos de confiança total e absoluta e pureza administrativa, moral e ideológica, capaz de levar o nosso projeto adiante. Então, dentro da própria SMS havia resistências entre nós mesmos em aceitar esses companheiros de outros partidos, para assumir responsabilidades grandes, de Administração Regional e de hospitais".

As opiniões dos dirigentes evidenciaram que o processo de trabalho desencadeado pela SMS foi permeado por inúmeros conflitos. Não foram raras as ocasiōes onde estabeleceram-se relações de confronto entre a Saúde e algumas secretarias-meio, como Finanças, Administração e Planejamento. 
Observou-se um enorme esforço da Secretaria para mobilizar e aglutinar forças em defesa da política municipal de saúde - para a implantação do SUS - junto ao governo, funcionários e movimentos populares.

Como se viu, em que pese as dificuldades internas do governo municipal, a SMS conseguiu implementar algumas diretrizes estratégicas da reforma sanitária, alicerçadas pelo incremento de recursos, pela reorganização da estrutura administrativa no sentido de garantir a autonomia decisória às Administrações Regionais e Distritos de Saúde, pelo estímulo à participação social e ao trabalho integrado, e pela valorização e desenvolvimento profissional dos servidores.

Os discursos dos dirigentes revelam unanimidade em torno da questão sobre a municipalização dos serviços/universalização da cobertura. Entretanto, mesmo entre outras secretarias municipais, surgiram críticas à tese da municipalização defendida pela Saúde, que se somaram aos argumentos de outros burocratas opositores nas esferas estadual e federal.

No que se refere à promoção da eqüidade, houve compreensões dispares entre os dirigentes. Esta prática pelo setor saúde, estava na dependência da construção de um novo modelo de atenção, cuja base conceptual pressupunha uma prática interdisciplinar intra-institucional, conjugada com diferentes saberes extra-institucionais, visando a integração da assistência de caráter individual com a produção da saúde, de caráter coletivo. Este modelo deveria apontar para a redistribuição dos recursos públicos, atentando para a concentração dos mesmos junto aos grupos sociais mais vulneráveis. Como se observou, esse processo de trabalho foi compreendido e implementado de diferentes formas. Segundo alguns dirigentes faltou maior clareza na definição da política de saúde, no uso de instrumentos gerenciais, na utilização de critérios epidemiológicos, definição de objetivos, metas e recursos disponiveis.

Quanto à descentralização administrativa, houve consenso entre os dirigentes que esta diretriz foi estratégica para dar autonomia às regiões e Distritos de Saúde. Este processo serviu para favorecer o trabalho integrado intersetorial que recebeu, em certo momento, apoio de instâncias superiores do governo municipal, através da criação dos núcleos regionais de planejamento. Apesar do considerável avanço da descentralização administrativa, alcançado ao final dos quatro anos do governo, foram levantadas algumas lacunas, como por exemplo, a persistência de conflitos de poderes entre as diferentes instâncias de decisão, a não existência de uma 
base material suficiente para suportar a complexidade da nova estrutura gerencial, e a ausência de mecanismos jurídico-legais que garantissem a continuidade do projeto político.

$\mathrm{Na}$ opinião dos dirigentes houve um grande avanço nos mecanismos de participação popular, com a implantação dos conselhos e comissões gestoras tripartites. Por outro lado, os funcionários públicos tiveram mais dificuldade para organizarem-se e, conseqüentemente, tiveram uma participação pouco expressiva nos conselhos de gestão. A diretriz participação social foi estratégica para a descentralização administrativa, com a redefinição dos mecanismos de tomada de decisão em todos os niveis gerenciais, e o estreitamento das relações comunicativas entre o poder público e os movimentos populares, e destes entre si. $\mathrm{Na}$ questão da comunicação externa, é consenso entre os dirigentes que o produto final ficou aquém do esperado. 


\section{CAPITULO $V$}

\section{O confronto entre as distintas visões: funcionários, cidadãos/usuários e dirigentes.}

A metodologia que escolhemos para realizar este estudo, partiu do princípio de confrontar as diferentes visões dos funcionários e cidadãos/usuários com o projeto da política municipal de saúde, na concepção dos dirigentes entrevistados. A seqüência de passos metodológicos nos permitiu apreender os discursos dos sujeitos coletivos em relação às questões da pesquisa, frente a estratégia adotada pela Secretaria. $O$ conjunto de informações obtidas reuniu elementos para refletir sobre a implementação de alguns aspectos do sistema único de saúde no município de São Paulo, entre 1989 e 1992, a respeito de temas como: mudanças estruturais, descentralização administrativa, democratização, participação, práticas sanitárias e modelo de atenção à saúde.

Frente à análise do conteúdo dos discursos dos funcionários, cidadãos/usuários e dirigentes, desenvolvemos as reflexões sobre a política de saúde desses quatro anos, na expectativa de contemplar as questões do projeto de pesquisa.

Inicialmente apresentamos um quadro com a síntese dos discursos dos sujeitos coletivos, sob a ótica dos funcionários e cidadãos/usuários, a respeito das quatro categorias temáticas estudadas: mudança de modelo de atenção à saúde, democratização/participação, trabalho integrado e desenvolvimento de pessoal.

Na página seguinte o quadro: 


\begin{tabular}{|c|c|c|c|}
\hline & funcionários & PAS & cidadãos/usuários \\
\hline $\begin{array}{l}\text { 1. categoria } \\
\text { temática: } \\
\text { mudança de } \\
\text { modelo de } \\
\text { atenção à } \\
\text { saúde }\end{array}$ & $\begin{array}{l}\text { há contradições entre os } \\
\text { discursos. Predominam as } \\
\text { opiniōes que a } \\
\text { administração anterior } \\
\text { promoveu mudanças no } \\
\text { modelo de atenção por } \\
\text { meio de: - estímulo às } \\
\text { ações programáticas e } \\
\text { preventivas em uma rede } \\
\text { de serviços integrada e } \\
\text { regionalizada; } \\
\text { - promoção da cidadania; } \\
\text { - estímulo ao planejamento } \\
\text { ascendente e participativo. } \\
\text { Existem outras opiniões } \\
\text { segundo as quais são } \\
\text { impossiveis mudanças no } \\
\text { modelo de atenção em } \\
\text { função do peso excessivo } \\
\text { da máquina administrativa. }\end{array}$ & $\begin{array}{l}\text { - Há consenso que a } \\
\text { administração L.E. } \\
\text { valorizou e promoveu o } \\
\text { trabalho em equipe. } \\
\text { - Para aqueles que não } \\
\text { trabalharam durante } \\
\text { aquela administração, a } \\
\text { qualidade dos serviços } \\
\text { mudou para melhor com a } \\
\text { introdução do PAS. }\end{array}$ & $\begin{array}{l}\text { Duas visões conflitantes: } \\
\text { - com a implantação do } \\
\text { PAS a qualidade dos } \\
\text { serviços de saúde mudou } \\
\text { para melhor; } \\
\text { - a qualidade dos serviços } \\
\text { não mudou, isto é, } \\
\text { continua ruim. }\end{array}$ \\
\hline $\begin{array}{l}\text { 2. categoria } \\
\text { temática: } \\
\text { democrati- } \\
\text { zação e } \\
\text { participação }\end{array}$ & $\begin{array}{l}\text { Há convergência de } \\
\text { opiniōes. Os funcionários } \\
\text { perceberam avanços na } \\
\text { democratização e } \\
\text { participação, decorrentes } \\
\text { sobretudo, das mudanças } \\
\text { organizacionais e do } \\
\text { exercicio de cidadania } \\
\text { promovido pelos } \\
\text { movimentos populares. }\end{array}$ & $\begin{array}{l}\text { Há divergência r de } \\
\text { opiniões: na administração } \\
\text { pública sempre houve } \\
\text { democracia e liberdade de } \\
\text { participação e essa } \\
\text { tendência é crescente; não } \\
\text { há e nunca houve } \\
\text { democracia; as decisões } \\
\text { são sempre de cima para } \\
\text { baixo; a administração } \\
\text { Erundina favoreceu a } \\
\text { participação ou, com } \\
\text { PAS velo } \\
\text { descentralização e e a } \\
\text { participação. }\end{array}$ & $\begin{array}{l}\text { São quatro visões: } \\
\text { - a democratização/ } \\
\text { participação (D/P) } \\
\text { aumentou em função da } \\
\text { política de saúde do } \\
\text { governo L. Erundina. } \\
\text { - a D/P é tributária do } \\
\text { direito à saúde o qual deve } \\
\text { ser garantido pelo Estado. } \\
\text { - a D/P aumentou em } \\
\text { decorrência do PAS } \\
\text { - não há D/P. }\end{array}$ \\
\hline $\begin{array}{l}\text { 3. categoria } \\
\text { temática: } \\
\text { trabalho } \\
\text { integrado }\end{array}$ & $\begin{array}{l}\text { Há contradições de } \\
\text { opiniōes: alguns } \\
\text { reconhecem a integração } \\
\text { enquanto o fortalecimento } \\
\text { do trabalho em equipe } \\
\text { multiprofissional; outros } \\
\text { como sendo apenas } \\
\text { episódico e pontual e } \\
\text { finalmente há aqueles que } \\
\text { negam a integração. }\end{array}$ & $\begin{array}{l}\text { São duas visões } \\
\text { contraditórias: uma, nunca } \\
\text { houve movimentos de } \\
\text { integração na Saúde, } \\
\text { outra, a integração da } \\
\text { Saúde com outros } \\
\text { movimentos sociais } \\
\text { recebeu estimulos durante } \\
\text { o governo Luiza Erundina. }\end{array}$ & $\begin{array}{l}\text { São duas visões } \\
\text { diferentes: } \\
\text { - o governo Luiza Erundina } \\
\text { promoveu a integração } \\
\text { para racionalizar o uso } \\
\text { dos recursos públicos. } \\
\text { - integração e participação } \\
\text { são promessas de eleição. }\end{array}$ \\
\hline $\begin{array}{l}\text { 4. categoria } \\
\text { temática: } \\
\text { desenvolvi- } \\
\text { mento e } \\
\text { valorização } \\
\text { do pessoal. }\end{array}$ & $\begin{array}{l}\text { Os funcionários } \\
\text { reconhecem o governo } \\
\text { Luiza Erundina como } \\
\text { promotor do } \\
\text { desenvolvimento e } \\
\text { valorização do pessoal. }\end{array}$ & $\begin{array}{l}\text { A opinião que prevalece } \\
\text { entre os que trabalharam } \\
\text { no governo Erundina é que } \\
\text { as diferentes } \\
\text { administraçöes municipais } \\
\text { têm, no decorrer do } \\
\text { tempo, dispensado os } \\
\text { mesmos tratamentos aos } \\
\text { funcionários. Entre aqueles } \\
\text { que não trabalharam, a } \\
\text { visão é que o PAS } \\
\text { valorizou o funcionário. }\end{array}$ & $\begin{array}{l}\text { Não foram colhidas } \\
\text { informações dos } \\
\text { cidadãos/usuários nesta } \\
\text { categoria temática. }\end{array}$ \\
\hline
\end{tabular}


O conteúdo dos discursos nos induz a pensar que a reforma administrativa da Secretaria Municipal da Saúde contribuiu para implementar os princípios e diretrizes do Sistema Único de Saúde no município de São Paulo, especialmente aqueles voltados à implantação dos Distritos de Saúde enquanto espaços processuais de transformação das práticas sanitárias. Com a reforma veio a reestruturação orçamentário-financeira da Secretaria que, segundo Castro $^{63}$, mostrou-se eficaz e efetivamente contribuiu para a melhoria dos serviços prestados, por meio da descentralização do poder e estímulo à prática democrática. Nesse caminho, gradativamente foram sendo construídas as bases das estruturas político-administrativas das regiões e Distritos de Saúde. E para prosperar, os princípios da reforma sanitária dependiam de inúmeros fatores, quer internos à Secretaria, quer fora dela, no âmbito do governo municipal, em outras esferas de governo e, na sociedade civil. Internamente, havia uma clara dimensão ideológica que sustentava o projeto de trabalho do grupo de dirigentes. A intencionalidade da política de saúde expressava-se "na busca de ruptura com a prática de políticas clientelistas e assistencialistas limitadas e de modelos de atenção que não asseguram a alocação eficiente de recursos e a eficácia técnico-administrativa e social. Por isso a sua intencionalidade abrange mudanças nos campos políticos, técnicos e operacionais, atingindo o aparelho estatal e administração pública, os modelos assistenciais e as práticas sanitárias"64.

Para levar seu projeto à frente, o comando da Secretaria procurou utilizar instrumentos metodológicos do pensamento estratégico e organizou cenários de discussão em todos os níveis organizacionais de sua estrutura, contando com a participação de servidores e representantes da população. Sob a ótica de dirigentes e funcionários, procurou-se criar um processo de trabalho no sentido da mudança do modelo de atenção à saúde, tendo como preocupação central a melhoria da qualidade da assistência e a promoção das condições de vida e saúde. Na opinião dos dirigentes essas diretrizes faziam parte do ideário do governo municipal que, no seu conjunto, trouxe a

\footnotetext{
${ }^{63}$ Paulo Carrara de Castro. Reestruturação Orçamentário-Financeirada Secretaria Municipal de Saúde de São Paulo, na Gestão 1989-1992. Tese de Mestrado. Faculdade de Saúde Pública, USP, 1996.

${ }^{64}$ Eurivaldo de Almeida Sampaio. Contribuição à Implementação do SUS: Estudo do Processo com a Estratégia NOB 01/93. Tese de Livre Docência. Faculdade de Saúde Pública/USP - Universidade de São Paulo. 1996, p. 263.
} 
proposta de participação popular como uma questão central de seu projeto político. Naquele início a participação popular era vista como capaz de promover a cidadania e conferir maior eficácia às ações administrativas. A participação social não era apenas uma necessidade, que a visão democrática do governo impunha a si própria mas, acima de tudo, um traço histórico do partido que assumia o poder municipal naquele momento, com o compromisso de renovar a administração pública do município como um todo. Descentralizar e democratizar não eram portanto, simplesmente questões técnico-administrativas. O que estava por trás dos discursos de descentralização, regionalização e distritalização do setor saúde, era fundamentalmente, uma questão política, de tal modo que a Secretaria pudesse se transformar em um instrumento a serviço da população. Os aspectos levantados pelos dirigentes relacionaram a saúde às questões sociais, de forma que as respostas aos problemas seriam encontradas dentro e fora do setor saúde.

Porém, com o passar do tempo, por ser um processo político, a descentralização e democratização da Saúde gerou um outro problema político para o governo municipal. Enquanto as demais Secretarias mantiveram-se num processo de auto-reconhecimento de suas situações, limites e problemas internos, a Secretaria da Saúde distanciou-se das demais e, assim que organizou o diagnóstico de sua situação, imediatamente apresentou uma proposta de reforma administrativa.

A análise das entrevistas junto dos dirigentes nos revela que, enquanto a Secretaria da Saúde mostrava clareza nos objetivos e firmeza na busca da descentralização e participação social, o governo municipal, apoiado em algumas Secretarias fundamentais, como Planejamento, Finanças e Administração, resguardava os interesses de uma administração centralizada. Naquele momento, a tendência centralizadora do governo era ainda muito forte. Essa indefinição persistiu e, no decorrer do tempo, o governo acabou por perder a capacidade de tomar decisões políticas e administrativas que pudessem sustentar o discurso da descentralização administrativa e do processo de democratização ao qual se propunha, justamente por não ter conseguido quebrar a estrutura centralizadora desses três grandes setores referidos. Isto fez com que aumentassem ainda mais os problemas no âmbito interno da Saúde como, por exemplo, a persistência de conflitos, disputas de poder e indefinições nos papéis e responsabilidades de cada nível gerencial-administrativo. Segundo a opinião dos dirigentes 
entrevistados, para que o processo de descentralização pudesse vir a prosperar, era imprescindivel a definição das competências específicas das autoridades regionais e distritais, com estabelecimento dos graus de autonomia de cada nível decisório. A Saúde, Secretaria com maior ímpeto e iniciativa para a democratização, foi prejudicada em suas diretrizes descentralizadoras por esse conflito interno - descentralização /centralização existente no interior do governo municipal. A resistência às reformas administrativas democratizadoras, talvez pudesse ser explicada pela permanência de mentalidades centralizadoras, que duvidavam da eficácia e eficiência de administrações descentralizadas e participativas, nos moldes propostos pela Saúde. Essa visão, predominante na estrutura administrativa central da Prefeitura e em outros órgãos do governo, também estava presente entre os próprios militantes do Partido dos Trabalhadores que haviam assumido cargos-chave na Secretaria da Saúde e em outras Secretarias municipais. Segundo Marsiglia ${ }^{65}$, a história pregressa da SMS registra vários outros momentos de resistência dos funcionários frente às mudanças administrativas. Os principais pontos levantados em seu trabalho dizem respeito às inseguranças do pessoal com a chegada de novos dirigentes, sem experiências prévias com a cultura da organização, e o conseqüente desrespeito aos "antigos saberes" dos servidores; também faz referências aos temores dos funcionários com os projetos de descentralização da administração, e a ameaça de maior envolvimento da instituição com as necessidades da população, o que poderia acarretar o aumento da jornada diária de trabalho.

Foi dentro deste cenário de conflitos, temores e indefinições que se desenvolveu a reforma administrativa na Secretaria da Saúde.

Segundo os discursos dos dirigentes, dos funcionários e dos cidadãos/usuários (destes menos notadamente), percebe-se que os propósitos que orientaram a política de saúde da Secretaria durante a gestão Luiza Erundina, apontaram na direção da reforma da máquina administrativa, com perspectivas de implementar as diretrizes e estratégias que sustentaram o movimento da reforma sanitária brasileira. Afirmam os entrevistados - muitas vezes com análises e percepções que revelam distintos graus de apoio e entendimento dos projetos elaborados - que a Secretaria buscou reestruturar os procedimentos gerenciais e administrativos e experimentar novas práticas sanitárias, criando mecanismos de participação e democratização na

\footnotetext{
${ }^{65}$ Marsiglia, R.M.G. 1993, opus cit.
} 
reorganização do processo de trabalho. Neste sentido, a estratégia adotada pela Secretaria muitas vezes coincidiu com os pensamentos de planificação em saúde desenvolvidos por Matus ${ }^{66}$, Testa ${ }^{67}$ e Habermas $^{68}$ pois, o que aquele governo propôs, foi mudar radicalmente a estrutura vigente $e$ desenvolver a capacidade política, crítica e criativa dos sujeitos envolvidos com a questão saúde. Isto é, capacitá-los técnica, política e administrativamente para que, relacionando-se entre si e com outros atores sociais, tivessem condições de participar coletivamente das análises e explicações dos problemas de saúde, das propostas de solução e da avaliação dos resultados pretendidos, com a adoção de planos de saúde inovadores. A análise das entrevistas dos trabalhadores da saúde nos induz a pensar que durante as inúmeras atividades pedagógicas desenvolvidas (reuniōes, procedimentos administrativos e/ou oficinas de trabalho realizadas nos diferentes Distritos), ênfases especiais foram dispensadas à análise da situação das realidades locais, assim como à mudança das estruturas organizacionais e das práticas sanitárias, tendo em vista a construção de um novo desenho da estrutura organizacional e a elaboração de planos de saúde capazes de provocar a intervenção concreta nas diferentes realidades, de forma integrada com outros setores sociais.

Analisando as observações dos entrevistados, percebe-se que as tendências em planificação desenvolvidas durante aquele governo indicam um trabalho em dimensões que extrapolavam o setor saúde, como questões de natureza política, social, econômica, técnica, administrativa, institucional, etc., permitindo que os sujeitos participantes, apreendessem ao máximo as especificidades de cada realidade vivida e de cada área de conhecimento, para poder confrontar seus pontos de vista com os de outras pessoas envolvidas no processo de crescimento e fortalecimento das políticas públicas. A todo momento buscava-se a relação da situação de saúde com a situação social mais ampla. Segundo os entrevistados, em determinados momentos, havia um acordo entre os sujeitos envolvidos no processo, enquanto em outras situações havia discordância, com predomínio de uma tendência sobre outra, o que sugeria que, em sua interação na Secretaria, as diferentes tendências ideológicas e movimentos sociais resguardavam certos

\footnotetext{
${ }^{66}$ Matus. C. 1987

${ }^{67}$ Testa. M. 1986

${ }^{68}$ Habermas, J. 1987
} 
interesses e/ou condicionamentos historicamente acumulados, que acabavam por se reproduzir no interior das instâncias de trabalho.

No que diz respeito ao modelo de planejamento em saúde, com base nos discursos dos entrevistados, arriscamos dizer que não houve um único padrão de planejamento. Do ponto de vista da concepção do desenho organizacional escolhido pela Secretaria, com estruturas administrativas descentralizadas, quase que autônomas e abertas à participação e à criatividade, pode-se afirmar que, pelo menos em parte, desenvolveu-se o modelo de planejamento estratégico. Os funcionários entrevistados revelaram que se envolveram e foram estimulados a pensar sobre os problemas com os quais se depararam, e que tiveram a oportunidade de propor meios e ações operativas como forma de enfrentá-los. Ou seja, tiveram a oportunidade de, no cotidiano de suas atividades, produzir conhecimento, e a aprender a lidar com ele. Este trabalho coletivo ajudou a construir um espaço institucional aberto ao diálogo crítico entre diferentes razões, dado o caráter multifacetado dos saberes envolvidos.

Em função do formato em que se configurou a estrutura gerencial da Secretaria, houve a possibilidade de serem instituídas comissões gestoras tripartites, de caráter deliberativo, em todos os níveis da administração. Pelo que disseram os entrevistados, podemos afirmar que o ideário das comissões gestoras era o estabelecimento de relações comunicativas entre as partes envolvidas, isto é, entre os representantes da administração, dos funcionários e dos cidadãos/usuários, visando à comunicação, ao entendimento e à legitimidade das decisões tomadas, possibilitando ao grupo instrumentais necessários para a definição de seus objetivos. A tendência predominante nas entrevistas, especialmente no segmento dos funcionários, é o reconhecimento do interesse do governo no desenvolvimento de consciências críticas, com estímulo ao exercício da criatividade e da cidadania, e no alargamento da base quantitativa de cidadãos e movimentos sociais envolvidos com a questão saúde. Esta foi uma prática que reconhecidamente cresceu dentro da administração, pois até hoje ouve-se dizer ( muitas vezes depreciativamente ) que "durante o governo do PT só se fazia reunião, para qualquer coisa eles ficavam horas e horas em reunião, discutindo".. Acontece que se vivia a todo momento, cotidianamente, situações problemáticas, nos limites de superação de uma condição ou na transição de um modelo para outro. Com base nessas observações, que também apareceram nas entrevista, acreditamos que a administração se caracterizou, exatamente pela 
valorização da dimensão comunicativa, feita principalmente através de um um número "excessivo" de reuniões que contribuíram para transformar idéias em planos de trabalho organizados, depois de exaustivamente debatidos, externalizados e acordados entre as partes envolvidas, mobilizadas para enfrentar, em conjunto, as situações-problema.

Percebe-se pela análise das entrevistas realizadas que a evolução de todos esses movimentos, desiguais, internos e externos ao setor saúde, provocou impactos no funcionalismo municipal, no que diz respeito às formas de conceber o modelo de atenção à saúde. Aparentemente o processo de trabalho instaurado alargou a visão crítica de parte dos servidores. Alguns dos discursos revelam a introjeção do modelo de atenção proposto pela Secretaria, mostrando o deslocamento de uma concepção assistencialista, centrada no hospital e nos cuidados curativos imediatistas, para um modelo que, preservando a atenção individual e curativa, inclui o trabalho integrado, as ações coletivas e voltado para o meio social, inclusive para a produção da saúde.

Entretanto, com o evoluir das mudanças e com a caracterização das novas estruturas gerenciais e administrativas, apareceram outras dificuldades, que podem ser identificadas, através das entrevistas, como externas e internas à Secretaria. Como externas estão aquelas relacionadas às abordagens da universalização da cobertura. Na opinião dos dirigentes, para se implementar os Distritos de Saúde sob a lógica do SUS, era preciso trabalhar os problemas de saúde na área metropolitana como um todo e não apenas na área geográfica do município de São Paulo. Do ponto de vista da administração municipal, foram feitas inúmeras tentativas para a muncipalização dos serviços de saúde, com poucos resultados práticos. Até a própria reforma da Secretaria Municipal de Saúde foi feita pensando na municipalização global, compatibilizando a área geográfica das ARS's com os ERSA's da época. O problema da universalização implicava, além do entendimento com o Estado, em contatos com outras duas áreas: a iniciativa privada e o governo federal. A relação de atrito com o governo federal foi ainda maior que aquela com o Estado e não se estabeleceram relações com a iniciativa privada. Para "forçar" a Secretaria de Estado da Saúde a engajar-se numa proposta para a área metropolitana como um todo, a Secretaria propôs uma estratégia e desenvolveu, juntamente com os outros 28 municípios da Grande São Paulo, um plano voltado aos atendimentos de emergência e 
urgência para toda a região metropolitana, que entrou em operação apenas no último ano do governo.

Quanto às questões internas ao governo, durante o processo vieram à tona as resistências existentes no próprio Secretariado municipal em relação à municipalização da saúde defendida pela SMS. Havia insegurança sobre o real interesse, para a Prefeitura, em assumir naquele momento, a grande quantidade de serviços oriunda do Estado - cerca de 10 hospitais e mais de 300 Unidades de Saúde ambulatoriais. A Saúde, que já pressionava o governo municipal por mais recursos, pela descentralização e pela autonomia administrativa quase absoluta, propunha agora a municipalização total dos serviços de saúde na capital, sem a garantia de repasse dos recursos financeiros provenientes dos governos estadual e federal. Além disso, durante o primeiro ano de governo, a Secretaria radicalizou sua reforma administrativa no sentido da descentralização, garantindo mais autonomia às ARS's e aos Distritos de Saúde. Continuou, porém, com a mesma estrutura orçamentária antiga, isto é, com número insuficiente e incompativel de Unidades Orçamentárias para o novo desenho organizacional adotado. A saída encontrada para superar esse impasse foi a de deslocar Unidades Orçamentárias de Hospitais e transformá-las em U.O's das ARS's e dos Distritos. Esse cenário de carência interna do próprio governo municipal, foi outro fator que contribuiu para arrefecer o impeto pela municipalização plena, dominante entre os dirigentes da Saúde.

Também de ordem interna são as questões relativas à redefinição do modelo gerencial e à construção de um novo modelo de atenção à saúde. A reforma administrativa, por deslocar poder do centro para a periferia do sistema, gerou conflitos de interesse. Alguns assessores de nível central da Secretaria, especialmente os localizados no Centro de Organização da Atenção à Saúde (COAS), continuaram insistindo em manter uma linha de mando direta sobre os níveis regionais, distritais e locais (dentro de uma concepção superada, do tempo da Superintendência Hospitalar e do Departamento de Saúde da Comunidade), desconsiderando o novo modelo gerencial implantado com a regionalização e distritalização.

Os discursos dos dirigentes e funcionários indicam que não ficaram claras as reais competências e atribuições das Administrações Regionais e dos Distritos. Havia documentos escritos sobre o problema, mas não havia estrutura material que desse sustentação à essas bases conceituais, nem precisão clara sobre as competências de cada nível gerencial. Isso gerou 
diferentes concepções sobre o modelo de organização e responsabilidades concorrentes entre as distintas instâncias de decisão da Secretaria, que foram explicitados nas entrevistas. O exemplo mais marcante foi o da construção dos Distritos de Saúde.

A diretriz de integração dos serviços de saúde sob um único comando no nivel distrital trouxe muitos problemas. Isto porque a estrutura hospitalar, historicamente, é uma estrutura com prestígio muito maior que a rede de serviços ambulatoriais. E a proposta de integração, segundo a concepção de Distrito de Saúde daquele governo, implicava na diluição do poder técnico e político dos hospitais, englobados numa estrutura administrativa mais ampla, compartilhada com as demais unidades de saúde da área. Com os Distritos, procurava-se conhecer os problemas do espaço territorial e social e reorganizar as ações e serviços, inclusive as atividades próprias do hospital, integrando-as às demais, de modo a responder aos problemas identificados no âmbito distrital.

Além desses problemas decorrentes da regionalização e distritalização, uma das principais diretrizes da administração era operacionalizar a produção da saúde. Não se tinha clareza de como fazê-la. Como produzir saúde, se toda a nossa experiência anterior era a de combater a doença? Esse era um dos maiores desafios. Nesse sentido, a estratégia da Secretaria muitas vezes foi vacilante. A maior parte do cotidiano de trabalho das equipes gerenciais foi destinado à organização dos mecanismos assistenciais. Embora fosse comum o uso de expressões como planejamento estratégico, participação, comunicação, entendimento entre as partes envolvidas, grande parte dos procedimentos administrativos adotados foram tradicionais. Podemos seguramente afirmar que boa parte do planejamento foi o tradicional. As normas que predominaram, em determinados momentos, foram convencionais e conservadoras, marcadas pela grande preocupação do quadro de dirigentes em aumentar a produtividade dos instrumentos e pela valorização da eficiência do sistema vigente. Como se sabe estas preocupações são próprias da planificação normativa, característica do pensamento conservador. Embora o planejamento, desde o início, fosse pensado enquanto um processo, de construção de baixo para cima, e não enquanto um procedimento centralizado, os traços marcantes de certas propostas foram definidos de cima para baixo. A explicação dos dirigentes para estas posturas foram de duas ordens. Em primeiro lugar, o planejamento estratégico/ascendente, do ponto de vista politico-administrativo seria muito 
lento, e não haveria tempo hábil para produzir impactos, num prazo políticoadministrativo tão curto como o de quatro anos. A outra explicação justifica a primeira, afirmando que o planejamento ascendente seria executado com base na cultura interna e "atrasada" da instituição, com a mentalidade arraigada do funcionalismo público $e$, desta forma, iria chocar-se com os princípios inovadores e "revolucionários" da reforma administrativa proposta pela Secretaria. Seria incompatível com a política de saúde concebida no Conselho Técnico Administrativo da Secretaria. Na verdade, havia uma centralização na tomada de decisões, que indicavam o caminho do planejamento ascendente, participativo e ao mesmo tempo, havia uma autonomização, uma tolerância com o processo de implementação das decisões assumidas no Conselho Técnico Administrativo da Secretaria. Isto é, cada Diretor Regional e sua equipe, implementaram a política de saúde a seus modos e vontades próprias. Desta forma, ao lado de propostas de planejamento ascendente, democrático, com envolvimento do funcionalismo e de setores organizados da sociedade civil, que buscavam o entendimento entre as partes interessadas na questão saúde, duas outras tendências também se fizeram presentes no cotidiano do planejamento, com igual ou maior intensidade. Uma delas derivava da cultura da instituição Prefeitura/Secretaria da Saúde, com marcantes traços do planejamento normativo e verticalizado, enquanto a outra, de ordem subjetiva, decorria do perfil político-ideológico-administrativo de cada dirigente, especialmente dos diretores regionais e dos diretores distritais, que acabaram imprimindo seu próprio ritmo ao processo.

A Secretaria estava inserida dentro de um governo que, na prática, investiu menos do que anunciou para promover o planejamento participativo e descentralizado. Por outro lado, como se constatou, a própria Secretaria convivia com suas contradições internas: uma estrutura administrativa forte, arraigada, e outra estrutura de natureza política, mais recente, decorrente do ingresso de novos dirigentes com características pessoais marcadas por um partido político comprometido com os interesses das classes populares. Além do mais, a comunicação entre essas duas instâncias não era suficientemente clara. A partir da análise das entrevistas, ficamos com a impressão de que predominou a estrutura administrativa forte, acarretando um planejamento realizado de cima para baixo e dominado pela cultura institucional repleta de procedimentos burocráticos e normatizadores. Esta constatação nos remete à visão de diagnóstico de saúde de Mario Testa. $O$ autor identifica três tipos de 
diagnósticos: o administrativo, que corresponde ao crescimento, o estratégico relativo à mudança, e o ideológico ligado à legitimação. Afirma que na visão administrativa o que interessa é a eficácia e a eficiência do sistema de saúde, um enfoque com raizes sólidas na planificação em saúde, que continua encontrando solos férteis para a sua reprodução ${ }^{69}$. Como de fato encontrou durante essa gestão.

Em função do perfil técnico-político de cada diretor regional e/ou distrital, e da compreensão de seu papel enquanto administrador e sujeito político, o padrão de planejamento variou de região a região e de Distrito a Distrito. Não existia uma concepção única sobre o serviço público, as principais tarefas a serem feitas, as prioridades, a formação das equipes de cada uma das Regionais e Distritos, e as bases ideológicas em que se assentava o modelo de atenção à saúde. Tudo isso perpassou a Secretaria e produziu padrões dispares de planificação em saúde.

Talvez essas considerações expliquem em parte, a ausência de mecanismos contínuos de avaliação sistemática do trabalho. Não havia muito interesse em avaliar. Como não se avaliava, não se sabia o quanto se estava errando ou acertando.

Entretanto, apesar das dificuldades e contradições internas, encontramos em parte dos funcionários entrevistados, percepções concordantes quanto ao enfoque dado ao modelo de atenção da Secretaria. A partir da análise das entrevistas, verificamos que os funcionários de nível local se sentiram mais envolvidos e atuantes. Parte dos servidores entrevistados entendeu o sentido das mudanças positivamente, percebendoas como estímulo às ações coletivas. As mudanças no sistema de informação, a preocupação em se apropriar da base territorial e do perfil epidemiológico da população da área geográfica de responsabilidade do serviço de saúde, a busca da integração e hierarquização das ações, a relação do Hospital com as Unidades Básicas de Saúde, a distribuição heterogênea dos principais problemas pelo território do Distrito, ocuparam, gradativamente, o cotidiano de trabalho dos funcionários, alterando sua concepção do modelo de atenção à saúde. Nesse sentido, pode se afirmar que foram empregadas novas tecnologias, por se tratar da introdução de instrumentos metodológicos inovadores até então, pelo menos no âmbito da SMS, pois buscava-se

\footnotetext{
${ }^{69}$ Testa. M. 1978.
} 
reorganizar as informações, desagregando-as, e o conhecimento a respeito dos problemas de saúde, dando-Ihes significação social.

Os discursos dos funcionários e dirigentes destacaram a importância dada ao desenvolvimento do pessoal, especialmente por meio de oficinas de trabalho, que tinham como método reforçar o sentido do trabalho coletivo, em equipe interdisciplinar e diluir o conhecimento, tradicionalmente centrado na figura do médico, para o restante da equipe de saúde.

As oficinas de trabalho ( territorialização em saúde, sistema de informação e desenho de operações para o enfrentamento dos principais problemas de saúde ) foram a principal estratégia utilizada para repensar a organização da atenção à saúde. Muitas delas contaram com a presença de três segmentos - administração, funcionários e cidadãos /usuários - visando à adoção de compromissos e responsabilidades comuns frente aos problemas encontrados. O primeiro passo para a análise da situação de saúde era o desvendamento das especificidades do espaço local, tido como ponto de partida para reconhecimento dos porquês e das razões dos agravos à saúde. O caminho percorrido para se chegar ao recorte de cada realidade local pressupunha a criação de uma rede de relações solidárias entre os participantes, com vistas à apropriação temporal e histórica do quadro sanitário local. Isto significou que os problemas de saúde não eram vistos, naquele momento, como questões isoladas e específicas do setor saúde. Pelo contrário, a disposição em trabalhar com problemas, gerava condições de serem propostas ações intersetoriais e, desse modo, aglutinar projetos comuns que reunissem elementos de impactação sobre o quadro social local. Esse modo de andar das oficinas abriu espaços de trabalho, onde os sujeitos envolvidos podiam procurar respostas aos problemas identificados. Segundo Mattos $^{70}$ "certos sujeitos puderam se constituir em sujeitos do processo de trabalho, de acordo com a perspectiva pretendida no projeto de Recursos Humanos da SMS. À medida que foram se realizando no cotidiano do trabalho, foram se constituindo em sujeitos coletivos e autônomos".

A consonância entre as partes envolvidas era condição fundamental para o êxito das ações, estabelecidas de comum acordo no cenário das oficinas de trabalho. Assim, pelo menos do ponto de vista do segmento que representou o funcionalismo público municipal, a estratégia da Secretaria resultou em desenvolvimento da capacidade crítica dos envolvidos na organização da atenção à saúde. Tanto é que os funcionários reconheceram o

Maria de Lourdes Mattos. Tese de Mestrado. UNICAMP. 1997. 
governo do período 89-92 como gerador de espaços de discussão que promoveram a capacitação e o desenvolvimento profissional, e valorizaram a participação como meio de encontrar soluções aos problemas. A impressão que ficamos é que esse processo teve um caráter pedagógico, amplo, que reforçou a consciência política, especialmente dos funcionários mais simples e dos cidadãos comuns, que se tornaram mais próximos, em função dos problemas e interesses levantados nas oficinas de trabalho.

Acreditamos que todo o processo representou avanços em relação ao modo de pensar as práticas de saúde, e contribuiu para a criação de novos sujeitos coletivos. Segundo Testa, "todo indivíduo se constitui como sujeito através do processo de ideologização que se produz pelas condições gerais em que se realiza seu processo de trabalho ( seu trabalho abstrato ); a transformação de um sujeito individual em sujeito coletivo - grupo ou classe vai depender dos interesses comuns do conjunto, os quais estão relacionados, quase sempre - pelo menos nos países capitalistas, subdesenvolvidos e dependentes - com as circunstâncias geradas nas condições específicas em que se realiza o processo de trabalho conjunto ( 0 trabalho concreto )"171. Portanto, sujeitos coletivos foram criados pelo conjunto dos movimentos sociais, e pela política de saúde que se desenvolveu durante o governo Luiza Erundina.

Segundo Chauí, o sujeito, embora coletivo, "não se apresenta como portador da universalidade definida a partir de uma organização determinada que operaria como centro, vetor e telos das ações sócio-políticas e para a qual não haveria propriamente sujeitos, mas objetos ou engrenagens da máquina organizadora (...) o novo sujeito encontra instituições em crise que experimentam a crise sob a forma de um descolamento com seus públicos respectivos, precisando encontrar vias para reatar relações com eles ${ }^{172}$.

Quando as mesmas estratégias são analisadas junto aos funcionários que aderiram ao plano de assistência à saúde (PAS), não se percebe o mesmo padrão de recepção às propostas da Secretaria. Mesmo depois de

\footnotetext{
${ }^{7}$ Testa, M. in: Rivera, F.J.U. Agir Estratégico e Planejamento Social (Uma Critica ao Enfoque Estratégico). Editora Fiocruz, Rio de Janeiro, 1997

${ }^{i 2}$ Marilena Chauí, in: SADER, E. Quando Novos Personagens Entram em Cena. Experiências e Lutas dos Trabalhadores da Grande São Paulo, 1970-80. Paz e Terra, São Paulo, 1988, p. 10 - 11 . Neste seu livro. Eder Sader escreve: "quando uso a noção de sujeito coletivo" a expressão indica "uma coletividade onde se elabora uma identidade e se organiza práticas através das quais seus membros pretendem defender interesses e expressar suas vontades, constituindo-se nessas lutas". Pensando desse modo, pode-se dizer que a política da participação social da Secretaria promoveu: um sujeito coletivo, espaços político-democráticos (os conselhos e comissões de saúde) e inovou na concepção da prática sanitária ( a saúde enquanto um direito).
} 
terem vivenciado o mesmo processo durante os quatro anos de trabalho, prevalece entre os entrevistados do PAS a opinião de que as distintas administrações públicas municipais têm dispensado, no decorrer do tempo, o mesmo tratamento ao funcionalismo e têm tratado da mesma forma os problemas de saúde. Por outro lado, parte deste mesmo grupo, reconhece que a administração Luiza Erundina promoveu e estimulou o desenvolvimento de trabalho entre a equipe multiprofissional. $O$ que, sem dúvida, não deixa de ser um enorme reconhecimento do processo de mudança nos mecanismos de decisão e de organização do trabalho, uma vez que aquela administração organizava práticas sanitárias com 0 desenvolvimento de atividades interdisciplinares

Por outro lado, fora do setor institucional da saúde, isto é, entre os cidadãos/usuários, predominaram duas impressões bastante distantes dos propósitos daquela administração. Em primeiro lugar, entre os usuários dos serviços de saúde, predomina a sensação de que o plano PAS melhorou a qualidade do atendimento. Neste caso, os entrevistados ou não se recordam da qualidade dos serviços de saúde durante a administração Luiza Erundina ou, quando o fazem, não guardam boas referências daquele governo. Outra afirmativa, vem dos não usuários, e diz respeito ou à manutenção ou à piora da qualidade dos serviços de saúde. A minoria dos cidadãos/usuários entrevistada conseguiu mencionar mudanças para melhor na qualidade dos serviços de saúde durante a administração Luiza Erundina. Talvez porque as entrevistas foram realizadas durante o período de propaganda eleitoral, e o PAS estava sendo apresentado como uma solução para a saúde pública.

Outro aspecto polêmico foi a percepção a respeito da participação social. A política da Secretaria visava estimular a participação de funcionários e representantes da população, na tentativa de promover a cidadania. Esse termo - cidadania - sempre teve caráter unificador no conjunto das diretrizes politicas. No entanto, não era compreendido de forma semelhante pelos dirigentes, servidores e cidadãos/usuários. A visão dominante entre os dirigentes era a de que a participação social contribuiria para as transformações, tanto no setor saúde, quanto em outras Secretarias do governo municipal e, portanto, favoreceria o exercício da cidadania. Esta visão reforça as teses de Benevides $^{73}$, segundo a qual a democratização

\footnotetext{
${ }^{-3}$ Benevides. M.V.de M. A Cidadania Ativa. Referendo, plebiscito e iniciativa popular. Ática. São Paulo. 1991. p. 194. Segundo Benevides. a "complementaridade entre representação popular tradicional
} 
depende "das possibilidades de mudança nos costumes - e nas 'mentalidades' - em uma sociedade tão marcada pela experiência do mando e do favor, da exclusão e do privilégio. A expectativa de mudança existe e se manifesta na exigência de direitos e de cidadania ativa; o que se traduz, também, em exigências por maior participação política - na qual se inclui a institucionalização dos mecanismos de democracia semidireta".

Os movimentos sociais aproveitaram o momento de abertura da administração pública municipal, de chamamento à participação, e se apresentaram com mais intensidade do que os próprios funcionários (mais distantes e retraidos), e portanto, tiveram oportunidade de exercer a cidadania. Chegaram inclusive a fornecer quadros para a administração municipal, pois muitos dos dirigentes e técnicos, eram provenientes dos movimentos sociais. O estímulo à participação, pelo menos no âmbito da Secretaria, foi de tal forma crescente que, ao final do governo, havia mais de uma centena de conselhos gestores implantados, envolvendo diretamente cerca de 1500 a 2000 representantes da população/usuários no planejamento e na definição de diretrizes e prioridades na área da saúde. Sob esta ótica, pode-se entender que houve redistribuição do poder dentro da Secretaria, deslocado para a periferia do sistema e para a sociedade civil, numa busca de aproximação da estrutura burocrática da instituição com cotidiano daqueles que assumiram o papel de representantes da população. Este percurso nos reconduz ao pensamento estratégico de Mario Testa onde o autor, menciona que as mudanças que interessam ao pensamento estratégico são as relativas à redistribuição do poder dentro da organização ${ }^{74}$.

Pelo lado do funcionalismo não houve o mesmo padrão de participação e de envolvimento. O diálogo com os servidores ficou mais restrito às Conferências Municipais de Saúde. Historicamente os funcionários ainda não haviam acumulado experiências em participação, e co-gestão da coisa pública, e nem reivindicavam este espaço para a corporação. Pelo contrário, a posição defendida pelo sindicato da categoria, foi pela não participação nas comissões tripartites. A tradição desse segmento, sempre mais voltada para a organização por categorias profissionais, se manteve desta forma durante os quatro anos de gestão. Podemos pensar num

(eleição de representantes no Executivo e no Legislativo, principalmente) e formas de participação direta ( votação em questões de interesse público) configura um sistema que pode ser denominado de democracia semidireta". p. 15.

${ }^{74}$ Testa, M. idem ibidem 
paralelismo com a teoria da produção social de Matus, ao abordar o fenômeno da produção e reprodução de uma dada formação social. Segundo o autor, esse fenômeno seria decorrente das inter-relações entre atores, movimentos e organizações sociais que mantém determinados comportamentos e condições $^{75}$. Mesmo resguardando condicionamentos historicamente acumulados, as entrevistas nos revelam que há consenso entre os servidores sobre os avanços na democratização e nos mecanismos de participação, decorrentes sobretudo das mudanças da estrutura organizacional da Secretaria e do processo de planejamento em saúde, especialmente depois da introdução das formas participativas deflagradas pelas oficinas de trabalho. Este padrão de percepção é identificado entre os funcionários que não aderiram ao PAS, e que se mantiveram como quadros efetivos da Prefeitura. De maneira distinta, entre os funcionários que optaram pela adesão ao PAS, não se constatou esta percepção. Entre os que afirmam que não há e nunca houve democracia no serviço público, há os que sustentam sempre ter havido liberdade e democracia, e que este fenômeno é uma tendência crescente em nosso meio, principalmente com a implantação do PAS. Relacionam liberdade e democracia, com a crescente incorporação da iniciativa privada ao setor público. Todos concordam em um ponto: não fazem referência à participação social na administração Luiza Erundina.

Entre os cidadãos/usuários também prevalecem opiniões distintas sobre o tema participação. Alguns associam a administração Luiza Erundina à democratização administrativa. Outros entretanto, têm percepções radicalmente opostas. No conjunto, são identificados quatro pensamentos neste segmento de entrevistas: a democratização dos serviços de saúde e a participação social são conseqüência do direito à saúde, direito este garantido constitucionalmente e, portanto, um dever do Estado, qualquer que seja ele; tanto a participação como a democratização aumentaram durante a gestão Luiza Erundina, em função de uma política de governo que procurou respeitar a Constituição e que estimulou a inserção da comunidade no planejamento da cidade; ambas, tanto a democratização quanto a participação aumentaram com a implantação do PAS; e, finalmente, não há participação e nem democratização nos serviços públicos. As entrevistas dos cidadãos/usuários revelam que esse segmento não percebeu a importância dada pelo governo municipal e pela Secretaria à participação social. Dentro desse segmento apareceram diferentes conceituações sobre o tema. A minoria, como se viu,

${ }^{-5}$ Matus. C. 1980 
mencionou que a participação ganhou força durante o governo Erundina. Talvez esse grupo veja a saúde como um problema social $e$, o seu enfrentamento, via participação, possibilitaria a identificação de meios mais adequados. Um número considerável de entrevistados afirma que a saúde é um direito do cidadão e dever do Estado. A leitura que fizemos desses discursos nos levou a pensar na visão tradicional e individual dos problemas de saúde, cuja solução estaria basicamente na dependência da atenção médica. Reforça essa hipótese os discursos dos cidadãos/usuários que apontam o aumento da democratização/participação depois da implantação do PAS.

Outro cotejo estabelecido entre a estratégia da Secretaria e a recepção dos funcionários e cidadãos/usuários reflete as opiniões a respeito da integração da Secretaria com outros setores sociais. Esta categoria temática recebeu variadas interpretações. Mesmo entre os dirigentes há discordâncias sobre o tema.

No início da administração Luiza Erundina, trabalhar integradamente era uma das principais diretrizes da política de governo. Os núcleos regionais de planejamento foram estrategicamente implantados para promover a integração das várias Secretarias em nivel regional/local e encontrar respostas através de ações concebidas e operadas transsetorialmente. Os nrp's deveriam contribuir para mudar as práticas de planejamento loco/regional e favorecer a comunicação e o compromisso intersecretarial. No entanto, quando os diferentes setores estavam começando a acumular experiências no trato coletivo dos problemas, os nrp's foram desinstitucionalizados, por questões de natureza política, ligadas ao comando do governo municipal. Isto ocorreu no início do segundo ano da administração, quando os dirigentes dos distintos setores já se conheciam e muitas propostas de trabalho já vinham sendo desenvolvidas de modo integrado, como se preconizou no início do governo. Graças a essa situação de fato, o processo de integração intersetorial não se interrompeu, embora tenha perdido o estímulo e a coordenação que vinha recebendo das instâncias superiores da administração municipal.

As entrevistas revelam que a maioria dos funcionários entrevistados teve consciência dos movimentos da Secretaria da Saúde no sentido de praticar o trabalho integrado, especialmente no que se refere ao estreitamento das relações de caráter interdisciplinar entre os servidores. Segundo os 
funcionários, a política de integração no restante da máquina administrativa municipal não foi suficiente para mudar as práticas governamentais estabelecidas. Quando muito, contribuiu para se chegar a respostas sobre problemas específicos. Entretanto, mesmo entre os funcionários que aderiram ao PAS, há um reconhecimento de que a administração Erundina favoreceu a integração, especialmente por promover o trabalho interdisciplinar entre a equipe multiprofissional.

Do ponto de vista dos cidadãos/usuários, as propostas de trabalho integrado não chegaram a produzir quaisquer impactos. A grande maioria dos entrevistados, vinte pessoas, sequer conseguiu manifestar-se sobre o tema, frustrando as expectativas daqueles que depositaram esperanças no projeto de integração, por considerá-lo exeqüivel num município com o potencial de possibilidades de São Paulo. Apenas dez se manifestaram e destes, seis relacionaram integração ao governo Luiza Erundina, e quatro, que não há ou nunca houve integração.

O cotejo das diversas opiniões a respeito da promoção da eqüidade, foi feito a partir das considerações sobre o desenho organizacional da Secretaria e das inovações no modelo de atenção à saúde. As respostas dos entrevistados refletem a intencionalidade da política de saúde na direção da eqüidade. Aliás, há indicações de que o governo como um todo, fez movimentos associados, pelos entrevistados, ao conceito de justiça social.

Para enfrentar o compromisso de expansão da cobertura de modo eqüitativo, a Secretaria realizou a reforma administrativa, implantou novas unidades, dobrou o número de servidores, investiu no desenvolvimento do pessoal e desenvolveu esforços pela municipalização dos serviços de saúde.

Dentro da politica de municipalização, a universalização da cobertura e a eqüidade foram as duas preocupações centrais dos dirigentes. No entanto, a análise e interpretação do discurso dos dirigentes revela diferentes compreensões sobre a temática, o que reforça nossa opinião sobre as contradições na implementação da política municipal de saúde. Entre os dirigentes destacam-se três opiniões sobre a promoção da eqüidade. A primeira delas é afirmativa, garantindo que houve promoção da eqüidade através da política global da Prefeitura, com deslocamento de recursos de diferentes Secretarias para a periferia da cidade, destinados à educação, bem-estar social, cultura, habitação e saúde. Especialmente no setor saúde, a expansão dos serviços caminhou nessa direção, com inauguração de 
inúmeras unidades periféricas e com a criação do "adicional a distância", que diferenciou o salário dos servidores, remunerando melhor aqueles que trabalhavam em locais mais distantes do centro. $O$ adicional à distância, foi um dos meios encontrados pela administração para despertar o interesse dos técnicos em se fixarem nos equipamentos localizados em áreas mais distantes.

Por outro lado, tentou-se inovar tecnologicamente o sistema de informação em saúde, ajustando-o com base em critérios epidemiológicos e socioeconômicos, com o intuito de gerar dados desagregados, espacialmente distribuidos em micro-áreas de risco, para melhor orientar as equipes de saúde no enfrentamento das iniqüidades. Ou seja, a Secretaria tentou construir modelos de intervenção e redefinição de ações programáticas, atentando para um quadro de justiça redistributiva e direcionando proporcionalmente, maior quantidade de recursos para as áreas identificadas como mais carentes e portanto, sob maior risco social de adoecer e morrer.

O segundo padrão de percepção dos dirigentes a respeito do tema é menos otimista. Este grupo afirma que a política municipal de saúde apenas tocou na questão da eqüidade, enfatizando-a mais no discurso do que na prática. Na realidade, conseguiu implementar apenas politicas especificas, voltadas para grupos determinados ou interesses particulares, como os dos portadores de deficiências físicas, os portadores de sofrimento mental e os idosos. Nesse caso, trabalhou-se exclusivamente com os olhos voltados para o interior da Saúde e, pode-se dizer, sem conseguir distinguir as diferentes necessidades de saúde, desconsiderando o delineamento do perfil epidemiológico e as necessidades da população como um todo.

A terceira compreensão dos dirigentes sobre eqüidade é de que não houve a promoção da eqüidade, pois a Secretaria não conseguiu criar mecanismos institucionais e nem abrir espaços democráticos onde as políticas de saúde pudessem ser livremente debatidas. Havia duas instâncias decisórias importantes onde, em tese, as decisões poderiam contemplar a eqüidade: a do Conselho Técnico Administrativo e a do Conselho Municipal da Saúde. Em ambas as instâncias, entretanto, a dinâmica de funcionamento não conseguiu dar conta de sua promoção. No CTA porque cada diretor regional buscava o maior número de recursos para a sua região. $E$ dentro do Conselho Municipal de Saúde porque os movimentos sociais competiam entre si pelos recursos. De modo amigável, porém competiam. O que se depreende disso tudo, é que a questão da eqüidade não foi suficientemente contemplada 
no interior da própria Secretaria. Pelo contrário, esteve à mercê das pressões das regionais, dos Distritos e das disputas entre os movimentos populares. 


\section{CAPITULO VI}

\section{Conclusões}

Lembrar-me de ti! Sim, pobre espectro, enquanto a memória tiver assento neste mundo enlouquecido.

Shakespeare

A partir das hipóteses da pesquisa, procedemos às reflexões sobre a política municipal de saúde da administração Luiza Erundina, tendo como referência os discursos dos funcionários, cidadãos/usuários e dirigentes, estabelecendo o confronto dos dois primeiros segmentos com o último. Os motivos que nos levaram a escolher este percurso - o de realizar o cotejo de duas visões, a dos funcionários e a dos cidadãos/usuários com o projeto de saúde dos dirigentes - estão ligados à nossa impressão de que a formulação e a implementação das ações de saúde passam necessariamente pelo pensamento desses três segmentos, e porque não há espaço de transformação das práticas sanitárias sem o envolvimento de cidadãos, funcionários e dirigentes do setor saúde.

Deste modo, nosso interesse centrou-se na percepção que os entrevistados tiveram das estratégias da Secretaria da Saúde, especialmente no que diz respeito ao processo de democratização, às mudanças gerenciais e do modelo de atenção, ao trabalho integrado e ao desenvolvimento do pessoal, dadas em um contexto de governo dirigido para a implementação das diretrizes do Sistema Único de Saúde no município de São Paulo, mais de um ano antes de ser sancionada a Lei Orgânica da Saúde pelo Governo Federal.

Para orientar nossa análise, construímos um quadro com as sínteses dos principais pontos concordantes e discordantes das diretrizes de saúde da Secretaria. 


\section{Quadro resumo dos principais temas identificados nos discursos, segundo a percepção dos três segmentos entrevistados: dirigentes, cidadãos/usuários e funcionários.}

Pontos de concordância com os principios e diretrizes da politica municipal de saúde

1. A descentralização administrativa, com a criação das ARS's e DS's. A escolha dos Distritos, enquanto espaços descentralizados e privilegiados de planejamento em saúde.

2. O setor saúde visto sob a ótica da mudança da cultura institucional e da prática de suas ações específicas relacionadas com questões sociais, políticas e ideológicas: o movimento pela integração intra e intersetorial.

3. A participação de servidores e população no processo de tomada de decisão: as comissões gestoras tripartites nas regiões, distritos e unidades de saúde. A busca de relações solidárias e comunicativas entre as partes envolvidas com os problemas de saúde.

4. A capacitação e desenvolvimento do pessoal para as ações coletivas e a prática da vigilância à saúde; a criação de espaços de planejamento, como as oficinas de trabalho, com participação da administração, de funcionários e da população: a busca da compreensão do coletivo, de suas desigualdades, e o desenho de operações voltadas às situações-problema.

5. As mudanças nos mecanismos de decisão e organização do processo de trabalho; o estímulo à cidadania e o espaço de manifestação às consciências criticas.
Aspectos que dificultaram a implementação da política municipal de saúde

1. Tensão persistente entre a SMS e demais Secretarias municipais; a falta de estrutura material e funcional que desse sustentação às Administrações Regionais e Distritos.

2. A não municipalização dos serviços e a não universalização da cobertura.

3. Responsabilidades concorrentes entre os distritos e regiões; a coexistência de assessores do COAS com funções de "linha de mando" na rede de serviços de saúde.

4. Modelo de planejamento tradicional, baseado em normas e verticalizado: maior disponibilidade para organizar a oferta de serviços e menor disponibilidade para organizar a produção da saúde. Predominio da estrutura burocratizada da instituição.

5. A coexistência de padrões dispares de planejamento em saúde, em função: a) da não existência de concepções homogêneas sobre o papel do serviço público; b) do não conhecimento sobre quais eram as tarefas prioritárias a serem feitas; c) das diferentes composições das equipes distritais e regionais $e, d)$ das diferentes concepções sobre a política e o modelo de atenção à saúde.

6. O pouco avanço no desenvolvimento de ações integradas com outros setores sociais, e na promoção da eqüidade pelo setor saúde. 
Estamos convencidos de que as reflexões que fizemos são parciais, e que não conseguiram dar conta da complexidade da produção do governo municipal e do setor saúde em particular. Há muito sobre o que refletir. No entanto, pode-se afirmar que o trabalho da Secretaria Municipal da Saúde durante o período de 1989 a 1992 foi amplo, concreto e visível. Por tudo o que se realizou e por tudo o que se idealizou, planejou e não houve condições de implementar.

Ao refletirmos sobre a política municipal de saúde e a inserção dos três segmentos de entrevistados, deparamos com algumas dificuldades relativas à análise dos discursos. Enquanto os dirigentes se expressaram de um modo mais abrangente sobre determinados temas (modelo de atenção, por exemplo), o mesmo não ocorreu com os funcionários, e principalmente com o segmento composto pelos cidadãos/usuários. Enquanto para estes o problema do modelo de atenção seria resolvido simplesmente com a presença da assistência médica de boa qualidade, para os dirigentes o caminho apontava para outra direção, num cenário muito mais completo, que exigia a transformação das práticas e a ruptura com o modelo hegemônico. Os funcionários ocuparam uma posição intermediária entre um polo e outro.

Todo o trabalho desenvolvido pela Secretaria foi inspirado nas teses do movimento da reforma sanitária, e enfrentou 0 modelo de atenção hegemônico, hospitalocêntrico e indiferente frente aos problemas de saúde da população. Nesse sentido, a política de saúde procurou inverter a tendência predominante: em lugar de um comando único e central, com linhas de mando verticalizadas, foram colocadas as propostas da gestão democrática; em lugar das práticas de saúde conservadoras, colocaram-se os ideais de um modelo inovador, apoiado nos princípios de justiça e solidariedade. $E$ não se esqueceram dos recursos humanos, investindo na formação e capacitação do pessoal, e na melhoria da condição salarial do funcionalismo.

Nesse sentido, procurou-se construir uma estrutura gerencial e administrativa suficiente para a implementação do SUS, com planos integrados regionalmente e com um quadro de pessoal devidamente qualificado e motivado para as novas práticas. Nessa linha de trabalho, 0 grupo de dirigentes pensava a (...)"valorização do profissional e a 
profissionalização no sentido de resgatar no trabalhador a consciência de seu valor, não só pela remuneração (...) mas pela sua importância profissional compromissada com o bom atendimento da população nos serviços públicos (...) A participação em todo o processo de trabalho, desde o seu planejamento até a sua execução, buscando resgatar o trabalhador do trabalho alienado e devolver a ele a capacidade de construção do conhecimento já acumulado, porém carente de sistematização e valorização, para devolvê-lo novo e vivo nas relações com a população (...) A interdisciplinaridade do conhecimento em saúde substituindo a hegemonia do conhecimento médico, elevando a consciência dos profissionais, sejam eles de nivel operacional, médio ou superior, no sentido da criação coletiva do conhecimento"7n.

A principal intenção da Secretaria Municipal da Saúde era a implantação do Sistema Único de Saúde no município de São Paulo. O novo modelo de atenção à saúde proposto exigiu do governo a presença de novas categoria profissionais, com diferentes formações, para a reorganização dos serviços e das práticas. Nesse sentido, os discursos dos dirigentes foram muito parecidos e deste modo foram vistos, especialmente pelo segmento dos funcionários, que reconheceu o aumento quantitativo e qualitativo não apenas de pessoal, mas também de recursos materiais e financeiros.

Quando se olha para trás, em direção aos sete pressupostos da pesquisa, vê-se que os três segmentos entrevistados têm posições muito diversificadas, especialmente com respeito à articulação intersetorial, à descentralização administrativa, à democratização das decisões e à participação social. É com base nesses pressupostos que definimos nossas conclusões.

A política de saúde da Secretaria foi pensada de forma integrada a outros setores do governo e ao contexto sócio-cultural do município. Como a categoria integração está estreitamente relacionada ao conceito de participação, não poderia haver relacionamento da saúde com outros setores ou mesmo com a sociedade civil, sem contar com propostas vindas das outras áreas. $\mathrm{Na}$ análise das entrevistas, muito embora tenhamos registrado inúmeras considerações a respeito da politica de integração, podemos dizer que as práticas desenvolvidas para implementar essa diretriz ficaram muito

\footnotetext{
${ }^{76}$ Prefeitura do Município de São Paulo, Secretaria Municipal da Saúde, Centro de Recursos Humanos CRH - dez. 1992.
} 
aquém do desejado. Esta constatação fica muito evidente quando se analisa as entrevistas dos cidadãos/usuários. O governo municipal não conseguiu sustentar a proposta dos núcleos regionais de planejamento, possiveis embriões das futuras "subprefeituras", desativados por razões politicas. Um dos momentos de maior visibilidade pública dos nrp's acontecia durante a elaboração da peça orçamentária de cada secretaria. A Prefeitura chamou esse momento de "orçamento participativo", porque os nrp's estimulavam os movimentos populares a participar da elaboração dos orçamentos setoriais anuais. Era uma estratégia para potencializar 0 uso de instrumentos administrativos, com o objetivo de redistribuir com mais eficácia e eqüidade os recursos públicos. Ainda que o processo tenha sido divulgado, até mesmo pela grande imprensa, o segmento população fez poucas referências à integração.

No caso do setor saúde, os dirigentes sempre manifestaram a vontade de desenvolver planos intersetoriais. No entanto, o que mais predominou foi o caráter cíclico ou sazonal e, sobretudo, pontual da integração. Por ocasião das chuvas de verão, por exemplo, com o alagamento de ruas e casas, aumentava o risco de leptospirose. Em vista disso, antes da estação das chuvas, procurava-se realizar o saneamento das áreas de maior risco através de um mutirão, com participação da Saúde, SAR, Educação e também da população. O mesmo pode ser dito em relação ao combate à dengue, ao cólera e a outros problemas específicos. No que diz respeito às atividades internas da Secretaria, as opiniōes tanto dos dirigentes quanto dos funcionários apontam para a integração dos equipamentos e das ações, sobretudo no Distrito de Saúde, onde as equipes tiveram oportunidades de estreitar suas relações e exercitar uma prática interprofissional.

As opiniōes sobre eqüidade ficaram restritas aos dirigentes. Entre eles não só registramos divergências sobre o quê fizeram e como atuaram, mas também observamos visões diferentes a respeito do próprio conceito de eqüidade. Assim, há passagens onde se afirma que a Secretaria procurou enfrentar a iniqüidade, porém, com recursos insuficientes para que o trabalho fosse efetivado. Nesse caso, pode-se pensar que se houvesse a municipalização, os equipamentos teriam sido oferecidos com maior cuidado de promover a eqüidade. Encontramos também algumas opiniōes que defendem a introdução de critérios epidemiológicos para a identificação de áreas prioritárias, de modo a favorecer a promoção da eqüidade. De fato, não 
foram poucas as equipes de saúde que se propuseram a analisar a situação de saúde de suas áreas de responsabilidade, com o intuito de encontrar as desigualdades sociais das comunidades locais. Nesse processo, geralmente eram utilizados cartogramas e identificadas micro-áreas, de acordo com os diferentes riscos sociais de adoecer e/ou morrer. Desse modo, conhecendose as diferentes bases populacionais distribuídas heterogeneamente no espaço, haveria a possibilidade de se identificar grupos sociais prioritários, que passariam a receber atenção diferenciada, de acordo com suas necessidades.

É de se perguntar se a tecnologia empregada para detectar as desigualdades, de fato contribuiu para a promoção da eqüidade. Pensamos que nas condições dadas, isto foi possivel, uma vez que o maior aporte de recursos poderia ser redistribuído considerando-se as áreas mais carentes. Talvez por isso a maioria dos dirigentes tenha afirmado que a Secretaria promoveu a eqüidade. Ou talvez, essa afirmativa tenha sido feita em função da expansão física da rede, que se deu em direção à periferia, tanto no que se refere ao número de equipamentos, quanto ao de recursos humanos e materiais.

Porém, é necessário registrar a ocorrência de opiniões discordantes. Outros dirigentes afirmaram que a simples expansão da rede física não conferiu eqüidade às ações, ou mesmo que as novas tecnologias utilizadas na identificação de micro-áreas prioritárias não foram suficientes para promover a eqüidade. $E$ reforçaram, ainda mais enfaticamente, que o modo de funcionar das duas grandes instâncias de tomada de decisão da SMS - O Conselho Técnico Administrativo e o Conselho Municipal de Saúde - foi fator limitante para que a promoção da eqüidade pudesse ser contemplada, pois nessas instâncias, invariavelmente, todas as representações solicitavam mais recursos para suas áreas, sem considerar as desigualdades existentes. Nesse caso, foi questionada a organização da instituição e seus mecanismos de decisão política.

A Secretaria Municipal da Saúde promoveu sua reforma administrativa num cenário de tensão com outras Secretarias municipais.

Logo no início do governo, procurou descentralizar o poder, criando as Administrações Regionais e respectivos Distritos de Saúde, enquanto os outros setores governamentais permaneciam com suas estruturas centralizadas. Esse modo de proceder do governo trouxe dificuldades internas 
à Secretaria, porque ofereceu resistências à plena implementação dos princípios e diretrizes do Sistema Único de Saúde. Para transformar essa situação, seria necessário que a Prefeitura como um todo descentralizasse o poder e suas estruturas administrativas.

Mesmo nessas condições, a reforma administrativa da Saúde, com os mecanismos de participação social e com as estruturas administrativas regionalizadas e distritalizadas, repercutiu amplamente em outros pontos do país, pois seu desenho gerencial criou um cenário favorável à implementação das teses do SUS e, deste modo, o município de São Paulo tornou-se alvo de interesse de amplos setores preocupados com a implementação da reforma sanitária no Brasil.

A reforma administrativa contribuiu para implementar o SUS e provocou impactos políticos que continuam repercutindo, não apenas na esfera municipal, mas em todo o país, particularmente no que se refere a implantação do SUS e a redefinição do papel do Estado frente às políticas públicas no Brasil. Nesse sentido, o trabalho desenvolvido pela Secretaria gerou repercussões junto ao Conselho Nacional de Secretários Municipais de Saúde ( Conasems ). Além do mais, a criação de regiões e Distritos em São Paulo contribuiu para a definição de importantes capítulos das leis federais números 8.080 e 8.142, que consolidam a Lei Orgânica da Saúde, de abrangência em todo território nacional.

Em termos de aplicação de recursos financeiros, a Saúde foi a Secretaria que mais expansão provocou nos serviços municipais oferecidos à população. À Saúde coube a média de $14 \%$ do orçamento anual da prefeitura. Foram inaugurados seis novos hospitais de médio e grande porte, quando em toda a história de São Paulo a prefeitura havia construído apenas dez unidades

Feita a reforma, a SMS conservou o mesmo número de Unidades Orçamentárias e de cargos funcionais durante praticamente os três primeiros anos de governo. Esta situação, aliada à postura da administração municipal, que manteve uma tendência centralizadora, limitou consideravelmente a construção de uma base material e conceitual sólida para que as mudanças nos mecanismos de decisão e organização do processo de trabalho fossem amplamente operacionalizadas pelo setor saúde. Em certas situações, para poder operacionalizar administrativamente a recém-construída estrutura do Distrito de Saúde, as soluções encontradas passavam pela retirada da unidade orçamentária e de cargos do Hospital, transferindo-os para o nível 
distrital. Este fato gerou interesses conflitantes e provocou movimentos reativos por parte do pessoal hospitalar, que se defendia para não perder poder e autonomia política, financeira e administrativa. A falta de sustentação de estruturas administrativas atingiu também a sede da Administração Regional de Saúde, e estas indefinições e inseguranças acabaram gerando composições diferentes nas equipes de trabalho tanto das ARS's quanto nas equipes dos DS's. Isto levou ao aparecimento de concepções heterogêneas sobre o papel de cada nivel gerencial e em conseqüência, a coexistência de poderes decisórios concorrentes entre a ARS, o DS e o Hospital.

A democratização e as experiências de participação social estimularam os movimentos sociais organizados e contribuíram para o alargamento dos espaços de manifestação pública, pois inspiraram condutas frente às políticas sociais. Deste modo, a administração promoveu a cidadania e demonstrou como é possivel conciliar a administração direta com a democracia representativa. À população e aos servidores, através das comissões tripartites em todas as instâncias administrativas, foram oferecidos espaços institucionais para o estabelecimento de relações comunicativas entre as partes interessadas e envolvidas com a saúde. Esta constatação parte do discurso dos entrevistados. Em alguns casos chegamos a pensar na possibilidade de existência de uma espécie de "resistência" dos funcionários à volta de um modelo autoritário e conservador. Entre os servidores praticamente há unanimidade quanto ao fato de que a administração Luiza Erundina favoreceu a expressão da consciência crítica e gerou condições para a participação social no processo de tomada de decisão. Entre os cidadãos/usuários, os discursos convergem para posições antagônicas: de um lado há os que reconhecem a saúde enquanto um direito do cidadão e dever do Estado e concordam que o governo Erundina promoveu a participação social e a democratização administrativa. Assim, caracterizam-no pela descentralização do poder. De outro lado, há os que pensam não haver democracia no setor público da saúde. Identificamos até mesmo discursos que afirmam que tanto a participação social quanto a democratização do setor saúde aumentaram com a implantação do plano PAS no municipio.

Mesmo entre os funcionários que aderiram ao PAS, existem discursos relacionando participação social e administração Luiza Erundina, muito embora, a maioria deste segmento tenha procurado não se referir a este governo, especialmente quanto à questão da participação social. 
Embora tenha havido empenho por parte da Secretaria no sentido de favorecer relações comunicativas entre os lados interessados na questão saúde, pensamos que os representantes da população não conseguiram participar o suficiente das tomadas de decisão, do planejamento das ações e das mudanças do setor saúde. No cotidiano, a gerência continuou centralizada nas mãos da administração. A exigência de tomadas de decisão rápidas, as dinâmicas administrativas intensas, o árduo e volumoso processo de admissão e desenvolvimento de pessoal e a complexidade dos procedimentos administrativos não permitiram que se garantisse, como se desejava, a presença qualificada da representação popular no processo de planejamento e tomada de decisão. A análise dos discursos revela a intencionalidade da administração em promover a participação social na definição dos rumos da política de saúde. Entretanto, essa prática apresentou inúmeros problemas, mesmo com a institucionalização dos mecanismos de participação. Em que pese a política de saúde ter caminhado em direção ao alargamento do espaço público e ao exercício da cidadania, ficamos com a impressão de que houve pouca participação dos funcionários e pouca presença de representação popular na reforma administrativa da Secretaria da Saúde, assim como na definição das bases conceituais, estruturais e na implementação da política municipal de saúde.

Em relação a esse modo de proceder, desejamos tecer algumas considerações. Em primeiro lugar, muitos funcionários foram contra a abertura da administração e a presença popular nos mecanismos de tomada de decisão. Foram os servidores os que menos participaram das comissões gestoras tripartites. De alguns deles, chegamos a ouvir que não seria justo e nem correto que funcionários fossem fiscalizados ou controlados por representantes da população. Quem teria a obrigação de fazer isso seria a chefia da Unidade. A compreensão que esse grupo de servidores teve da participação popular foi de fiscalização e não de direito de expressão.

Também consideramos que, na inserção da representação popular na comissão gestora tripartite da Unidade de Saúde, alguns movimentos populares -os mais organizados- acabaram influenciando demasiadamente alguns dos dirigentes da Secretaria, especialmente aqueles provenientes dos movimentos sociais, a ponto de eles, muitas vezes, não conseguirem mais distinguir seu próprio papel junto à comissão gestora. Essa situação trazia o risco de, muitas vezes, serem priorizados os interesses dos grupos populares mais fortes em detrimento de outros mais frágeis, o que acabava por 
reproduzir e acentuar as desigualdades sociais já existentes, obstaculizando, uma das principais diretrizes da Secretaria: a diminuição das injustiças e a promoção da eqüidade ${ }^{77}$.

Quanto à representatividade, observamos que alguns representantes da comunidade não conseguiam, de fato, ser representativos da população. Não havia por trás deles movimentos populares organizados, que garantissem sua necessária representatividade junto às comissões gestoras.

No que diz respeito aos representantes da administração, surgiram problemas semelhantes. Muitos dos administradores haviam participado, em anos anteriores, de experiências junto aos movimentos populares por melhores condições de vida e saúde, sendo oriundos desses movimentos. Quando passaram à condição de gestores dos serviços públicos, representando o poder municipal, ficaram indecisos entre continuar lutando ao lado da população ou assumir o ônus de serem governo, pois nem sempre os interesses eram os mesmos. Daí a razão da existência das comissões tripartites, onde nem sempre os interesses dos três lados são coincidentes.

Outros problemas que ocorreram durante a gestão diziam respeito à qualidade da participação em si. Os questionamentos levantados pela população na maioria das vezes giravam em torno da oferta de serviços, considerada insuficiente tanto no que se refere à falta de funcionários, quanto à escassez de materiais e medicamentos e a problemas estruturais crônicos da rede física. A prática da participação, portanto, foi mais reivindicatória. Há quem afirme, entretanto, que "só existe cidadania se houver a prática da reivindicação, da apropriação de espaços, da pugna para fazer valer os direitos do cidadão. Neste sentido, a prática da cidadania pode ser a estratégia, por excelência, para a construção de uma sociedade melhor. Mas o primeiro pressuposto dessa prática é que esteja assegurado o direito de reivindicar os direitos, e que o conhecimento deste se estenda cada vez mais a toda a população"178

A ênfase na prática reivindicatória aparecia nas questões debatidas nas comissões gestoras. Poucas vezes elas diziam respeito à política de saúde, ao planejamento a médio e longo prazos, à avaliação da execução

\footnotetext{
${ }^{77}$ CEDEC. Centro de Estudos de Cultura Contemporânea. São Paulo. elaborou uma série de Boletins Informativos. numerados de Um a Seis. denominados Participação e Saúde, com o objetivo de acompanhar e divulgar a experiência da proposta de descentralização e participação na área da saúde. O Boletim número 6 é sobre o balanço da participação no periodo do governo Luiza Erundina.
}

${ }^{78}$ Manzini-Couvre. O que é Cidadania, Ed. Brasiliense, São Paulo, 1991, p. 10 - 11. 
orçamentária, às prioridades a serem enfrentadas ou ao modelo gerencial e de atenção à saúde. Geralmente esses temas ficavam restritos aos dirigentes da Secretaria e reservados às reuniões do Conselho Municipal da Saúde e do Conselho Técnico Administrativo do Gabinete da SMS.

A participação da população levou, em alguns casos, a definição de prioridades, consubstanciando uma interferência de fato. Apesar disso, não temos condições de saber em que medida a participação social contribuiu efetivamente para o atendimento das necessidades básicas da população e para o enfrentamento efetivo das iniqüidades. Mas sem dúvida houve um contato próximo da administração com os movimentos e organizações sociais dos bairros, e com o cotidiano das pessoas mais simples, na busca de conhecer melhor os espaços em que elas viviam. Aumentando o espaço público de participação social, a administração contribuiu para demonstrar que é possível conciliar democracia direta com democracia representativa. Apesar de todos os problemas na construção desse processo, a Secretaria criou a possibilidade concreta de ampliar a participação social e de democratizar suas estruturas administrativas. Para a população foi uma experiência interessante, pois passou a ter canais para reivindicar mudanças na prestação de serviços. Nas Comissões Gestoras das Unidades de Saúde, por exemplo, existia a possibilidade de uma interlocução direta com os gerentes, sem intermediários, desprovida das relações de clientelismo. Ou seja, o governo criou formas de participação da sociedade na administração municipal, o que é indicativo do deslocamento de poder do centro para a periferia, e do desejo de contribuir para a promoção da cidadania.

Pode-se concluir afirmando que esse "novo espaço" possibilitou o crescimento da participação e, por que não, o desenvolvimento de consciências criticas e o exercicio da cidadania. Se houve algum avanço em termos de participação, este se deu na direção do fortalecimento dos movimentos populares. Nesse sentido, a Saúde reciclou seu papel enquanto função de Estado e reafirmou seu caráter público, pois respeitou o direito à cidadania e promoveu os movimentos populares, ganhando importância na história e no cenário político local.

A busca de um novo modelo de atenção levou à implantação de novos serviços, com a introdução de práticas de saúde inéditas na rede municipal, 
que também foram implementadas nos serviços preexistentes. Duas dessas práticas merecem destaque. Uma delas ficou conhecida pelo nome de Grupo de Orientação e Recepção à Demanda ( GORD ), onde o enfoque principal era 0 acolhimento à demanda espontânea. Muitas das Unidades Básicas de Saúde destacaram um grupo de servidores devidamente preparados para acolher e orientar toda e qualquer demanda à Unidade, mesmo aquelas colocadas acima de sua capacidade resolutiva. A segunda atividade implantada ficou conhecida por Hospital Aberto: todos os hospitais municipais assumiram o compromisso de garantir acomodação a um acompanhante durante o período de internação do paciente. A percepção da importância dessas práticas foi reconhecida inclusive pelos funcionários que aderiram ao PAS.

Em decorrência das quatro programações de saúde eleitas como estratégicas para o combate à violência urbana, outras atividades de saúde foram introduzidas na rede de serviços. Comitês de Prevenção de Mortalidade Materna foram instalados na quase totalidade dos Distritos de Saúde e outros serviços foram criados, como os Centros de Convivência e Cooperativa, programados para acolher minorias e excluidos, os Hospitais-Dia, que viabilizaram a política de desospitalização do portador de sofrimento mental, e os Centros de Referência de Saúde do Trabalhador, unidades programadas para prevenir e acompanhar as doenças relacionadas às atividades ocupacionais, com projetos de intervenção ambiental sobre as condições de trabalho. A grande maioria dos funcionários entrevistados revelou em seus discursos o reconhecimento e valor dessas atividades.

Com a distritalização da Secretaria, os profissionais e trabalhadores da saúde começaram a aprender a delimitar e a dar importância aos espaços geográficos de responsabilidade de cada Unidade de Saúde, e um novo conceito foi introduzido no cotidiano do planejamento: o de território. Com as informações desagregadas por micro-áreas no território, as equipes locais conseguiram ver com mais clareza as desigualdades e passaram a identificar os principais problemas de saúde. O esforço concentrado dos dirigentes no sentido do desenvolvimento do pessoal tinha pelo menos uma razão: estimular o planejamento local e buscar respostas aos principais problemas identificados.

Em que pese o enorme esforço para a admissão de pessoal por meio da realização de dezenas de concursos públicos, o grande trabalho ficou reservado à capacitação e ao desenvolvimento dos funcionários. A 
interpretação das entrevistas dos funcionários e dirigentes nos leva a concluir que a experiência acumulada no município de São Paulo valorizou o processo de capacitação e treinamento de pessoal voltado para as práticas coletivas e de vigilância à saúde, visando ao enfrentamento dos problemas identificados.

"Na administração passada o trabalho não era só dentro do Posto, mas nas áreas de risco. Havia um trabalho extensivo com a comunidade, com atividades preventivas sobre DST/AIDS e gravidez na adolescência. Hoje os trabalhos estão totalmente diferentes"(...)

\section{Nutricionista, 6 anos de Prefeitura.}

Este movimento de mudança do modelo de atenção foi percebido de diversas maneiras pelos funcionários. As opiniões foram divergentes e, algumas vezes, contraditórias. Assim, parte dos trabalhadores da saúde foi sensibilizada com a mudança da lógica do modelo de atenção, percebendo a passagem de um enfoque assistencialista para um eixo mais complexo de atuação no âmbito distrital/local, ou seja, para a lógica da vigilância à saúde. Este grupo de trabalhadores detectou, portanto, o trabalho voltado para o enfrentamento dos problemas e o atendimento às necessidades de saúde da população. Diga-se de passagem que esta expressão "necessidades de saúde da população" nunca foi suficientemente debatida pelo coletivo dos trabalhadores do setor $e$, por essa razão, não se chegou a uma definição precisa sobre o seu real significado. No entanto, o que a Secretaria desejava enquanto discurso institucional, e cuja percepção se constatou através da análise de parte das entrevistas dos funcionários, era a busca de respostas aos problemas do coletivo ${ }^{79}$.

Enfim, o que se buscava era um novo objeto de trabalho no setor saúde, cuja especificidade, pode-se dizer, era dada pelas "inflexões sócioeconômicas, políticas e ideológicas relacionadas ao saber teórico e prático sobre saúde e doença, sobre a institucionalização, a organização, a administração e a avaliação dos serviços e a clientela dos sistemas de Saúde"180. Restou dessa visão, com seu enfoque interdisciplinar e estratégico, o reconhecimento, ao menos por parte do funcionalismo, de que o campo da Saúde abrange uma realidade complexa, que demanda conhecimentos integrados de várias áreas, o que coloca de forma imediata o problema da intervenção.

\footnotetext{
${ }^{-9}$ Ver. a esse respeito. trecho da entrevista com o funcionário psicólogo, 10 anos de Prefeitura: "Havia mais contatos com Educação. Bem-Estar e Cultura. Todos os serviços passaram a atender os doentes mentais".

${ }^{84}$ Minayo. M.C.S. O Desafio do Conhecimento, Pesquisa Qualitativa em Saúde, Hucitec-Abrasco, São Paulo-Rio de Janeiro. 1992, p. 13
} 
Podemos dizer que, nas circunstâncias criadas no processo de trabalho dos Distritos de saúde, com a delimitação dos territórios de responsabilidade das Unidades Básicas de Saúde e especialmente depois que se disseminaram pela rede as Oficinas de Trabalho, a definição de necessidades da população partiu do reconhecimento prévio das diferentes condições sociais de vida dos indivíduos. Esta concepção de trabalho, que caracterizou - projeto da política de saúde da Secretaria, revelou uma posição radicalmente oposta a outra, ainda hegemônica, que também esteve presente nas entrevistas dos funcionários e cidadãos/usuários. Esta última posição, predominantemente centrada no diagnóstico médico, tem como prioridade 0 combate dos efeitos das doenças, e é sustentada por uma concepção segundo a qual, "as necessidades tornam aqueles, para quem este processo assim se realiza, cidadãos alienados de sua cidadania, seres da sociedade alienados de sua sociabilidade e sujeitos tolhidos no exercicio da subjetividade. $O$ produto desse processo é uma tal naturalização das demandas que elas aparecerão sem história ou sem razão social, e apenas impulso ou propensão de ordem natural-biológica"81.

Neste momento podemos identificar uma certa coesão de posições entre o segmento dos dirigentes e o dos funcionários, a respeito da reforma administrativa e do modelo de atenção. É consenso entre os dois segmentos que o processo de trabalho reformulou por inteiro os objetivos e a organização da Secretaria: promoveu a descentralização do poder e deu mais autonomia às Unidades, retroalimentando a prática e as bases teóricas do conhecimento, especialmente no que diz respeito aos trabalhadores do nível local. Desenvolveu projetos no âmbito dos Distritos de Saúde, buscando reconhecer os problemas da população de um dado território, com sua base populacional e perfil epidemiológico definidos. Fez isso com o objetivo reformular a história do planejamento em saúde, com um pensamento inovador, que visava não apenas encontrar respostas aos problemas mais imediatos, mas se voltava para o futuro, para que os problemas pudessem ser processados de modo integrado, com intervenção de outros setores do governo e da sociedade civil.

Segundo nossa compreensão das entrevistas, em função dos diferentes perfis dos dirigentes e das diferentes composições das equipes gerenciais, esse trabalho foi desenvolvido de forma desigual entre as regiões

\footnotetext{
${ }^{81}$ Schraiber \& Mendes-Gonçalves, Saúde do Adulto, programas e ações na unidade básica, Hucitec. São Paulo, 1996, p. 31.
} 
e Distritos. Cada diretor, em função de seu perfil técnico-políticoadministrativo e de sua equipe de trabalho, imprimiu um ritmo próprio ao processo de mudança, no Distrito ou na região de saúde. Por esse motivo, podemos dizer que a maioria de funcionários continuou trabalhando dentro da concepção tradicional, voltada para a crescente demanda de assistência por parte da população, e oferecendo respostas aos problemas mais imediatos dos usuários. Esta desigualdade está explicitada no discurso dos funcionários, que perceberam de forma diferenciada o modelo de atenção proposto pela Secretaria.

As entrevistas com os dirigentes revelam percepções diferenciadas. Há os que entenderam que a maior parte do tempo dispendido foi destinado a organizar a oferta de serviços e as ações convencionais, sobrando pouco espaço para a produção, para a promoção da saúde ou para o enfoque por problemas.

(...) "Dentro da Secretaria da Saúde o discurso de que saúde é muito mais do que atendimento médico é claro. O que não era muito claro é que, tendo o atendimento médico para a população, fazer as duas coisas ao mesmo tempo. Aí a estratégia da Secretaria muitas vezes titubeava. Não sabíamos, e aí eu ponho todo mundo junto, como fazer. Se você não fizer uma análise muito rigorosa dos problemas da população, você não vai conseguir um atendimento médico perfeito. Isso você pode tirar da sua cabeça. Nós não sabíamos como organizar 0 atendimento sem que este nos consumisse. Isso não conseguimos fazer. Na hora de operacionalizar a produção da saúde, nós não tínhamos clareza de como fazer. Esta era a grande questão. Uma coisa que saía do plano teórico, do discurso, todo mundo sabia, (...) a dificuldade era operacionalizar o atendimento médico como um compromisso da questão mais ampla da saúde, e nós não conseguimos fazer com que ele não consumisse todas as nossas forças"(...)

Para estes, predominou a cultura burocratizada da instituição, com a manutenção do planejamento tradicional, de cima para baixo, baseado em procedimentos rígidos e normatizadores, com a busca de um equilíbrio entre a demanda espontânea e o perfil do serviço. De acordo com esta lógica, houve pouca preocupação em se avaliar os impactos das atividades desenvolvidas sobre os perfis epidemiológicos das populações e valorizou-se o tradicional e sempre presente cuidado com a eficiência, produtividade e custo do sistema.

(...) "Você não tinha um pensamento estratégico. Tinha um pensamento administrativo, baseado em emergências. Isto também é absolutamente tradicional. Você tinha dificuldades em ter uma discussão política mais geral"(...) 
(...)"Você pode ter tido processos que foram mais ou menos coletivos. Eu não acredito que possa ter tido processos de verdade, muito coletivos (...) E você teve sim, mas um planejamento cujas diretrizes foram determinadas de cima para baixo. $E$ era um pouco esse modelo, porque se você viesse com o planejamento ascendente, com a cultura que você tinha na Prefeitura, você ia chocar com a visão de quem estava chegando. Dá até para compreender porque ele tinha que ser um pouco impositivo. Se ele viesse de baixo para cima ele vinha com a cultura, com a mentalidade do funcionalismo da SMS. Porque 0 planejamento não tem uma dimensão técnica só. la chocar com essa revolução toda que estava acontecendo. Então, o planejamento nem poderia deixar de ser um pouco impositivo na minha opinião, se você quisesse fazer algum tipo de transformação. Porque se ele viesse como manda o figurino, ele viria naqueles padrões que você conhece melhor que eu, porque você esteve mais próximo da máquina do que eu (...) Você não pode ser ingênuo, imaginar que você vai fazer o planejamento ascendente, quando chegar aqui em cima, isto estaria completamente fora das diretrizes políticas da administração, estaria, com certeza estaria. Então é um pouco a minha visão acerca do planejamento" (...)

No entanto, para outros dirigentes, cidadãos/usuários e funcionários, foram criados espaços que estimularam a criatividade do pessoal, com abertura de canais de relação solidária entre os trabalhadores de saúde e destes com os movimentos e entidades sociais.

Dentre todas as atividades promovidas pela Secretaria, percebe-se claramente a impressão provocada pelas Oficinas de Trabalho entre o funcionalismo. Estas se tornaram o exemplo das situações problematizadoras, pois ficaram marcadas na memória de muitos entrevistados. Talvez porque nas oficinas os próprios participantes construíssem seu conhecimento sobre os problemas de saúde e condições de vida, juntamente com os moradores do território objeto de estudo. As Oficinas não eram, como não são, teoria: eram práticas, espaços em constante reconstrução. Dentro destes espaços eram produzidos os conhecimentos e procurava-se desenvolver a capacidade dos participantes "estranharem" a realidade, estabelecendo um diálogo crítico com esta mesma realidade.

A metodologia das oficinas, pela multiplicidade de ações envolvidas, reforçou no conjunto do funcionalismo a consciência da importância do trabalho em equipe, da integração e do sentido da relação interdisciplinar, uma vez que eram aplicadas a funcionários com diferentes formações, inclusive não-universitários e representantes da comunidade.

A interpretação que fizemos das entrevistas nos encoraja a afirmar que as Oficinas de Trabalho se transformaram no principal foco de construção e 
apropriação de conhecimento pelo conjunto do funcionalismo. Foram processos que incluíram dinâmicas de reflexão coletiva, em que 0 conhecimento levou à análise de uma dada situação concreta e permitiu a abertura do grupo a práticas inovadoras. Através delas foi possível reunir informações e identificar problemas cujas raízes atingiam outros setores sociais. A impressão que ficamos é que estavam sendo estabelecidas novas redes de trabalho, orientadas pelas necessidades descortinadas, visando a melhoria da infra-estrutura urbana, com a construção de moradias, transportes, saúde e educação. Os resultados apontaram para o descobrimento de um novo objeto: o coletivo e suas desigualdades. Pois as oficinas permitiram a aproximação com as necessidades dos vários grupos sociais, por meio da identificação de grupos de população adscritos a microáreas geográficas.

(...) "Foi uma tentativa de você trazer os instrumentos de planejamento e de informações em saúde, para associá-los com as informações gerenciais. Mas ao lado disso uma nova concepção: não o planejamento visto como sendo pessoas que detinham determinado conhecimento em planejamento, mas tentar trazer a dinâmica dos vários órgãos com espaço onde o planejamento se faria num encontro dessas várias dinâmicas. Por outro lado, a idéia de que essa participação deveria existir de forma ascendente, ou seja, para você planejar a política da Secretaria não apenas de cima para baixo, mas tinha que ser um movimento conjugado de baixo para cima, ou seja, das Conferências e dos Encontros para definir prioridades anuais, mas ao mesmo tempo, a partir do dia-dia do trabalho da Unidade de Saúde, do Distrito, dentro daquela lógica de fazer a territorialização, de trabalhar a visão da vigilância em saúde, de trazer diferentes elementos de cada Distrito, de cada Região, que não eram necessariamente iguais, portanto, exigiam ritmos diferenciados por parte da própria gestão da Secretaria. Eu acho que esse processo a gente conseguiu começar, mas houve uma interrupção brutal" (...)

O que se constatou é que existiu uma relação estreita entre a metodologia das Oficinas e da epidemiologia, especialmente no que diz respeito aos meios empregados para conhecer e analisar os problemas de saúde da população local. Nesse sentido, pode-se dizer que alguns conceitos básicos da epidemiologia foram indispensáveis às oficinas. As noções de coletivo, de população, do caráter social do processo saúde-doença e o conceito de risco ${ }^{82}$ não constituíram apenas um arcabouço teórico, um

\footnotetext{
${ }^{8}$ ALMEIDA FILHO.N. Epidemiologia Sem Números, uma introdução critica à ciência epidemiológica, Ed. Campus. Rio de Janeiro. 1989.
} 
conjunto de categorias a serem apreendidas. Mais que isso, foram instrumentos de reelaboração de concepções, que contribuíram para o planejamento de ações transformadoras. Constatamos que as Oficinas serviram de cenário para a interação de grupos com interesses muitas vezes conflitantes. Profissionais de saúde de diferentes formações, representantes da população e de outros setores sociais foram envolvidos no mesmo processo de trabalho, o que favoreceu a abertura do setor a outras áreas de atuação comunitária. A diversidade e a multiplicidade de pontos de vista envolvidos no processo acabaram construindo um ambiente favorável às mudanças sobre o modo de pensar e conhecer, permeável às críticas sobre as práticas sociais vigentes e propício à renovação do campo de aplicação da saúde coletiva, que tinha por base a apropriação do território.

$\mathrm{Na}$ prospecção desses territórios vivos, humanos e sociais, acompanhamos a psicanalista Sueli Rolnik ${ }^{83}$, que desloca o conceito de território das meras configurações geográficas para regiões mais amplas, que prevêem a travessia de percursos culturais e imaginários. De acordo com a ensaista, "...territórios são configurações mais ou menos estáveis, atravessam terras e grupos os mais variados: são transversais, transculturais".

Desse modo, o processo de trabalho desencadeado para a mudança do modelo de atenção, teve como eixo fundamental a descoberta do território e das especificidades do espaço local, e o desejo de intervir neles, de forma coletiva e integrada. Esta nova visão dos problemas retroalimentou, na prática, a metodologia empregada. As diferentes análises tornaram possível a formulação de respostas resultantes da investigação empreendida pelos setores envolvidos no processo. Como se pode observar através das entrevistas, a metodologia adotada viveu das intervenções e contribuições dos participantes, fenômeno este que, caso tivesse tido continuidade, poderia permitir a consolidação de uma nova maneira de gerenciar os serviços de saúde.

(...) "Dentro dessa visão, de você ter uma estrutura horizontalizada, com colegiados que discutem as coisas nos vários niveis e no nível central, com assessores de Gabinete, responsáveis por alguns órgãos e com operadores de decisões no próprio CTA, para mim tudo isso, é uma visão que tínhamos do planejamento estratégico situacional. Alguns diretores regionais, com mais experiência, conseguiram ter uma aplicação desta mesma metodologia

\footnotetext{
${ }^{83}$ ROLNIK.S. Cartografia Sentimental. Transformações contemporâneas do desejo, Estação Liberdade, São Paulo, 1989, p. 57.
} 
nas regiões. Houve experiências localizadas na minha visão e, com colaborações externas, para ajudar nesse processo" (...)

Dado o caráter diversificado dos grupos, os participantes tiveram condições de identificar os setores sociais mais atingidos pelos problemas, gerando novos subprojetos que visavam à intervenção naquela situação encontrada, tendo em vista o enfrentamento dos problemas e das iniqüidades.

(...) "Em termos de modelo de atenção à saúde a gente deixou uma mensagem importante, deixamos alguns germes, deixamos uma determinada concepção de integração da política de saúde com o intersetorial. Rompemos com aquela lógica de separar a atenção ambulatorial da atenção hospitalar, de programas que na verdade, chegavam a ponto de, a partir do Gabinete do Secretário, você ter um controle sobre o que era feito na Unidade de Saúde. Isso eu acho que a gente conseguiu romper" (...)

Isto nos leva a refletir sobre o caráter político do desenvolvimento de pessoal. Ao contribuir para a ampliação do saber e para a compreensão de uma dada realidade social, o processo desencadeado pela Secretaria se comprometeu com interesses de determinados grupos sociais. $E$, através desse comprometimento, desnudou a desigualdade dos conglomerados sociais. E passou a exigir uma ampliação do campo de ação, que se deslocou das práticas específicas da saúde pública para um enfoque multissetorial ${ }^{84}$.

Apesar da presença simultânea de padrões díspares de pensamento em saúde no coletivo da gerência, das concepções heterogêneas sobre o sentido do setor público e do modelo de atenção à saúde, das diferentes composições das equipes de trabalho regional e distrital e de indefinições sobre tarefas e competências de cada nível, pode-se seguramente afirmar que o caminho seguido pela Secretaria levou à formulação de novos projetos sociais e contribuiu para planejar a reorganização das práticas de atuação do setor público. O mais importante a destacar é que se conseguiu abrir espaço para a construção de novos caminhos a partir da base, ou seja, a partir dos usuários dos serviços e dos funcionários de nível local que, estimulados a exercer o papel de agentes de um trabalho coletivo, desenvolveram uma consciência crítica que os fortaleceu e lhes permitiu participar ativamente do

\footnotetext{
${ }^{84}$ De acordo com Minayo (1995), as dimensões estruturais e políticas da Saúde só podem ser entendidas dentro de uma sociologia de classe ... "que conceba sua realização tanto nos espaços formais da economia e da politica como nas matrizes essenciais da cultura como a família, a vizinhança, os grupos etários, os grupos de lazer etc., considerando como espaços inclusivos de conflitos, contradições, subordinação e resistência tanto as unidades de trabalho como o bairro, o sindicato como a casa, a consciência como o sexo, a politica como a religião".
} 
processo de transformação. Permitiu também reflexões sobre a organização e os mecanismos de avaliação dos serviços de saúde, à medida que seu processo conseguiu estabelecer relações entre as contradições do meio e a situação de saúde. Por estimular análises sócio-econômicas e políticas relacionadas às práticas sanitárias, a detecção das desigualdades do território pôde despertar entre os diferentes atores sociais envolvidos a necessidade de um trabalho para a promoção da eqüidade no setor saúde

Nesse sentido, as nossas reflexões sobre a política de saúde desenvolvida pela Secretaria Municipal de Saúde de São Paulo focalizaram mais o compromisso assumido pela Instituição com os princípios e diretrizes do Sistema Único de Saúde e, mais especificamente, com os meios que pudessem favorecer sua implementação, como por exemplo, a descentralização administrativa e a implantação das Regiões e dos Distritos de Saúde. Estas medidas foram consideradas estratégicas para a municipalização dos serviços, para a participação social e para a democratização das decisões. O modelo de atenção à saúde foi repensado, com a introdução de práticas inovadoras nos serviços, em outras instituições e na comunidade. Não se pode dizer que o processo não tenha sido contraditório. Teve múltiplas implicações $e$, como se viu, diferentes apreensões. Recebeu recusas, mas teve aprovações.

A partir da análise das entrevistas, pudemos evidenciar que existem sujeitos receptivos à transformação das práticas. Ao mesmo tempo, a partir das respostas dos entrevistados, nos fizemos novas perguntas. De que forma resgatar as experiências de transformação ocorridas e as esperanças de mudança? De que forma reagir às lutas perdidas? Como deve-se desenvolver um trabalho que leve à participação continuada de funcionários e cidadãos na tomada de decisões? Como retomar, radicalizar e aprofundar os processos de democratização que foram interrompidos? Como dar continuidade às metodologias de trabalho que levam à construção coletiva de conhecimentos a partir da base? Que modelos gerenciais e de atenção à saúde são respostas a atual crise da saúde?

Mesmo com essas novas indagações, podemos afirmar que tanto os dirigentes quanto os funcionários e cidadãos/usuários entrevistados tiveram consciência do sentido da política da Secretaria Municipal da Saúde, conseguindo inscrevê-la na política social do governo Luiza Erundina. Esta constatação é suficiente para continuarmos sonhando que somos capazes de 
dar um sentido transformador às nossas práticas e, solidariamente, produzir saúde. 


\section{Referências Bibliográficas}

ALMEIDA E.S. Contribuição à Implementação do SUS: Estudo do Processo com a Estratégia NOB 01/93. Tese de Livre Docência, Faculdade de Saúde Pública/USP - Universidade de São Paulo, 1996.

ALMEIDA FILHO, N. Desconstruindo o conceito de risco.In: A Clínica e a Epidemiologia. APCE-ABRASCO, Rio de Janeiro,1992.

ALMEIDA FILHO.N. Epidemiologia Sem Números, uma introdução crítica à ciência epidemiológica, Ed. Campus, Rio de Janeiro, 1989.

AYRES,J.R.C.M. Epidemiologia e Emancipação. Hucitec-Abrasco, São PauloRio de Janeiro, 1995.

BARDINI, L. Análise de conteúdo. Edições 70, Lisboa, 1979.

BENEVIDES, M.V. de M. A Cidadania Ativa. Referendo, Plebiscito e Iniciativa Popular. Ática, São Paulo, 1991.

CAMPOS,G.W.S. Modelos de atenção em Saúde Pública: um modo mutante de fazer saúde. Revista Saúde em Debate,37, CEBES,1992.

CAMPOS, G.W.S. Sobre a peleja dos Sujeitos da Reforma, ou da Reforma dos Sujeitos em Peleja. In: Saúde e Sociedade,1/2, FSP, São Paulo, 1992.

CASTELANOS, P.L. Sobre el concepto de salud-enfermedad: un punto de vista epidemiológico. Cuadernos Médico-Sociales, CESS. Rosario, Argentina, Deciembre, 1987.

CASTRO, P.C. Reestruturação Orçamentário-Financeira da Secretaria Municipal da Saúde de São Paulo, na Gestão 1989-1992, Tese de Mestrado, Faculdade de Saúde Pública, Universidade de São Paulo, 1996.

CHAUÍ, M. in: SADER, E. Quando Novos Personagens Entram em Cena. Experiências e Lutas dos Trabalhadores da Grande São Paulo, 1970-80. Paz e Terra, São Paulo, 1988. 
CHORNY, A.H. El Enfoque Estratégico Para El Desarrolo de Recursos Humanos. In: Educación Médica y Salud, Vol. 24, No.1 (1990).

COHN, A. O Conhecimento e a Prática em Saúde Coletiva: o desafio permanente. In : Saúde e Sociedade,1/2, FSP, APSP, São Paulo,1992.

COSTA,N.R. Ciências Sociais e Saúde: considerações sobre o nascimento da saúde coletiva no Brasil, Revista Saúde em Debate, 36, CEBES,1992.

COUTO, C.G. O desafio de ser governo: o PT na Prefeitura de São Paulo, Paz e Terra, São Paulo, 1995.

DECRETO MUNICIPAL número 27.724, publicado no D.O.M. em 12 de abril de 1989.

DI VILLAROSA, F.N. GRECO, C. TASCA, R. in: Teixeira, C.F., Mello, C. (org.) Construindo Distritos Sanitários: a experiência da cooperação italiana no municipio de São Paulo. Hucitec, São Paulo-Salvador, 1995.

DIÁRIO OFICIAL DO MUNICIPIO - D.O.M. - Suplemento Especial - Quartafeira, 2 de agosto de 1989.

DISTRITALIZAÇÃO DO MUNICÍPIO DE SÃO PAULO: Estratégias para a implantação do SUS. Texto mimeografado da Secretaria Municipal da Saúde, São Paulo, 1991.

ELIAS, P.E.M. Análises Sobre a Reforma Sanitária e Concepções Políticas Subjacentes: A Visão Autoritária do Ideário Progressista. In: Saúde e Sociedade, São Paulo, 2 (1): 59-73, 1993.

ESPING-ANDERSEN, G. As Três Economias Políticas do Welfare State. In: Lua Nova, Revista de Cultura e Política, No. 24, setembro 91, CEDEC / Marco Zero, São Paulo.

FALCÃO, M.C. A Seguridade na Travessia do Estado Assistencial Brasileiro. In: Sposati, A. et alli, Os Direitos (dos desassistidos) Sociais. Cortez, São Paulo, 1989. 
FLEURY, S. Saúde Coletiva? Questionando a Onipotência do Social, RelumeDumará, Rio de Janeiro, 1992.

FLEURY, S. (org.) Saúde e Democracia - A Luta do Cebes. Lemos Editorial \& Gráficos Ltda. São Paulo, 1997.

FOLHA DE SÃO PAULO, Caderno Especial de 7 de outubro de 1996.

FOLHA DE SÃO PAULO de 13 de setembro de 1996.

GALLO, E.(et al), Planejamento Criativo: Novos Desafios em Políticas de Saúde, Relume-Dumará, Rio de Janeiro, 1992.

GALLO, E.(org.) Razão e Planejamento: reflexões sobre política, estratégia e liberdade, Hucitec-Abrasco, São Paulo-Rio de Janeiro, 1995.

HABERMAS, J. Teoria de la Acción Comunicativa. Taurus, Madri, 1987.

HUERTAS, F. Entrevista com Carlos Matus, o Método PES, Edições Fundap, São Paulo, 1995.

JARDANOVSKI, E. e GUIMARÃES, P.C.V. Revista de Administração de Empresas. São Paulo, 33 (3): 38-51, maio/junho 1993.

LAURELL, A. C. La política social en la crisis. Una alternativa para el sector salud. (Documento de Trabalho n. 27). Fundacion Friedrich Ebert, México, 1991.

LAURELL, A. C. Estado y Políticas Sociales en el Neoliberalismo. Friedrich Ebert, México, 1992.

MANZINI-COUVRE, M. L. O que é Cidadania. Ed. Brasiliense, São Paulo, 1991.

MARSIGLIA, R. M. G. Servidor, Funcionário, Trabalhador: interesses e culturas organizacionais no setor público de saúde. Tese de Doutorado, Faculdade de Filosofia, Letras e Ciências Humanas, USP, 1993.

MATTOS, M.L. Recursos Humanos e o Novo Trabalhador em Saúde: a experiência da Secretaria Municipal de Saúde na cidade de São Paulo durante 
a gestão do Partido dos Trabalhadores (1989-1992), Tese de Mestrado, Universidade Estadual de Campinas, UNICAMP, 1996.

MATUS, C. La Planificación de Situaciones. Fondo de Cultura Económica, México, 1980.

MATUS, C. Politica, Planificación y Gobierno. Borrador, Washington, 1987.

MEIRELLES, H. L. Direito Administrativo Brasileiro. Malheiros Editora Ltda. $17^{\text {a }}$. Ed., São Paulo, 1990.

MENDES, E.V. (org.) Distrito Sanitário: o processo social de mudança das práticas sanitárias do Sistema Único de Saúde. Hucitec-Abrasco, São PauloRio de Janeiro, 1992.

MINAYO, M.C.S. Os Muitos Brasis: saúde e população na década de 80 , Hucitec-Abrasco, São Paulo-Rio de Janeiro, 1995.

MINAYO, M.C.S. (org.) Pesquisa Social: teoria, método e criatividade. Vozes, Petrópolis, 1996.

MINAYO, M.C.S. O Desafio do Conhecimento, Pesquisa Qualitativa em Saúde, Hucitec-Abrasco, São Paulo-Rio de Janeiro, 1992, p. 13.

OLIVEIRA, J. A. Reformas e Reformismos: para uma teoria política da Reforma Sanitária (ou, reflexões sobre a Reforma Sanitária de uma perspectiva popular). In: Demandas Populares, Políticas Públicas e Saúde. Vozes, Rio de Janeiro, 1989.

OMS, OPAS, Di Villarosa, F. N. A Estimativa Rápida e a Divisão do Território no Distrito Sanitário, série de desenvolvimento de serviços de saúde, Brasília, 1993.

PAIM, J. S. Recursos Humanos em Saúde no Brasil: problemas crônicos e desafios agudos. AdSaúde - série Temática. FSP/USP,1994.

PAIM,J.S. A reorganização das práticas de saúde em distritos sanitários. In: MENDES,E.V. Distrito Sanitário: o processo social de mudança das práticas 
sanitárias do sistema único de saúde. Hucitec-Abrasco, São Paulo-Rio de Janeiro, 1994.

PAOLI, M. C. Movimentos Sociais, Cidadania, Espaço Público: Perspectivas Brasileiras para os anos 90. Revista Crítica de Ciências Sociais, 33, Coimbra, Portugal, 1991.

PARTICIPAÇÃO E SAÚDE - Boletim Informativo do Centro de Estudos de Cultura Contemporânea - CEDEC, 1 a 6, São Paulo, 1991 a 1992.

PREFEITURA do Município de São Paulo, Plano de Emergência para a cidade de São Paulo, janeiro de 1989 ( mimeo ).

POSSAS, C. Estado, Movimentos Sociais e Reformas na América Latina: Uma Reflexão Sobre a Crise Contemporânea. in: Revista Crítica de Ciências Sociais, No. 35, junho 92, Coimbra, Portugal.

PREFEITURA do Município de São Paulo, Secretaria Municipal da Cultura, A Secretaria de Higiene e Saúde da Cidade de São Paulo, História e Memórias. Documento Comemorativo de Quadragésimo Aniversário, 1985.

PREFEITURA do Município de São Paulo, Secretaria Municipal da Saúde, Documento Número Um, fevereiro de 89 (mimeo).

PREFEITURA do Município de São Paulo, Secretaria Municipal de Planejamento - Seplan - documento inicial intitulado "Planejamento, descentralização e democratização da gestão municipal", a respeito da concepção e função dos Núcleos Regionais de Planejamento. Texto mimeografado.

PREFEITURA do Município de São Paulo, Balanço Geral, 1989 - 1992 Relatório Final de Governo.

PREFEITURA do Município de São Paulo, Secretaria Municipal da Saúde, Distritalização do Município de São Paulo, texto mimeografado, sem data. 
PREFEITURA do Município de São Paulo, Secretaria Municipal da Saúde, Centro de Epidemiologia Pesquisa e Informação (CEPI), 1992 (mimeo).

PREFEITURA do Município de São Paulo, Secretaria Municipal da Saúde, Distritalização do município de São Paulo - estratégia para implantação do SUS, mimeo.

PREFEITURA do Municipio de São Paulo, Secretaria Municipal da Saúde, Documento Municipalização - mimeo.

PREFEITURA do Município de São Paulo, Secretaria Municipal da Saúde, Centro de Recursos Humanos - CRH - dezembro de 1992.

PREFEITURA do Município de São Paulo - Secretaria das Administrações Regionais - SAR - Memorando Circular número 012 de 30/03/91.

PREFEITURA do Município de São Paulo - Experiências de Participação Popular - Programa Integrado de Educação e Participação Popular (PIEPP), março de 1992. Texto mimeo.

REIS, E.P. Política e Políticas Públicas na Transição Democrática. In: Moura, A. S. (org.) O Estado e as Políticas Públicas na Transição Democrática. Vértice, São Paulo, 1989.

RELATÓRIO Preliminar das Propostas Elaboradas pelo Grupo de Trabalho para o Enfrentamento das Condições Violentas de Vida no Município de São Paulo,Secretaria Municipal da Saúde. Texto mimeografado, São Paulo,1990.

RIVERA, F.J. U. Planejamento e Programação em Saúde: um enfoque estratégico. Cortez, São Paulo, 1989.

ROLNIK, S. Cartografia Sentimental. Transformações contemporâneas do desejo, Estação Liberdade, São Paulo, 1989, p.

SADER, E. Quando novos personagens entram em cena. Experiências e lutas dos trabalhadores da Grande São Paulo, 1970 - 1980, Ed. Paz e Terra, São Paulo, 1988. 
SOUSA SANTOS, B. O Estado, A Sociedade e as Políticas Sociais - o caso das politicas de saúde. In: Revista Crítica de Ciências Sociais, No. 23, setembro 87, Coimbra, Portugal.

SANTOS, M., SOUZA, M.A., SILVEIRA, M.L. (org.) Território - Globalização e Fragmentação. Hucitec - Anpur, São Paulo, 1996.

SCHRAIBER, L. B. \& MENDES-GONÇALVES, R. B. Saúde do Adulto, programas e ações na unidade básica, Hucitec, São Paulo, 1996.

SELLTIZ et al. Métodos de pesquisa nas relações sociais. EPU, São Paulo, 1965.

SIMIONI, A.M. Recursos Humanos em Saúde como Processo Social. Dissertação de Mestrado, Faculdade de Saúde Pública, USP, 1996.

SINGER, P. Um Governo de Esquerda para Todos, Ed. Brasiliense, São Paulo, 1996.

TASCA,R. KADT,E. Promovendo a Eqüidade-um novo enfoque com base no setor da saúde. Hucitec, São Paulo - Salvador, 1993.

TEIXEIRA,C.F. Planejamento e programação situacional em distritos sanitários: metodologia e organização. In: MENDES, E. V. Distrito Sanitário: o processo social de mudança das práticas sanitárias do Sistema Único de Saúde. Hucitec-Abrasco, São Paulo - Rio de Janeiro, 1994.

TEIXEIRA, C. F. MELO, C. (org.) Construindo Distritos Sanitários: a experiência da cooperação italiana no município de São Paulo. HucitecAbrasco, São Paulo-Rio de Janeiro, 1995.

TEIXEIRA, S. F. Representando la história de las políticas de salud en América Latina. In: Cuadernos Médico Sociales, No. 55, março 1991.

TESTA, M. Pensar em Saúde, Ed. Artes Médicas, Porto Alegre, 1992.

TESTA, M. Planificación de salud en América Latina; un replanteo. Boletín Salud Problema, n. 4, 1978. México, Universidad Autónoma Metropolitana, Xochimilco. 
TESTA, M. Pensamento Estratégico y Lógica de la Programación. Estratégia y Programación. Buenos Aires, Argentina, 1986.

TESTA, M. in: Rivera, F.J.U. Agir Estratégico e Planejamento Social (Uma Crítica ao Enfoque Estratégico). Editora Fiocruz, Rio de Janeiro, 1997.

THOMPSON, F. J. health policy and bureaucracy: politics and implementation, Sae MIT Press, 1984.

TRIVIÑOS, A.N.S. Introdução à pesquisa em ciências sociais: a pesquisa qualitativa em educação. Ática, São Paulo, 1987.

UNGLERT, C. V. S. Territorialização em sistemas de saúde. In: Distrito Sanitário: o processo social de mudança das práticas sanitárias do Sistema Único de Saúde. Hucitec-Abrasco, São Paulo-Rio de Janeiro, 1994.

UNGLERT, C.V.S Territorialização em Saúde: a conquista do espaço local enquanto prática do planejamento ascendente. Tese de Livre Docência, Faculdade de Saúde pública, USP, 1995.

VILLAROSA, F. N. et alli. Sistemas de informação em saúde para distritos sanitários. In: Distritos Sanitários:o processo social de mudança das práticas sanitárias do Sistema Único de Saúde. Hucitec-Abrasco, São Paulo-Rio de Janeiro, 1994. 


\section{APÊNDICE}

Completa a Pesquisa um conjunto de documentos: anexos I, II e III que compõem os roteiros utilizados nos trabalhos de campo, e as entrevistas na íntegra dos dirigentes, funcionários e cidadãos/usuários. Destes dois últimos segmentos, o resultado das entrevistas aparece organizado por categoria temática, sujeito por sujeito, segundo a metologia empregada para a identificação do discurso do sujeito coletivo, na seguinte seqüência: as expressões-chave, as idéias-centrais e a ancoragem. 


\section{ANEXO I}

\section{ROTEIRO DE ENTREVISTA PARA OS FUNCIONÁRIOS DA SMS}

1.Idade 20 a $25 \quad 26$ a $30 \quad 31$ a $35 \quad 36$ a $40 \quad 41$ a $45 \quad 46$ a $50 \quad 50$ e mais anos.

2.Assinale o sexo masculino feminino

3.Qual a sua formação profissional
a)enfermeiro
h)psicólogo
b)assistente social
i)fonoaudiólogo
c)dentista
j)nutricionista
d)médico
k)auxiliar de enfermagem
e)terapeuta ocupacional
l)ACD/THD
f) fisioterapeuta
m)administrativo
g)farmacêutico
n)educador
o) outro

4.Há quanto tempo trabalha na SMS anos

\section{Leia Atentamente e Fale Livremente Sobre o Texto Abaixo :}

Cada Administração Municipal que vem procura imprimir sua visão de organização de serviços de saúde. Assim, algumas privilegiam a assistência médica, outras enfatizam o trabalho multiprofissional. Algumas administrações valorizam seu pessoal e estimulam o trabalho intersetorial, outras, têm posturas radicalmente opostas. Fale como você vê (ou viu ) o trabalho na SMS enquanto um (a) funcionário (a) com respeito a:

- democratização do processo de trabalho

- tomada de decisões;

- mudança do modelo de atenção à saúde;

- aperfeiçoamento dos procedimentos gerenciais e administrativos;

- trabalho integrado com outros setores sociais; 
- valorização do pessoal.

Fale o que você pensa ( ou sente) sobre cada um dos pontos citados.

6. Ao se falar em mudanças, pensa-se em sair de uma situação em direção à outra. Se você sentiu mudanças em algum governo municipal, fale sobre elas. Fale sobre suas reações, seus sentimentos frente as mudanças que aconteceram na Secretaria da Saúde.

7. Discorrer sobre :

a) noção de novo ou moderno a partir da administração municipal de 1989. 
b) práticas de saúde.

d) consciência sanitária.

e) desenvolvimento profissional.

f) cidadania ( direito à saúde).

g) participação e/ou controle social

8. Você já desenvolveu trabalhos de saúde fora de sua Unidade de Saúde, junto a movimentos sociais, entidades, associações, etc., etc..

a)não sim quando

9. Você trabalha ou já trabalhou integradamente com outras secretarias? Em que local?
a)กão
$\operatorname{sim}$
quando
explique 
Se você respondeu sim às 2 questões anteriores, responda a questão 10 .

10. Na sua opinião, qual foi o resultado deste trabalho de integração?

11. Enquanto funcionário da SMS você participa ou já participou de quais cursos ou atividades abaixo relacionadas:

a)curso de saúde pública quando onde

b) oficinas de planejamento local em saúde(também conhecidas com o nome de oficinas italianas - "Territorialização em Saúde, Sistemas de Informação,

Planejamento Local em Saúde" ) quando onde

c)revisão do modelo de atenção à saúde(projeto para instauração de uma nova forma de desenvolver as práticas sanitárias) quando? onde?

como foi feito o trabalho de revisão? O que foi revisto?

d)curso de $A C D / T H D$ quando onde

e)curso de Auxiliares de Enfermagem quando onde

f)supervisão em saúde mental quando onde

g)curso supletivo quando onde

h)outro qual quando onde

12. Desde que você trabalha, alguma vez percebeu movimentação da Secretaria, no sentido da descentralização administrativa?
a)não
b) $\operatorname{sim}$
c)quando
d) explique 
13. Você já ouviu falar de Hospital Aberto ( sim, não ), Política Antimanicomial ( sim, não ), Hospitais-Dia ( sim, não ), Centros de Referência de Saúde do Trabalhador ( sim, não ), Centros de Convivência e Cooperativa ( sim, não ) ? Disserte sobre cada um dos pontos relacionados.

14.Descrever porque os serviços melhoraram ou pioraram M.:

P.:

15.Escores a serem atribuídos ao funcionário, segundo participação ou não em cursos oficinas e/ou outros abaixo relacionados (número de pontos). 

a)curso de saúde pública-5 pontos- ( )
b)participação em oficinas de planejamento local-6 pontos-( )
c)projetos de revisão do modelo de atenção à saúde-4 Pontos-( )
d)acd/thd -2 pontos-( )
e)curso de auxiliar de enfermagem-2 pontos-( )
f)curso supletivo-2 pontos-( )
g)supervisão em saúde mental-3 pontos-( )
h)outro -1 ponto-( )
ESCORE FINAL.
Nome do entrevistador.
Data 


\section{ANEXO II \\ ROTEIRO DE ENTREVISTA AOS CIDADÃOS/USUÁRIOS}

1. Há quantos anos o Sr. (Sra.) usa os serviços de saúde da Prefeitura?

2.Pelo que o Sr.(Sra.) tem ouvido falar, ou pelo que sabe, houve mudanças na qualidade dos serviços de saúde da Prefeitura?

a) houve mudanças para melhor

b) houve mudanças para pior
c) não houve mudanças
d) não sei informar

e) explique

3. Está havendo empenho ou preocupação da Prefeitura em melhorar os serviços de saúde do município?

a) está havendo muito empenho

b) está havendo pouco empenho

c) não está havendo empenho

d) não sei

e) explicar porque está havendo ou não empenho

4.Voce se lembra da Prefeitura ter criado condições para que os usuários e/ou cidadãos e/ou funcionários e/ou entidades representativas pudessem participar dos processos decisórios e do planejamento da Secretaria da Saúde? ( Dar exemplos das Comissões Gestoras, Conselhos de Saúde ou Conselho Municipal de Saúde na época da administração Luiza Erundina ).
a) não me lembro
$\begin{array}{ll}\text { b) sim, me lembro } & \text { c) quando }\end{array}$ 
d) explique

5. Leia atentamente e comente o texto abaixo:

"Alguns prefeitos e seus auxiliares, procuraram integrar os trabalhos de algumas Secretarias como Saúde, Educação (escolas) e Bem-Estar-Social (creches). Nestas ocasiões, o pessoal da Secretaria da Saúde pensava que os principais problemas de saúde eram decorrentes das condições de vida das pessoas e por isso, procurou dar mais atenção aos mais necessitados. Ao mesmo tempo, a Secretaria da Saúde estimulou a participação dos funcionários e da população nas tomadas de decisão. Valonizou o seu pessoal, pagando melhores salários. Melhorou a qualidade da assistência, enfatizando a medicina preventiva."

Fale se alguma vez você percebeu esse tipo de conduta da Prefeitura e da Secretaria Municipal da Saúde. E em qual governo esse modo de governar aconteceu mais

6. Fale sobre participação popular na Secretaria da Saúde. ( Se a pessoa falar em democracia, pergunte o que ela representa ).Procure caracterizar o período, isto é, em qual governo que mais ocorreu a participação. 
7. Fale sobre direito à saúde. Isto Ihe diz respeito? ( Se a pessoa falar em cidadania, peça para ela falar sobre o que pensa sobre isso).

8. Você já ouviu falar de Hospital Aberto (sim, não), Política Antimanicomial, quer dizer, desospitalização dos doentes mentais, (sim, não), Hospitais-Dia (sim, não), Centros de Convivência e Cooperativa (sim, não) ? Comentar cada um dos temas. H.A.

P.A.

H.D.

CecCo.

9. Descrever porque os serviços de saúde melhoraram ou pioraram.

M.:

P.:

10.Dados classificatórios do respondente

a) sexo: masculino feminino

b) idade: 15 a $20 \quad 20$ a $25 \quad 25$ a $30 \quad 30$ a $35 \quad 35$ a $40 \quad 40$ a $45 \quad 45$ a 50

50 a $55 \quad 55$ a $60 \quad 60$ e mais 
c) instrução ( até que ano da escola freqüentou? ).

-sem instrução/primário incompleto

-primário completo

-ginasial completo

ginasial incompleto

-colegial completo

-colegial incompleto

-superior completo

-superior incompleto

d) nome do serviço de

saúde.

e) bairro

f) nome da entidade que representa

tempo de existência da entidade.

g) nome do respondente

h) endereço da residência (Bairro)

11. Nome do entrevistador

Data da entrevista 
ANEXO III

ROTEIRO DE ENTREVISTA AOS DIRIGENTES DA SMS DE SÃO PAULO DURANTE O PERIOODO ENTRE 1989 E 1992.

1.Quais as razões ou os porquês da escolha das diretrizes básicas, que orientaram o processo de reforma administrativa da Secretaria Municipal da Saúde a partir de $1989 ?$

2. Como foi a aplicação dessas diretrizes ou pressupostos teóricos, sobre a realidade encontrada pela Secretaria durante aquela administração?

3. Houve durante o processo de mudanças da SMS no periodo de 89 a 92 , uma clara definição das competências e responsabilidades para cada um dos diferentes niveis e Unidades de Saúde ? Explique.

4. Quais foram os principais problemas encontrados pela administração e o que foi feito para enfrentá-los?

5. Como você vê o modelo de planejamento adotado pela administração da SMS durante aqueles quatro anos?

6. E o trabalho integrado? Você acha que a Secretaria contribuiu para a integração entre as diferentes Secretarias Municipais? Ou, foram tomadas medidas no sentido de se superar as limitações da atuação setorial, diante da necessidade de se trabalhar com problemas que abrangem outros diferentes setores?

7. Como você viu o lugar reservado ao sujeito, ao cidadão, ao funcionário comum, na construção do projeto de transformação das práticas de saúde?

8. Você teria alguma coisa a falar sobre a promoção da eqüidade pela SMS?

9. Na sua avaliação, qual foi o produto, o resultado do trabalho da Secretaria, findo aqueles quatro anos?

IDENTIFICAÇÃO DO RESPONDENTE

Nome

Função que exerceu 


\section{O TRABALHO DE CAMPO}

\section{AS ENTREVISTAS}

Tabela 1. Resumo das entrevistas junto aos funcionários públicos, por categoria profissional entre os que aderiram e os que não aderiram ao PAS:

\begin{tabular}{|c|c|c|c|c|c|c|c|c|c|c|c|}
\hline & $\begin{array}{c}\text { médi } \\
\text { cos }\end{array}$ & $\begin{array}{c}\text { edu } \\
\text { cador }\end{array}$ & $\begin{array}{c}\text { enfer } \\
\text { meiro }\end{array}$ & $\begin{array}{c}\text { psi } \\
\text { cólog }\end{array}$ & $\begin{array}{c}\text { serv. } \\
\text { social }\end{array}$ & $\begin{array}{c}\text { nutri } \\
\text { cion. }\end{array}$ & $\begin{array}{c}\text { t. ocu } \\
\text { pacio. }\end{array}$ & $\begin{array}{c}\text { Aux. } \\
\text { enfer. }\end{array}$ & $\begin{array}{c}\text { Aten } \\
\text { dente }\end{array}$ & $\begin{array}{c}\text { admi } \\
\text { nistra }\end{array}$ & total \\
\hline não & 3 & ---- & 2 & 2 & 2 & 2 & 1 & 3 & 1 & 4 & 20 \\
\hline sim & 4 & 1 & 2 & 1 & 1 & --- & --- & --- & -- & --- & 09 \\
\hline total & 7 & 1 & 4 & 3 & 3 & 2 & 1 & 3 & 1 & 4 & 29 \\
\hline
\end{tabular}

legenda - não: não aderiram ao PAS; sim: aderiram ao PAS

\section{FUNCIONÁRIOS PÚBLICOS QUE NÃO ADERIRAM AO PAS}

\subsection{Categoria Temática: Mudança de Modelo de Atenção.}

a) nutricionista, 6 anos de funcionalismo

expressões-chave:

A funcionária considera que a partir de 1989 surgiu uma nova forma de gerenciamento, comprometido em definir a área de atuação da Unidade e, em identificar as áreas de risco. "Na administração passada o trabalho não era só dentro do Posto, mas nas áreas de risco. Havia um trabalho extensivo com a comunidade, com atividades preventivas sobre DST/AIDS e gravidez na adolescência. Hoje os trabalhos estão totalmente diferentes. O PAS foi uma mudança radical, brusca. deixando os funcionários revoltados. Desabou uma estrutura que funcionava. É incompetência administrativa".

\section{idéia central -}

A idéia central da funcionária é que a partir de 89 , surge uma nova forma de gerenciamento, com identificação da área de atuação da Unidade e das áreas de risco.

ancoragem -

O que sustenta o discurso da funcionária é a concepção de que, a partir de 1989, surgiu uma nova forma de gerenciamento, comprometido em definir a área de atuação da Unidade e em identificar as àreas de risco.

\section{b) enfermeira, 13 anos de funcionalismo}

\section{expressões-chave}

A funcionária julga que durante a administração anterior havia trabalhos educativos e preventivos nas escolas. $\mathrm{Na}$ Unidade, fazia-se a avaliação do crescimento e do 
desenvolvimento das crianças por meio de gráficos. Depois de fornecido o leite, por exemplo, discutia-se com as mães a situação das crianças e a importância de outros alimentos para 0 seu crescimento. "A administração atual cortou tudo pela raiz, como se fosse um arrastão na saúde, sem a preocupação com nada, como se nada tivesse existido. Muitos colegas foram mandados para outras Secretarias. Estão em escolas, creches, parques, em desvio de função".

\section{idéia central}

A idéia central do discurso da funcionária é a de que, entre 1989-92, trabalhos educativos e preventivos foram realizados junto à população e às escolas.

\section{ancoragem}

A funcionária acredita que durante a administração anterior havia trabalhos educativos e preventivos nas escolas. A Unidade, priorizava a avaliação do crescimento e do desenvolvimento das crianças por meio de gráficos.

c) administrativo, 6 anos de funcionalismo expressões-chave

O funcionário considera que na administração Luiza Erundina havia mais profissionais trabalhando. Os representantes da população participavam das decisões sobre como 0 trabalho deveria ser, durante as reuniões do Conselho de Saúde. "Tinha reuniões de grupo, trabalhos preventivos e educativos com a população. Começou o Curso Larga-Escala, para a formação de auxiliar de enfermagem. Para melhorar o atendimento. Agora tudo mudou, tem menos gente trabalhando. Separação das pessoas e deslocamento do lugar de trabalho. Estamos jogados e sem saber o que vai acontecer".

idéia central

A idéia central da entrevista é a de que, no governo Erundina havia participação social e desenvolvimento de pessoal.

\section{ancoragem}

O funcionário acredita que representantes da população participavam das decisões sobre como o trabalho deveria ser, durante as reuniões do Conselho de Saúde, e também através de reuniões de grupo, trabalhos preventivos e educativos com a população.

\section{d) auxiliar de enfermagem, 5 anos de funcionalismo}

\section{expressões-chave}

"A administração anterior pecou por dar muita liberdade ao pessoal. Foi melhor em relação aos cuidados e qualidade da assistência aos pacientes. Principalmente aos mais carentes e aos portadores de doenças como a AIDS, que precisam de cuidados especiais. O que eu 
aprendi eu mantenho. A administração atual foi restritiva demais. Reduziu os salários e provocou a demissão de pessoal".

\section{idéia-central}

O funcionário acredita que na administração anterior havia mais cuidado com o paciente.

\section{ancoragem}

"A administração anterior pecou por dar muita liberdade ao pessoal. Foi melhor em relação aos cuidados e qualidade da assistência aos pacientes".

\section{e) médico, 6 anos de funcionalismo}

expressões-chave: decepção em não poder continuar como era antes. Sensação de perda e frustração. Quem sou eu? O que fazer? Como? A gente vê as coisas acontecendo e não tem condições de interferir. Como deixamos as coisas acontecerem assim? Com o tempo os serviços foram se desorganizando. Eu tenho uma sensação estranha porque em muitos lugares continuaram as mesmas pessoas que antes, só que desestimuladas, que acham que não vale mais a pena. É uma sensação de perda, de derrota. Antes eu achava que o trabalho era como deveria ser, como aprendi na faculdade. Havia préconsulta, consulta, pós-consulta e visita domiciliária. Havia compromisso e a gente achava que resolvia a maioria dos problemas.

idéia-central: realização com trabalho na administração anterior. Sensação de perda e frustração depois.

ancoragem: Com o tempo os serviços foram se desorganizando. Eu tenho uma sensação estranha porque em muitos lugares continuaram as mesmas pessoas que antes, só que desestimuladas, que acham que não vale mais a pena. É uma sensação de perda, de derrota. (ações programáticas em saúde e atendimento integral).

\section{f) administrativo, 8 anos de funcionalismo}

expressões-chave: "a administração anterior foi super humana. Olhou mais para o social. Teve aberturas para 0 trabalho multiprofissional. Os treinamentos de pessoal se intensificaram. Existia trabalhos de prevenção em relação à AIDS e outras doenças sexualmente transmissiveis. Criou-se o Hospital-Dia para Saúde mental. As escolas de primeiro grau forneciam refeição completa para os alunos. Na administração atual o PAS escolhe quem atender, não atende os aidéticos e encaminha os casos complexos para fora da rede municipal. Nas escolas só dão leite".

idéia-central: a administração anterior olhou mais para o social. Promoveu a integração multiprofissional e treinamento de pessoal.

ancoragem: Olhou mais para o social. Teve aberturas para o trabalho multiprofissional. Os treinamentos de pessoal se intensificaram. 
(saúde e condições de vida, educação continuada e trabalho multiprofissional).

\section{g) atendente de enfermagem, 25 anos de Prefeitura}

expressões-chave: o funcionário entende que há muita burocracia e pouca atenção às pessoas que procuram os serviços. "Quando se precisa de médico, joga-se para cá e para lá. Tudo é muito complicado. Deveria ser mais simples e rápido. No tempo da Erundina tinha mais medicação. Com o PAS piorou. Comparativamente com a gestão anterior, refere que agora há menos gente para atender, sua explicação para a existência de mais conflito com a população.

idéia-central: há muita burocracia e pouca assistência direta às pessoas.

ancoragem: excesso de burocracia no serviço público em detrimento da qualidade da atenção.

\section{h) administrativo, 8 anos de funcionalismo}

expressões-chave: "a partir de 89 a idéia que eles passaram para a população de baixa renda era muito boa, mas muitas idéias que eles passaram não conseguiram sair do papel. Eles não conseguiram colocá-las em prática. Tinha mais visitas domiciliárias, tinha mais remédios nas Unidades. A vigilância epidemiológica funcionava bem. Depois veio o PAS. Os funcionários tiveram que mudar a vida completamente, indo de um lugar para outro. Foi a pior mudança nos últimos 60 anos para o pessoal da saúde".

idéia-central: muitas boas idéias depois de 89 não conseguiram sair do papel.

ancoragem: a partir de 89 a idéia que eles passaram para a população de baixa renda era muito boa, mas muitas idéias que eles passaram não conseguiram sair do papel. Eles não conseguiram colocá-las em prática. ( Só boas idéias não basta, é preciso colocá-las em prática).

\section{i) auxiliar de enfermagem, 15 anos de funcionalismo}

expressões-chave: "o que vi de novo no governo do PT foi o treinamento e reciclagens dos funcionários. Tinha muito. Nessa época, as condições de trabalho eram melhores. Com o PAS estão acabando com a saúde. É uma mudança radical. Não existe mais prevenção. Eu não consigo entender porque tem gente fazendo pouco e ganhando muito e gente fazendo muito e ganhando pouco".

idéia-central: muitos treinamentos e reciclagens de funcionários durante o governo do PT. ancoragem: o que vi de novo no governo do PT foi o treinamento e reciclagens dos funcionários. Tinha muito.

j) psicólogo, 10 anos de funcionalismo 
expressões-chave: o discurso do funcionário revela que no governo do PT houve a preocupação de se praticar ações preventivas e educativas nas escolas e nas creches. "Havia mais contatos com Educação, Bem-Estar e Cultura. Todos os serviços passaram a atender os doentes mentais". Percebeu com clareza que a política da Secretaria era com a desospitalização dos doentes mentais.

idéia-central: no governo do PT valorizaram-se ações preventivas e integração com outros setores sociais.

ancoragem: no governo do PT houve a preocupação de se fazer ações preventivas e educativas nas escolas e nas creches. (Trabalho integrado e aplicação de medidas preventivas).

\section{k) médico, 5 anos de funcionalismo}

expressões-chave: "esse processo de mudança de modelo de atenção já vem acontecendo há muito tempo. Mas muitos programas que existiam, muitas coisas foram ficando para trás, foram esquecidas. Desde a década de 70 há um discurso de prevenção na saúde, que vem se mantendo independentemente dos governos. Com o sistema de coleta de dados sobre mortalidade, implantado pelo governo anterior no serviço funerário da cidade de São Paulo (PROAIM), sabe-se do que se morre hoje em São Paulo e assim pode-se melhorar a prevenção". O funcionário também se refere às propostas de participação popular e diz, "com o PAS a implementação dessas propostas tornou-se inviável".

idéia-central: inovações no sistema de informação e aplicação de medidas de caráter preventivo.

ancoragem: Com o sistema de coleta de dados sobre mortalidade, implantado pelo governo anterior no serviço funerário da cidade de São Paulo (PROAIM), sabe-se do que se morre hoje em São Paulo e assim pode-se melhorar a prevenção. (A informação e a planificação em saúde).

\section{1) médico, 12 anos de funcionalismo}

expressões-chave: "no governo da Erundina houve grande avanço. A proposta de saúde pública tinha uma direção". Com a leitura de seu discurso observam-se referências às ações coletivas, sobre as necessidades das pessoas carentes, sem deixar de aplicar a assistência ou de usar os recursos tecnológicos. "A mudança do modelo de atenção para o PAS foi prejudicial à população. $O$ enfoque administrativo é bom. Administra-se melhor o pessoal. Mas a assistência à saúde está tenebrosa, não se leva em conta as necessidades dos usuários. O Maluf foi destruindo lenta e gradualmente o sistema do PT, até implantar o PAS, cujo objetivo é destruir o sistema público e repassar recursos para o setor privado. $O$ modelo PAS é imediatista, é assistencialista puro, não se pratica a medicina preventiva". 
idéia-central: no governo Erundina grande avanço na saúde pública com aplicação de medidas preventivas.

ancoragem: Desenvolviam-se ações coletivas, sobre as necessidades das pessoas carentes, sem deixar de aplicar a assistência ou de usar os recursos tecnológicos. (Critérios epidemiológicos e ações coletivas).

\section{m) terapeuta ocupacional, 6 anos de funcionalismo}

expressões-chave: "durante a administração anterior havia respeito pela pessoa, qualquer que fosse ela, independente do sexo, cor. A Secretaria trabalhou pela melhoria dos serviços e para que todos pudessem ser atendidos. Eles criaram condições para os Postos atenderem os doentes mentais, criaram os Centros de Convivência e Cooperativa e os Hospitais-Dia". idéia-central: respeito pela pessoa na administração anterior. ancoragem: durante a administração anterior havia respeito pela pessoa, qualquer que fosse ela, independente do sexo, cor. (A saúde enquanto direito do cidadão).

\section{n) assistente social, 7 anos de funcionalismo}

expressões-chave: "antes havia mais participação, mais entusiasmo dos funcionários em participar das discussões. Foram criadas as regiões e Distritos de Saúde e o pessoal sempre se reunia em equipe para discutir os programas de saúde. Teve a luta pela desospitalização dos doentes mentais e a história do Hospital-Aberto para melhorar a internação. Hoje quase não se fala mais nisso".

idéia-central: estímulo à participação para mudar o modelo de atenção.

ancoragem: antes havia mais participação, mais estímulo aos funcionários para participar das discussões. (Planejamento ascendente).

\section{o) nutricionista, 7 anos de funcionalismo}

expressões-chave: "antes a gente era chamado sempre para reuniões, com a chefia, com os outros colegas. O Conselho de Saúde existia. Tinha mais ações educativas e preventivas, também fora da Unidade. Com a nova administração o mais importante é curar os doentes". idéia-central: medidas educativas e preventivas na administração anterior. ancoragem: Tinha mais ações educativas e preventivas, também fora da Unidade. (Promoção das condições de saúde).

\section{p) auxiliar de enfermagem, 6 anos de funcionalismo}

expressões-chave: sua experiência profissional na SMS foi em Pronto Socorro. Ao se referir a modelo de atenção à saúde, imediatamente pensa nos médicos: "havia uma época em que os médicos faziam rodizio e isso complicava os pacientes. Eles tinham um esquema, um 
atendia numa hora e outro em outra hora. Era um arranjo deles mesmo". Com a implantação do PAS manifesta arrependimento de ter vindo trabalhar na Prefeitura: "estou arrependida de ter saído do Estado e de um hospital particular para vir trabalhar na Prefeitura. Eu achava que renderia mais se tivesse um único emprego e ganhasse bem. Nessa época muita gente veio para a Prefeitura. Agora estou arrependida porque o Maluf entrou e acabou com tudo. Eu achava que o PAS não ia lá no PS. E nós saímos como indigentes. Eu me senti muito mal mesmo".

Idéia-central: com o plano PAS muda-se o modelo de atenção na SMS e isso frustra suas expectativas de trabalho.

ancoragem: durante a administração Erundina tornou-se atrativo trabalhar na SMS. Muita gente foi para lá. Os funcionários eram valorizados, ganhavam melhor. As propostas do PAS não interessaram, talvez em função de ter que deixar de ser funcionária pública.

\section{q) psicólogo, 5 anos de funcionalismo}

expressões-chave: a funcionária diz que a administração atual está provocando retrocessos na saúde: "antes havia mais organização no atendimento. A saúde mental foi a área mais desmantelada. A visão da saúde mental era mais moderna e arrojada no governo PT. Nesse governo há retrocesso, esta é uma forma de desmanchar o sistema de saúde".

Idéia-central: a administração atual está desmantelando o sistema de saúde.

Ancoragem: houve um grande investimento na organização dos serviços do atendimento da saúde mental na rede de unidades de saúde. Praticamente todos os equipamentos passaram a contar com equipes para a atenção à saúde mental.

\section{r) enfermeiro, 6 anos de funcionalismo}

expressões-chave: o funcionário remete seu discurso ao plano PAS: "tive uma ansiedade muito grande por não aderir ao PAS e ser deslocada para outro lugar. Aqui no Hospital-Dia o atendimento é bom. Com o PAS aumentou a reclamação do pessoal com o atendimento. Nesta administração os materiais foram sucateados".

Idéia-central: com o PAS aumentou a reclamação dos usuários com o atendimento.

Ancoragem: para a funcionária a atual administração não tem interesse em organizar a saúde. Há um processo de desestruturação que culminou com a implantação do PAS.

\section{s) assistente social, 21 anos de funcionalismo}

expressões-chave: a funcionária sempre trabalhou em hospital em todos os seus anos de funcionalismo; percebeu preocupações da administração anterior (do PT) para organizar os serviços de saúde; recentemente foi transferida para uma unidade ambulatorial: "na administração anterior procurava-se conhecer a situação de saúde da população e dos 
serviços para melhor orientar e encaminhar os pacientes, e para reorganizar o trabalho. Aqui no Posto há mais tempo para se cuidar do paciente do que no hospital. Agora, com o PAS eu senti ódio, descaso com a gente. Fica-se numa situação difícil porque não se sabe o que vai acontecer amanhã".

Idéia-central: na administração anterior procurava-se conhecer a situação de saúde da população e dos serviços para melhor orientação.

ancoragem: é possível que a funcionária esteja pensando nos processos de desenvolvimento de pessoal produzidos durante a administração Erundina, quando nos níveis regionais e distritais realizaram-se análises das condições de saúde das populações. Os propósitos que norteavam essas atividades eram os das mudanças nas ações de saúde.

\section{t) servente, 12 anos de funcionalismo}

expressões-chave: "agora eu não vejo mais pessoas amontoadas nas macas no corredor do hospital. Antes era mais fácil de internar. Eu sempre trabalhei no laboratório do hospital. Não sei se teve muitas mudanças com o PAS".

idéia-central: agora eu não vejo mais pessoas amontoadas nas macas no corredor do hospital.

ancoragem: o funcionário passa a idéia de ter percebido mudanças com a introdução do PAS, embora afirme o contrário. É suficientemente claro ao afirmar que não vê mais macas amontoadas pelos corredores dos hospitais e, imediatamente completa, dizendo que agora é mais dificil de se conseguir internação hospitalar, o que nos leva a pensar que o plano PAS mudou os critérios para as internações hospitalares.

\subsection{Categoria Temática: Democratização, Descentralização, Participação}

\section{a) auxiliar de enfermagem, 15 anos de funcionalismo}

expressões-chaves: "não acontecia reunião sem a participação de líderes comunitários. Havia participação popular nas decisões. Um grupo da comunidade estava bem integrado no Posto na época da Erundina. Ela tinha uma preocupação social. Não percebi descentralização administrativa. Tinha mais preocupação da chefia com funcionários e lideranças da comunidade na administração anterior".

idéia-central: havia participação popular na época da Erundina. Ela tinha uma preocupação social.

ancoragem: um grupo da comunidade estava bem integrado no posto na época da Erundina.

b) psicólogo, 10 anos de funcionalismo 
expressões-chaves: "no governo do PT nos chamavam para tomar decisões". O funcionário discorre sobre a maior preocupação com participação popular mas, diz que não havia muita organização nas reuniões. "Eles tentaram imprimir sua visão de trabalho. Havia muitos trabalhos educativos sobre como se cuidar, como se prevenir das doenças". Percebeu que a saúde foi trabalhada enquanto um como um direito. "Eles criaram as administrações regionais e os Distritos de Saúde".

idéia-central: havia maior preocupação com participação popular mas, não havia muita organização nas reuniões.

ancoragem: havia maior preocupação com participação popular mas, não havia muita organização nas reuniões.

\section{c) médico, 5 anos de funcionalismo}

expressões-chaves: "na administração houve a preocupação de se discutir mais. Os funcionários participavam das reuniões do Conselho Técnico Administrativo. Na atual administração os CTA's foram aos poucos sendo substituídos por decisões autoritárias. Existiam várias instâncias de decisão com participação da comunidade como as Comissões Gestoras. As pessoas eram incentivadas à participar, a exercer a cidadania. Eu nunca participei da chefia da Unidade, por isso fica difícil para mim saber se a participação era mesmo para valer". O funcionário percebeu as mudanças provocadas pela reforma administrativa com a criação das administrações regionais e Distritos de Saúde.

idéia-central: na administração anterior havia as Comissões Gestoras. Era uma diretriz da Secretaria.

ancoragem: na administração anterior existiam várias instâncias de decisão com participação da comunidade como as Comissões Gestoras.

\section{d) médico, 12 anos de funcionalismo}

expressões-chaves: "o texto do sistema único de saúde diz que todos têm acesso à saúde. Cada administração tem sua visão: a da Erundina era mais aberta, as decisões mais compartilhadas. O PAS não teve a menor participação. O PAS é inconstitucional à medida que restringe $O$ acesso. Eles estão subvertendo a consciência popular. A população tem capacidade mas não a usa. Na gestão anterior teve a descentralização administrativa com a criação das regiões e dos Distritos de Saúde. Aí você reinava mas não administrava. O modelo anterior era mais rigoroso com o dinheiro público mas não se administrava os funcionários. Com o PAS você tem mais condições de administrar os serviços e os funcionários".

idéia-central: na administração da Erundina as decisões eram mais abertas, mais compartilhadas. 
ancoragem: cada administração tem sua visão: a da Erundina era mais aberta, as decisões mais compartilhadas.

e) enfermeiro, 13 anos de funcionalismo

expressões-chave: o funcionário diz que na gestão anterior as decisões eram democráticas, tomadas junto com a equipe multiprofissional e com representantes da população. "Decisão como um todo. O chefe da Unidade participava junto com você, delegando atribuições a cada integrante da equipe, segundo as necessidades. Havia um trabalho de base, feito de baixo para cima, que identificava as necessidades locais de saúde, com participação da população. O trabalho era multidisciplinar. Havia abertura e liberdade de criatividade no trabalho, para se buscar várias alternativas de respostas para os problemas de saúde. Hoje não há condições para se trabalhar, não se está fazendo absolutamente nada. Hoje eu estou aqui e amanhã nem sei onde vou estar. $O$ pessoal está muito confuso e intranqüilo. Nem a vaga que você escolheu por concurso público você tem mais direito. Temos direitos? Cidadania? Nem se pode reclamar. Se estiver insatisfeito, o negócio é sair da Prefeitura. Fui jogado de um lugar para outro". Na entrevista o funcionário se refere a questão do poder ao mencionar que na administração anterior o poder estava descentralizado, nos Distritos

idéia-central: havia abertura e liberdade de criatividade no trabalho, para se buscar várias alternativas de respostas para os problemas de saúde.

ancoragem: idem.

\section{f) terapeuta ocupacional, 6 anos de funcionalismo}

expressōes-chaves: "no governo Erundina o poder foi descentralizado para mais perto dos funcionários e da população. Depois de 92 a participação foi diminuindo, o Conselho Gestor se manteve como aparência até a mudança total com o PAS. A população nunca mais foi ouvida. O direito à saúde está menos respeitado nesta administração".

idéia-central: poder mais perto da população na gestão Erundina.

ancoragem: no governo Erundina o poder foi descentralizado para mais perto dos funcionários e da população. (Descentralização administrativa e participação).

\section{g) assistente social, 7 anos de funcionalismo}

expressões-chaves: "na gestão da Luiza Erundina havia incentivos à participação, considerada importante por ela. Nesta administração o poder está cada vez mais longe dos funcionários. As decisões são tomadas e jogadas para os funcionários. É impossível tentar alguma coisa. Os funcionários tentam realizar seu trabalho nas condições que existem".

idéia-central: na gestão Luiza Erundina havia incentivos à participação.

ancoragem: idem. (Participação social). 


\section{h) nutricionista, 7 anos de funcionalismo}

expressões-chaves: "nesse período tinha o conselho gestor. Existiam condições de participação. Mexia muito com a ansiedade da população. A gerência da Unidade tinha mais poder. A gente podia confiar na palavra dele. Depois de 92 não há mais participação, a população não é consultada. As decisões agora estão no Diário Oficial".

idéia-central: entre 1989-92 existiam condições de participação.

ancoragem: idem. (A participação fortalece o nível local).

\section{i) administrativo, 6 anos de funcionalismo}

expressões-chave: "antes tinha mais liberdade. As decisões antes eram em grupo, mais abertas. As decisões de hoje são mais fechadas. Acho que a participação tem seu lado bom. É bom saber o que o povo está achando. Na época da Erundina só não concordava com aquilo que acontecia na minha Unidade. O Conselho Gestor queria ver o livro de ponto dos funcionários, para controlar o horário do pessoal. Isso é errado. Cidadania é o direito do cidadão à saúde, educação, lazer, transporte, não sei o que. Sei que nós temos muitos problemas de saúde e precisamos permanecer unidos e com esperança. Depois de 89 a Secretaria foi dividida em regiões e depois vieram os Distritos de Saúde, que cuidavam de 7 ou 8 Unidades e assim, era mais fácil de administrar do que 50 Unidades de uma só vez". idéia-central: acho que a participação tem o seu lado bom. ancoragem: idem. (Participação enquanto fiscalização).

\section{j) auxiliar de enfermagem, 5 anos de funcionalismo}

expressões-chaves: o funcionário reflete que durante a administração Luiza Erundina havia mais união entre o corpo do pessoal. Participava-se de trabalhos em equipe com psicólogos, assistentes sociais e enfermeiros. "As visitas domiciliárias me conscientizaram. Vi que muitos usuários não têm cuidado com a saúde porque suas condições de higiene são precaríssimas. Hoje há pouca participação. Não há entrosamento entre os funcionários. A população está alheia à situação".

idéia-central: entrosamento e trabalho em equipe.

ancoragem: trabalhava-se em equipe com psicólogos, assistentes sociais e enfermeiros. (Equipe multiprofissional)

\section{k) médico, 6 anos de funcionalismo}

expressões-chave: "antes havia mais gente participando, era coisa de um grupo maior, de mais niveis. O processo era mais democrático, tanto na organização como na condução. Na minha idéia tem que haver participação. Esse espaço é extremamente importante. É a 
população que se atende e nada mais justo que ela participe. Agora é assim, eu decido, você faz. Hoje as coisas já vêm prontas, de cima, decididas. Falar como não falar agora, é a mesma coisa. Eu imagino que consciência sanitária é ter informações a respeito de saúde, não só sobre doenças mas também sobre outras coisas, como meio ambiente, etc.. Ter noção de tudo isso é importante e na medida que comecei a trabalhar no serviço público, comecei a ganhar mais noção disso. Uma grande parte dos funcionários tem esse tipo de consciência. Eu me surpreendi com a qualidade do pessoal da Secretaria. Cidadania é você ser uma pessoa, ter um espaço, condição de vida, de poder dizer aquilo que pensa, de fazer parte de um grupo, de poder lutar pelos seus direitos. A minha idéia é que antes havia divisão de poder e diferentes níveis de decisão".

idéia-central: a democratização como estímulo à cidadania.

ancoragem: cidadania é você ser uma pessoa, ter um espaço, condição de vida, de poder dizer aquilo que pensa, de fazer parte de um grupo, de poder lutar pelos seus direitos. (Democratização e estímulo à cidadania).

\section{I) nutricionista, 6 anos de funcionalismo}

expressões-chave: "na administração anterior a chefia do Posto foi escolhida pelos funcionários. As decisões eram democráticas. Tanto o trabalho do médico como o dos demais profissionais eram valorizados. O funcionário era respeitado e importante. Hoje há imposição e autoritarismo, sem programação de saúde e sem conteúdo, sem uma linha a seguir. 0 trabalho está centralizado no médico, considerado o mais importante. Hoje não há participação. $O$ trabalho multiprofissional está esquecido. Os funcionários estão tentando fazer algum trabalho em equipe. O meu interesse é esse. Cidadania é o direito de se exprimir, de lutar por alguma coisa".

idéia-central: democratização e respeito pelos funcionários durante a gestão anterior.

ancoragem: as decisões eram democráticas; tanto o trabalho médico como o dos demais profissionais eram valorizados. (Democratização e trabalho em equipe multiprofissional).

\section{m) administrativo, 8 anos de funcionalismo}

expressões-chave: "eu não sei falar sobre participação e democratização. Não conheço os critérios que a administração usa para tomar decisões". O funcionário entende que não houve mudanças administrativas e nem na forma de gerenciar os serviços, com a troca de governo. idéia-central: eu não sei falar sobre participação e democratização.

ancoragem: idem. (Não quer se comprometer).

n) atendente de enfermagem, 25 anos de funcionalismo 
expressões-chave: "geralmente as decisões são de cima para baixo. Existem algumas diferenças entre os chefes, alguns dialogam mais, outros menos. Participei de Conselhos de Saúde mas não acho que houve melhorias com participação. A gente deve opinar para melhorar o trabalho. Cada um tem uma idéia. Minha consciência está muito triste por falta de amor ao ser humano, de apoio ao ser humano e da própria situação da Secretaria. Isto piorou, já foi bem melhor. A população deveria ser mais respeitada, mais cuidada, tanto do lado social, como no da saúde. Agora com o PAS a situação piorou. A propaganda do PAS é enganosa. Até os representantes do Conselho de Saúde pensaram que com o PAS iria ser melhor e que nós éramos do contra por acomodação, para as coisas ficarem do mesmo jeito. Esta administração não gosta de funcionário público. Não sei explicar o que é cidadania mas, acho que qualquer pessoa, sem distinção de raça, sexo, deve ser valorizada como cidadã, porque faz parte do povo do país".

idéia-central: a proposta de participação não refletiu na melhoria da atenção.

ancoragem: participei de Conselhos de Saúde mas não acho que houve melhorias com participação.

o) administrativo, 8 anos de funcionalismo

expressões-chave: "desde que estou na Prefeitura o trabalho não é democrático. A atual diretora do Posto é quem resolve os problemas e toma as decisões. Antes havia participação através dos Conseihos Gestores. As pessoas da comunidade e funcionários se reuniam de dois em dois meses para tirar as prioridades. Agora não. Mas acho que ela (a diretora) tem preconceitos, como por exemplo, em relação aos tuberculosos e hansenianos. Ela tem medo de pegar essas doenças".

idéia-central: o trabalho na Prefeitura nunca foi democrático.

ancoragem: antes as pessoas da comunidade se reuniam de dois em dois meses para tirar as prioridades. (Contradição entre autoritarismo e democracia).

\section{p) auxiliar de enfermagem, 6 anos de funcionalismo}

expressões-chave: a funcionária refere-se à administração anterior enquanto promotora da participação social: "antes a Prefeitura era aberta à participação. O pessoal sempre foi muito bom e amigo. Ali no PS Bandeirantes onde trabalhei, a chefia sempre consultava o pessoal para tomar as decisões e informar sobre as coisas. Tinha mais reuniões. A população também ia lá para discutir".

idéia-central: antes a Prefeitura era aberta à participação social.

ancoragem: a administração Luiza Erundina era sensivel a participação social e estimulou a criação de mecanismos favorecedores dessa prática política. 


\section{q) psicólogo, 5 anos de funcionalismo}

expressões-chave: "hoje a administração não é democrática. As decisões vêm de cima, prontas. São de cúpula, autoritárias. A participação social é baixa, e a população gosta do PAS; ela foi contra a implantação de um serviço de doença infecto contagiosa lá no Posto na época do PT. Nesse tempo havia mais autonomia dos Distritos de Saúde".

idéia-central: hoje as decisões vêm de cima, prontas; são de cúpula, autoritárias.

ancoragem: o discurso do funcionário é sustentado por uma concepção de administração pública autoritária, que apresenta seus planos de trabalho prontos e não sujeitos a participação; tem o respaldo da população. A administração anterior era mais democrática.

\section{r) enfermeiro, 6 anos de funcionalismo}

expressões-chave: "No governo da Erundina a população era muito presente. Havia reunião com os dirigentes para discutir sobre os profissionais e as necessidades da população. A população da zona leste era politizada. Na Vila Prudente havia participação. Atualmente não há. O PAS foi instalado sem diálogo. A atual administração desconhece o que é cidadania. Só oferece sopa aos doentes internados".

Idéia-central: na administração anterior havia reuniões com os funcionários e com a população.

ancoragem: o governo Luiza Erundina tinha interesse na participação social, e criou canais institucionais para estimular essa prática de cidadania.

\section{s) assistente social, 21 anos}

expressões-chave: "antes os diretores do Posto apresentavam seus programas e a equipe multiprofissional colocava seu trabalho. Havia respaldo da chefia. Hoje está tudo muito confuso. Ninguém decide nada. O gerenciamento é feito sob pressão, é autoritário. Antes havia o Conselho Gestor da Unidade. A participação era com as mulheres da comunidade que se reuniam, lutavam e levavam suas reivindicações para o Secretário da Saúde. Eu mesma participava das reuniões. A Igreja ajudava na mobilização das mulheres. As reivindicações eram bem recebidas e procuravam soluções. Cidadania tem a ver com direitos, deveres, esperança e democracia".

idéia-central: na administração anterior o Conselho Gestor da Unidade era atuante. ancoragem: o governo anterior estimulou a prática da cidadania.

t) servente, 12 anos de funcionalismo

expressões-chave: "não percebi mudanças na administração; algumas decisões são democráticas".

idéia-central: algumas decisões são democráticas. 
ancoragem: as diferentes administrações públicas têm posturas semelhantes frente à democracia e a tomada de decisão.

\subsection{Categoria Temática: Trabalho Integrado}

a) atendente de enfermagem, 25 anos de funcionalismo

expressões-chave: "trabalhei como auxiliar de dentista em escolas municipais, nas administrações da Erundina e do Maluf".

idéia-central: integração com escolas municipais.

ancoragem: trabalhei como auxiliar de dentista em escolas municipais.

\section{b) nutricionista, 6 anos de funcionalismo}

expressões-chave: "a partir de 89 houve trabalhos de integração com escolas, creches, secretaria das administrações regionais e associações de bairro".

idéia-central: trabalhos integrados a partir de 89.

ancoragem: a partir de 89 houve integração com outros setores.

c) médico, 6 anos de funcionalismo

expressões-chave: "eu tenho a impressão de que na administração anterior alguns funcionários buscaram contato com outros setores do governo. Atualmente a situação está muito mais complicada nesse sentido".

idéia-central: no governo anterior alguns funcionários buscaram contato com outros setores. ancoragem: alguns funcionários buscaram contato com outros setores.

d) administrativo, 6 anos de funcionalismo

expressões-chave: o funcionário percebeu que durante a administração Erundina as Educadoras e as Assistentes Sociais viviam saindo do Posto para trabalhar com outros setores. "É o caso por exemplo do tracoma. Naquele tempo elas iam muito às escolas para examinar os alunos. Isso depois foi se acabando".

idéia-central: integração com outros setores na época da Erundina.

ancoragem: na época da Erundina as Educadoras e as Assistentes Sociais viviam saindo do Posto para trabalhar com outros setores.

\section{e) médico, 17 anos de funcionalismo}

expressões-chave: "durante a administração anterior se tentou mas no final, permaneceram as mesmas dificuldades de se conseguir alguma integração com outras Secretarias. Até a população se desinteressou de participar". 
idéia-central: tentativas fracassadas de integração.

ancoragem: durante a administração anterior se tentou mas no final, até a população se desinteressou de participar.

\section{f) nutricionista, 7 anos de funcionalismo}

expressões-chave: "entre 89-92 havia entrosamento com outras secretarias, especialmente com a do Bem-Estar Social, por causa dos trabalhos nas creches. Existia muita ansiedade da população e ela participava de todos os movimentos da Secretaria".

idéia-central: entre 89-92 entrosamento com outras secretarias.

ancoragem: entre 89-92 existia muita ansiedade da população ela participava de todos os movimentos da Secretaria.

\section{g) assistente social, 7 anos de funcionalismo}

expressões-chave: "entre 1989-92 eu participei de trabalhos junto com outras Secretarias, o que me foi muito gratificante. Trabalhei mais com as Secretarias de Esportes, Educação e Cultura. Havia trabalhos em parques, escolas, centros esportivos, etc.. Nesta administração a integração acabou.

idéia-central: integração com outras Secretarias entre 1989-92".

ancoragem: entre 89-92 participei de trabalhos junto com outras Secretarias, o que me foi muito gratificante.

\section{h) terapeuta ocupacional, 7 anos de funcionalismo}

expressões-chave: "no governo do PT tive oportunidade de trabalhar juntamente com o pessoal da Cultura e dos Esportes. Agora eu nem sei o que vai acontecer amanhã".

idéia-central: trabalhos integrados na administração anterior.

ancoragem: no governo do PT tive a oportunidade de trabalhar juntamente com outras Secretarias.

i) enfermeiro, 12 anos de funcionalismo

expressões-chave: com a análise da entrevista depreende-se que o funcionário reconheceu a administração anterior como empenhada em estimular o desenvolvimento de trabalho em equipe. "Foram constituídos vários tipos de grupos com o pessoal das Unidades de Saúde". Segundo ele, essa mesma dinâmica era reproduzida pelo Centro de Orientação da Atenção à Saúde, ligado ao Gabinete da Secretaria, que promovia a troca de experiências entre os Distritos de Saúde.

idéia-central: trabalho em equipe e trabalho em grupo na administração anterior. 
ancoragem: na administração anterior se estimulou o desenvolvimento do trabalho em equipe.

j) médico, 12 anos de funcionalismo

expressões-chave: este funcionário também percebeu que durante a administração anterior a política de saúde era de integração com a população e com outras Secretarias. "Eu mesmo tive a oportunidade de representar a minha Unidade em reuniões com outras Secretarias. Com o PAS mudou a política de saúde. O Conselho Municipal de Saúde foi relegado. Para esta administração não existem forças sociais".

idéia-central: eu mesmo tive a oportunidade de representar a minha Unidade em reuniões com outras Secretarias.

ancoragem: política de integração na administração anterior.

\section{k) médico, 5 anos de funcionalismo}

expressões-chave: o funcionário diz que durante a administração anterior a política de saúde indicava o caminho da integração. "Essa diretriz transpassava todos os niveis da Secretaria. Nesta administração existem apenas iniciativas isoladas".

idéia-central: integração como diretriz política na administração anterior.

ancoragem: A diretriz da integração transpassava todos os niveis da Secretaria.

\section{I) psicólogo, 10 anos de funcionalismo}

expressões-chave: "no governo anterior a preocupação era de integração e ocorreu bastante. Houve trocas de experiências entre nós da Saúde com funcionários de outras Secretarias. Eu tive a oportunidade de trabalhar com pagens da SEBES e professores de escolas de primeiro grau. Neste governo este trabalho acabou".

idéia-central: integração com outras Secretarias.

ancoragem: houve trocas de experiências entre nós da Saúde com funcionários de outras Secretarias.

m) administrativo, 8 anos de funcionalismo

espressões-chave: "nunca houve trabalho integrado".

idéia-central: nunca houve trabalho integrado.

ancoragem: idem.

n) auxiliar de enfermagem, 5 anos de funcionalismo

expressões-chave: o funcionário diz que desconhece trabalhos integrados.

idéia-central: idem. 
ancoragem: idem.

o) auxiliar de enfermagem, 15 anos de funcionalismo

expressões-chave: não sabe o que dizer sobre trabalho integrado.

idéia-central: idem.

ancoragem: idem.

p) auxiliar de enfermagem, 6 anos de funcionalismo

expressões-chave: "vi mais integração entre o pessoal da saúde. No resto eu não sei".

idéia-central: integração na saúde.

ancoragem: a percepção da integração foi pequena, restrita. O funcionário sentiu-se mais integrado a seus pares, dentro de seu ambiente de trabalho.

q) psicólogo, 5 anos de funcionalismo

expressões-chave: "teve integração com as escolas, creches, com ong's, associações de moradores, etc".

idéia-central: integração da saúde com outros setores sociais.

ancoragem: as aproximações da saúde com os outros setores sociais e da Prefeitura foram percebidas como práticas de integração.

r) enfermeiro, 6 anos de funcionalismo

expressões-chave: "não percebi integração".

idéia-central: não houve integração.

ancoragem: a política de integração da saúde com outros setores não chegou a ser percebida pelo funcionário.

s) assistente social, 21 anos de funcionalismo

expressões-chave: "não senti mudança".

idéia-central: idem.

ancoragem: a política de integração da saúde intra e extra-institucional não foi percebida pelo funcionário.

t) servente, 12 anos de funcionalismo

expressões-chave: "não teve integração".

idéia-central: não houve integração.

ancoragem: a política de integração da saúde intra e extra-institucional não foi percebida pelo funcionário. 


\subsection{Categoria Temática: Desenvolvimento e Valorização do Pessoal}

a) auxiliar de enfermagem, 6 anos de funcionalismo

expressões-chave: "na gestão anterior o respaldo era grande por parte da chefia de enfermagem e do diretor da Unidade. Nós éramos mais valorizados. Cuidava-se mais das pessoas e dos equipamentos. Nesta gestão houve uma mudança da situação e nós fomos tratados como pessoas não importantes. Nada nos foi participado sobre os rumos da Secretaria. A qualidade do pessoal foi desconsiderada".

idéia-central: na administração anterior nós éramos mais valorizados.

ancoragem: na gestão anterior nós éramos mais valorizados. (Maior cuidado, valorização e consideração com o funcionário).

b) administrativo, 6 anos de funcionalismo

expressões-chave: o discurso do funcionário traduz seu sentimento que no governo da Erundina os salários eram melhores, havia mais diálogo e respeito com o pessoal. "Valorizouse mais o funcionário. Na administração atual não há respeito e incentivo algum".

idéia-central: no governo Erundina valorizou-se o pessoal.

ancoragem: no governo Erundina os salários eram melhores, havia mais diálogo e respeito com o pessoal.

\section{c) médico, 6 anos de funcionalismo}

expressões-chave: "antes havia investimento em pessoal, o funcionário era mais valorizado, tinha uma importância maior. Nesta administração, mesmo permanecendo o mesmo chefe, ele mudou, acabou o diálogo, a participação. Eu acho que como funcionário poderia me desenvolver mais, participando de cursos, aproveitando melhor as coisas".

idéia-central: na administração anterior o funcionário tinha uma importância maior.

ancoragem: antes havia investimento em pessoal, o funcionário era mais valorizado, tinha uma importância maior.

d) médico, 12 anos de funcionalismo

expressões-chave: "atualmente a Secretaria não tem política de desenvolvimento de pessoal. Muito diferente da administração Erundina, que investiu no pessoal e melhorou os salários. Naquele governo o custo/benefício foi mais moderno. Se equipou mais os serviços. Atualmente o desenvolvimento pessoal é zero. O PAS avacalhou as condições médicas. Muitos se demitiram da Prefeitura por causa do PAS".

idéia-central: investimento em pessoal 
ancoragem: atualmente a Secretaria não tem política de desenvolvimento de pessoal, muito diferente da administração Erundina, que investiu no pessoal e melhorou os salários.

e) enfermeiro, 13 anos de funcionalismo

expressões-chave: "na administração anterior havia uma política de integração entre os servidores. Havia trabalho em equipe e sensibilização do pessoal, para participação e conscientização sobre problemas de saúde. Naquele tempo havia troca com a população. A gente crescia com o trabalho, havia um aprendizado mútuo entre a população e o pessoal do serviço".

idéia-central: integração, conscientização, trabalho em equipe.

ancoragem: na administração anterior havia trabalho em equipe e sensibilização do pessoal, para participação e conscientização sobre problemas de saúde.

\section{f) terapeuta ocupacional, 7 anos de funcionalismo}

expressões-chave: "na administração tive crescimento pessoal. Aprendi muito. Trabalhei sobre projetos, construção do conhecimento sobre projetos, como o projeto de saúde mental para a rede básica de saúde. Esta administração deixou tudo, absolutamente tudo a desejar, salários, cursos"...

idéia-central: construção do conhecimento na administração anterior.

ancoragem: na administração anterior tive crescimento pessoal, cresci muito.

\section{g) assistente social, 7 anos de funcionalismo}

expressões-chave: "na administração anterior o salário não era bom, mas havia valorização em outros aspectos, como motivações para o desenvolvimento profissional. Hoje, você valoriza mais a administração anterior por causa da situação negativa atual. Hoje a motivação é para que os funcionários peçam demissão".

idéia-central: na administração anterior havia motivações para o desenvolvimento profissional.

ancoragem: hoje você valoriza mais a administração anterior por causa da situação negativa atual.

\section{h) nutricionista, 7 anos de funcionalismo}

expressões-chave: "no governo passado tinha respeito e valorização do funcionário. Depois veio a falta de respeito e desvalorização".

idéia-central: respeito e valorização do funcionário.

ancoragem: no governo passado tinha respeito e valorização do funcionário. 
i) médico, 17 anos de funcionalismo

expressões-chave: o funcionário entendeu que entre 89-92 houve grande valorização do pessoal em função das melhorias das condições de trabalho. Havia mais recursos, mais equipamentos e medicamentos. Reconhece que os salários eram melhores. A preocupação em desenvolver Cursos. Ações coletivas e integração com outras Secretarias. "Hoje há apenas medicina curativa, com perda da qualidade. Desvalorização do pessoal na gestão Maluf, que disse uma vez que se os médicos tivessem vergonha na cara, pediriam demissão por causa dos baixos salários e das condições de trabalho".

idéia-central: melhorias das condições de trabalho e valorização do pessoal.

ancoragem: entre 89-92 houve grande valorização do pessoal em função das melhorias das condições de trabalho. Havia mais recursos, equipamentos. Os salários eram melhores. Cursos.

\section{j) nutricionista, 7 anos de funcionalismo}

expressões-chave: o funcionário entende que do ponto de vista do desenvolvimento está havendo continuidade da política de pessoal: "cursos de desenvolvimento de pessoal sempre teve. como atualmente com os cursos de capacitação para AIDS, que a Secretaria vem desenvolvendo".

idéia-central: sempre teve desenvolvimento de pessoal, como hoje.

ancoragem: cursos de desenvolvimento de pessoal sempre teve, como atualmente com os cursos de capacitação para AIDS, que a Secretaria vem desenvolvendo.

\section{k) administrativo, 8 anos de funcionalismo}

expressões-chave: "na gestão anterior investiu-se mais no desenvolvimento do pessoal. Pagava-se melhor. A administração atual tirou alguns direitos dos funcionários e o salário está muito ruim".

idéia-central: salário e desenvolvimento de pessoal.

ancoragem: na gestão anterior investiu-se mais no desenvolvimento do pessoal. Pagava-se melhor.

\section{1) atendente de enfermagem, 25 anos de funcionalismo}

expressões-chave: "todos os últimos governos me desvalorizaram. Somente no governo Covas me senti valorizada. Nessa época eu trabalhei no Hospital e me desenvolvi, porque aprendi muitas técnicas de enfermagem. Desde o governo Erundina que eu quero fazer 0 Curso Larga Escala, para formação de Auxiliar de Enfermagem e não sou convocada". idéia-central: somente no governo Covas me senti valorizada. 
ancoragem: todos os últimos governos me desvalorizaram. Somente no governo Covas me senti valorizada.

\section{m) psicólogo, 10 anos de funcionalismo}

expressões-chave: "no governo do PT a saúde mental foi muito promovida com expansão de atividades e admissão de pessoal. Houve crescimento profissional porque você tinha espaço para trocar idéias e discutir práticas de atendimento com o supervisor de saúde mental. Foram promovidos cursos, reciclagens. Houve valorização do pessoal e da saúde como um todo".

idéia-central: no governo do PT houve valorização do pessoal e da saúde como um todo. ancoragem: houve crescimento profissional porque você tinha espaço para trocar idéias e discutir práticas de atendimento com o supervisor de saúde mental.

\section{n) auxiliar de enfermagem, 15 anos de funcionalismo}

expressões-chave: "na época da Erundina o salário era bem melhor que hoje. $\mathrm{Na}$ área da enfermagem eu participei de vários cursos. A gente se sentia mais valorizada".

idéia-central: a gente se sentia valorizada.

ancoragem: na época da Erundina o salário era bem melhor que hoje.

\section{o) médico, 5 anos de funcionalismo}

expressões-chave: "na administração da Erundina foi criado o Cefor, para dar cursos e treinamentos de pessoal, de todos os níveis de formação. Havia essa preocupação, de capacitar o pessoal da rede. Hoje a gente sente a diferença. Não existe mais aquela responsabilidade do Cefor".

idéia-central: o Cefor e o desenvolvimento de pessoal.

ancoragem: na administração da Erundina foi criado o Cefor, para dar cursos e treinamentos de pessoal, de todos os niveis de formação. Havia essa preocupação, de capacitar o pessoal da rede. Hoje a gente sente a diferença.

\section{p) auxiliar de enfermagem, 6 anos de funcionalismo}

expressões-chave: "agora eu me sinto desvalorizada, abandonada. Antes a gente estava sempre em atividade, agora não. Até o salário piorou. Dá vontade de ir embora".

idéia-central: agora a situação piorou

ancoragem: a funcionária passa a idéia que antes era mais valorizada que atualmente.

q) psicólogo, 5 anos de funcionalismo 
expressões-chave: "sinto-me valorizada pelos colegas e pelos pacientes. A área da saúde mental por ser muito dinâmica exige reciclagens e cursos de especialização. Os treinamentos são insuficientes. A Prefeitura não nos considera".

idéia-central: sinto-me valorizada pelos colegas e pelos pacientes. A Prefeitura não nos considera.

ancoragem: a valorização pessoal vem dos colegas e dos pacientes.

\section{r) enfermeiro, 6 anos de funcionalismo}

expressões-chave: "a parte salarial piorou neste governo. Continua tendo treinamentos, mas deixa muito a desejar".

idéia-central: os salários pioraram.

ancoragem: o funcionário não se sente valorizado.

s) assistente social, 21 anos de funcionalismo

expressões-chave: "nesta gestão o funcionário não é valorizado, virou um lixo. Já era para estarmos na rua se não houvesse Constituição. A escolha pública do local de trabalho, que saiu no DO, foi desrespeitada. O funcionário foi mandado para qualquer lugar. Antes havia muito mais chances de você participar de cursos e treinamentos".

idéia-central: o funcionário não é mais respeitado.

ancoragem: a administração atual desvaloriza e desconsidera o funcionário público.

t) servente, 12 anos de funcionalismo

expressões-chave: "sempre me senti valorizada na Prefeitura".

idéia-central: idem.

ancoragem: idem.

\section{FUNCIONÁRIOS QUE ADERIRAM AO PAS}

Observação: subdividimos este grupo de funcionários em dois, um que teve a oportunidade de vivenciar a administração Luiza Erundina, representado pelos sujeitos a a e, e outro, que não teve essa oportunidade, por ter entrado na Secretaria após o término daquela gestão, representado pelos sujeitos $f$ a $i$.

\subsection{Categoria Temática: Mudança de Modelo de Atenção} Vivenciaram a administração Luiza Erundina

a) Educador Sanitário, 21 anos de funcionalismo 
expressões-chave: "com o governo Covas houve incentivos para o trabalho multiprofissional, valorização de atividades extra-muros e trabalhos fora da Unidade. Sempre houve mudanças na administração. Na administração anterior ( Erundina ) era muito difícil de resolver os problemas funcionais, como por exemplo, as situações dos funcionáriosproblemas. Com o PAS essa situação melhorou, há possibilidades de mudanças, de reciclagens muito mais rápidas. De novo após 1989 ocorreu a discussão e implantação do PAS, que se deu em 1995. Depois, entre 1990-92, teve muito trabalho preventivo, sobre parasitose, verminose e saúde bucal. Os técnicos de higiene dental e os auxiliares de cirurgião dentista trabalharam nos equipamentos da Secretaria e fora dela, como creches e escolas. Depois as coisas mudaram e hoje eles trabalham só dentro dos serviços de saúde". idéia-central: entre 1990-92 trabalhos preventivos e educativos fora da Unidade de Saúde. ancoragem: $\mathrm{Na}$ administração anterior (Erundina) era muito difícil de resolver os problemas funcionais, como por exemplo, as situações dos funcionários-problemas. (ações programáticas em saúde).

\section{b) médico, 10 anos de funcionalismo}

expressões-chaves: o funcionário evita mencionar a administração L.Erundina, ao indicar que mesmo antes de 1989 já havia proposta de trabalho multiprofissional, envolvendo médico, educador, assistente social e outros. Segundo ele, falava-se em sistema único de saúde antes da gestão anterior. "Já havia sido iniciado o processo de aproximação da população, para facilitar o acesso da população aos serviços de saúde. Mesmo antes de 1989 já havia discussões sobre o SUS e sobre tendências para se desenvolver ações preventivas, mesmo que sem eficácia. $E$ tendências para abordagem multiprofissional e também sobre como discutir com a população. O PAS trouxe muitas mudanças. Toda a Secretaria agora está mudando. Mais agilidade para o sistema de saúde do que o PAS é impossível". Conclui o seu discurso afirmando que com o PAS ocorreu a descentralização administrativa, respeitando a realidade de cada local, desde a seleção de pessoal.

idéia-central: trabalho em equipe multiprofissional, medidas preventivas e participação social já haviam antes de 1989.

ancoragem: antes de 1989 já havia proposta de trabalho multiprofissional, envolvendo médico, educador, assistente social e outros. Já se falava em sistema único de saúde. Já havia sido iniciado o processo de aproximação da população, para facilitar o acesso da população aos serviços de saúde. Mesmo antes de 1989 já havia discussões sobre o SUS e sobre tendências para se desenvolver ações preventivas, mesmo que sem eficácia.

c) assistente social, 15 anos de funcionalismo 
expressões-chave: "cada administração tem sua própria característica em relação ao modelo de atenção à saúde. Há o lado positivo e o lado negativo em todas as administrações. Em cada mudança de administração sempre haverá outro modelo a ser seguido. Vejo como crescimento profissional. Até em visão negativa há esse crescimento. Na administração anterior trabalhei no Hospital de Ermelino Matarazzo, junto aos familiares de pacientes portadores de AIDS de outras doenças doenças. Havia essa tentativa de trabalhar a relação paciente-familia, para fortalecer o vínculo, para reabilitar o paciente junto à família. Isso agora também está ocorrendo no PAS".

idéia-central: as mudanças promovem o crescimento profissional, mesmo as negativas.

ancoragem: cada administração tem sua própria característica em relação ao modelo de atenção à saúde. Há o lado positivo e o lado negativo em todas as administrações. Vejo como crescimento profissional. Até em visão negativa há esse crescimento.

\section{d) médico, 6 anos de funcionalismo}

expressões-chave: "só o médico responsável pelo atendimento não é correto. O certo é o atendimento multiprofissional, sempre com uma estrutura governamental, pelo menos para manter o mesmo sistema a longo prazo. O que houve de moderno após 1989 foi exatamente o trabalho multiprofissional, forte no governo Luiza Erundina. O PAS também é moderno. $O$ PAS é uma tentativa prática, muito interessante. É uma tentativa de mudar a mentalidade de praticar a saúde. Ele precisa ser ampliado mas, atualmente está isolado. Dessa forma, isolado, o PAS não irá funcionar. Ele requer tempo e colaboração do governo do Estado e do governo federal. No início o PAS provocou desconfiança e depois foi ganhando crédito. Hoje há um pouco de preocupação porque depende de outras esferas governamentais".

idéia-central: trabalho multiprofissional forte no governo Luiza Erundina.

ancoragem: só o médico responsável pelo atendimento não é correto. O certo é 0 atendimento multiprofissional, sempre com uma estrutura governamental, pelo menos para manter o mesmo sistema a longo prazo. O que houve de moderno após 1989 foi exatamente o trabalho multiprofissional, forte no governo Luiza Erundina.

\section{e) enfermeiro, 27 anos de funcionalismo}

expressões-chave: "quanto ao modelo de atenção, mudaram os atores mas a peça é a mesma. Meus sentimentos frente ao PAS são os piores possiveis. Os profissionais esperavam uma coisa e aconteceu outra. A expectativa era de melhorar mas nada disso aconteceu. A idéia de cooperativa pode ser moderna mas falta muito para se chegar ao novo. O pessoal não está preparado para o cooperativismo".

idéia-central: mudam as pessoas mas a situação permanece.

ancoragem: quanto ao modelo de atenção, mudaram os atores mas a peça é a mesma.

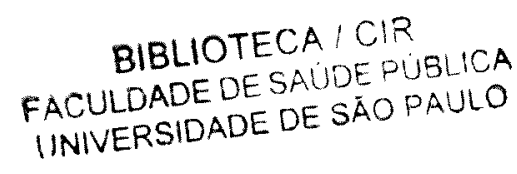


Grupo de funcionários que não vivenciaram a administração Luiza Erundina:

f) médico, 3 anos de funcionalismo

expressões-chave: "com o PAS mudou para melhor. Há mais recursos e mais agilidade no atendimento. O movimento quadruplicou. É um modelo moderno, novo, que valoriza o pessoal, pois cada um trabalha em sua área. Por exemplo, hoje eu sou um cirurgião. Isso faz o atendimento público melhorar".

idéia-central: com o PAS mudou para melhor. Há mais recursos e mais agilidade no atendimento.

ancoragem: idem.

g) enfermeiro, 3 anos de funcionalismo

expressões-chave: "atualmente existe um atendimento mais eficaz e multiprofissional, com exames mais específicos para complementar o diagnóstico. Eu acompanhei as mudanças do PAS e achei que a principal mudança foi no aumento de recursos que a gente dispõe hoje. Eles deram mais dinheiro para o PAS, mais condições e assim melhorou o atendimento em relação aos exames, aos diagnósticos. $O$ problema é que agora eu não sei se os interesses vão ser os mesmos".

idéia-central: a principal mudança com o PAS foi o aumento de recursos.

ancoragem: com mais recursos melhorou o atendimento em relação aos exames, aos diagnósticos.

\section{h) médico, 3 anos de funcionalismo}

expressões-chave: "eu vejo a mudança para o PAS de maneira positiva. O atendimento agora está mais ágil, mais descentralizado. O PAS desburocratizou o funcionamento do Pronto Socorro e a gente tem mais liberdade para trabalhar, além de ter melhorado muito os recursos materiais e humanos. Antes do PAS era um mecanismo burocrático, atravancado Hoje há mais agilidade em todos os níveis".

idéia-central: menos burocracia, mais agilidade, mais recursos com o PAS.

ancoragem: idem

\section{i) psicólogo, 1 ano de funcionalismo}

expressões-chave: "é um modelo bem organizado, com mais recursos do que antes do PAS A Secretaria delegou poderes para os módulos, o que é excelente. Com o PAS há participação da sociedade".

idéia-central: é um modelo bem organizado, com mais recursos do que antes do PAS ancoragem: idem. 


\subsection{Categoria Temática: Democratização, Descentralização, Participação}

Vivenciaram a administração Luiza Erundina

a) Educador Sanitário, 21 anos de funcionalismo

expressões-chave: "sempre houve possibilidades de discussões. A democracia está presente. As decisões nunca foram fechadas. Sempre tive oportunidade de trabalhar com liberdade. Também já trabalhei fora da Unidade de Saúde e o trabalho é diferente. Desenvolvi trabalhos educativos com a população. A população tem pouca consciência e se submete à diferentes situações sem reagir. $\mathrm{Na}$ administração anterior, com a criação das dez Administrações Regionais de Saúde, senti que houve descentralização".

idéia-central: a democratização está presente. Sempre trabalhei com liberdade.

ancoragem: sempre houve possibilidades de discussões. A democracia está presente. As decisões nunca foram fechadas. Sempre tive oportunidade de trabalhar com liberdade.

\section{b) médico, 10 anos de funcionalismo}

expressões-chave: "o processo de trabalho nunca é muito democrático. Parece que é, quando se está administrando mas, quando se está na ponta da linha operacional, isso não ocorre. Poucos funcionários são ouvidos. As decisões quase sempre são de cima para baixo. Em relação às principais ações, não passa do coordenador da Unidade, do gerente local da Unidade. Só na parte final é que o profissional toma conhecimento das decisões. Hoje há mais consciência sanitária por parte da população. Ela está mais preocupada, embora o que ela entenda por saúde seja um pouco limitado, inadequada. Observa-se dentro da representação da comunidade que na prática sempre há uma distorção. O Conselho de Saúde não traduz a necessidade da comunidade. Há uma baixa participação. No entanto, é melhor que nada. O que eu vi de descentralização na Secretaria desde 1988 é que antes era - Departamento de Saúde da Comunidade (DSC), depois vieram as 10 Administrações Regionais de Saúde e os Distritos de Saúde. Agora vieram os Módulos do PAS".

idéia-central: o processo de trabalho nunca é muito democrático.

ancoragem: o processo de trabalho nunca é muito democrático. Parece que é, quando se está administrando mas, quando se está na ponta da linha operacional, isso não ocorre. Poucos funcionários são ouvidos. As decisões quase sempre são de cima para baixo.

\section{c) assistente social, 15 anos de funcionalismo}

expressões-chave: "sempre teve incentivos para a democratização do serviço público. As decisões sempre foram tomadas com participação da equipe multiprofissional da Unidade. Para se tomar uma decisão é necessário compartilhar com outros colegas, de outras áreas, para se chegar a um denominador comum frente aos problemas e soluções. Vem ocorrendo 
melhorias na administração, visando o atendimento de boa qualidade. É preciso haver maior comunicação com a população, mais atividades educativas, por exemplo, em relação ao prénatal. A população hoje questiona mais a respeito do atendimento. $O$ paciente está mais esclarecido. É politizado quanto aos seus direitos, sabe de seus direitos. Há participação da população em função do interesse na melhoria da saúde".

idéia-central: a democratização do serviço público é um processo contínuo.

ancoragem: sempre teve incentivos para a democratização do serviço público. As decisões sempre foram tomadas com participação da equipe multiprofissional da Unidade. Para se tomar uma decisão é necessário compartilhar com outros colegas, de outras áreas, para se chegar a um denominador comum frente aos problemas e soluções.

\section{d) médico, 6 anos de funcionalismo}

expressões-chave: "não acredito em democratização, uma vez que não há uma condição cultural e educacional da população. Se não se conhece a estrutura da Secretaria, como é possivel se tomar decisões por meio de votação, com participação? Nesse caso, que se mude a decisão do grupo inteiro. Cada administração que vem muda o que a administração anterior fez. Não há uma linha a ser seguida por mais tempo. Ela é interrompida de quatro em quatro anos. Essa descontinuidade do sistema acarreta uma desorganização da saúde com prejuizos financeiro, profissional e de assistência à saúde. Na administração do PT houve participação social mas, uma participação absurda, de segmentos sociais não representativos da comunidade. No PAS a participação está num processo de acertos porque o PAS é recente. Com o PAS vivenciei uma descentralização administrativa, por vivenciar uma das cooperativas. Na outra administração ( do PT) não tinha a quem me referir, a me reportar. $A$ população não se vê como cidadã. A cidadania fica só no papel".

idéia-central: participação sim mas, com educação e cultura.

ancoragem: não acredito em democratização, uma vez que não há uma condição cultural $e$ educacional da população. Se não se conhece a estrutura da Secretaria, como é possivel se tomar decisões por meio de votação, com participação? Na administração do PT houve participação social mas, uma participação absurda, de segmentos sociais não representativos da comunidade.

\section{e) enfermeiro, 27 anos de funcionalismo}

expressões-chave: "não há democracia no trabalho. As decisões não são compartilhadas com os funcionários. O pessoal da saúde tem consciência sanitária. A população não exercita sua cidadania, não há participação social. A descentralização administrativa aconteceu com o PAS. A administração anterior, quando regionalizou e distritalizou, não promoveu a descentralização. 
idéia-central: a descentralização administrativa aconteceu com o PAS".

ancoragem: não há democracia no trabalho. As decisões não são compartilhadas com os funcionários. O pessoal da saúde tem consciência sanitária. A população não exercita sua cidadania, não há participação social.

Não vivenciaram a administração Luiza Erundina:

f) médico, 3 anos de funcionalismo

expressões-chave: "o processo de democratização é lento porém, já avançou com o PAS. Eu acho que deveria haver regionalização das tomadas de decisão. Os procedimentos administrativos devem ter melhorado com o PAS porque agora o Pronto Socorro está funcionando melhor. Deve melhorar mais ainda, porque está no começo, o pessoal está engatinhando. A consciência sanitária das pessoas continua na mesma. Direito à saúde todo mundo tem e com o PAS melhorou muito. Não há participação ou controle social porque a população não tem consciência de seu próprio direito. A população deveria ser melhor orientada. Na época da Erundina eles sempre falavam de descentralização administrativa mas isto nunca foi feito".

idéia-central: Não há participação ou controle social porque a população não tem consciência de seu próprio direito. A população deveria ser melhor orientada. Na época da Erundina eles sempre falavam de descentralização administrativa mas isto nunca foi feito.

ancoragem: idem.

\section{g) enfermeiro, 3 anos de funcionalismo}

expressões-chave: "não existe democracia no processo de trabalho. Tudo vem de cima para baixo. Com o PAS mais ainda. Você vai à uma reunião e sua opinião não é considerada. Não existe uma comissão multiprofissional. Na época da Prefeitura a gente tinha condições de participar da administração. Hoje isso não existe mais. Como o salário melhorou com o PAS, os funcionários têm mais consciência sanitária do estado de saúde dos pacientes. O PAS está melhorando o que já havia antes. Antigamente o pessoal do bairro vinha até aqui e colocava sua opinião. Hoje me parece que isso não ocorre mais".

idéia-central: não existe democracia no processo de trabalho. Tudo vem de cima para baixo. Com o PAS mais ainda.

ancoragem: idem e contradições.

\section{h) médico, 3 anos de funcionalismo}

expressões-chave: "eu vejo como democratização do trabalho o fato de agora se trabalhar fora do setor público. Hoje as decisões são tomadas levando-se em conta o pessoal que está na base, no atendimento. Atualmente os problemas são resolvidos de modo descentralizado, 
dentro de cada módulo, sem burocracia. Consciência sanitária: a minha realidade no posto é diferente. A gente pega a doença aguda, não pega o problema sanitário. Cidadania: está completamente respeitada. Antes todos tinham e hoje todos continuam tendo direito à saúde. No PAS existe um compartilhamento da sociedade nos Conselhos de Gestão".

idéia-central: eu vejo como democratização do trabalho o fato de agora se trabalhar fora do setor público. Hoje as decisões são tomadas levando-se em conta o pessoal que está na base, no atendimento.

ancoragem: democracia e privatização.

i) psicólogo, 1 ano de funcionalismo

expressões-chave: "a administração é super-positiva, democrática, aberta às idéias dos colegas. As decisões são compartilhadas. Consciência sanitária: muitos trabalhos relacionados com a higiene estão sendo desenvolvidos, principalmente com os moradores do Cingapura. Tem grupos comunitários com grande participação. As pessoas têm medo que 0 PAS acabe".

idéia-central: a administração é super-positiva, democrática, aberta às idéias dos colegas. As decisões são compartilhadas. As pessoas têm medo que o PAS acabe.

ancoragem: idem.

\subsection{Categoria Temática: Trabalho Integrado}

Vivenciaram a administração Luiza Erundina

\section{a) educador sanitário, 21 anos de funcionalismo}

expressões-chave: "a partir do governo Covas trabalhei com creches, comunidade e igreja, desenvolvendo trabalhos educativos, ensinando. Atualmente também trabalho com creches. A integração com a assistência social tem sido importante, por exemplo, para a implantação de hortas comunitárias. Os resultados desses trabalhos tem sido positivos principalmente quanto ao conteúdo educativo".

idéia-central: integração é importante.

ancoragem: a partir do governo Covas trabalhei com creches, comunidade e igreja, desenvolvendo trabalhos educativos, ensinando.

\section{b) médico, 10 anos de funcionalismo}

expressões-chave: "na administração anterior trabalhou-se muito com a Secretaria da Educação. Variou de lugar para lugar. Os equipamentos sociais que mais se integraram com a saúde foram as escolas, os centros de juventude, as creches, os centros esportivos, a Secretaria da Cultura. Os resultados desses trabalhos foram muito bons. Ampliou-se a consciência, a cidadania. Com esses trabalhos identificam-se os problemas da população e pode haver intervenções, como por exemplo em casos de parasitoses e anemia". 
idéia-central: integração com outros setores.

ancoragem: na administração anterior os equipamentos sociais que mais se integraram com a saúde foram as escolas, os centros de juventude, as creches, os centros esportivos, a Secretaria da Cultura.

c) assistente social, 15 anos de funcionalismo

expressões-chave: "sempre existiu trabalhos integrados com outros setores. Atualmente há interesse do PAS, que ocorra essa integração. No momento não existe. Mas está havendo mobilização junto a vários setores com o objetivo de se formalizar a integração. Hoje existem trabalhos de grupo com gestantes, tuberculosos, planejamento familiar. Outros programas estão sendo montados como programas de diabetes, hipertensão, adolescentes e terceira idade".

idéia-central: sempre existiu trabalhos de integração com outros setores.

ancoragem: sempre existiu trabalhos integrados com outros setores. Atualmente há interesse do PAS, que ocorra essa integração. Está havendo mobilização junto a vários setores com 0 objetivo de se formalizar a integração.

d) médico, 6 anos de funcionalismo

expressões-chave: "não existem trabalhos integrados com outros setores. Já teve na época da Erundina; tinha muitas reuniões mas, sem resultados práticos. A assistência médica é privilegiada em algumas administrações, mas também sem resultados práticos, porque saúde depende de condições socio-econômicas da população".

idéia-central: não existem trabalhos integrados; já houve trabalhos integrados na época da Erundina

ancoragem: não existem trabalhos integrados com outros setores. Já teve na época da Erundina; tinha muitas reuniões mas, sem resultados práticos.

e) enfermeiro, 27 anos de funcionalismo

expressões-chave: "nunca desenvolvi trabalhos integrados, fora da Unidade de Saúde. Existem resistências de dentro para fora, para que não haja trabalhos integrados com outros setores".

idéia-central: há pressões contra integração.

ancoragem: nunca desenvolvi trabalhos integrados, fora da Unidade de Saúde.

Não vivenciaram a administração Luiza Erundina

Os sujeitos $\mathbf{f}, \mathbf{g}, \mathbf{h}, \mathbf{i}$, não se pronunciaram sobre a categoria temática trabalho integrado. 
ancoragem: a falta de considerações representa a não compreensão sobre o sentido do termo integração.

\subsection{Categoria Temática: Desenvolvimento e Valorização de Pessoal}

Vivenciaram a administração Luiza Erundina

\section{a) educador sanitário, 21 anos de funcionalismo}

expressões-chave: "a valorização de pessoal tem variado muito com as administrações. A pior administração foi a do Jânio. Tem havido possibilidade de crescimento pessoal. Se o funcionário tem interesse ele é considerado, ele se desenvolve, se não, não. Dentro da Prefeitura eu progredi de escriturária para assistente social e agora sou educadora".

idéia-central: se o funcionário tem interesse ele se desenvolve.

ancoragem: Tem havido possibilidade de crescimento pessoal. Se o funcionário tem interesse ele é considerado, ele se desenvolve, se não, não.

b) médico, 10 anos de funcionalismo

expressões-chave: "tem sido razoável a valorização profissional. Não é o ideal, mas também não se pode dizer que nunca houve valorização. Por exemplo, como dermatologista tive oportunidade de desenvolvimento profissional durante a instalação do Ambulatório de Especialidades de Ermelino Matarazzo ( que hoje está fechado ). Depende da disponibilidade do profissional junto da Instituição".

idéia-central: a valorização pessoal depende da sua disponibilidade junto da Instituição. ancoragem: tem sido razoável a valorização profissional; depende da disponibilidade do profissional junto da Instituição.

c) assistente social, 15 anos de funcionalismo

expressões-chave: "o meu trabalho é valorizado; sempre sou incentivada com elogios e apoios. Há interesse político e administrativo para que o trabalho seja bem realizado. Me vejo como uma ótima profissional. Valorizo muito minha profissão dentro e fora da saúde. Procuro desenvolver da melhor forma o meu trabalho".

idéia-central: me valorizo e sou valorizada profissionalmente.

ancoragem: o meu trabalho é valorizado; sempre sou incentivada com elogios e apoios. Há interesse político e administrativo para que o trabalho seja bem realizado.

\section{d) médico, 6 anos de funcionalismo}

expressões-chave: "a nível prático nenhuma administração sabe das necessidades de desenvolvimento profissional. Todas as administrações oferecem cursos, treinamentos, só que para um público privilegiado, que tem disponibilidade e condições econômicas 
favoráveis, para poder se afastar do trabalho e freqüentar cursos. Nenhum deles me favoreceu. Meu desenvolvimento se deve exclusivamente às minhas iniciativas pessoais".

idéia-central: nenhuma administração sabe das necessidades de desenvolvimento profissional.

ancoragem: a nível prático nenhuma administração sabe das necessidades de desenvolvimento profissional. Meu desenvolvimento se deve exclusivamente às minhas iniciativas pessoais.

\section{e) enfermeiro, 27 anos de funcionalismo}

expressões-chave: "não há nenhuma diferença entre as administrações quanto à valorização do pessoal, por causa do apadrinhamento político. Em nenhuma administração houve essa preocupação de desenvolvimento profissional, inclusive na da Erundina".

idéia-central: em nenhuma administração houve essa preocupação de desenvolvimento profissional, inclusive na da Erundina.

ancoragem: não há nenhuma diferença entre as administrações quanto à valorização do pessoal, por causa do apadrinhamento político.

Não vivenciaram a administração Luiza Erundina

f) médico, 3 anos de funcionalismo

expressões-chave: "a valorização melhorou um pouco, pela remuneração. Falta melhorar mais. Quanto ao desenvolvimento de pessoal não mudou. O profissional sempre aprende no local de trabalho".

idéia-central e ancoragem: idem, idem.

g) enfermeiro, 3 anos de funcionalismo

expressões-chave: "o funcionário hoje está mais valorizado em termos monetários. desenvolvimento profissional continua o mesmo. A Prefeitura manteve os mesmos cursos". idéia-central e ancoragem: idem, idem.

h) médico, 3 anos de funcionalismo

expressões-chave: "nós estamos tendo melhores condições de atendimento dos pacientes, com a melhoria das condições humanas e materiais".

idéia-central e ancoragem: idem, idem.

i) psicólogo, 1 ano de funcionalismo

expressões-chave: "há democracia, há valorização. O PAS propiciou o desenvolvimento do pessoal". Idéia-central e ancoragem: idem, idem. 


\section{CIDADÃOS / USUÁRIOS}

Foram realizadas trinta entrevistas, na seguinte proporção: seis na zona norte, cinco na zona sul, sete na zona leste, sete na oeste e cinco na zona central. Todas ocorreram durante o mês de setembro de 1996 e estão relacionadas pelos respectivos bairros e tempo de uso dos serviços de saúde da Prefeitura, segundo cada entrevistado.

Tabela 1. Resumo das entrevistas junto aos cidadãos/usuários que usam e que não usam os serviços de saúde, segundo a categoria temática:

\begin{tabular}{|c|c|c|}
\hline & usam os serviços & não usam \\
\hline $\begin{array}{c}\text { categoria temática } \\
\text { modelo de atenção }\end{array}$ & $\begin{array}{l}\text { - os serviços melhoraram - } 13 \text { pessoas } \\
\text { - os serviços pioraram - } 2 \text { pessoas } \\
\text { - os serviços estão iguais - } 2 \text { pessoas }\end{array}$ & $\begin{array}{l}\text { - os serviços estão iguais - } 8 \text { pessoas } \\
\text { - os serviços pioraram - } 5 \text { pessoas }\end{array}$ \\
\hline $\begin{array}{c}\text { categoria temática } \\
\text { participação social }\end{array}$ & $\begin{array}{l}\text { - enquanto direito de cidadania - } 5 \\
\text { - enquanto direito de cidadania por } \\
\text { pagar impostos - } 3 \text { pessoas } \\
\text { - a participação aumentou - } 2 \text { pessoas } \\
\text { - a participação diminuiu - } 5 \text { pessoas } \\
\text { - não soube opinar - } 2 \text { pessoas }\end{array}$ & $\begin{array}{l}\text { - enquanto direito de cidadania - } 8 \\
\text { - a participaçāo social diminuiu - } 2 \\
\text { - não soube opinar - } 3 \text { pessoas }\end{array}$ \\
\hline $\begin{array}{c}\text { categoria temática } \\
\text { trabalho integrado }\end{array}$ & $\begin{array}{l}\text { - integração ocorreu no governo Luiza } \\
\text { Erundina - } 3 \text { pessoas } \\
\text { - não soube opinar - } 14 \text { pessoas }\end{array}$ & $\begin{array}{l}\text { - não há ou nunca houve - } 4 \text { pessoas } \\
\text { - integração ocorreu no governo Luiza } \\
\text { Erundina - } 3 \text { pessoas } \\
\text { - não soube opinar - } 6 \text { pessoas }\end{array}$ \\
\hline total & 17 & 13 \\
\hline
\end{tabular}

\subsection{Categoria Temática: Mudança de modelo de Atenção}

\section{Santana, 8 anos de uso}

expressões-chave: "a qualidade dos serviços mudou para melhor. $O$ atendimento é mais rápido, a emergência é mais rápida. Os médicos são mais atenciosos que antes. Agora sim a Prefeitura está dando o devido valor à saúde, está se empenhando para melhorar a saúde". idéia-central: a qualidade da atenção melhorou. ancoragem: a qualidade dos serviços mudou para melhor. $O$ atendimento é mais rápido, a emergência é mais rápida. 


\section{Santana, 4 anos de uso}

expressões-chave: o cidadão/usuário diz que houve mudanças na qualidade para melhor, porque atualmente tem mais especialistas que antes, tem mais médicos, oftalmologista, e outros funcionários. "Antes só tinha clínico, ginecologista e pediatra. A Prefeitura agora está se empenhando bastante para atender a população pobre que não tem condições de pagar um convênio".

idéia-central: a qualidade da atenção melhorou porque tem mais médicos.

ancoragem: a Prefeitura agora está se empenhando bastante para atender a população pobre que não tem condições de pagar um convênio.

\section{Santana, 5 anos de uso}

expressões-chave: segundo o cidadão/usuário, depois da implantação do PAS houve mudanças na qualidade para pior. "A documentação do meu filho não foi encontrada. Agora é essa fila enorme. Um dia uma mulher ficou esperando um tempão e quase morreu na fila de atendimento. A Prefeitura não tem interesse em melhorar os serviços. Eu não sei porque está assim pior".

idéia-central: a qualidade da assistência piorou.

ancoragem: a Prefeitura não tem interesse em melhorar os serviços.

\section{Santana, primeira vez que usa}

expressões-chave: "pelo que vejo na televisão não tem remédios nos Postos de Saúde, tem gente passando mal nos Postos. Acho que a qualidade dos serviços não mudou. Agora a Prefeitura está se empenhando bastante para melhorar, porque acho que eles estão querendo ganhar as eleições".

idéia-central: a qualidade não mudou.

ancoragem: faltam remédios, tem gente passando mal nos Postos.

\section{Santana, 10 anos de uso}

expressões-chave: "a qualidade do atendimento melhorou. Está mais rápido, mais ágil mas, eu não entendo porque a Prefeitura não se empenha mais".

idéia-central: a qualidade melhorou.

ancoragem: a qualidade do atendimento melhorou, está mais rápido, mais ágil.

\section{Santana, primeira vez que usa}

expressões-chave: segundo o cidadão/usuário, não houve mudanças na qualidade dos serviços. "Eu estou precisando de uma medicação e não a encontro em Posto nenhum. Agora 
está havendo muito empenho em melhorar os serviços, só por causa das eleições. Depois de três meses volta tudo a mesma coisa de sempre".

idéia-central: não houve mudanças na qualidade do atendimento.

ancoragem: idem.

\section{Santa Cecilia, 5 anos de uso}

expressões-chave: "agora com o PAS o serviço mudou bastante; a qualidade mudou para melhor. Não se sabe por quanto tempo o PAS vai ser bom. Está havendo muito empenho da Prefeitura em melhorar os serviços de saúde. Fizeram o PAS para melhorar".

idéia-central: a qualidade mudou para melhor.

ancoragem: fizeram o PAS para melhorar.

\section{Santa Cecilia, não usa os serviços}

expressões-chave: para o cidadão/usuário não houve mudanças na qualidade dos serviços. "Continua ruim. Acha que não está havendo empenho da Prefeitura para melhorar os serviços".

idéia-central: não houve mudanças, os serviços continuam ruins.

ancoragem: idem.

\section{Santa Cecilia, 2 anos de uso}

expressões-chave: "depois do PAS não tem tanta fila e os médicos atendem melhor os pacientes. A Prefeitura está se empenhando para melhorar os serviços. Mudou para melhor". idéia-central: mudou para melhor.

ancoragem: a Prefeitura está se empenhando para melhorar os serviços; mudou para melhor.

\section{Santa Cecilia, não usa}

expressões-chave: "a vizinhança diz que o Posto melhorou bastante. A Prefeitura está se empenhando para melhorar. Acho que é por causa das eleições".

idéia-central: mudou para melhor.

ancoragem: a vizinhança diz que o Posto melhorou bastante.

\section{Santa Cecília, não usa}

expressões-chave: "eles mudaram os serviços. Não sei dizer se para melhor ou pior. Pelo menos se vê que estão tentando fazer alguma coisa diferente. A Prefeitura está se empenhando para melhorar os serviços".

idéia-central: pelo menos se vê que estão tentando fazer alguma coisa diferente. 
ancoragem: idem.

12. Vila Madalena, 15 anos de uso

expressões-chave: a percepção foi que os serviços melhoraram. "Com o PAS o atendimento é mais rápido. Está havendo empenho para melhorar. Espera-se que não seja só por causa das eleições".

idéia-central: os serviços melhoraram.

ancoragem: está havendo empenho para melhorar.

\section{Vila Madalena, não usa}

expressões-chave: a percepção do cidadão/usuário é que está havendo empenho da Prefeitura em melhorar os serviços mas, ainda não houve mudanças na qualidade. "Numa cidade tão grande, por mais que se faça sempre é pouco".

idéia-central: não houve mudanças.

ancoragem: numa cidade como São Paulo por mais que se faça sempre é pouco.

\section{Vila Madalena, não usa}

expressões-chave: segundo o cidadão/usuário a Prefeitura está se empenhando para melhorar os serviços. "Hoje há mais organização, mais remédios. Mudou para melhor".

idéia-central: mudou para melhor.

ancoragem: hoje há mais remédios, mais organização.

\section{Vila Madalena, 4 anos de uso}

expressões-chave: "houve mudanças na qualidade para melhor. O PAS melhorou muito o atendimento, tanto dos médicos como dos funcionários. Está havendo muito empenho da Prefeitura para melhorar. Acho que deveria melhorar o atendimento dentário". idéia-central: mudou para melhor. ancoragem: o PAS melhorou muito o atendimento, tanto dos médicos como dos funcionários.

\section{Vila Madalena, 20 anos de uso}

expressões-chave: "acho que está melhorando, não sei se é por causa das eleições. Hoje tem mais funcionários. $O$ atendimento é mais rápido. A Prefeitura está tentando melhorar mas tem muito ainda o que melhorar".

idéia-central: mudou para melhor.

ancoragem: acho que está melhorando, não sei se é por causa das eleições.

17. Vila Madalena, mais de $\mathbf{1 0}$ anos de uso 
expressões-chave: "o atendimento está mais rápido, está melhor".

idéia-central e ancoragem: idem.

\section{Vila Madalena, 13 anos de uso}

expressões-chave: "antes os Postos eram lotados. Faltavam médicos. Mesmo consulta com hora marcada era três horas depois. Agora não, o serviço está mais tranqüilo. Mudou para melhor. Eles deviam melhorar os hospitais, principalmente à noite, quando faltam médicos". idéia-central: mudou para melhor.

ancoragem: idem, há mais médicos.

\section{9. Água Funda, 20 anos de uso}

expressões-chave: "depois do PAS o serviço mudou para melhor". idéia-central e ancoragem: idem.

\section{0. Água Funda, anos de uso}

expressões-chave: "antes a desumanidade com a mulher era total. Melhorou depois do PAS. Falta melhorar mais. Está havendo empenho para isso. As mulheres que freqüentam o serviço e os funcionários pensam assim. Hoje os médicos dão mais atenção".

idéia-central: melhorou depois do PAS.

ancoragem: melhorou depois do PAS. Falta melhorar mais. Está havendo empenho para isso. As mulheres que freqüentam o serviço e os funcionários pensam assim.

\section{1. Água Funda, não usa}

expressões-chave: "a Prefeitura está se empenhando para melhorar os serviços por causa das eleições. Está havendo mudanças mas tenho dúvidas sobre elas. Não sei se está havendo melhorias".

idéia-central: tenho dúvidas sobre as mudanças.

ancoragem: a Prefeitura está se empenhando para melhorar os serviços por causa das eleições.

\section{2. Água Funda, não usa}

expressões-chave: "estou ouvindo falar que os serviços estão melhorando. Acho que a Prefeitura está se empenhando por causa das eleições. São interesses politicos".

idéia-central: melhoria em função das eleições.

ancoragem: acho que a Prefeitura está se empenhando por causa das eleições. São interesses políticos. 


\section{3. Água Funda, não usa}

expressões-chave: "parece que no início o PAS foi bom mas depois piorou. Há pouco empenho da Prefeitura para melhorar os serviços. É só política".

idéia-central: há pouco interesse em melhorar.

ancoragem: parece que no início o PAS foi bom mas depois piorou . É só política.

\section{São Miguel Paulista, não usa}

expressões-chave: segundo o cidadão/usuário não houve mudanças para melhor na qualidade dos serviços de saúde da Prefeitura. "Os beneficiados são os políticos e os governantes. Eles tentam mostrar que a Prefeitura está se empenhando para melhorar os serviços de saúde mas, na verdade, isso não acontece".

idéia-central: os beneficiados são os políticos e governantes.

ancoragem: eles tentam mostrar que a Prefeitura está se empenhando para melhorar os serviços de saúde mas, na verdade, isso não acontece.

\section{São Miguel Paulista, 20 anos de uso}

expressões-chave: "houve mudanças para melhor; o atendimento é mais rápido; tem médico a toda hora. Está havendo muito empenho da Prefeitura para melhorar".

idéia-central: houve mudanças para melhor.

ancoragem: está havendo muito empenho da Prefeitura para melhorar.

\section{São Miguel Paulista, 2 anos de uso}

expressões-chave: "não houve mudanças na qualidade; está a mesma coisa que antes. Cheguei no pronto-socorro às $13: 00 \mathrm{H}$ e estou saindo só agora, às $15: 30 \mathrm{H}$. Não há atendimento rápido. Pode até mudar".

idéia-central: não há mudanças na qualidade.

ancoragem: não houve mudanças na qualidade; está a mesma coisa que antes.

\section{São Miguel Paulista, não usa}

expressões-chave: "a qualidade está do mesmo jeito. Uma hora melhora e outra piora. Há pouco empenho da Prefeitura em melhorar os serviços. Faltam médicos e enfermeiros".

idéia-central: uma hora melhora e outra piora.

ancoragem: idem.

\section{São Miguel Paulista, 7 anos de uso}

expressões-chave: "não houve melhoria na qualidade do serviço. As filas não acabaram. Os funcionários do PAS são mais bem pagos mas, não são experientes e não são melhores. 
Eles dão pouca atenção, não examinam, não medem a pressão. Os funcionários da Prefeitura foram postos para fora".

idéia-central: não houve melhoria na qualidade do serviço.

ancoragem: não houve melhoria na qualidade do serviço. Os funcionários da Prefeitura foram postos para fora.

29. São Miguel Paulista, 8 anos de uso

expressões-chave: "houve mudanças na qualidade para pior. Está havendo muita propaganda do PAS por causa das eleições. Depois das eleições isso vai acabar".

idéia-central: a qualidade piorou.

ancoragem: está havendo muita propaganda do PAS por causa das eleições.

\section{São Miguel Paulista, não usa}

expressões-chave: na visão deste cidadão/usuário, com o PAS o serviço melhorou. "Não existem mais aquelas filas imensas, os médicos não saem mais do hospital para tomar cafezinho e ficar batendo papo no bar. A Prefeitura está se empenhando para melhorar os serviços. O médico deveria orientar mais, fazer trabalho educativo e preventivo".

idéia-central: com o PAS o serviço melhorou.

ancoragem: os médicos não saem mais do hospital para tomar cafezinho e ficar batendo papo no bar.

\subsection{Categoria Temática: Participação/Democratização}

1. Santana, 8 anos de uso

expressões-chave: "todos têm esse direito, de participar e de ser atendido".

idéia-central e ancoragem: idem.

2. Santana, 5 anos de uso

expressões-chave: "o povo tem o direito de ser bem atendido e de ganhar o remédio quando não pode comprar".

idéia-central e ancoragem: idem.

\section{Santana, 4 anos de uso}

expressões-chave: "nós temos o direito de ser atendidos".

idéia-central e ancoragem: idem.

\section{Santana, 10 anos de uso}




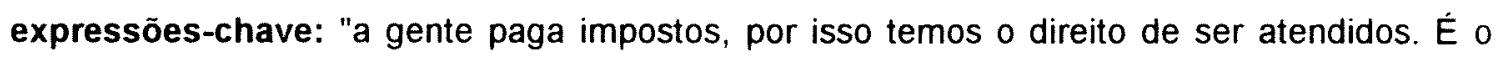
atendimento básico, como consultas e vacinas".

idéia-central: direito de ser atendido.

ancoragem: a gente paga impostos, por isso temos o direito de ser atendidos. (direito do cidadão e dever do Estado).

\section{Santana, primeira vez que usa}

expressões-chave: "é você poder ser bem atendido e bem tratado e ter o seu problema resolvido".

idéia-central e ancoragem: idem.

\section{Santana, primeira vez que usa}

expressões-chave: "não tenho nada a dizer".

\section{São Miguel Paulista, não usa}

expressões-chave: "agora o povo participa mais, está reagindo, não só na saúde mas, em geral. As pessoas cobram mais, exigem seus direitos à saúde para serem atendidos. Sei dos Conselhos de Saúde do Estado, não sei se a Prefeitura tem Conselhos".

idéia-central: hoje as pessoas cobram mais, exigem seus direitos à saúde.

ancoragem: agora o povo participa mais, está reagindo, não só na saúde mas em geral.

\section{São Miguel Paulista, não usa}

expressões-chave: "na época da Erundina procurou-se dialogar com a população mas, a falta de experiência e a dificuldade de se comunicar complicou o trabalho da Prefeitura. A população não está preparada para uma administração popular, mais voltada para o social. Os funcionários comentavam que o PT falava demais mas, não resolvia os problemas. As pessoas não estão acostumadas a pensar. Falta consciência à população. Durante o governo da Erundina foram formados dois grupos: um que se interessava pelo que estava acontecendo, participava, debatia. Muitos eram militantes do PT. Outro grupo era dos que não gostavam de participar, de debater, de pensar".

idéia-central: na época da Erundina procurou-se dialogar com a população mas faltou experiência e capacidade de comunicação à administração.

ancoragem: a dificuldade de se comunicar complicou o trabalho da Prefeitura. A população não está preparada para uma administração popular, mais voltada para o social. Os funcionários comentavam que o PT falava demais mas não resolvia os problemas. As pessoas não estão acostumadas a pensar. 


\section{São Miguel Paulista, 8 anos de uso}

expressões-chave: "atualmente o sistema é fechado, não permite que as pessoas tenham informações. Não se exercita a democracia. Todos têm direitos à informação, ao atendimento, a remédios".

idéia-central: hoje o sistema é fechado

ancoragem: não se exercita a democracia.

\section{São Miguel Paulista, 7 anos de uso}

expressões-chave: "duas épocas em que as pessoas participavam mais, não faltavam médicos e remédios: Mário Covas e Erundina. $\mathrm{Na}$ época da Erundina tinha mais preocupação com o bem-estar do povo, com o direito de todos serem atendidos. Outro dia fui atendida no PAS e fui obrigada a fazer exame no Posto do Estado".

idéia-central: na época da Erundina preocupação com direito, com o social.

ancoragem: na época da Erundina tinha mais preocupação com o bem-estar do povo, com o direito de todos serem atendidos. idem.

\section{São Miguel Paulista, não usa}

expressões-chave: "eu sei que tenho direitos porque pago impostos mas, também tenho o dever de ver se os serviços estão funcionando bem".

idéia-central: direitos e deveres de cidadão.

ancoragem: eu sei que tenho direitos porque pago impostos mas, também tenho o dever de ver se os serviços estão funcionando bem.

\section{São Miguel Paulista, 2 anos}

expressões-chave: "participação da população só vi na administração anterior. Eu tenho o direito de ser examinado, avaliado e saber o que está acontecendo comigo. Só olhar não resolve".

idéia-central: participação da população só vi na administração anterior. ancoragem: idem.

\section{São Miguel Paulista, 20 anos de uso}

expressões-chave: "todo mundo tem o direito de ser atendido porque paga imposto". idéia-central e ancoragem: idem.

\section{4. Água Funda, não usa}

expressões-chave: "não há participação em nada".

idéia-central e ancoragem: idem. 
15. Água Funda, não usa

expressões-chave: "a população não tem direito à saúde".

idéia-central e ancoragem: idem.

16. Água Funda, não usa

expressões-chave: "esse direito à saúde parece que não é respeitado".

idéia-central e ancoragem: idem.

17. Água Funda, usa há anos

expressões-chave: "não sei falar sobre isso".

idéia-central e ancoragem: idem.

18. Água Funda, 20 anos de uso

expressões-chave: "desconheço participação na saúde e não há respeito ao direito de todos serem atendidos".

idéia-central e ancoragem: idem.

19. Vila Madalena, não usa

expressões-chave: "com a implantação do PAS a Prefeitura deu mais direito à saúde para a população".

idéia-central e ancoragem: idem.

\section{Vila Madalena, 13 anos de uso}

expressões-chave: "meu marido já participou de reuniões sobre saúde, que nunca deram em nada. $\mathrm{Na}$ época da Erundina o pessoal participava mais mas, parou por acomodação. Todos deveriam ter direito à saúde, principalmente os pobres mas hoje, eles não estão dando esse direito. Não há mais participação e nem informação".

idéia-central: na época da Erundina a participação não deu em nada.

ancoragem: na época da Erundina o pessoal participava mais mas, parou por acomodação.

\section{Vila Madalena, 4 anos de uso}

expressões-chave: "mesmo quem tem plano de saúde particular está usando o PAS.

direito à saúde aumentou depois do PAS".

idéia-central: o direito à saúde aumentou depois do PAS.

ancoragem: idem. 


\section{Vila Madalena, 15 anos de uso}

expressões-chave: "acho que a participação é importante. Atualmente as pessoas participam mais e com o PAS aumentou o direito à saúde".

idéia-central: atualmente as pessoas participam mais e com o PAS aumentou o direito à saúde.

ancoragem: idem.

\section{Vila Madalena, não usa}

expressões-chave: "todos deveriam ter direito à saúde. Não existe participação".

idéia-central e ancoragem: idem.

\section{Vila Madalena, usa há muito}

expressões-chave: "no governo anterior tinha participação da população".

idéia-central e ancoragem: idem.

25. Vila Madalena, 20 anos de uso

expressões-chave: "todo mundo tem direito à saúde. A população vem cada vez mais participando da saúde".

idéia-central: a população vem cada vez mais participando da saúde.

ancoragem: idem.

\section{Santa Cecília, 5 anos de uso}

expressões-chave: "as pessoas pagam a previdência a vida toda e deveriam ter direito a serem atendidas com dignidade. Está na Constituição. Nunca existiu participação".

idéia-central: nunca existiu participação.

ancoragem: nunca existiu participação.

27. Santa Cecília, não usa

expressões-chave: "deveria haver mais participação da população, para cobrar melhor assistência".

idéia-central e ancoragem: idem.

\section{Santa Cecília, não usa}

expressões-chave: "todos deveriam ter assistência médico-hospitalar de boa qualidade, com bons aparelhos, bons médicos, tudo gratuitamente. Deveria ter participação".

idéia-central: todos deveriam ter assistência médica gratuita.

ancoragem: idem. 


\section{Santa Cecilia, 2 anos de uso}

expressões-chave: "não existe participação. Nunca houve. Toda pessoa tem o direito de ter assistência de boa qualidade".

idéia-central: não existe participação; nunca houve.

ancoragem: idem.

\section{Santa Cecília, não usa}

expressões-chave: "nunca houve participação na Prefeitura. O povo tem o direito de ter saúde gratuita, hospitais bons, médicos atenciosos e capazes".

idéia-central: nunca houve participação na Prefeitura.

ancoragem: idem.

\subsection{Categoria Temática: Trabalho Integrado}

\section{Santa Cecilia, não usa}

expressões-chave: "trabalhos de integração e participação popular só em época de eleição". idéia-central: idem.

ancoragem: trabalhos de integração e participação popular só em época de eleição.

Obs.: os demais entrevistados de Santa Cecilia não se pronunciaram sobre este tema.

\section{Santana, não usa}

expressões-chave: "não, isso de integração nunca aconteceu".

idéia-central: idem; ancoragem: idem.

Obs.: os demais entrevistados de Santana não se pronunciaram sobre este tema.

\section{Vila Madalena, não usa}

expressões-chave: "acho que houve alguma coisa de integração no governo anterior mas, não sei explicar o que foi".

idéia-central: integração no governo anterior.

ancoragem: acho que houve alguma integração no governo anterior mas, não sei explicar o que foi.

4. Vila Madalena, 13 anos de uso 
expressões-chave: "no governo da Erundina teve algum tipo de integração porque ela se preocupava mais com as condições de vida".

idéia-central: idem; ancoragem: idem.

\section{Vila Madalena, não usa}

expressões-chave: "pelo que eu vejo na televisão sobre o PAS, acho que o governo está dando mais atenção aos pobres".

idéia-central: idem; ancoragem: idem.

Obs.: os demais entrevistados da Vila Madalena não se pronunciaram sobre este tema.

\section{6. Água Funda, não usa}

expressões-chave: "melhorar as condições de vida e priorizar os mais necessitados, só se for jogada política".

idéia-central: idem; ancoragem: idem.

Obs.: os demais entrevistados da Água Funda não se pronunciaram sobre este tema.

\section{São Miguel Paulista, não usa}

expressões-chave: "na época da Erundina teve integração com creches e escolas".

idéia-central: idem; ancoragem: idem.

\section{São Miguel Paulista, 7 anos de uso}

expressões-chave: "a Erundina se preocupou mais com isso. la mais nos bairros ver o que estava acontecendo".

idéia-central: idem; ancoragem: idem.

\section{São Miguel Paulista, 8 anos de uso}

expressões-chave: "no governo anterior havia mais recursos à disposição da população". idéia-central: idem; ancoragem: idem.

\section{São Miguel Paulista, não usa}

expressões-chave: "na época da Erundina ela procurou integrar os serviços e melhorar as condições de vida e dar mais atenção aos mais necessitados. Mas os dirigentes não conseguiram passar isso à população. Ficou apenas na intenção. Acho que não teve tempo para isso".

idéia-central: política de integração e promoção das condições de vida. 
ancoragem: na época da Erundina ela procurou integrar os serviços e melhorar as condições de vida e dar mais atenção aos mais necessitados.

Obs.: os demais entrevistados de São Miguel Paulista não se pronunciaram sobre este tema. 


\section{ENTREVISTAS COM DIRIGENTES}

1.Quais as razões ou os porquês da escolha das diretrizes básicas, que orientaram o processo de reforma administrativa da Secretaria Municipal da Saúde a partir de 1989 ?

\section{Virgínia Junqueira}

Estava tentando lembrar do Eduardo Jorge, porque foi ele o grande empreendedor da descentralização, não só da Secretaria Municipal da Saúde, mas da Prefeitura porque, você pensar que aos três meses de gestão ele já partiu para a regionalização, para a divisão em 10 regionais de saúde e deu inicio à construção dos Distritos. Olha, eu diria antes que houve uma necessidade. A compreensão de uma realidade extremamente complexa que é o município de São Paulo, com uma estrutura de serviços que aliava a atenção hospitalar com a atenção ambulatorial, a necessidade de apreender essa realidade e de dar conta dela, obriga um dirigente que tenha um conteúdo de democracia nos seus valores e crenças, abriga 0 dirigente a fazer isso de imediato. Se você pegar uma cidade desse porte, de quase 10 milhões de habitantes, como é que você vai pensar poder dar conta, se você tem consciência dessa complexidade? Ai eu acho claro que a qualidade do governante de uma cidade de 10 milhões de habitantes é centralizar tudo.

Agora, se você é um dirigente democrático, como era o caso do Eduardo, você imediatamente percebe a necessidade de democratizar, para dar conta da realidade, na medida em que você tem uma relação de responsabilidade com essa realidade, e o Eduardo tem. Ele é uma pessoa extremamente responsável. A questão da responsabilidade dele acho que é muito pesada. Você tem que dar conta dessa responsabilidade, da questão saúde, ainda que fosse sob o prisma da assistência médica de uma cidade de 10 milhões de habitantes, você tem que descentralizar. Eu acho que é uma questão de necessidade, que a visão democrática impõe. Para mim no fundo, aí está uma questão de democracia, de responsabilidade.

Porque você descentralizar não é só uma questão técnica-administrativa. O que tem por trás da descentralização, da regionalização, da distritalização, no meu entendimento e no entendimento do Eduardo, não é só uma questão técnico-administrativa, mas é uma questão política; política no sentido de você ter a responsabilidade, ter o poder sobre uma questão, a questão saúde, para uma cidade de 10 milhões de habitantes. E como é que você vai resolver isso? Então, a divisão do poder é uma coisa que permite você fazer uma aproximação da realidade, que está muito mais colada às necessidades da população do que qualquer outra escolha. Eu tenho a impressão que isto fez o Eduardo a se conduzir desta maneira, democraticamente. 
Coloca-se a divisão do poder e não a divisão do poder só entre os técnicos, mas uma divisão do poder tal que vai permitir que a população se aproxime daquela esfera de governo, no caso municipal, que você tinha na mão.

- Eduardo que é uma pessoa que sempre teve relação com os movimentos populares. sabia que só aproximando as esferas de governo do local de trabalho, de moradia, onde as pessoas podem realmente operar, é que você pode conseguir, não digo dominar esta realidade, mas entendê-la melhor e trabalhar melhor com ela. Para mim é a questão de democracia e da responsabilidade. Fundamentalmente é a divisão, é compartilhar o poder, enfim, deixar esse poder que você detém, que é o poder administrativo, que ele seja dividido. Encarar isso como uma forma de relação entre as pessoas, e não só da esfera técnicoadministrativa. Eu acho que foi isso.

$\mathrm{Na}$ figura do Eduardo eu sinto muito isso. Apesar de a gente ter trabalhado junto só um ano e três meses. A noção de responsabilidade, desse peso da responsabilidade, em uma pessoa que tem isso muito presente. Isso deu força, não é gratuito, não. É o Eduardo que conseguiu fazer isso e pronto, em um ano e três meses. Não é gratuito, ou seja, não seria qualquer outro secretário que poderia fazer isso, que teria condições de fazer isso. Por que? Porque ele é uma pessoa que acumulou anos de trabalho junto ao movimento popular, desse exercicio de participação, por mais frágil que ele seja, e a gente sabe que o movimento popular é frágil, de exercício dessa democracia junto à população, nas formas possiveis que ela tem, discussão com a população, de decisão com a população, de estar junto, apoiando o movimento popular. Esta pessoa aprende. Se a pessoa já é trabalhada, se já é assim, vai aprendendo, vai tocando. Isso dá condições para fazer esse tipo de coisa, para tomar esse tipo de atitude administrativa, que tem um significado político muito grande para mim. $O$ que está por trás é isso. a democracia e a responsabilidade.

Agora, isso para mim não estava bem elaborado, quando a gente pensa anos depois. Mas acho que analisando esse processo, o que permitiu o Eduardo fazer isso naquele momento, é porque ela tinha isso presente. E ele era uma pessoa que sentia uma urgência danada em fazer, em implantar os Distritos Sanitários, a todo momento ele falava disso.

\section{Alex Nemes Filho}

As diretrizes da política de saúde tem muito a ver com a história do PT, com a entrada do PT na administração. Na verdade, no seu conjunto já traz uma proposta de participação na gestão, traz uma proposta de participação da população, como uma questão nuclear da proposta. A idéia da descentralização e algumas prioridades, isto é, a prioridade voltada para a questão social. As áreas sociais, saúde, educação, etc., são conjuntos de propostas que o PT traz para administração como um todo. 
$\mathrm{Na}$ área da saúde a gente traz, além da vivência dentro do $\mathrm{PT}$, aquilo que a gente aprendeu na Secretaria de Estado da Saúde. A gente que eu digo é o seguinte: a composição do PT tem muito sanitarista e a gente traz a experiência da Secretaria de Estado da Saúde, construindo uma rede básica de saúde que contemplasse o conjunto das necessidades da população, privilegiando a questão de saúde coletiva, mas tentando dar conta da prestação de serviços, através de uma rede pública que tivesse os três níveis de serviços.

Juntando essas duas coisas ${ }^{85}$ a gente tem ai, o que eu acho que é o traço da nossa administração. E o que a gente tentou fazer? Tentou readequar as nossas Unidades com pessoal qualificado e multiprofissional. Tentou melhorar o aporte de recursos materiais aos serviços, e tentou criar uma certa tecnologia que fosse baseada, orientada pela visão epidemiológica, ou seja, tentou construir modelos de intervenção, programas de saúde, com essa orientação. Também tem toda experiência de cada um no pedaço. O pessoal da Saúde Mental trazendo já uma experiência de Saúde Mental na rede básica, de porta-de-entrada para atender as questões mais importantes. A gente vivia aquela temática de não fazer uma prestação de serviços baseada na atenção médica individual. Havia as referências epidemiológicas, e a partir dai seria construída a atenção orientada por critérios epidemiológicos.

Isso vem muito até da área da Medicina Preventiva da USP, que tem desenvolvido esse tema, que trabalha muito com isso, e também da nossa experiência em Programação, na época em que a Secretaria de Estado da Saúde trabalhava com isso, desenvolvia seus programas. A idéia era dar resolutividade e ao mesmo tempo alguma eficácia para os serviços. Não ficar só atendendo a demanda pontual, mas tentar resolver os problemas de saúde, pegar os grupos mais desfavorecidos, conseguir contemplar a eqüidade. $E$ também ter locução com a população.

Ainda na questão dos modelos epidemiológicos, a gente tinha interesse em inovar um pouquinho mais, não ser aquele modelo clássico de epidemiologia, mas ser alguma coisa um pouquinho mais ampliada. A gente não chegou a desenvolver muito isso na linha do atendimento dos programas, a questão da comunicação um pouco maior, com o usuário na hora de atender, montar os trabalhos em grupo, botar a equipe multiprofissional para se integrar. Nós não elaboramos isso muito tecnicamente, mas na prática a gente caminhou para montar equipes que fizessem isso.

Caminhamos também para incorporar as questões de humanização no atendimento. A história do Hospital-Dia, para que pudesse diminuir a violência institucional no cuidado ao portador de sofrimento mental. Mas eram programas tradicionais, epidemiológicos clássicos. Referencial só de saúde pública. Mas incorporaram algumas questões importantes. Dai essa

\footnotetext{
${ }^{85}$ Essas duas coisas sâo as seguintes: a diretriz da participação social e a proposta em organizar a rede de serviços de modo regionalizado. hierarquizado e integrado.
} 
historia da tecnologia que eu estou falando. Na prática a gente trabalha. Teoricamente a gente não trabalha muito.

Não sei se dava, nem sei se na Secretaria há condições de se pensar muito em teoria. A não ser que haja uma pessoa que seja muito importante, um Paulo Singer, um Paulo Freire, alguém que pudesse fazer uma reflexão enquanto você desenvolve a política. Em geral nas Secretarias é muito dificil. A academia acaba depois pegando essa experiência. Os Conselhos de Saúde foram muito importantes. O Conselho Municipal de Saúde, os Conselhos Gestores Regionais, os Conselhos Distritais e Locais, com o movimento popular já constituido. tinham alguma expressão.

\section{Pedro Dimitrov}

As diretrizes básicas constam de documentos oficiais. Um dos principais ficou conhecido como Documento Número Um. Eu não vou me lembrar de todos os aspectos deste documento agora. Outro documento, foi na linha sobre como reestruturar a Secretaria da Saúde. Na realidade, esta segunda visão é uma visão mais administrativa. As questões básicas que se colocavam na época era a de se ter uma unificação dos serviços de saúde, das UBS, dos laboratórios, dos Hospitais, os serviços de epidemiologia, sob um único comando, numa determinada área geográfica, e descentralizar o poder, levar o poder mais próximo do usuário e mais próximo do prestador de serviços. Eu acho que esta é uma questão central da restruturação da Secretaria. Lógico que, vinculado a isso, estão subentendidas aquelas idéias que estão no Documento Número Um, como a possibilidade de controle pela população, possibilidade para que os Conselhos Gestores pudessem ser mais concretos de poder, a questão de você ter uma racionalização do uso dos recursos e reduzir a quantidade de recursos humanos utilizados na área administrativa, colocando mais pessoas na atividade-fim, reduzindo as ações dos serviços verticais. Na hora que você reduz, você acaba com o serviço vertical, unifica sob um único comando no nivel local, você simplifica e reduz a quantidade de pessoas ligadas à parte administrativa. As outras questões que você coloca ai, valeria a pena retomar pelo Documento Número Um, que fala dos recursos humanos, dos recursos financeiros e dos vários compromissos do governo com o setor saúde.

\section{Álvaro Escrivão Júnior}

Você encontra nos documentos da época, mais ou menos escrito, o que se propunha em termos formais. Em termos da tentativa de implantação, eu acho que o principal foi o enfoque da descentralização, no sentido de integrar os dois pedaços da Secretaria. a Superintendência Hospitalar e o Departamento da Saúde da Comunidade, e com o discurso muito grande de se tentar organizar o trabalho das Unidades, de modo voltado para o que se chamava de "reais necessidades" da população. Então tinha um esforço grande, eu acho que 
de restruturação administrativa mesmo, a "la Leser", de quem todo mundo é meio filhote. Eu acho que sanitarista gosta de uma reforminha administrativa, não sei se ainda gosta, mas era chegado a uma reforminha administrativa e carreira. Duas coisas que sanitarista gosta, de reforma administrativa e fazer discurso de carreira. Eu acho que é um tipo de pensamento, de visão, que a gente tinha. Você tinha esse pedaço e tinha um pedaço de realmente você tentar fazer um diagnóstico de saúde, uma análise da situação de saúde da população e uma certa vontade, talvez até mecanicamente, de organizar o trabalho voltado para o diagnóstico de saúde. Então era a idéia da democracia, da participação, que se acreditava muito, que isso aí devesse ter um peso muito grande. Pessoalmente eu sempre achei um discurso idealista mesmo, com o compromisso de tensionar os limites do possivel. Aquela história de que os navegadores, não sei quem disse isso, se orientam pelas estrelas para chegar a meta. Acho que algumas pessoas tinham um pouco de fantasia de chegar às estrelas. Acho que outras não. Acho que em linhas gerais as diretrizes eram essas, a humanização, a profissionalização. Isso tudo está no Documento Número Um.

\section{Carlos Alberto Pletz Neder}

Boa parte da equipe que acabou dirigindo a Secretaria era egressa do Movimento da Reforma Sanitária. Pessoal já com experiência na rede estadual de saúde. Alguns com vinculo na rede municipal. Progressivamente as pessoas foram se incorporando até de forma mais definitiva como funcionário da rede municipal, prestando concurso, mas havia um compromisso com aquelas diretrizes, com o movimento da reforma sanitária, das Conferências Nacionais de Saúde, que culminaram com texto Constitucional. Então, eu acho que estava bem estabelecido na equipe, já desde a época do Eduardo, a necessidade de implantar o Sistema Único de Saúde. De outubro de 88 (a gente assume em janeiro de 89) essa era a grande novidade: como fazer o SUS sair do papel, lembrando que a lei orgânica da saúde só veio em 90 . Então o ano de 89 inteirinho, nós tivemos que conviver com a transição do governo Sarney, que não apostava na implantação do SUS. A proposta dele era o SUDS. Sem apoio do nivel estadual, com as dificuldades de entendimento com os governos do $P M D B$, e a nível municipal, tendo que enfrentar todo o sucateamento da máquina.

Então, eu vejo que o nosso trabalho passou por alguns momentos. Um momento de tentativa de implantação do SUS, com base na legislação, e no segundo momento, que eu chamaria de momento de criatividade, no sentido de buscar adequar a proposta à realidade de São Paulo, que foi o momento em que nós tivemos que discutir as estratégias, que foi a primeira, a segunda e a terceira Conferência Municipal de Saúde, e analisar até que ponto nós priorizariamos a questão dos Distritos de Saúde, como é que ficava a proposta da vigilância à saúde, que peso nós dariamos aos programas de saúde pública, aos trabalhos de promoção, de prevenção, dado que toda a história anterior da Secretaria, era centrada nos 
programas verticalizados e na prioridade para o atendimento de urgência, médico-hospitalar, individual e curativo, mas sobretudo de urgência, e havia um discurso de que essa era a função do município. Com a proposta do SUS e com a análise que se fez sobre o problema de saúde do município de São Paulo, chegou-se a conclusão de que era necessário a gente introduzir a discussão da proposta da vigilância à saúde de forma mais abrangente, e dos programas de saúde pública. Então eu acho que este foi um momento importante dentro da equipe, de você reorientar as atividades da Secretaria num grau de radicalidade maior, tanto no que diz respeito à descentralização, com a formação dos Distritos enquanto Unidades Orçamentárias. Sempre houve uma polêmica em torno disso, como entender os equipamentos, mas sobretudo, como entender os programas dentro das propostas da Secretaria.

\section{Eduardo Jorge Martins Alves Sobrinho}

Em primeiro lugar, a questão fundamental é por acreditar que a reforma de Estado prevista na Constituição Brasileira de 88 que instituiu o Sistema Único de Saúde, foi necessária e viável, e que as suas bases filosóficas deveriam ser aplicadas às últimas consequiências, mesmo que naquele ano de 1989, é bom lembrar, não houvesse ainda nenhuma lei regulamentadora da Constituição. Portanto, a Constituição, nesse campo da saúde e quase todos os outros, ainda estava no papel. Dependia de leis regulamentadoras. Na saúde só saiu em setembro de 1990. Então, no começo de 89 nós estávamos ainda com um sistema de saúde pré-constituição, porque não havia regulamentação. Mas aqui, a Prefeitura Municipal de São Paulo, mesmo não tendo a lei regulamentadora, resolveu aplicar os princípios da Constituição. Quais eram os principios? Primeiro, a universalização; segundo, a democratização; terceiro, a descentralização e quarto, a integralidade da assistência.

$\left.1^{\circ}\right)$ A universalização: implicava em você organizar um serviço que tendencialmente deveria atender todo 0 conjunto da população paulistana. Tendencialmente, porque não havendo municipalização, nem lei, a Prefeitura continuaria com seus serviços, até que houvesse a lei regulamentadora que garantisse a transferência dos serviços federais e estaduais para o municipio. Mas, nós já deveríamos ir nos preparando para organizar um serviço que tivesse uma geografia ou um esqueleto, que deveria ser responsável por $100 \%$ da cobertura universal, com a municipalização.

$2^{\circ}$ ) A questão da democratização: outro principio do SUS é que o usuário ou cidadão, tem que fiscalizar, tem que coogerir, tem que ser co-responsável com o Estado pelos serviços que ele e sua família vão receber. Não é uma questão paternalista de simplesmente abrir mão de uma parcela do poder para o cidadão, por uma questão ideológica. É uma questão de direito, também administrativo, como também de cobrança a esse cidadão que vai receber os serviços financiado por ele próprio, mas que ele vai participar da gestão. Isto 
implica em um certo sacrifício porque, uma mãe de família, um trabalhador, qualquer cidadão, que já tem mil obrigações com o trabalho e com a familia, e ainda vai ter que despender um pouco do seu tempo para fiscalizar, para sugerir, para co-participar da gestão. Mas é uma questão fundamental, para que o serviço tenha qualidade, não seja impessoal, não seja brutal, seja um serviço realmente humano. Que tenha participação do trabalhador, do usuário, da dona-de-casa.

$\left.3^{\circ}\right)$ A questão da descentralização: que é você levar o serviço para perto da casa da família, do trabalhador, da criança. Para organizar uma estrutura geográfica de serviços que fique acessivel, tanto para o acesso, quanto para o controle do cidadão, e seja assim, um serviço mais eficiente e novamente, um serviço mais humano.

E finalizando, o último principio que orientou a reforma é o da integralidade da atenção, para você fazer tanto a parte preventiva qunto a curativa, de tal modo que sejam o máximo possivel integrada, para que não haja essa dicotomia que sempre foi tradicional no Brasil. A integralização de certa forma implicava em você estender os fluxos de integração para fora da SMS, em direção às outras Secretarias, como Educação, Saneamento, Transporte, SAR, etc., porque a saúde necessita de uma integração. Então, foi por esses quatro princípios da Constituição que em 1989 , fizemos a proposta de reforma administrativa da Saúde. Aliás, uma coisa que é muito importante e caracterizou uma certa diferença no ritmo da saúde em relação a outras áreas de políticas públicas da gestão Luiza Erundina, é que a Saúde tinha, ao contrário de outras áreas, uma política constitucional bastante clara sobre como fazer uma reforma. $E$ uma reforma da qual nós tínhamos participado, de longa data já, que desembocou na Constituinte, mas já vinha sendo gestada na área pública, nas universidades, nos movimentos populares. Então esse parâmetro, esse balizamento constitucional na área de saúde, é que possibilitou você logo no começo do governo Luiza Erundina, ter uma proposta bastante clara para ser implementada.

\section{Paulo Eduardo Mangeon Elias}

Eu direi que tem dois aspectos aí que eu acho que são relevantes: um de sua pergunta mesmo, nuclear, de me perguntar, o por que a Secretaria fez o que fez. Se a Secretaria fez isso porque o grupo que assumiu a SMS, mais do que um grupo de administração, era tributário de um pensamento na área da saúde que era o pensamento da Reforma Sanitária. Esse é um núcleo de resposta que você está querendo. Isto é, por que fez isso? Porque era tributário desse pensamento da Reforma Sanitária. Não só o grupo que estava na Secretaria, como na administração, eram tributários desse pensamento e portanto, nuclearmente porque fez, por causa disso, e porque também tinha uma concepção do pensamento da Reforma Sanitária. 
Tem um outro aspecto que eu acho importante. Como foi feito isso? Isto começou a ser gestado na Casa Rosada, que era a cada da mãe do Suplicy. Ganhou-se a Prefeitura de São Paulo numa situação tão inusitada, tão inesperada, que não se tinha nem lugar para fazer reuniões e precisava a mãe do Suplicy emprestar uma casa. Lá o grupo da saúde de reunia. Eram 11 pessoas, que começaram a se reunir para fazer essa transição. Das 11 pessoas, só 2 não foram para a administração. Eu e a Amélia Cohn. Os outros foram. Eu fui depois. A única que não foi, foi a Amélia, até o final. Eu fui depois. Nós começamos a reunião logo depois da eleição, logo depois do 15 de novembro. Eram 11 pessoas. Nesse grupo começou a se estruturar o segundo aspecto. Foram feitos também outros contatos. Foi feito contato com o pessoal da Santa Casa, com o Guedes. Começou a se delinear dois processos, um de organização para buscar contatos, informações sobre máquina da administração municipal e, uma outra linha, que não era um subgrupo, mas uma outra linha que produzia uma visão, uma diretriz geral para a Secretaria. Essa diretriz foi consubstanciada num documento chamado Documento Número Um. Aquele Documento Número Um consubstanciaria as grandes diretrizes da Secretaria, e que foram discutidas e formuladas neste grupo dos 11. Mas se você analisar bem aquele Documento Número Um, tem alguns elementos ali, que são característicos de quem redigiu aquele documento, de quem participava mais diretamente, de maneira que é um pensamento tributário da Reforma Sanitária Brasileira. Em poucas palavras eu diria isso para você, o porque a Secretaria fez a reforma que fez, mas eu acho que é importante também como fez. Depois, aquele documento foi colocado para apreciação dos Diretores Regionais.

\section{Como foi a aplicação dessas diretrizes ou pressupostos teóricos, sobre a realidade encontrada pela Secretaria durante aquela administração?}

Pedro Dimitrov

Na realidade houve uma facilitação, porque foi utilizada uma legislação antiga, autoritária, que permitia a restruturação dos serviços públicos por decreto, antes da Constituição de 88 e da Lei Orgânica Municipal. Portanto, nós fizemos uma reformulação de cima para para baixo, do Gabinete para baixo e aproveitando a experiência acumulada com a reforma havida na Secretaria de Estado da Saúde. Várias pessoas que participaram deste processo eram pessoas que vinham do Estado, que já tinham participado de restruturações organizacionais da Secretaria de Estado da Saúde. Na realidade, eu acho que essas diretrizes que estão no Documento Número Um, puderam ser implementadas em uma boa parte depois da reforma. A questão de você unificar todos os órgãos e descentralizar tudo. $O$ Gabinete ficou um órgão de pequenas dimensões e, ao mesmo tempo, integrador. Todas as assessorias que havia por programas, por especialidades, por profissionais, tudo isso foi 
desmontado e tudo isso foi reorganizado em 3 grandes áreas: a área de epidemiologia, pesquisa e informação, num único bloco - 0 CEPI - ( no Estado isso tudo é separado, tem o Centro de Vigilância Epidemiológica, tem o Centro de Vigilância Sanitária, tem o Instituto de Saúde, todos esses órgãos, o antigo DTN - Departamento Técnico Normativo - o CADAIS, todos esses órgãos são em nível central, de Gabinete e que cumprem essa função de Epidemiologia, Pesquisa e Informação ). Na Secretaria Municipal de Saúde, isso tudo ficou sob um único órgão; o segundo bloco, de assessoria para o desenvolvimento dos programas foi o Centro de Organização da Atenção à Saúde - COAS - com a perspectiva de ser um órgão enxuto, com poucas pessoas, e que trabalhasse com pessoas da própria rede, que dariam assessoria para o desenvolvimento de programas e apoio às UBS nas regiões e Distritos de Saúde e, o terceiro bloco, o terceiro órgão criado, foi o Centro de Recursos Humanos - $\mathrm{CRH}$ - vinculado aos recursos humanos, e que envolveria todos os aspectos de recursos humanos, desde os processos que se conseguiu trazer da Secretaria Municipal da Administração, como os processos relativos a concursos públicos, seleção e alocação de pessoal e também, desenvolvimento de pessoal, discussão de cargos, salários, esta história toda.

Na realidade, o que é que avançou e não avançou? Acho que nós avançamos muito em Epidemiologia, Pesquisa e Informação. Restruturamos todo o sistema, remontamos um novo sistema de informação na Secretaria Municipal de Saúde, o que era um dos objetivos da gente. Avançamos muito na área de recursos humanos, puxando tudo da Secretaria Municipal da Administração, assumindo a responsabilidade da área de administração e $\mathrm{RH}$, todos os concursos, fazendo todas as nomeações e tudo o mais na Secretaria, e avançamos um pouco na área de organização dos programas. Aí foi a área de mais conflito. Porque havia uma estrutura muito forte, por categoria profissional e por programas, e havia então um conflito entre os programas e os diretores de região, uma tendência de recentralização dos programas e a tendência maior de assumir o poder nas regiões. Essa é uma área onde houve muito conflito. E o terceiro aspecto que eu acho que avançou mais após um primeiro ano de muito dificuldade, onde nós radicalizamos reformas, radicalizamos no sentido de descentralizar $e$ dar autonomia para as ARS's e Distritos Sanitários, foi na estrutura orçamentária. Aquela do governo anterior, ela era antiga, com as Unidades Orçamentárias antigas. Então nós tivemos que deslocar as Unidades Orçamentárias de hospitais, transformá-las em U.O's das regiões, por exemplo. Nós tínhamos mais ARS's e Distritos Sanitários do que U.O's. As Unidades Orçamentárias antigas, em número menor, tiveram que dar conta de um número maior de regiões e Distritos. Só no ano seguinte nós conseguimos abrir mais U.O's, agora, de acordo com as regiões e Distritos criados. $\mathrm{E}$ a área de compras também teve uma dificuldade muito grande porque era uma área extremamente centralizada, e que se fez um esforço muito grande para que as regiões e Distritos passassem a ter um papel mais independente na área 
de compras. Então esse foi um processo também demorado. Então, finanças e compras, processo demorado, dada a estrutura centralizada existente, inclusive na Secretaria Municipal de Administração e Secretaria Municipal de Finanças. A área de Recursos Humanos, a que avançou mais, porque conseguimos descentralizar mais, trazer por delegação da prefeita para a Secretarıa Municipal de Saúde, atribuições que eram da Secretaria Municipal de Administração.

\section{Virginia Junqueira}

Uma palavra que sintetiza tudo isso é o "conflito". Conflito, como eu estava dizendo agora a pouco, é a contradição. Essas foram as duas coisas que regeram esse processo de democratização, não só dentro da Secretaria, mas na Prefeitura, que tinha como mote a questão da administração democrática ou, o governo democrático popular. Mas o que regeu foi o conflito e a contradição, de tal forma que não só para a população em geral, que nunca usou os serviços de saúde municipais, ou seja, que morava na cidade. Eu acho que para a população deve ter parecido uma coisa muito confusa. Porque aí, eu acho que a liderança máxima do governo, que era a prefeita, eu acho que ela começou num pique que eu acho que não persistiu. Eu tenho esse sentimento. Se no começo ela despontava como alguém que tinha a capacidade de manter esse relacionamento com a população mais pobre, com a maioria da população, conversar com a população, interpretando suas necessidades, enfim tentando aproximar essa população desta esfera de poder, ainda limitado, poder administrativo municipal limitado, a partir de um certo momento, ela (a prefeita) perdeu essa capacidade. Eu sinto assim. E essa perda de capacidade pelo governante máximo, que no caso era a prefeita, de fazer essa vinculação com a população e de tomar decisões administrativas que estivessem dando a sustentação ao discurso da democratização, fez com que a coisa fosse mais embolada ainda nos planos na Secretaria da Saúde

A nossa Secretaria era a que tinha o maior impeto, a maior iniciativa para a democratização. Até nos processos administrativos ela foi extremamente emperrada pelo conflito existente no interior do governo municipal. Eu acho que a maior demonstração disso foi a incapacidade de fazer com que o projeto da Reforma Administrativa, que era um projeto extremamente interessante, de criação das subprefeituras, de extinção das Secretarias da forma como eram, de constituição de Secretarias mais abrangentes, que articulavam melhor o setor social, articulavam e integravam os serviços do setor social, articulavam melhor todas as Secretarias e davam uma primazia realmente para o setor social. Esta é a maior demonstração. Não é que ela não conseguiria fazer a Reforma Administrativa ser aprovada pela Câmara. Não estou nem colocando isso. Estou dizendo que ela não conseguiu, que este projeto de Reforma Administrativa, que era extremamente interessante para a população da cidade, fosse discutido com a população da cidade. Fosse discutido. Fosse discutido com o 
cidadão. Tornasse-se pelo menos uma polêmica, no mínimo uma polêmica. Uma briga que fosse com a Câmara Municipal, onde a população de alguma maneira, no mínimo estivesse engajada na defesa deste projeto. Então eu acho que esta incapacidade foi uma incapacidade do governo municipal, que tinha um conteúdo de Reforma Administrativa muito bom, muito interessante, tanto que foi retomado por uns e outros candidatos na campanha passada. Alguns candidatos até de direita falaram em subprefeituras, que tinha um conteúdo extremamente interessante e não foi explorado. Foi perdido para a cidade. Foi perdido como discussão, como alavanca para democratização de uma cidade desse porte e que envolve uma população que está vivendo uma desigualdade muito grande. Então esse projeto de Reforma Administrativa da Prefeitura, eu acho que foi perdido no momento em que a Luiza Erundina perdeu a capacidade de ter a direção certa para a democratização real, que ela saísse do discurso para a realidade e para a articulação com a população. Ela perdeu para mim essa capacidade de se vincular com a população, que era a maioria da cidade. E aí se perdeu tudo. O tanto de energia que você perde e ai, o Secretário que sucedeu o Eduardo, o Neder, ele perdeu para desembolar os problemas administrativos. Consome tanto a capacidade das pessoas que as coisas que foram feitas, se continuou fazendo as coisas no caminho da democratização. Acho que a nossa Secretaria mostrou um caminho ainda que muito restrito porque estava cerceada por todos os lados. Cada coisa administrativa minima que se queria fazer no sentido de se descentralizar tinha 500 obstruções, 500 emperramentos. O que se consome da energia, que a pessoa poderia estar gastando em outros embates políticos mais importantes, em discussões com funcionários e população sobre o projeto mais geral. A pessoa é consumida, é complemente consumida. Não só o dirigente maior da Secretaria que é o próprio Secretário, mas todo mundo. Consome todo mundo nessa história. O sentido da Instituição acaba se perdendo nos problemas administrativos. Os exemplos são aquelas reuniões intermináveis que, isso de maneira nenhuma eu estou aqui ensinando o padre-nosso para o vigário, só que eu não sei como poderia ser resolvido naquela situação, que era extremamente complicada, de disputa de poder, intra-administração, da administração com o partido, e aí se colocava sempre o problema da sucessão, esse emperramento todo. Então eu vejo assim, se eu tivesse de citar duas coisas que resumem é: conflito e contradição. Entre o discurso e a prática. No interior da administração, no interior do partido, partido versus administração.

\section{Alexandre Nemes Filho}

Ai tem dois momentos. Tem um momento em que a gente fez uma rede estruturada por outro objetivo do que o objetivo mais assistencial. Na verdade a Prefeitura Municipal de São Paulo era muito desintegrada. Os Postos de Saúde eram separados dos hospitais e produziam não só atendimento médico, mas seguiam uma tradição da Secretaria Estadual de 
Saúde, não de planejar a ação de saúde pública, no sentido da concepção, mas o pessoal executava muito as diretrizes da Secretaria Estadual de Saúde. Então, o antigo Departamento de Saúde da Comunidade tinha um pouco essa visão, com muitas distorções, burocráticas, do funcionalismo. Por exemplo, a história da Saúde Escolar era um pouco um cabide de emprego. Os PAM's tinham mais clínicas. Então, nosso primeiro momento foi o de enfrentar essa situação e tentar puxar um modelo para dar um caráter de planejamento em saúde, principalmente nas UBS's, onde o pessoal não estava acostumado com isso. Então nós resolvemos isso muito mais no campo político, tentando ganhar politicamente o pessoal. Foi 0 primeiro obstáculo. A segunda coisa, o segundo momento, era que nem sempre as pessoas tinham clareza das propostas. Para você ganhar politicamente, você tem que convencer que aquilo é viável e tem que ter uma prática coerente. Algumas propostas não tinham. Por exemplo, a proposta de Saúde do Trabalhador foi gestada sem ter uma base para sua realização, e isso causava muitos problemas porque você colocava práticas e tecnologias na Unidade de Saúde, que já eram desacreditadas logo no começo. Tanto que depois, o pessoal achou melhor montar os Centros de Referência de Saúde do Trabalhador e dai então, as Unidades referirem os problemas para eles. Eu acho que foi uma saída, porque do jeito que se propunha, de montar a saúde do trabalhador nas Unidades Básicas de Saúde, desse modo a gente ia ter muitos problemas.

Um outro problema era articular os hospitais com a rede básica. A nossa proposta era trabalhar com muita gente. Quando você põe muita gente na rede dá confusão. Há problemas pessoais muito grandes. Tem problemas de espaço de trabalho, que não são muito claros nas programações e as pessoas acabam disputando esse espaço. Então eu acho que esses dois primeiros anos foram muito tensos. Depois nós começamos a ter um rendimento maior em termos de consultas. Os programas tinham uma certa cara. Eu acho que aí começou a render um pouquinho mais o nosso trabalho. Melhorou o aporte de recursos. Nós começamos trabalhar com pouco dinheiro, terminamos com mais recursos. Isso facilitou também.

Eu diria que numa avaliação quantitativa, nós produzimos mais do que quando entramos e as Unidades tinham uma programação razoável. Já não era tão solto assim. Por exemplo, na área da Saúde Mental para o atendimento das emergências, havia o Hospital Dia como referência. Agora a gente precisa avaliar um pouco mais programa por programa. Eu diria que a gente precisava de mais quatro anos.

\section{Álvaro Escrivão Júnior}

Na minha análise, a gente encontra duas dificuldades. Eu faço uma leitura entre aspas, mais técnica e menos política, porque eu não estava mais ligado a este tipo preocupação. Não tinha uma responsabilidade direta com a direção da Secretaria. Na primeira fase do governo, com o Eduardo eu tinha mais responsabilidade como assistente 
dele. Depois, com o Neder, passei para uma função "mais técnica". Então eu acho que a implementação na verdade esbarrava em duas dificuldades. A primeira dificuldade que eu acho, talvez não houvesse, ainda, uma operacionalização dessas metodologias de você, partindo das necessidades de saúde da população, conseguir operacionalizar políticas intimamente relacionadas com as necessidades identificadas.

A intenção das ARS's e DS's, era bastante sincera. A primeira dificuldade apareceu quando a gente fez um diagnóstico de saúde para as ARS's, por meio de um questionário com metodologia padronizada. Vieram 10 coisas completamente diferentes, esbarradas um pouco na imaturidade, na inexperiência administrativa, na qualidade técnica das equipes e da própria urgência que o pessoal tinha de administrar isso aí. Afora isso, acho que havia muita improvisação e pouco profissionalismo. O pouco conhecimento do funcionamento da máquina, eu acho que dificultou muito. Por um lado eu acho que a gente teve uma Reforma rápida, porque as pessoas tinham bastante experiência nesse tipo de questão. Precisava fazer rápido porque encerrava o prazo lá de fazer por decreto. Eu me lembro, por exemplo, que mudei o nome da Secretaria, praticamente na hora que estava indo para o Diário Oficial do Município. A rapidez com que se faziam as coisas era uma coisa fantástica. Por exemplo, tinha lá, Secretaria de Higiene e Saúde e aí o pessoal foi mexendo, consolidando como é que ia ficar, etc. Eu me lembro que os procuradores diziam que não podia mudar o nome da Secretaria por decreto. Nós estávamos mudando todas as funções e não podia mudar 0 nome? No final, batemos de novo o decreto, mudando o nome da Secretaria. Só para dar exemplo de como a coisa era em alta velocidade, com um nivel grande de falta de informação, informações contraditórias, algumas dizendo que sim, outras dizendo que não.

Então acho que tinha essa ordem de dificuldade, de tentar fazer tudo muito correndo, com uma dose grande de voluntarismo. Talvez a gente tenha deixado de ficar atento para a particularidade social, para a particularidade do funcionamento da máquina. Com o tempo a gente fez uma escolha por gastar o tempo do jeito que a gente gastou. Deve ter sido consciente ou inconsciente. A gente ficou muito tempo mexendo com esse tipo de coisa, pensando na reforma e contratando pessoal. Eu acho que o processo de mais participação, de envolvimento de setores da população, de educação dos funcionários, eu acho que foram sendo postergados. Eu acho que até a gente tenha pago um preço por conta disso. Conseguir fazer um monte de modificações que depois foram revertidas quase que com a mesma facilidade que foram implementadas.

Agora, acho que a gente teve avanços muito importantes. Eu acho que a gente conseguiu algumas coisas importantes. Talvez o que caracterize muito esse processo, acho que foi, até por caracteristicas do próprio Eduardo, "uma certa liberdade", uma autonomia muito grande, em alguns momentos eu poderia chamar até, sei lá, de uma falta de comando político do processo. Eu acho que as regionais acabavam tendo muita autonomia no mau 
sentido, não no bom sentido. Os mecanismos que você tinha para coordenar esse processo, eram muito corpo a corpo, muita reunião, tudo era discutido, naquelas reuniões lá, do Conselho Técnico Administrativo. Então isso tudo tem uma eficácia, você sabe, relativamente pequena. Não passa do papel, cada um lê do jeito que quer, bem ou mal intencionalmente, lê do jeito que quer. Acredito até que as grandes partes das diferenças as pessoas não tenham lido, o que era para acontecer mesmo. Para mim, acho que foi um pouco confuso e difícil. Por um lado acho que de tudo o que a gente queria fazer, um pouco a gente fez. Acho que foi um pouco confusa a maneira como a gente colocou em prática. A sensação que eu tenho é que foi tudo muito confuso. Em alguns lugares onde você tinha mais tradição de participação social, como na zona leste, isso ai andou. Em alguns lugares onde você tinha menos participação, demorou para o pessoal cuidar dessa temática.

\section{Carlos Alberto Pletz Neder}

Na prática eu acho que a gente teve que enfrentar várias dificuldades. Primeiro é que a legislação do SUS era suficientemente abrangente e genérica para não responder aos problemas concretos que nós tínhamos que enfrentar. Segundo, nós vínhamos de uma eleição onde era pouco provável a eleição da Luiza Erundina, e onde nosso programa de governo era pouco detalhado no sentido de um diagnóstico mais preciso da realidade da cidade e da definição de prioridades no sentido de impacto epidemiológico das medidas que fossem adotadas, e isso não é nenhuma crítica. Nós não tínhamos como saber isso, estando fora da máquina. Quer dizer, nós conseguimos sair do governo com um grau de avaliaçăo muito mais preciso sobre os problemas, sobre a realidade e sobre como fazer, talvez como fazer num tempo muito mais curto do que o que nós utilizamos para implementar as medidas que nós julgamos que eram as mais importantes. Por outro lado, a estratégia da Saúde de fazer a definição das políticas com participação dos trabalhadores e com participação da população, acabou sendo num grau mais elevado do que se fez no conjunto do governo. Isso também foi motivo de atritos e de dificuldades de entendimento dentro do próprio governo. Sobre qual era o papel do Conselho Municipal de Saúde, até onde ia a sua autonomia, até onde ele era não era manipulado pelo próprio Secretário, até onde o corpo dirigente da Saúde não usava o Conselho como um instrumento para pressionar a direção maior do governo. Eu acho que com o tempo foi-se percebendo que o Conselho, embora parte da Secretaria, tinha uma relação com a organização da sociedade, em diferentes segmentos, portanto, tinha uma vida própria, a tal ponto que outras Secretarias passaram a organizar os seus respectivos conselhos, e essa proposta acabou sendo consubstanciada num projeto de lei, que não foi aprovado na Câmara. Ele foi retirado tão logo o Maluf assumiu, mas que disciplinava os mecanismos e as possibilidades de participação popular no governo. Por outro lado, todo discurso nosso era um discurso de aproximação com os servidores, e acho que nós tivemos 
muita dificuldade para fazer esse trabalho junto aos servidores. Primeiro, porque a gente teve que ousar um enfrentamento contra o corporativismo, com práticas já consolidadas de uma cultura do servidor não priorizando o serviço público, e propriamente se adequando às suas próprias conveniências. Tivemos que fazer a remoção geral dos servidores, o que implicou num atrito importante com a categoria, sobretudo a dos médicos, mas também com as outras. Fomos obrigados a rever a questão da jornada de trabalho e o cumprimento da jornada. A questão dos plantões. Então, ao mesmo tempo que nós abríamos espaço para que os funcionários se organizassem no local de trabalho, eu acho que a relação do movimento sindical, do funcionalismo municipal com o governo e também com a saúde, foi no sentido de não aproveitar totalmente a possibilidade que estava aberta naquele momento, ou seja, no sentido de participar da definição da política de forma mais intensa. Muita dúvida por parte deles, se eles deveriam participar ou não dos conselhos gestores, com medo de atrelamento, com medo de serem cooptados pelo governo. Acabaram priorizando a participação no Conselho Municipal de Saúde, para terem informação e praticamente se ausentaram dos Conselhos Gestores, com alguma diferença de uma região para outra, e no fundo não aproveitaram aquela oportunidade para enraizar a organização do Sindicato, com formação de comissões sindicais nos locais de trabalho, nos hospitais, etc., mesmo tendo acesso aos anfiteatros, tendo possibilidade de reunião, sem que isso prejudicasse o atendimento à população. Depois, isso ficou fazendo falta no momento de oposição ao Maluf, e é muito comum o comentário que a radicalidade que se tinha no questionamento ao nosso governo, não se observou no governo Maluf, e também não tem a mesma intensidade hoje no governo do Pitta. Então, ao lado disso nós tínhamos um conjunto de servidores que vinha de uma política de favores. Nós fomos obrigados a criar mais de trinta mil cargos na Câmara Municipal, o que é uma coisa espetacular. Só a Secretaria da Saúde realizou mais de oitenta concursos e foi através desse processo que nós conseguimos partir de um grau de efetivação de funcionários. da ordem de $30 \%$ e deixamos a Secretaria com quase $90 \%$ de funcionários concursados e efetivados. Evidentemente que não os mesmos que já estavam, e com um acréscimo de pessoal extremamente importante. Nós aumentamos de 24.000 mil servidores para 42.000 servidores, portanto, houve um acréscimo de 18.000 funcionários, proporcional à expansão que houve na abertura de novos serviços, na ampliação dos programas, na abertura do acesso, e dentro daquela filosofia de acesso universal a todos que necessitavam dos serviços. Ai acho que cabe uma avaliação de qual foi exatamente o percentual da população que nós conseguimos atender, com toda esta expansão dos serviços. Será que chegamos a atender $30 \%$ ou $40 \%$ da população da cidade? Você vê, hoje o Plano de Atendimento à Saúde, se propõe a fazer o atendimento a 5 milhões e 100 mil habitantes. Com certeza essa não era a nossa meta, de atender a 5,1 milhões de habitantes. Não que o discurso não fosse o da universalização, mas na prática, nós tínhamos a consciência de que a 
capacidade instalada no município, com toda a expansão de serviços que fizemos, não era compativel com essa meta. Então, eu acho que seria interessante se analisar também, do ponto de vista da capacidade instalada, os dados de produção, qual foi a população efetivamente atendida, e qual foi o grau de qualidade no atendimento que pudemos oferecer naquela ocasião. Então, eu acho que nós tivemos que enfrentar também o problema da cultura do funcionalismo. Um funcionalismo que na sua maior parte, tinha sido contratada pela lei 9.160, a título precário, muitas vezes por indicação política, e de repente, assume um governo de esquerda, em que há toda uma expectativa de que esse governo vai priorizar o funcionário público, e não propriamente a questão da população, e a gente é obrigada a introduzir esse contraponto, mostrando que antes de tudo ele tinha que ser servidor do povo, e que portanto, a política do funcionalismo teria que estar adequada a um objetivo maior. E a Saúde não poderia ser um enfoque isolado de outras políticas sociais, de outras políticas de governo, e que ao lado disso, era necessário mudar a prática desses servidores. Daí inclusive a importância do Cefor e de todo o trabalho que se fez no investimento de pessoal, na qualificação da mão de obra. Eu acho que a gente acabou não tendo tempo suficiente para consolidar uma proposta, que era uma proposta que vinha no sentido correto, que era de introduzir novas práticas, e ao mesmo tempo trabalhar a visão das pessoas sobre o trabalho que desempenhavam e, nesse sentido, eu temo que boa parte de nossas propostas não tenham chegado a implicar numa mudança efetiva no dia-dia do trabalho das pessoas. Em que pese toda a radicalidade da proposta, eu não sei se nós conseguimos chegar a mudar a prática de saúde no seu cotidiano, do ponto de vista das ações de saúde. Pegar uma cidade com 10 milhões de habitantes, 1.500 quilômetros quadrados de área geográfica, com toda a sorte de problemas, com a diversidade muito grande entre as regiões, ter que formular uma política de saúde que tivesse diretrizes comuns, mas que tivesse a flexibilidade para que as prioridades e os programas fossem compativeis com o diagnóstico epidemiológico de cada região, que você tivesse mecanismos de aferição de cumprimento de metas. Então, tendo que implantar as dez Administrações Regionais de Saúde, que acho que foi uma decisão correta, depois gradativamente implantar os Distritos de Saúde e readequar o papel das regionais, e sempre me pareceu que as regionais não deveriam ser extintas. Quer dizer, alguns advogavam uma redução tal do papel das regionais, a ponto de chegar a uma extinção das regionais. Eu já entendia de uma forma diferente, que acho que ficou expressa na proposta que fizemos no decreto de dezembro de 92, e no projeto de lei que a gente acabou não conseguindo fazer chegar até a Câmara, que era uma Administração Regional bastante enxuta, com papel de coordenação numa área geográfica maior, mas com grande grau de autonomia para os Distritos, ainda que tendo que dialogar entre si em torno de metas e objetivos a serem cumpridos. Então, eu acho que este esforço de definição de diretrizes nas Conferências, de definição de prioridades naqueles encontros que nós faziamos no começo 
de cada ano, para definir prioridades e metas a partir das diretrizes das Conferências, a avaliação permanente das metas nos Conselhos instituídos na Secretaria, sobretudo os Conselhos Técnico-Administrativos, e a tentativa de mudar a prática, foi um processo gigantesco. Agora, é impensável achar que nós conseguimos consolidar um processo desse em quatro anos, ainda que sabendo as dificuldades que nós tivemos para encontrar os melhores caminhos, para poder implementar essa proposta num prazo mais curto. Então, eu acho que surgiram vários problemas no percurso.

\section{Eduardo Jorge Martins Alves Sobrinho}

Tem quatro questões. A primeira delas é sobre a universalização da cobertura. A questão da universalização implicava em contatos com três outras áreas: com a iniciativa privada, com o governo do Estado, e com o governo Federal. Na verdade sendo o primeiro grande governo do PT em uma grande cidade, esse contato com outras esferas governamentais e com a iniciativa privada, foi muito marcada com uma certa visão que o PT tinha de si próprio e da sociedade brasileira. $E$ também marcado pela visão que os outros tinham de nós mesmos. Portanto, a relação institucional buscando atingir a universalização foi muito difícil. A relação com o governo estadual era com muito atrito. A relação com o governo federal maior ainda, e a relação com a iniciativa privada era nenhuma. Porque a visão que nós tínhamos na verdade é que o SUS era visto por uma questão de circunstâncias, mas o que nós queriamos mesmo, era a estatatização total do sistema. Portanto, a relação com a iniciativa privada era passageira, destinada a ser superada pela estatização a médio e longo prazo. Então, a relação com a iniciativa privada não existia. Mesmo com entidades tipo Santa Casa, que é uma entidade filantrópica muito tradicional, conservadora, mas com um atendimento muito grande à população, inclusive população pobre, praticamente a relação foi muito pequena. Com o governo estadual, uma relação de guerra permanente porque não tinha critérios de repasses de verbas do governo federal, que é o dinheiro básico para a saúde e, o governo estadual, usava critérios essencialmente políticos para distribuir os recursos financeiros, beneficiando municípios $A, B$, ou $C$ e prejudicando os municipios $D, E$ ou $F$. Com o governo federal era uma relação de beligerância total. $O$ Lula e o Collor tinham disputado a presidência, e a nossa relação era de inimigos. Interessante que, em virtude do governo estadual ter fechado completamente as portas ao repasse dos recursos federais, nós fomos obrigados a fazer uma negociação com esse inimigo, governo federal, com o ministro da saúde da época, que levou o município de São Paulo a receber alguns recursos para a saúde nos últimos anos. Porque nos primeiros anos, o repasse do governo federal via governo do Estado foi zero. Não houve. Só se conseguiu depois, em negociação direta com o governo federal. Coisa aliás, que do ponto de vista doutrinário não deveria ser feita, porque a negociação deveria ser feita com o governo do Estado. Essa é a primeira questão. 
A segunda questão é sobre a reforma administrativa da Secretaria. Em relação a descentralização, para facilitar o entrosamento com o governo do Estado, nós estudamos a descentralização já existente no âmbito do governo estadual, que tem uma estrutura grande aqui na cidade de São Paulo e fizemos uma proposta, um estudo de descentralização que acompanhasse a descentralização do governo do Estado para facilitar o processo de municipalização, que nós achávamos que viria, apesar das dificuldades. Então a cidade foi dividida nas 10 regiões de saúde. 0 Estado era dividido em 8 . Nós preferiamos seguir a geografia das 8 , mas como havia 2 muito grandes, nós chegamos a 10 regiões de saúde do município.

Estas 10 regiões de saúde por sua vez foram inicialmente subdivididas em 30 Distritos, com tendência a chegar a um pouco mais de 40 Distritos. Trinta, porque era 0 número de Unidades Orçamentárias existentes na ocasião, na SMS. Cada Distrito deveria ser responsável por cerca de 250 mil habitantes, número que a gente achava razoável para ter o Sistema Local de Saúde. Isto foi feito discutindo com as regiões, discutindo com os responsáveis pelos Hospitais e tendo em mente não só facilitar o acesso, o controle social, mas também facilitar o entrosamento futuro e necessário com o governo do Estado, no processo de municipalização. Esse processo de distritalização envolveu uma ampla discussão dentro da SMS.

Na questão da democratização, a terceira questão, antes do governo se instalar, nós fizemos uma discussão com os movimentos populares da cidade de São Paulo, em assembléias, em várias regiões, gente da zona sul, da zona norte, mas muita gente mesmo da zona leste, que tinha um movimento mais forte. Leste e sudeste. $E$ a idéia que os militantes do movimento popular tinham era que, com a nossa vitória, eles teriam participação e controle da gestão das Unidades Básicas, e eles queriam ter uma administração direta com as UBS's. A discussão com eles serviu para ver que, para isso acontecer, teria que haver, por um lado, um amadurecimento dos administradores, dos funcionários e dos próprios militantes do movimento popular e, que fosse algo processual, que passasse por instituir organismos permanentes de gestão. Caso contrário, você poderia ter pessoas que desestruturassem completamente os mecanismos de gestão de uma região. A nossa proposta era de que aonde houvesse um predomínio total dos movimentos populares, nós dividíssemos a gestão em 3 partes: entre os dirigentes, os funcionários e a população, gerando um sistema de gestão tripartite. Foi daí que nasceu inclusive a idéia de se formar os Conselhos de Gestão nas próprias Unidades, que é o local onde os movimentos eram mais fortes. Para eles poderem exercer diretamente a sua influência na gestão.

Onde os movimentos eram mais fortes era no nivel local, onde eles poderiam exercer uma influência mais direta. Isto não era previsto no horizonte da Legislação. Nós abrimos um debate com eles, com os movimentos. A possibilidade de criar os Conselhos de 
Gestão nas Unidades, nos quais eles participariam dividindo as responsabilidades conosco, numa estrutura tripartite e, ao mesmo tempo, para acelerar a integração, e ai a nossa presença na Prefeitura, facilitaria o entrosamento com os movimentos que tinham pouco contato entre si, zona sul, zona norte, zona leste, para a constituição mais rapidamente possivel de um Conselho Municipal de Saúde, que foi um dos primeiros do Brasil a se formar. Que tivesse também uma responsabilidade crescente e progressiva na política de saúde do município.

Quanto a questão da integralidade, a quarta questão, a discussão foi com os dirigentes nossos que já estavam responsáveis pelos hospitais, pelas regiões de saúde, pelas Unidades e pelos programas especializados. Para você montar o esqueleto das regiões de saúde e dos Distritos numa gestão integrada entre a parte hospitalar, a parte ambulatorial, a parte dos programas, a parte da vigilância epidemiológica e sanitária, de forma crítica, como previa a filosofia do SUS. Isto trouxe muitos problemas, porque a estrutura hospitalar é uma estrutura que tradicionalmente tem muita força, muito mais prestígio do que a estrutura ambulatorial, de prevenção, de vigilância. E uma proposta desse tipo implicava em os hospitais diluírem seu poder técnico e administrativo, em uma estrutura muito mais ampla. Então aconteceram resistências nesse sentido, dizendo que isso iria prejudicar a gestão dos hospitais, isso iria tirar a autonomia dos hospitais, ia subordiná-los na prática aos Centros de Saúde, à visão de prevenção, quando os hospitais são uma estrutura que precisam de uma agilidade administrativa muito maior do que um Centro de Saúde, de um serviço de vigilância, etc. Então esse tipo de debate e de problemas aconteceu dentro do nosso próprio campo.

A evolução disso, de todos esses quatro movimentos, convergiu para a proposta de reforma administrativa da Secretaria, que acho que surgiu cerca de 2-3 meses depois do inicio do governo. Ai nós tivemos condições de apresentar uma proposta para a prefeita de reforma administrativa, que praticamente orientou o governo nos 4 anos seguintes. Estava praticamente acabada, vamos dizer assim, com 2-3 meses.

Foi uma coisa interessante porque o ritmo das outras Secretarias era ainda de estar tateando, de estar tomando pé de situação, e a SMS já apresentou logo no comecinho do governo, 2-3 meses depois, uma proposta praticamente acabada e ampla de reforma, na direção desses quatro pontos.

Isso criou um problema político muito grande porque as outras Secretarias estavam ainda tomando pé. A tendência centralizadora do PT era ainda muito forte naquela ocasião, centralizadora no sentido da prefeita, centralizadora no sentido (veja que a discussão da Prefeitura Municipal de São Paulo era a de descentralização/democratização, e quanto o governo era centralizador) da Secretaria da Administração, centralizadora no sentido de Secretaria Municipal de Finanças e centralizadora no sentido da filosofia e ideologia nossa, 
que era naquela época, muito tradicionalista em relação a esta questão. Decidiram então que a Secretaria Municipal de Saúde saísse na frente.

Foi preciso muita discussão dentro do secretariado que tinha resistência em relação a isso. A Administração, a área de Finanças, resistiram com uma visão centralizada, como estou dizendo. Os outros que achavam que se deveria esperar mais, para fazer com mais segurança e, a própria prefeita, porque ela aspirava fazer uma reforma administrativa ampla global. É natural, não é?

Então na verdade, todas essas resistências foram vencidas por uma relação direta com a prefeita. O fato dela se convencer com uma relação direta conosco, com um número muito grande de militantes que estavam envolvidos no processo, comigo mesmo que tinha uma relação política muito estreita com ela, com pessoas do movimento popular que fizeram audiência com ela, é que levaram a prefeita a ultrapassar essas resistências, dela própria e inclusive, a elaborar uma reforma própria da SMS, antes, muito antes da reforma das outras Secretarias. Aliás, a tal reforma global que se falava no governo não foi feita. Terminou o governo e não foi feita. Passaram-se os 4 anos e não se conseguiu fazer. O que mostra que nós estávamos absolutamente certos em fazer a nossa reforma, já que tínhamos clareza, agimos certo em fazer a reforma logo no começo do governo. Uma coisa importante é que a Luiza Erundina condicionava para aceitar e lançar uma reforma, contra a opinião dos outras Secretarias, que nós não tivéssemos nenhum cargo a mais e nenhuma Unidade Orçamentária a mais. Ela disse: "já que vocês querem descentralizar, que usem os cargos e Unidades Orçamentárias que têm nos niveis centrais". Então esse desafio foi aceito e todo o decreto que reorganizou foi feito assim, sem criar um cargo e sem criar uma U.O. Repartindo tudo o que havia nos niveis centrais para criar os Distritos. Isto por sua vez limitava. Na verdade uma estrutura desse tipo exigia mais U.O's para dar mais agilidade administrativa e exigia mais cargos para dar mais estrutura em algumas regiões. Mas foi o preço político que a Prefeita exigiu e o que foi correto e com isso, ela conseguiu dobrar as resistências dentro de seu próprio governo. E assim foi feito.

\section{Paulo Eduardo Mangeon Elias}

Eu tenho um interregno. Eu só cheguei à administração em junho de 89 . Eu acompanhava algumas dificuldades, porque eu ia lá na Secretaria uma vez por mês, conversar com o Eduardo e foi ai que ele me colocou contra a parede, da necessidade de mais quadros e de fazer uma relação com o Parlamento.

Eu vou te dar um depoimento dessa fase inicial. Depois de junho de 89 , aí sim, eu acompanhei mais de perto. O que fica prá mim foi o seguinte: existia um desconhecimento muito grande na máquina administrativa. Os que mais tinham conhecimento, ainda assim tinham desconhecimento. Você tinha pessoas por exemplo, que iam desde pessoas como eu, 
que não tinham nenhum conhecimento, nunca tinham passado na máquina, não conheciam absolutamente nada, até pessoas como o Morimoto, como o Paulo Carrara, que estavam neste grupo e tinham um nível de conhecimento maior, mas mesmo assim era um conhecimento insuficiente perante a complexidade da máquina. Esse é um aspecto, que eu acho da aplicação das diretrizes. Um outro aspecto da aplicação, e isto foi formulado pelo grupo e começou com um processo de discussão diária. O Documento Número Um foi levado para os diretores regionais e a partir daí, foi discutido para legitimar o documento. $O$ problema que eu acho é que existiam compreensões dispares acerca daquele documento, daquelas diretrizes políticas. As palavras eram as mesmas, mas o conteúdo das palavras e mais do que isso, como é que aquilo era lido e implementado nas regiões, isto foi uma situação bastante dispare. $E$ aí isso tem a ver com o perfil de quem era o administrador regional e, quando eu estava falando deste perfil, estava também pensando na inserção destes administradores regionais no partido e fora dele. Porque havia muitos que nem eram filiados ao PT. $O$ problema era a visão ideológica que esses administradores tinham, e a visão, as concepções que eles tinham sobre o que era serviço público, qual era a tarefa, isto é, não existiam concepções únicas. Isto para mim é muito claro. $E$ frente a complexidade da máquina administrativa e a extensão da máquina, era impossível você imaginar processos únicos. Era evidente que você não ia imaginar mesmo. Imagine um município do tamanho de São Paulo, com 10 regionais de saúde, cada regional às vezes é maior do que muitos municípios paulistas. Então imagine que era impossível você ter um processo único. $E$ com as particularidades e peculiaridades também da formação das equipes de cada uma dessas regionais, das concepções que elas tinham etc. tal.

Então eu diria que tem padrões díspares aí. Eu estou dando alguns traços do que você me perguntou. Estou tentando puxar pela memória e ver coisas que acho importante porque eu também não fiz uma reflexão aí... se eu estivesse preparado para isso... eu compreendo, é de sopetão mesmo.

Então um aspecto é esse. O outro aspecto eu acho que é da compreensão de qual era o papel. Eu acho que também tem padrões díspares na construção do socialismo. Havia uma percepção de que você ao conquistar a administração, você tinha conquistado o poder. Eu acho que foi um equivoco. Esta leitura que aconteceu em parte, nada lá foi homogêneo. Isso é bom que se diga. Pode parecer que saía como homogêneo, mas não era. Claro, você tinha uma diretriz, mas você não tinha uma homogeneidade de pensamento. Conquistada a administração, "começou-se" a construir o socialismo. Esta era uma tarefa política e eu acho que isso explica um pouco certas diferenças de implementação de processos a niveis regionais. Enfases que eram dadas à certas coisas em prejuízo de outras, enfim, tinha também essa visão. Existia também uma glamourização dos funcionários públicos a partir de um esquema muito simples: como eles eram explorados, proletários, etc. e tal, 
automaticamente eles eram aliados ideológicos do PT e essa percepção, no inicio da administração, era muito forte. Depois, com o conhecimento maior diminuiu, e eu acho que ela reflete um pouco um certa ingenuidade política, uma certa insuficiência de politização, de entender a realidade, não da Secretaria, mas a brasileira. Uma certa insuficiência grave que a esquerda tem ao fazer uma leitura do Brasil real, do Brasil concreto, e muito mais então idealizada. Então existia um pouco essa idealização dos funcionários. Achavam então que era só chegar lá. Nós tínhamos o caminho, as diretrizes, as grandes bandeiras, vamos fazer a redenção, se não do povo brasileiro, pelo menos do povo paulistano e com isso nós contávamos já de saída com um exército de funcionários. Os únicos funcionários que eram tidos para se tomar cuidado, eram os que ocupavam os cargos mais altos da administração, porque, se ocupavam os cargos mais altos, provavelmente eles eram aliados da burguesia, eles eram comprados. Mas fora desse grupo, a maior parte do funcionalismo, já era nosso aliado. Depois com o correr do tempo, começaram a ocorrer surpresas em relação a isso. $E$ a reação ao meu ver foi de intensidade violentíssima. O que eu chamaria de $2^{a}$ fase. Onde as pessoas se deram conta de que não era bem assim. De que entre os funcionários públicos, tinham os que eram reacionários, tinham os que sabotavam a administração pelos seus interesses pessoais. Não sabotaram nem por organização ideológica, mas sim por coisas muito menores, uma loucura. A reação eu vi, em alguns momentos, e nós do Gabinete da Secretaria Municipal de Saúde, nessa $2^{\mathrm{a}}$ fase, fui encarregado algumas vezes pelo Eduardo de ir lá e apagar, eu vou chamar de apagar incêndios, e tratar de certas questões, porque a reação também foi violenta e virulenta. Isto mostra um pouco uma insuficiência de uma leitura politica, de uma realidade política, quer dizer, num momento, a glorificação total e num outro, pega-se mais do que o chicote e execra. São lados da mesma moeda. O problema nosso é trocar a moeda e muitas vezes nós não soubemos trocar a moeda.

Como foi a aplicação das diretrizes na prática? Em resumo eu acho que, primeiro, você não vai encontrar um padrão homogêneo, isso vai variar de região para região. Você pode encontrar padrões próximos e eu acho que isso tem muito a ver com o papel. Eu acho esse papel, essa liderança intelectual e política e técnica do diretor da região. Apesar que o modelo não supunha isso.

O modelo supunha uma construção coletiva e tinha também um discurso ideológico que era muito forte, muito presente, mas que não tinha substrato na realidade concreta para que ele vicejasse. Essa que é a verdade. Então tinha uma vontade, uma intencionalidade e uma concretude das coisas que dependiam de outros fatores e que faziam as coisas andarem de um certo jeito. É isso que eu estou dizendo. O papel do diretor era muito importante. A cultura meio hierárquica. A hierarquia da Secretaria era uma coisa muito cara ao funcionalismo e eu creio que esse papel, por menos que ele quisesse ( o Diretor), e ai eu vou entrar em um terreno especulativo, eu acho que às vezes, no ideário dele ele não queria, 
mas na prática ele queria. Então tinha essa idéia, os famosos coletivismos. Tudo era construção coletiva. Tudo era coletivo, mas quando você olhava a realidade - eu fui nesse sentido um observador privilegiado - eu via que a realidade não se construia daquela forma. Então você tinha o ideário, você tinha uma realidade que constrangia aquilo, não era uma coisa única, e não era porque as pessoas não queriam. É que você não tinha bases materiais para sustentar aquele pensamento. É como se você tivesse um pensamento imenso e uma base material muito pequena que não dava sustentação a ele, ou seja, aquilo era o ideário, que eu chamo de ideário, era no plano ideológico, e aí você tem que ver as relações sociais concretas que se estabeleciam, os constrangimentos estavam dados ali. $E$ as pessoas ficavam muito desesperadas e qualquer momento que se apontava essa tensão, entre ideário e bases concretas, era o motivo para as mais variadas dissensões e às vezes, até problemas de relação pessoal por causa disso. As pessoas tomavam pessoalmente. Por que? Porque elas tinham uma missão. Então eu estava dizendo: primeiro, você não vai encontrar um padrão único; segundo, este padrão vai perpassar. $E$ aí há uma proeminência muito grande de cada Diretor Regional. Mesmo quem não quisesse. Porque nesta estrutura ele era 0 diretor, e ele tinha os assessores dele. $E$ aí vai descendo, tudo isso. $E$ aí, essas diretrizes todas, elas também iam sendo lidas de formas distintas. Quando chega lá na ponta, provavelmente o funcionário vai tomar isso esvaziado, de todo o conteúdo político e de todo o conteúdo de transformação que isso tem. Ele vai tomar de uma forma como uma ordem a ser cumprida. Porque era essa a estrutura da Secretaria. Então você não implanta, e eu fico à vontade pra falar isso, porque eu sempre fui essa voz de quem participava das reuniões da Gabinete da Secretaria Municipal de Saúde.

Você não implanta, não faz mudanças de mentalidade em 4 anos, você não faz isso. E essa era a questão, pra você não tomar isso de forma burocrática lá na ponta. Era uma mentalidade, como você disse, era uma cultura que tinha na Prefeitura. Então começa aqui, politizado lá em cima e chega lá embaixo, que é onde vai operar, de uma forma como uma ordem, porque era essa a estrutura e é até hoje a estrutura do serviço público. Então essa idéia de que todos pensam, primeiro porque nem todos tem as informações indispensáveis. Para isso exigiria mudanças gigantescas, e as pessoas achavam iam fazer isso na base da vontade, da conversa, da solidariedade, do compromisso. Então você vai encontrar padrões bastante dispares e uma das explicações para isso, eu acho, é o perfil do administrador regional. Por exemplo, você citou uma, a Dagmar, que tinha a visão de construir a revolução a partir da Prefeitura de São Paulo. Eu não estava fazendo juizo de valor, eu estava fazendo uma análise. Esse é um padrão. Você tinha um outro padrão, de Diretor Regional, que era um padrão absolutamente administrativo, de funcionário da Prefeitura. Então vamos dizer assim, nos limites deste espectro, nas suas polaridades, nós temos duas idéias e você tinha nesse 
meio de campo aí, composições desses dois pólos aí, as mais variadas possiveis. Então é evidente que isto foi implementado de formas muito distintas.

\section{Quais foram os principais problemas encontrados pela administração e o que foi feito para enfrentá-Jos?}

\section{Pedro Dimitrov}

A questão central nesse período de quatro anos, eu colocaria como externa à própria Secretaria. Vamos dividir isso em partes. Eu vou pegar um conjunto de questões externas à Secretaria da Saúde e um conjunto de questões internas. Como externas, eu coloco as relações com o Estado. Por que? Porque na realidade ou se constrói o SUS com alguma competência - significa você realmente trabalhar a questão da saúde na área metropolitana como um todo, incluindo os serviços da Secretaria de Estado da Saúde, e aí você consegue montar um sistema de saúde municipalizado, hierarquizado, regionalizado e aproveita todo o seu potencial de assistência à saúde - ou fica uma situação extremamente difícil e, na medida em que não foi possível fazer a municipalização, aí já bloqueou muito o potencial de trabalho da Prefeitura. Então, por mais que nós melhorássemos os nossos serviços, os serviços municipais de saúde, por mais que abríssemos hospitais novos e tentássemos ampliar as nossas Unidades, esses serviços eram absolutamente insuficientes para atender a população do município. Quanto mais nós melhorávamos os serviços municipais, os serviços estaduais pioravam na mesma proporção. O resultado é zero a zero. Esta é a questão central do nosso período.

Agora as questões internas. As questões internas da Secretaria, eu vejo como a dificuldade central, a política supercentralizada da administração da Prefeitura, e mesmo com as pessoas fazendo o discurso da descentralização, tendo boa vontade, tendo uma certa visão de que seria melhor descentralizar, as pessoas eu digo as que tinham algum poder dentro do governo, ficaram impossibilitadas de desenvolver esta política, porque a máquina da Prefeitura era uma máquina administrativa estruturada para ser extremamente centralizada. Ela teria que ser implodida de uma só vez. É impossível você achar que vai consertar a máquina aos poucos. É como a nossa Secretaria, nós só conseguimos fazer a nossa reforma porque nós implodimos a Secretaria. Ela foi transformada em todos os seus segmentos, tanto na área de recursos humanos, como na área de finanças e na área técnica. Enquanto que a Prefeitura como um todo, embora tivesse um discurso de descentralização, a Secretaria de Finanças e a Secretaria de Administração tinham uma política altamente centralizadora. Eu acho que este é um conflito que durou os 4 anos. Nós conseguimos avançar na área de recursos humanos, avançamos na área de compras, um pouco, mas mesmo assim ainda permaneceu uma série de compras centralizadas na Secretaria Municipal 
de Administração. Avançamos muito pouco na área de finanças. Para escapar um pouco da estrutura extremamente centralizada da Secretaria de Finanças, foram criadas unidades orçamentárias. A medida que foram sendo criados novos Distritos, foram sendo criadas novas U.O's. Então, enquanto U.O., você tem um pouco mais de autonomia, mas mesmo assim você tem a questão da execução orçamentária. Você fica o tempo todo sendo bloqueado e fica negociando, mesmo que você remaneje recursos de uma Unidade para outra, para não deixar faltar medicamentos, não deixar faltar material básico para o trabalho. Eu acho que as principais dificuldades foram estas: do ponto de vista externo, as dificuldades com a Secretaria Estadual da Saúde, que não criou condições para a municipalização e construção do SUS e, as dificuldades internas, fundamentalmente com a Secretaria de Finanças e a Secretaria Municipal da Administração.

Em relação a municipalização não havia mais o que ser feito. Foram feitas todas as tentativas. Há uma série de documentos que podem ser levantados, que foram produzidos na época, com objetivos muito concretos, que podem ser até quantificados financeiramente, 0 que significava municipalizar região por região. Havia uma proposta de municipalizar todos os serviços de saúde por região. Tanto que a reforma da Secretaria Municipal de Saúde foi feita compatibilizando a área geográfica com os ERSA's da época. Exceto os ERSA's da zona leste e da zona norte, que eram muito grandes e nós colocamos 2 ARS's em cada um desses ERSA's. Eram 8 ERSA's e 10 ARS's nossas. Mas o perímetro externo era compativel. Portanto, era perfeitamente possivel nós juntarmos um ERSA com uma ARS nossa, municipalizarmos os serviços de saúde daquele local, organizarmos os serviços lá, utilizando os hospitais e todos os equipamentos. Não foi possível fazer a municipalização conforme tinha sido proposto e com os planos descritos. Foram escritos dois documentos em relação a essa questão, com propostas de municipalização, que podem ser vistas nos próprios documentos. O impedimento central foram os recursos financeiros. $O$ Estado não estava disposto a investir nesta área naquele momento. O que é que foi possivel fazer? Foi possivel identificar o principal problema que havia na época para a população e que não se dava solução, que era fundamentalmente $O$ atendimento às emergências. Em relação a este nó-crítico, à esta questão, dentro do planejamento na Secretaria, com aquela visão de planejamento estratégico situacional, propôs-se então a desenvolver um acúmulo de forças junto aos outros municípios da área metropolitana, junto ao movimento de saúde e com isso, articulando o movimento de saúde, a associação Sebastião de Moraes, com os 28 municipios da área metropolitana, foi possivel forçar a Secretaria de Estado da Saúde a entrar numa proposta para a área metropolitana. Esta proposta para atendimento de urgência/emergência para a área metropolitana, foi aprovada, foi sancionada. Há alguns documentos, inclusive publicados em D.O., com prefeitos, secretários municipais, assinando o documento com 0 compromisso de trabalho conjunto. A partir daí então, começou a funcionar um sistema para a 
área metropolitana, tanto do ponto de vista para o atendimento pré-hospitalar como do ponto de vista hospitalar.

O pré-hospitalar é o resgate, com as ambulâncias da própria Prefeitura do município de São Paulo e com ambulâncias do corpo de bombeiros para os municípios da área metropolitana. Isto para o pré-hospitalar, a questão do resgate dos pacientes acidentados. $\mathrm{Na}$ questão hospitalar, foram identificados os hospitais de alta complexibilidade, que serviram de referências para as cirurgias mais complexas ou para as intervenções mais complexas em termos de acidentados. Houve inclusive uma certa especialização de alguns hospitais. Alguns hospitais se voltaram mais a cirurgia craniana, outros para cirurgia na área buco maxilo-facial, outros para cirurgia oftalmológica e assim sucessivamente. Então, foi possível organizar um atendimento dos politraumatizados e queimados, acidentados de forma geral, na área metropolitana, que funcionava de forma bem razoável, durante um ano e meio a dois anos. Esta estrutura foi desativada a partir do primeiro ano subseqüente ao governo do PT.

Virgínia Junqueira

Havia um caminho tão prévio. Uma das grandes barreiras para o avanço era a questão da articulação intersetorial, se nós entendermos saúde como uma questão muito mais ampla do que o atendimento médico. Mas não havia clareza disso naquele momento. Ai é difícil de dizer quantas pessoas na Secretaria pensavam assim e quantas não. Agora, as evidências de que muitas pessoas pensavam nisso são claras, são presentes, e não era só na nossa Secretaria que a questão intersetorial era importante. Os núcleos regionais de planejamento são a prova do interesse. Tanto é que mais tarde se matou os NRP's.

Dentro da Secretaria da Saúde o discurso de que saúde é muito mais do que atendimento médico é claro. $O$ que não era muito claro é que, tendo o atendimento médico para a população, fazer as duas coisas ao mesmo tempo. Aí a estratégia da Secretaria muitas vezes titubeava. Não sabíamos, e aí eu ponho todo mundo junto, como fazer. Se você não fizer uma análise muito rigorosa dos problemas da população, você não vai conseguir um atendimento médico perfeito. Isso você pode tirar da sua cabeça. Nós não sabiamos como organizar 0 atendimento sem que este nos consumisse. Isso não conseguimos fazer. Na hora de operacionalizar a produção da saúde, nós não tínhamos clareza de como fazer. Esta era a grande questão. Uma coisa que saía do plano teórico, do discurso, todo mundo sabia, está até na lei 8080 , na Constituição. Todo aquele pessoal que estava lá na Secretaria, tinha vindo do movimento da reforma sanitária, era um pessoal de ponta.

A dificuldade era operacionalizar o atendimento médico como um compromisso da questão mais ampla da saúde, e nós não conseguimos fazer com que ele não consumisse todas as nossas forças. Porque, na medida em que a gente tentava fazer esse atendimento médico da melhor maneira possível, nós também nos debatíamos com a retaguarda das três 
Secretarias, aonde você precisava, para fazer um bom atendimento médico, ter mais agilidade financeira e administrativa, agilidade na gerência de pessoal, coisas que você não tinha. Você não tinha resolvido com a Secretaria da Administração a questão de reposição do pessoal. Depois isso tudo passou para a Secretaria da Saúde, mas consumindo uma energia tremenda. Todo o tempo que você podia gastar em processos de democratização, de desenvolvimento de funcionários, da população, enfim, o que realmente fazia avançar o processo, ficava de lado. Esses eixos eu acho fundamentais, de democratização das decisões e vinculação com as necessidades da população. Nós não sabíamos operacionalizar isso. Não é qualquer coisa. Nós não estamos falando de qualquer coisa. É muito complicado. Agora, a gente se propunha a resolver. Nós tivemos a pretensão, não de uma maneira perfeita, mas a gente se achava competente para resolver. Eu acho que a gente consegue resolver isso. Não é uma questão que não dá para resolver. Eu acho que tem que ousar, tem que se atribuir, tem que arriscar. Era disso que as pessoas tinham medo. Tem que ousar mesmo, tem que meter a cara. Tem que fazer o que o Eduardo fez aos três meses de administração para frente. Quebrar aquela porcaria de superintendência hospitalar, pelo menos no plano do papel, porque senão você não quebraria nunca mais. É uma experiência que você vai acumulando, que essas coisas devem ser feitas logo de inicio, porque senão elas se consolidam, as pessoas vão ficando apegadas aqueles procedimentos administrativos já conhecidos, vão ficando com medo de arriscar outras coisas. Vai pegar a argumentação do Amir Kahir, do Paulo Singer, vai pegar a argumentação deles. Qual é? "Ah, porque né, escapa, as pessoas começam a fazer muita coisa, não se consegue dominar mais, porque essa máquina é complicada"..., e o peso administrativo vai preponderando sobre a vontade política de democratizar.

\section{Alexandre Nemes Filho}

Essas limitações que eu levantei antes são problemas. Você vai na ponta da linha e olha o que você fazia, havia uma dificuldade muito grande de você implantar serviços. Tinha dificuldades de por o profissional ali treinado para trabalhar. Tinha dificuldade de fazer 0 serviço funcionar. Isso aí não é só uma questão desse jeito de administrar ser muito complicado, porque ele não rende na ponta da linha. Porque do mesmo jeito que nós queríamos ser inovadores, nós administrávamos da forma mais tradicional possivel, no sentido da administração direta, seguindo todos os fluxos, seguindo todas as normas dessa coisa de ter muitos níveis. Nós tínhamos muitos níveis eu acho. Ficar a Unidade de Saúde, o Distrito Sanitário, a ARS, o Gabinete, é muita conversa, é muito esforço para botar o serviço para funcionar.

Nós não conseguimos essas coisas, acho que por duas razões: um impasse político não tínhamos força política para negociar na Câmara e não tínhamos uma proposta gerencial 
melhor - não tínhamos nada. Hoje por exemplo, a história do PAS é uma inovação. Não estou comparando, não estou dizendo que o PAS é melhor, não é, nós sabemos disso, mas de qualquer forma, a gente não tinha essa coisa na cabeça de mexer na administração direta. Toda vez que alguém queria fazer a coisa funcionar, passava por cima de tudo, dos diferentes niveis, causava muita ciumeira. Essas passagens de um nivel para outro que, ou a pessoa faz isso ou não resolve. Alguns também faziam isso para criar intrigas, havia todo esse tipo de cultura institucional. Nós não conseguimos dar autonomia de fato à Unidade, para a Unidade poder andar. Nós conseguimos ter grandes programas de treinamento que atingiram toda a rede, e não conseguimos fazer com que as Unidades tivessem um pouco mais de autonomia. Acho que a gente tinha muito mais uma coisa de inculcar na cabeça deles um determinado eixo. Eu não vejo isso como crítica. Eu acho que se você pega uma rede, que foi entregue falida, desestruturada, com arranjo institucional muito ruim, não sei se a gente teria outra coisa a fazer. A alternativa seria ir contra as leis $e$ fazer menos reformas administrativas/institucionais, menos grandes movimentos como o da remoção geral e criar mais projetos-piloto que pudessem dar para a gente mais visibilidade.

O que eu sinto é isso, isto é, a grande limitação - dinheiro - a gente teve no início do governo, depois passou a não ter tanto. Serviço que a gente queria por para funcionar a gente fez. Os serviços foram inaugurados, isso é bastante importante, mas não conseguimos criar uma cultura diferente, uma cultura que pudesse intensificar...

Refletir sobre o que você está fazendo é que é complicado. Não é só o que se faz, é quando você está explorando o que está fazendo, divulgando também para a imprensa, para a população, fazer marketing sobre o que se faz. É o problema de se fazer muitas coisas, é o "fazismo", o "fazejamento". Tem gente que critica o planejamento, diz que é o fazejamento, mas quando você faz demais fazejamento você tem a sensação de estar realizando uma política, mas não está aproveitando o suficiente do ponto de vista político, do ponto de vista de marketing, do ponto de vista da inovação. Você pega algumas administrações menores, Santos, por exemplo, o rendimento que eles tiveram, eles fizeram coisas diferentes da gente, mas eles fizeram intervenções pontuais que eles valorizaram muito e jogaram a administração para cima.

No caso de São Paulo não, faziam tudo ao mesmo tempo e esse tudo ao mesmo tempo era o básico. Eu me lembro do Giovani reclamando do Hospital do Servidor e ele tinha razão. Ele queria transformar aquilo em Hospital de excelência para algumas coisas, ele queria fazer cirurgias oculares que seriam pioneiras aqui em São Paulo. Não conseguiu fazer. $E$ isso que eu estava the dizendo que a Unidade não conseguia fazer, porque ela tinha que dar conta de tudo. De botar as pessoas para dentro, de fazer reuniões, não conseguia aproveitar melhor o potencial de seus funcionários. 
Agora, que foi uma gestão que atendeu muito mais, melhorou muito o atendimento no setor público, isso é indiscutivel. Não tinha jeito de não fazer uma política que não respondesse aos interesses de grupos da Secretaria Municipal de Saúde como o da Saúde Mental, Saúde do Trabalhador, etc., que traziam propostas acumuladas há muito tempo. Tinha que fazer. Pagar esse preço de ter pouca visibilidade, de ser pouco laureado pelos grandes investimentos.

Agora, nós tínhamos problemas no cotidiano, muito difíceis. Para montar equipes nas áreas de finanças e compras, por exemplo, não havia pessoal qualificado e nem em número suficiente. Quando você abriu os Distritos Sanitários, você pulverizou um pouco o pessoal qualificado. A infra-estrutura administrativa com a criação dos Distritos Sanitários ficou insuficiente, não tinha viaturas, etc. Talvez a gente tenha voado um pouquinho demais, não sei.

\section{Álvaro Escrivão Júnior}

Você não tinha um pensamento estratégico. Tinha um pensamento administrativo, baseado em emergências. Isto também é absolutamente tradicional. Você tinha dificuldades em ter uma discussão política mais geral. Você tinha as dificuldades políticas do governo. Os problemas que eu vejo são as dificuldades políticas do governo. Isto é um outro ponto muito sério, porque se fazia muita confusão em função disso. Os grupos dentro do partido. A ciumeira em torno da Luiza Erundina. Embora a gente tenha feito com certeza a administração mais solidária e integrada do ponto de vista dos diversos setores, que eu conheça, e que eu já tenha vivido. Havia realmente uma preocupação de integração, mas mais uma vez na prática, você tinha dificuldades de você fazer isso na prática.

Eu acabei sendo um cara que convivi muito com as utopias. Quando por exemplo, eu coordenei o projeto "São Paulo - Cidades Saudáveis", a gente via muitas dificuldades. As diferentes Secretarias adoravam a conversa, mas na hora de você dispor de um certo xis do orçamento da Prefeitura, para o planejamento conjunto das Secretarias, começavam aparecer as dificuldades. $O$ cara perdia a autonomia. Por mais que a gente dissesse que a Secretaria da Saúde não era mapeada politicamente, que não era dividida por grupos e tal, você tinha desconfianças de parte a parte. Esse era um problema muito sério. No Gabinete da Secretaria Municipal da Saúde freqüentemente você tinha trombadas, que eram trombadas onde 0 problema precisava ser enfrentado enquanto o problema, e não enquanto interpessoal, e a gente enfrentava enquanto as pessoas, entre os personagens que estavam envolvidos com os problemas, e não enquanto problemas. Então, se eu estava discordando de alguma coisa do COAS, por exemplo, é porque o CEPI tinha algum problema político com o COAS, ou porque eu não era da "vertente socialista", sei lá quem era e tal. O Eduardo tentou coordenar, mas ele acabava sendo mais influenciado pela corrente política dele. 
Eu acho que o Neder, entrou com outro estilo. O Neder, entrou com um estilo mais fechado mesmo, mais afirmativo, para o bem e para o mal. Algumas coisas, o Neder, vamos dizer, tinha um estilo que eu achava mais correto, no sentido de cobrar, de exigir, de colocar o dedo na ferida, de ser um pouco mais rápido na decisão, mas nenhum dos dois fez muita política. O Eduardo fez mais, porque é um político. O Neder vai começar a virar um político agora. Então, uma das coisas que o Eduardo tinha que fazer é tomar conta da parte externa da Secretaria e eu acho que uma das funções do Secretário é articular politicamente fora da Secretaria. Então, como você tinha uma coesão muito frágil, a palavra do Eduardo era a palavra final. E a presença dele era obrigatória. Se o Eduardo não estivesse presente nos fóruns, os fóruns não funcionavam. Reunião sem o Eduardo complicava. Você não tinha coordenação. Uma coordenação que precise tanto de um coordenador tão forte, tem que se desconfiar de que ela não está funcionando muito bem. Não tem regras claras. Não tem regras de jogo. Quando tem regras de jogo não precisa de juiz, se todo mundo cumprir a regra. Se não tem regra e está todo mundo tentando descumprir a regra, o juiz fica apitando o tempo todo.

Outros problemas sérios estavam na Câmara. Você não tinha acordo político na Câmara, e era muito difícil passar alguma coisa na Câmara.

A gente tinha problemas orçamentários importantes. Eu acho que não ter havido um acordo com a Secretaria de Estado da Saúde foi uma outra coisa que atrapalhou. Tem vários problemas aí, estou me lembrando aos poucos. Eu acho que realmente a nossa proposta era a de implantação do SUS no município de São Paulo e você tinha um pedaço estadual se relacionando muito mal com a gente, muita desconfiança e muita disputa.

\section{Carlos Alberto Pletz Neder}

Enfrentamos os problemas que eu já mencionei, de todo o sucateamento da rede pública, em particular da saúde, e também muitos desacertos internos ao governo, na relação de poder, de como se tomavam as decisões de governo, das relações entre as Secretariasmeio e as Secretarias-fim, sobretudo a relação nossa com a Secretaria de Administração, com a Secretaria de Finanças, com a Secretaria de Planejamento, que tinha uma dificuldade de, no momento em que eles tinham que coordenar todo um processo de otimização de recursos do município, entender o trabalho de uma Secretaria que demandava cada vez mais recursos como a nossa. Então, basta analisar, por exemplo, qual foi o investimento feito na área da Saúde de 89 até 92 , e a gente percebe que se elevou os gastos a um patamar muito superior que historicamente se gastava. Em toda a história da Secretaria nunca se gastou mais do que 8 a $9 \%$ do orçamento municipal em Saúde, e nós já fomos para um patamar de 10, depois passamos para 11, para 12 e acabamos gastando $14,7 \%$ do orçamento em 1992. Então eu acho que isso gerou alguns conflitos também. 
Nós sabemos que enfrentamos muitas dificuldades. Pessoas que se apegaram aos seus respectivos programas, tiveram uma dificuldade de entender que nós devíamos levar a questão dos assessores para dentro do corpo de assessores dos Distritos, e dando um apoio mais efetivo às Unidades de Saúde. Isso acabou se refletindo na prática daquele servidor mais distanciado do processo de gestão da Secretaria, no sentido dele acabar não percebendo que isso tinha que implicar numa mudança de sua própria postura, no dia-dia de sua prática em saúde. E acho que aí contribuíram algumas indefinições na equipe gerencial $e$, por outro lado, essas dificuldades que eu já mencionei do próprio Sindicato, que poderia ter contribuído conosco num grau de adesão maior dos servidores à proposta, e que trabalharam permanentemente no sentido de manter um grau de desconfiança do trabalhador da saúde em relação a qualquer proposta que viesse da administração.

\section{Eduardo Jorge Martins Alves Sobrinho}

Tirando os problemas naturais de perda de prestígio de alguns órgãos, na SMS havia centenas de militantes do PT, que eram funcionários da saúde, diferente de outras Secretarias e, ao mesmo tempo, eram militantes de um partido. Nós tínhamos muitos dirigentes que vinham do governo do Estado, do governo Federal e que não conheciam a estrutura da SMS estabelecida, não eram aceitos e reconhecidos, porque não eram daquela corporação, vamos dizer assim, que era tradicionalmente tida como uma Secretaria de prestigio. Que tinha programas tradicionais há muito tempo implantados na cidade. Essa era a primeira questão que tivemos de contornar. Essa resistência foi mais fácil de ser superada porque havia uma unidade muito grande entre os dirigentes municipais, estaduais e federais. Havia resistência da máquina, da corporação tradicional, mas havia uma unidade muito grande entre os dirigentes nossos, que vinham da área estadual e federal, porque a questão política era uma questão muito forte e a ideologia era muito presente naquela época. Muito mais do que hoje.

As questões de resistência e problemas para enfrentar uma reforma desse tipo, uma das maiores, eu atribuo à mentalidade centralizadora que duvidava, que desconfiava da eficácia de uma administração descentralizada e participativa. Essa mentalidade centralizadora, é importante frisar, não estava somente na estrutura tradicional da Prefeitura e em outros órgãos governamentais do país. Ela estava na cabeça dos próprios militantes de esquerda, porque a tradição da esquerda era uma tradição centralizadora. É uma tradição unificadora por cima, própria de uma estrutura organizativa, de vanguarda que nós sempre achamos, uma tradição nossa, necessária para vencer as resistências existentes de fusão de uma ideologia dominante e burguesa, no seio do próprio povo, do próprio trabalhador.

Essa visão era uma visão da máquina tradicional da Prefeitura e de outros órgãos de governo, mas era visão também na cabeça dos militantes do PT que estavam assumindo 
o governo, com uma visão tradicional, centralizada, autoritária do Estado brasileiro, com a mentalidade da tradição vanguardista, autoritária nossa, dos militantes de esquerda que estavam assumindo o governo via Prefeitura Luiza Erundina. Então você chega para discutir com a Secretaria Municipal de Administração, você chega para discutir com a Secretaria Municipal de Finanças, você encontra com essas duas tendências casadinhas, uma reforçando a outra, para não entrar aqui, numa questão mesquinha e perda de prestígio político pessoal dos dirigentes. Isso, se aconteceu foi secundário. Tanto o secretário da administração como o de finanças tinham muita tradição na esquerda. Eu não vou identificar interesses mesquinhos desse tipo neles. Era uma questão de mentalidade. Era uma questão de mentalidade deles, nossa, de dirigentes de esquerda tradicionais, casada com a tradição de corporação e da Secretaria. Então, a Secretaria da Administração não podia admitir que a SMS se responsabilizasse totalmente pela administração de seus recursos humanos, incluindo a questão da admissão do pessoal, no ritmo que nós achássemos necessário. Diziam eles, "năo! quem vai fazer isso seremos nós. É assim que sempre foi feito e é assim que sempre será. Porque se não for assim, os interesses corporativos de cada Secretaria iriam estraçalhar a Prefeitura Municipal de São Paulo. Só nós é que podemos e temos condiçð̃es e assim é que é correto. Vocês não vão ter condiçð̃es técnicas". Segundo, "não vão ter condições políticas porque vão levar seus interesses especificos às últimas conseqüencias. prejudicando a Prefeitura". Então era a argumentação do ponto de vista tradicional, autoritário, centralizador, muito sólido para ser vencido. Novamente a mesma coisa era em relação às finanças. A mesma coisa em relação à Secretaria do Planejamento. A mesma coisa em relação à Secretaria dos Negócios Jurídicos. Cada uma em sua área. As secretarias se defendiam com uma retaguarda tradicional e corporativa, mas com um discurso lógico, racionalizador, da mentalidade autoritária da direita e da esquerda, muito forte em suas posições, todas elas. Planejamento: "nós é que devemos fazer a divisão, a proposta. Como é que vocés văo fazer uma proposta de divisão da Saúde em regiðes, sem termos feito a divisão da estrutura administrativa das prefeituras regionais"? A Secretaria dos Negócios Juridicos: "nós é que temos que julgar se tal posição deve ser dada. Como é que vocês vão ter autoridade para isso? Vocês não têm competência técnica. Vocês vão ser parciais, autoritários nessa questão. Nós é que temos o distanciamento necessário para fazer isso". Secretaria de Finanças: "não, vocês vão gastar além das contas. Nós é que temos condições de fazer a racionalizaçăo, a distribuição, a divisão, as compras centralizadas, que são muito mais baratas. Vocês vão fazer as compras na periferia, vai sair muito mais caro. Vai ser muito mais fácil de haver corrupção". E a Secretaria Municipal da Administração, é a que vai dizer quantos cargos, quem vai fazer a admissão, quem vai dividir os cargos. É uma questão que vem da tradição da direita, mas também da tradição da esquerda, mas que tem um discurso racionalizador e um apelo forte. Vencer todos esses obstáculos não foi fácil e novamente a 
saída foi ter uma proposta, ter apoio popular, ter apoio dos funcionários que se identificaram com a proposta de trabalho e negociar direto com a prefeita.

Para forçar a descentralização nós éramos obrigados a apelar para o rei. É uma coisa paradoxal mas é a única forma política de fazê-lo. Vou contornar as resistências das secretarias-meio, com um diálogo direto, presidencialista com a prefeita. Isso era um diálogo e uma pressão constante em cima da prefeita como única forma de você vencer de uma forma aguda esse tipo de resistência que eu descrevi aqui. Por exemplo, nós tínhamos uma defazagem de pessoal muito grande e, no entanto, a visão da Secretaria da Administração era que a Saúde já tinha muita gente. Que inclusive tinha que demitir gente da Saúde, já que havia leis dos governos anteriores de fazer muito pouco concurso. Oitenta por cento dos 20.000 funcionários que havia, não eram concursados. Desses $80 \%$, existia uma lei que boa parte deles, já tinha vencido sua contratação e teriam que ser demitidos imediatamente. E foram demitidos. A SMS ficou sabendo da demissão pelo Diário Oficial do Município. Pessoas de Hospitais, Pronto Socorros, Centros de Saúde e de Serviços de Controle, foram demitidas pelo jornal, numa atitude tão autoritária e centralizadora, que não se diferenciava em nada de qualquer outro governo de direita. Isso levou a uma negociação muito dura com a prefeita para que ela permitisse que parte da autoridade da Secretaria da Administração passasse para a nossa autoridade. Ela autorizou experimentalmente que nós fizéssemos alguns concursos, com toda a má vontade da máquina da SMA, que não nos repassava informações, criava obstáculos burocráticos para repassar os procedimentos aos nossos técnicos, que não tinham experiência. Mas a primeira leva de concursos provou definitivamente à prefeita e a outros Secretários, que o processo descentralizado era muito mais ágil, muito mais correto e muito mais eficiente. Nós fizemos mais concursos que todos eles, sem nenhuma contestação jurídica, sem nenhum problema legal, mas numa agilidade muito maior, a ponto da SMS ter feito muito mais concursos que a Prefeitura inteira. E ter tido a capacidade de ter feito, submetido a concurso aquela massa imensa de funcionários que eram não concursados da SMS, e eles eram milhares. Com a ampliação dos serviços chegou-se a $90 \%$ de aproximadamente $\mathbf{2 0 . 0 0 0}$ funcionários, concursados. Numa capacidade de responder a essa questão de RH que a Prefeitura nunca teve em nenhuma outra área. Mas essa prova foi na prática, treinando o pessoal da Secretaria para fazer, depois o treinamento do pessoal das regiões para participar do processo, de forma democrática, colocando as várias regiões discutindo entre si. racionalizando a distribuição de cargos e, é claro, em algumas ocasiões, usando o poder de juiz do Secretário Municipal de Saúde, quando às vezes acontecia o confronto entre as várias regiões ou atrito maior. Mas foi o exemplo dos concursos o exemplo prático, de resistência e de como se conseguiria superar, de como é possivel superar esse tipo de resistência. Não é uma Prefeitura comum. É um país. É o 
mesmo em relação às finanças e a outras Secretarias, mas acho que esse exemplo de SMA, é o exemplo melhor para retratar esses problemas que nós vivemos.

Dois outros aspectos eu acho importante frisar: a relação com a Câmara Municipal e a relação do aprofundamento da descentralização da gestão dentro da própria Secretaria da Saúde.

$1^{\circ}$. O aspecto da Câmara Municipal:

Evidentemente nós fizemos uma reforma por decreto. Usamos os cargos e U.O's., que nós tínhamos. Foi a condição que a Luiza Erundina nos colocou para vencer a resistência dentro do secretariado, mas logo em seguida nós não poderiamos fugir da criação de novos cargos e U.O's. Porque estava prevista uma expansão da rede, novos hospitais iam ser colocados em funcionamento, exigiam uma expansão do quadro de pessoal e novos cargos, e exigiam mais U.O's, porque mais Unidades iriam ser abertas. E a SMS teve também uma visão que acho que faltou às outras Secretarias, que é a de dar importância e se representar junto à Câmara Municipal.

A visão nossa tradicional, mais uma vez da esquerda, levou a subestimar e dar o necessário respeito à Câmara Municipal de São Paulo. A necessária negociação com outras forças políticas, mesmo que fossem conservadoras, de direita, que evidentemente eram. $A$ SMS procurou ter uma relação mais aberta com a Câmara Municipal de São Paulo. Havia pessoas de alto gabarito responsáveis por esse contato com os vereadores, com os partidos. Que iam à Câmara Municipal dar satisfação a eles, explicar os processos, dizer os nãos necessários aos pedidos clientelistas, mas dizer os nãos e explicando que existia uma política de pessoal, explicando que ia haver uma reforma, por isso é que não podia ser atendido tal caso. Sempre numa relação que procurasse respeitar o mandato de vereador, seja ele de direita, de centro ou de esquerda, como um legítimo representante eleito da população. Esta relação com a Câmara Municipal ajudou muito a SMS a levar adiante, quando precisava, a cotação de seus projetos de criação de cargos e de U.O's. A Câmara Municipal e é preciso que se diga isso, quando a SMS precisava da criação de cargos e de U.O's., pela expansão da rede, não nos faltou. Votou e aprovou praticamente tudo que nós queríamos. Isso ajudou muito a SMS. Coisa que faltou, vamos dizer assim na relação do conjunto do governo com a Câmara Municipal, que se caracterizou por uma relação de beligerância total. Como se fosse possivel governar à revelia da Câmara Municipal. "Se fosse preciso esmagariamos os representantes burgueses, com manifestação de milhares de trabalhadores". Dizia-se.

Outra questão política fundamental que nos prejudicou barbaridade foi o fato que nós queriamos governar sozinhos. Isso afetou a SMS e afetou o governo como um todo. A idéia do PT era a de governar sozinho. Tendo ganho a eleição com $30 \%$ dos votos e tendo $30 \%$ da Câmara Municipal, acho que nem isso. Só uma mentalidade muito autoritária poderia pensar que apenas com a ajuda das grandes massas, com a opinião pública, nós poderiamos 
ultrapassar essas barreiras reais, físicas até, da falta de apoio político. Então essa foi uma postura permanente do governo Luiza Erundina que só no final procurou reverter, mas aí já não havia mais tempo e que prejudicou o governo e prejudicou a nós também na SMS, porque essa mentalidade absolutista também existia entre nós, embora menos, porque já no começo nós absorvemos pessoas de outros partidos em cargos de responsabilidade. Ou não eram militantes de partido nenhum, ou eram simpatizantes do PSDB, como por exemplo, na direção do Hospital Menino Jesus e no Hospital da Vila Nova Cachoeirinha.

Era um movimento a meu ver para o qual encontramos resistências entre nós mesmos. A tendência era dar mais e mais cargos entre os militantes do PT, porque eram os únicos de confiança total e absoluta e pureza administrativa, moral e ideológica, capaz de levar o nosso projeto adiante. Então dentro da própria SMS havia resistência entre nós em aceitar esses companheiros de outros partidos, para assumir responsabilidades grandes, de região e de hospitais. Nós tentamos fazer um movimento desde no início, mas eu acho muito insuficiente, e em relação ao governo como um todo foi totalmente insuficiente, e eu acho que foi uma das causas de nossa derrota na sucessão de Luiza Erundina. Inclusive uma das causas das derrotas no âmbito nacional do PT.

Uma terceira questão, em relação a esse processo todo, è que depois que eu sai da SMS e voltei ao Congresso, tendo participado da regulamentação das leis em 1990, e tendo tido contato com outras experiências administrativas, eu passei a ter uma idéia, que precisava haver uma descentralização e agilidade administrativa entre nós mesmos. Porque nós haviamos criado as 10 ARS's, e estávamos criando os D.S's. Existia uma tendência à autonomia administrativa dificultada porque não havia cargos, nem mecanismos, nem leis suficientes, mas havia esse esforço e existia a meu ver uma mentalidade uniformizadora muito grande entre nós. Uma tendência a achar o seguinte: tinha que caminhar todo mundo junto, todo mundo no mesmo ritmo. O que eu passei a ver, e até depois eu tentei conversar com vocês, já como deputado, mas sem sucesso, é que nós precisávamos de um modelo de administração mais descentralizado e com mais autonomia entre nós mesmos, nas ARS's e nos DS's. De forma que se estimulasse a produtividade e a qualidade de serviços, mais do que eram, e que isso fosse feito mediante uma certa competição de qualidade e quantidade, que desse inclusive do ponto de vista salarial, tratamento diferenciado entre as regiões $A, B$, ou C, ou DS's 1,2 ou 3. De acordo com a capacidade deles em atingir as metas de produção e satisfação da população. Esse tipo de administração não uniforme, que admitisse esta força, esta certa regulação entre os DS's e as regiões, e um tratamento diferenciado para quem trabalhasse melhor do que os outros, isso não foi absorvido por nós. Quando isso foi colocado pela primeira vez, era uma posição que levava à anarquia e quase uma posição liberal que ia desestruturar os serviços, que iria desorganizar os serviços. Então esse passo de acreditar na 
descentralização até o fim, esse passo adiante, não foi dado. Apesar da SMS se destacar no empenho e na tarefa descentralizadora muito maior que outras Secretarias.

Uma questão que me vem agora é que a SMS apostou na integração com outras Secretarias, nos NRP's, para a partir dai ser o embrião da descentralização integrada da Prefeitura em várias regiões, encaminhando-se para uma verdadeira Prefeitura regional, que se responsabilizasse no âmbito, por exemplo, de uma região como Itaquera ou Pirituba, por todas esses tarefas possiveis de serem descentralizadas na Prefeitura, como saúde, educação, cultura, etc. A SMS apoiou, participou da definição dessa estrutura descentralizadora, mas isso avançou muito pouco, também em um ritmo insuficiente na Prefeitura, de forma que, vou ter essa cidade de 10 milhões de habitantes dividida em 20 estruturas regionais, com estrutura inclusive de legislativo local, eleito pelo povo, com essa responsabilidade, dividindo o poder com a Prefeita e com com a Câmara Municipal de São Paulo. Era uma verdadeira revolução democrática que o PT poderia ter feito e não foi feito, $\mathrm{e}$ não se avançou e até hoje ficou inviabilizado, porque criaria 20 Prefeituras regionais, integrando essas várias áreas. Democratização porque nessas 20 Prefeituras regionais teria uma câmara de vereadores locais, eleitos, fiscalizando, controlando, discutindo política e, ao invés de 50 vereadores, 1000 vereadores na cidade de São Paulo. Isso não foi feito também porque a meu ver, existiam resistências grandes, era verdade, não havia maioria na Câmara Municipal, era verdade, mas um problema maior era dentro da própria cabeça de nós militantes do PT, que víamos nisso uma forma de você diluir o poder, que concentrado na mão da prefeita, era a única forma de quebrar resistências para impor nosso programa. Essa visão descentralizadora é a visão que acredita na sociedade civil, que acredita na politização, no crescimento, na possibilidade do povo assumir responsabilidades muito mais do que a consciência político ideológica de meia dúzia de dirigentes. Mas isso nós não tivemos a clareza de fazer.

\section{Paulo Eduardo Mangeon Elias}

Eu vou falar o que ocorreu. Vou começar pelo maior deles que era o seguinte: a Secretaria da Saúde tinha uma concepção no plano do ideário, de descentralização muito radical, num governo que não tinha esse ideário, homogeneamente. Este é o primeiro grande problema. Como é que você vai fazer uma descentralização numa Secretaria, sendo que boa parte do que ia ser descentralizado, tinha relações intimas com o restante do governo, com as outras Secretarias que não tinham essa concepção. E eu quero deixar claro o seguinte: eu não sou daqueles que acha que a descentralização estava certa e a centralização errada. Eu acho que tem que ser visto isto, mas em conjunto, mas esta foi uma tensão grande. Eu acho que a partir dai você gerou problemas de toda ordem. Problemas de ordem política no interior do governo, administrativos e problemas de ordem operacional. Desencontros de toda ordem. 
$E$ daí de novo você tinha uma leitura que era muito despolitizada e insuficiente, e que só contribuía para aumentar o grau de tensão que existia, que já estava embutido frente a essa situação e que é o seguinte: de achar que a Secretaria da Saúde era a vanguarda, era a quem tinha o caminho, quem tinha o caminho iluminado e os outros, eram aqueles que eram atrasados, aqueles que não enxergavam, que por razões... e por ai vinham várias explicações. Então era um esquema que era assim, o bem e o mal, maniqueista, e mais do que isto, pessoal. Claro que isto não perpassava o conjunto da Secretaria, não é todo mundo que achava isso. Eu estou dizendo que era uma visão muito presente, se não enunciada desta forma, mas o comportamento das pessoas era voltado para este tipo de visão. Isto causou problemas muito intensos. Já havia problemas. Esta leitura só contribuiu para piorar o que já havia. O que eu acho mais fundamental era isso. Eu diria que esta diretriz, ela perpassou também a Secretaria da Saúde internamente. Esse pensamento e essa diretriz de que você tinha centralização e descentralização. Teve uma tensão aí, também interna à Secretaria da Saúde, em determinados segmentos da Secretaria. Isto não perpassou totalmente a Secretaria, mas esta tensão se reproduziu também no interior da Secretaria. $E$ havia também, o que eu acho no fundo, no fundo dessa história, é o seguinte: quando esse ideário da Reforma Sanitária, certo ou errado, pelo bem ou pelo mal, ele não estava ainda, como ainda não está até hoje, não tem uma concepção técnica que lhe dê respaldo. Ou seja, o que eu quero dizer com isso é que, no momento em que a Reforma Sanitária é convocada a dizer, o que fazer, tá perfeito. O como, que aí precisa vir com um discurso técnico, que a dimensão técnica tem que comparecer para demonstrar como é que você opera isso. Ai, você tem uma assimetria completa. Eu acho que esta é um pouco a situação. E também essa tensão entre centralização/descentralização que tinha no governo e que foi reproduzida na Secretaria da Saúde e com efeitos dispares e dependendo da situação, e de novo eu falo, às vezes você queria fazer as coisas sem as bases materiais. É como se você falasse, no "peito e na raça", mas você não faz nada no peito e na raça. Você pode não ter a estrutura completa, acabada, etc. e tal., mas também sair do nada para construir alguma coisa, sem nenhuma base, sem nenhum alicerce, é complicado. E tão mais complicado isso fica, tão mais perto é de coisas que são mais fundamentais na Secretaria. Mais fundamentais na dinâmica do funcionamento cotidiano da Secretaria. Porque aí as repercussões são muito intensas. Eu me lembro, por exemplo, da descentralização orçamentária. Mas como você vai fazer descentralização se você não tem capacitação nem no nivel regional, nem no distrital para processar isso aí? É uma insanidade fazer isso. O resultado disso não é avançar. Pelo contrário, é recuar. Porque a descentralização, ela foi entendida na Secretaria como um fim. E ela não é um fim. Ela é um meio. Ela foi entendida sempre como um fim em si. A descentralização em si. Se você descentralizar você estará avançando, porque em si mesmo, ela está eivada desta positividade, e ela nunca foi. Em raros momentos a descentralização 
pode ser considerada um fim. Em raríssimas situações ela pode ser considerada um fim. Na maior parte das situações ela é sempre um meio. Então tinha tensões.

Eu estava exemplificando, como é que você vai fazer isso se você não tem capacitação e essa capacitação você não pega no supermercado, não faz do dia para a noite. Essa capacitação não existia e se conseguiu a duras penas fazer isso a nivel de região, mas a nivel de reforma sanitária a coisa vai piorando e a idéia era você criar U.O's mais descentralizadas possiveis.

Claro que a intencionalidade era das mais meritórias possíveis, mas você tem que ter uma idéia etapista. Mas o etapismo não era uma grande virtude na SMS. Era coisa de não ter etapas, de fazer a coisa naquele momento. O que existia era o imediato. O mediato não existia. Era uma visão imediatista para todas as coisas. O problema é como isso era concebido enquanto um problema. Isso não era problematizado em todas as dimensões. Isso era reduzido a um problema que você disse que o fulano, o ciclano, isto é, o problema era personalizado; depois, a leitura era essa: está atrasando ou está avançando o processo. Então. o problema era concebido nesses termos e nesses termos tratado. E não em toda a sua complexibilidade, sua dimensão. Eu não quero dizer que não pudesse haver esta dimensão também, que estou chamando de dimensão do plano do político, de haver dimensões politicas, com concepções distintas. Isto deveria haver também. Não estou dizendo que quem não implementasse estaria sempre do lado bom e com a boa causa. Não é isso. Às vezes, também tinha dimensões politicas, de visões distintas, mas como as regiões também tinham autonomia muito grande e os DS também tinham, então o sujeito implementava segundo a sua visão. Ele sabia usar muito bem esse controle. De toda sorte, no conjunto, isso aparecia sempre como só este pedaço, como se não tivesse por exemplo, problemas que já citamos aqui de competitividade desses processos, problemas de estrutura, de administração, de mentalidade, de capacitação, problemas que vêm da dimensão técnica também. Como se esses não existissem de forma nenhuma. Isto não tem nenhuma importância, não tem nenhum problema. O político superaria tudo isso. Não só superaria, como o problema era concebido com um certo recorte no plano do político, que não era nem na totalidade do político, era um certo recorte, que era isso, que era pessoal. O fulano é meio lerdo, não tem muito "elã". Como se tivesse assim um grande painel de classificação do compromisso político-ideológico de cada Diretor de Distrito ou Regional, e tal, com as causas do povo. Eu estou fazendo uma caricatura, mas é isso, quer dizer, primeiro o problema era personalizado, e assim o problema era tratado, quando o era, porque esse já é um problema mais delicado. E os problemas que se apresentavam como administrativos, várias vezes, eu $\mathrm{vi}$, pessoas que tinham poder, cargo e mando administrativo, tratarem as coisas administrativas como se fossem da vontade das pessoas, na base do voluntarismo. Esses problemas eram tratados na base do voluntarismo, como se diz, no peito e na raça. Quem 
era mais cauteloso em relação a isso ficava em desvantagem. Eu não quero ser o juiz da verdade, eu estou tentando analisar, porque eu acho que isso não era suficientemente avaliado. Eu não estou pretendendo fazer juizo de valores. Mandaram fazer e muita gente fez, alguns com sucesso. Mas outros estão pagando com processos administrativos e de outro tipo, porque fizeram também. Você sabe como é a administração pública, cheia de regras. Não fizeram isso de má fé, de forma nenhuma. Mas atropelaram nesse processo algumas regras e é claro que também aí tem uma dimensão de retaliação política. É evidente. $E$ aí tem lá uns depoimentos em Proced e por aí vai. É um pouco isso.

4. Como você viu o lugar reservado ao sujeito, ao cidadão, ao funcionário comum, na construção do projeto de transformação das práticas de saúde?

\section{Pedro Dimitov}

Em relação à população foi uma coisa muito tranqüila porque havia uma experiência muito grande, acumulada de participação popular. As pessoas que estavam na direção da Secretaria tinham experiência com participação popular. A maioria que estava a nivel central tinha passado de alguma forma por experiências de participação popular e por isso havia clareza nas nossas diretrizes.

No Documento Número Um havia questões sobre controle popular dos serviços de saúde, através dos Conselhos. Então, havia propostas de implantação de Conselhos, desde o Conselho Municipal de Saúde, com o qual eu tive uma participação mais direta e me envolvi mais, até os Conselhos Gestores das Unidades. Então havia clareza da direção da Secretaria quanto à importância e necessidade de se montar os Conselhos Gestores, deliberativos, tripartites, que era a garantia de que a reforma administrativa que foi feita de cima para baixo viesse a dar certo. Ela só daria certo se houvesse o controle do nivel local pelo usuário. $\mathrm{Na}$ medida que foi uma reforma imposta de cima para baixo, em cima do conjunto dos servidores, a expectativa era que houvesse um movimento em pinça. A direção da Secretaria que tinha este projeto, que tinha esta visão, que era oriunda do movimento popular, agora tinha a possibilidade de estar no poder. Então, com a reforma, foi reestruturado o aparelho de Estado.

Com esta visão, fazia-se uma pressão de cima para baixo, em cima dos funcionários e com a expectativa que a população se organizasse na base, nos Conselhos Gestores e fizesse um movimento contrário, no sentido oposto, de baixo para cima e de controle nas Secretarias. Ou seja, seria um movimento de cima para baixo e de baixo para cima, no sentido de consolidar uma democratização dos serviços de saúde. Eu acho que houve dificuldade em relação ao servidor, que também seria um dos elementos da comissão 
tripartite, do Conselho Gestor, que é tripartite, mas eu acho que os servidores historicamente, não estavam habituados com a participação. Eles estavam habituados a se organizar por categorias. A de educadores era uma coisa, a de assistentes sociais era outra coisa, a de farmacêuticos e bioquimicos, tinha o colegiado de farmacêuticos e bioquímicos, tinha 0 colegiado de fisioterapeutas, ou seja, cada categoria profissional tinha um colegiado e tinha uma estrutura vertical. Então não havia uma articulação interprofissional a nível local. As articulações se davam verticalmente por categorias profissionais. Essa foi uma dificuldade. A visão tradicional dos funcionários era por categoria profissional, de forma vertical. Não havia experiência de trabalho interprofissional nos vários serviços, nas várias esferas.

O Sindicato dos Servidores Municipais não aproveitou o espaço que tinha para poder reorganizar os servidores e atuar de uma forma mais conseqüente em relação aos serviços de saúde. Na realidade acabava ficando o Sindicato como um instrumento reivindicatório, de reivindicar salário, isto ou aquilo, mas o Sindicato não teve competência política, competência para discutir a questão do sistema de saúde de uma forma mais abrangente com o conjunto dos servidores, e ter uma intervenção dos servidores de uma forma mais organizada na construção dos suS no nível municipal. O que acabou ocorrendo foi então apenas esse aspecto de construção do SUS, pela administração de nível central e com a abertura dos colegiados dos Conselhos Gestores, tripartites, para que houvesse então um controle desses serviços a nivel local, nas Unidades prestadoras de serviços. Mas nesses locais, como os servidores não estavam organizados adequadamente e o Sindicato não conseguiu cumprir este papel de organização desses servidores, a coisa ficou acabando mais com a administração, digo, os representantes da administração no nível central e mais com a organização da população. Os servidores tiveram um papel, do meu ponto de vista, muito pobre na construção do SUS aqui em São Paulo.

\section{Virginia Junqueira}

Eu acho que ai de novo teve o problema da contradição. Acho que para os funcionários não-médicos, talvez a maior queixa é que não houve suficiente envolvimento na definição do que deveria ser feito, na condução mesmo dos processos de decisão. O diálogo com os funcionários, e é muito importante aí o papel do Secretário - ninguém pode substituir ele nisto - diretamente com os dirigentes sobre o que está acontecendo, foi uma coisa que acabou ficando reservada para o momento das Conferências de Saúde. A Conferência era aquele momento que o funcionário podia falar alguma coisa, mas era, eu acho, precário ter só este momento de Conferência, distrital, regional e municipal, como fórum para o funcionário se expressar. Eu acho que isso é a comunicação maior de como é que você operacionalizava essa questão de democracia no interior do funcionalismo, que tem muitos problemas, que está viciado com anos e anos de muitas práticas que não são do interesse da população e 
nem sequer de si mesmo. Porque o que acontece é que acaba o funcionalismo ficando com essa má fama, que permite a um governante como o Maluf destroçar tudo, botar todo mundo para escanteio. Até contrariando seus próprios interesses, o funcionário desenvolve uma prática que precisa ser mostrada como má, e que precisa ser mudada, e que para isso não tem que ter benevolência. Então eu acho que da nossa parte houve essa contradição, de querer fazer a democratização e estar muitas vezes passando a mão na cabeça dos funcionários, principalmente na dos médicos, por uma suposta preocupação com a democratização. Eu acho que houve isso, ou seja, timidez excessiva com certos contingentes do funcionalismo, como o dos médicos, e a não participação real da maior parte do funcionalismo. Eu acho que não houve um real processo de participação do funcionário em seu dia-a-dia. Eu acho que isso é uma coisa mais complicada a fazer. Tem receita para fazer isso? Eu não sei. Para mim têm procedimentos que ajudam, técnicas que ajudam, como a questão do planejamento estratégico, com você discutindo lá no Posto de Saúde, lá no Pronto-Socorro.

Agora, eu não vejo outra maneira de fazer a coisa, que não seja com o envolvimento da funcionário no planejamento do que esta Unidade vai fazer em niveis sucessíveis de complexidade. Eu não vejo outra maneira de fazer. Eu acho que aí está a questão da gente conseguir desenvolver o planejamento, os planos locais de saúde, os planos regionais de saúde, e discutir a questão maior da Instituição que é a questão da saúde, das condições de vida da população e de como é que os funcionários estão envolvidos na resolução desses problemas. Eu penso que isso falhou completamente, digo completamente sim. Falhou porque em seguida vem uma coisa que destroçava o que a gente fez, que acaba com tudo que a gente fez. O governo Maluf faz terra arrasada. Eu então acho que a gente falhou. Eu não sei como é que deveriamos fazer. Isso tudo agora é outra discussão, que é outro momento histórico também. Agora eu vejo que o caminho seria, a falha foi, e eu digo não só no plano da Secretaria pois, num primeiro momento a Prefeitura tinha os núcleos regionais de planejamento, tinha as visitas da prefeita, a Prefeita ia lá, prestigiava, acabou.

Então você vê, essa questão do planejamento e não só o planejamento em saúde, mas o planejamento da vida da cidade, com o envolvimento de funcionários junto com a população, de poder ter esses fóruns, seria a marca da diferença e isso foi uma coisa embrionária e abortada. Abortaram o embrião, rapidinho. Porque era uma coisa realmente explosiva, dificil de se lidar. Agora, em outras cidades, como é que o PT tem sucesso? Pegue Porto Alegre, o que é que eles fazem lá para conseguir tal respaldo da população? Que eu saiba, o prefeito não fez viadutos, túneis e pontes. $O$ que foi que os prefeitos fizeram, que envolveram a população a esse ponto de representatividade, de aprovação popular, de fazer o sucesso, em sendo o mote, o tal do orçamento participativo? Eu acho que a gente ficou devendo. Eu enfatizo muito mais o que a gente ficou devendo, do que na força que tem um 
governo de direita arrasar quanto quiser, sem dúvida. Para mim tem uma questão pontual, mas que mostra o que se ficou devendo.

Eu lembro que foi uma discussão que a gente queria ter feito no ano anterior mas, no último ano se conseguiu fazer, que era transformar os Distritos Sanitários em unidades orçamentárias. Incluir os Distritos Sanitários como U.O's, que era um troço que, a briga começava entre nós, que tinha gente que achava que não dava, que ia se tornar inadministrável. Então tinha o nosso pessoal mesmo, que eu achava um absurdo e ainda acho até hoje, não sei. E também o pessoal maior, das Finanças, eu não sei se o Amir Kahir ( ex-secretário de finanças ) reconsiderou e hoje não acha mais um absurdo.

$\mathrm{Na}$ verdade era transformar coisas maiores, coisas intersetoriais entre saúde e educação, nesse troço de unidade orçamentária, para que fossem gerenciados juntos todos os recursos. Tudo bem, que os embriões de democracia também deveriam ter sido o mote, deveriam, mas a gente não poderia ter deixado apenas os embriões tão pequenininhos, como a gente deixou. É disso que eu me queixo. Não é que a gente não sabia como é que ia fazer, tanto do ponto de vista mais geral da cidade, que se iniciou como os núcleos regionais de planejamento e depois se matou os NRP's, quanto dentro da própria Secretaria Municipal da Saúde, quando a gente viu que não ia acontecer nada do plano intersetorial, teve problemas para efetivar os Distritos Sanitários como unidades orçamentárias. Eu me lembro da votação onde o diretor de região votou contra seu Distrito Sanitário, isto é, contra a unidade orçamentária para o seu Distrito, e depois no interior da região, teve que responder por isso. Eu me lembro disso. Para você ver o grau de hesitação, de vacilação, de dificuldades que havia. Já que o caminho da reforma administrativa, do trabalho intersetorial tinha desandado, pelo menos aquilo, os Distritos Sanitários como U.O's, deveriam ser deixados. Então eram os pequenos passos, sabia-se que tinha que haver descentralização, articulação intersetorial, descentralizar o pessoal.

Tudo teria de voltar atrás numa administração Malufista. Sabia-se o que deveria ser feito. Não é que não se sabia.

\section{Alexandre Nemes Filho}

Esses dois pedaços, eu acho que para a população foi uma experiência interessante, porque a população tinha um canal para reivindicar, de pleitear mudanças na prestação de serviços, tinha esse canal que eram os Conselhos. Tinha uma interlocução direta sem intermediários, com os gerentes, com os gestores, isso é uma coisa interessante, menos provida da idéia do clientelismo. Quer dizer, não é aquela proximidade do compromisso pessoal do cara. Nesse caso, a participação tinha um outro caráter, que era solicitar uma mudança no serviço, que beneficiasse muito mais o conjunto da população do que a pessoa em si. Então eu acho que foi uma experiência interessante para vários grupos que 
participaram dos Conselhos. Eu acho que conhecendo melhor os serviços de saúde, conhecendo melhor o planejamento de saúde, sabendo entender essa coisa de pleitear para a comunidade, não só em proveito próprio, que era a coisa que a gente queria, de muito mais solidarıedade. Foi uma experiência muito importante no nivel local. Acho que no nível do Conselho Municipal de Saúde foi uma experiência tão importante que está funcionando até hoje. Não sei se está agora no momento, até há uns seis meses atrás estava funcionando. As pessoas que participaram do Conselho Municipal de Saúde aprenderam muito com essa coisa, em conhecimento e combatividade.

Essa participação da população levou à uma certa definição prioridades em alguns casos. Tiveram interferência de fato. Ganharam bastante com isso. Aprendizado político mesmo. de cidadania e de ter um serviço próximo que fosse melhor

Os interesses nem sempre são os mesmos. Construir alguma coisa e ter ProntoSocorro, sempre permeou as discussões. Até sair disso para uma coisa mais elaborada levou muito tempo, mas eu acho que foi uma experiência muito positiva. Do lado dos funcionários, eu acho que eles tiveram ganhos salariais importantes, senão nós não conseguiriamos fazer o que fizemos.

Tinha um problema sério que era o Sindicato, com uma visão bastante corporativa e que em algumas situações houve grandes problemas, como foi o caso da remoção-zerada. 0 Sindicato dos Médicos, as greves, e esse pessoal tinha um peso enorme.

O que eu acho pior na intervenção do Sindicato é sempre aquela idéia do funcionalismo como uma coisa única, igual para todo mundo, argumentos iguais. Não tem muita flexibilidade. Então isso amarra a administração. Então nosso compromisso com eles fazia com que a gente continuasse nessa política global. $E$ você administra trinta mil funcionários de uma só vez, não pode pagar mais para um neurologista, nem mais para um funcionário que tem um desempenho de mais qualidade.

Então essas amarras do corporativismo foram muito problemáticas para a administração. Eu acho que a administração fez um esforço muito grande para dar alguma coisa para o funcionário e eles ganharam melhores postos de trabalho, ganharam melhores salários, ganharam oportunidades de novos treinamentos.

O Larga Escala foi um negócio muito interessante, a formação em serviço, de dar a educação formal para aqueles que não tinham o primeiro grau completo

Os funcionários gostam até hoje da administração, reconhecem o esforço muito grande pelo funcionário. Agora, eu acho que eles também sofriam com a nossa improvisação. Montar Distrito Sanitário, montar Regional, a definição de papéis, a alocação de pessoal, com essas coisas eles sofreram. Muita concorrência entre si

Álvaro Escrivão Júnior 
Eu acho que a gente tem que ir direto à questão da comunicação, processo que a gente não conseguiu comunicar e, mais uma vez, a mesma coisa que a gente estava conversando, comunicar isso que a gente quer comunicar, uma nova abordagem sobre o modelo de atenção e que não teve receptividade aos ouvidos da população.

Na área da comunicação da gente acabou ficando muito enfatizada a prática da participação direta. Não ficou claro para as pessoas o que se pretendia com esse tal falado novo modelo de atenção ou qualquer coisa assim. Para os funcionários, menos do que para a população, principalmente para aqueles que em principio, tinham uma certa simpatia pela idéia. O grosso dos funcionários, também não entendia direito essa história de novo modelo de atenção.

A gente não fez uma política de comunicação que fosse capaz de passar claramente o que se pretendia e ganhar apoio sincero, ideal, espontâneo do pessoal. Acho que era muito em reação a aquilo que a gente fazia. A gente propunha e tal. Aí você tinha alguns que resistiam e outros que concordavam com a gente.

A maioria dos funcionários não conseguiu entender o que a gente queria ou não, mesmo porque eles não conseguem enxergar. Ouvir isso aí é muito difícil para eles. Ouvir e prestar atenção. Essa é a minha idéia. Eu acho que os funcionários, menos. A população como um todo entendeu muito pouco e eu acho que o que se criou, foi um grupo de pessoas da população que passou a aderir aos conselhos, que muitas vezes era o pessoal mais interessado em se organizar. Já não era organizado, mas interessado e que foi estimulado pela gente, pela Secretaria, pela Prefeitura, e passou a participar. Esta é a visão que eu fiquei ao cabo dessas coisas. Na verdade, eu acho que faltou para a gente a politica de comunicação e a prática da comunicação.

\section{Carlos Alberto Pletz Neder}

Há uma tese, de uma companheira nossa, que entrevistou dirigentes do Sindicato naquela ocasião, e o que sempre me pareceu como uma possibilidade. confirmou-se. Foram feitas reuniões de diretoria do Sindicato onde se deliberou pela não participação nos Conselhos Gestores. Não era uma coisa casual, era uma estratégia definida e, mais do que isso, eles trabalhavam com a hipótese, que nós estávamos nos preparando para utilizar a nossa presença na estrutura da Secretaria da Saúde para disputar a direção do Sindicato com eles, entendeu? Então você imagina a que ponto a coisa chegou. Isso na relação com os servidores. Agora, com a população, talvez o próprio Eduardo já tenha colocado qual foi a importância dos movimentos populares de saúde em toda experiência anterior a 88 , na própria definição da proposta que foi embutida na Constituição de 88 , da idéia dos Conselhos de Saúde. Não era uma idéia tranqüila no meio da esquerda. Quando em 79 foi eleito o primeiro Conselho de Saúde no Jardim Nordeste (Zona Leste), a esquerda nos questionou - e 
na época nós estávamos junto com a população, ajudando na organização desse processo dizendo que nós estávamos criando ilusões de fazer a população participar junto ao governo, junto ao Estado, dizendo que a população iria ser cooptada, que os funcionários também acabariam sendo desmobilizados nas suas lutas por esses Conselhos e coisas do tipo Durante muito tempo a esquerda conviveu com esse dilema: até de ponto participar ou não desses mecanismos de gestão democratizada do aparelho de Estado? Portanto, embora a proposta da Constituição preveja tanto a possibilidade da participação direta, quanto da participação através de representantes eleitos, ou seja, democracia direta e democracia representativa, na prática, a Constituição acabou detalhando mais a questão da democracia representativa, por exemplo, através dos Conselhos de Gestão, e o que nós procuramos fazer - tempo todo no município de São Paulo, foi o tempo todo associar as duas formas, de participação direta, como de participação através de representação desses segmentos sociais, seja no sentido de ampliar os segmentos representados, seja no sentido de estimular que houvesse um grau de representatividade maior nessas funções de representação dentro do Conselho Municipal, nos Conselhos Regionais, Distritais e depois até nos Conselhos Locais. Exemplo disso foi a tentativa de estimular a existência da Plenária de Saúde. Foram poucos os municípios que estimularam a existência da Plenária Municipal de Saúde, da Plenária Estadual de Saúde, como espaços de organização autônomos dos servidores, da população, das entidades da sociedade civil, para que lá eles pudessem elaborar suas próprias propostas e para que eles pudessem trazer suas propostas para dentro dos Conselhos de Saúde e disputar a hegemonia em torno dessas propostas. Já em 89 foi feito um Encontro Municipal de Saúde, e a partir de 90 nós fizemos a primeira Conferência Municipal de Saúde. São Paulo fez Conferências anuais de saúde, até porque é isso que está previsto na lei orgânica do municipio, e as pessoas passaram a ter essas opções de participação: a Plenária Municipal, a Conferência como uma situação transitória, que era um momento de grande participação, mas também com o apoio do governo, e os Conselhos de Gestão, como espaços da própria adminıstração, de fiscalização, de democratização da política e de acompanhamento da implementação das propostas. Sempre pagando o preço do estágio de organização de cada segmento, e até onde o governo poderia interferir ou não de forma legítima nesse processo. A gente percebeu que o dinamismo do governo, na definição das políticas e na sua implementação, sempre foi muito maior do que do próprio movimento. Isso gerava então um descompasso entre você ficar numa política, numa posição passiva de esperar o amadurecimento do próprio movimento, para que ele ocupasse este espaço, ou por outro lado, que essas incompreensões pudessem ser superadas por parte do Sindicato, o receio em relação ao governo. Por parte do movimento popular, a confiança quase que integral no governo, como sendo um governo que representava os seus interesses. Então, não havia tanta necessidade de se mobilizar, de se organizar e de pleitear as mudanças, porque o 
governo era sensivel às suas necessidades, portanto o governo por si só acabaria detectando esses problemas e ajudando a encontrar soluções. A gente no meio dessa história toda, discutindo o seguinte: nós temos que nos contentar com a existência de movimentos onde eles historicamente já se constituíram, ou nós devemos ajudar e estimular a existência de movimentos onde eles não existem? Eu sempre defendi a idéia de que nós deviamos incorporar, frente às nossas diretrizes, não só a idéia de fortalecer os movimentos onde eles já existiam, mas também a idéia de estimular o crescimento e o surgimento deles nos espaços onde eles não estavam dados. Portanto, rompendo com uma visão espontaneísta, e mostrando que não necessariamente isso significava o governo se impor diante da população e condicionar a sua forma de organização. Essa discussão toda é importante quando se considera que a palavra de ordem mais significativa que estava embutida no governo Luiza Erundina era a formação dos conselhos populares, e nós já vínhamos com experiência na área da saúde, na tentativa de formação dos Conselhos Populares de Saúde, que em parte se confundiam com a idéia dos conselhos gestores, com os conselhos do SUS, mas em parte guardavam relação com a organização autônoma dos movimentos, das comissões de saúde dos bairros, que vinham com uma outra lógica, com uma outra trajetória, que não era a trajetória pela institucionalização dos movimentos. Inclusive na dissertação de mestrado que eu estou fazendo, eu tento trabalhar exatamente essa questão, da organização institucional e da organização autônoma. Eu estou mais preocupado em analisar como vem se dando nesses últimos anos, a partir da formação das comissões de saúde, dos movimentos populares de saúde, essa forma de organização dos movimentos, nem sempre podendo contar com o apoio do poder executivo, do poder legislativo, mas no momento em que pode contar, sem também se deixar condicionar totalmente pela lógica que vinha por dentro da instituição e do aparelho de Estado.

\section{Eduardo Jorge Martins Alves Sobrinho}

Tem o cidadão comum e tem o "cidadão comum" . O cidadão comum está tão envolvido na tarefa de sobreviver, de criar a família, enfrentar o transporte, trabalhar, que não acha tempo nenhum para ser cidadão mesmo, para exercer o papel político, que é o papel nobre, que é a co-responsabilidade de governar sua própria cidade. Ele tem uma relação com o poder público, com o governo, de simplesmente votar, depois se queixar, cobrar, xingar, se os serviços vão mal, ou elogiar se os serviços vão bem. O que nós queriamos é que este cidadão, além de tudo isso, ele dividisse conosco a responsabilidade de governar no dia-dia. E desse um pouco do seu tempo para fazer isso. Ou seja, nós estávamos exigindo dele algo a mais do que votar, do que criticar, do que apoiar uma política. Tudo isso eu preciso dizer, porque têm questões de falta de tradição, por questões de dificuldades objetivas numa cidade desumana como essa, em que você passa 8-9 horas do dia no trabalho e depois 3 horas no 
trânsito. É uma cidade muito desgastante. $O$ que aconteceu no final das contas é que houve uma ampliação muito grande dos Conselhos de Gestão, do Conselho Municipal da Saúde. No final do governo nós tínhamos mais de uma centena de conselhos. O Conselho Gestor das Unidades, inclusive o defendido em todo o Brasil, começou aqui em São Paulo. Isto não estava previsto na lei do SUS. Foi para responder à uma pressão dos movimentos já organizados de longa data, que foram criados os Conselhos de Gestão, como uma forma de intervenção direta nas Unidades, não só no Conselho Municipal de Saúde, mas na própria Unidade. Quando terminamos a gestão havia mais de uma centena de conselhos. Isto envolvia pelo menos de 1500 a 2000 pessoas da população, usuários, participando junto conosco da co-gestão, num nivel razoavelmente intenso. Isso num universo de 10 milhões de pessoas é pouquissimo. Eu reconheço isso aí. É um passo muito importante, mas altamente incipiente, e a grande falha neste ponto de vista é a falta de trabalho com a comunicação externa da SMS, na Prefeitura Municipal de São Paulo como um todo, mas particularmente na SMS que tinha mais clareza disso ai. Com a falta de capacidade de trabalhar com a comunicação de massa e com a falta de capacidade de colocar canais de intervenção de massa mais efetivos. Porque eu falo isso? Comunicação de massa é você ter condições de atingir essa grande massa de cidadãos desta cidade pelos mecanismos modernos, de imprensa, de televisão, de radio. Sejam os privados, ou sejam os mecanismos próprios, da Saúde. Não se avançou quase nada nisso.

Em segundo lugar, não se criaram os canais para voltar essa influência, que seriam as pesquisas de opinião, seriam mecanismos de receber sugestões e informações reais rápidas dos cidadãos, que não tinham tempo ou não queriam se envolver com esses mecanismos que nós estávamos montando. Então você acaba privilegiando os dois ou três mil cidadãos que participavam dos movimentos populares, que eram de certa forma uma elite. Não uma elite econômica, mas uma elite política porque dispunham um pouco do seu tempo para ajudar na gestão política, e praticamente ignorou os outros, os quase 10 milhões, do ponto de vista da comunicação e da influência. Não quero fazer uma democracia direta permanente. Para isso você tem a Câmara, você tem os NRP's, você tem os conselhos de gestão, eleitos, mas a chamada comunicação direta, democracia direta, também é necessária. Principalmente agora que nós temos os meios de comunicação, que antigamente não existiam. Capazes de influenciar milhões de pessoas. $E$ a gente não fez isso. Eu acho que faltaram os meios de comunicação de massa para gente chegar até eles e eles chegarem até nós, sem obrigá-los a despender um pouco mais do seu tempo, de sua família, para influenciar em nossa administração. Isso não foi feito. Foi praticamente zero.

A questão dos funcionários. No início de nossa administração eu fiz uma série de assembléias nas regiões da SMS. As assembléias eram impressionantes, eram maciças. Tinha assembléia com 500-600 pessoas. Os auditórios dos hospitais não davam. As pessoas 
ficavam nas portas. Eu acho que havia uma expectativa muito grande dos funcionários, que refletia de certa forma o que existia na cidade. Os funcionários, como cidadãos, tinham uma expectativa em relação à nossa proposta, muito grande. É justiça fazer isso a eles e à população. Talvez até um desejo de mudança além da nossa capacidade institucional de realizar. Pelas próprias posturas que nós agimos em relação aos governos anteriores, de muita agressividade, muita cobrança, existia na população e nos funcionários em particular, uma expectativa de mudança muito grande.

Nem sempre a mudança vamos dizer assim, que nós desejariamos fazer. Mas existia. Em seguida, quando a relação do governo com os funcionários evoluiu em três direções, que considero fundamentais, a resposta não foi, nem sempre foi, do jeito que nós esperávamos.

\section{Quais eram as três direções?}

A primeira: mudança de modelo, de integração da medicina preventiva com a curativa; a forma de tratar a população, respeitando a população; o funcionário é um agente do poder público que tem que respeitar a população, servir a população.

A segunda: cobrar dos funcionários as obrigações e deveres deles em relação ao seu trabalho, em termos de horários, de tarefas, de compromissos.

A terceira: abrir um espaço aos funcionários através de seus representantes eleitos, de seus sindicatos, para dividir a responsabilidade de governar conosco. Dividir a responsabilidade de tomar decisões, às vezes difíceis, às vezes duras em relação aos serviços.

Os Conselhos de gestão, os conselhos regionais e o CMS estavam abertos à representação dos funcionarios, alguns eleitos diretamente, ou via representação dos sindicatos, para vir a dividir a responsabilidade de gestão conosco. Essas três tarefas foram contrapostas à uma visão puramente salarial e de condições de trabalho. Os sindicatos e os funcionários queriam imediatas e impossiveis mudança das condições de trabalho e de salário, e usavam esse tipo de reivindicação como pretexto para não assumir as tarefas ou os três caminhos que nós propusemos para eles. Então essa tensão foi permanente. Após aquele momento mágico, de se identificar conosco na possivel mudança mágica também, que não era possivel quando se concretizaram os três caminhos, a mudança de modelo, a mudança de forma de tratar a população, respeitando a jornada de trabalho, a necessidade de dividir a responsabilidade que nós colocávamos para eles (a co-gestão), houve um refluxo de boa parte desse sentimento de identificação. É claro que os funcionários continuaram ajudando muito a administração. Não vou fazer essa injustiça, mas não no nível de envolvimento que nós gostariamos. E essa questão salarial, essa questão puramente sindical, colocou-se o tempo todo como tensão em relação aos três caminhos. Chegou a ponto de se formular junto a setores mais organizados, uma visão que é a seguinte: "nós não temos a 
responsabilidade de governar com vocês. E vocês da administraçăo, estão colocando os representantes da população para nos fiscalizar". Esse tipo de divisão que envolvia uma imaturidade de parte a parte, nós vivemos os quatro anos de governo. $E$ isso foi se acentuando. Eu preciso dizer isso, e os funcionários foram uma parte importantíssima desse projeto que a gente conseguiu desenvolver. 0 entusiasmo deles, 0 trabalho deles evidentemente foi crescente, foi principalmente naqueles locais em que a gente conseguiu implantar programas com sucesso. Mas essa tensão foi o tempo todo durante o governo.

\section{Paulo Eduardo Mangeon Elias}

Ai tem dois aspectos: o primeiro, era o discurso e a vontade que as pessoas tinham. Era de incorporar esses segmentos todos numa perspectiva da construção da cidadania. Isso era uma coisa muito forte para as pessoas e havia uma tentativa muito grande. De novo, o que era cidadania, aí vai variar, essa palavra era uma palavra unificadora, mas o que era cidadania para cada uma dessas pessoas, ou para cada um dos diretores, ou para quem tinha necessidade de mando, para quem tinha poder de mando mesmo. Precisa ver qual a leitura que se tinha de cidadania. A palavra era a mesma. Mas o que era ser cidadão para cada um deles? Então eu acho que isso também passa por um filtro político e ideológico. Eu acho que tem essa dimensão, tem isso e esse esforço foi feito com muita intensidade. Quem se apresentou mais freqüentemente ai foram os movimentos sociais organizados. Isso era de se esperar. Eu acho que o esforço era dirigido a todos, mas evidentemente tem uma proeminência de quem? Dos movimentos sociais organizados, porque eles se apresentam mais que os desorganizados. Aí eu acho que tem essa dimensão que eu acho que é extremamente importante. Esse desejo, depois tem de novo a realidade. Qual o papel que os funcionários tiveram? Eu acho que de novo você não pode falar em homogeneidade. Acho que os papeis são distintos. Eu acho que de maneira geral, os organizados tiveram poder de interlocução, de pressão e de participação nessa construção, maior do que aqueles que não eram organizados. Isto vale em geral, desde o movimento social, o movimento de saúde, passando pelo funcionário, pelo funcionalismo. Então, eu acho que foi uma administração e, aqui não vai nenhuma crítica, eu estou fazendo uma leitura da realidade, não como um militante do PT, ou de alguém que participou, mas também com o olhar que tenho. Eu também tinha um papel ambíguo. Eu acho que a gente tinha aqui, um pouco um papel ambíguo. Eu acho o que poderia ser o movimento social organizado. A administração teve um interlocução muito grande com os movimentos sociais organizados, mas os desorganizados, o conjunto da sociedade, eu tenho muitas dúvidas sobre como é o que foi o processo. Eu acho que em alguns momentos a Secretaria contemplou isso, em outros não. Sem dúvida que os movimentos sociais organizados e os funcionários tiveram influência na nova estrutura administrativa da Secretaria. Em graus distintos. O que unifica tudo isso é o pensamento da 
Reforma Sanitária que penetra no movimento social, ele penetra principalmente, se você for estudar os movimentos de saúde, por exemplo, você vai reconhecer lá o pensamento da reforma sanitária. Então nesse sentido sim. E mais, não só o pensamento da reforma sanitária. Eu acho que pelas características de quem era o Secretário e quem era o grupo que estava ali na Secretaria, esse movimento de saúde teve seu ideário, suas expectativas contempladas, senão totalmente, pelo menos significativamente, eu diria.

No caso do funcionalismo essa penetração do ideário da reforma sanitária, eu acho que era mais esmaecido esse ideário da reforma sanitária. Mas mesmo assim ele existia e também foi contemplado. O que eu quero dizer é que no caso do movimento de saúde, o movimento de saúde forneceu quadros para a administração. No caso das Instituições, dos sindicatos, etc. e tal, eles não forneceram quadros. Mas o movimento de saúde forneceu quadros para a administração. Não se pode esquecer disso. Para começar, o próprio Secretário, começou sua vida política no movimento de saúde, para não falar de outros exemplos, como por exemplo, assessores de todos os níveis, lá desde o serviço de saúde até o alto escalão da Secretaria, ele era permeado de pessoas vindas do movimento de saúde. No caso dos sindicatos, isto não acontecia. Ou porque não tinham quadros para oferecer ou porque também havia uma tensão muito presente entre esses sindicatos e esse modelo de reforma sanitária que é o caso, por exemplo, do Sindicato dos Médicos. Era uma tensão entre o ideário da reforma sanitária que tensionava certas concepções do Sindicato dos Médicos de São Paulo. Ele não forneceu quadros sindicais. Aliás, não é verdade, ele forneceu quadros sim, mas de uma maneira muito pequena. Eu me lembro, por exemplo, que a direção do Hospital Jabaquara era do Sindicato dos Médicos. Quem forneceu quadros mesmo foi o movimento de saúde, em todos os níveis. Eu acho que isto é uma coisa diferenciada.

\section{Você teria alguma coisa a falar sobre a promoção da eqüidade pela Secretaria Municipal da Saúde?}

Pedro Dimitrov

Veja, de novo nós precisamos de ações internas à Secretaria e ações externas à Secretaria, feitas pela Prefeitura. Saúde como assistência é uma coisa. Saúde, como deve ser vista é outra. Do ponto de vista do papel da Secretaria Municipal de Saúde, para enfrentar esta situação a gente pode dizer o seguinte: ela enfrentou, mas os seus serviços são absolutamente insuficientes. Mesmo abrindo 6 hospitais, ampliando seu atendimento, passando de 20 para 40 mil servidores, desativando órgãos de nivel central, descentralizando as pessoas para os niveis regionais/distritais mais próximos do atendimento da população, todo esse movimento teve a finalidade de melhorar a qualidade de atendimento da população. Eu acho que isso nós fizemos. Agora, isso é insuficiente, dada a população que a 
gente tem, e o tamanho da rede dos serviços municipais. Então, nós enfrentamos esta questão da eqüidade, nós caminhamos neste sentido, mas nós não demos solução para 0 conjunto da população.

É impossivel o municipio ter a solução sozinho. Este é um processo de construção do SUS, e necessariamente tem que ter recursos dos governos federal e estadual colocados aqui. Basta lembrar que a cidade de São Paulo representa $1 / 3$ da população do Estado. Então, deveria ter $1 / 3$ dos recursos da Secretaria Estadual da Saúde jogados no município de São Paulo, o que não ocorre. Além de nós termos de considerar que a capital atrai pessoas de outras cidades, de outras regiões, para assistência de saúde aqui. Portanto, não seria apenas $1 / 3$. Seria mais do que $1 / 3$ de recursos de saúde jogados aqui dentro. $E$ isso não ocorre. A mesma coisa em relação ao governo federal, que deveria estar colocando recursos aqui. Portanto, a minha visão mais simples, quanto à assistência à saúde, é que durante os 4 anos nós invertemos as prioridades da Secretaria, direcionamos a Secretaria para atender realmente a população de forma mais adequada, para enfrentar os problemas da população mais carente. Isso foi feito, foram jogados mais recursos para a periferia, recursos humanos, materiais, equipamentos, enfim recursos para a periferia, mas a rede da Prefeitura é insuficiente para mudar qualitativamente a situação de saúde para o conjunto da população da capital. Isto em relação aos problemas internos.

A segunda questão diz respeito aos problemas externos à Secretaria Municipal de Saúde. Acho que o governo do PT como um todo, em relação a todas as outras Secretarias teve a mesma preocupação. Tanto o atendimento das escolas na periferia teve um papel importante, $o$ atendimento das bibliotecas da Secretaria da Cultura na periferia teve um papel importante, e assim sucessivamente em relação à todas as Secretarias. $O$ governo como um todo teve esta mesma preocupação e neste sentido, eu acho que houve mudança importante. Basta se fazer análises do uso dos recursos. É pegar os orçamentos municipais dos quatro anos da gestão petista e verificar aonde é que o dinheiro foi aplicado, em que região, em que lugar, para se verificar que esses recursos foram aplicados na área social e de preferência na periferia. Então eu acho que nós fizemos esforços para enfrentar essas questões relativas à iniqüidade.

Eu acho que a Secretaria Municipal de Saúde teve um papel fundamental. Teve participação importante, teve uma participação organizada e intervenções significativas. Por exemplo: a luta na Câmara Municipal para a aprovação dos projetos de leis de criação dos Distritos de Saúde e dos Hospitais. Uma luta politica que teve de ser levada para dentro da Câmara e, a administração junto com a população, fez com que esses projetos fossem aprovados. Basta ver que foi a Secretaria Municipal de Saúde que conseguiu aprovar projetos na Câmara. Ninguém conseguiu aprovar na Câmara. Na minha opinião nós tivemos uma articulação de altissima competência com a nossa assessoria parlamentar. 
A Secretaria Municipal de Saúde tinha uma assessoria parlamentar muito competente. Conseguiu ter um relacionamento de alto nivel, competente, sem nenhum clientelismo de baixo nivel, com os vereadores, no sentido de mostrar a importância dos projetos e convencer os vereadores que a aprovação desse projetos traria votos para os próprios vereadores.

Na realidade nós tivemos um trabalho articulado entre o Gabinete da Administração, diretores regionais, com assessoria pariamentar, com assessoria de participação popular, que subsidiava a população com informações e com tudo o que era necessário para a população poder se organizar e tudo isso articulado, fazia uma pressão em cima da Câmara para a aprovação dos projetos. Eu acho que a gente teve um papel fundamental neste sentido e com muita competência.

As outras Secretarias, embora fossem tão importantes quanto a da Saúde, como Educação, Bem-Estar Social, etc., não conseguiram aprovar projetos. Eu acho que isto está ligado à competência que a gente trabalhou a discussão popular e a participação dentro da Câmara. Nossa assessoria dentro da Câmara foi muito competente. A participação nas lutas sociais, na conquista dos interesses dos trabalhadores, da população de um modo geral. Foi inclusive um episódio muito atrapalhado que a Câmara tentou fazer, o de impedir a Luiza Erundina de trabalhar, a partir das contas da Prefeitura rejeitadas pelo Tribunal de Contas e na Câmara. Foi uma avaliação absolutamente política e não técnica e, que depois, durante a votação na Câmara, uma grande parcela da população ligada ao movimento popular de saúde, esteve na Câmara fazendo pressão para aprovação das contas da Luiza. Então as contas da Luiza que foram aprovadas pela Câmara, dependeram em parte da pressão popular, e esta pressão popular por sua vez, uma grande parcela dessa pressão popular, foi oriunda do movimento popular de saúde.

Virgínia Junqueira

Procurava-se encarar as desigualdades da cidade e oferecer à essas desigualdades respostas a altura. A mesma coisa dentro do funcionalismo, onde a gente teve muitas falhas, pois não tratamos os médicos da mesma forma que tratamos os demais funcionários. Eu acho que sequer a gente aflorava a questão da eqüidade. Ela entrou muito no discurso, mas na realidade, na execução do trabalho, ficou muito aquém do previsto. Deixe-me ver, por exemplo, quando você tratava da questão das mulheres, você estava tentando promover a eqüidade já que a mulher é relegada, historicamente e tal. Vamos pegar a questão mais específica, que aborda essa questão da eqüidade, não como um todo é verdade. O portador de deficiência, que a Prefeitura tinha inclusive gente no Gabinete da prefeita preocupada com isso. Nós tínhamos na Secretaria Municipal de Saüde gente preocupada com isso. Era uma questão de dar enfrentamento a desigualdade, com uma resposta que significasse eqüidade. 
Ou seja, fazendo com que a cidade pudesse ser desfrutada, vivida pelos portadores de deficiências, em condições não de igualdade, mas em condições menos desfavoráveis, que era fazer guias, botar ônibus assim, assado, enfim, condições apropriadas para os portadores de deficiências e uma série de outras coisas. Os idosos foi uma questão que a gente se preocupava tanto, fizemos até um evento, junto com o pessoal do Corpo Municipal de Voluntários, sobre a condição do idoso na cidade de São Paulo, que resultou até num livro muito interessante, que eu tenho lá em casa, do Sergio Paschoal. Enfim, mostra a preocupação do poder municipal com segmentos da população, que experimentam da maneira mais aguda a desigualdade, que além de ser uma desigualdade social, é uma desigualdade por faixa etária, é uma desigualdade por ser portador de alguma coisa. Mas a gente aflorou sim, a gente mostrou que a administração tinha essa intenção de enfrentar a questão da eqüidade, através dos idosos, da questão das mulheres, dos portadores de deficiências, do sofrimento mental, etc.. O potencial que havia para desenvolver coisas nesse sentido era muito grande. Poderia ter sido eleita uma prioridade, por exemplo, dos idosos, dos deficientes. Nós vamos tornar essa cidade habitável para os portadores de deficiências, ou que fosse a prioridade dos portadores de doença mental. Enfim, um grande problema de administração foi não ter uma prioridade muito clara. Tudo bem, precisava enfrentar uma diversidade monstruosa. Dane-se. Tinha que haver algumas prioridades para a tal da visibilidade, da intenção, visto que o governo municipal não vai resolver a tal da desigualdade social. Não vamos resolver o problema da desigualdade que é uma questão social muito mais ampla. É a pessoa cidadã que vai resolver isso, não vai ser o governo municipal, o governo é uma alavanca para isso. A Luiza Erundina, que podia brilhar com a questão dos idosos, dos portadores de deficiências, com a questão da saúde mental, não brilhou. Isto pode adquirir importância para a sociedade, à medida que a comunidade se envolve para resolver os seus problemas. Isso aborda a democracia, isso aborda a democracia desde a base dela no nível local.

Então eu acho que a gente perdeu ótimas oportunidades. É outra coisa que eu tenho um sentimento de desperdício muito grande. A questão da saúde é tão sensível para a pessoa, e se você sabe fazer essa discussão, ela toca essa sensibilidade das pessoas e a gente não soube explorar isso. Não soube e acho que aí houve novamente disputas dentro do governo municipal, que não permitia que o setor saúde se sobressaísse e assim, trouxesse questões que tocariam de perto as necessidades da população. Ou você tem opção pela saúde, educação e habitação, mesmo, ou fica essa coisa toda confusa, de dispersão de iniciativas. A administração criou coisas para tudo que é lado, era muito criativa, havia pessoas com muitas idéias e capacidades. Eu não tinha esse sentimento de gente inexperiente, não é isso. Eram pessoas extremamente competentes. E O Paulo Singer, 
podemos falar tudo dele, menos da incompetência. Agora, essas pessoas não conseguiram personalizar essas coisas e aparecer, ter visibilidade.

Como é que se resolve isso? Eu não sei. Precisamos de um comunicólogo que saiba transformar essas coisas. Mas o que eu acho é que faltaram decisões politicas, de dizer que vamos fazer tal coisa porque. como não dá para enfrentar a realidade como um todo, vamos enfrentar isto e vamos tornar aquilo ali, até uma situação denunciadora das outras, já que não é possivel enfrentá-las todas ao mesmo tempo. Não vamos tapar buracos e dizer que vamos enfrentando tudo. Não. Não é isso. Vamos enfrentar tal e tal coisa e vamos mostrar mais um monte de coisas que nós não vamos dar conta. Eu não sei, sei lá.

\section{Alexandre Nemes Filho}

Eu acho que a Secretaria Municipal de Saúde promoveu a eqüidade. Nós privilegiamos a população mais carente ao fortalecer o serviço público, ao montar Unidades mais consistentes, com maior número de profissionais e com equipes multiprofissionais. Eu acho que a população se beneficiou muito com a nossa política. Se você junta saúde com a creche, com a escola pública, a administração privilegiou a eqüidade. Eu não tenho dúvidas disso. A justiça para o funcionário nem sempre bate com a justiça do PT. É uma idéia meio maluca. Os funcionários no começo pensavam que nós iríamos fazer uma justiça sanguinária. A nossa sorte é que o grosso dos dirigentes da Secretaria Municipal não era do município e dessa forma..., de certa forma a gente soube lidar com isso.

Nós aumentamos o salário e cobramos trabalho. Acho que as pessoas trabalhavam bastante na administração. De qualquer forma o PT teve esse realismo de justiça sem a justiça revolucionária e a justiça corporativa. É complicado jogar isso para dentro da administração. Houve uma certa segmentação nessa história. Havia gente engajada nesta proposta. Um grupo que assumiu a proposta, pelo lado da valorização do setor público e, o pessoal que nunca concordava com isso, mais interessado em ter um espaço sem grandes problemas. E tinha gente que não concordava com essas idéias.

Eu diria que de uma maneira geral os funcionários gostavam do serviço. Queixavamse muito da improvisação de ter que fazer tudo sempre correndo. De ter muita gente dando palpites. O conjunto sabia que havia uma proposta para atingir a população. Nós quase não tivemos grupos de funcionários reativos à nossa proposta. Eu sentia uma solidariedade de grande parte dos funcionários à nossa proposta. Tanto que elegemos dois vereadores próximos à saúde, o Adriano e o Neder, o que mostrou que os funcionários apoiavam a nossa proposta, e o mesmo quanto à população.

Álvaro Escrivão Júnior 
Isso é uma das coisas que eu não tenho dúvidas. Tenho dúvidas sobre quase tudo. Com certeza a gente avançou muito. Eu acho que toda a nossa política de voltar o atendimento para a periferia era um critério praticado de priorizar a periferia, de superar as dificuldades. $O$ adicional à distância, todas as políticas indicam que a gente queria realmente trabalhar isso dai, a eqüidade.

Pessoalmente eu participei de um projeto que gerou um livro sobre a população de rua, livro da Cleísa, que foi assim, uma política séria do pessoal inclusive mostrando o tamanho da população de rua. Não era do tamanho tão grande como se falava, e eu participei de reuniōes discutindo políticas para isso, para a população de rua.

Eu acho que toda a área da Secretaria da Educação (uma pessoa que vale a pena bater um papo, é o Mário Sérgio), foi toda voltada para essa questão. Acho que melhorou demais a qualidade da rede municipal de ensino. Para mim acho que educação talvez seja mais fundamental que saúde para a população pobre. Reduzir as diferenças de acesso à formação e informação, enquanto políticas mesmo. Eu não tenho nenhuma dúvida que a principal responsável pela entrada da vacina contra a rubéola no Estado de São Paulo foi a Secretaria Municipal de Saúde - SP, porque eu participei ativamente disso, desde o primeiro dia, em cima de uma linha de raciocínio assim: por que que os pobres não podem ter, se tem vacina? Bem em cima disso mesmo, até que depois a Secretaria de Estado da Saúde tomou a frente.

Em relação aos servidores, o primeiro o processo que eu recebi depois que sentei na Secretaria, era um processo de mais ou menos $20 \mathrm{~cm}$ de altura, com pareceres de todos os professores de Moléstias Infecciosas de S.Paulo, sobre vacinação de servidores contra hepatite por vírus B. Nós instituímos essa vacinação. Então a vacinação de servidores municipais certamente foi propulsionada na nossa gestão.

Os próprios Conselhos Gestores e Municipal de Saúde, acabaram sendo estímulos para os servidores se organizarem. Eles acabaram se organizando para defender coisas deles. Eu acho que a Luiza tinha um posicionamento extremamente receptivo para as reivindicaçōes do pessoal.

\section{Carlos Alberto Pletz Neder}

A eqüidade sempre foi colocada como sendo uma diretriz fundamental. Nós incorporamos a idéia da eqüidade não como sendo tudo igual para todo mundo, mas dentro do conceito de que nós tínhamos de dar mais para aqueles que tinham menos. Isso aí foi muito discutido entre nós. Qual era o conceito de eqüidade entre a gente? Era garantir, dentro da filosofia que acabou imperando no governo, com o lema São Paulo para todos, que nós deveriamos dar igualmente a distribuição dos recursos, para todos os setores da sociedade, independente da forma como eles estavam inseridos no contexto do município, indiferente 
das injustiças e da exclusão social, ou se nós deveríamos dar mais a quem tinha menos, e se isso não era um componente importante dentro do conceito de eqüidade que nós estariamos adotando. Eu acho que acabou imperando dentro do nosso governo e da própria Secretaria da Saúde a idéia que nós tínhamos que nos voltar cada vez mais aqueles que tinham menos, sem que isso significasse voltar as costas para aqueles que, sendo cidadãos com direitos respeitados e com uma inserção diferenciada na economia, na sociedade, o direito também de freqüentar e usar os serviços. A própria experiência mostrou que à medida em que os serviços foram melhorando, setores crescentes da classe média e até mesmo setores da burguesia utilizaram serviços municipais, e ficaram surpresos com a qualidade dos serviços que nós estávamos oferecendo, e nós não nos recusamos a ofertar esses serviços a esses segmentos. A prioridade nossa estava colocada para aqueles setores mais excluídos. Isso foi mais intenso na Secretaria da Saúde do que propriamente no governo. O governo quando fez a opção pelo lema São Paulo para todos, na verdade ele acabou tendo decorrências dessa opção feita, seja no sentido da radicalização da proposta política de governo, seja no sentido da radicalização da proposta da descentralização da gestão. Coisa que na Saúde nós tentamos fazer com ritmo e com um enfoque diferenciado. Já na época em que o Eduardo era - Secretário, e depois eu tentei dar continuidade, dando seqüência à algumas diretrizes que a gente já havia definido desde o começo da gestão, em 89. Isso aí você pode ter exemplos em cada um dos programas, em cada uma das ações que se fez. A questão por exemplo do GORD, ou da UOT que era a unidade de orientação e triagem, aquelas várias tentativas de você fazer com que diminuísse a violência institucional. O lema São Paulo para todos foi importante no sentido de uma compreensão de que nós não poderiamos governar a cidade apenas para um partido ou para um segmento, mas por outro lado, sempre me pareceu insuficiente no sentido de que nós tivéssemos uma definição mais clara de quais eram os nossos aliados preferenciais, até para dar continuidade a esse projeto político e de governo. $\mathrm{Na}$ área da Saúde, no momento em que nós resolvemos procurar aqueles que estavam nos cortiços, aqueles que estavam nas áreas de risco, aqueles que estavam sujeitos à inundação, à leptospirose, aqueles que estavam excluidos de qualquer possibilidade de participação na sociedade e no sistema de saúde, na verdade nós optamos pela eqüidade, mesmo mantendo as Unidades abertas à burguesia, à classe média e à pequena burguesia. Nós procuramos alguns setores que poderiam se aliar com a gente na consolidação desse projeto, pelo menos na área da saúde. Nós terminamos o nosso governo com a avaliação positiva do trabalho em algumas áreas. No final, o saldo do governo foi um saldo positivo, em que pese as criticas $e$ as avaliações, que eu acho que a gente tem que continuar fazendo. Acho que a área da saúde, como educação e algumas outras, foram bem avaliadas, inclusive pelo pessoal de fora do partido, seja pelos resultados obtidos na ampliação dos serviços, na redução da mortalidade infantil, inclusive num grau superior ao decréscimo que houve nos governos 
anteriores e posteriores ao nosso. $\mathrm{Na}$ questão da mudança qualitativa, na gestão da Secretaria e das ações de saúde. Mas eu acho que faltou ainda uma consolidação disso, que seria um grau de unidade maior do corpo de servidores e da população para sair em defesa desse projeto. A tal ponto que eles puderam de 93 até 95 , desestruturar tudo que nós fizemos, e a partir de 95 , entrar com a proposta de terceirização, ou de privatização, totalmente oposta a tudo aquilo que nós fizemos. Eu acho que do ponto de vista do resultado para a cidade, da oferta de serviços e das ações, foi uma coisa muito importante. Do ponto de vista pessoal de cada um de nós que participou dessa experiência, eu acho que nós saímos engrandecidos e até orgulhosos do trabalho que nós fizemos. É difícil você ir a um lugar, onde não se tenha um exemplo positivo, onde não se faça uma comparação como era o nosso governo e como está hoje, e acho que nós crescemos também profissionalmente como pessoas. Apesar de todas as dificuldades, todos os embates que nós tivemos, muitas vezes os atritos que nós tivemos dentro da equipe, eu acho que a equipe saiu satisfeita e sabendo que estava em condições de dar novos passos. Infelizmente nós não fomos aproveitados como poderiamos ter sido. Exemplo disso foi a vitória do PSDB no governo do Estado de São Paulo, inclusive com apoio do PT no segundo turno, que poderia ter aproveitado boa parte do corpo técnico que esteve na Secretaria Municipal de Saúde, e que por insegurança do próprio PSDB, ou por razões outras que eu desconheço, não teve a grandeza de incorporar todo esse corpo técnico e inclusive, de aprofundar a implementação do SUS no Estado e na cidade de São Paulo, até podendo fazer um contraponto com o abandono das políticas públicas de saúde, pelo PAS em todo o município. Nós temos um imenso potencial acumulado dessas pessoas, e de documentos, e aí eu vejo a importância de sua tese. Ao fazer o resgate de todo esse trabalho, conversando com os atores, recuperando documentos, e ao mesmo tempo, lançando um olhar crítico sobre o que foi positivo e o que foi negativo, mas o que ficou dessa experiência. $\mathrm{Na}$ verdade, nós estamos dizendo para todo o movimento da reforma sanitária, ou o que ainda resta dele, que a experiência da cidade de São Paulo ainda não foi analisada com o respeito que merece e com a grandiosidade do trabalho que foi feito aqui.

\section{Eduardo Jorge Martins Alves Sobrinho}

Consciente ou não, nós fizemos. Porque a expansão dos serviços foi em direção à periferia. A Luiza Erundina conseguiu inaugurar hospitais em regiões com um milhão de habitantes que tinha zero leitos. Campo Limpo, por exemplo, tinha um milhão de habitantes e zero leitos. É um belíssimo hospital que estava lá se arrastando desde o governo Covas. $E$ assim foram os outros hospitais como o de Sapopemba e o de Ermelino Matarazzo. Então, na própria política de investimentos e expansão dos serviços, essa questão de eqüidade foi levada à concretização. 
A outra questão, você se lembra, a gente criou aquele sistema diferenciado de três tipos de pagamento de pessoal, para poder fixar o servidor, principalmente médico e outros profissionais universitários, na periferia mais distante, pagando diferentemente para quem trabalhava na Cidade Tiradentes, de quem trabalhava na Vila Mariana ou no Tatuapé.

Eu acho que a política de saúde como um todo, foi nessa direção da eqüidade. Se foi insuficiente, ela foi, é claro, como toda política nossa, mas o vetor era esse. $E$ vendo hoje também, acho que uma coisa que a gente não fez e poderia ajudar muito nessa questão da eqüidade e até na melhoria dos serviços, era o Programa de Saúde da Família, com agentes comunitários e de internação domiciliar. Eram todos programas estratégicos e nós não tivemos clareza, nós não os desenvolvemos. Até a internação domiciliar começou em Sapopemba, mas começou por iniciativa deles. Não era orientação da Secretaria.

E ao Programa de Saúde da Família e agentes comunitários, havia uma posição contrária nossa. São dois programas que ajudam muito a questão da eqüidade, porque vai na direção dos mais carentes, do mais pobre, do mais idoso, da criança. Até o fato de você se deslocar para a UBS, mesmo que seja descentralizada, é mais difícil para o mais velho, para o mais pobre, para a criança. Então o Estado tem que buscá-los, aonde eles estão. Na casa deles. Então eu sinto nós não termos tido clareza para desenvolver esses dois programas que eu acho que ajudaria muito na busca da eqüidade. Mas no conjunto da politica de pessoal e de investimento, ela foi nessa direção. Não poderia reformar o mundo da noite para o dia, mas que ela foi nessa direção foi.

\section{Paulo Eduardo Mangeon Elias}

Eu acho que o problema da eqüidade passou muito longe da Secretaria Municipal de Saúde. E nem poderia deixar de ser desta forma, porque a forma como foi organizada a gestão da Secretaria Municipal de Saúde, dificultava a busca da eqüidade. Por que? Porque você tinha de um lado o Conselho Técnico Administrativo e de outro você tinha uma outra instância que é muito importante, que é o Conselho Municipal de Saúde. Em ambas essas instâncias, a dinâmica de funcionamento delas não contemplava a eqüidade. Por que não contemplava? Cada diretor regional chegava ao Conselho Técnico Administrativo para defender a sua região. Buscava o maior número de recursos para a sua região. Quem era o poder moderador disso aqui? Era o Secretário ou seus assessores. Então o que você tinha era uma relação fratema, mas competitiva entre as regiões. Entre as diversas regiões. Então você não tinha uma concepção de eqüidade muito bem fundamentada do município de São Paulo. Você tinha as regiões e os Distritos que competiam fraternalmente. Essa coisa de eqüidade. diz respeito a recursos materiais e financeiros. Você tinha um poder moderador que era do Secretário, e isso aqui dificultava você ter uma visão mais global do municipio. Você ficava com uma visão muito regional. Esta que é a desvantagem de você ter uma estrutura 
regionalizada. Você tem vantagens, mas como tudo na vida, tem desvantagens. A Secretaria nunca se preocupou em buscar mecanismos institucionais para corrigir ou controlar esta desvantagem.

De outro lado, você tinha o Conselho Municipal de Saúde que funcionava mais ou menos do mesmo jeito. Você tinha os movimentos sociais competindo entre si fraternalmente, pelos recursos. Não como inimigos, mas competindo pelos recursos. Na verdade você tem demandas imensas, e as demandas eram muito maiores do que as possibilidades que você tem. Então é inevitável. Como é que você vai decidir? Cadê a instância que poderia contribuir? Qual a dinâmica de funcionamento? Eu não estou dizendo que em alguns momentos a eqüidade não foi contemplada. Não me interessava a exceção. Estou falando da regra. A dinâmica de funcionamento da Secretaria não contemplava a eqüidade.

Como é que você vai tratar desigualmente aquilo que é desigual. $E$ aí, como é que faz? Na base do que? Na base do convencimento? Mas as dificuldades, as deficiências, as demandas eram muito grandes em todas as regiões. A única coisa que eu acho que tinha nessa linha da eqüidade e isso é muito mais um primado político que qualquer outra coisa, era a coisa de se voltar para a periferia.

Os mais pobres, os debaixo, os da periferia. Mas isso muito mais como uma procuração daquele ideário político que passava por essa concepção de política mesmo, de que estamos com o poder, e então agora nós vamos construir uma sociedade com os debaixo, com este. com aquele, com aquele outro, do que propriamente alguma coisa no plano mais técnico e gerencial da Secretaria. Você quer ver um exemplo típico, que não privilegia a eqüidade? A remoção zerada. Além dos aspectos políticos de como ela foi feita, ela foi invocada em nome de uma justiça, em abstrato.

A Secretaria resolveu então redimir todas as injustiças, com bastante aspas, que foram cometidas em todos os governos passados, desde o começo, em todos os tempos. Então com o preceito da justiça, nós vamos fazer a remoção zerada. Só que, com o critério que foi montado para fazer a remoção zerada, qual foi o resultado dela? Ela esvaziou a periferia. Não era a intenção, muito menos no discurso. Eu tenho críticas à remoção zerada, todo mundo sabe disso, no momento político em que ela foi feita. Eu achava que ela deveria ser feita nos primeiros meses da administração. E não no final. $E$ nem muito menos como uma morte anunciada como foi, que paralisou todo o sistema administrativo. Ficou rolando 8 meses. Se vai fazer, se não vai fazer, como é que vai fazer, e parou toda a máquina.

Então eu tinha esse tipo de crítica. O resultado dela, aqui é um resultado aparente, ela deixou buracos na periferia. Não é que ela provocou os buracos. Já tinha buracos na periferia. Ela acentuou esses buracos na prática. Isso é uma coisa que é trancada a sete chaves, mas isso era falado à boca pequena, de que ela aumentou um pouco os buracos. Mas isso é de se esperar, porque ninguém quer trabalhar na periferia. Os médicos brigaram 
contra a remoção num primeiro momento, porque eles imaginavam que iria haver grandes mexidas na Secretaria, mas se você for estudar aquele desenho que foi feito para os critérios, você vai ver que primeiro ela mexia muito pouco com as pessoas mais estabelecidas, com os quadros mais estabelecidos. Não mexia praticamente nada. Portanto, esse discurso que vou corrigir injustiças, que aconteceu desde sempre na Secretaria, não se efetiva. Você percebe? No plano do discurso e no plano da prática. E o que a Secretaria fez? Ela acabava mexendo mais na periferia porque no centro estavam os quadros mais antigos, estabelecidos pelas regras, pela lógica já estabelecida na Secretaria. O pessoal já tinha conseguido vir para os cargos melhores. Ela mexeu bem na periferia e no núcleo intermediário, entre a periferia e o centro. Onde é que estavam os maiores privilégios? No centro. Você não quebra com essas coisas pela vontade sua, você precisa estudar profundamente isso para você ver como é que se aplica isso. Se é conveniente aplicar, se não vai desestruturar todas as coisas. Você não vai fazer justiça no plano abstrato. Isso que eu falo que é um pouco ingênuo. Porque o resultado social disso vai ser muito ruim. Você faz justiça em abstrato aqui, que no caso acho que nem fez, mas vamos supor que tenha feito. O resultado social não é dos melhores. Então, do que você está falando, quer dizer, a eficácia social desta sua justiça não é das melhores. O que é eficácia social? Atrapalhar o funcionamento dos serviços? Entre essas duas coisas: o serviço funcionar melhor ou você fazer uma justiça em abstrato que redime toda a história, o que você escolhe?

É isso que o administrador público tem que fazer. E é aí que vai mostrar onde está o compromisso desta história. O que você vai fazer? É isso que eu estava chamando de um pouco de ingenuidade. É o principismo. A Secretaria trabalhava muito com princípios. Principismo. Eu sou concordante com boa parte desses princípios. Mas o problema não é esse quando você está na administração. O problema é você pegar esse princípio e ver ele operado, o que é que vai acontecer com, qual vai ser o resultado oficial dele. Porque ser objetivo é prestar serviço de saúde e com a melhor eficácia possivel.

6. Na sua avaliação, qual foi o produto, o resultado do trabalho da Secretaria, findo aqueles quatro anos?

\section{Pedro Dimitrov}

Veja, eu acho que nós estávamos em um processo de construção do SUS com qualidade, competência e com uma boa organização. A perspectiva de construção das 10 ARS's e dos 31 DS's foi possivel fazer, dado o fato de não ter ocorrido a municipalização. Qual era a perspectiva disso? Era que ocorresse a municipalização, ampliasse-se o número de Distritos de Saúde e reduzisse-se a estrutura administrativa das regiões. Na realidade a 
perspectiva era que você chegasse a um momento em que você teria basicamente $50 \mathrm{e}$ poucos Distritos Sanitários com autonomia total.

Nesse sentido o que impediu que nós pudéssemos avançar mais e mais rapidamente, não foi a não municipalização, mas a proposta de estrutura da Secretaria com as 10 regiões e os 31 Distritos Sanitários, que num futuro próximo deveriam estar chegando a 50 e poucos. Essa proposta caminhava no sentido de você fortalecer o Distrito Sanitário, dar autonomia para o Distrito Sanitário, todos eles como U.O's, dando autonomia do ponto de vista dos recursos humanos, da vigilância epidemiológica, da integração com a vigilância sanitária, realmente trabalhando na linha da vigilância à saúde e da solução dos problemas de saúde coletados naquela região, reduzindo a estrutura das ARS's e mantendo uma pequena estrutura a nivel central da Secretaria. Este era o desenho, era neste sentido que se estava caminhando. No entanto, a medida em que se reforçavam os Distritos Sanitários, as regiões reduziram o seu tamanho. A experiência da ARS-2, por exemplo, que consolidava os seus 3 Distritos Sanitários, do Butantã, Lapa e Pinheiros, a ARS ficou com uma estrutura muito pequena no momento da implantação do último Distrito Sanitário. Praticamente todos os recursos da região, foram deslocados para a constituição de seu último Distrito Sanitário.

Então a perspectiva era essa, era uma perspectiva de uma estrutura, dentro do possivel, dadas as amarrações administrativas existentes, de utilizar-se do menor número possivel de pessoas em atividades-meio, para que as pessoas fossem colocadas em atividades-fim, prioritariamente. Por isso é que se propunha uma estrutura muito pequena a nivel central, a nivel regional e uma estrutura mais de apoio administrativo a nivel distrital, mais próximo da execução.

Este projeto todo, esta proposta toda, ela não se consolidou, primeiro porque não houve a municipalização, segundo, porque não houve a reforma geral da Prefeitura, e naquela época, eu já tinha uma visão em relação a esta questão, tanto que eu colaborei na elaboração do projeto de reforma da Prefeitura e continuo pensando desta forma. Óbvio que não tem nada a haver com que ocorre na administração Maluf e agora, na futura administração do Pitta, mas uma visão correta de administração para uma cidade do tamanho de São Paulo, seria a de radicalizar a descentralização de todos os serviços prestados à população e eu colocaria no nível dos 96 Distritos criado por lei.

Foi uma lei correta e adequada, que corresponde a necessidade de planejamento, da criação dos 96 Distritos da cidade de São Paulo. Esses 96 Distritos, já com alguns estudos realizados posteriormente pela Aldaiza Sposatti, em relação à distribuição da qualidade de vida, ou seja, o mapa da exclusão, mostra claramente como é possivel você trabalhar agora a partir de dados muito concretos de exclusão social, para poder fazer o investimento da Prefeitura, para realmente melhorar a qualidade de vida da população excluída. 
$\mathrm{Na}$ área da saúde, nós poderíamos perfeitamente estar trabalnando com esses 96 Distritos, poderiamos agregar um ou dois Distritos em alguns lugares, para se transformar em um único Distrito Sanitário, e em outros, por questões até de referência e contra-referência nos serviços de saúde, agregar alguma coisa nessa linha, mas a unidade de planejamento nossa deveria ser mesmo o Distrito, os 96 Distritos, e na minha visão, se fosse possivel fazer um governo realmente democrático nesta cidade, seria você ter coordenações intersetoriais distritais, em que você agregaria um bloco de secretarias sociais, como saúde, educação, promoção social, habitação, uma série de coisas e assim, se trabalharia essas Secretarias todas como um colegiado em nível distrital. $O$ colegiado identificaria os principais problemas existentes naquele Distrito e faria uma intervenção conjunta, para se resolver os problemas da educação, da saúde, da habitação, coisas nessa linha. E num outro conjunto de Secretarias, seria para a intervenção sobre o meio físico da cidade, como as vias públicas, as grandes construções, etc. Eu montaria uma estrutura nessa linha, eu acho que a saúde estava caminhando neste sentido. A saúde seria compativel com a reforma que tinha sido proposta para a Prefeitura como um todo.

Como este projeto não foi encaminhado em tempo hábil para a Câmara Municipal, como foı retirado pelo governo seguinte e aí, os governos autoritários preferem administrar de uma forma centralizada e ter o completo domínio sobre as Secretarias fundamentais, como finanças, obras, administração e outras. Então, acho que o projeto deste tipo teria que ser trabalhado pela esquerda na cidade de São Paulo. Acho que os partidos de esquerda teriam que fazer um movimento conjunto para democratizar a administração pública em São Paulo.

\section{Virgínia Junqueira}

Era a principal coisa que a gente queria. A gente dizer que o resultado foi zero, também é demais. Eu acho que não. As pessoas foram tocadas pelo projeto de governo. A gente mesmo, eu olho para a minha própria pessoa, o que eu era no começo e o que era no final, o quanto eu aprendi, o quanto eu discuti, o quanto eu li, abriram-se novos horizontes para mim. Se você pensa só em você o quanto se avançou nesses quatro anos, com todo o gasto de energia, com todo o conflito e sofrimento que foi. Isso aconteceu com outras pessoas também. Eu não tenho a menor dúvida que muitas pessoas foram tocadas, envolvidas, discutiram, avançaram, abriram horizontes, perspectivas, muita gente. Isso não é uma coisa perdida. E a sensação que eu tenho quando digo que os nossos Distritos Sanitários foram arrasados é assim, que a gente podia ter deixado mais, ainda que numa situação desfavorável, se você for pensar, refletir, ah!, mas agora é que nós pensamos nisso. Não, não é assim não. As coisas já estavam todas lá. Estavam todas postas. Eu tenho muita insuficiência de poder realmente localizar o que foi o problema. Já que o problema é compartilhado, eu não posso jogar nas costas da Luiza Erundina a responsabilidade. A 
responsabilidade é nossa. Agora, é claro que ela tem, como a pessoa mais vivida do governo, a eleita, a responsabilidade maior. Isso ninguém vai tirar das costas dela, nunca. Se não era a responsabilidade solitária, era a maior.

O que exatamente faltou? Agora, se você pudesse fazer um novo governo, num novo momento político, será que as coisas seriam retomadas nesse sentido de se ter clareza, de apontar prioridades, de conseguir fazer uma coisa do começo até o fim, de enfrentar a questão da descentralização como um instrumento da democracia, com muito mais responsabilidade, de enfrentar a questão do funcionalismo, conseguir fazer a vinculação do funcionalismo às questões da população, inventar fórmulas de fazer essa vinculação no plano local. Será que hoje nós seriamos capazes disso? Eu não sei. O caminho, não tem outro. Você vê quando chega uma administração de direita. Claro que ela não quer vincular o trabalhador à questão da população. Ela quer usar o trabalhador de uma forma que, gastou, joga fora e pega outro. Mas, ela fala na descentralização. Se você pega hoje a Secretaria Municipal de Saúde, qual a grande peça de resistência? É a descentralização. É estar no nivel local para atender a população. Esse discurso, eles também têm. Acho que hoje as pessoas não deixariam as Secretarias serem tão tradicionais. Tenderiam a fazer algo muito mais intersetorial, desde o início. Acho, enfim, descentralizadamente.

Essa administração Luiza Erundina foi pouco analisada. Eu não sei o que fazem naquela Instituição que é do Paulo Singer. Mas eu acho que essas coisas deveriam ser extraídas como experiências e incorporadas pelo PT, e transformar isso em novos compromissos de seus dirigentes. Eu não tenho a menor dúvida que aquela administração contribuiu para alargar o espaço público e promover a cidadania. Agora o que a gente fica sentida é com as não-amarrações. e eu nem sei se isto é possível, se amarra alguma coisa em alguma coisa. As coisas são tão dinâmicas. Eu não tenho experiência suficiente nessa coisa política e nem formação para fazer análise dessa administração e tudo o que ela significa.

\section{Alexandre Nemes Filho}

Eu acho que nós fizemos uma experiência de política pública nitidamente voltada para a promoção da cidadania. Eu tendo a ver as políticas de outro jeito. Isto é, dando esse primeiro passo de cidadania, essa coisa contaminaria linearmente e a população iria crescer e tal. Até por conta das porradas que a gente vem levando, a gente já sabe que a coisa não é bem assim. Por mais que isso consiga atingir diretamente a necessidade de uma pessoa, de um coletivo, você tem ai nesse meio, um conjunto de mediações que fazem de fato a imagem da coisa que interfere nesse processo. Eu tendo a ver a coisa assim: naqueles quatro anos nós fizemos uma política social? Fizemos. Isso atingiu a população? Com certeza atingiu nas suas carências, e contribuiu para a população crescer, ter uma idéia de cidadania, o que é 
que é, chamar para um orçamento participativo, chamar para uma plenária pública, para participar de um conselho, quer dizer, eu acho que de fato teve uma política social. É importante demonstrar que é possivel administrar abrindo essa frente. Isso eu acho que a gente mostrou para muita gente. Muita gente ficou satisfeita com isso e só saber que é possivel alguma coisa, que isso rende, que a participação direta é importante, eu acho que nesse sentido foi uma experiência vitoriosa.

Agora, quais foram as limitações? Acho que é de que as coisas têm mediação e o tamanho da cidade. Numa cidade como a nossa é muito complicado mesmo. Você tem que trabalhar com a midia, com setores da classe média, com os empresários, para tentar diminuir um pouco a força das mediações e também para atender esses grupos, pois a cidade na verdade também é deles. Isso a gente fez pouco. Pagou o ônus de não fazer. Tem todo um grupo social de elite que é contra o PT. Mas a minha compreensão é esta, eu acho que se você abre a porta e mostra o que existe, eu acho que você está cumprindo o seu papel. Porto Alegre e Santos tiveram mais êxitos no sentido de dizer que este tipo de gestão é melhor que a do tipo autoritário. E nós não conseguimos fazer, nós não conseguimos mostrar que nossa administração era melhor que uma administração autoritária. E aí a gente acaba atribuindo ao tamanho da cidade, ao estilo de vida. Em outras cidades nós conseguimos, como Porto Alegre, onde o modo participativo, democrático, é hegemônico na forma de administrar a cidade. Eu acho que a gente pensou que montando a estrutura formal, a gente garantiria mudando a gestão mais para frente, manter as pessoas, etc. Mas isso não é verdade.

Acabou a administração e essa preocupação de fazer tudo correndo traz um desgaste muito grande para quem está fazendo. Você, para implementar uma prática rapidamente, você soma a implantação de 32 Distritos Sanitários, a remoção zerada, que foi outra medida administrativa de fôlego, para tentar recolocar o pessoal na rede como um todo, fazer justiça aos funcionários mais antigos, você junta essas duas intervenções, é uma coisa que desgasta muito e aí, o retorno político é muito pequeno. Eu acho que vale a pena fazer menos reformas e mais implantação de serviços de qualidade e excelência, atuar um pouco mais em assistência do que em reforma administrativa. Eu acho que isso perde politicamente depois, porque a população reconhece é a assistência direta e não o que acontece no meio, no que faz a coisa funcionar. Os resultados na saúde são muito palpáveis. Quantitativamente e qualitativamente. No global nós fizemos muita coisa.

\section{Álvaro Escrivão Júnior}

Eu acho que do ponto de vista da Secretaria a gente na verdade atirou para todos os lados, conseguiu alcançar o alvo muitas vezes, perdeu muita bala, muita energia. Se você for avaliar custo e beneficio, esforço e resultado, eu acho que a gente gastou muita energia para um resultado não correspondente em termos de energia que a gente gastou. Acho que a 
gente fez vários avanços. Acho que a gente consolidou pouco as coisas, mas a gente tem um efeito demonstrativo que está sendo resgatado aqui e ali. Por exemplo, na minha área, eu acho que se você pegar o PROAIM, o PROAIM é na minha opinião o mais bem sucedido programa de estímulo à cidadania. Colocou para a cidade de $\mathrm{S}$. Paulo uma (com dados de mortalidade) possibilidade de se conhecer do que se morre, portanto, do que se adoece, como se vive, o que não havia antes. Isto é indiscutivel e permanece até hoje. E continua prestando diferentes serviços.

O outro exemplo é a própria participação. Eu me lembro quando a $D^{a}$ Zulmira na primeira reunião em que o Eduardo me mandou fazer uma apresentação, eu me lembro que emocionado, peguei um monte de tabelas, em preto e branco, com dados de tudo que era lado. Fiz uma bela apresentação e na hora que acabou, a $D^{a}$ Zulmira veio me cumprimentar e falou: "não dava para vocé fazer algumas coisinhas tipo Folha de S. Paulo, assim, porque a gente tem dificuldade de ler essas tabelas". Então, toda a maneira de apresentar as coisas foram em função de uma sincera vontade de fornecer informação, de dar possibilidade de participação para o pessoal e etc. Eu acho que lideranças importantes do movimento popular foram construídas, por exemplo, o Sr. Naelson, seguramente fez um curso de participação, só para pegar as pessoas mais visíveis, mas havia muitas outras.

Eu vejo lá em Pirituba, por exemplo, ecos da administração. As pessoas guardam os ecos da administração e não é aquela coisa só, que tem de ser bom aquilo que passou, não. Acho que você teve mudanças de algumas pessoas. Em parte eu acho que esta própria resistência ao Maluf é uma resistência seguida a uma administração Erundina. Eu acho que o Maluf teve mais dificuldades para tentar as malandragens dele do que se fosse seguida a uma administração Jânio.

Acho que as pessoas tinham certos balizamentos. As pessoas ouviram da administração anterior um outro tipo de discurso e também observaram um outro tipo de prática. Eu me lembro, por exemplo, que os motoristas do Gabinete da Secretaria Municipal de Saúde, quando eu comecei a andar de carro, que eu ia até a minha casa, deixava o carro, pegava meu filho e voltava com meu carro, os motoristas diziam: "os outros doutores aí, a gente levava as mulheres para o Guarujá, para não sei aonde".

Essas pequenas coisas refletem no conjunto a maneira como você governava. Isso é indiscutivel. A imprensa mal intencionada que esta aí pode falar o que quiser, mas nosso modelo era completamente diferente do ponto de vista de compromisso discursado e da intenção de ser mais um governo voltado para os interesses da maioria da população e é seguramente, disparadamente mais sério. mais honesto. Isto é um dado do nosso governo.

Em resumo, eu acho que a gente precisava de mais 4 anos para implantar objetivos visiveis para a sociedade. Eu acho que um problema que houve foi o seguinte: nós trabalhamos prá burro, mexemos com um monte de coisas, muita coisa ficou pela metade na 
minha área, lamentavelmente a pesquisa de saúde bucal, por exemplo. É um crime parar aquela pesquisa no meio, depois de todo o esforço que se fez. Muita coisa ficou pelo meio e eu acho que a gente não conseguiu ter visibilidade por dois motivos: um que a gente não conseguiu comunicação, é um pouco essa visão, confronta essa visão interna, utópica, técnica de administração versus a realidade da administração, a necessidade de aparecer para a sociedade.

Não adianta fazer, tem que parecer que fez. Haja vista o Maluf. Não fez nada na Saúde a não ser porcarias, e aparece como um cara que resolveu a Saúde. Lógico, eu não e estou propondo isso. O que eu quero dizer é que faltou para a gente este cuidado. Era uma das coisas que me preocupava. Me irritava o voluntarismo, um certo amadorismo. Numa segunda administração, minha expectativa era que a gente fosse muito mais profissional e menos voluntarista.

Com certeza não foi uma administração que passou em branco. Na minha área, o SIMIS procurava ser coerente com as propostas de governo e de ser um instrumento de auxilio à decisão. Agora mesmo eu apresentei lá em Portugal essa discussão de indicadores epidemiológicos. O pessoal se surpreendeu de se ter tentado fazer e usar esses indicadores numa cidade como São Paulo.

\section{Carlos Alberto Pletz Neder}

Em termos de modelo de atenção à saúde a gente deixou uma mensagem importante, deixamos alguns germes, deixamos uma determinada concepção de integração da política de saúde com o intersetorial. Rompemos com aquela lógica de separar a atenção ambulatorial da atenção hospitalar, de programas que na verdade, chegavam a ponto de, a partir do Gabinete do Secretário, você ter um controle sobre o que era feito na Unidade de Saúde. Isso eu acho que a gente conseguiu romper, mas eu acho que nós não conseguimos introduzir um novo processo de trabalho no cotidiano do funcionamento das Unidades e das equipes de saúde, que fosse totalmente coerente com essa nossa preocupação. E não porque a gente não tenha tentado, quer dizer, eu acho que nós abrimos as nossas Unidades, eu acho que a gente rompeu com aquela idéia de Unidade de Saúde que ficava passivamente esperando uma demanda espontânea. Nós mostramos a necessidade da equipe em procurar, de fazer a territorialização, de procurar os problemas, de detectar de forma mais abrangente 0 que interferia nas condições de saúde e na qualidade de vida da população. Mostramos para a equipe que ela era parte de um exercício de cidadania, portanto, o servidor também era um cidadão com direitos, com opiniões, e com possibilidade de interferir nessa dinâmica, mas eu acho que do ponto de vista do processo de trabalho, nós tivemos dificuldade de demonstrar para cada um dos servidores qual era a lógica que nós estávamos tentando implementar, quer dizer, o que é que justificava esse governo da Luiza Erundina, e o que diferenciava esse 
governo em relação aos governos anteriores. Mesmo com toda política que se fez de valorização dos servidores, acabou ficando aquela marca do reajuste salarial que foi dado no último mês de governo, em que pese todo o esforço que se fez de recuperação do salário, das condições de trabalho. Então isso mostra que nós não conseguimos mostrar com um grau de radicalidade maior, que todo o discurso que se tinha da seguridade social, de articular a saúde com assistência social, com a questão da previdência, com as mesmas diretrizes, com aquele arcabouço centrado nas Conferências, nos Conselhos, com a forma de democratização da definição das políticas, de horizontalizar os programas e levar os programas para os Distritos de Saúde.

Saiu o governo do PT e entrou o governo Maluf, onde fica até difícil avaliar qual a viabilidade da proposta que nós apresentamos se nós estivéssemos minimamente num governo de centro-esquerda na cidade de São Paulo. Nós entramos num governo de direita que procurou quebrar toda a lógica, voltando à uma centralização das políticas, uma centralização das compras, uma centralização das Unidades Orçamentárias. Todos os esquemas de corrupção que nós combatemos voltaram a ser instalados na Secretaria. Então. com uma mudança tão radical fica difícil você analisar o que ficou de toda a experiência. Agora, os dados, sejam qualitativos ou quantitativos, a introdução de novos elementos na discussão da proposta de saúde, mesmo como traduzir o sUS numa cidade com as características de São Paulo, eu acho que foram coisas muito criativas as que nós fizemos. Eu me recordo, logo que eu assumi, companheiros nossos da reforma sanitária defendiam. não de dentro da Secretaria, gente de fora que não conhecia a realidade da cidade, defendiam a tese de que nós deveriamos escolher uma única região da cidade, investir grande parte do orçamento nesta região, e usá-la como modelo para toda a cidade, para mostrar que o SUS era possivel, e portanto, se quisessem para a cidade como um todo, que nos dessem mais quatro anos. Só que era uma visão a meu ver, simplista dos problemas da cidade, porque a cidade vinha já de uma tradição de organização dos movimentos em todas as regiões, havia uma expectativa criada em todas as regiões da cidade sobre respostas que deveriam ser dadas num prazo mais curto possivel para problemas que vinham se acumulando historicamente, e portanto, o que nós poderíamos fazer era pegar alguns programas, algumas ações, algumas atividades e usá-las de forma mais criativa, para demarcar uma imagem mais positiva na opinião pública sobre o conjunto do trabalho. que era extremamente significativo e complexo, e que no dia-dia do governo o pessoal da área de propaganda, não conseguia traduzir isso de forma que fosse aceita pela opinião pública como sendo verdadeiro. Os relatórios de produção da Secretaria são muito expressivos. Os dados qualitativos mais ainda. Inúmeras propostas, como associar a visão de vigilância à saúde. incorporando a questão do meio ambiente com a questão da epidemiologia, a questão da vigilância sanitária, da idéia do movimento da cidade saudável, de trazer a discussão de que 
era possivel você trabalhar a saúde de forma mais abrangente e não apenas vinculando à questão assistencial, tirar do equipamento nospital, do equipamento ambulatorial, do equipamento Unidade Básica de Saúde, mostrar que o servidor tinha condições de exercer um papel na sociedade, interferindo nesses outros fatores condicionantes. São coisas muito importantes e que acabaram permeando as propostas do SUS em outros municípios também. Eu acho que nós tivemos muita dificuldade de. ao mesmo fazer um trabalho que era muito abrangente, complexo e com um grau de dificuldade enorme colocado para todos nós e, ao mesmo tempo, conseguir demarcar para a opinião pública pelo menos alguns dos pontos mais importantes de todo esse trabalho que foi realizado. Então, nós ficamos num dilema: entre escolher uma região, ou fazer o trabalho como um todo. Ter a expectativa que nós poderíamos na cidade de São Paulo seguir o ritmo da implementação do SUS, que já vinha sendo feito em municípios com 100,200, 300 mil habitantes, foi dificil trabalhar isso dentro da equipe também. Que a equipe compreendesse que para a gente, se nós conseguissemos acompanhar o que os outros já estavam fazendo, já era uma coisa espetacular, dadas as dimensões da cidade. Agora, se além disso nós conseguíssemos apresentar propostas inovadoras, na questão da garantia do acesso, na questão da democratização da gestão, na forma de você garantir a universalização do atendimento, de você conseguir a integração do atendimento cada vez mais complexo, coisas desse tipo, isso já seria até além do que era possivel pensar naquele momento. Na verdade a equipe o tempo todo colocou desafios como se nós estivéssemos gerindo e administrando uma cidade de 10 mil, 50 mil ou cem mil habitantes. Então, nas cidades de porte médio ou pequeno, o ritmo de implementação das propostas do SUS, ainda que com muitas dificuldades da ordem de recursos e outras mais, poderia ser até superior daquele que nós tínhamos para a cidade de São Paulo. Mas eu faço um balanço bastante positivo, e acho que na questão do planejamento, nós conseguimos mostrar que era possivel ter uma forma democrática de planejar e que o planejamento era necessário, ainda mais num momento que o planejamento estava muito em desuso e até mesmo sendo questionado pela própria esquerda, que endeusou o planejamento durante muito tempo, e a partir de um certo momento passou a menosprezar e quase que abandonar a idéia de planejamento como sendo um instrumento válido. Mas aí a discussão era sobre o tipo de planejamento para uma cidade com as caracteristicas de São Paulo. Eu acho que a gente conseguiu com a ampliação dos CTA's, com a criação dos conselhos gestores, mesmo com a criação do polêmico conselho dos Distritos de Saúde, com os Encontros feitos no começo de cada ano, detalhar as prioridades e metas da Secretaria, como a forma em que se discutiu o orçamento dentro da Secretaria, em que pese todo o calendário muitas vezes enxuto, e a forma como essa discussão era conduzida no governo como um todo. A existência das Conferências de Saúde e o dia-dia da definição das políticas e sua execução, eu acho que a gente introduziu conceitos importantes de planejamento e práticas 
diferenciadas de planejamento, mas houve uma quebra significativa na medida que assumiu um outro governo, com uma outra lógica.

\section{Eduardo Jorge Martins Alves Sobrinho}

Em primeiro lugar, quando eu voltei para o Congresso, essa experiência concreta de ter sido Secretário Municipal da Saúde da cidade de São Paulo e ter feito esse processo de descentralização e democratização sem leis, só com os princípios constitucionais, isso aí, teve uma influência grande na discussão das Leis 8.080 e 8.142 .

Lá em Brasília essa mentalidade centralizadora, essa desconfiança na capacidade de democratização da gestão dos municípios, existia entre os deputados. E eu usei minha experiência aqui de São Paulo, o tempo todo nos debates. Para a Lei 8080 , eles me chamavam, eu ia lá, participava dos debates, como Secretário e deputado licenciado. Depois, a Lei 8142, eu junto com o deputado Raimundo Bezerra do PMDB, fomos os únicos que negociamos com o Alcenir Guerra as questões de fiscalização e democratização. Eu usava o tempo todo a nossa experiência de trabalho, numa cidade muito grande, com problemas muito complexos, e que o governo tinha que ter coragem de fazer. Eu acho que primeiro teve essa experiência institucional, que ajudou o processo no Brasil todo, ajudou no processo de definir as leis do SUS. Em segundo lugar, houve o resultado objetivo, material, concreto, da SMS. Foi a Secretaria que mais realizou em termos orçamentários, em termos de expansão de rede, em termos de expansão de serviços públicos para a população de São Paulo. Em terceiro lugar, fica a estrutura organizativa, a estrutura de consciência entre os funcionários e entre a população, de participação, que esse processo todo proporcionou. Foram milhares de funcionários e pessoas da população que presenciaram os processos de participação, de conscientização na administração pública, do papel do usuário. que é uma coisa que não se esquece, é difícil. Tanto que hoje, passados mais de quatro anos. o Conselho Municipal da Saúde e os funcionários continuam resistindo, apesar de todas as dificuldades de um governo altamente repressivo, certamente de direita. Eu diria isso: primeiro, um resultado institucional a nivel nacional, de como esse processo de São Paulo ajudou na definição das leis federais 8.080 e 8.142 e segundo, o resultado daqui, de expansão da rede. dos serviços em direção à periferia e também, as repercussões junto ao conselho dos secretários municipais de saúde; terceiro, esse saldo organizativo de consciência de muitas pessoas, da administração, dos funcionários e da população que participava conosco do processo e aprenderam muito. Finalmente, é que esse movimento nosso de 89-92, foi parte de um processo de construção de uma reforma, eu considerava reforma, mas uma reforma com a visão mais clara do que é uma reforma de Estado frente as políticas públicas no Brasil, que é o SUS.

O SUS tem tido muita dificuldade de ser implantado e implementado nesses 10 anos porque tem enfrentado uma posição adversa do nível federal. Apesar disso, sua força interna, 
sua lógica, é tão forte que ela (a reforma para o SUS) vem se expandindo à revelia dos níveis federais e vem se impondo gradativamente como a única possibilidade de se ter um sistema decente de serviços de saúde em um país como o Brasil. A experiência mais recente é esta: o governo Fernando Henrique Cardoso demitiu um ministro, Adib Jatene, que defendia esse modelo, colocou um outro ministro com a tarefa aparentemente de desmontar o sistema, e ele apresenta, depois de 3 meses de debate, um plano de metas e ação que nada mais é do que o reforço das diretrizes do SUS, mostrando que a sua lógica e a falta de possibilidade alternativas concretas a ele é real. E que ele vai se impor e até vai ser modelo para outras áreas de políticas públicas no Brasil.

\section{Paulo Eduardo Mangeon Elias}

Aumentou a universalidade, no sentido da cobertura. Talvez não por méritos só da Secretaria. Foram inaugurados seis novos hospitais. A cobertura pode não ter aumentado como a gente desejava. Mas acho que aumentou a universalidade. Quanto à eqüidade, igualmente acho que a Secretaria não se comportou exatamente como vem se comportando a efetivação da reforma sanitária. Ai, ela se comportou dentro dessa tendência, do modo como a reforma sanitária vem sendo efetivada. Acho que aí, não tem muita contradição. $\mathrm{Na}$ reforma sanitária você tem um ideário e tem uma prática, uma efetividade, isto é, você tem bases reais, concretas. Você não está mexendo nessas bases. Então o que aconteceu? ideário tem uma base concreta de efetivação, mas que não cola direito, que não dá alicerce de sustentação para esse ideário, pelo menos da forma como ele está. Quando você chega na administração você tem que trabalhar com o concreto; por isso começa pintar também esse descolamento, porque aí é uma dificuldade muito grande você administrar uma Secretaria dessas

Pelo volume de problemas que você tem, você não tem, você não consegue ter projetos, não consegue pensar coisa nenhuma, porque você tem que pensar e é consumido. Toda a energia é consumida para tocar o dia-a-dia, para tomar as decisões. Prá você formular alguma coisa, você precisa ter uma espécie de inteligência que dê contribuição. Não é ela que vai ser iluminadora, mas você vai ter que contar com alguém que esteja fora da máquina. Porque quem está na máquina não tem tempo.

Você pode pegar a maior sumidade em planejamento, mas ele vai ser consumido para responder o remédio que falta, o pneu que furou, o funcionário que faltou, etc. E aí, é este dia-a-dia que é tipicamente brasileiro, não incorpora o planejamento, que é o tempo todo, vamos dizer assim no jargão, você correr atrás do prejuizo. Isto desde a UBS até o Gabinete do Secretário. Então para você pensar algum projeto, para você pensar. definir, formular, você não pode ter estas tarefas, você não pode estar em cargos que te consomem, cargos de mando, cargos administrativos, porque senão você não consegue fazer. Então você tem as 
dificuldades ai também nesse tipo de coisa. Há o ideário e a efetivação, que é constrangida pela realidade concreta em que você está. A SMS teve as virtudes da reforma sanitária e os defeitos da reforma sanitária. $O$ que é que ficou? Essa pergunta é muito abrangente. Eu diria para você que tem vários planos:

1. em termos da saúde da estrutura do município de S.Paulo ficou: uma racionalização que não havia antes, de organização da assistência, que não foi desmontada, nem com o PAS. Com a descentralização, regionalização e distritalização, começou a mudar uma cultura e ai que é importante. É impensável governar São Paulo como estava antes. Primeiro a segmentação entre assistência primária e secundária, hospitais e UBS, e tudo centralizado na avenida Paulista. Desse modo, você não tinha como operar coisa nenhuma Isso aí, deixa correr do jeito que está, porque você não tem como operar, como instrumentalizar. Essa eu acho que foi uma grande contribuição, que veio nesse processo da reforma sanitária, de ter estruturas mais operacionais, mais orgânicas do que tinha antes. Tudo isso é verdade, que eles mudaram muita coisa na Educação, em outras Secretarias.

$\mathrm{Na}$ Saúde eles praticamente não mexeram neste arcabouço institucional que foi montado. Não se mexeu, mesmo com o PAS. Eles fizeram o PAS em cima do quê? Das regiões de saúde praticamente. Modelo que não era concepção deles. Então eu acho que esta era a coisa. quer dizer, esta é uma inflexão importante, a cultura da SMS. Claro que isso não se traduz em coisas materiais, mas essas coisas têm importancia porque geralmente as pessoas começam avaliar em termos materiais. Quanto aumentou disso ou daquilo, apesar que isto alcança muito as pessoas, quanto aumentou do atendimento, quantos leitos a mais foram oferecidos, quantos ambulâncias, quanto isso, quanto aquilo. Eu não estou querendo essa conta porque eu acho que aumentou muito.

A importância política da SMS emergiu na administração Erundina e de lá não mais saiu. em termos orçamentários, políticos, financeiros. E isso não é pouca coisa. É que as pessoas começam a fazer contas; quantos atendimentos tinha, quantas ambulâncias, o que alcança muita gente. Eu não quero dizer que isto não é importante, mas a questão central para mim não está aí, está nesta outra parte que é a invisível, que é a inflexão da cultura institucional, que é uma inflexão da importância política que a Saúde tem e que de lá não mais saiu. Então essas coisas são importantes, apesar de invisivel. E mesmo essa coisa do número de ambulâncias, das inovações de concepção, de se regionalizar a emergência, essas contribuições foram importantes.

2. a questão da participação foi muito importante. É impressionante a leitura que se tem das várias instâncias de participação. Mostrar que você pode compatibilizar a democracia representativa, que é baseada na estrutura da SMS, com a democracia participativa. com a democracia direta. Mostrar que isto não é incongruente, não excludente, as duas coisas. Isto é o que eu chamo de a "teia invisivel". Aumentar a politização da saúde, no sentido estrito de 
disseminar na sociedade a informação. Atingir os movimentos sociais mais organizados, mas em cheio. É verdade, mas isso não tira o mérito, porque isso também é uma dinâmica da sociedade brasileira. A cidadania não é constituída pelo Estado. Um certo tipo de espaço público foi ampliado, eu tipificaria, o espaço público que é instituído pela administração. Nesse sentido aumentou sim, aumentou sim a relação que a Secretaria teve com a Câmara Municipal e eu acho que foi exemplar, tanto que ela deu resultados. Não foi uma relação que tenha se reproduzido no conjunto do governo. Isto não se traduz só pelo número de projetos aprovados. Quando se vê a área da saúde, vê-se que é diferente, numa concepção de interlocução, entre executivo e legislativo, que foi favorecida por situações concretas, que favoreceram isto, ou seja, a implementação desta concepção. Isto também é uma contribuição, mostrando que é possível você fazer uma interlocução do Executivo com o Legislativo em outras bases, em bases distintas das tradicionais desta relação, da cultura política brasileira.

\section{Houve durante o processo de mudanças da SMS no período de 89 a 92, uma clara definição das competências e responsabilidades para cada um dos diferentes niveis e Unidades de Saúde ? Explique.}

\section{Álvaro Escrivão Júnior}

Acho que ficou muito pouco clara a definição de competência dos diferentes níveis da Secretaria. Eu tinha uma concepção que esses órgãos, eram órgãos (COAS, CEPI, CRH, etc.) de assessoria do conjunto diretivo da Secretaria, que era composto pelo Secretário e 10 diretores regionais. Eu acho que alguns desses órgãos (do Gabinete da Secretaria Municipal de Saúde) acabaram acumulando funções de mando, e na prática centralizando. Embora a decisão fosse toda tomada no Conselho Técnico Administrativo, eu acho que o CTA na verdade funcionava não só como uma reunião de decisão, talvez nem tanto uma reunião de decisão, mas um lugar onde todos se informavam sobre tudo o que estava acontecendo. Mais um mecanismo de comunicação, do que um mecanismo realmente de decisão. Da maneira como ele funcionava, ele não tinha condições de funcionar como centro de decisões. Se você pensar nele como órgão legislativo, você teria que ter pareceres com antecedência, para os diretores poderem discutir em suas regiões. E cada vez mais se entrava em coisas atropeladamente, claramente para se legitimar no Conselho Técnico Administrativo.

Isto era um processo de centralização da decisão. Eu resisti muito a isso. Por isso que me chamavam muitas vezes de tecnocrata ou qualquer coisa deste tipo, mas um pouco a visão que eu tinha no Gabinete era de resistência a esse tipo de comportamento. Eu achava ruim. Isso tudo era colocado em função da necessidade de agilizar. Mas eu achava que era um processo bastante contraditório. Estava valorizando um pouco mais o processo. Talvez as 
pessoas estivessem valorizando mais os resultados. E achava que bons resultados derivados de processos ruins, talvez não fossem tão obviamente bons. Normalmente se diz isso, o que interessa é o resultado, não interessa o processo. Eu tinha uma concepção que o importante era criar processos democráticos, competentes, profissionais, de funcionamento da máquina. Eu achava que essas coisas acabavam esbarrando em algumas dessas três coisas, na democracia, na competência ou na responsabilidade. Acho que qualquer processo onde você não se sinta participante, você não se sente responsável. Isto é claro que as pessoas não diziam. Você não dizia para o Eduardo ou para qualquer um que você não iria se responsabilizar mais e fazer corpo mole. Acho que então nesse sentido a gente começou a reproduzir a hegemonia do funcionamento da máquina.

As coisas mais importantes acabavam sendo aquilo que a prática tradicionalmente considerava as mais importantes, que é a área financeira, de recursos humanos, a área hospitalar... Isto então tomava grande espaço na vida de todo mundo. Do Secretário aos Diretores de ARS's. Nós acabamos fazendo isso. Isso é absolutamente hegemônico, nenhuma novidade adicional. Gasta-se muito tempo com isso. Então, acho que as grandes diferenças eram nas doenças, nas intenções, que eram as melhores possiveis, mas o "modus faciendi" era muito complicado. A mim me irritava profundamente, diariamente eu tinha ataques de irritação com essa maneira voluntarista e pouco profissional, que em nome de uma democracia se passava no Conselho Técnico Administrativo, de uma maneira a não responsabilizar ninguém, nem dar tempo das pessoas concretamente se manifestar, nem dar tempo de consultar os demais niveis de organização como os Distritos de Saúde. Não dava tempo de consultar, e esse processo gerava consciente ou inconscientemente uma não responsabilização do pessoal. Se eu me sinto atropelado, a minha reação é achar que eu não tenho grandes compromissos com aquela idéia. Pessoalmente eu acho que era isso.

No CEPI eu tinha muita dificuldade porque as minhas questões nunca entraram com essa aura de urgência/emergência. Eu na verdade não sofria muito pessoalmente, porque entendia que não fazia sentido tocar qualquer coisa que não houvesse adesão à idéia por parte dos diretores regionais, ou para as coisas que concretamente você tivesse dificuldade de implantar a nivel local e distrital. Por exemplo, se eu quisesse organizar o sistema de informação de modo a garantir essa responsabilização, essa participação, sempre eram os assistentes de direção que estavam acompanhando esse processo. O que é muito interessante, porque mostra que o processo decisório não precisava de informação. As decisões eram tomadas em geral sem uma leitura organizada da realidade. Se os diretores julgassem fundamental, se a máquina da maneira como a gente conseguiu montá-la para fazer, tivesse considerado isso fundamental, isso seria a prioridade número um. A partir do momento em que não era, e aí não é um lamento não, é o reconhecimento de uma dificuldade do processo decisório hegemônico. Hegemonicamente o processo decisório de 
qualquer lugar não leva em consideração a informação. Muitas das coisas que a gente propôs na Secretaria, através do SIMIS, eu vejo hoje ser utilizada, é claro que sem aquela intenção integradora das partes, mas eu vejo ser utilizada pelo pessoal do PAS, pelas Seguradoras, que é o planejamento baseado em morbidade, baseado em tempo de permanência no hospital, para utilizar melhor os recursos. O pessoal do PAS utilizava muito, lá em Pirituba, mas é claro que eles tomam do SIMIS o pedaço que thes permite responder as perguntas deles, quem é que eu atendo, o que atendo. Depois, fazem as continhas para ver se está caro, se está barato. Eu acho que a questão é de como foram aplicadas as diretrizes, acho que passa por tudo isso.

\section{Carlos Alberto Pletz Neder}

Essa definição de competências e/ou responsabilidades tem que ser vista de uma forma dinâmica, porque foram momentos diferentes e com aprendizados diferentes. Lembrando que eu vim para a Secretaria em abril de 90 , então eu perdi um ano e três meses do trabalho da Secretaria, que eu acabava observando à distância, em função de estar lá no cargo de Chefe de Gabinete da Prefeita. Quando eu entrei, já encontrei o processo em determinado estágio de definição, sobretudo no que diz respeito à estrutura da Secretaria, à definição dos papéis, e a distribuição de poder, sobretudo do papel das Administrações Regionais de Saúde. A implantação dos Distritos ainda estava em um estágio bem embrionário. Nós, num primeiro momento, achamos que era possivel partir para um grau de descentralização radical, meio que prescindindo de uma reestruturação do Gabinete a nivel central. Rapidamente isto se mostrou incorreto. Quer dizer, para você poder avançar na descentralização e fortalecimento dos Distritos, era necessário que você tivesse toda uma retaguarda. Essa retaguarda teria que ser dada tanto pelo conjunto do governo, mas aí a reforma administrativa do governo não veio a tempo de nos ajudar nesse processo, como era necessário que você tivesse uma reestruturação do nivel central da Secretaria, sobretudo nos vários subsistemas mais importantes, como o de execução orçamentária e financeira, na parte de recursos humanos, e na parte administrativa, para que dessem suporte ao grau de descentralização que nós gostariamos de estar realizando. Então, se num primeiro momento o discurso simplista poderia levar à idéia de que bastaria jogar uma bomba dentro do Gabinete, e com isso os estilhaços iriam permitir a gente organizar os Distritos, com grau de radicalidade e num prazo muito mais curto, a prática mostrou que nós tínhamos que contar com uma estrutura de nivel central exatamente para poder dar suporte ao funcionamento das regionais, e gradativamente implantar os Distritos com grau de autonomia maior. Sempre correndo o risco de que o nível central pudesse se acomodar no sentido de não dar o apoio efetivo e tentar se preservar. Nós tivemos vários problemas desse tipo. O Centro de Controle de Zoonoses, por exemplo, o tempo todo jogou contra a idéia da regionalização e da 
integração deles com a política das regionais e dos Distritos. Sempre tentando se manter vinculado ao Gabinete do Secretário. $E$ assim nós poderiamos citar vários outros. Da mesma forma que houve controvérsias sobre qual era a quantidade de unidades orçamentárias que seria conveniente ter numa Secretaria. Porque como nós não tínhamos no município a mesma estrutura da Secretaria de Estado da Saúde, com as unidades orçamentárias e as unidades de despesa, a gente ficava tolhido, isto é, você não tinha como reduzir o número de unidades orçamentárias e, ao mesmo tempo, conferir o grau de liberdade maior que se queria dar para o nível local, não tendo a figura da unidade de despesa que se tem no Estado. Então, nós fomos obrigados a aumentar o número de unidades orçamentárias, de tal forma a permitir uma descentralização orçamentária. A tese feita pelo Paulo Carrara mostra em que medida se conseguiu a descentralização dos recursos na Secretaria, do Gabinete do Secretário para o nivel regional e o nível local, com os diferentes elementos de despesa, e em que medida a gente conseguiu que houvesse uma inflexão no controle e execução da gestão orçamentária. A dificuldade que nós tivemos em toda a discussão no CTA, para chegar numa proposta de projeto de lei para a reforma da Secretaria, era a expressão mais acabada das incompreensões da própria equipe. Não que as pessoas não soubessem o que queriam, mas as pessoas não tinham uma proposta hegemônica colocada entre si, a não ser algumas diretrizes gerais, que nós sabiamos, que era aprofundar o processo de descentralização, que era garantir o Distrito de Saúde, fazendo com que a política e a definição das políticas estivessem vinculadas à idéia de um sistema local de saúde, com todas aquelas diretrizes sendo implementadas e permeando o processo de trabalho. Havia um conjunto de indefinições sobre: vamos manter ou vamos acabar com as Administrações Regionais de Saúde? (Eu já disse que a minha proposta era a de manutenção). Vamos manter com que perfil? A administração Regional de Saúde como unidade orçamentária ou como um suporte para o funcionamento dos Distritos de Saúde, muito mais preocupada com a definição das diretrizes técnico-políticas da Secretaria? Ou, interferindo na execução da política de saúde? Na minha concepção nós tínhamos que ter uma Administração Regional enxuta, gradativamente nós tínhamos que tirar a unidade orçamentária da ARS, porque a existência da unidade orçamentária na ARS, significaria manter sempre uma tendência à hipertrofiá-la em detrimento dos Distritos, mas não minimizar a importância do papel da regional de saúde, no sentido da definição das diretrizes daquela area geográfica, de forma articulada com os Distritos. Os Distritos eram de diferentes portes e com diferentes características. Distritos com Hospitais e Distritos sem Hospitais. Distritos com Hospitais Especializados de quase grau terciário e Distritos com Hospitais Gerais. Então, não dava para você ter uma política única. Eu admitia até mesmo a hipótese de alguns Hospitais permanecerem como unidades orçamentárias, embora a linha mais geral que nós estávamos construindo, era a idéia de manter a unidade orçamentária no Distrito de Saúde, de tal forma 
que o DS pudesse suprir as necessidades dos diversos ambientes, inclusive da Unidade de Internação, da Unidade de Apoio Técnico e Diagnóstico, que na prática estavam dentro da estrutura física do Hospital. Mas não dava para desconhecer a existência de um equipamento importante como o Hospital. Seria uma abstração, uma forma ilusória pensar que você poderia desmembrar o Hospital em uma parte de internação, uma parte de apoio diagnóstico e tal pois, ele tem uma figura, ele tem uma razão de ser, ele tem uma história, mas ao mesmo tempo, nós não poderíamos nos deixar subjugar pela história do Hospital e pela forma sempre hospitalocêntrica de como o sistema de saúde foi organizado. Então, esse era um dilema nosso. Como não reconhecer que um Hospital como o da Vila Nova Cachoerinha, com uma maternidade de alto-risco, ou então um Hospital como o do Jabaquara, que eram Hospitais com caracteristicas diferentes, que mesclavam esse atendimento nas áreas básicas, clínica médica, clínica cirúrgica, pediatria, gineco-obstetrícia, mas também com um enfoque especializado, que em algumas áreas, cumpriam um papel diferenciado dentro da própria rede? Então, até que ponto não seria artificial simplesmente dizer, a partir de agora o Distrito vai ficar como unidade orçamentária e o hospital como parte desse Distrito? Então, esse era um problema que nós tinhamos que administrar. Isso tomou um tempo enorme de todos nós.

Um outro problema que nós tivemos foi a descentralização dos programas. Nós relutamos durante todo o governo em aceitar o termo programa, com toda carga de concepção verticalizada que traz dentro de si, procuramos mostrar que essas atividades, essas ações de saúde tinham que estar integradas entre si. $O$ assessor teria que ser um assessor dos programas de saúde e não um assessor do programa $A, B, C$ ou $D$, mas na prática, até pela estratégia de implementação da proposta, nós tivemos dificuldades de convencer as coordenações dos programas e as equipes que se constituíram em torno de cada um desses programas, de que era necessário avançar esse corpo de assessores estabelecidos nos Distritos, vendo o conjunto da proposta do Distrito de uma forma mais integrada. Por outro lado, o próprio processo de implementação dos programas, gerou um outro tipo de controvérsia, por exemplo, o programa de saúde do trabalhador. Vamos implantá-lo nas Unidades de Saúde já existentes, ou vamos tentar ou estimular a organização dos Centros de Referência de Saúde do Trabalhador? Programa de Saúde Mental, vamos implantar nas Unidades de Saúde já existentes e em instalação, ou vamos estimular a existência dos CecCo's, dos Hospitais-Dia em saúde mental, e outras propostas do gênero? Para cada programa nós tivemos que enfrentar esse dilema também. Porque ao mesmo tempo em que você permitindo a instalação de um equipamento próprio daquele programa, você estava dando condições dele se viabilizar enquanto tal, por outro lado, você sabia que ali você estava correndo o risco de acabar tendo uma dissociação entre aquele equipamento e o conjunto de equipamentos existentes na Secretaria. A avaliação que eu faço é que não foi errado permitir a existência desses equipamentos. $O$ grande problema que nós tivemos foi o 
ritmo de implementação da reforma administrativa do governo, a dificuldade que nós tivemos de consensualizar uma proposta, num prazo mais curto, de reforma da Secretaria da Saúde no município em decorrência, e com toda a dificuldade nossa de fazer essa reforma na Câmara, porque até o momento em que eu assumi, que era antes da promulgação da Lei Orgânica do Município, essa reforma poderia ser feita por decreto. Só que naquele momento nós tinhamos consciência de um certo nivel de reforma que estava para ser feita e foi feita logo no início do governo pelo Eduardo, em 89. O que nós podíamos ter feito antes da promulgação da Lei Orgânica do Municipio, eu assumi no dia 6 de abril de 90 e, se não me engano, a Lei Orgânica foi promulgada no dia 5 de abril de 90 . Um dia antes. Portanto, até aquele momento nós poderiamos ter feito a reforma por decreto. Desde então, a reforma só poderia ser feita por lei. Nós tínhamos um quadro altamente desfavorável na Câmara Municipal, não tínhamos maioria, tanto é assim que, com exceção dos projetos de criação de cargos, que implicavam na abertura de Hospitais, e era muito difícil para eles impedir e justificar para a opinião pública não criar esses cargos. Os outros projetos mais importantes que nós apresentamos, como a questão do Código de Saúde do Município ou então, o projeto de instituição de diversos programas ou então, a questão da participação popular, esses ficaram simplesmente arquivados e nós não tivemos condição e nem força política. Até mesmo aquele projeto 270 , que era para abrir o provimento de cargos de diretoria das Unidades de Saúde, para outros profissionais, que não apenas da categoria médica, desde que tivessem formação em administração pública, saúde pública, nem isso nós conseguimos aprovar, tal era a situação desfavorável para a gente na Câmara. Essa estratégia de viabilizar alguns equipamentos específicos por programas era uma estratégia de alto risco, considerando a possibilidade deles se consolidarem enquanto propostas verticalizadas de programa, mas ao mesmo tempo, na medida em que nós fomos implementando o Distrito de Saúde. e sempre se discutiu isso como sendo a prioridade da gestão do município de São Paulo, eu acho que a gente conseguiu pelo menos inibir a tentativa de consolidá-los enquanto tal, buscando sempre uma integração. O que nós não tivemos foi tempo hábil para consolidar a proposta quanto à legislação, mas eu acho que é importante retomar o decreto de dezembro de 92, porque ali está contido pelo menos o germe do que seria a nossa proposta a ser efetivada na Câmara Municipal, e ali expressa também qual o grau de acordo possível naquele momento, dentro da equipe gerencial.

\footnotetext{
Alexandre Nemes Filho

A idéia geral era descentralizar. O mecanismo gerencial fundamental para a descentralização era a criação dos Distritos Sanitários. A coisa "geralzona" estava clara, mas a hora que você vai implantar é uma coisa bastante confusa. Primeiro é uma questão institucional, legal. Muito difícil você trabalhar com o grau de dificuldade que o PT tinha de
} 
viabilizar os seus projetos na Câmara de vereadores. Quer dizer, transformar uma idéia em lei, transformar uma idéia em cargos, uma idéia em modelo institucional para poder gerenciar. Então a gente sempre fez o que pode. Conseguiu criar legalmente alguns Distritos Sanitários. outros não foram criados, e a hora que você não faz isso, quer dizer, você cria determinadas estruturas de Distritos Sanitários de um jeito e as outras estruturas ficam diferentes. Isso dá uma confusão terrivel, além de você não ter dinheiro para pagar as pessoas, uma coisa assim de militância, que junta com a dificuldade de institucionalização dos tais Distritos Sanitários.

A outra questão é a própria concepção de Distrito Sanitário, que era muito variável. Tinha gente que entendia o Distrito mais do lado administrativo. O Pedro Dimitrov por exemplo. Ele via o Distrito Sanitário assim: queria dividir a Secretaria em muitos Distritos Sanitários, queria aquela coisa toda. Se de um lado ele via administrativamente, de outro ele tinha uma proposta muito pequena de Distrito Sanitário, de modo que você não conseguiria ter uma estrutura administrativa adequada para o nivel distrital. Para ele, era uma coisa mais para mobilizar a população, de ser um canal de participação da população. Mas não se conseguiria ser uma gerência administrativa. Ele defendia que o número de Distritos Sanitários fosse o mesmo dos Distritos da cidade de São Paulo, o que não era factivel.

Essas indefinições, trabalhar com muita gente, incorporar muita gente, também traziam confusões junto com as indefinições sobre como montar os Distritos Sanitários e tal, porque também tinha que caber todo mundo dentro da estrutura. Essa coisa não foi muito clara até o final da gestão, mas bem o mal, a gente montou 32 Distritos Sanitários que começaram a trabalhar. Mas não houve tempo suficiente para se estruturar e não podendo se legalizar, ter cargos para todos, o trabalho fica limitado porque não se tem uma estrutura legal. Não ter, fica sempre aquela coisa improvisada. Eu vejo assim, a improvisação, as limitações legais e o afã de querer fazer tudo, de fazer muita reforma, de enfatizar o meio, eu faria menos, bem menos.

\section{Pedro Dimitrov}

Não há uma resposta única. Na realidade nós não tínhamos a possibilidade de estar definindo uma coisa fixa, estanque. Por que? Porque cada região tinha uma capacitação de trabalno com um dado nivel de amadurecimento. Cada região teve momentos que avançou mais ou menos em determinados setores. Com um processo extremamente complexo em que você mexe com recursos humanos, recursos financeiros, recursos materiais e com as questões técnicas. Alguns Distritos avançaram mais num aspecto, outros Distritos Sanitários mais em outros. O que eu sempre insisti na época, é que fossem definidas as instâncias aonde as coisas fossem discutidas e definidas as atribuições, muito mais como um processo, do que como uma coisa acabada como um decreto, uma lei, uma resolução ou coisas do 
gênero. Tanto que grande parte da preocupação nossa era consolidar as instâncias de decisão da Secretaria, como o Conselho Técnico Administrativo.

O Conselho Técnico Administrativo cumpriu o seu papel de ser um fórum de permanente discussão e de negociação sobre a política de saúde da Secretaria, e as atribuições que cada um deveria estar desempenhando. Neste fórum se sentia muito essas diferenças. Alguns diretores que conseguiram dar condução à essas questões de recursos humanos, outros que não conseguiram dar conta dos recursos humanos, outros que davam conta da área de finanças, outros não davam conta da área de compras. Então nesta instância - CTA - surgiram as dificuldades e ai eram organizadas as reuniões especificas. Você tinha o Paulo Carrara com a área de finanças. Ele fazia reuniões específicas com os diretores para acertar as questões de finanças. A Isamara comandava as reuniões para acertar os problemas dos recursos humanos. Todas as dificuldades eram trazidas para o CTA e este criava fóruns específicos para negociar as várias soluções .

Quanto aos novos órgãos criados como o CEPI, o COAS e o CRH, eu acho que o órgão que mais clareou o seu papel e aos poucos foi construindo uma proposta para a Secretaria foi o CEPI. Quero dizer, ficou com a tarefa de pesquisa e informação na área de epidemiologia e conseguiu montar uma equipe enxuta e ágil. Conseguiu ter uma boa assessoria na área de informática, conseguiu dar uma certa direção de incorporação de tecnologia na área de informática, que era uma novidade para a Secretaria. Teve uma dificuldade muito grande com a PRODAM, que tinha o monopólio dos equipamentos de informática. Tinha uma dificuldade de relacionamento porque a PRODAM não permitia que as Secretarias tivessem seus próprios equipamentos. Isso foi um trabalho muito grande para poder superar alguns aspectos. Isto foi uma coisa positiva porque contribuiu para a construção de um certo conhecimento na área de informática na Secretaria, com assessoria específica na área de informática, e criando também toda a sistemática do SIMIS, que até hoje funciona apesar do PAS. Apesar de tudo, é o sistema que até hoje vem registrando as informações das Unidades, o prontuário e tudo o mais, as fichas de atendimento para as Unidades de Saúde. Então foi um trabalho assim. Quem vê de fora poderia imaginar como um trabalho um pouco lento, mas foi um trabalho construído com muita competência, com envolvimento dos atores de nivel local, com envolvimento de vários programas, de vários profissionais, com discussões sobre o que deveria ou não deveria entrar no prontuário. Um certo conflito muito grande com os vários especialistas que queriam incorporar um grande número de informações nos documentos. Então, o esforço de manter os documentos com um número menor de informações, que pudessem ser utilizadas, e fossem viáveis. Essa é a área que mais avançou

A segunda área que mais avançou para mim, foi a área de Recursos Humanos. Entendo que avançou bastante, às vezes de uma forma atrapalhada, porque é um 
envolvimento muito grande de trabalho, isso tem que ser reconhecido. Um número muito grande de trabalho com os concursos públicos, de processos que mexiam com os envolvidos e com a dificuldade que você fazia os concursos, mas não éramos nós que fazíamos os concursos. Era preciso contratar empresas externas para se fazer os concursos, por uma legislação própria da Prefeitura. Então, a cada concurso era uma negociação para realizar esse trabalho. Uma instituição externa, e isto é mais trabalho, é mais confusão. Às vezes as instituições externas cobram e não realizam o trabalho conforme se espera. Os prazos que a gente tinha eram sempre prazos muito curtos. Há uma dificuldade da instituição externa em entender a necessidade da gente, do ponto de vista de prazos. É uma dificuldade grande. Mas acho que a área de Recursos Humanos foi uma das áreas que cresceu muito, inclusive com o desenvolvimento e a contribuição do CEFOR, que não pode ser esquecido, pois foi um momento dentro da Secretaria de criar uma Escola. Uma escola própria para desenvolvimento de Recursos Humanos, da força de trabalho na área da saúde. Isto foi um ponto importante dentro da Secretaria. E por último, acho que a área de maior conflito e dificuldade, foi realmente o COAS e ai fica claro.

Gostaria de registrar a minha visão sobre isso. Na realidade você teve uma situação inicial, por características do Eduardo Jorge, de envolvimento de um grande número de pessoas, o que é correto, um grande número de pessoas para poder assumir a gestão da Secretaria. Esse fórum que se criou antes de se iniciar o governo, o fórum da Saúde e que depois foi para a Secretaria Municipal de Saúde, era constituído por um grande número de profissionais, especialistas de várias áreas, que depois, no processo de discussão política e na reforma da Secretaria com a criação das regiões, alguns dos profissionais foram sendo designados para exercer funções executivas, como diretores de regiões, de Distritos e de hospitais. Algumas pessoas que participavam deste fórum desde o início, não assumiram funções executivas deste tipo, e acabaram ficando nos órgãos assessores, no CEPI, no COAS ou no $\mathrm{CRH}$, que são órgãos assessores e não órgãos com linha de mando. Mas algumas dessas pessoas que ficaram no COAS, e que eram responsáveis por alguns programas especificos ( Saúde do Trabalhador, Saúde da Mulher, Saúde Mental e assim sucessivamente) insistiram em ter uma linha de mando. Não admitiram a reforma da própria Secretaria que tinham contribuído para fazer. $E$ aí, havia um conflito permanente entre o diretor da região que, como diretor tinha que escolher seus assessores nas várias áreas e os assessores do $\mathrm{Sr}$. Secretário, dessas várias áreas que estavam no COAS, querendo indicar os assessores para os diretores de regiões. É como se voltasse a ter uma estrutura vertical, por programas, comandada pelo COAS. Coisa que não era essa a estrutura proposta pela Secretaria. Então aí, foi um órgão que demorou mais para entender o seu papel, e teve algumas pessoas, que ficaram os quatro anos e não entenderam. Ficaram até o final da gestão criando conflitos com os diretores. Veja, esta é uma avaliação muito particular que eu 
tenho desta questão. A função que eu desempenhei no Gabinete da Secretaria Municipal de Saúde não me permitiu acompanhar de perto o processo a nivel distrital, mesmo porque nós encerramos a nossa gestão com 28 Distritos Sanitários, 32 criados e 28 instalados. O que eu imagino, o que eu consigo perceber na época, é que havia de novo uma grande disparidade.

Alguns Distritos Sanitários, bem mais estruturados, com grande participação, com grandes debates sobre o que fazer, como fazer, elaboração de orçamento, compras, principalmente a discussão de compras, compras de equipamentos. Isto chegava até o Gabinete da Secretaria Municipal de Saúde porque uma boa parte dessas compras era feita com recursos do FUMDES, e eu era o coordenador de despesas do FUMDES. Essas compras, por demandas, vindas dos Distritos Sanitários, por projetos apresentados pelos Distritos Sanitários. Então o que eu vejo é isso, na realidade você teve duas situações: uma situação em que no nível central se constituiu o Conselho Municipal de Saúde, com uma certa representatividade, um certo peso, com uma participação importante e inclusive, com as pessoas de militância política da população, com maior clareza, participando do CMS. E no outro extremo, você teve uma boa parte das UBS, onde havia movimento popular mais organizado, também com uma participação no Conselho Gestor, com alguma competência, com algum peso. Enquanto que no nível distrital, essa participação popular deveria estar sendo construida, mas seguramente teve, deve ter tido um diferencial muito grande entre os vários Distritos Sanitários, na composição desses Conselhos Distritais. Alguns Distritos Sanitários, com maior competência e outros Distritos Sanitários com muita dificuldade. Alguns inclusive nem chegaram a instituir os Conselhos Distritais com participação regular, com reuniões regulares.

\section{Virgínia Junqueira}

Posso começar falando de conflitos e contradições do COAS, que é a coisa que eu coordenei. Eu acho que ele é a expressão própria da contradição, porque você tinha ali pessoas que tinham sido escolhidas em vários fóruns para, enfim, para expressar reivindicações de vários tipos de movimentos. Desde os movimentos de mulheres que tinham delegado para que uma pessoa estivesse representando suas reivindicações, suas problematizações junto a Secretaria Municipal de Saúde, até o assessor de Saúde Mental, a luta antimanicomial, enfim e por aí vai. Você tinha pessoas lá dentro da Secretaria que tinham se imposto por esses movimentos, os mais diversos. Eram pessoas que tinham chegado lá, não por uma escolha do Secretário, mas tinha havido uma negociação entre o Secretário e esses movimentos, essas representações, seja lá o que fosse. O problema é que essas pessoas que vinham dessas representações, muitas vezes se confrontavam com o movimento da descentralização. Esta articulação da problematização que elas traziam com todas as outras necessidades de descentralização que a Secretaria tinha, a descentralização 
como um instrumento da democratização, muitas vezes elas acabavam tendo um conflito, batendo até de frente com a Secretaria. Não que essa coisa fosse má. Eu nunca vi como uma coisa ruim para a Secretaria o fato dessas pessoas terem chegado à Secretaria dessa maneira e de haver a instância dos Distritos. Agora, o que era ruim na verdade é que na medida em que o ímpeto para descentralização, para a distritalização era ainda muito frágil, muitas vezes a problematização que vinha do pessoal do COAS acabava se impondo. E ai é uma questão de opinião pessoal. Eu achava que o que poderia até representar melhor e atender melhor a problematização dos tais movimentos era esse movimento de democratização, que era a primeira necessidade do próprio movimento. Isso você pode conversar com o movimento de mulheres, com o pessoal da luta antimanicomial, com quem você quiser. A primeira coisa que você reivindica é a democratização. E a distritalização para mim expressava, da maneira melhor na época, ainda com toda a restrição, expressava a democratização. Só quem nem sempre as pessoas dos movimentos entendiam isso ou consideravam que isso ia atender melhor as suas necessidades. Então foi todo um trabalho para eles entenderem. Ao final, ao cabo, elas se tornaram defensoras dos Distritos. Houve muitos problemas no meio deste processo, mas eu estava lá no centro do conflito, e eu não achava ele ruim. Eu achava até um processo dinâmico, uma coisa que animava, que provocava discussão e que fazia a coisa ir em frente. O que eu vejo, eu acho que não veio daqui, desses assessores chamados assessores programáticos, eu acho que não veio daqui o principal emperramento do nosso projeto político. Vinham muitos problemas daqui, mas não era o caso de emperrar. Eu acho que o maior emperramento veio do governo municipal, das áreas que detinham o real poder para efetuar ou não a descentralização. Não a descentralização da Secretaria Municipal de Saúde, mas a do plano mais geral. O que eu quero dizer é o seguinte: eu acho que o que matou nossos Distritos veio do governo municipal. Eu era uma defensora em um certo momento, que o dirigente regional fosse mais um articulador político do que um dirigente do ponto de vista administrativo. Acho que o que matou os nossos Distritos não foi o conflito que esses representantes de movimentos traziam para a Secretaria. Eu acho que esse conflito, quando bem articulado, ele produzia avanços, pelo diálogo se avançava, e eu acho que se avançou barbaramente. Eu acho que a gente conseguiu dialogar e fazia avançar. Um representante do movimento com o qual se tinha muito conflito, era o da Saúde Mental. Eu acho que se pode contabilizar no final da administração um imenso avanço na questão da Saúde Mental. E houve falhas e falhas, montes de brigas. Não só com o representante da Saúde Mental, mas de maneira geral e no entanto. se avançou barbaramente.

Ficaram os Hospitais, os Distritos, os CeCCo's, as equipes de Saúde Mental para tudo quanto é lado. Enfim se avançou um horror, praticamente do nada, para uma coisa que realmente deixou uma ampla realização. Agora, para mim o mais grave foi a timidez com que 
a Prefeitura encarava a questão das Finanças, da Administração e do Planejamento, que eram as três áreas centrais.

Eu sempre dizia que o Diretor do Distrito Sanitário só iria ter força, quando fosse favorecido pela Prefeitura, pela descentralização, de tal forma que quando ele chegasse para o representante de qualquer movimento que fosse, saúde mental, mulher, criança, gato, cachorro, não importa, se ele tivesse um respaldo tal no interior da máquina administrativa da Prefeitura, ele poderia chegar e dizer para o representante: olha aqui, a minha apreensão da realidade é esta e eu quero discutir com você, que é representante de tal movimento, e nós vamos ver o que é que vamos fazer, juntos. Agora, o que nós tivemos foram diretores de Distritos Sanitários de tal forma fragilizados, que não conseguiram fazer muitas vezes essa discussão. O maior problema era que alguns que tinham mais experiência e maior liderança não estavam favorecendo, não estavam abrindo campo, para que estes dirigentes de Distritos Sanitários pudessem tomar às mãos, com respaldo, com segurança e apoio, das Secretarias de Finanças, Administração e Planejamento, para exercer a descentralização. Porque era impossivel estar na guerra que se instaurou, com um dirigente verde, pouco experiente. Conseguir dialogar aí com o representante da Saúde Mental, da Saúde da Mulher, que vinha cobrando isso, aquilo e aquilo lá. A pessoa já estava fragilizada aqui atrás e ainda tinha que enfrentar um representante de um dito movimento para discutir qual era a melhor política. Vai te catar, quer dizer, nenhum dirigente consegue fazer essas coisas. $E$ ai eu acho que, como é que foi a definição dos papéis? Foi uma definição apenas incipiente. Tanto do diretor regional como do diretor distrital, que estavam no meio dessa confusão toda. As várias pessoas estavam confusas por conta de uma confusão maior. Em todos os níveis, todos. Essa confusão começou na Prefeitura, claro. Ela não era uma confusão que se instala em uma Secretaria por si. Ela começa na Prefeita que começou a titubear a partir do segundo ano, quando era preciso quebrar o poder das três Secretarias, Finanças, Administração e Planejamento.

\section{Paulo Eduardo Mangeon Elias}

Eu acho que a grande reformulação foi administrativa. Foi a grande mudança. Porque nesta outra parte, das responsabilidade, isso não foi precisado. $O$ que se fez foi uma grande mudança administrativa. O Gabinete mudou mas não mudou. Não sei se consigo te dizer como é que é. Não sei como era antes. Ele mudou mas não mudou. É evidente que a administração fez, a meu ver, mudanças fantásticas. Eu acho que deixou coisas na linha da racionalização. Isto é inequívoco. A criação das ARS's foi um movimento racionalizador. Afinal de contas nós eramos tributários da Reforma Sanitária Brasileira. A Reforma Sanitária, o seu eixo, é um eixo racionalizador, apesar do ideário, da discussão política. De concreto é um eixo racionalizador. Até nisso nós fomos tributários da Reforma Sanitária Brasileira, nós 
optamos por um eixo de racionalização e fizemos outras coisas também no plano político, mas eu acho que a grande coisa é isso. Então quando você fala que mudou a Secretaria, mudou. Foram criadas as ARS's, foram criados os DS's, etc. e tal. Foi feita uma grande reforma. Mas eu insisto em dizer, dentro de uma cultura. Não dá pra você esquecer, qual era a cultura, qual era a base material dissc aí. A definição de competência por exemplo, esta não ficou clara, objetiva, de maneira geral, em todos os níveis. Eu acho que em algumas atribuições você conseguiu objetivar isso. Mas de maneira geral não. Não ficou claro, por exemplo, qual era o papel da ARS. Tinha um discurso sobre isso, mas você não tinha uma estrutura, nem uma estrutura material, nem precisão inequivoca de quais eram as competências daquilo. Você tinha as coisas emitidas no papel, idéias, diretrizes que não consubstanciam responsabilidades imediatas. E digo mais, você tinha responsabilidades concorrentes entre o nível central da Secretaria, a Administração Regional, o Distrito, que eram concorrentes, e os grandes hospitais. Onde todos podem, ninguém é responsável. Onde é que estava a responsabilidade disso? Eram responsabilidades indefinidas, esmaecidas, que eram concomitantes, concorrentes.

Esta responsabilidade aconteceu mais definida, mais intransferida, esta responsabilidade aconteceu em atribuições muito particulares. Ai, eu consigo ver em algumas, mas no geral não. Em geral eu não consegui ver isso.

\section{Como você vê o modelo de planejamento adotado pela administração da SMS durante aqueles quatro anos?}

Álvaro Escrivão Júnior

O hegemónico se implanta sozinho. O novo tem que ser construido. Tem que ter um plano operacional para que isso aconteça. E a operacionalização dessas idéias todas é que é muito complicado. Porque ela é absolutamente contra-hegemônica, sai completamente fora do lugar comum. Eu acho que a gente conseguiu avançar em muitas coisas, certamente conseguiu avançar em muitas coisas. Nossa dificuldade principal foi conseguir ir tendo consciência do que a gente estava fazendo, organizando, sistematizando, regulamentando, normatizando. Eu defendia por exemplo, uma normatização democrática e uma vez normatizado, esta normatização teria que ser cumprida, "duela a quien duela". Isto por exemplo não era uma coisa que acontecia. Você faria os estudos baseados em técnicas, nas tecnologias disponiveis, uma leitura organizada sobre a realidade, tomava uma questão, tirava uma diretriz, tirava uma norma. discutia ela amplamente, sem problemas, eu acho que é isso mesmo que deveria ter acontecido. Uma vez isto estabelecido, está normatizado. Então uma norma democrática, não deixa de ser menos nova pelo fato de ela ter sido construída 
democraticamente. A responsabilização e a aplicação de medidas corretivas quando você fugisse destas determinações, tinham que ser absolutamente feitas. Então esta é uma questão contraditória. Se por um lado eu achava centralizado, por outro lado você tinha uma autonomia muito grande do processo decisório porque você não tinha um processo de normatização estabelecido. Você voltava muitas vezes à mesma discussão. Tinha que haver algumas normas que cumpra-se e quem não cumprir, arque com as conseqüências.

Este arco de alianças que o Eduardo estabeleceu para o governo, complicava muito em relação a isso. Dava margem a personalismo, dava margem à uma série de coisas. Você tinha diretor que queria, que não queria, diretor mais forte, diretor mais fraco, diretor que cumpria, diretor que não cumpria, talvez seja inevitável, talvez não seja. A gente sabe como é um comando político forte de cima para baixo e fim de papo. Certas coisas que a gente via em algumas regionais, processos de verdadeira insubordinação, contra as coisas decididas, é porque o processo permitia esse certo espaço de insubordinação. Tolerância fazia parte do processo. Isso para mim é uma coisa contraditória daquilo que eu estava falando da centralização. Na verdade havia uma centralização, no sentido do que se decidir, mas também havia uma autonomização de como implantar. Não havia mecanismos de avaliação. Estava-se sempre discutindo problemas e fazendo propostas, como se fosse o primeiro dia de governo. Nós fomos até o último dia de governo quase que como se nós estivéssemos no primeiro dia, fazendo propostas e implantando novidades. Os processos de avaliação não davam certo. Mesmo dessa maneira, veja bem, eu acho que o Conselho Técnico Administrativo, o CTA precisa ser melhor olhado. O CTA era um compromisso com a democratização, de dividir responsabilidades. Agora, mesmo no CTA, pelo que eu lembro, os processos de avaliação de uma maneira ou de outra, acabavam ficando para lá. Porque chegava alguém com alguma novidade, queria resolver tal coisa, mudar a Tabela de Lotação de Pessoal não sei da onde, resolver a falta de medicamentos de não sei do que, comprar não sei quantas ambulâncias, e para quem vão ficar as ambulâncias, e para quem não vão ficar os computadores e, um processo de avaliação mais organizado, não era feito. Nunca houve nenhum processo de avaliação, e se você não avalia o que você esta fazendo, você pode estar acertando ou errando. Acho até que a gente acertou mais do que a gente errou, porque a gente contava com um grupo de pessoas muito bem intencionadas, trabalhando 1617 horas por dia, mas não porque você tenha encontrado um maneira de racional de fazer as coisas. Foi muito passional, voluntarista.

\section{Carlos Alberto Pletz Neder}

Eu acho que a gente tem que se reportar ao governo como um todo. As dificuldades que nós tivemos por indefinições no programa de governo, pela forma como foi composta a equipe de governo. Naquele momento a lógica das tendências acabou imperando. A lógica 
das tendências dentro do Partido. Foi um governo bastante centrado no Partido dos Trabalhadores. Só no final é que ele foi se abrindo para a idéia da participação de outras forças políticas, sejam partidárias, seja na questão do Fórum da Cidade. Houve uma dificuldade muito grande em definir o núcleo de poder dentro do governo, e eu acho que o momento mais significativo desse embate teórico, vamos dizer assim, no bom sentido, foi ao final do ano de 89 , onde diferentes teses foram apresentadas para discussão dentro do governo, sobre qual era a forma mais adequada de gestão pública no município de São Paulo. Naquela ocasião, nós elaboramos conjuntamente, eu tive participação nisso, o Eduardo também, um documento que questionava a falta de um planejamento estratégico no governo, a falta de um comando político no governo, e a necessidade de nós definirmos com maior radicalidade, qual seria o caminho da descentralização do poder e de toda gestão municipal. O governo optou por um outro caminho. Optou pelo não planejamento estratégico, optou por não fazer a gestão política através de um comando, através de programas e de políticas que fossem definidas em função de campanhas centradas e que dessem visibilidade às ações de governo e, ao mesmo tempo, acabou optando por uma estratégia gradualista na implantação da reforma administrativa. $E$ ai todas as secretarias pagaram um preço por isso, por todos esses componentes. No caso da Saúde, nós tentamos fazer aquilo que a gente propôs para o governo e que não conseguiu que fosse uma proposta de governo, que é tentar fazer o planejamento, onde você tinha um órgão esclerosado de planejamento, que era a Assessoria Técnica de Planejamento, e cabia à ela planejar todo o trabalho da Secretaria. E introduzir a idéia do planejamento a partir de um dinamismo dado pelo próprio trabalho, ou seja, você teria uma representação de órgãos, portanto uma representação de diferentes dinâmicas, uma representação de diferentes modalidades de implementação de ações de saúde. Isso se expressava num colegiado, que era um colegiado técnico de planejamento, assessor do colegiado técnico administrativo da Secretaria, de tal forma a trazer não o planejamento como sendo uma técnica para dentro da Secretaria, embora isso não seja de menor importância, tanto é assim que eu acho que o CEPI foi muito importante no sentido de associar as informações epidemiológicas com as informações gerenciais, o Sistema Municipal de Informação em Saúde, a própria existência do PROAIM, quer dizer, foi uma tentativa de você trazer os instrumentos de planejamento e de informações em saúde, para associá-los com as informações gerenciais. Mas ao lado disso uma nova concepção: não o planejamento visto como sendo pessoas que detinham determinado conhecimento em planejamento, mas tentar trazer a dinâmica dos vários órgãos com espaço onde o planejamento se faria num encontro dessas várias dinâmicas. Por outro lado, a idéia de que essa participação deveria existir de forma ascendente, ou seja, para você planejar a política da Secretaria não apenas de cima para baixo, mas tinha que ser um movimento conjugado de baixo para cima, ou seja, das Conferências e dos Encontros para definir prioridades anuais, mas ao mesmo tempo, a 
partir do dia-dia do trabalho da Unidade de Saúde, do Distrito, dentro daquela lógica de fazer a territorialização, de trabalhar a visão da vigilância em saúde, de trazer diferentes elementos de cada Distrito, de cada Região, que não eram necessariamente iguais, portanto, exigiam ritmos diferenciados por parte da própria gestão da Secretaria. Eu acho que esse processo a gente conseguiu começar, mas houve uma interrupção brutal.

Virgínia Junqeira

Eu só posso refletir sobre o resultado dado. Agora, eu acho que foi uma coisa importante, que as pessoas travaram conhecimento com uma outra possibilidade de planejar e que pode ser usada de maneira democrática. Agora, travaram conhecimento de uma maneira muito dispersa, fragmentada. A Secretaria não tinha uma assessoria de planejamento. Não era uma assessoria de planejamento. Tinha várias pessoas que intervinham no planejamento, toda a assessoria do Gabinete da Secretaria Municipal de Saúde intervinha no processo.

O Paulo Carrara como a pessoa mais responsável pela questão das finanças, tinha um peso enorme no que ia ser planejado. Então não havia uma pessoa, uma pessoa delegada para planejar, então ficava tudo muito fragmentado. A possibilidade de se botar realmente um planejamento estratégico a serviço da democracia foi muito frágil. Então foi um aceno, um acenozinho assim que passou pela Secretaria. As pessoas falavam: olha que legal, que não sei o que..., quem ouvia falar de planejamento estratégico, da Carmem Teixeira, que era uma autoridade em planejamento estratrégico situacional, ela já fez cursos no exterior sobre isso. Enfim era a especialidade dela. Nesse sentido, foi uma pessoa pouco aproveitada e tinha outras pessoas aqui em São Paulo que trabalhavam com planejamento estratégico. Para mim o que importava era o resultado. O planejamento estratégico situacional possibilita um uso democrático do conhecimento. Pode ter um uso autoritário, mas possibilita um uso democrático, pelo envolvimento, pela consideração que você tem de opiniões diversas, pela busca, pela articulação, vinculação, enfim, pelas derivações de um planejamento estratégico. Mas ficou como um aceno de possibilidades. Mas eu não vejo o problema só no interior da Secretaria Municipal de Saúde. Para mim o problema era da Secretaria de Planejamento como um todo. Eu lembro de uma conferência na Regional de Saúde de Pirituba, e que lá eu ouvi a Raquel Rolnik falando de uma coisa que nunca tinha ouvido antes. Eu fiquei boba, quando eu vi os folhetos e a fala dela, que era uma coisa brilhante. E para que serve isso tudo? Sim, porque eles eram a Secretaria de Planejamento. Eles tinham que ter conduzido isso. Eu lembro que fui com os italianos à uma reunião na Secretaria de Planejamento. Os italianos estavam trazendo alguém de Genebra, que era entendida em Sistema de Informação Geográfico e, discutindo lá com o pessoal da SEPLAN, vi que os italianos eram mais interessados do que o pessoal da SEPLAN em fazer funcionar o SIG. Não havia interesse por 
parte da SEPLAN em difundir esse processo para as demais Secretarias. O que me impressionou foi a incapacidade da SEPLAN em articular intersetorialmente as diversas secretarias do setor social. Eu não entendo. Não se abriu para isso. Não considerava que o planejamento da cidade se faz com todo mundo junto, local e regionalmente. Quando eu ouvi a palestra da Raquel Rolnik, fiquei com a sensação de desperdício, de um imenso desperdício. Vou me lembrar disso para sempre. Um Secretário de planejamento com aquele brilho, não conseguiu traduzir o que a Raquel Rolnik pensa, não conseguiu fazer chegar ao povo. Tinha que descer da estratosfera. Isso nós que sempre vivemos em Unidades Básicas de Saúde sabemos o que representa.

\section{Alexandre Nemes Filho}

A visão administrativa da Secretaria Municipal de Saúde foi mais tradicional na forma de mexer com os recursos. Não houve de fato uma descentralização, uma autonomia das Unidades. Botar um hospital para se autogerenciar, para enfim, você criar locais mais autônomos que competissem entre si, na criação de modelos, competindo entre si com diferentes graus de autonomia. Nesse sentido é que eu acho que a gente não conseguiu avançar muito. E os mecanismos administrativos mesmos eram bem tradicionais. As regras, as normas, eram muito rígidas. Então acho que não mexemos muito nisso. Aí não era fácil mexer

Do ponto de vista mais gerencial, das decisões, das grandes diretrizes, implementações, a gente tentou avançar, mas também houve dificuldades muito grandes, que são a própria colisão dos interesses do nível central com o nível periférico. Dos times entre os dois niveis. Isso é uma coisa que dá muito pepino. De repente o time do nivel central é fazer política, é capitalizar tal e tal coisa, enquanto que o time do nível local é fazer territorialização, diagnóstico de saúde, é um momento diferente. Então nós tínhamos uma heterogeneidade muito grande nos vários pedaços. Eu tenho a impressão que o pessoal do nivel local se sentia como planejador, mais envolvido. A população também participava muito mais. Então teve um lado inovador de realmente criar algum nivel de planejamento local. Mas eu não sei se foi uma prática ascendente, se conseguiu assim fazer um processo mais completo de planejamento ascendente.

Eu acho que não. A gente tinha uma coisa mais inicial mesmo. Um exercício inicial. Planejamento participativo. Você pega, por exemplo, a discussão de orçamento participativo em São Paulo, foi incipiente. Depois que acabava aquele momento de discussão, as pessoas acompanhavam? Cobravam do regional? Não era assim. Nós tentamos isso. Algumas regiões introduziram métodos de planejamento importantes. Contaram com um suporte técnico melhor, eu acho. Onde não teve esse suporte o pessoal ficou meio perdido. Mas no âmbito dos Distritos Sanitários, se foi inovador, eu acho que sim. Incorporação em algumas regiões 
da população e algumas iniciativas em alguns locais foram mais firmes. Por exemplo, na ARS2, as propostas de novos serviços foram concebidas por critérios epidemiológicos, com participação do pessoal do nível local. As adaptações foram feitas no Distrito da Lapa por iniciativas locais. Meu discurso está parecendo um pouco contraditório, mas é muito mais assim, o quanto a gente projeta e o quanto você quer de autonomia para isso.

\section{Paulo Eduardo Mangeon Elias}

Essa é uma idéia um pouco mais distante. Eu tenho certas impressões sobre isso. Primeiro, eu acho que de novo tem o ideário que é uma parte. No ideário, o planejamento era ascendente. Era o velho modelo da Reforma Sanitária do planejamento ascendente, da base para ser consolidado nas grandes estruturas da Secretaria. Aí eu já acho que tem duas ordens de problema. A Secretaria tinha uma estrutura mais administrativa, vamos dizer, e uma estrutura política ou administrativo-política. Então você já tinha duas instâncias e a comunicação entre as duas não era muito clara. Entre a estrutura administrativo-política ( o CTA, todos os CTA's das regiões e dos DS's) e a estrutura administrativa ( no Gabinete do Secretário, nas ARS's e nos DS's), com funcionários que operavam estas coisas todas. Aí eu acho que a comunicação entre essas duas estruturas, formalmente ela não estava concebida. Informalmente então ela se deu de maneiras muito diferenciadas. Essa era uma primeira dimensão dessa história do planejamento. No plano do ideário, o planejamento era concebido de uma forma ascendente, mas você tinha duas estruturas aqui.

$\mathrm{Na}$ verdade, o ápice desse planejamento ascendente seria o Conselho Técnico Administrativo da Secretaria da Saúde, mas não estavam definidas as instâncias de decisão política. Onde se daria a decisão entre visões conflitantes, por exemplo? Qual o mecanismo de decisão? Onde era isso? Por isso que eu estou falando da existência de duas estruturas. Porque se era no CTA e eu imagino que sim, cadê a representação dessa outra estrutura aqui? Como é que se faz isso? São problemas extremamente complexos. Isto no plano do ideário. No concreto, na realidade como se deu isso, de novo eu acho que vai te dar padrões muito distintos, dependendo de qual a região que você está, de qual o DS e, aí de novo, não há como fugir daquelas características que nós falamos, da estrutura da Secretaria. E aí eu acho que muitas vezes você teve sim. Você pode ter tido processos que foram mais ou menos coletivos. Eu não acredito que possa ter tido processos de verdade, muito coletivos. Eu insisto em dizer que não fui um observador muito privilegiado, porque sou de uma área, que tive uma visão muito geral da Secretaria, mas a impressão de quem estava nessa posição é de que não teve uma coisa muito ascendente. $E$ você teve sim, mas um planejamento cujas diretrizes foram determinadas de cima para baixo. $E$ era um pouco esse modelo, porque se você viesse com o planejamento ascendente, com a cultura que você tinha na Prefeitura, você ia chocar com a visão de quem estava chegando. Dá até para 
compreender porque ele tinha que ser um pouco impositivo. Se ele viesse de baixo para cima ele vinha com a cultura, com a mentalidade do funcionalismo da SMS. Porque 0 planejamento não tem uma dimensão técnica só. la chocar com essa revolução toda que estava acontecendo. Então, o planejamento nem poderia deixar de ser um pouco impositivo na minha opinião, se você quisesse fazer algum tipo de transformação. Porque se ele viesse como manda o figurino, ele viria naqueles padrões que você conhece melhor que eu, porque você esteve mais próximo da máquina do que eu.

Você não pode ser ingênuo, imaginar que você vai fazer o planejamento ascendente, quando chegar aqui em cima, isto estaria completamente fora das diretrizes políticas da administração, estaria, com certeza estaria. Então é um pouco a minha visão acerca do planejamento.

\section{Pedro Dimitrov}

Veja, algumas pessoas que estavam em nivel central tinham alguma clareza disso. Tinham um modelo pensado, na teoria, latente o tempo todo. Atrás de todas as propostas de nivel central, tinha o modelo do planejamento estratégico situacional. Toda a reforma da Secretaria foi pensada em cima disso. Veja, quando eu falei na primeira questão sobre os órgãos de nivel do Gabinete, não foi criado um Departamento de Planejamento, uma divisão de planejamento, porque planejamento desde o início foi pensado como um processo, e não como um órgão, e quem deveria planejar eram as pessoas que executavam as atividades.

Portanto, todo o Planejamento foi pensado, num primeiro momento, como o próprio Conselho Técnico Administrativo do Gabinete da Secretaria Municipal de Saúde, para estar levando este planejamento mais global, e num momento mais interno, numa situação mais interna, um colegiado de apoio de planejamento para o Secretário, com um número menor de pessoas, que eram os órgãos do Gabinete do Secretário, com representação dos diretores de região. Então. na realidade nós tínhamos o diretor de Recursos Humanos, do CEPI, do COAS, mais chefia de Gabinete, mais o Secretário Adjunto e mais um ou dois representantes dos diretores das ARS's, que constituíam o colegiado de Planejamento. Na realidade era uma preparação de pauta para o Conselho Técnico Administrativo, onde as decisões deveriam ser tomadas, e esse colegiado que apoiava o Secretário, tinha por tarefa também estar acompanhando as várias decisões que eram tomadas e as providências em relação aquelas decisões. Na realidade eram operadores das decisões do Conselho Técnico Administrativo.

Então, dentro dessa visão, de você ter uma estrutura horizontalizada, com colegiados que discutem as coisas nos vários níveis e no nível da Secretaria, com assessores de Gabinete, responsáveis por alguns órgãos e com operadores de decisões no próprio CTA, para mim tudo isso, é uma visão que tínhamos do planejamento estratégico situacional. 
Alguns diretores regionais, com mais experiência, conseguiram ter uma aplicação desta mesma metodologia a nível regional. Houve experiências localizadas na minha visão e, com colaborações externas, para ajudar nesse processo, que foi a Cooperação Italiana, com o planejamento estratégico situacional para o nivel local. Algumas experiências positivas também. Mas havia um conflito muito grande também, porque na realidade você tinha um tempo político de quatro anos e que era necessário desenvolver as ações para que os serviços funcionassem. E havia uma outra perspectiva de você construir uma coisa de baixo para cima de planejamento, com envolvimento da população, dos funcionários, processo mais lento também necessário, também importante mas que, do ponto de vista do tempo político, é que seria muito lento. Então na realidade você teve esses dois movimentos: um movimento de alguns diretores com experiência, e que conseguiram tocar um pouco mais o planejamento estratégico situacional para as suas regiões e as coisas avançaram, tanto que construíram seus Distritos Sanitários com mais facilidade. Seus próprios Distritos Sanitários passaram a ter este tipo de conduta dentro dos colegiados de diretores de suas Unidades, e a coisa até chegou a funcionar com uma certa qualidade do processo de decisão, do processo de planejamento mais coletivo das ações a serem desenvolvidas. $E$ um processo mais lento em outras regiões onde isso não ocorreu, não chegou a ocorrer com facilidade, onde as pessoas tinham mais dificuldade, tinham menos experiência e, por outro lado, a colaboração de instituições externas à própria Secretaria, tentando ajudar em algumas regiões e incorporar alguns procedimentos mais adequados na área de planejamento.

É mais ou menos esta visão que eu tenho, mas mesmo em todos esses lugares, permanecia um conflito do COAS com este processo, com alguns técnicos do COAS, digamos assim. Os especialistas por programas, em algumas regiões eles acabavam entrando e acirrando conflitos e em outras regiões eles entravam e não criavam conflitos porque eles eram colocados na sua devida posição de assessores e não de executores diretos das ações. Então na realidade os programas, eu insistia muito em dizer que nós não tínhamos programas na Secretaria, nós tínhamos problemas de saúde que deveriam ser enfrentados de uma forma organizada. O tempo todo no Conselho Técnico Administrativo se discutia e a gente colocava que nós não tínhamos programas verticais como Saúde da Mulher, Saúde do Trabalhador, Saúde não sei do que. Nós tínhamos problemas de saúde que deveriam ser localizados em cada área geográfica e, uma vez identificados os problemas, utilizar a assessoria especializada para tentar resolver aquele problema. Os problemas eram diferentes em cada Distrito Sanitário, em cada ARS, em cada micro-região. Portanto, não tinha nenhum sentido ter programas homogêneos verticais para todo o municipio. Esse conflito entre uma visão do planejamento estratégico situacional com identificação de problemas e a partir da identificação dos problemas, você tem eventualmente a assessoria de um especialista para ajudar na solução. Esta conduta vivida por alguns diretores, entrava em conflito com outros 
diretores que não conseguiram ter este procedimento, e acabavam tendo uma tentativa de colocação de programas verticais, homogêneos. Esta é uma situação que ocorreu na Secretaria. Na minha visão predominou o encaminhamento mais adequado. Em algumas regiões com menor número de técnicos, as regiões mais distantes, com pessoal menos preparado, vivenciaram este outro aspecto que coloquei.

Atrás de todas as propostas de nivel central, tinha 0 modelo do planejamento estratégico situacional. Toda a reforma da Secretaria foi pensada em cima disso. Veja, quando eu falei na primeira questão sobre os órgãos de nível do Gabinete, não foi criado um Departamento de Planejamento, uma divisão de planejamento, porque planejamento desde o início foi pensado como um processo, e não como um órgão, e quem deveria planejar eram as pessoas que executavam as atividades.

Portanto, todo o Planejamento foi pensado, num primeiro momento, como o próprio Conselho Técnico Administrativo do Gabinete da Secretaria Municipal de Saúde, para estar levando este planejamento mais global e, num momento mais interno, numa situação mais interna, um colegiado de apoio de planejamento para o Secretário, com um número menor de pessoas, que eram os órgãos do Gabinete do Secretário, com representação dos diretores de região. E havia uma outra perspectiva de você construir uma coisa de baixo para cima, de planejamento ascendente, com envolvimento da população, dos funcionários, processo mais lento também necessário, também importante mas que, do ponto de vista do tempo político, é que seria muito lento. Então, na realidade você teve esses dois movimentos: um movimento de alguns diretores com experiência e conseguiram tocar um pouco mais o PES para as suas regiões e as coisas avançaram, tanto que construíram seus Distritos Sanitários com mais facilidade; seus próprios Distritos Sanitários passaram a ter este tipo de conduta dentro dos colegiados de diretores de suas Unidades, e a coisa até chegou a funcionar com uma certa qualidade do processo de decisão, do processo de planejamento mais coletivo das ações a serem desenvolvidas. Esta é uma situação que ocorreu na Secretaria. Na minha visão predominou o encaminhamento mais adequado.

9. E o trabalho integrado? Você acha que a Secretaria contribuiu para a integração entre as diferentes Secretarias Municipais? Ou, foram tomadas medidas no sentido de se superar as limitações da atuação setorial, diante da necessidade de se trabalhar com problemas que abrangem outros diferentes setores?

\section{Álvaro Escrivão Júnior}

Acho que foi o lugar onde eu mais vi acontecer isso. Se você comparar com as nossas expectativas, você pode dizer que a gente não chegou lá. Mas se você comparar com 
o que existe por aí, eu acho que houve um conjunto enorme de iniciativas tanto na Secretaria da Saúde, na Prefeitura, quanto nos níveis regionais. Eu pessoalmente vivi experiências que achei muito interessantes do projeto "São Paulo - Cidade Saudável", que eu acho que dá para formular algumas coisas interessantes. Até o texto, o relatório daquele evento que a gente fez, tem a fala do Paulo Freire, que acho que é uma fala muito interessante, até histórica. Tem a fala da Marilena Chaui. Então eu acho que havia realmente essa tentativa de integração.

Algumas experiências ligadas à Comissão de Cólera foram muito interessantes. 0 Fórum da Cidade de São Paulo escolheu a Cólera como uma questão para tocar, eu acho que foi, vamos dizer assim, uma amostra grátis, ou uma ilustração do que pode ser feito quando você realmente junta todas as Secretarias, vários níveis de governo, e a própria sociedade para tocar um projeto. Então como ilustração, como é o caso, o Fórum Cidade de São Paulo trouxe experiências, exemplos, bastante interessantes do que pode ser feito de modo integrado. Algumas questões eram interessantes, mostravam uma certa "insuficiência tecnológica", sobre como você fazia para trabalhar integradamente. Por exemplo, eu me lembro que o pessoal da Secretaria de Obras, uma época solicitou para que a gente dissesse quais eram os pontos onde as obras da cidade deveriam ser priorizadas, em relação a enchentes e tal, do ponto de vista de doenças, tanto do risco de cólera como de leptospirose, etc. $E$ a gente não sabia muito como responder isso para eles. Porque talvez o indicador epidemiológico não seja o único, não haja indicadores em que seja possivel, sem medo de se fazer injustiças, de você afirmar que aqui, talvez seja melhor canalizar este córrego e não aquele, porque aqui o risco de doença é maior, por isso e por aquilo. Mas eu estou apontando assim, o interesse dos caras em querer colocar dentro das prioridades deles, indicadores da área de saúde. Por outro lado, houve dificuldades estranhas. Por exemplo, aquela integração que a gente tentou fazer entre Zoonoses e Vigilância Sanitária. Eu acho que aquilo é todo um exemplo de dificuldades que a gente teve, alimentadas pela corporação dos médicos veterinários, mas na verdade encontrou talvez um corpo mole do lado da Secretaria do Abastecimento em algum momento, e nos deu um grande desgaste violento. Gastamos um tempo desgraçado para não conseguir avançar muito, apesar do apoio da Luiza Erundina.

Eu acho que houve de tudo, experiências positivas e experiências negativas mas, de qualquer sorte, eu acho que a intenção de trabalhar integradamente era bastante grande. Eu realmente não vi nenhum outro lugar que tenha trabalhado antes, que tenha experiências de integração mais sérias que essas da Prefeitura Municipal de São Paulo. A da Saúde, foi uma das Secretarias que mais avançou em termos de integração.

Alexandre Nemes Filho 
Tem os dois niveis. Tem o nivel de governo e o nível da Secretaria Municipal da Saúde. A gente tinha a facilidade de pensar projetos integrados com a Cultura, os Parques, a SAR, Educação, etc. A minha avaliação é que nós fizemos sem muita visibilidade. Pouca gente ficou sabendo.

Os Centros de Convivência e Cooperativa foram implantados em parques, com grupos marginalizados como os portadores de sofrimento mental e os idosos. As nossas ações potencializaram o combate a Leptospirose com ações intersetoriais. Tinha facilidade para fazer isso. O quanto isso foi, acho que isso estava se transformando em político.

\section{Pedro Dimitrov}

Aí nós voltamos à mesma matriz de dificuldades em relação ao COAS. Houve integração na gestão petista e na proposta de planejamento em nivel local integrado, puxado pela SAR e com a SEPLAN, visando a criação do Núcleos Regionais de Planejamento. Os nrp's passaram a ter um papel importante, a ter um caráter político, para tentar integrar as várias Secretarias e dar solução para os problemas vistos pelas Secretarias setoriais, e aí ocorreu o conflito entre o órgão nivel local intersetorial, ou seja, um órgão horizontal, com as Secretarias que são verticais setorializadas. Os conflitos chegaram a um ponto de intensificação, o que fez com que a corda rompesse para o lado mais fraco, e os nrp's foram desativados. Na minha visão foi um erro político. Nós teríamos tido uma boa gestão, muito mais competente, muito mais ligada às necessidades da população, se tivéssemos reforçado os nrp's e tivéssemos proposto a reforma da administração pública da Prefeitura. Naquela oportunidade, desde o início, já construindo o nrp como base de sustentação de uma nova estrutura administrativa para a Prefeitura. Aí, o que houve? Houve um conflito, houve um rompimento deste processo, retornando tudo para o sentido verticalizado das Secretarias. Cada Secretaria se fechou no seu feudo e ai se reabriu a discussão sobre a reforma da Prefeitura, que demorou dois anos, para ser elaborada, e quando foi para a Câmara Municipal já não havia mais tempo hábil e nem acordo político para a sua aprovação. 